
Nacimiento y consolidación de la historiografía griega 


\section{RODRÍGUEZ HORRILLO, Miguel Ángel}

Nacimiento y consolidación de la historiografía griega / Miguel Ángel Rodríguez Horrillo. - Zaragoza : Prensas de la Universidad de Zaragoza, 2012

495 p. ; 23 cm. - (Monografías de filología griega; 22)

Bibliografía: p. 449-486. - ISBN 978-84-15770-11-4

Grecia-Historia-Hasta 146 a. C.-Historiografía

$94(38) \ll \ldots /-146 »: 930$

Cualquier forma de reproducción, distribución, comunicación pública o transformación de esta obra solo puede ser realizada con la autorización de sus titulares, salvo excepción prevista por la ley. Diríjase a CEDRO (Centro Español de Derechos Reprográficos, www.cedro.org) si necesita fotocopiar o escanear algún fragmento de esta obra.

(C) Miguel Ángel Rodríguez Horrillo

(C) De la presente edición, Prensas de la Universidad de Zaragoza 1. a edición, 2012

Colección Monografías de Filología Griega, 22

Coordinador de la colección: Miguel Ángel Rodríguez Horrillo

Diseño de cubierta: David Guirao

La edición de este volumen ha contado con la ayuda del Vicerrectorado de Investigación de la Universidad de Zaragoza y del Departamento de Ciencias de la Antigüedad.

Prensas de la Universidad de Zaragoza. Edificio de Ciencias Geológicas, c/ Pedro Cerbuna, 12, 50009 Zaragoza, España. Tel.: 976761 330. Fax: 976761063

puz@unizar.es http://puz.unizar.es

UITe Esta editorial es miembro de la UNE, lo que garantiza la difusión y comercialización de sus publicaciones a nivel nacional e internacional.

ISBN: 978-84-15770-11-4

ISSN: $1136-0860$

D.L.: Z-70-2013

Impreso en España

Imprime: Servicio de Publicaciones. Universidad de Zaragoza 


\title{
Nacimiento y consolidación de la historiografía griega
}

\author{
Miguel Ángel Rodríguez Horrillo
}

MONOGRAFÍAS DE FILOLOGÍA GRIEGA, 22 • 2013 


\title{
MONOGRAFÍAS DE FILOLOGÍA GRIEGA
}

\section{Nueva etapa}

(Publicación anual)

\section{CONSEJO EDITORIAL}

\author{
Director: Carlos Schrader García (Universidad de Zaragoza) \\ Director Ejecutivo: José Vela Tejada (Universidad de Zaragoza) \\ Secretario de Publicaciones: Vicente Ramón Palerm (Universidad de Zaragoza)
}

\section{COMITÉ CIENTÍFICO}

José Antonio Caballero López (Universidad de La Rioja), José Luis Calvo Martínez (Universidad de Granada), José $\mathrm{M}^{\mathrm{a}}$ Candau Morón (Universidad de Sevilla), Emilio Crespo Güemes (Universidad Autónoma de Madrid), José Antonio Fernández Delgado (Universidad de Salamanca), Carlos García Gual (Universidad Complutense de Madrid), José García López (Universidad de Murcia), Fernando García Romero (Universidad Complutense de Madrid), Manuel García Teijeiro (Universidad de Valladolid), Manuela García Valdés (Universidad de Oviedo), F. Javier Gómez Espelosín (Universidad de Alcalá de Henares), Juan Antonio López Férez (UNED - Madrid), Marcos Martínez Hernández (Universidad Complutense de Madrid), Antonio Melero (Universidad de Valencia), José Guillermo Montes Cala (Universidad de Cádiz), Jesús M. ${ }^{a}$ Nieto Ibáñez (Universidad de León), Anastasios Nikolaidis (Universidad de Creta, Grecia), Aurelio Pérez Jiménez (Universidad de Málaga), Emilio Suárez de la Torre (Universidad de Valladolid), Gocha R. Tsetskhladze (Universidad de Melbourne, Australia), Joana Zaragoza Gras (Universidad Rovira i Virgili de Tarragona)

Monografías de Filología Griega (MFG) publica un número al año. Los originales no solicitados deberán remitirse, al menos, a dos miembros del Comité Científico y a uno del Consejo Editorial, para poder proceder a su publicación una vez aprobada la misma. MFG mantendrá intercambio con cualquier publicación periódica que contenga aportaciones científicas originales relacionadas con el ámbito de los estudios de Filología Griega.

Redacción y Administración

Área de Filología Griega

Departamento de Ciencias de la Antigüedad

Facultad de Filosofía y Letras

Universidad de Zaragoza

E-50009 Zaragoza

e-mail: schrader@posta.unizar.es

jvela@posta.unizar.es

vmramon@posta.unizar.es 
Monografías de Filología Griega 22 (2012)

Nacimiento y consolidación de la historiografía griega

Área de Filología Griega. Departamento de Ciencias de la Antigüedad Facultad de Filosofía y Letras. Universidad de Zaragoza. ISSN: 1136-0860

ÍNDICE
ABSTRACT
1. LITERATURA, PENSAMIENTO Y CONTEXTO
EN LA HISTORIOGRAFÍA ANTIGUA
1.1. La interpretación de la historiografía antigua. De Creuzer a Jacoby
1.1.1. De los orígenes a Jacoby
1.1.2. Nuevas tendencias de interpretación
1.1.3. Objeto del presente estudio.
$\quad$ Forma y contenido en el origen de la historiografía
1.1.3.1. Pensamiento, forma y contexto: condicionantes de la aparición
$\quad$ del género historiográfico

2. LA PREHISTORIA DE LA HISTORIOGRAFÍA GRIEGA

2.1. Los primitivos proemios en prosa: tendencias y relación autor-público $\ldots \ldots \ldots \ldots \ldots \ldots . . . . . . . . .33$

2.2. De lo oral a lo escrito: la teoría de los proemios epistolares

2.3. Microestructura literaria: la prosa arcaica

2.4. Macroestructura literaria: el ejemplo de la épica $\quad 60$

2.5. Hecateo de Mileto

2.5.1. El estilo de Hecateo de Mileto

2.5.2. El pensamiento de Hecateo

2.5.3. Contexto literario y social de Hecateo

3. HERÓDOTO, PADRE DEL GÉNERO LITERARIO HISTORIOGRÁFICO_............. 85

3.1. Publicación de la obra: fechas y contexto

3.2. Heródoto, I 1-5: pautas estilísticas $\ldots$

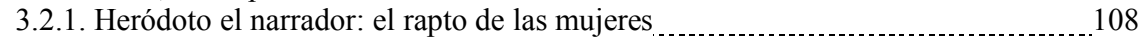

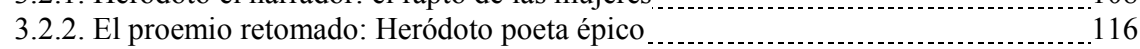

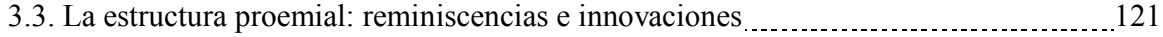

3.4. El léxico proemial: precisión y unidad de la obra

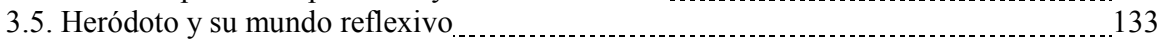

3.5.1. La metodología herodotea

3.5.2. Las intervenciones del autor

3.5.3. Las versiones dobles en la metodología herodotea

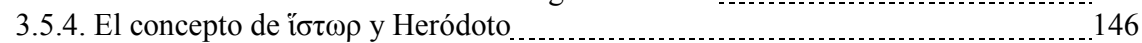

3.5.5. Sistematicidad del modelo herodoteo $\ldots \ldots \ldots$

3.5.6. El diseño del mundo herodoteo

3.5.7. La irrefrenable fuerza de los hechos: el denominado segundo proemio _............176

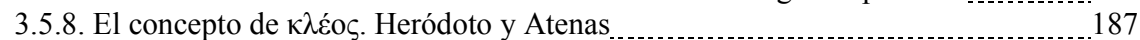

3.6. La finalidad de la obra herodotea

4. ANTÍOCO DE SIRACUSA, EL HERÓDOTO OCCIDENTAL $\ldots \ldots \ldots \ldots \ldots \ldots \ldots \ldots \ldots$ 
5. TUCÍDIDES

5.1. Publicación de la obra. La cuestión tucidídea

5.1.1. La cuestión hoy: unidad y sentido literario de la obra

5.1.2. El segundo proemio

5.2. La estructura interna del proemio: unidad arcaica y razonamiento polémico $\ldots \ldots \ldots \ldots . . .251$

5.2.1. El segundo proemio

5.3. Pautas para una interpretación del estilo de Tucídides:

entre la exactitud y lo literario

5.3.1. La interpretación del estilo tucidídeo

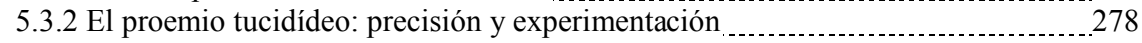

5.3.3. Desarrollo de la frase $\quad 290$

5.3.4. Tucídides en la encrucijada de la prosa griega $\ldots \ldots$

5.4. Hacia un léxico técnico de la historiografía _........................................ 300

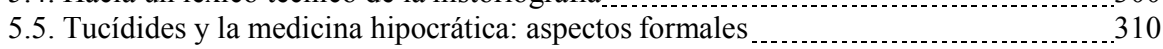

5.6. De Hecateo a Tucídides: pensamiento y expresión en el mundo oral y escrito .......... 313

5.7. El universo intelectual de Tucídides

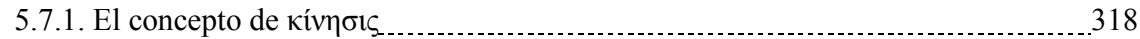

5.7.2. La situación de los contendientes: la $\pi \alpha \rho \alpha \sigma \kappa \varepsilon v \eta ́$

5.7.3. La metodología de Tucídides _ _

5.7.4. Contextos del modelo metodológico tucidídeo

5.7.5. El poder político y sus consecuencias

5.7.6. El capítulo del método

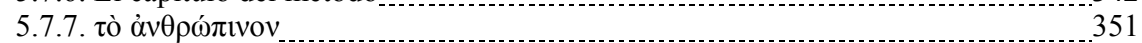

5.7.8. El concepto de tiempo

5.7.9. Tucídides y la dimensión política de la historiografía

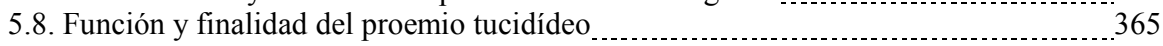

6. LA CONSOLIDACIÓN DEL GÉNERO HISTORIOGRÁFICO:

EL SIGLO IV A. C.

6.1. Constitución del texto de los autores fragmentarios

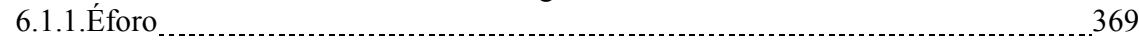

6.1.2. Teopompo

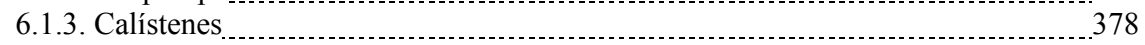

6.1.4. Duris de Samos

6.2. La estructura del proemio historiográfico en el siglo IV a. C.

6.3. Timeo de Tauromenio y los proemios menores __....... 385

6.4. Hacia un modo de expresión regular: el estilo historiográfico $\ldots \ldots \ldots \ldots$

6.5. Crátipo _

6.6. Polis, literatura e historiografia

6.6.1. Educación y sociedad $\ldots \ldots \ldots$

6.6.2. La historiografía y el historiador

6.6.3. Historiografía y crítica literaria: la historiografia trágica

6.6.4. El estilo literario y su análisis en la historiografía _................................. 428

7. EPÍLOGO

BIBLIOGRAFIA

INDEX LOCORUM

Monografias de Filología Griega, 22. ISSN 1136-0860 
Monografías de Filología Griega 22 (2012)

Nacimiento y consolidación de la historiografía griega

Área de Filología Griega. Departamento de Ciencias de la Antigüedad Facultad de Filosofía y Letras. Universidad de Zaragoza. ISSN: 1136-0860

\section{CONTENTS}

ABSTRACT

1. LITERATURE, THOUGHT AND CONTEXT

IN ANCIENT HISTORIOGRAPHY

1.1. The study of the Ancient historiography: from Creuzer to Jacoby

1.1.1. From the origins to Jacoby 15

1.1.2. New trends of interpretation

1.1.3. Aim of this study. Form and context and the origin of historiography

1.1.3.1. Thought, form, and context as determinants in the development

of the historiographic genre

2. THE PREHISTORY OF GREEK HISTORIOGRAPHY 33

2.1. The early prose proems: trends and autor-public relationship $\ldots \ldots \ldots \ldots \ldots$

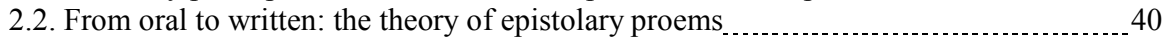

2.3. Literary microstructure: the archaic prose

2.4. Literary macrostructure: the example of the epic $\ldots$

2.5. Hecataeus of Miletus 73

2.5.1. The style of Hecataeus of Miletus

2.5.2. The thought of Hecataeus

2.5.3. Literary and social context of Hecataeus 82

3. HERODOTUS,

FATHER OF THE LITERARY GENRE OF HISTORIOGRAPHY $\ldots \ldots \ldots$

3.1. Publication of the work: dates and context

3.2. Herodotus, I 1-5: stylistic guidelines $\ldots$

3.2.1. Herodotus the narrator: the rapt of the women $\ldots \ldots \ldots$

3.2.2. The proem resumed: Herodotus epic poet

3.3. The proemial structure: reminiscences and innovations .............................. 121

3.4. The vocabulary of the proem: precision and unity of the work

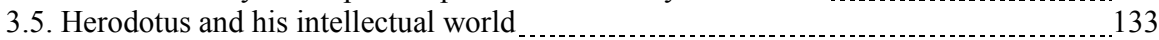

3.5.1. The herodotean methodology

3.5.2. The author's voice

3.5.3. The double answers and the herodotean methodology

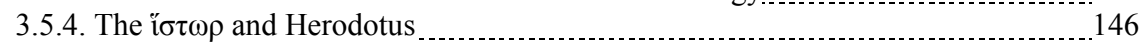

3.5.5. The systematic interpretation of Herodotus $\ldots$

3.5.6. The design of Herodotus' world 160

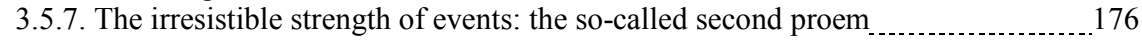

3.5.8. The $\kappa \lambda \dot{\varepsilon}$ o $\varsigma$ concept. Herodotus and Athens $\ldots 187$

3.6. The purpose of Herodotus' work

4. ANTIOCHUS OF SYRACUSE, THE HERODOTUS OF THE WEST $\ldots \ldots \ldots \ldots \ldots \ldots . . . . . . .211$ 
5. THUCYDIDES

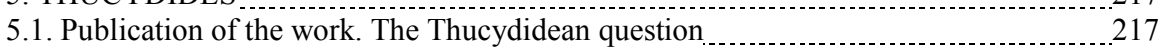

5.1.1. The Thucydidean cuestion today: unity and literary sense of the work

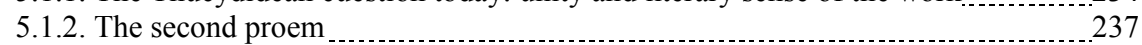

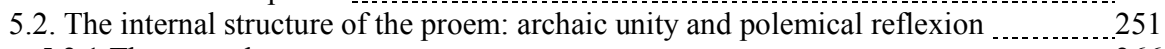

5.2.1 The second proem

5.3. Patterns for the interpretation of Thucydides' style:

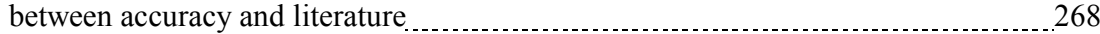

5.3.1. The interpretation of Thucydides' style 268

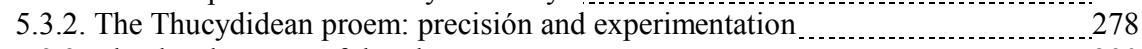

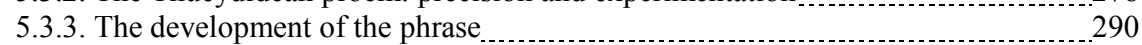

5.3.4. Thucydides at the crossroad of the Greek prose $\ldots$

5.4. Towards a technical vocabulary of the historiography ................................300

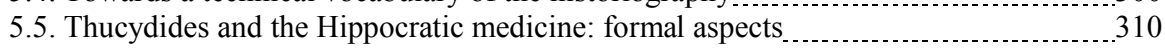

5.6. From Hecataeus to Thucydides:

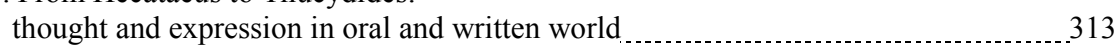

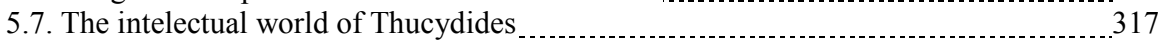

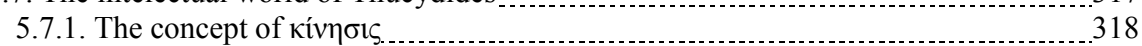

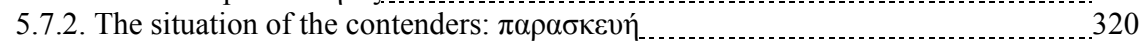

5.7.3. The methodology of Thucydides _

5.7.4. Contexts of the methodological model of Thucydides

5.7.5. Political power and its consequences

5.7.6. The methodological chapter

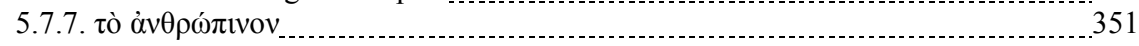

5.7.8. The concept of time

5.7.9. Thucydides and the political dimension of historiography

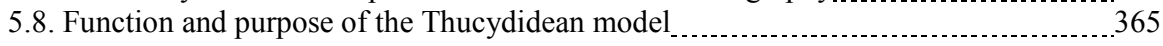

6. THE CONSOLIDATION OF THE HISTORIOGRAPHICAL GENRE:

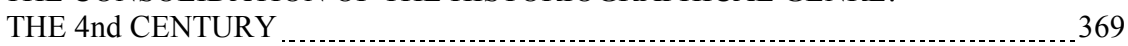

6.1. Constitution of the fragmentary text of the proems

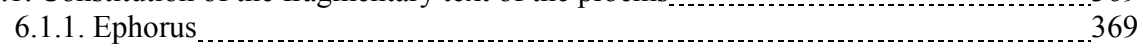

6.1.2. Teopompus

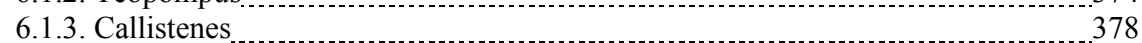

6.1.4. Duris of Samos

6.2. The structure of the historiographical proem in the 4nd century B. C.

6.3. Timaeus of Tauromenium and the lesser proems

6.4. Towards an regular expression: the historiographical style $\ldots \ldots 389$

6.5. Cratippus

6.6. Polis, literature and historiography

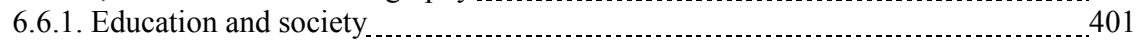

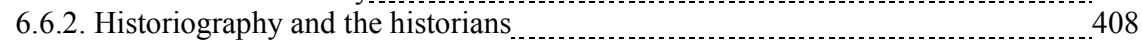

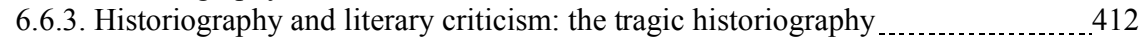

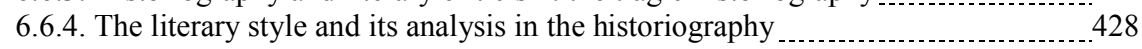

7. EPILOGUE

BIBLIOGRAPHY

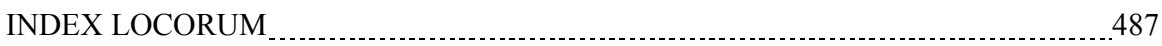

Monografias de Filología Griega, 22. ISSN 1136-0860 


\begin{abstract}
1. The study of ancient historiography has been approached from a preconceived assumptions derived from the interpretative patterns of the Ancient World. Creuzer's work originated a perspective that entailed the development of historiography as a progression culminating with Thucydides. This author was taken as the culmen of that process, in the same way as functioned the evolution from myth to logos.

The monumental edition of the fragments of the Greek historians due to Jacoby sanctioned this scheme, but gradually the recent work on the field understands the Ancient historigraphy from a no biased perspective, giving more importance to the literary nature of the Historians' work.
\end{abstract}

According to the literary nature of the genre, and with the advantage of the recent work, we propose a study of the origin and development of historiography, taking as starting point the indissoluble unity of form and thought in Ancient literature. We study the origin of Historiographical proems as a key element in the shaping of the historiographical genre. The birth of the genre in the period of transition beetwen the oral and written world will be fundamental for the genre.

2. The study of the early historiography proems implies the knowledge of the relationships between them and the remaining literature of the time. The oldest proems in prose are examinated, paying attention to its special characterization, to the nature of early Greek prose, and its possible role in the development of historiography. The role of the epic in the configuration of the proems is also studied. These two literary universes will configured the microstructure and macrostructure of the future genre respectively.

The figure of Hecataeus of Miletus is presented merely as a precedent of future historians. His thought is still piecemeal, while the stylistic nature of its fragments is limited and very close to that of the prose-proems studied in the early prose. With this author, we have many of the features of future genre, but still without the creation of something new.

3. The time of publication of the Herodotean work is essential for its proper study. An examination of the data and the nature of the work confirm 
the written nature of the first work of the genre. This character of the Histories forces us to place it in a symposial context.

The stylistic nature of the proem is studied in view of this conditions. Attention is given to reminiscences, games and innovations developed by Herodotus, which represents the final step in the birth of the historiography. Particular importance has the complex structural pattern of the proem, which is among the greatest achievements of the author, and of particular importance to Herodotus' tought.

In regard to the vocabulary, Herodotus presents numerous parallels with the writers of his time, locating the thought of Herodotus in the rich intellectual world of his time. The methodology is discussed, with special attention to its relationship with the work of other writers of the time. It presents a dynamic nature due to the continuous intervention of the author

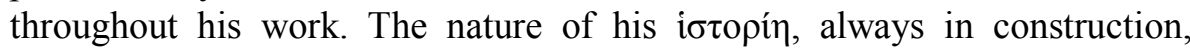
motivates the emergence of dual explanations to some of the issues.

This leads to a systematic universe of ideas that presents a great relationship with the philosophical world of ancient Greece. The archaic and aristocratic nature of Herodotus' tought is the key to interpreting the concept of $\kappa \lambda \varepsilon \dot{\delta}$. It is strongly linked with the traditions of the aristocratic families. Their mechanisms of memory are gradually relegated by the importance of the democratic model of remembrance of the past. Moreover, the study of funerary epigraphy confirms these tensions. This helps to explain many of the literary features of the work, and gives us an image of Herodotus far away from the usual interpretation of the Histories.

4. Antiochus represents the link between the work of Herodotus and Thucydides in a geographical location far from Ionia and Athens. His preface exemplifies many of the features that we meet again in the case of Thucydides.

5. The Thucydidean question is always the starting point in the study of Thucydides' work. It is discussed briefly, and the main aspects of the problem are examinated in order to evaluate their signification in a literary analysis of the work.

The structure of the two proems is analized on the basis of the archaic thought and style. Thus, its complex nature highlights its controversial sense. This polemical view is very evident in the second preface, wich constitutes a deviation from the stylistic uses of the archaic literature. In regard to style, 
Thucydides presents a transitional stage in the evolution of Greek prose. This allows the historian to innovate and experiment in order to facilitate the expression of complex thoughts. We also explore Thucydides' special interest in accuracy, as in the case of variatio, which is best example in the rich vocabulary of the work.

It is precisely the study of vocabulary that allows us to demonstrate that the relationship with Hippocratic medicine has to be softened: possible influences are part of the complex cultural world of this period, and do not permit in any way the establishment of an ideal figure of Thucydides as a scientific historian.

The concept of kínors is central to the Thucydidean ideology. In the Archeology, the historian develops the justification of such importance by the analysis of the $\pi \alpha \rho \alpha \sigma \kappa \varepsilon v \eta$ of the contenders. To study this phenomenon, Thucydides develops a methodology that has many points in common with the Herodotean system. The observation of the causes and their meaning are presented in a way opposite to that seen in Herodotus, but always with an interpretative model very similar to the system that we can see in Herodotus' work.

Herodotus and Thucydides also share the importance of the political perspective in his work. The repetition of the events according to human nature facilitates a dynamic that pervades the work with their best exponent in the Athenian imperialism. The power of Athens exemplifies a process of decay which alerts us that, in matters of time, we are still in an archaic mode of thought.

6. The analysis of the proemial fragments of the fourth century leads us to confirm the creation of the structure that we will see throughout the history of the genre. This structure meets the needs of works of great length, and also host in an organized manner the different ideas presented by proems, far away from the archaic structural models.

In regard to style, there is a process of regularization of the features that we can see in Thucydides. The Thucydidean experimentation leads to the creation of a regularized style that accommodates the complex thought of historiography. In addition, we examine the importance of Isocrates in the creation of this style.

The historical thought of this period is related to the development of the polis. Different philosophical approaches point to a concern about the 
paideia among the historians. The exempla play an important role in this regard, a literary use that links the historiography with the world of the fourth-century prose.

The historian as an individual assumes great importance in the development of the work. Its formation plays a key role in the development of the historiography, and we detect a new section highlighting the historian's personality and paideia. This importance of the author is best exemplified in the development of literary polemics. The so-called tragic historiography is a good example of this type of literary reflections. 


\section{LITERATURA, PENSAMIENTO Y CONTEXTO EN LA HISTORIOGRAFÍA ANTIGUA}

La historiografía es, seguramente, el género más incómodo de la literatura antigua. ${ }^{1} \mathrm{Su}$ carácter relativamente tardío en comparación con géneros como la tragedia, la épica o la lírica, y su vinculación con el despertar del pensamiento racional occidental son dos lastres en el estudio de un género analizado, por otra parte, de manera exhaustiva por la gran filología de todo tiempo y lugar.

La historiografía era una ciencia, una ciencia nacida al calor de los acontecimientos políticos, crucial para la comprensión de la realidad de la Antigüedad y también de la realidad que rodeaba a sus críticos. El análisis de la historiografía avanzó bajo los designios de unas pautas de comprensión cuyo examen previo es fundamental para alcanzar un punto de partida fiable para conocer el origen y desarrollo del género historiográfico.

\subsection{La interpretación de la historiografía antigua. De Creuzer a Jacoby}

\subsubsection{DE LOS ORÍGENES A JACOBY}

Es una labor titánica el tratar de desarrollar de manera exhaustiva un recorrido por las perspectivas desde las que se ha abordado el género historiográfico. La importancia de un género considerado una ciencia moderna en potencia, ${ }^{2}$ soporte de un caudal de datos inagotable para el conocimiento del mundo antiguo, hizo que prácticamente cada crítico desarrollara un patrón de análisis para cada historiador. En líneas generales, el análisis total del género ha recibido un tratamiento, si cabe, más

\footnotetext{
${ }^{1}$ El presente estudio se inserta en el marco del proyecto FFI2011-27501.

${ }^{2}$ Cf. una defensa programática de esta idea en Ulrici, 1833, p. 9.
} 
sistemático y fuertemente coherente, ${ }^{3}$ de modo que es posible seguir la línea moderna de interpretación que va desde la obra de Creuzer hasta las modificaciones de la teoría de Jacoby por parte de Marincola. ${ }^{4}$

El optimismo positivista con el que se abordó la reconstrucción crítica del mundo antiguo en el inicio del siglo XIX determinó una perspectiva, unos métodos $\mathrm{y}$, en definitiva, una manera de comprender a los historiadores antiguos. El desarrollo de los postulados de un método científico pronto dejó su impronta en el ámbito humanístico, y los historiadores modernos asumieron que la naturaleza del sistema empleado por sus colegas antiguos respondía a ese mismo paradigma científico, único e indivisible, monolíticamente construido en torno a un inamovible concepto de verdad.

«Das Wesen aller Historie ist Wahrheit», decía Creuzer ${ }^{5}$ en una de las obras que sentaron los fundamentos de la clasificación y, sobre todo, de la interpretación de la historiografía, en este caso griega. Creuzer, ya olvidado por la crítica, al menos la no especializada, nos sale al paso en muchos de los planteamientos de Jacoby, heredero de esa gran tradición de análisis de la historiografía que tuvo su gran obra en Die historische Kunst der Griechen, en la que por primera vez se hacía realidad la imagen general de la historiografía antigua.

Así, la historia, y con ella la historiografía, es decir, su narración, se abordaba como la cara opuesta del mito, que como tal no era verdad, sino -como aún afirman los antropólogos- un elemento útil, un elemento que permite dotar de sentido a la realidad, ${ }^{6}$ pero que no es reflejo de esa misma realidad.

Era este el origen mismo de un movimiento idealista, porque se construye obviando lagunas y contradicciones, e idealizado, dado que se basa en un juicio a priori de carácter progresista que respondía a la necesidad de establecer un progreso intelectual en el mundo antiguo desde lo religioso y mítico -Creuzer equiparaba los conceptos sin lugar a duda

\footnotetext{
${ }^{3}$ Considerado como una unidad superior a la casuística individual ya desde Ulrici, 1883, p. 10.

${ }^{4}$ Respecto a Friedrich Creuzer y su importancia para la historiografía griega, puede verse el informado y al tiempo crítico trabajo de Momigliano, 1969a, p. 76 y ss.

${ }^{5}$ Cf. Creuzer, 1845 , p. 33. La primera edición data de 1806. Ulrici, 1833, acoge, desde una perspectiva más trascendental, a los autores latinos.

${ }^{6}$ Así, ya Creuzer, 1845, p. 36 y ss. 
alguna $-{ }^{7}$ hasta lo racional en un sentido moderno. De este modo, el proceso cultural vivido en el siglo XIX encontraba, una vez más, su paralelo en el mundo antiguo.

La literatura griega se funda con el género épico, y ya pronto surgió la duda si, por el hecho de narrar hechos históricos, era Homero un historiador. Para esta pregunta no había respuesta en el Mundo Antiguo, lo que hoy sabemos que es quizá la mejor respuesta. Y es que no cabía duda para los antiguos de que un fondo histórico permanecía latente tras los versos de Homero, y también, tras la posterior y prodigiosa aventura de la arqueología en planos supuestamente míticos de la Grecia antigua, para los modernos.

La respuesta tuvo que ser, pues, deficiente, y el propio Creuzer dejó sin Wahrheit a Homero -seguramente, por ser el inicio de esa ascensión hacia la Razón historiográfica-, simplemente, afirmando que el interés principal de Homero no era narrar de manera fiel los hechos. ${ }^{8}$

Superado este primer escalón, la progresión del modelo de interpretación partía de la narración homérica hacia los denominados logógrafos, en lo que era el primer paso para el abandono de esos esquemas míticos, pero todavía con el lastre que suponía el dar cabida a fenómenos míticos en sus relatos. La valoración que Creuzer hizo de Dionisio de Mileto es, probablemente, la mejor expresión de la estima dotada de cierta compasión demostrada por la reflexión de esta época: «so war diess nicht anderes, als der Fehltritt eines wissbegierigen Neulings auf einem schülpfrigen Boden». ${ }^{9}$

Sin embargo, y aquí se presenta una de las grandes contradicciones del estudio de la historiografía antigua, con la llegada a Heródoto, en teoría el primer historiador -aunque no hubiese alcanzado la plenitud de un Tucídides-, la crítica reconoció ya desde fecha tan temprana como la que

\footnotetext{
${ }^{7}$ Cf. Creuzer, 1845 , p. 57 y ss. Ha de señalarse cómo en ocasiones se equipara de manera inconsciente el sacerdocio que actualmente conocemos con el sacerdocio antiguo. Sin embargo, y como bien se puede observar en lo que nos ocupa, en la figura de los $\dot{\varepsilon} \xi \varepsilon \gamma \eta \tau \alpha i ́$, el concepto de sabio portador de tradiciones de la comunidad y el de carácter más puramente religioso caminan juntos. Para los $\dot{\varepsilon} \xi \varepsilon \gamma \eta \tau \alpha i$, cf. Jacoby, 1949, p. 19 y ss.

${ }^{8}$ Cf. Creuzer, 1845 , p. 43.

${ }^{9}$ Cf. Creuzer, 1845 , p. 69 y ss. La cita corresponde a la página 70 . No hemos de obviar el hecho de que fue Creuzer el que definió prácticamente lo que conocemos como logógrafos, y con ello determinó muchos de los prejuicios que incluso hoy tenemos, empezando por su total aislamiento de los historiadores posteriores por motivos únicamente intelectuales y no formales.
} 
nos ocupa la fuerte influencia de Homero en su obra, sin que ello supusiera ninguna contradicción respecto a ese esquema ideal. ${ }^{10}$

La deuda de Heródoto con los poemas homéricos no se reducía simplemente a ecos espirituales, sino que las imágenes, los recursos literarios, estaban en clara conexión con Homero. Aun a pesar de este reconocimiento, Creuzer dejaba a un lado esta incómoda perspectiva y continuaba trazando la línea que conducía a Tucídides, la perfección misma del género, y por ello modelo de la labor de los historiadores positivistas. ${ }^{11}$

Como decimos, esta idea de la historiografía fue recuperada y sancionada en época posterior de un modo en cierta manera matizado, pero conservando muchos de los prejuicios propios de la época en que fue planteada. En el año 1909, Felix Jacoby publicó un artículo programático sobre la nueva edición de los fragmentos de los historiadores que iba a sustituir a la de los hermanos Müller. Pero ese artículo fue más allá de un simple programa o adelanto de la futura obra monumental: la particular visión de Jacoby sobre los diferentes géneros del narrar histórico así como su teoría del desarrollo y perfección del género en la figura de Tucídides adquirieron una dimensión que resultó potenciada por la importancia de la monumental colección de fragmentos.

Resumiendo las ideas de Jacoby, se puede subrayar la importancia que presentaba el concepto de desarrollo en la formalización del género historiográfico y los subgéneros que Jacoby delimitaba. Para empezar,

${ }^{10}$ Que era ya un aspecto reconocido por los antiguos, cf. e. g. Pseudo Longino, De Sublimitate, XIII 3. Rhys Roberts, 1899, p. 227, señaló, tras recoger las diferentes referencias a

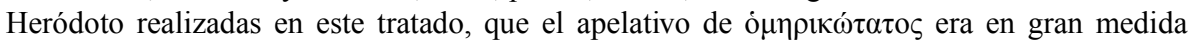
laudatorio. Cf. además Dionisio de Halicarnaso, Ad Pompeium, III 11. Cf. Creuzer, 1845, p. 114 y ss. Es especialmente interesante constatar que el breve análisis sobre la lengua de Heródoto, en p. 149 y ss., se centra en unas escuetas referencias al empleo del dialecto jonio, que rápidamente relaciona Creuzer con el concepto de verdad. Las recientes investigaciones nos permiten señalar que este apelativo fue empleado ya en el siglo II a. C. por Halicarnaso para destacar el valor de Heródoto, cf. Isager, 1999, p. 1 y ss. Cf. además Boedeker, 2002, p. 97 y ss.

${ }^{11}$ Cf. Creuzer, 1845, p. 202 y ss. Gran parte de este juicio se debe a las palabras de Tucídides en el proemio que se conocen como el método. Cf. Niebuhr, 1847, p. 205, quien reconoce este pasaje como la primera página de la historiografía en sentido moderno. Fundamental, Meyer, 1899, p. 269 y ss. Para una sanción autorizada de este esquema cf. Schwartz, 1938a, p. 65 y ss., quien defiende la vuelta al pasado de la historiografía helenística en oposición a la historia contemporánea de un Tucídides. Para este prejuicio cf. Parmeggiani, 2011 , p. 10 y ss. 
Jacoby negaba a los griegos una historia como la entienden los modernos, ${ }^{12}$ y lo que podría a primera vista parecer una cuestión bizantina reside en el fondo de una concepción de la historiografía por parte de Jacoby que acoge en su seno una idea que es crucial para la comprensión de nuestras futuras reflexiones sobre ella.

Jacoby tenía una visión de la historia aquejada del ya conocido pantucidideísmo que remonta a Creuzer, y que le llevaba a situar la obra de este autor como la cumbre de la producción historiográfica griega y hacia la cual todos los restantes autores convergían: la primera etapa, con Hecateo y sus dos obras, daba paso a un Heródoto díptico, ${ }^{13}$ de modo que las dos obras de Hecateo se verían recogidas en la de este último, cuya primera parte respondería a la obra «etnográfica» del de Mileto, en tanto que la segunda parte se referiría a las Genealogías: además, la parte final de la obra sería el trasunto de las futuras 'E $\lambda \lambda \eta v i \kappa \alpha ́$, mientras que la primera parte lo sería de

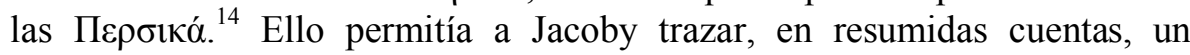
vínculo perfecto entre las tradiciones jonias que recogía Hecateo y lo que era el paradigma de la madurez histórica, Tucídides: ${ }^{15}$

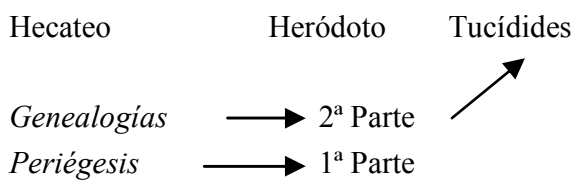

Esa madurez histórica era lo que Jacoby denominaba Zeitgeschichte, que no pocas críticas ha despertado. ${ }^{16}$ La denominación de iotopía no era válida

${ }^{12}$ Cf. Jacoby, 1956a, p. 20. La afirmación suscitó las iras de Fornara, 1983, p. 2 y ss., en la que es la mayor crítica quizá de este autor a Jacoby, al que sigue en sus planteamientos, si bien añade matices que perfilan sus ideas. Dicha afirmación, seguramente más complicada de lo que podría parecer a primera vista, fue silenciada por la crítica posterior. Cf. la valoración de Momigliano infra; sin embargo, es probable que los enigmáticos planteamientos de Wilamowitz, 1909, p. 16, puedan ir en esta dirección.

${ }^{13}$ Cf. esta idea también en Momigliano, 1984c, p. 135, y Lendle, 1992, p. 45.

${ }^{14}$ Cf. Jacoby, 1956a, p. 40.

${ }^{15}$ Cf. también Strasburger, 1966, p. 16 y ss.

${ }^{16}$ Fornara, 1983, p. 2 y ss. La equiparación de la Zeitgeschichte a los restantes géneros creaba el problema, en palabras de Fornara, de la aparición de un grupo que era, por cierto, muy numeroso, y cuyas semejanzas eran mayores en otros aspectos que en la simple narración del presente, si bien la principal complicación para Fornara era la minusvaloración de lo que 
para Jacoby por cuanto era posible aplicarla a todas las obras, desde las de Hecateo hasta las últimas producciones del género. ${ }^{17}$ Más allá de las complicaciones de nomenclatura, lo importante es que es con Tucídides con quien se alcanza la naturaleza misma de lo que conocemos como historiografía, como ya vimos que decía Creuzer. ${ }^{18}$

Esta exposición se ve complementada además por el famoso paso del mito al logos, del que ya hablamos, cuya progresión se puede observar en la crítica inicial de Hecateo al tiempo heroico, como señala también Fornara, ${ }^{19}$ en el paso de esos elementos míticos y su crítica a las secciones etnográficas de la primera parte de la obra de Heródoto (consideradas como elementos de solaz en la obra del de Halicarnaso), ${ }^{20}$ y en su desaparición en la obra de Tucídides. Todo ello daba una visión cabal de la evolución del género y su convergencia hacia la perfección en Tucídides.

\subsubsection{NUEVAS TENDENCIAS DE INTERPRETACIÓN}

Esta interpretación de la evolución del concepto de historiografía ha sido corregida de manera clara por los estudiosos con nuevas definiciones del género, ${ }^{21}$ que han tomado conciencia de la continuidad de los hechos narrados, analizados bajo un esquema causal que daba paso a un examen

él consideraba la historia en términos modernos. La defensa modélica de la primacía de la historia contemporánea se puede ver en Schwartz, 1938b, p. 67.

${ }^{17}$ Cf. Jacoby, 1956a, p. 34, nota 53.

${ }^{18}$ Cf. Jacoby, 1956a, p. 36. Jacoby caracterizaba este género como panhelénico, como de temática contemporánea y narrado desde una perspectiva griega, lo que de nuevo nos lleva a Tucídides como ejemplo paradigmático. Quizá esta idea está detrás de los planteamientos de Strasburger, 1966, p. 19, que hacían de Heródoto padre de las variantes no «puramente» historiográficas.

${ }^{19}$ Cf. Fornara, 1983, p. 7. No parece lógico hablar como hace, según veremos, de la definición de un spatium historicum en Hecateo en su tratamiento del mito: incluso aceptando los planteamientos más racionalistas, la crítica del pasado mítico se puede dar sin necesitar una separación entre tiempo mítico e histórico, que por otra parte, privaría de sentido a esa crítica, dado que tal separación elimina el valor de todo lo acontecido en el espacio mítico, que queda relegado a una posición secundaria respecto a la Zeitgeschichte, verdadera historia frente al falso mito.

${ }^{20}$ Cf. Fornara, 1983, p. 14 y ss.

${ }^{21}$ Cf. e. g. Meister, 1992, p. 4 y ss.; la propuesta esquemática de Meister es desarrollada por Schrader, 1997, p. 86 y ss. 
crítico del pasado, todo ello bajo una formalización literaria más o menos compleja.

En esta línea, Marincola ${ }^{22}$ ha propuesto una nueva caracterización del género historiográfico tras reconocer las dificultades del examen de Jacoby. Marincola se hace eco de la importancia del concepto de género en las últimas décadas, y de su interpretación como algo flexible, sujeto a innovaciones y a cambios, en la que el autor goza de una posición clave a la hora de definirlo. Ello hace que la clasificación de Jacoby, así como las puntualizaciones de Fornara, le parezcan insuficientes y en exceso rígidas, por lo que propone, en consonancia con esas ideas, una serie de características definitorias del género, ${ }^{23}$ referidas al contenido y a la organización temporal y espacial de la obra, lo que nos pone sobre aviso de que las pautas empleadas siguen siendo las de Jacoby.

Por una parte, Marincola opone el carácter estático de las narraciones etnográficas al examen de hechos diacrónicos, lo que además conlleva la aplicación de un esquema de causación y nos conduce a la propuesta de Schrader y Meister. ${ }^{24}$ En íntima relación con esta primera característica, Marincola da cuenta de la posibilidad de narrar por años, reinados, pueblos, etc., lo que de nuevo hace en parte referencia a la primera propuesta de Meister en el plano formal de la cohesión de la narración.

Como segunda gran característica, habla Marincola de la focalización, que hace referencia a la perspectiva que adopta el autor respecto a la narración, como puede ser una ciudad, una guerra, etc., recogiendo así una idea ya defendida por Jacoby en su clasificación. Vinculada con esta idea está la propuesta respecto al contenido de la obra, que puede hacer referencia a una guerra, a hechos religiosos, culturales, etc.

Finalmente, la limitación cronológica hace referencia al amplio arco temporal que se presenta ante el autor, que puede elegir dentro de un marco que se extiende desde los orígenes hasta el tiempo del autor.

Como decimos, esta caracterización adolece de un problema de partida, que no es otro que el estar construida sobre la clasificación de Jacoby, extrayendo las características generales comunes a los diferentes géneros, lo que hará que en la crítica que realizaremos de la propuesta de Jacoby se vea

\footnotetext{
${ }^{22}$ Cf. Marincola, 1999a, p. 281 y ss.

${ }^{23}$ Cf. Marincola, 1999a, p. 302 y ss.

${ }^{24}$ Cf. Meister, 1992, p. 4, y Schrader, 1997, p. 87.
} 
implicada también la de Marincola: la primera característica, que enfrenta lo estático y lo dinámico, responde a la necesidad de incluir obras como la Periégesis de Hecateo o la Índica de Arriano, y las de Heródoto o Tucídides, y de dar cuenta a su vez de sus diferencias. Por su parte, la focalización responde a la oposición entre la historia universal y las narraciones de un Tucídides o un Heródoto, mientras que la limitación cronológica trata de dar cuenta de la oposición existente entre las genealogías y una obra como la Historia de la guerra del Peloponeso; la estructuración temporal se apoya, por su parte, en la necesidad de conjugar obras como las crónicas, las obras etnográficas, etc., en tanto que la última característica reside de nuevo en la necesidad de aunar etnografía, Zeitgeschichte, crónicas, etc. Todo ello da cuenta del movimiento circular que plantea la caracterización de Marincola, por cuanto sigue trabajando sobre ideas de Jacoby.

En lo que se refiere a la organización cronológica de los autores, Fowler mostró lo engañoso de ese esquema de evolución propuesto por Jacoby que, entre otras cosas, dejaba aislado a Heródoto respecto a sus contemporáneos, ${ }^{25}$ por la necesidad de dotar a su teoría de la evolución del género de una clara nitidez a lo largo de los tres pasos señalados antes. Así, afirma de manera sugerente: «rather than thinking of a step-by-step development, we would be wise to think in terms of a long and mutually beneficial exchange of work and ideas between Herodotos and his many contemporaries». ${ }^{26}$ Es esta una de las ideas más importantes a tener en cuenta en el futuro examen de las relaciones entre los diferentes autores, como después veremos.

Pero quizá aún más grave que plantear una evolución ideal del género es la inexplicable detención de esa evolución con Tucídides, como ya señaló Strasburger, ${ }^{27}$ a pesar de que, como decíamos, la historia del género prácticamente no se interrumpe hasta el fin de la Antigüedad. A pesar de ello, es este un defecto que se repite incluso en obras recientes y que se encuadra dentro de la tendencia a detener el estudio de la Antigüedad en el final de clasicismo.

\footnotetext{
${ }^{25}$ Cf. las reflexiones de Momigliano, 1984c, p. 139.

${ }^{26}$ Cf. Fowler, 1996, p. 69.

${ }^{27}$ Cf. Strasburger, 1977, p. 8 y ss. 
Con todo ello parece, pues, claramente superada la tendencia de análisis «progresista» de la historiografía antigua, pero aún queda por abordar una pregunta clave: ¿es la historiografía antigua un género literario, como apuntan los más recientes estudios?

Seguramente, la propia generación de Creuzer afirmaría que sí, aunque jamás admitiría un estudio literario profundo del género, dado que la idea de arte, de poesía, se asimila al empleo de unos mecanismos con fin último en la belleza o en el placer, pero no en la verdad; ${ }^{28}$ si los autores antiguos perseguían la belleza, no podrían ocuparse de la verdad, dado que los mecanismos empleados para la consecución de la primera habían de alejar al historiador de la verdad, idea que, por otra parte, no es ajena al mundo antiguo. $^{29}$

Fue esta idea la que prácticamente bloqueó el estudio profundo de la historiografía como género literario, hasta la aparición en 1974 del libro de Hayden White Metahistoria. El salto cuantitativo que supuso esta obra fue de dimensiones insospechadas, aunque en el fondo no dijera nada que de otra manera no se hubiera dicho ya.

Quizá lo más importante, y lo que más problemas causó, fue el establecimiento de una serie de tramas, concepto cercano al que propone Veyne, ${ }^{30}$ que determinan una estructura que puede ser tragedia o sátira, dando lugar a visiones historiográficas asimiladas al concepto del eterno retorno, o tramas de comedia o romance, propias de visiones de progreso. ${ }^{31}$

Obviamente, y como el propio autor reconoce, esta explicación literaria de la historiografía por medio de conceptos de crítica literaria modernos conlleva una consecuencia que resulta inaceptable para los historiadores, el hecho de que, como el propio Hayden White reconoce, es la ideología la que determina la forma de la obra, ${ }^{32}$ lo que supone viciar el posible objetivo de verdad, dado que el pensamiento del autor determina los moldes en los que se vierte la realidad, forzosamente dañada en ese ajuste.

\footnotetext{
${ }^{28}$ Así, e. g. Strasburger, 1966, p. 6.

${ }^{29}$ Recuérdese, sin ir más lejos y en un ambiente tradicional, la afirmación de Hesíodo

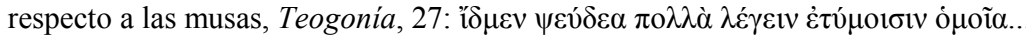

${ }^{30}$ Cf. Veyne, 1984, p. 34.

${ }^{31}$ Cf. White, 2001, p. 18 y ss.

${ }^{32}$ Cf. White, 2001, p. 36.
} 
La polémica fue amplia, pero un artículo del gran Arnaldo Momigliano publicado en 1981 es, a nuestro entender, el que mejor resume esta oposición a la obra de White. ${ }^{33}$ Se queja Momigliano de, precisamente, esa falta de la búsqueda de verdad como objetivo central de la historiografía, al tiempo que la reducción a los cuatro paradigmas propuestos por White parece escasa aun incluso para los historiadores del siglo XIX, a los cuales el autor aplicaba el esquema. $^{34}$ Momigliano, pese a lo tardío de la fecha, 1981, y como historiador de amplio recorrido, se movía en esquemas que bien se podrían aplicar a Mommsen o a cualquier otro historiador decimonónico, pues fundamenta su acercamiento a la historiografía en la confianza de que esta ha de buscar en la evidencia -de manera inexcusable- el camino a la verdad, y que es esta en último término la causa de que se escribiesen incluso en la Antigüedad obras que eliminaban de manera crítica historias anteriores, respecto a las cuales mejoraban el examen de esa evidencia. ${ }^{35}$

En lo que nos interesa, fue Anthony Woodman quien en 1988 adaptó, privado de todo el aparato de tramas de White, la perspectiva literaria o, como dice el propio Woodman, retórica, al ámbito grecolatino. ${ }^{36}$

Una de las claves de lo transgresor del estudio de Woodman es la separación clara y definida de la historiografía antigua de su paralelo moderno: la historiografía antigua es un género retórico y por ello es literatura. ${ }^{37}$ Esta afirmación, por muy novedosa que parezca, es tan antigua como los estudios de Schwartz sobre el proemio tucidídeo, ${ }^{38}$ y conlleva, a

\footnotetext{
${ }^{33}$ Cf. también Hornblower, 2011 b, p. 61 y ss.

${ }^{34}$ Cf. Momigliano, 1984a, p. 50 y ss.

${ }^{35}$ Cf. Momigliano 1984a, p. 51 y ss. No es este el lugar adecuado para examinar el idealismo de la afirmación de Momigliano acerca del discurrir de la historiografía en la Antigüedad. Basta con señalar que Momigliano parte de una noción de historia monolítica que se corresponde con una idea de verdad que permance necesariamente inmutable a lo largo de diez siglos de historia.

${ }^{36}$ Cf. Woodman, 1988, passim. Las indicaciones relativas a cada autor las recogemos en los análisis individuales.

${ }^{37}$ Cf. Woodman, 1988, p. 197.

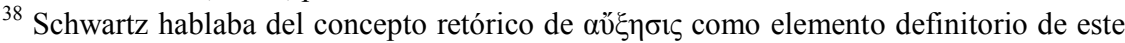
proemio, y ello no era razón para que el sabio alemán dudara de la naturaleza de la obra de Tucídides, una naturaleza literaria que defendió sin paliativos para el género. Schwartz, 1938a, p. 47; cf. recientemente Schwinge, 2008, p. 13. Un exceso claro de esta postura es la consideración por parte de Woodman 1988, p. 2, de Heródoto, VII 20, 2-21, 1, como un

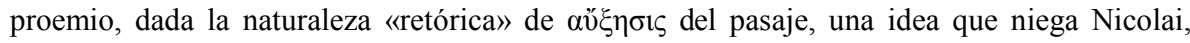
2001, p. 263. Ya Connor, 2009, p. 31, hablaba de la distancia no tan grande que separa las interpretaciones tradicionales del género y las innovadoras. Por lo demás, distinguir entre una
} 
nuestro entender, una dislocación no menor: ya Momigliano, en el trabajo que antes examinamos, alertaba del hecho de que es imposible hablar de retórica en la historiografía antigua antes de la época de Isócrates. ${ }^{39} \mathrm{La}$ realidad es que la retórica entendida como tal es un fenómeno, como veremos con más detalle, tardío, al menos posterior al nacimiento de la historiografía como género, ${ }^{40}$ por lo que, en nuestra opinión, difícilmente podría producirse una influencia de la retórica, en el sentido en el que habitualmente interpretamos este concepto, en la configuración del género historiográfico: se impone, pues, partir de la evidencia formal y no de una teoría apriorística.

A nuestro entender, uno de los artículos más interesantes en esta polémica que estamos reseñando sumariamente fue el publicado por el historiador Rhodes en $1994 .^{41}$ Esto es así por la interesante perspectiva empleada en el acercamiento a los historiadores, dado que Rhodes, aun reconociendo la existencia de literarios más o menos formalizados, no niega que estos puedan ser sometidos a juicio por el historiador, porque la literatura también puede aportar datos de interés histórico: ${ }^{42}$ simplemente, se trata de separar historia y verdad y literatura y mentira, ${ }^{43}$ y de este modo poder avanzar a un tiempo en el plano literario y reflexivo del género. ${ }^{44}$

naturaleza retórica, otra probatoria y otra indagadora, como propone Moralejo, 1981, p. 16 y ss., es algo realmente difícil de discernir por la semejanza de estos universos literarios.

${ }^{39}$ Cf. Momigliano, 1984a, p. 58.

${ }^{40}$ Cf. el análisis de esa etapa de retórica oral por parte de López Eire, 2008, p. 67 y ss. Obviamente, nos referimos a una retórica sancionada al modo de la existente en el siglo IV a. C., y no al concepto de retórica entendido como pautas de composición estilística y de relación entre público y autor, como la crítica viene defendiendo en tiempos recientes para este periodo, conforme a lo que dispone la etapa oral.

${ }^{41}$ Cf. Rhodes, 1994, p. 156 y ss., con un interesante resumen de algunos títulos que reservamos para tratar en el desarrollo del estudio.

${ }^{42}$ Cf. Rhodes, 1994, p. 157 y ss. Cf. también Dover, 2009, p. 47.

${ }^{43}$ Para no caer en exageraciones como la de Lendon, 2009, p. 43, negando el carácter literario del género en una crítica que ni el propio Mommsen se permitía, comprensible ante afirmaciones como las de Wiseman, 1979, p. 32, quien poco menos que considera inevitable para un historiador el mentir. Lo importante, como señala el propio Wiseman, 2011, p. 316, es que los historiadores siempre indican cuándo se alejan de la verdad, lo que garantiza un control sobre la información que se proporciona.

${ }^{44}$ Cf. Pelling, 2000, p. 1: «It [a literary text] may or may not be true, or have some relation to the truth; we do what we can to discover how true it is. But true, false, or something between, it is always a piece of rhetoric». 


\subsubsection{OBJETO DEL PRESENTE ESTUDIO. FORMA Y CONTENIDO EN EL ORIGEN DE LA HISTORIOGRAFÍA}

Los avances en el estudio de la historiografía antigua están entre los más prodigiosos de las últimas décadas en la disciplina filológica. Al tiempo que proporcionaron nuevas perspectivas y permitieron comprender de manera más profunda a los historiadores antiguos, abrieron no pocos interrogantes respecto a algunas verdades asumidas. Seguramente, el mayor problema sea el que afecta al origen y desarrollo del género historiográfico, cuya versión «canónica» dependía del modelo jacobiano y que necesariamente ha de ser considerado atendiendo a las nuevas reglas del juego.

Aspectos como la oralidad en el mundo griego, la complejidad del desarrollo literario del momento, así como el rico panorama intelectual de la época son puntos de partida obligados en cualquier acercamiento al origen y desarrollo de la historiografía.

Además, se impone tener presente una serie de consideraciones que, no por poco sabidas, suelen quedar orilladas. Por una parte, la historiografia es un género de aparición relativamente tardía en el mundo griego, al menos respecto a los géneros tradcionales, lo que nos obligará a definir la posición de la historiografía en este complejo universo. En segundo lugar, hemos de tener presente que hablar de historiografia como tal es algo ajeno al mundo antiguo hasta una época relativamente tardía - prácticamente, solo se podrá hacer cuando lleguemos al final del presente volumen-, lo que tiene como consecuencia clara la debilitación de las fronteras que separan los diferentes géneros literarios de la época. Con estas dos ideas presentes, habremos de abordar el análisis del origen del género, rindiendo cuentas ante un principio básico de la estética literaria, como es el de la vinculación entre fondo y forma. Esta unión entre lo que se dice y lo dicho, un leitmotiv del análisis literario de la gran filología, es seguramente la mejor solución a la división en los estudios sobre la historiografía entre lo literario y lo histórico: la riqueza formal del género es un elemento inseparable de los complejos desarrollos intelectuales de la época y de los respectivos autores. ${ }^{45}$ Esa imbricación de los dos aspectos establecerá un juego de tensiones que evitará

${ }^{45}$ No busque el lector un tratamiento de las «helénicas» en el presente trabajo: la tipología del análisis presentado hasta el momento habrá hecho patente que, a nuestro entender, esta suerte de «historiografía» pertenece a un subgrupo literario que no se corresponde exactamente con la historiografía tal y como fue cultivada por Heródoto o Tucídides. 
desatender la realidad doble del género, una realidad que ha de guiar nuestro estudio: la historiografía es un género literario de fuerte contenido reflexivo, porque, en definitiva, la ciencia también puede tener valor estético.

Esta última idea perfilará también un aspecto fundamental en nuestro estudio. La necesidad de respetar esa dualidad determinará cuál será el punto de atención de nuestro análisis. Los proemios son el punto fundamental del género historiográfico para definir su naturaleza literaria y a la vez reflexiva. La importancia del incipit en el desarrollo formal de la literatura oral, que, en definitiva, va a ser el contexto en el que tengamos que afrontar nuestro acercamiento a la aparición del género, tiene un valor paradigmático en la definición formal de la historiografía en sus primeros pasos. Además, la importancia meramente formal se combina con la fuerte carga reflexiva que presenta esa primera intervención del autor, lo que permitirá aplicar la tensión antes referida entre lo formal y lo reflexivo. Por lo tanto, nuestro análisis se centrará en los proemios conservados de los historiadores griegos, atendiendo a su valor intrínseco y a la importancia que adquieren en el diseño del conjunto de las obras.

Las tendencias recientes de investigación de la historiografía han propiciado el aumento exponencial de los estudios sobre los diferentes proemios, y han deparado también la aparición de obras que, a pesar de no tener el proemio como objetivo fundamental, han supuesto un apoyo fundamental para su mejor conocimiento. ${ }^{46}$

En el plano meramente intelectual de análisis de los proemios, y dentro de la tendencia de reformulación de los planteamientos de Jacoby realizados por Fornara, Marincola abordó en su tesis el análisis de las intervenciones autobiográficas de los historiadores en sus obras. Ello se hacía desde una perspectiva decididamente vinculada a la historia contemporánea y al análisis de la autopsia en las obras, ${ }^{47}$ lo que nos lleva a los planteamientos antes referidos en relación con la teoría de Fornara. Obviamente, muchos de estos planteamientos se verifican en pasajes proemiales, lo que aportó cierta sistematización a los mismos, dejando de lado la simple clasificación por tópicos.

\footnotetext{
${ }^{46}$ Cf., en términos generales, la introducción de Hornblower, 2004b, p. 1 y ss., que, si bien persigue unificar los estudios particulares que precede, presenta un examen de urgencia del género en Grecia hasta época imperial.

${ }^{47}$ Que ocupa aproximadamente un tercio de la obra, Marincola, 1985, pp. 8-59.
} 
En esta misma línea, pero con mayor ambición, el propio Marincola abordó en su Authority and Tradition in Ancient Historiography una profundización en esa teoría, con una mayor sistematicidad y un corpus más amplio, que en teoría admite todos los autores desde Heródoto a Amiano Marcelino. ${ }^{48}$ Lo importante de esta obra, en lo que nos ocupa, es su análisis de los famosos tópicos historiográficos sine ira atque studio, $\mathrm{y}$ su consideración como algo serio que no nos lastra con la habitual soberbia de la crítica moderna respecto a los historiadores retóricos. ${ }^{49}$

Fundamental por lo riguroso y en cierta manera conciliador de su discurso es el trabajo de Nicolai sobre la posición del género en la escuela y su relación con la retórica. De este modo, tuvimos que esperar hasta el año 1992 para asumir que el género historiográfico se movía en lo relativo a sus planteamientos teóricos en un limbo que, por una parte, dificultaba en demasía la determinación de algo semejante a una teoría de la historiografía ${ }^{50}$-que siempre se mueve entre fantasmas como Teofrasto y su

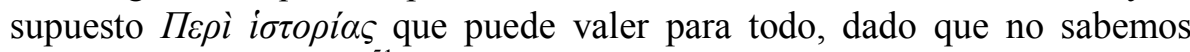
nada de dicha obra-, ${ }^{51}$ y que, por otra parte, nos llevaba al simple reconocimiento de la falta de esa teoría por los antiguos. ${ }^{52}$

Lo fundamental en lo que a nosotros interesa es la constatación de que los escasos planteamientos teórico-estilísticos conocidos se refieren de

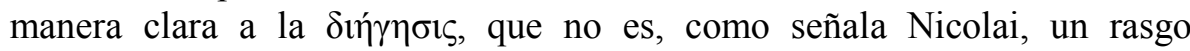
exclusivamente historiográfico, y por ello está abierto a muy diferentes géneros, de los que se toma la caracterización estilística. ${ }^{53}$ Todo ello nos permite confirmar algunos de los rasgos observados en el examen formal de los proemios, y desembarazarnos de la siempre incómoda e ineficaz teoría

\footnotetext{
${ }^{48}$ Marincola, 1999b, p. 1.

${ }^{49}$ Cf. Marincola, 1999b, p. 2 y ss.

${ }^{50}$ Siempre tardía, como señala Nicolai, 1992, p. 49, y de muy difícil aplicación a las obras. Sobre este aspecto, cf. los breves apuntes de Strasburger, 1966, p. 10 y ss.

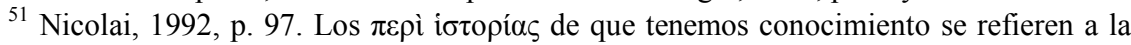
acepción de investigación del término iotopía, cf. Jacoby, 184 F 2; 150 F 1; y Cecilio de Caleacte, F 2. De manera más optimista al respecto se mostraba Walbank, 1960, p. 219, que, sin embargo, se hacía eco de la opinión de Avenarius, 1956, p. 170, quien señalaba la inexistencia de esta tratadística sobre la historiografía antigua.

${ }^{52}$ Nicolai, 1992, p. 96.

${ }^{53}$ Dentro, claro está, de una visión de la historiografía muy particular en las escuelas, cf. Marincola, 2009, p. 14. 
historiográfica, ${ }^{54}$ que para no ser una realidad ha causado no pocos problemas en el estudio del género. ${ }^{55}$

\subsubsection{PENSAMIENTO, FORMA Y CONTEXTO: CONDICIONANTES DE LA APARICIÓN DEL GÉNERO HISTORIOGRÁFICO}

Las propuestas más recientes de acercamiento a la historiografía no han hecho otra cosa salvo acentuar la verdad asumida pero no aplicada en todas sus consecuencias de su carácter literario. Ello conlleva, como es natural, una reinterpretación de las constantes bajo las que apareció el género historiográfico en Grecia que, a pesar de haber sido intuida, no ha sido sistematizada.

Pero la naturaleza literaria de la historiografía griega no ha de ser excusa para no abordar los aspectos de pensamiento como una realidad en extremo dependiente de la configuración formal. En definitiva, estamos ante dos realidades fuertemente dependientes que se condicionan de manera recíproca, no tanto por aspectos meramente fisiológicos como de orden meramente literario. No es la aparición de la prosa la que facilita la concreción de un pensamiento sumamente intelectualizado, ni tampoco el desarrollo de mecanismos más o menos depurados de expresión, sino la ordenación misma de los géneros literarios de la Grecia arcaica y clásica. La literatura ha de ser necesariamente entendida en el arcaísmo griego como una emanación social no solo en el sentido habitualmente dado a esta idea en lo que se refiere a la creación literaria, sino en un sentido mucho más amplio y como consecuencia de la naturaleza oral de la literatura griega de este periodo.

La función social de la literatura se acentúa por su condición de garante de todo un entramado social que deposita en ella un sinnúmero de principios

54 Como ya señalaba Walbank, 1960, p. 220, el centrarse en la teoría era contraproducente para entender el fenómeno de la historiografía trágica.

${ }_{55}^{55}$ Modélico nos parece el que, a nuestro entender, es el mejor estudio de conjunto sobre la rétórica y la historiografía, debido a López Eire, 2008, quien distingue tres grandes etapas, la de la retórica oral, p. 67 y ss.; la de la retórica de Hermes, p. 80 y ss., asimilada a la retórica helenística de escuela, y la retórica clasicista, p. 105 y ss., sustentada en la imitación de los grandes autores, todo ello aunando aspectos formales, funcionales y conceptuales de manera magistral. En lo que se refiere a los escasos pasajes teóricos, los abordaremos de modo polémico en el análisis de los diferentes autores. 
e ideas de especial importancia para la sociedad, entendidas en parte bajo la expresión de enciclopedia tradicional. ${ }^{56}$ No se trata de una negación clara de la existencia de una realidad y un pensamiento paralelo a ese mundo de la enciclopedia tradicional, como en caso de la moral agonal tampoco se trataba de negar la existencia de un mundo interior más o menos desarrollado en los héroes homéricos, sino de la fuerte sistematicidad que presenta ese modelo. Ese encaje preciso de los diferentes elementos tiene como consecuencia fundamental la poca permeabilidad de los espacios de representación de los distintos géneros a innovaciones drásticas $\mathrm{y}$, sobre todo, la imposibilidad de una expresión personal decidida en ambientes en los que lo subjetivo tiene poca o ninguna cabida.

Creaciones literarias como la epopeya o la lírica de grandes escenarios presentan un compromiso con la sociedad ineludible, materializado en su función de transmisores de esos valores e informaciones de raigambre social. Este compromiso lleva aparejado naturalmente una limitación en el desarrollo de innovaciones intelectuales de carácter individual que tienen su ejemplo palmario en la famosa palinodia de Estesícoro:

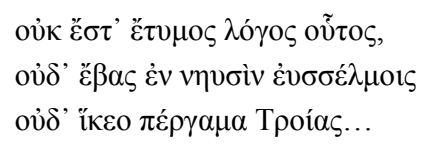

La transmisión del texto en un contexto platónico nos sumerge de lleno en un mundo que, dejando atrás posibles complicaciones ${ }^{57}$ rezuma sabor platónico, tanto por el tema -de una altura literaria propia de Platón- como por inscribirse dentro de la defensa del mundo literario tradicional realizada por Platón. ${ }^{58}$ Sobre la genialidad de Estesícoro poco o nada nuevo puede decirse, pero lo importante es valorar la oposición que Platón nos crea entre la figuras de Sócrates y Lisias, por una parte, y las de Homero y Estesícoro y

\footnotetext{
${ }^{56}$ Cf. Gentili, 1996, p. 20.

${ }^{57}$ Para la doble palinodia, que en último término no afecta a nuestro razonamiento, baste tener presente Woodbury, 1967, p. 161, que rechaza la doble redacción a partir de lo poco fiable de la fuente, y la razonada defensa de la misma en Gentili, 1996, p. 275, nota 27. Cf. además, Astin, 2008, p. 102, nota 23, para un examen reciente de una cuestión de difícil resolución.

${ }^{58}$ Cf. Platón, Fedro, 277e5 y ss. Cf. Astin, 2008, p. 103, para la importancia, casi en clave religiosa, del momento en el diálogo platónico. 
su palinodia, por otra parte. Si aceptamos esta equiparación, el universo tradicional que se esconde detrás de la escena gana claridad: el valor arquetípico de la palinodia, de la purificación ante una ofensa a la divinidad, tiene un sentido claro como una limitación de esas posibles innovaciones poéticas en un ámbito tradicional. ${ }^{59}$ Homero, nos dice Platón, no incurrió en tal error, lo que, a nuestro entender, debe ser entendido dentro de esa unidad propia de la literatura tradicional, que en el caso de Estesícoro se rompió a ojos de generaciones posteriores de manera algo pueril, ${ }^{60}$ pero con implicaciones no menores en un momento de funcionamiento casi agónico de este mundo literario. Nos movemos en un escenario en el que lo irónico y lo real conviven por igual, por lo que tampoco ha de llevarse a extremos la interpretación de este pasaje, si bien es sintomático de la existencia de las tensiones que desempeñarán un papel fundamental en el desarrollo de las condiciones en que aparecerá la historiografía.

En definitiva, la interacción entre esos escenarios tradicionales y la reflexión no vinculada a ellos es una de esas tensiones habituales en el mundo griego que, a pesar de suponer en apariencia un trastorno para el desarrollo de la literatura griega y en concreto de la socialización de esas corrientes no canónicas, tiene la ventaja de establecer un diálogo muy interesante entre uno y otro ámbito, y que se manifiesta en cierta manera con más claridad en el ocasiones confuso Eurípides.

Pero, seguramente, lo más productivo de esta exploración sea tener en cuenta los posibles paralelos que un autor no muy lejano en el tiempo ${ }^{61}$ presenta con Hecateo. La excelente interpretación de López Eire del universo cultural de Estesícoro es la mejor prueba de eso que precisamente el maestro salmantino denominaba decadencia: la reorientación de la narrativa y el espíritu épico hacia lo detallista y concreto, rozando en ocasiones lo absurdo, tiene mucho que ver con la pérdida progresiva del

${ }^{59}$ Lo que encajaría bien con la idea de Woodbury, 1967, p. 172 y ss., de interpretar la famosa ceguera de Estesícoro con un tópico literario ligado a su falta de inspiración, lo que nos llevaría a la progresiva degradación de esos maestros tradicionales. Sobre esta idea de la inspiración cf. Gentili, 1996, p. 30.

${ }^{60}$ Quizá ese sea el origen de lo confuso de la tradición en generaciones posteriores, poco capaces, ya en un contexto no tradicional, para aislar lo que eran simples variantes de una versión y cambios excesivamente profundos de una narrativa.

${ }^{61} \mathrm{La}$ cronología de Estesícoro no deja de presentar problemas a pesar de tener conservados años exactos en la Suda. La propuesta de López Eire, 1974, p. 56, supone ampliar demasiado el arco cronológico, en tanto que la de West, 1971, p. 306, de ubicarlo en el siglo VI a. C. tiene el beneficio de precisar más el espacio cronológico. 
sentimiento heroico de estos textos. ${ }^{62}$ Pero más que de decadencia, hemos de hablar de evolución, de una de esas interferencias entre uno y otro escenario, y de ahí la palinodia, ${ }^{63}$ que entre burlas y veras permite ver las tensiones literarias.

Los rasgos racionalistas de Hecateo tienen su precedente en este universo que podemos intuir en las ruinas de la obra de Estesícoro y que seguramente por ubicarse en la obra de un poeta nadie interpretaría en tal sentido. El considerar que Helena no marchó a Troya tiene, a ojos de un moderno, tanto de pueril o de inocente como lo son en último término los fragmentos de Hecateo F 19 o F 27a, pero la diferencia -y esto es lo importante- se localiza en el género, en el escenario en el que se verifica esa ruptura del mito y de su uniformidad. Es necesario iniciar una palinodia

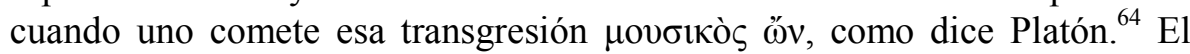
problema es una cuestión que transciende lo literario y afecta a la evolución social, ideológica y cultural del mundo griego del momento. La prehistoria de la historiografía griega nacerá precisamente en este escenario de tensiones literarias y culturales solo comprensibles asumiendo que la idea de una progresión ascendente del racionalismo ha de dejar paso necesariamente a un escenario de cambio, duda y experimentación a nivel literario que favorecerá la aparición de nuevos tiempos forzosamente deudores de la tradición que los precede.

Estamos ante un proceso de gran duración, cuya prehistoria se sumerge en estadios de la literatura de gran complejidad, pero cuyo resultado final podremos ver en Heródoto. Ello hace que un autor como Hecateo sea un precedente, uno de los condicionantes que forman parte del complejo escenario en el que se desarrollará la historiografía. Solo cuando las tensiones cedan ante los nuevos modelos de literatura podremos observar con nitidez el fruto de esas tensiones que terminaron por perfilar el género y dotarlo de esa naturaleza característica que admitimos como propia de la historiografía.

\footnotetext{
${ }^{62}$ López Eire, 1974, p. 39.

${ }^{63}$ Pensar en una dramatización de la escena, como ingeniosamente proponía Sider, 1989,

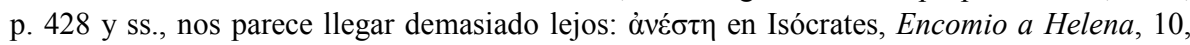
64, es seguramente un pasaje de interpretación más que dudosa.

${ }^{64}$ Respecto a la idea de que la palinoida o palinodias se debieran al propósito de agradar al público o a los patronos, como propone Gentili, 1996, p. 274 y ss., puede apoyarse en el rechazo por parte del público de versiones no precisamente «canónicas», entendido siempre este término con la mayor de las prudencias.
} 


\section{LA PREHISTORIA DE LA HISTORIOGRAFÍA GRIEGA}

El comenzar este estudio con la figura de Hecateo es algo que de por sí necesita justificación. Y ello es así porque la crítica, en uno de esos vaivenes habituales en la interpretación de los antiguos, devolvió el valor perdido al testimonio de la Suda que pone en tela de juicio la afirmación de Cicerón ${ }^{65}$ acerca de la atribución de la paternidad de la historiografía a Heródoto. La construcción de una teoría que hunde sus cimientos en el Romanticismo y Creuzer, y que evolucionó a un modelo positivista, fue sancionada con la efectista inclusión de Hecateo en las colecciones de fragmentos, abriendo la monumental obra de Jacoby con el número uno.

Si asumimos la historiografía como una realidad literaria, el análisis de las cuestiones formales ha de ser paso obligado en el estudio de Hecateo, principalmente para valorar esa naturaleza, cada vez más ambigua, del de Mileto. La ubicación literaria de Hecateo es algo que necesariamente ha de explicarse en un contexto realmente complejo que nos sumerge en una tradición que por momentos se aleja de lo que podríamos considerar como la ortodoxia historiográfica. Es, seguramente, poco provechoso preguntarse por la clasificación genérica de las obras de un autor que, lamentablemente, conocemos menos de lo que sería recomendable, y ello hace que el universo a analizar sea realmente amplio, pero muy esclarecedor de la posición de Hecateo en la historia literaria y cultural de la Grecia del momento.

\subsection{Los primitivos proemios en prosa: tendencias y relación autor-público}

La particular situación de la literatura griega en prosa en época clásica -entendida en el modo más laxo y amplio posible- hace que el proemio sea

\footnotetext{
${ }^{65}$ Cicerón, Sobre las leyes, I 5.
} 
una atalaya excepcional para asomarse a la realidad del contexto y de las intenciones de la misma. La deriva que el perfilado de esta estructura inicial tiene en aspectos meramente compositivos y de definición de la relación entre público y autor explica que sea especialmente interesante abordarlo a fin de clarificar las consecuencias que tiene para la definición de la realidad literaria que pudiese presentar la obra de Hecateo. Para la valoración de este fragmento, tenido por crucial en el estudio de la aparición de la historiografía antigua, parece necesario devolverlo a la posición que ocupaba en el tablero de la literatura griega desde el pedestal que la crítica le concedió como primer historiador: a nuestro entender, existe un mundo literario y cultural en el que se inserta la obra de Hecateo en una igualdad de condiciones con el resto de los autores que lo componen que en ocasiones se olvida -y este es, seguramente, el mayor problema-, principalmente por la tendencia a aislar a los diferentes autores bajo criterios clasificatorios propios del universo literario moderno, pero ajenos a los planteamientos de la sociedad y la cultura de la época.

Teniendo en cuenta esta necesaria vuelta de Hecateo al mundo literario de la prosa del momento, se abre la posibilidad de ganar perspectiva por medio de un estudio comparado de los fragmentos de igual naturaleza. Fowler elevó a diez ${ }^{66}$ el número de proemios en prosa conservados pertenecientes a los siglos VI-V a. C., y si bien la elevada cifra nos debería facilitar la labor, las complicaciones son importantes. Además, a este número se han de sumar los cinco tratados hipocráticos más antiguos. ${ }^{67}$ Respecto a los primeros, se trata en la mayoría de textos de autores presocráticos cuya prosa se presenta con una caracterización muy compleja, en la que el estilo sentencioso y poético es fuerte, y no se puede incluso saber a ciencia cierta si son los comienzos mismos de las obras. Y es que Diels, en su edición, defendió la corrección generalizada de los textos, añadiendo a los

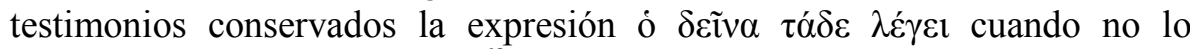
hallaba en el texto transmitido. ${ }^{68}$

El primero de esos proemios, el fragmento DK 22 B 1 de Heráclito dice lo siguiente:

\footnotetext{
${ }^{66}$ Cf. Fowler, 1996, p. 69, nota 60.

${ }^{67} \mathrm{Cf}$. infra, para un estudio detenido.

${ }^{68}$ En el caso de Demócrito, cf. infra. 


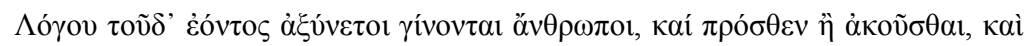

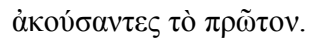

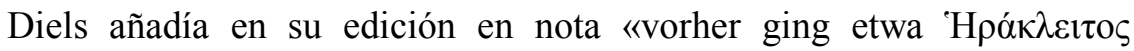

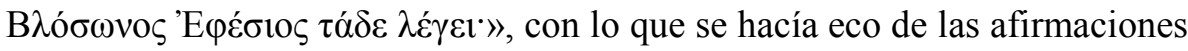
de Wilamowitz, quien, al analizar la existencia de títulos para las tragedias de Eurípides, daba por sentada la idea de que esta estructura de frase respondería a algo semejante a un título, idea que, por otra parte, ya expresara el propio Diels antes con ciertas dudas, ${ }^{69}$ y que finalmente recogió y sancionó Pohlenz, aplicada ya a Heródoto. ${ }^{70}$ Posteriormente, en su fundamental estudio sobre la forma de la obra literaria antigua, van Gronningen apoyó esta reconstrucción del inicio de dichas obras sin mayores problemas que la presencia, en este caso, del patronímico. ${ }^{71}$ A ciencia cierta, es complejo determinar si eso era así, pero, si recurrimos a Sexto Empírico, el autor que nos transmite el fragmento, a nuestro entender, sería imposible que la obra hubiera incluido la frase introductoria, ya que sería redundante con la propia narración del autor, ${ }^{72}$ lo que perfectamente podría justificar su falta en el texto. ${ }^{73}$ Ello de entrada nos da un sentido claro para esta sección introductoria, dependiente de la contextualización del texto en el escenario de su lectura, casi de un modo semejante a lo que ocurre con la fórmula empleada por el propio Sexto Empírico.

El siguiente proemio es el de Alcmeón de Crotona, y algo parecido se nos muestra en el desajuste entre la fórmula inicial y la que la sucede,

${ }^{69}$ Wilamowitz, 1959, p. 125, nota 4; Diels, 1887, p. 436.

${ }^{70}$ Cf. Pohlenz, 1961, p. 2.

${ }^{71}$ Cf. van Groningen, 1958 , p. 224 , nota 5. Las dudas se plantean, en primer lugar, por la aparición del nombre del padre en lugar de la habitual referencia al lugar de origen, de especial importancia en los proemios, según veremos. Además, hay dudas respecto al patronímico en sí, dado que testimonios papiráceos parecen indicar una lectura diferente quizá debida a un defecto del material del soporte.

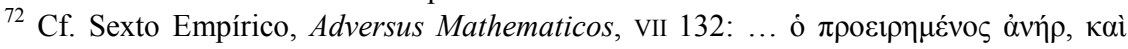

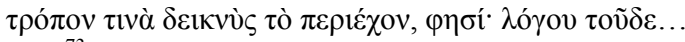

${ }^{73}$ Recientemente, Brunt, 1991, p. 337, ha señalado la fuerte distorsión que puede presentar un fragmento al ser incluido en el texto seguido del autor que nos lo transmite, dado que puede desde realizar cortes arbitrarios hasta, sencillamente, parafrasearlo, cosa que apoyaría lo que tratamos de decir. 
retrasándose todavía más el comienzo de la obra en sí, marcada con el habitual $\pi \varepsilon \rho i ̀ . . .:^{74}$

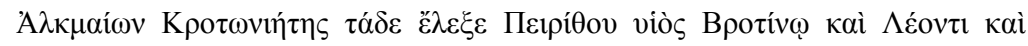

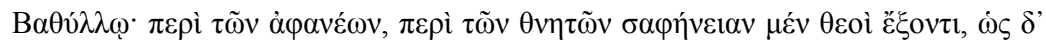

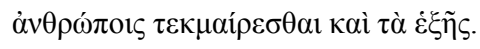

Siguiendo el orden cronológico, Filolao sigue la exposición: ${ }^{75}$

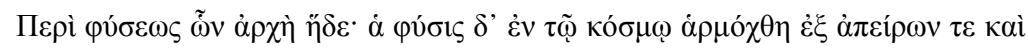

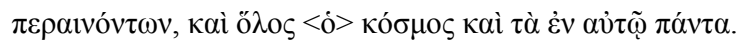

En este caso, el desajuste de Diels va aún más allá, dado que el texto está incompleto: falta el antecedente del $\tilde{\omega} v$, que está referido a $\beta \imath \beta \lambda i ́ \alpha$, y todo ello pertenece al texto de Diógenes Laercio, ${ }^{76}$ que dice exactamente:

Toṽ

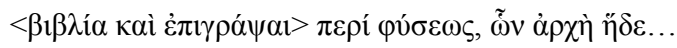

El propio Diels lo reconocía así en nota, pero es interesante observar que en este caso no se hace sugerencia alguna sobre la incorporación de la expresión en cuestión, aun a pesar de que la introducción que Diels coloca

74 Alcmeón de Crotona, DK 24 B 1: «Alcmeón de Crotona, hijo de Pirito, dice lo siguiente a Brotino, a León y a Bacilo: acerca de lo invisible, de lo mortal, gozan los dioses de seguridad, pero a los hombres solo queda el reconocer la sucesión de los hechos». Muy controvertida es la datación de Alcmeón, pero todo parece apuntar a que su nacimiento se sitúa en torno al 500 a. C. Cf. Guthrie, 1984, p. 338.

${ }^{75}$ Filolao, DK 44 B 1: «Sobre la naturaleza, de cuyos [libros] éste es el comienzo: la naturaleza existente en el cosmos se conformó a partir de lo ilimitado y lo limitado, también el cosmos y todo lo que hay en él».

${ }^{76} \mathrm{Cf}$. Diógenes Laercio, VIII 85. 
en el fragmento pertenece al texto de Diógenes Laercio, cosa que también ocurre en el fragmento del proemio de Diógenes de Apolonia: ${ }^{77}$

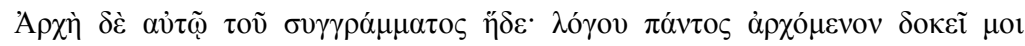

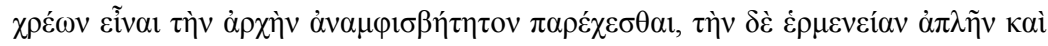
$\sigma \varepsilon \mu \nu \eta \dot{v}$.

El siguente proemio pertenece al Triagmos de Ion de Quíos, y dice: ${ }^{78}$

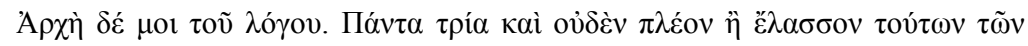
$\tau \rho เ \tilde{\omega} v$.

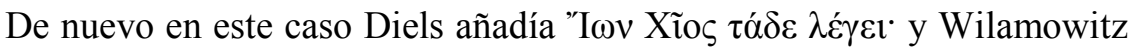
no tenía ningún problema en admitir la oposición casi redundante entre el texto conservado y el añadido, ${ }^{79}$ dado que además permitía justificar el $\delta \dot{\varepsilon}$, propuesta a la que se sumó van Groningen, ${ }^{80}$ apoyado en el caso de Heráclito. A nuestro entender, es difícil justificar esta inclusión, por cuanto en este caso la redundancia es con el propio texto, y el $\delta \dot{\varepsilon}$ parece poco convincente con un significado de contraposición o adición entre los dos periodos. ${ }^{81}$ Por ello, creemos que no es necesario colocar la fórmula de introducción en el caso de Ion, y en lo relativo al $\delta \varepsilon \dot{\varepsilon}$, parece más sencillo considerarlo simplemente como inceptivo, dados sus valores conversacionales, ${ }^{82}$ e incluso polémicos, habida cuenta de la naturaleza de

${ }^{77}$ Diógenes de Apolonia, DK 64 B 1: «El comienzo de su obra es el siguiente: Tengo la impresión de que es necesario que, cuando uno comienza desde el principio su obra, proporcione un comienzo libre de ambigüedades, y una forma de expresión simple y elevada».

${ }^{78}$ Ion de Quíos, DK 36 B 1: «Este es el comienzo de mi obra: Todo es tres y nada más ni nada menos que esos tres».

${ }^{79}$ Wilamowitz, 1959, p. 125, nota 4.

${ }^{80}$ Cf. van Groningen, 1958 , p. 224 y nota 6.

${ }^{81}$ Porciani, 1997, p. 49, admite sin problemas la reconstrucción; cf. también Jacoby, 1949, p. 301, nota 36; la traducción que propone Diels es al menos rara: «Ion von Chios spricht folgendes. Anfang aber meines Wortes ist: ».

${ }^{82}$ Denninston, 1960, p. 172 y ss. Nótese además que el carácter exhortativo de la expresión recuerda mucho al proemio épico y a los textos de naturaleza épica, cf. infra. Ion de 
estos escritos. ${ }^{83}$ El último aspecto es además crucial para entender mucho de la contextualización de estos textos y por ello de su naturaleza literaria.

El último proemio conservado pertenece a Critias, el tío de Platón, y presenta una tendencia plenamente lírica: ${ }^{84}$

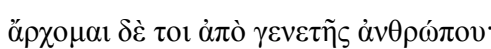

El propio Diels alertaba sobre el parecido de este proemio con el de $L a$ república de los lacedemonios. ${ }^{85} \mathrm{El}$ texto gemelo de esta obra, La república de los atenienses, algo anterior, nos permite observar otro tipo de proemio característico de obras de tinte sofístico. El proemio de la obra pseudojenofontea se abre con $\pi \varepsilon \rho \grave{~} \delta \dot{\varepsilon} \tau \tilde{\eta} \varsigma$ 'A $\theta \eta v \alpha i ́ \omega v \pi \mathrm{o} \lambda \iota \tau \varepsilon i ́ \alpha \varsigma$, es decir, con una formulación muy característica de las obras de naturaleza polémica, macrogénero que da cabida desde discursos a obras de tinte científico, y presenta además un elemento $\delta \varepsilon ́$ como los vistos hasta ahora. En este caso, van Groningen apunta $^{86}$ a un hecho que puede arrojar luz a nuestro razonamiento, con una propuesta que asume que el elemento fue agregado al realizarse la edición reunida de los tratados menores de Jenofonte y las obras dudosas. Más allá de las cuestiones de transmisión textual, basta que pensemos en un texto continuo en mayúsculas para darnos cuenta de la necesidad de un $\delta \dot{\varepsilon}$ que marque el inicio de una obra. De este modo, parece interesante tener presente de nuevo, como hicimos al hablar de Sexto Empírico, la dislocación que supone la inclusión de una obra en que aún se rastrean rasgos orales en un contexto escrito, si bien no ha de desecharse la idea de que se trate de un elemento apodíctico de carácter polémico, propuesta que, como veremos, tiene una funcionalidad clara en el contexto en el que se desarrollan estas obras: más allá de realidades ecdóticas, la aparición de este elemento puede tener una explicación cabal dentro de la propia realidad literaria del texto, que nos permita además comprender todo

Quíos era además un autor de cuño poético, lo que nos proporciona un contexto adecuado para pensar en posibles transferencias como las que más arriba sugerimos.

${ }^{83}$ Cf. Caballero López, 1997, p. 108 y ss., con un examen de las diferentes posturas, con la posibilidad de considerarlos nexos introducidos al transcribir de forma seguida toda la producción, en este caso de Jenofonte, concluyendo el autor que es un rasgo de herencia preliteraria, aunque esto no explica realmente su origen, simplemente desplaza el problema lejos del campo de trabajo del autor.

${ }^{84}$ Critias, DK 88 B 32: «Comienzo, pues, por la creación del ser humano».

${ }^{85}$ Cf. Diels, DK 88 B 32 ad loc.

${ }^{86}$ Cf. van Groningen, 1958, p. 236, nota 1. 
el formulario inicial de las obras que nos han venido ocupando y que una imagen tan poco clara arrojan.

Fowler no recogía el comienzo de las obras de Protágoras, seguramente por no constituir proemios como tales, pero uno de $\operatorname{ellos}^{87}$ nos permite

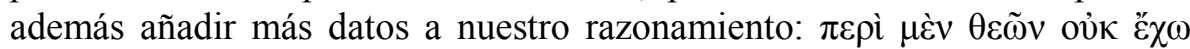
$\varepsilon i \delta \delta \varepsilon ́ v \alpha \iota \kappa \tau \lambda .{ }^{88}$ De nuevo, junto a una forma que tradicionalmente caracteriza los comienzos de varias obras del periodo, sin que podamos hablar de proemio -van Groningen habla de nuevo de título- $-{ }^{89}$ tenemos el empleo de una partícula sin clara funcionalidad, pero, en este caso, el citado autor se decanta por seguir a Denninston ${ }^{90}$ y admitir valores no conectivos para estos elementos, evidenciando una falta de sistematicidad en los razonamientos que, más que ausencia de rigor filológico, muestra la complejidad de una situación literaria orillada ante la aplastante profundidad intelectual de unos textos que requerían atenciones de otro tipo, y no meramente estilísticas.

El análisis general de estos proemios nos permite establecer como seguro el hecho de que el empleo de la partícula $\delta \varepsilon ́$ apodíctica era algo usual y, a nuestro entender, responde a la naturaleza polémica de esas obras: el contenido favorece claramente dicho valor, diseñando una red casi «agonal» de obras que se enfrentan entre sí con ideas contrapuestas, que tienen un muy pálido reflejo en el universo de los placita philosophorum y que evidencian un mundo en cierta manera perdido para nosotros pero de una riqueza excepcional, en el que las diferentes propuestas, fuera con una oposición abierta a un autor determinado o -las más de las veces- a un planteamiento, eran asumidas de modo polémico e individual. De este modo, las diferentes propuestas planteadas en cada una de las obras serían piezas de un enorme rompecabezas cultural y filosófico tejido por medio de estos escritos.

Al tiempo, y corrigiendo los excesos de Diels, podemos distinguir dos tipos de proemios, los encabezados por la fórmula ó $\delta \varepsilon \tau i v \alpha ~ \tau \alpha ́ \delta \varepsilon ~ \lambda \varepsilon ́ \gamma \varepsilon 1$ y los que presentan una formulación más poética, si se quiere, con una exhortación -incluso con un verbo- que recuerda a la formulación propia de la retórica oral, lo que nos permite afirmar que estamos ante dos

87 Además conservamos el comienzo del $A \lambda \eta ́ \theta \varepsilon 1 \alpha$, DK 80 B 1, con una forma que recuerda a lo que tradicionalmente se llama estilo gnómico.

${ }^{88}$ Protágoras, DK 80 B 4.

${ }^{89}$ Cf. van Groningen, 1958, p. 235, nota 1.

${ }^{88}$ Cf. ibidem; Denninston, 1960, pp. 359 y 371. 
formulaciones distintas desde sus orígenes y sus planteamientos: una, la segunda, heredera de la retórica oral, por cuanto el exordio implica un contexto y una acción por parte del poeta, y otra, la primera, desligada de ese ámbito tradicional y asimilada al universo polémico antes referido.

Todo ello, sin embargo, da cuenta de un uso propio de la prosa escrita que es interesante por cuanto prefigurará la configuración del proemio historiográfico desde un punto de vista meramente literario. A este respecto, defendía Wilamowitz que fueron las obras de los trágicos los primeros libros en conocerse en la época, pero la muy avanzada investigación sobre la transmisión textual y el libro en la Antigüedad nos han demostrado que no es así. Turner probó que las primeras obras en difundirse de esta manera fueron las de los autores técnicos, precisamente aquellos de los que conservamos estos proemios, ${ }^{91}$ porque realmente era imposible que sus obras pudiesen sobrevivir como meros apuntes de circulación restringida, como señalaba Wilamowitz. Ante esta situación, el escenario en el que circularían estas obras desde un plano meramente literario parece claro, máxime si tenemos presente el funcionamiento que tenían las obras con un escenario oral claramente definido. La plasticidad que presenta cualquier obra oral es una realidad harto lejana de la que ofrecen este tipo de obras. Los proemios desempeñan por ello una función determinante en el establecimiento de la relación entre público y autor y requieren, por dar precisamente inicio a la composición - entendida esta como un todo- $-{ }^{92}$ unos principios compositivos

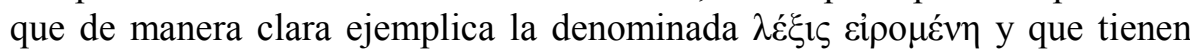
una importancia fundamental para la articulación de la primitiva prosa oral. Todo ello nos llevará a definir mejor el escenario literario en el que se ubica Hecateo.

\subsection{De lo oral a lo escrito: la teoría de los proemios epistolares}

Habida cuenta de que se trata de proemios escritos, hemos de preguntarnos por las circunstancias que determinan su formación. Haberle ${ }^{93}$ indicó que el proemio de Hecateo y su configuración formal recordaban a los

\footnotetext{
${ }^{91}$ Cf. Turner, 1995, p. 38 y ss.

${ }^{92}$ Lo que no implica, como señala recientemente West, 2011, p. v, que las obras orales, tal y como las conocemos, deban ser compuestas de principio a fin.

${ }^{93}$ Cf. Haberle, 1938, p. 84 con nota 1. Cf. además Sancisi Weerdenburg, 1999, p. 107 y ss.; Stein, 1962, II, p. 47. 
textos de la cancillería oriental. Pero fue Fehling quien desarrolló de manera completa la ligazón de estas estructuras con paralelos orientales, de forma, a nuestro entender, errónea. La ausencia en la poesía griega de paralelos que sustenten este tipo de estructura, es decir, la ausencia del yo y del pronombre demostrativo, es la clave, a juicio de este autor, para sustentar dicha afirmación. ${ }^{94}$ Por ello, Fehling trata de buscar, como indicara Haberle, los orígenes de este esquema en la literatura oriental, tanto en las inscripciones persas, que trata de pasada, ${ }^{95}$ como en la literatura judaica, cuya influencia se ve apoyada, de manera insostenible, creemos, en las relaciones con el ámbito fenicio que dieron lugar a la adquisición del alfabeto, concluyendo que «Die Prosaiker haben die Form direkt aus dem Orient. Sie ist nicht aus älterer griechischer Dichtung abzuleiten». ${ }^{96}$ Todo ello parte de un apriorismo de difícil defensa, como es el pensar que Grecia no tuvo una prosa primitiva o tradicional: cosa diferente es que la conservemos como tal. El propio Fehling da cuenta de que esta formulación aparece en ocasiones en el material epigráfico griego. ${ }^{97}$ Creemos que no es necesario pensar en préstamos, sino en simples paralelos antropológicos explicados por razones de naturaleza humana, según veremos.

Siguió y amplió esta línea de estudio Porciani, quien recogiendo toda la tradición oriental desde Sargón de $\mathrm{Akad}^{98}$ trató de demostrar la procedencia de estas fórmulas de la epistolografía oriental, apoyado además en la idea de que la obra de Hecateo surgió como oposición a la historiografía persa. ${ }^{99}$

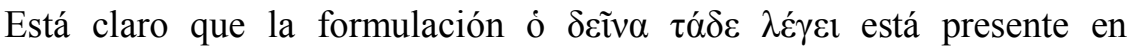
inscripciones antiguas de los aqueménidas, como demuestra el caso de la inscripción de Behistun, ${ }^{100}$ en la que esta fórmula se repite de manera

${ }^{94}$ Cf. Fehling, 1975, p. 64 y ss. La ausencia de paralelos se extiende incluso al sello de los versos de Focílides y Demódoco, de los que afirma: «Doch kommt bei dieser Gattung der Autor in Text niemals vor». Esto es cierto, dado que el sphragis queda fuera del poema; lo que no señala Fehling es que ocurre también en la fórmula ó $\delta \varepsilon i ̃ v \alpha ~ \tau \alpha ́ \delta \varepsilon ~ \lambda \varepsilon \dot{\gamma \varepsilon 1 . ~}$

${ }^{95}$ Cf. Fehling, 1975, p. 62 y ss.

${ }^{96}$ Cf. Fehling, 1975, p. 72 y ss.

${ }^{97}$ Cf. Fehling, 1975, p. 63. Cf. además infra.

${ }^{98}$ Cf. Porciani, 1997, p. 6 y ss.

${ }^{99}$ Cf. Porciani, 1997, pp. 5 y 46; sobre esta idea de la historiografía como método de enfrentamiento al persa, cf. además Canfora, 2006, p. 31; la idea, según veremos, nos parece por completo insostenible.

${ }^{100}$ Cf. Porciani, 1997, p. 22 y ss. Cf. además Asheri, Medaglia y Fraschetti, 1997, p. 365 y ss., para una traducción italiana del texto y un estudio del monumento. No creemos 
sistemática a lo largo del texto. Sancisi Weerdenburg habla además de considerar la posibilidad de un dictado por parte de Darío, ${ }^{101}$ si bien nada puede afirmarse con rotundidad al respecto según este autor, aun a pesar de que el apartado 70 de la misma parece dar por sentado el dictado; pero de la simple existencia de semejanzas no puede desprenderse una dependencia que en ocasiones parece alentada por el famoso ex oriente lux.

Sea como fuere, muchos años antes afirmaba el propio Diels que los proemios de esta particular forma recordaban en cierta manera a los comienzos de las inscripciones griegas, ${ }^{102}$ a lo que no atendió Porciani, cuyas observaciones están necesitadas de generalización en un fenómeno que se manifiesta de manera global en la creación literaria en prosa de la época. A nuestro entender, afirmar que es este un fenómeno fruto -aunque sea de reminiscencias- de la epistolografía supondría hacer de este género el origen de toda la prosa, y situar el nacimiento de esta en un lugar y momento concreto. Por todo ello, parece interesante delimitar de manera clara la naturaleza de esta configuración, que es fundamental para los proemios de la historiografía griega y su comprensión, y por extensión, del escenario literario del género.

Para las sociedades orales, la palabra dicha gozaba de una función vital, por cuanto era el único medio de ratificar juramentos, promesas, etc. La antropología moderna se ha planteado la dificultad que representa el texto escrito en oposición al acto comunicativo como tal, único medio de comunicación en las sociedades orales. ${ }^{103}$ Ello hace que en estas situaciones

necesario insistir en que este monumento no ejerció influencia alguna en la configuración de la historiografía griega; baste ver Schrader, 1997, p. 80 y ss., con traducción española.

${ }^{101}$ Cf. Sancisi Weerdenburg, 1999, p. 102: «The idea that the original text was spoken or dictated by Darius fits well with some features of the text. Almost each paragraph begins with says Darius the king, and it is not hard to imagine a procedure where the scribes duly wrote down the royal words». Balcer, 1987, p. 22 y ss., defiende la idea de ese testimonio «oral» del que dependen las transcripciones, que Balcer une, a nuestro entender, de manera errónea, a una tradición épica, dada la caracterización del rey como el prototipo del héroe épico, cf. p. 61. Que el rey persiguiera exaltar su valor es algo lógico que no tiene que llevarnos a pensar en que la inscripción dependa de un modelo épico. Interesante, sin embargo, nos parece el hecho de que, como Balcer mismo señala, p. 31, los mecanismos orales permanecían vivos en el mundo en el que la inscripción se realizó.

${ }^{102}$ Cf. Diels, 1887, p. 436, nota 1: «Die Form dieser Prooemien (richtiger Titel) erinnert

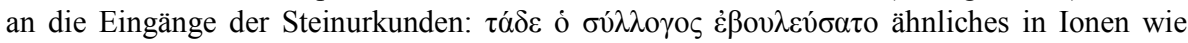
Überall».

${ }^{103}$ Cf. Vansina, 1985, p. 66. Para la adaptación de los esquemas de Vansina al mundo griego, cf. Murray, 2001, p. 16 y ss. 
se deba hablar de testimonio y no de un acto mismo de comunicación. ${ }^{104}$ Para un individuo sumido en una cultura escrita, esta dislocación es difícil de percibir, dado que en gran manera está acostumbrado a una comunicación privada de los elementos ambientales propios de la comunicación oral, ${ }^{105}$ pero para un individuo tradicional, principalmente si se encuentra en un estadio cultural mixto ${ }^{106}$ entre la oralidad y la escritura, esa dislocación es muy difícil de superar.

Ello explica que haya recelos respecto a la aparición de la escritura como soporte de esa palabra, ${ }^{107}$ lo que hace necesario el empleo de mecanismos que aseguren que esa palabra se presenta como lo haría en un acto oral de comunicación, de modo que es el soporte el que toma carácter humano y

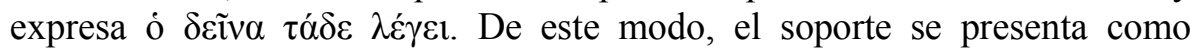
elemento garante de ese acto de comunicación, como un paso posterior a las palabras del autor. Esto supone la superposición de dos planos de comunicación presentes en usos posteriores, como es el caso de los estilos indirectos, o simplemente en la cita de un autor -recuérdese el caso antes expuesto de Sexto Empírico-, y que se presenta además en la muy conocida invocación a las musas, con el poeta como intermediario: ${ }^{108}$

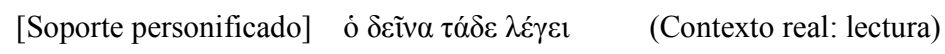

[Autor] ----Obra---- (Contexto figurado: falso contexto oral)

La formulación de un soporte parlante es muy conocida en las inscripciones, principalmente en las ofrendas, que en muchos casos presentaban incluso formas que facilitaban ese tránsito entre el objeto y el objeto personificado. ${ }^{109}$ Las inscripciones más antiguas, como la aparecida

${ }^{104}$ Modificamos la terminología de Vansina, que habla de testigo en lugar de testimonio.

${ }^{105}$ Cf. Detienne, 1981, p. 59 y ss.; cf. Iliada, I 234 y ss., y Kirk, 1985, p. 77, ad loc.

${ }^{106}$ Cf. Thomas, 1989, p. 29; cf. además apartado siguiente.

${ }^{107}$ Cf. Pelling, 2000, p. 2.

${ }^{108}$ Cf. Calame, 1986, p. 21 y ss.: Musa - Poeta

$$
\text { Poeta - Público. }
$$

${ }^{109}$ La lista de epígrafes que recogen la forma $\left.\mu \varepsilon \dot{\alpha} v \varepsilon \dot{\theta} \theta\right\rceil \kappa \varepsilon$ es muy amplia: e. g. IG I ${ }^{2} 404$, $410,428,444,455,472,497,503$, o los famosos epigramas a los muertos en Salamina, IG $\mathrm{I}^{2}$ 927, si bien el monumento no se conserva completo y Pausanias, I 29, 4, no habla nada más que de una estela, por lo que hemos de ser cautos. 


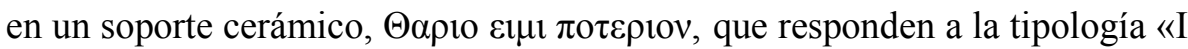
am X's, X wrote me», o «X gave me to Y», como señala Jeffery, ${ }^{110}$ dan cuenta de este tránsito, producido a mediados del siglo VII y en el VI a. C.,

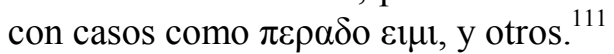

Una inscripción del comienzo del siglo VI a. C., la estela de Fanódico, ${ }^{112}$ es paradigmática para la explicación de nuestra teoría:

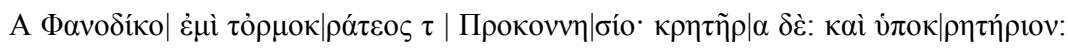

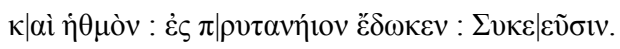

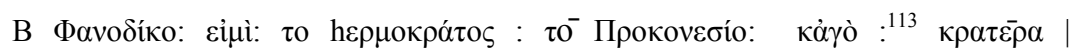

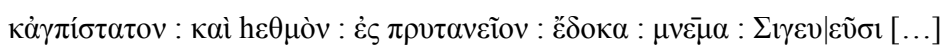

Señala el editor en la descripción que aparecían en la estela dos figuras

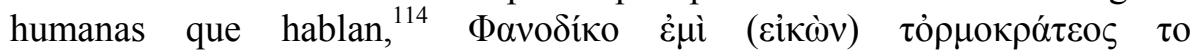
Прокоvvпбío, parafrasea Dittenberger, lo que apunta a la idea señalada antes: la estela se hace persona gracias, en este caso, a la imagen del propio Fanódico, pero nótese la vacilación entre la primera y la tercera persona con el paso a ह̌ $\delta \omega \kappa \varepsilon v$. A este respecto, Roehl no da más explicaciones que por «arbitrio artificum», ${ }^{115}$ en tanto que Dittenberger afirmaba: «lllic imago de vivo Phanodico velut de tertia persona ( $\check{\varepsilon} \delta \omega \kappa \varepsilon v)$, hic ipse Phanodicus

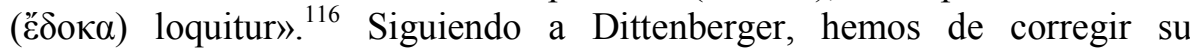
afirmación y señalar que el cambio de persona no se debe a la referencia al

\footnotetext{
${ }^{110}$ Cf. Jeffery, 1961, p. 69.

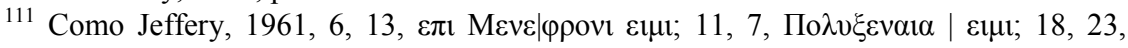
Патрок $\lambda \varepsilon о \varsigma<\varepsilon>\mu$.

${ }^{112}$ SIG 2. En su día Boeck, CIG 8, dudó de su autenticidad, presentándola como una
} falsificación de época helenística, si embargo, hoy se admite como auténtica, cf. Elter, 1911, p. 202 y ss., así como los comentarios de Dittenberger y Hicks y Hill. Mordtmann, 1880, p. 92 y ss., presenta un caso semejante, $\mathrm{SIG}^{2} 464$.

${ }^{113}$ Señala Elter, 1911, p. 206, en contra de la edición de Dittenberger y otros, que ha de leerse la inscripción sin una pausa fuerte tras кảyò, lo que evita el asíndeton y un uso

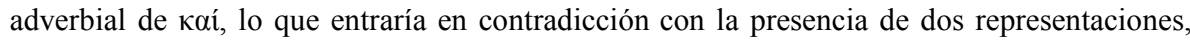
que, por otra parte, es algo dudoso, cf. Hicks y Hill, 1901, p. 9 y ss.

${ }^{114}$ Así también Roehl, IGA 492, con la imagen de la estela, afirma: «a margine inferiore olim pictas fuisse colligi potest ex superficie in illis partibus optime servata».

${ }_{116}^{115}$ IGA, p. 134.

${ }^{116}$ Cf. SIG 2. 
Fanódico vivo o al ya muerto, idea quizá apoyada por la más tardía escritura en ático del apartado B. ${ }^{117}$ Estamos, a nuestro entender, ante la personificación del soporte, que toma la palabra frente al propio Fanódico, en tanto que el segundo caso es un ejemplo de hipercorreción, causado seguramente por ser lo habitual que la inscripción se refiera a la donación del objeto sobre el que la misma se presenta, ${ }^{118}$ pero que, en lo que nos interesa, revela la conciencia clara que se tenía del soporte como elemento transmisor con entidad propia, conciencia que se ve potenciada por la aparición física del propio Fanódico, que en este caso sustituye a la estela como interlocutor y facilita esa transposición del plano comunicativo y con ello la forma

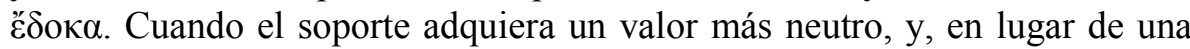
estela o vaso, tengamos una carta o un decreto, aparecerá la expresión ó

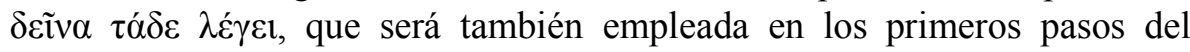
desarrollo de la prosa, de modo que facilitará la creación artificial de un acto de comunicación contextualizado. Este hecho puede ser entendido, por su persistencia, como perteneciente a la epistolografia, ${ }^{119}$ pero parece difícil que la cancillería persa pensase en algo diferente a la personificación aquí expresada al hacer uso del recurso, habida cuenta además del hecho de que en el monumento de Behistun aparece el propio Rey, en un caso semejante al de Fanódico. ${ }^{120}$ Por otra parte, se trata de un fenómeno que, desde una perspectiva propia de la moderna narratología, nos aporta de nuevo un acercamiento más cabal a la naturalidad de estas expresiones. En un estudio relativo a las frases prospectivas en Heródoto, Vignolo Munson ha aportado $\mathrm{luz}^{121}$ a dicho aspecto al determinar la naturaleza metanarrativa de estos recursos, ejemplificados, en palabras de la autora, en el proemio herodoteo y en el de Hecateo. ${ }^{122}$ Se trata, pues, de elementos que ponen en relación al autor y a su audiencia, en una forma que nos ha de hacer pensar en la lectura y no en las exposiciones orales que tradicionalmente se plantean para estos autores y obras.

Todo ello nos lleva a hablar más de un hecho antropológico generalizado que de un fenómeno de imitación polémica por parte de los griegos de esquemas orientales. El intento de acotar todas estas expresiones al género

\footnotetext{
${ }^{117}$ Respecto a la cual cf. Elter, 1911, p. 204 y ss.

${ }^{118}$ Cf. SIG 1, 3, 4, etc.

${ }^{119}$ Cf. Suárez de la Torre, 1979, p. 21 y ss.; Cugusi, 1990, p. 385 y ss.

${ }^{120}$ Cf. Sancisi Weerdenburg, 1999, p. 102.

${ }^{121}$ Cf. Vignolo Munson, 1993, p. 29.

${ }^{122}$ Cf. Vignolo Munson, 1993, p. 31.
} 
epistolográfico hace que Porciani sostenga la oposición, dentro de un

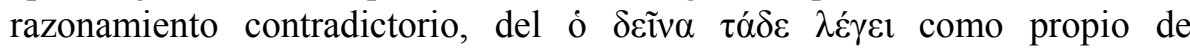

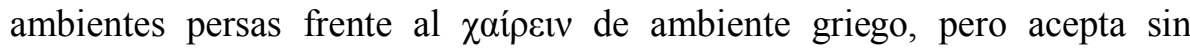
reservas la reconstrucción de Diels, lo que hace que Ion de Quíos y Heráclito se enfrenten también a esa «historiografía» ${ }^{123}$ persa, cosa fuera de lugar por la temática, y excesivo por cronología en el caso de Ion de Quíos, olvidando además que uno de los rasgos clave de la epistolografía es la existencia de un destinatario definido, ${ }^{124}$ que en la historiografía, como en la épica, son inexistentes, al menos en el caso griego. ${ }^{125}$

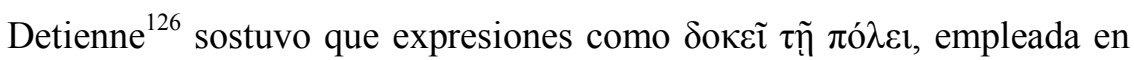
las inscripciones, se encuadraba dentro de un fenómeno generalizado de «secularización» de la palabra religiosa, y que el empleo del concepto de $\delta$ ó $\xi \alpha$ era un hecho que hemos de oponer a la verdad poética que hasta Simónides gozaba de un gran peso. En esa línea, nos atrevemos a decir que la expresión objeto de nuestro análisis, en consonancia con las ideas expuestas acerca de la oposición oral-escrito, se equipara a este fenómeno, de forma que son elementos paralelos de creación de una escritura quizá no secularizada, sino simplemente opuesta a la oralidad literaria y su espectro espiritual, en tal forma que constituye una manifestación intelectual absolutamente independiente de los procesos que pudieran darse en el ámbito persa. De este modo, los posibles contactos se deben, como indicábamos, a simples concomitancias derivadas de la naturaleza antropológica del proceso.

Pero a pesar de todas las razones aducidas, dejamos para el final la mayor dificultad que se puede presentar ante la defensa de la influencia de la epigrafía persa en Heródoto, la lengua. El estudio de los empleos de términos no griegos por Heródoto apunta a un desconocimiento de cualquier lengua que no sea griego, ${ }^{127}$ y la referencia continuada a informadores por

${ }^{123}$ Porciani, 1997, p. 47 afirma: «Una matrice orientale, [...] significherebbe che lo storico greco, nell' enunciare il suo discurso, si mette in una posizione di concorrenza en el contempo di contestazione rispetto alla storiografia delle inscrizioni persiane».

${ }^{124}$ Es decir, el famoso concepto de colloquia absentium, con una dimensión personal e individual muy marcada, cf. van den Hout, 1949, p. 22.

${ }^{125}$ Cf. Herkommer, 1968, p. 25.

${ }^{126}$ Cf. Detienne, 1981, p. 120.

${ }^{127}$ Cf. Schmid y Stählin, 1948, p. 557 y ss.; Pohlenz, 1961, p. 191; Schrader, 1988, p. 517. Las consideraciones de Vignolo Munson, 2005, p. 29, en torno a la impostura de Heródoto no afectan, como señala la propia autora, a estos aspectos. 
medio de fórmulas sistematizadas hace que sea posible y necesario defender el empleo de escritos orientales en cuanto a su contenido. ${ }^{128}$ Pero afirmar, como hace Patzek ${ }^{129}$ en línea con las indicaciones de Porciani, que existe una dependencia formal es, a nuestro entender, imposible. La adquisición de principios organizativos y composicionales para la obra de Heródoto por medio de un intérprete es insostenible, y más aún cuando esta está construida con recursos propios de la cultura griega, o, simplemente, de un carácter cultural antropológico que los hace universales.

Fue con el tiempo como la expresión adquirió una naturaleza neutra que permitió que se aplicara de manera sistemática y que evolucionara, cuando su funcionalidad se diluyó, dando lugar a formas más artísticas, como el caso de, en lo que nos ocupa, Tucídides o Antíoco de Siracusa, con su total inclusión en el texto, o su desaparición en época tardía, e incluso su eliminación en la transmisión, cuando ya no tuviera sentido para los lectores. Preguntarse si esa expresión formaba parte del texto es inútil, aunque una posible respuesta se verá en el análisis del proemio de Antíoco de Siracusa.

\subsection{Microestructura literaria: la prosa arcaica}

Si bien es Heródoto el primer autor en prosa que conservamos, los fragmentos de los prosistas anteriores al de Halicarnaso han permitido caracterizar de manera clara, aun a pesar de los problemas que lo fragmentario del corpus plantea, ${ }^{130}$ la prosa de los autores del siglo VI a. C. -el siglo de la prosa jonia, en palabras de Haberle-, ${ }^{131}$ y del V.

La primera de las cuestiones que plantea esta prosa es su relación con la poesía, cuyo desarrollo -merece la pena recordar- estaba en su máximo punto, un asunto fundamental para el posterior análisis de la obra de

${ }^{128}$ Con los consabidos errores, cf. Schrader, 1988, p. 517 y ss.

${ }^{129}$ Patzek, 2002, p. 21 y ss.

${ }^{130}$ Cf. Lilja, 1968, p. 13 y passim. En este, como en todos los aspectos que tengan que ver con el análisis de textos fragmentarios en el desarrollo del presente trabajo, tenemos, como es natural, presentes las indicaciones de Brunt, 1991, p. 324 y ss.

131 Cf. Haberle, 1938, p. 2. Sorprendentemente, Goldhill, 2002, p. 5, sitúa el «nacimiento» de la prosa en torno al surgimiento de la democracia, en contra de lo cual cf. incluso ya Aly, 1921, p. 2. 
Heródoto. ${ }^{132}$ Norden fue defensor primero de una fuerte influencia de lo poético en la creación de la prosa jonia, para después reducir esa influencia a la luz de las observaciones de Jacoby, quien veía pocos datos en Hecateo que permitieran tal afirmación. ${ }^{133}$ En esta línea, Haberle, apoyado en testimonios antiguos que hacían derivar la prosa de la poesía, ${ }^{134}$ defendía ese influjo poético a partir del análisis léxico de los fragmentos, estableciendo una progresión que alcanzaba su máximo punto en Heródoto. Aly, por su parte, aportó $^{135}$ de una manera muy avanzada para la fecha la idea de que la prosa era tan antigua como la poesía, presentando así una perspectiva que en cierta manera se ha desarrollado actualmente gracias a los estudios de la moderna antropología, ${ }^{136}$ ciencia que, por cierto, desmiente la postura de Schick, quien defendía que el mundo tradicional empleaba únicamente la poesía, ${ }^{137}$ lo que permite evitar la distorsión que presentaba el acercamiento a la prosa arcaica desde una absoluta primacía de la poesía. ${ }^{138}$

En el caso de Lilja, la estudiosa concluye que ha reducirse esa influencia, dando cuenta de la necesidad de aislar los autores por géneros. ${ }^{139} \mathrm{Al}$ tiempo, aporta la que a nuestro entender es la clave del estudio del léxico de estos autores, de gran importancia en el análisis de sus relaciones con la poesía, que no es otra que la dificultad de reconstruir una imagen completa del léxico empleado que nos permitiese hablar de poetismo, cultismo o habla popular, habida cuenta de nuestro poco conocimiento de la lengua jonia estándar de la época y, añadiríamos, de lo escaso del corpus.

Más interesante parece el estudio de reminiscencias rítmicas o de empleos de expresiones de cuño homérico, cuya aparición Lilja destaca

${ }^{132}$ Cf. Lilja, 1968, p. 15, quien hace referencia de manera interesante a este aspecto por las posibles influencias que pudiera tener sobre la prosa, que, como veremos, suaviza.

${ }^{133}$ Jacoby, 1912, col. 2748.

${ }^{134}$ Cf. e. g. Plutarco, De Pythiae oraculis, 406 E, con las indicaciones de paralelos en el propio Plutarco de Schröder, 1990, p. 387; Estrabón, I 2; y Norden, 1958, p. 32 y ss.

${ }^{135}$ Cf. Aly, 1921, p. 2 y ss. No ha de olvidarse que Aly fue además el primer estudioso de las primitivas narraciones populares, de donde seguramente surgió ese convencimiento, amparado en un conocimiento de primera mano de los testimonios más antiguos de la narrativa.

${ }^{136}$ Cf. Finnegan, 1977, p. 41 y ss.

${ }^{137}$ Cf. Schick, 1955, p. 133.

${ }^{138}$ Cf. Aly, 1921, p. 11, que adopta incluso la postura contraria: «Sie [Die Prosa] ist die Mutter auch der Poesie, die nur die feste Form voraus hat».

${ }^{139}$ Cf. Lilja, 1968, pp. 16 y 31 y ss. 
como no casual, ${ }^{140}$ y que en cierta manera, cuando son realmente verificables, ${ }^{141}$ han de hacernos pensar en la esencia misma de su uso, por cuanto pueden expresar desde un simple afán de emulación a un juego polémico, ${ }^{142}$ lo cual no implica la idea tradicional de relación de la prosa respecto a la poesía, ni por supuesto, puede entenderse como simple deuda.

Respecto a esa diferenciación entre géneros que propuso Lilja, ${ }^{143}$ y que apoya López Eire, ${ }^{144}$ los propios datos que obtuvo Haberle apuntaban a la clara separación de los diferentes autores. Así, Haberle destacaba el poco tinte poético de Hecateo, ${ }^{145}$ como hace Lilja, ${ }^{146}$ en tanto que Heráclito es más poético, principalmente por el hecho de que emplea más metáforas, dado que la certificación del empleo de elementos de ritmo se presenta como algo inseguro. ${ }^{147}$

Con estos datos, y habida cuenta de que las teorías antiguas sobre el origen de la prosa no son para nosotros válidas, cabe preguntarse por la significación de lo poético en estos autores. A nuestro entender, el empleo de léxico no es concluyente, ya que no podemos asumir el conocimiento de esa supuesta connotación poética, en tanto que el ritmo es incluso hoy un tema abandonado en la práctica en un momento de gran estudio, por otra parte, de la métrica. ${ }^{148}$ Por ello, parece interesante retener el concepto de metáfora como aspecto clave de esa influencia, y tener presente que no es otra cosa que un empleo figurado del lenguaje. La moderna antropología ${ }^{149}$ nos aporta datos de valor sobre la presencia de este recurso en culturas primitivas, lo que nos ha de hacer pensar en esta no como un recurso poético elevado, sino

${ }^{140}$ Cf. Lilja, 1968, p. 33.

${ }^{141}$ Cf. Dover, 1997, p. 160 y ss., para lo difícil de delimitar esos ritmos en prosa, en donde no contamos con un esquema métrico definido que nos permita decidir en casos dudosos respecto a cantidades.

${ }^{142}$ Aspecto importante en la denominada literatura científica, cf. Thesleff, 1966, p. 103.

${ }^{143}$ Queremos señalar, aunque sea en nota, el intento de Schick, 1955, de determinar la naturaleza de la primitiva prosa por medio de un estudio que tuviera como eje la diferenciación, en un modo poco científico, entre las diferentes razas griegas, lo que prácticamente invalida un trabajo que aporta ideas como que el estilo científico es dorio por la austeridad de estos, cosa en todo punto discutible. Cf. Schick, 1955, p. 132 y ss.

${ }^{144}$ Cf. López Eire, 1985, p. 44.

${ }^{145}$ Cf. Haberle, 1938, p. 22.

${ }^{146}$ Cf. Lilja, 1968, p. 23.

${ }^{147}$ Cf. Lilja, 1968, p. 33 y ss. En contra, cf. Norden, 1958, p. 44

${ }^{148}$ Cf. Dover, 1997, p. 160 y ss., para una postura poco optimista a la hora de esperar resultados concluyentes en este aspecto.

${ }^{149}$ Cf. Vansina, 1985 , p. 86 y ss. 
como un recurso similar al lenguaje abstracto. Los medios de expresión de las culturas tradicionales se mueven en un sistema muy diferente al nuestro, de modo que esas metáforas son propias de un género, sentidas como medios de expresión válidos para la comunicación de un determinado concepto ${ }^{150}$ en un determinado género. Es esto lo que, a nuestro entender, nos permite hablar de influencia poética en Heráclito e incluso, como veremos, en Heródoto, ${ }^{151}$ pero no establecer una jerarquía de dependencias entre prosa y poesía, sino una posición paralela.

En este sentido, y más recientemente, López Eire ha zanjado el tema ${ }^{152}$ simplemente abriendo el ángulo de visión y recordando que tanto poesía como prosa son dos caras de la expresión del lenguaje literario, y, nos atreveríamos a añadir a partir de los datos de la antropología, son dos fenómenos paralelos de la expresión lingüística, con la salvedad que más tarde apuntaremos.

El segundo aspecto a tener en cuenta es el orden de palabras. Es este un tema que Haberle no trata, pero sí Lilja, aunque con los consiguientes problemas en un campo de estudio de por sí complejo y, a nuestro entender imposible en unos autores cuyo corpus se reduce en ocasiones a unas pocas líneas. Así, los datos aportados y recogidos por Lilja en dos tablas ${ }^{153}$ tienen el poco crédito que puede otorgar el que un cien por cien de casos correspondan a un solo ejemplo.

Más interesante es el apartado relativo a la construcción de la frase y de los periodos, lo que tradicionalmente se ha denominado, a partir de una

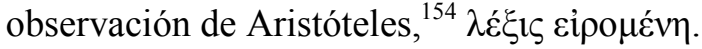

Dentro de este estilo se han de recoger los habituales recursos de carácter sintáctico relacionados con la expresión paratáctica, frente a los usos hipotácticos, que, según Lilja, ${ }^{155}$ se verán paulatinamente introducidos en los usos de la prosa arcaica y que son propios de épocas más tardías. La autora nos hace saber que el estilo $\delta \varepsilon ́$ se relaciona con los contenidos narrativos, en tanto que los usos de kaí se asimilan más a los catálogos o enumeraciones, ${ }^{156}$

\footnotetext{
${ }^{150}$ Cf. Vansina, 1985, p. 12.

${ }^{151}$ Cf. Haberle, 1938, p. 28.

${ }^{152}$ Cf. López Eire, 1985, pp. 39 y ss. y 63.

${ }^{153}$ Cf. Lilja, 1968, p. 52 y ss.

${ }^{154}$ Cf. Aristóteles, Retórica, 1409a.

${ }^{155}$ Cf. Lilja, 1968, p. 73.

${ }^{156}$ Cf. Lilja, 1968, p. 75.
} 
al tiempo que desmonta sin afirmarlo la teoría que relaciona mayor

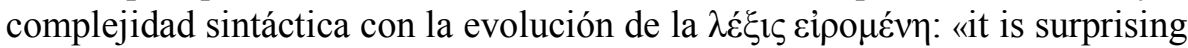
to observe that the very earliest prose writer, the philosopher Pherecydes, has almost as many sub-clauses as Hellanicus...», ${ }^{157}$ siendo además Helánico el autor con mayor subordinación del estudio. ${ }^{158}$ A esta idea en parte ya apuntaban los datos recogidos por Webster, que indicaba un claro aumento de la parataxis a fines del siglo V a C., ${ }^{159}$ y que recientemente Müller ha confirmado dando cuenta, al estudiar el estilo herodoteo, de la poca diferencia entre el grado de subordinación de éste y Tucídides. ${ }^{160}$ Es precisamente dicho aspecto, uno de los habitualmente defendidos como característicos de la prosa arcaica, el que se nos presenta como punto de partida para un nuevo acercamiento al estudio de la prosa arcaica y su configuración literaria.

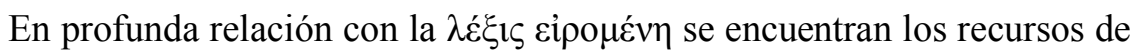
repetición, aliteración y juego de palabras, recursos de amplia repercusión en el nivel oral y aural de la expresión. ${ }^{161}$ El análisis de los fragmentos lleva a Lilja a diferenciar entre los usos de los logógrafos, que apuntan a un afán de claridad en la expresión, frente a los filósofos, que perseguían un mayor énfasis en su expresión. ${ }^{162}$ Sin embargo, de lo dudoso de esta finalidad hablaba ya la misma Lilja, al dar cuenta de lo difícil de la elección en cada caso, en lo que, a nuestro entender, es una diferenciación arbitraria.

Ante estos datos, cabe preguntarse por la verdadera esencia de este tipo de $\lambda \dot{\varepsilon} \xi 1 \zeta$, aún más si tenemos en cuenta que Aristóteles presenta como ejemplo paradigmático el comienzo del proemio herodoteo. ${ }^{163} \mathrm{La}$ definición

${ }^{157}$ Cf. Lilja, 1968, pp. 99 y 82.

${ }^{158}$ Cf. Lilja, 1968, p. 87.

${ }^{159}$ Cf. Webster, 1941, p. 392.

${ }^{160}$ Cf. Müller, 1980, p. 47 y ss., con tabla número 7 en p. 48, en la que el nivel de parataxis de Heródoto se mueve desde el $76,1 \%$ al $81,9 \%$, en tanto que los datos del libro VII de Tucídides se sitúan en el $81,0 \%$. Para un completo análisis de la casuística de la parataxis herodotea cf. Lamberts, 1970, quizá demasiado apoyado en una semántica referida más a la traducción que al texto, y sin unas necesarias conclusiones, que no empecen en modo alguno la amplia acumulación de datos.

${ }^{161}$ Cf. Lilja, 1968, p. 35; Denninston, 2000, p. 2 y ss.

${ }^{162}$ Cf. Lilja, 1968, p. 51.

${ }^{163}$ Cf. Aristóteles, Retórica, 1409a27; el texto presenta problemas de transmisión por presentarse la famosa referencia a Turio y un orden diferente de palabras, lo que llevó a la atetización del pasaje. En contra, la edición de la academia, en la cual cf. aparato crítico, y Cope, 1887, p. 92 y ss., quien justifica claramente el problema, cuyo origen está seguramente 


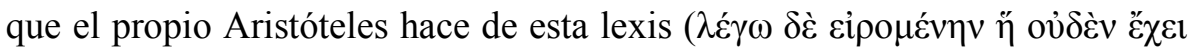

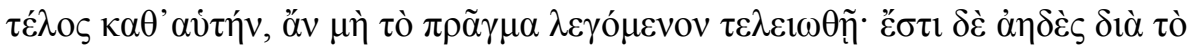

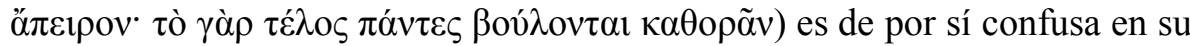
interpretación. A primera vista, la definición parece decir poco, y el ejemplo presentado por Aristóteles termina por complicar la definición, dado que el proemio de Heródoto plantea no pocos problemas, y su longitud parece

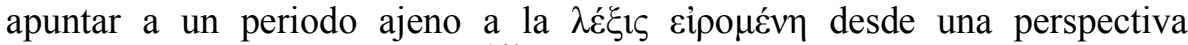
sintáctica, como señaló Müller. ${ }^{164}$

Parece, pues, más interesante recurrir a la reconstrucción propuesta por López Eire, ${ }^{165}$ que partiendo de los esquemas de las antiguas genealogías, con construcciones del tipo sustantivo más genitivo referido al anterior, más sustantivo, etc., define estas estructuras como compuestas por $\kappa \tilde{\omega} \lambda \alpha$ -pequeños o no-, engarzados por un elemento repetido, que puede ser sustituido por un pronombre. ${ }^{166}$

Así, por el marco temporal en el que se desarrolla este tipo de $\lambda \dot{\varepsilon} \xi 1 \zeta$, hemos de pensar en primer lugar en una sociedad que está recién salida -si es que aún no se encuentra en ese estadio, como nosotros opinamos- del mundo tradicional, con una cultura de carácter oral, y esa cultura oral se manifiesta con una caracterización que en líneas generales se repite de

en la cita de memoria de un Aristóteles que poseería una copia en la que figuraría la referencia

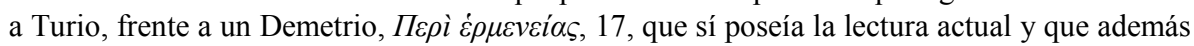
cita correctamente el orden del texto. Powell, 1939, p. 63, atetizaba el pasaje en la idea de que

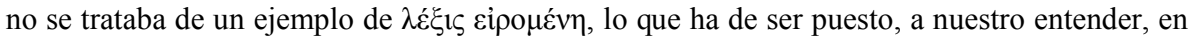
cuarentena. Por otra parte, las referencias a Turio eran en la Antigüedad abundantes, cf. Bauer, 1878, p. 172 y ss. Es precisamente esta hipótesis la explicación más clara a la tradición que propone Turio, que no sería otra cosa que una corrección erudita del manuscrito a la luz de las tradiciones sobre la vida del autor, cf. Erbse, 1979a, pp. 143 y ss. y 152 y ss. para las dificultades de la cita de Aristóteles, que Erbse no se propone resolver. La lectura fue admitida por Legrand, 1931.

164 Cf. Müller, 1980, p. 5: «Als einzigen Vertreter der $\lambda$. $\varepsilon$. nennt Aristoteles erstaunlicherweise Herodot und führt dessen Einleitungssatz als Beispiel an».

${ }^{165}$ Cf. López Eire, 1985, p. 44 y ss.

${ }^{166}$ Errónea nos parece la afirmación de Immerwahr, 1966, p. 88, quien defiende la independencia de los elementos en el estilo paratáctico: la unidad que se consigue por la subordinación se alcanza en la parataxis por otros medios, como señala López Eire. 
manera sistemática en los ejemplos estudiados por la moderna antropología. ${ }^{167}$

Uno de los aspectos más destacables de estos estadios culturales es la consideración de la escritura como un medio ajeno a la expresión: esta puede ser empleada de manera funcional durante mucho tiempo sin que ello impida la existencia de una cultura literaria aún oral, aunque tarde o temprano se vea modificada por ese instrumento. ${ }^{168} \mathrm{El}$ cambio de mentalidad que representa el asumir un vehículo escrito para lo que habitualmente se conservaba de manera oral supone un auténtico punto de inflexión en la sociedad y en el individuo que más tarde analizaremos, dado que por ahora basta con considerar un hecho tan obvio como olvidado: que la prosa como tal corre pareja a la poesía en las sociedades tradicionales, ${ }^{169}$ y que posee su propia retórica, una retórica tradicional, que persigue dos características claves del quehacer literario en las sociedades tradicionales, se trate de prosa o poesía: la finalidad y la supervivencia del texto. ${ }^{170}$

Desde una mentalidad escrita parece imposible la supervivencia de un texto como un poema épico sin la escritura, igual que ocurre en el caso de los textos narrativos orales, que no conservamos como tales en el mundo clásico, y ello ha hecho que habitualmente se aduzcan motivaciones fisiológicas, que apuntan a una gran capacidad memorística por parte de sujetos que se desenvuelven en una cultura ágrafa, para justificar esa superior capacidad de memorización de textos, y con ello la conservación de los mismos, hecho por completo desmentido por los estudios al respecto. ${ }^{171}$ Los individuos de las sociedades tradicionales orales no tenían mejor memoria, sino recursos que les permitían conservar esos textos por medio de una memorización más fácil. Vansina recoge tres tipos de recursos: objetos, lugares y ritmo o música. ${ }^{172}$ En el caso griego, los estudios de Parry han dejado clara constancia de los recursos empleados en la épica homérica para

167 Cf. Vansina, 1985, p. 39 y ss. A este respecto, piénsese, por ejemplo, en las genealogías presentes en textos que, aunque tardíos, parecen recoger elementos tradicionales, como el árbol de Jesé, en Mateo 1, 1, o Tito Livio, i 3, 6.

${ }^{168}$ Cf. Thomas, 1989, p. 2 y ss.

${ }^{169}$ Cf. Vansina, 1985, p. 14.

${ }^{170}$ Cf. Vansina, 1985, pp. 100 y 42 y ss.; para su aplicación al ámbito griego cf. Thomas, 1989, p. 6.

${ }^{171}$ Cf. Thomas, 1989, p. 4 y nota 7; Finnegan, 1977, pp. 54 y 69

${ }^{172}$ Cf. Vansina, 1985, p. 42 y ss. 
facilitar esa memorización y en lo referente a la prosa, cabe preguntarse si no estarán presentes esos recursos en los primeros autores.

Volviendo a la definición de Aristóteles, se coincide en que habla de una expresión que no queda completada hasta que se termina aquello que se examina o discute, ${ }^{173}$ mientras que el estilo periódico es aquel conformado por periodos que tienen su fin en sí mismos, ${ }^{174}$ y por ello se habla de un elemento compacto. Es este último término el que puede entrar en

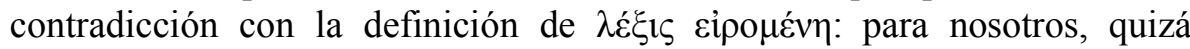
presente un estado más compactado el fragmento de Ferécides DK 7 B 2 que un texto de Isócrates, pero para un lector antiguo, con las consabidas dificultades de lectura, era complicado desenvolverse con un texto de ese tipo, en tanto que los normalmente breves periodos de orador serían más fáciles de seguir con la vista, dado que, por ejemplo, no habría repetición continua de elementos, lo que, unido al hecho de que las piezas tendrían la suficiente independencia como para abarcarlas por unidades completas de sentido, facilitaría la lectura. Pero hay algo en los fragmentos de los autores arcaicos que en parte recuerda a esa ilación: ${ }^{175}$

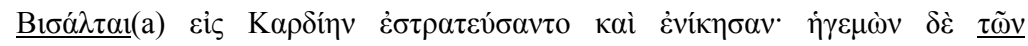

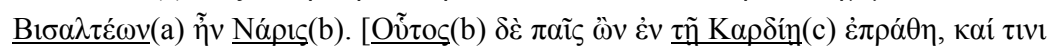

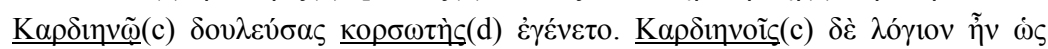

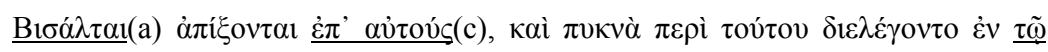

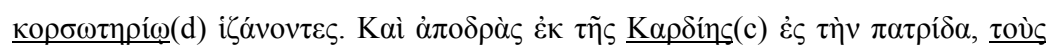

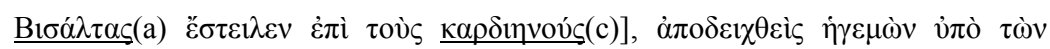

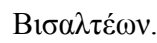

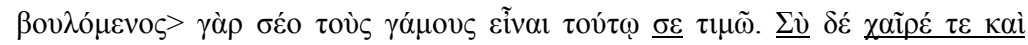

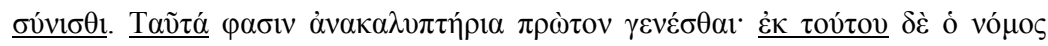

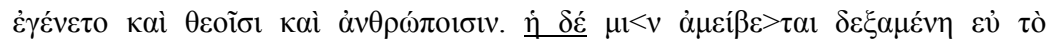
фа̃рos... ${ }^{176}$

\footnotetext{
${ }^{173}$ Cf. Cope, 1887, p. 92.

${ }^{174}$ Cf. Aristóteles, Retórica, 1409a27; Cope, 1887, p. 94.

${ }^{175}$ Caronte de Lámpsaco, F 1.

${ }^{176}$ Cf. Ferécides, DK 7 B 2 col. 2.
} 


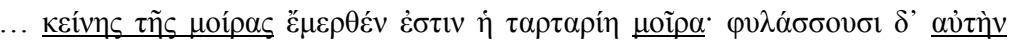

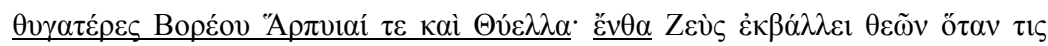

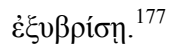

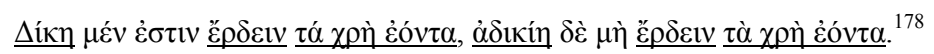

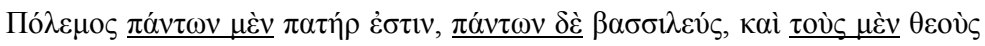

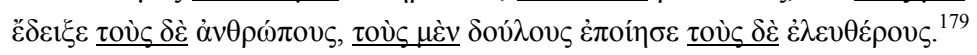

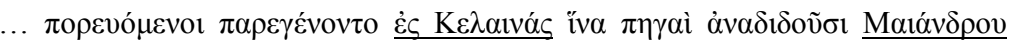

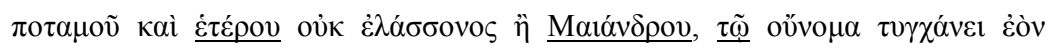

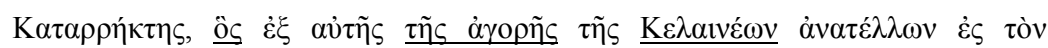

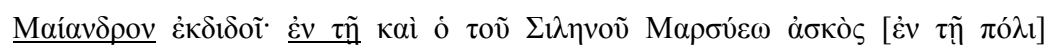

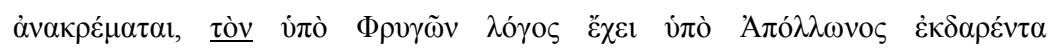
$\dot{\alpha} v \alpha \kappa \rho \varepsilon \mu \alpha \sigma \theta \tilde{\eta} v \alpha{ }^{180}$

Se presentan subrayados los elementos inventariados por Lilja como característicos de la prosa más primitiva. Todos esos rasgos cohesionan el texto, crean un bloque que, como dice Aristóteles, solo está completo por sí mismo y cuando acaba, lo que, si lo presentamos en un escenario de cultura oral, responde a unos mecanismos que facilitan la memorización y conservación del texto. Los diferentes elementos llaman al siguiente de manera solidaria, de modo que la falta de uno de ellos imposibilita la sensación de que el texto está completo; así, aparecen paralelismos que hacen que los elementos se presenten como interdependientes, o el empleo de expresiones repetidas apunta a la necesidad de articular un encuadre claro de elementos que permita añadir detalles sin que se pierda el hilo general de

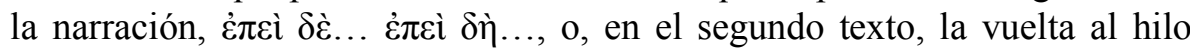
inicial de la narración por medio del pronombre $\dot{\eta} \delta$.́.

\footnotetext{
${ }^{177}$ Cf. Ferécides, DK 7 B 5.

${ }^{178}$ Cf. Demócrito, DK 33 B 256.

${ }^{179}$ Cf. Heráclito, DK 22 B 53.

${ }^{180} \mathrm{Cf}$. Heródoto, VII 26.
} 
El último texto pertenece precisamente a Heródoto, y es el conocido «exceso sintáctico», ${ }^{181}$ en el que se presenta un abuso de oraciones subordinadas relativas, pero que en último término mantienen esa cohesión, que ya señaló como crucial Fränkel. ${ }^{182}$ Finalmente, el empleo de correlaciones como $\mu \varepsilon \dot{v} v, \delta \varepsilon$, o $\tau \varepsilon \ldots \kappa \alpha$ é en el texto apunta a lo mismo, a la creación de elementos de carácter solidario cuya aparición no puede ser aislada, y el empleo de elementos apodóticos incide en esa idea y responde a un criterio de cohesión que para un lector es, como bien dice Aristóteles, tedioso, pero que para una cultura oral conforma los rasgos propios de su retórica, en la que ningún periodo queda sin ligazón con el anterior: no sobra ni falta nada, decía Fränkel ${ }^{183}$ en referencia al fragmento de Caronte de Lámpsaco, que presenta solo cuatro ideas clave en seis líneas.

De este modo, los seis estilos propuestos por López Eire ${ }^{184}$ pasarían a englobarse en dos grupos, los propuestos por Aristóteles, aquellos que favorecen esa cohesión, y los que no, diferencia observable además en la comparación de los estilos narrativos de un Heródoto y un Jenofonte. ${ }^{185}$ Para afianzar el razonamiento, citemos algunas líneas del ejemplo que examina Vansina en traducción al inglés, en la que trata de recoger esos rasgos, lo que nos permitirá ver la naturaleza antropológica del fenómeno: ${ }^{186}$

There was once a hunter who lived in the bush. The daughter of the a-yo went to the bush. She saw the hunter in the bush. The hunter saw the woman. The woman asked, "Are you here?" He answered, "Yes, I am here." She asked him: "What have you eaten? I have eaten meat...

${ }^{181}$ Cf. Lesky, 1989, p. 354.

${ }^{182}$ Cf. Fränkel, 1960b, p. 52: «Das technische Problem dieses Stiles lag in der Auswahl, Anordnung, und Verbindung der vielen einzelnen Wirklichkeitsstäubchen», cosa que confirma la moderna teoría literaria del mundo tradicional. La idea defendida entre otros por Thesleff, 1966, p. 90, relativa a una falta de unidad entre los diferentes elementos dentro de las obras de este periodo seguramente deba ser reconsiderada a la luz de un hecho tan importante como que en la mayoría de los casos tratamos con autores fragmentarios.

${ }^{183}$ Cf. Fränkel, 1960, p. 67.

${ }^{184}$ Cf. López Eire, 1985, p. 49 y ss.

${ }^{185}$ Como ya indicó Webster, 1941, p. 389. Excluimos a Platón, a diferencia de Webster, porque el filósofo es un auténtico artista en el uso de los diferentes «estilos» de la prosa.

${ }^{186}$ Cf. Vansina, 1985, p. 71 y ss. Cf. además Finnegan, 1977, p. 100 y ss., para multitud de ejemplos.

Monografias de Filología Griega, 22. ISSN 1136-0860 
El examen de este pequeño texto, que recoge una narración oral de Mali, recuerda en su constitución a los fragmentos observados a modo de ejemplo: la lectura es en verdad tediosa, con repeticiones a los ojos de un lector moderno innecesarias, pero que constituyen la forma propia de una prosa oral.

Desde esta perspectiva, cabe replantearse las observaciones citadas en lo

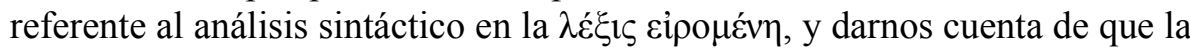
supuesta dificultad que suponía el amplio desarrollo sintáctico no es tal; este estilo persigue una unidad que se puede alcanzar incluso con la aparición continuada de subordinación, siempre que se respeten esos criterios que apuntan a la cohesión del texto. A todo ello hemos de unir lo poco sostenible de una visión de la evolución estilística de la prosa griega que reposa en una idea de progreso muy afín al espíritu del siglo XIX, pero que no parece tan sólida en nuestro tiempo: el desarrollo de la prosa y de la subordinación sería un fenómeno parejo a la evolución hacia una mente «científica» y «racional» desde otra mítica. ${ }^{187}$

A este respecto, el propio López Eire $^{188}$ ya apuntó en cierta manera tal posibilidad, al examinar la aparición de diferentes variantes en el sistema formular homérico, unas con subordinación y otras sin ella. Y es que está claro que una mayor pericia en la técnica estilística oral facilita un mayor desarrollo de la subordinación, como es el caso de la epopeya homérica, ${ }^{189} \mathrm{o}$ de la tragedia; ${ }^{190}$ la poesía presenta unos recursos aún mayores, según vimos, para la estructuración y cohesión del texto, lo que justifica que sea más fácil la progresiva eliminación de esos elementos redundantes y tediosos, como dio cuenta Fränkel, ${ }^{191}$ porque el metro acude en apoyo del sostenimiento de la estructura del texto. Ello permite una mayor evolución y con ello la posibilidad de presentarse como algo avanzado frente a la prosa, e incluso

\footnotetext{
${ }^{187}$ Como ya señaló Snell en lo relativo a los usos léxicos de abstractos, cf. Snell, 1982, p. 227 y ss.

${ }^{188}$ Cf. López Eire, 1985, p. 51.

${ }^{189}$ Cf. Lilja, 1968, p. 73. Las indicaciones de Schwyzer, 1959, p. 633 y ss., no parecen convincentes.

${ }^{190}$ Cf. Webster, 1941, p. 386, quien afirma que obras como Agamenón, Ayax, Prometeo o Antígona tienen frases de mayor extensión que Heródoto, «due to the forward rythm of verse»!.

${ }^{191}$ Cf. Fränkel, 1960b, p. 62, quien afirma que estos recursos de cohesión están más presentes en la prosa que en la poesía.
} 
cederle recursos, en una relación entre dos ámbitos que está demostrado que ni son tan lejanos ni tienen primacía alguna el uno sobre el otro. ${ }^{192}$

Hemos de tener en cuenta que los rasgos señalados hasta ahora se presentan, además de en el nivel de microestructuración, en la conformación de la macroestructura de la obra literaria oral, de modo que la cohesión es, pues, un fenómeno que parte desde las unidades más elementales hasta las más elevadas, con fenómenos paralelos aplicados en los diferentes niveles. ${ }^{193}$

Los estudios de Lilja, Aly y Norden nos han permitido observar una nómina de características que se presentan en los fragmentos de estos autores, y los estudios de Vansina, Finnegan y Thomas nos han permitido enfocar los resultados de forma que se han salvado las complicaciones que se desprendían de los datos. De gran importancia es el hecho de delimitar la vitalidad y subsistencia de los recursos propios de esta retórica oral por cuanto hemos de tener en cuenta su presencia en Heródoto y Tucídides, y las implicaciones que se desprenden de esa aparición. No es necesario repetir una vez más la imposibilidad de aislar de manera clara el ámbito de lo oral y el de lo escrito: la coexistencia de ambas tendencias en el mundo griego es quizá muy amplia y compleja en comparación con lo que habitualmente se suele determinar para otras culturas, y no es de extrañar que una tradición literaria oral tan importante y que está presente hasta una época tan tardía como es el siglo IV a. C. influya en la naciente literatura escrita. Los estudios de Lord, el discípulo de Parry, supusieron un gran avance, pero aportaron una complicación de no poco calado: Lord defendía la total separación entre lo oral y lo literario, ${ }^{194}$ cosa que no es cierta, ya que existen periodos de

\footnotetext{
${ }^{192}$ Cf. López Eire, 1985, p. 48 y ss.

193 Entendemos por elementos de microestructuración la repetición de palabras, las anáforas $\mathrm{y}$, en definitiva, todos aquellos recursos que cohesionan el texto en niveles prácticamente de sintagma o de frase, asimilado a lo que recientemente West, 2011, p. 58, definía como expansiones subepisódicas. Por su parte, los elementos de macroestructuración son aquellos que organizan unidades mayores de texto, como la Ringkomposition, las repeticiones de estribillos o estrofas, o incluso de versos enteros, dentro de una composición, a distancia. Para la relación entre ambos planos y sus recursos, cf. van Otterlo, 1944, p. 21, y Cobet, 1971, p. 81.

${ }^{194}$ Cf. Lord, 2003, p. 129: «the two techniques are [...] contradictory and mutually exclusive». Cf. además p. 137, sobre el efecto pernicioso del mercado librario en la literatura oral.
} 
interacción de manera habitual, precisamente el escenario que a nosotros se nos presenta y en el que nace la historiografía. ${ }^{195}$

Quizá lo más relevante de esos periodos de interacción sea lo que respecta a los escenarios de representación de la composición oral ${ }^{196}$ y su contextualización. Frente a esos espacios bien y exclusivamente delimitados de la literatura puramente oral, la literatura mixta se presenta como excluida de esos ambientes bien determinados, lo que afecta a la definición global del género literario, dado que la naturaleza del espacio de recepción es fundamental para su clarificación.

Es precisamente esa desvinculación con el contexto de lo oral, que asimila de manera clara y exclusiva determinados elementos a un género y a su performance concreta, lo que permite a la literatura escrita incluir elementos propios de un género en otro que no está sometido a una formalización reglada, hecho que además facilita esa elasticidad. De este modo, los primeros historiadores recogerán muchos elementos orales, sin que ello signifique que su obra no fuese desde un primer momento una obra escrita, como señaló de manera concluyente Finnegan. ${ }^{197}$ Este hecho será además demostrado por la falta de elementos de microestructuración del texto, es decir, los relativos al nivel de $\lambda \dot{\varepsilon} \xi 1 \zeta$, frente a una aparición continua de elementos de macroestructuración, tales como, por ejemplo, la Ringkomposition, ${ }^{198}$ de modo que la presencia de determinados rasgos no asegura oralidad, ${ }^{199}$ pero nos pone sobre aviso del ambiente mixto entre oralidad y mundo escrito en que se desenvuelve la obra. De esta forma, las estructuras presentes en la tragedia, en especial en las partes corales, así como las presentes en las composiciones estróficas en el ditirambo, la lírica

${ }^{195}$ Cf. Finnegan, 1977, p. 160 y ss. Cabe pensar además en el ámbito literario del Nuevo testamento y su marcado caracter oral (cf. López Eire, 1985, p. 48 y ss.), y compararlo con la literatura de la época; la literatura neotestamentaria es fruto de una amplia tradición oral que cristaliza en los Evangelios, en una época que aparentemente poco tiene de tradicional y que presenta unos niveles de complejidad sintáctica elevados; si consideramos este aspecto desde la perspectiva propuesta, los problemas son menos.

${ }^{196}$ Cf. Finnegan, 1977, p. 118 y ss.

${ }^{197}$ Cf. Finnegan, 1977, p. 70, en referencia a la poesía: «Theorists have now to accept that since there can be both an oral and a literary use of formulae one cannot necessarily discriminate between oral and written on the basis of a formulaic style».

${ }^{198}$ Para la definición canónica de la misma cf. van Otterlo, 1944, p. 3.

${ }^{199}$ En contra de lo que apuntaba Hartog, 2003, p. 259. 
coral, y, simplemente, en el resto de la literatura del periodo que nos ocupa, responden a este criterio de estructural oral. ${ }^{200}$

Los datos hasta ahora recogidos nos permiten afirmar con seguridad que la posible dependencia de la prosa respecto a la poesía es una falsedad reforzada por los caprichos de la transmisión textual y por la construcción de un modelo de desarrollo progresivo del pensamiento racional. Eliminada esta dificultad, parecía necesario señalar la existencia de los recursos que hemos desgranado y que responden a esa imagen propia de una cultura tradicional. Pero queda todavía por examinar uno de los aspectos más importantes y característicos de la literatura oral, como es el principio de plasticidad, que, de modos en ocasiones muy artísticos, dibuja la estructura y desarrollo de las obras, uno de los principios artísticos fundamentales de la futura historiografía.

\subsection{Macroestructura literaria: el ejemplo de la épica}

Como es característico de las narraciones de los pueblos tradicionales, la épica se constituía en Grecia como un continuo cuya suma daba lugar a una narración consecuente de un periodo o etapa del pasado. La naturaleza oral de la épica hace que su estructura se nos antoje flexible y como una corriente continua en la que era posible comenzar desde donde se desease. ${ }^{201}$ Es esa una de las razones por las que el proemio goza de gran peso en la configuración de la obra, por cuanto delimita el tema elegido y con ello el desarrollo total de la performance del aedo. No es, pues, una función de título en el sentido moderno del concepto, ${ }^{202}$ sino un elemento de íntima unión con el desarrollo de la composición oral, dado que determina el punto exacto de la corriente en que se sitúa el aedo, una marca que hace referencia a un punto dentro de ese torrente sin divisiones claras, al tiempo que permite abrir un amplio y rico abanico de escenas.

${ }^{200}$ Cf. Finnegan, 1977, p. 102.

${ }^{201}$ Cf. e. g. Odisea, I 10.

${ }^{202}$ Así se expresa el propio van Groningen, 1958, p. 65. A ello solo cabe añadir que el concepto de título es anacrónico, por cuanto la naturaleza oral de la obra hace imposible la necesidad del mismo. 
Los proemios épicos, excepción hecha de las obras de Hesíodo, ${ }^{203}$ comparten una serie de rasgos que determinan que, tras las semejanzas compositivas, se esconda un proceder igual en la ejecución del poema ante el público, definiendo un momento crítico de los aspectos literarios de la obra. La naturaleza mecánica de las composiciones épicas, ajustadas a un esquema métrico perfectamente sancionado, hace que el comienzo sea especialmente complejo por cuanto la posterior ilación de la obra depende de ese primer verso: tanto la distribución de los elementos y su posición en los versos como la naturaleza de la sintaxis de la obra vienen definidas por ese primer comienzo en un efecto dominó. Además, esa primera chispa literaria es la que organiza y define todo desarrollo literario de este tipo de composiciones, dado que guarda en su interior la fórmula que confiere carácter literario a esas progresiones.

Las investigaciones pioneras de Milman Parry demostraron que la posición de determinados elementos en el verso homérico se presentaba de forma regular y matemática, jugando con una serie de elementos dados, de sintagmas y epítetos con los que el poeta trabajaba en la realización de su poema. Es esta la razón por la que, además de la cuestión relativa a la elección del tema dentro del ciclo, en lo que a la configuración del periodo se refiere hemos de tener en cuenta la naturaleza del propio verso épico. Este nos determinará la configuración de ese arranque, de una manera semejante en todos los conocidos, puesto que, como decimos, su funcionamiento venía dado por un mecanismo oral que tenía su punto crítico precisamente en el inicio mismo de la composición.

Así, van Groningen señaló acertadamente que en todos los proemios conservados, Ilíada, Odisea, Pequeña Ilíada y Tebaida, el comienzo se produce por medio de la aparición de un término clave para la definición del tema: ${ }^{204}$

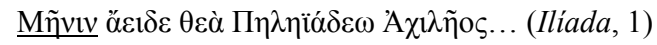

${ }^{203}$ Excluimos el examen de los proemios hesiódicos por ser estos buenos ejemplos del amplio grado de desarrollo de la estructura que hallamos con mayor simplicidad en Homero. Así, en el proemio de la Teogonía, con más de un centenar de versos, encontramos la misma

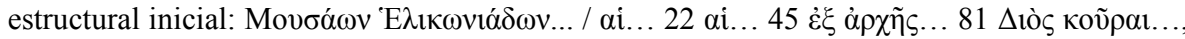
que abrazan además tres excursos, respectivamente, en versos 11-21, 44-50 y 77-80; cf. para ello Schwabl, 1963, p. 389 y ss. El caso de los Erga presenta un proemio, en este caso muy breve, construido sobre el mecanismo de la aretalogía, para lo cual cf. infra.

${ }^{204}$ Cf. van Groningen, 1946, p. 284. 


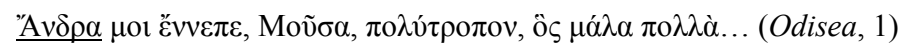

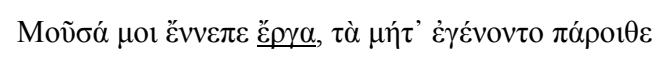

$\mu \eta \tau^{\prime}$ '̌́ $\sigma \alpha \iota 1 \mu \varepsilon \tau$ ó $\pi 1 \sigma \theta \varepsilon v . .$. (Pequeña Ilíada, 1 y ss.)

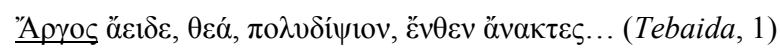

Más interesante es la observación de que ese elemento es posteriormente adjetivado por medio de un epíteto y después por una cláusula relativa. ${ }^{205}$ Fue Eduard Norden ${ }^{206}$ en su ya clásico estudio sobre la forma del discurso religioso quien dio cuenta de la combinación de la forma $T u$ o Ille de súplica a la divinidad con recursos de predicación, concretamente la adjetivación participial y la relativa, fenómeno que en cierta manera nos lleva a la estructura analizada. Sin embargo, a nuestro entender, conviene tener presente que lo que en un primer momento debería presentarse como una herencia formal de la expresión religiosa ${ }^{207}$ es simplemente un rasgo general aplicado quizá con más insistencia al discurso religioso, lo que evita que tengamos algo semejante a una influencia del discurso religioso en la épica, fenómeno de difícil comprensión, al menos desde una perspectiva moderna. La investigación actual sobre las religiones primitivas y la mejor comprensión de la literatura oral nos permiten observar fenómenos paralelos en los que la religión es un hecho que impregna toda la cultura de la sociedad, lo que impide establecer esa separación. De este modo, la súplica a los dioses o el canto de los $\kappa \lambda \dot{\varepsilon} \alpha \dot{\alpha} v \delta \rho \tilde{\omega} v$ de manos de las musas es algo que conecta con la divinidad, ${ }^{208}$ lo que pone en igualdad de naturaleza religiosa el himno a los dioses y el canto épico, y, más tarde, como señala a modo de ejemplo el propio Norden, el canto a Eros de Sófocles. ${ }^{209}$

${ }^{205}$ Cf. West, 2011, p. 81 .

${ }^{206}$ Cf. Norden, 1956, p. 166 y ss.

${ }^{207}$ Idea que encontramos en trabajos recientes como el de Long, 1987, p. 12.

${ }^{208}$ Cf. Detienne, 1981, p. 26, sobre la sacralidad de la memoria de los aedos.

${ }^{209}$ Cf. Norden, 1958, p. 169. 
En esta misma línea de reinterpretación, y si bien van Groningen ${ }^{210}$ afirmaba que era este un ejemplo de fluidez de ideas y de un esquema de pensamiento asociativo, los estudios de Parry y Lord nos ponen sobre aviso de que, frente a esa dinámica de asociación de ideas, es la estructuración del verso la que determina la conformación de los siguientes elementos de la composición. Lord señalaba la idoneidad del hexámetro como unidad para la expresión de un pensamiento, que en ocasiones ocupaba incluso menos de un verso, ${ }^{211}$ lo que hacía que un nuevo pensamiento o idea comenzase a expresarse en ese mismo hexámetro, asegurando así la continuidad de esta primera sección.

Obviamente, el proemio recoge el inicio de los pensamientos que van a ser expresados en el poema, materializados en la palabra clave de que hablaba van Groningen y que determina la temática de la obra, de modo que desde el comienzo se determina la direccionalidad del tema de la obra, en un modo muy estudiado. ${ }^{212}$ Ya Milman Parry habló de «unperiodic style», ${ }^{213} \mathrm{y}$ más recientemente Kirk lo ha definido como «estilo progresivo», afirmando que «[este estilo] occurs when a sentence which could be regarded as grammatically complete at the verse end [...] is extended by the addition of adjetival, adverbial or verbal ideas...». ${ }^{214}$ Así, ha precisado las afirmaciones de van Groningen antes vistas, de modo que los primeros versos del poema se constituyen, a nuestro entender, no de una manera progresiva, expresión que preferimos reservar para otros usos estilísticos, ${ }^{215}$ sino en espiral, dado

${ }^{210}$ Cf. van Groningen, 1946, p. 285: «is a quite different way of thinking, a passive, automatical and flowing one, which does not choose the succesive ideas on account of their suitability for a broad context, but immediately accepts them when they spontaneously arise».

${ }^{211}$ Cf. Lord, 2003, p. 148

${ }^{212}$ Cf. Kirk, 1985, p. 31, quien señala: «The idea of the oral singer as improviser has been much exaggerated», lo que completa y actualiza las afirmaciones de van Groningen. Ya Notopoulos, 1949, p. 13, decía: «organic literature is the result of a disciplined artistic mentality wich plans the architecture of a work of art», indicando además que es este un fenomeno que se incardina en la mentalidad propia de la época.

${ }^{213}$ Desechamos, como aparatentemente hace Kirk, la definición propuesta por Parry de «unperiodic», tomada de Dionisio de Halicarnaso, De ordine verborum, XXII, y que parte de la perspectiva retórica propia del autor, poco avezado en la valoración de los mecanismos orales; véase así lo relativo a la Ringkomposition en Tucídides, De Thucydide, xx 1. En definitiva, supone confundir los términos y los conceptos de la retórica tardía y la composición oral. El propio Parry, 1971, adelanta sus dudas en la p. 253.

${ }^{214}$ Kirk, 1985, p. 32.

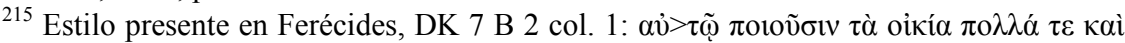

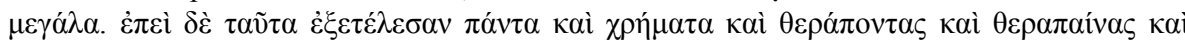


que los diferentes nuevos elementos se añaden y gravitan en torno a uno central.

Por su parte, en la demostración de la oralidad de los poemas homéricos, Lord analizó los primeros versos de la Ilíada en un esquema ya clásico en el que demostró el continuo uso de esquemas formulares en su configuración: ${ }^{216}$

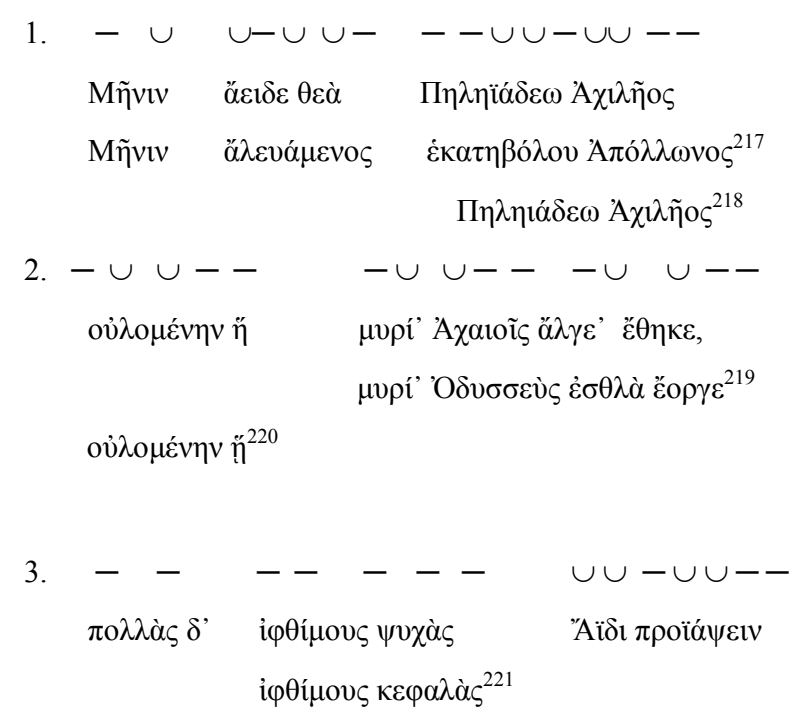

En el caso de la Odisea:

1. $-\cup \cup-\cup \cup-\cup$

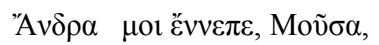

$\cup-\cup \cup-$

$\pi \circ \lambda v ́ \tau \rho о \pi \circ \mathrm{ov}$ ö

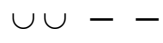

$\mu \alpha ́ \lambda \alpha \pi \mathrm{o} \lambda \lambda \grave{\alpha}$

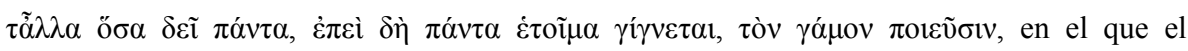
pensamiento avanza de forma progresiva recogiendo ideas anteriores. Cf. Haberle, 1938, p. 39, e infra.

${ }^{216}$ Cf. Lord, 2003, p. 143 y notas finales, así como Parry, 1971, p. 301 y ss., de donde tomamos los datos.
${ }^{217}$ Ilíada, v 444.
${ }^{218}$ Ilíada, I 322.
${ }^{219}$ Ilíada, II 276.
${ }^{220}$ Ilíada, v 876.
${ }^{221}$ Ilíada, XI 55. 


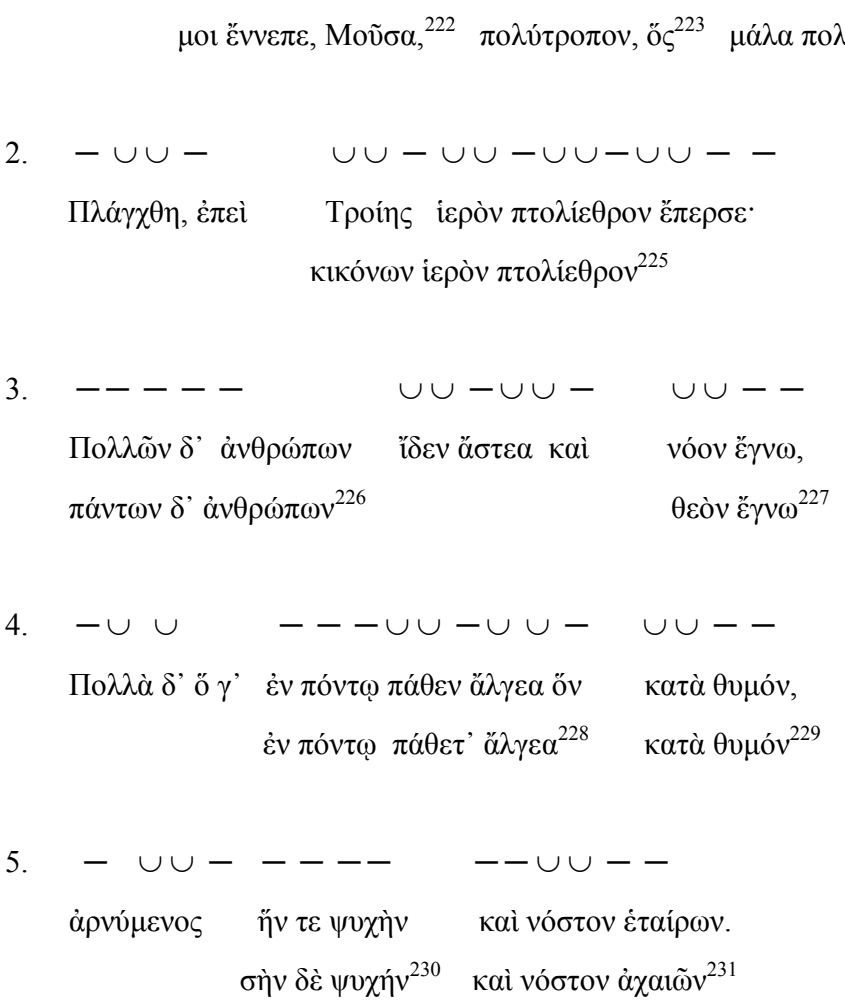

Todo ello da cuenta del muy estructurado pensamiento del proemio del poema, que no avanza, sino que, a nuestro entender, se construye en forma de espiral sobre la idea básica expresada por el concepto clave, que se ve complementado de diferentes formas y que permite observar cómo se realiza la construcción del verso sin variar la idea inicial. Esta ocupa una posición

\footnotetext{
${ }^{222}$ Ilíada, II 761.

${ }^{223}$ Odisea, x 330.

${ }^{224}$ Ilíada, v 197.

${ }^{225}$ Odisea, IX 165.

${ }^{226}$ Ilíada, XVI 621

${ }^{227}$ Odisea, I 420.

${ }^{228}$ Odisea, $\mathrm{x} 458$.

${ }^{229}$ Ilíada, XIII 8.

${ }^{230}$ Iliada, XXII 257.

${ }^{231}$ Odisea, $\times 15$.
} 
central en los primeros versos, como ocurre en el caso de la Ilíada, la Odisea, la Pequeña Ilíada y la Tebaida, en las que a un verbo de exhortación se añade un objeto que es adjetivado de manera repetida, uso presente también en los himnos homéricos por su especial ligazón con la poesía épica, y que será recogido, solo en lo que al empleo de los epítetos se refiere, por la posterior poesía, aunque con esta estructuración del periodo únicamente está presente en dicho estadio épico y no se presenta siquiera en Hesíodo, en el que la complejidad es mayor.

Es de destacar que el estilo en espiral de estos elementos presenta como una de sus características principales que los citados elementos están en gran manera cohesionados. Como demuestran los ejemplos de paralelos recogidos por Parry y Lord, los elementos adjetivales expresados por los participios y los periodos relativos se presentan íntimamente ligados por construir una unidad creada por la suma de los constituyentes del verso, de modo que, al igual que ocurre en el estilo progresivo, la cohesión del pensamiento expresado se ve reforzada por la referencia al término clave en uno y a la continua vuelta a los diferentes conceptos claves en el otro. Así si comparamos ambos estilos, valiéndonos del fragmento de Ferécides DK 7 B 2 antes citado y de los primeros versos del proemio de la Ilíada, se observará la idea de la detención del pensamiento expresado:

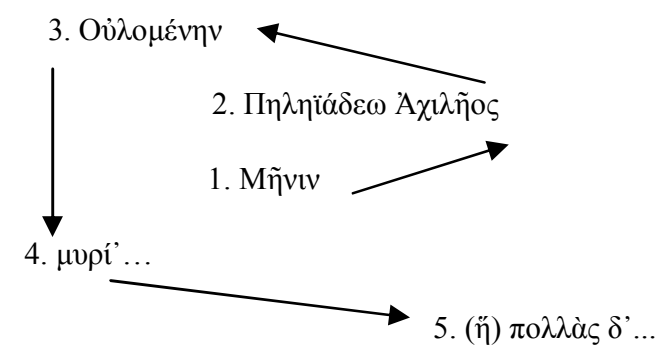

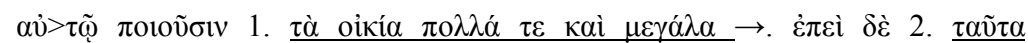

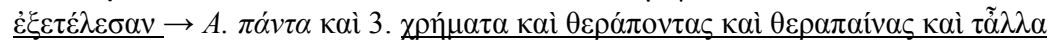

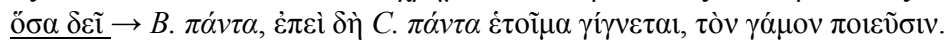

Como hemos visto con más detalle, es esta una de las características fundamentales de la «retórica oral», en la que es necesario que se establezca 
una relación solidaria entre sus diferentes elementos para que la composición se presente como un todo que garantice la fácil supervivencia de la obra literaria en un contexto donde el único soporte es la memoria.

Esta primera parte del proemio da paso a una segunda de mayor extensión, que en el caso de la Ilíada llega hasta el verso 56, y en el de la Odisea hasta el 25. En esta última obra, se observa con mayores dificultades la estructuración general de las primeras decenas de versos, y ello se debe a que la complejidad ${ }^{232}$ en la narración es superior, lo que pone de manifiesto el mayor avance en capacidad narrativa de este poema. Los saltos temporales así como la división de la narración ocasionada por lo que se conoce como la Telemaquia dan lugar a una cierta desvirtuación de la estructura, pero, a pesar de ello, se puede seguir la línea que enlaza proemio y narración propiamente dicha. Tras la inicial invocación y los procesos de complementación propios del estilo acumulativo en los versos 1 a 5 , se presenta, dada la complejidad narrativa del poema, una breve digresión referida a los compañeros de Odiseo en los versos 6 a 9, que apunta, siguiendo la expresión de «arrows» de Lang, a lo que se contará en los cantos VIII-XIII. ${ }^{233}$ En el verso 10 se recoge un elemento que apunta de nuevo al verbo inicial del poema en lo que podemos denominar una segunda invocación, con la presencia del término $\tau \tilde{\omega} v \dot{\alpha} \mu o ́ \theta \varepsilon v$, correspondiente al verbo inicial, ${ }^{234}$ recogido por cỉ $x \dot{\varepsilon}$ y que de nuevo se construye en espiral en torno al término clave inicial. Los versos 11 a 25 nos refieren el motor de la acción narrativa, con la situación de Odiseo en la isla de Calipso y la causa verdadera, la inquina del dios Poseidón, para pasar después con un elemento temporal, है $v \theta \alpha$, a la narración de la asamblea de los dioses. Gráficamente, sería como sigue:

${ }^{232}$ De Jong, 2001, p. 5, habla de mayor vaguedad en la Odisea frente a la Ilíada, por cuanto frente a la cólera se habla del «hombre» término menos concreto, si bien a nuestro entender eso no es vaguedad: la Odisea es el poema del «hombre», como la propia de Jong afirma 2001, p. 6, concepto que ha de ser entendido como referencial: como antes decíamos, es el hombre por antonomasia.

${ }^{233}$ Nótese además cómo la narración pasa de la asamblea de los dioses a la narración de Telémaco, cantos I a IV, y es de nuevo la asamblea de los dioses la que nos lleva a la narración de Odiseo en el canto V. La plasticidad está en consonacia con la idea al comienzo expresada, y da cuenta del engarce que supone la Telemaquia, de modo tal que se superpone a la narración de Odiseo:

Proemio [Asamblea de los dioses $\rightarrow$ Telemaquia I-IV] Narración conjunta XIII-XXIV [Asamblea de los dioses $\rightarrow$ Odiseo VIII-XVIII]

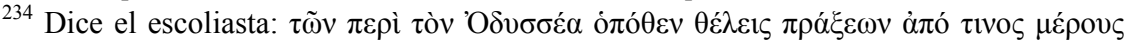

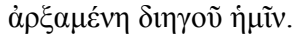


1. Invocación

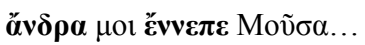

1a. Complementación al término clave

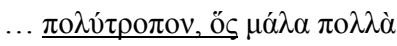

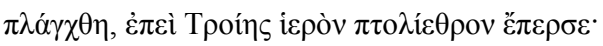

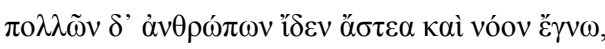

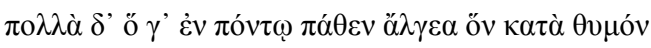

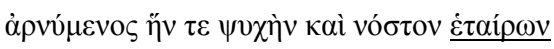

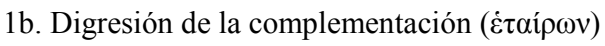

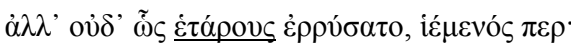

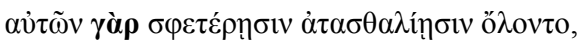

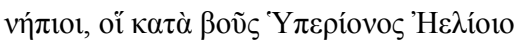

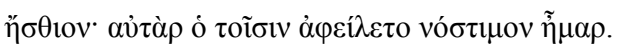

2.Invocación secundaria

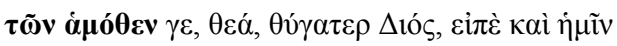

2a. Causa de la narración

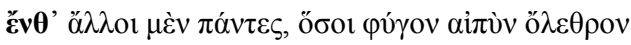
ойко है $\sigma \alpha \nu . .$.

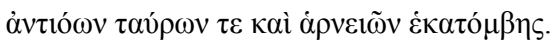

2b. Primera escena: La asamblea

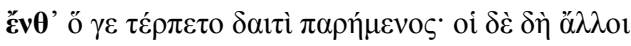

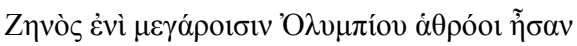

En negrita se señalan los términos clave para la estructuración del texto, de modo que con su seguimiento se puede distinguir cómo el aedo en ningún momento pierde la línea central de la narración que acaba de iniciar, e introduce todos aquellos aspectos necesarios para la cabal comprensión de la narración sin abandonar su objetivo; y, lo que es más importante, de nuevo la estructura global de estos primeros 26 versos responde al esquema estilístico 
en espiral: partiendo de la exhortación inicial a cantar sobre el hombre, por medio de adverbios temporales que estructuran y cohesionan el pasaje hasta el inicio real de la narración en el verso 27 , todos los elementos giran no solo formal, sino también conceptualmente, en torno al término clave, del que dependen incluso las digresiones. Se debe señalar además que la repetición del verbo $\varepsilon i \pi \varepsilon ́$ en el verso 10 se debe a la inclusión de la digresión identificada como $1 \mathrm{~b}$, que supone una demora más en el objetivo del poeta, ${ }^{235}$ como señala de Jong, ${ }^{236}$ y que se ve justificada por la necesidad de proporcionar datos sobre la soledad del héroe, y por oponer la $\alpha \tau \alpha \sigma \theta \alpha \lambda i ́ \eta$ de los compañeros a la grandeza del este. Se ha de señalar además que el apartado que nosotros denominamos «Causa de la narración» ha sido entendido por de Jong como el comienzo propiamente dicho de la narración, lo que le lleva a hablar de movimientos de avance, o de retroceso en el caso de la Ilíada, pero, a nuestro entender, la autora no considera la necesidad que tiene el poeta de precisar los antecedentes antes de iniciar la narración, de modo que lo que se hace es dar cuenta del problema, en el caso de la Odisea, el no regreso de Odiseo, que da principio a la narración. ${ }^{237}$

La misma estructura, pero aún, si cabe, más clara, se nos presenta en la Ilíada:

\section{Invocación}

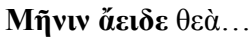

${ }^{235}$ De Jong, 2001, p. 5, habla de Ringkomposition, a nuestro entender muy laxa; Notopoulos, 1949 , p. 18, afirma que este elemento se refiere a la momentánea actualización del poema según la audiencia, lo que nos parece excesivo: simplemente, se refiere al verbo inicial, como señala van Groningen, 1946, p. 286.

${ }^{236}$ Cf. de Jong, 2001, p. 7; obsérvese además, como indica la autora, la oposición existente entre los adjetivos aplicados a Odiseo en los primeros versos y a sus compañeros: de nuevo un fenómeno de cohesión por polarización.

${ }^{237}$ Cf. de Jong, 2001, p. 8. Este error se debe en parte a la consideración de que la narración había «avanzado» hasta el momento en que desaparecen los compañeros de Odiseo, aunque, como señala la propia autora, esos versos constituyen una digresión. En apoyo de esta idea acuden paralelos tardíos que demuestran que en época alejandrina se entendía así la estructuración del comienzo de los poemas épicos: cf. Apolonio de Rodas, versos 5 a 18, en que se explican los motivos que condujeron a Pelias a organizar la expedición de la Argos, con la particularidad de que la aemulatio lleva al poeta a amplificar la narración con un largo catálogo que, en virtud de la idea de cohesión aquí defendida, pone de manifiesto la naturaleza no oral de la épica alejandrina. 
1a. Complementación al término clave

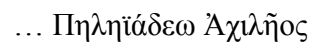

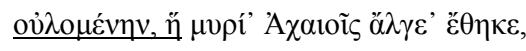

oì

2. Causa de la narración

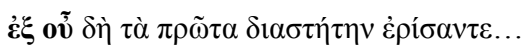

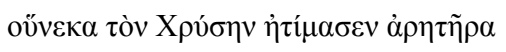

A $\tau \rho \varepsilon \hat{i ̂ \delta} \eta \varsigma^{\circ . . .}$

2a. Causa de la narración: Crises

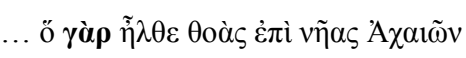

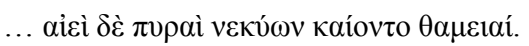

3. Primera escena: la cólera

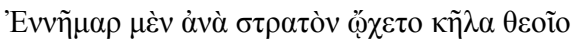

La mayor simplicidad compositiva del proemio de la Ilíada se debe a la falta de digresiones como las presentes en la Odisea, en tanto que, aun a pesar de la mayor extensión en versos del proemio, la cohesión es mayor por cuanto el pensamiento permanece siempre en torno a la idea inicial. De nuevo aparecen marcas como $\dot{\varepsilon} \xi$ ỡ ${ }^{238}$ o $\dot{\varepsilon} v v \tilde{\eta} \mu \alpha \rho$, que remiten al verbo inicial; de nuevo, y al igual que ocurría con la complementación del término clave, la estructuración general del proemio en su totalidad responde a un

${ }^{238}$ Kirk, 1985, ad loc., p. 53, apunta a una doble interpretación de este elemento adverbial, referido bien al momento en que se cumple la voluntad de Zeus, o al verbo inicial

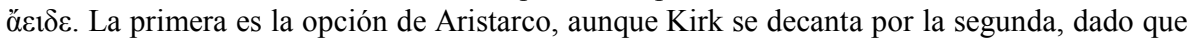
se busca que la musa cante desde el enfrentamiento. A ello nos permitimos añadir el paralelo

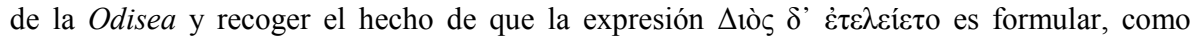
señala Parry, 1971, p. 302, y aparece en Odisea, XI 297, cerrando un verso en situación

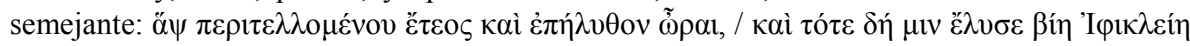

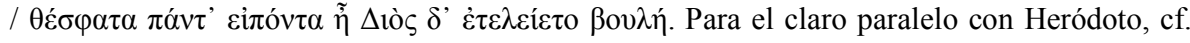
infra y Bakker, 2002, p. 6. 
desarrollo en espiral en torno a una idea central, a la que se añaden digresiones para aportar datos externos a la narración del proemio, pero que recogen información necesaria para la comprensión de lo narrado y cuyo marco temporal cae fuera del propio de la epopeya. Es este un rasgo, la exposición de detalles en el transcurso de la composición, que, según indicó tiempo atrás Notopoulos, responde a la naturaleza oral de la épica, a la interacción del autor con su público, de un poeta que, pertrechado con sus recursos, añade todo aquello que cree necesario para la comprensión de su obra. $^{239}$

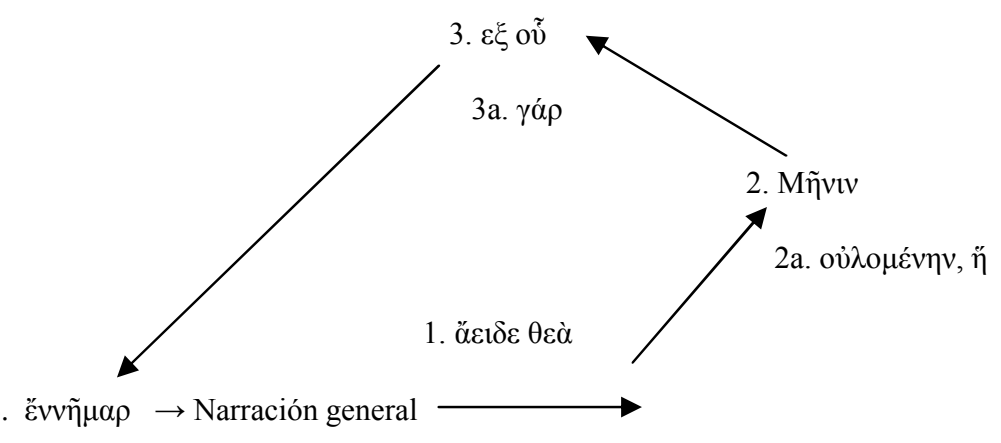

O en el caso de la Odisea:

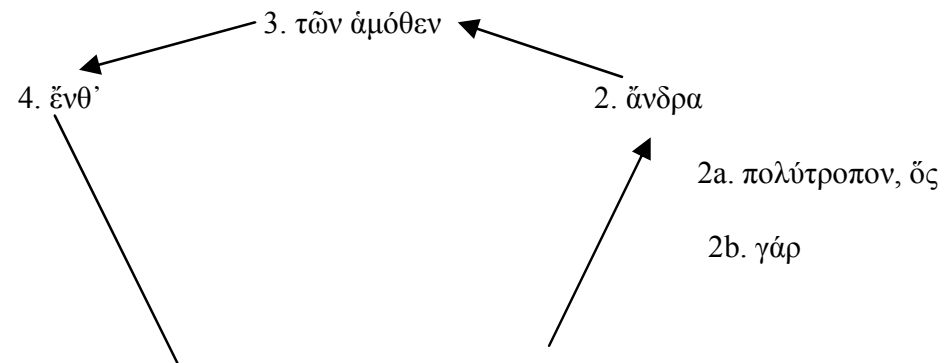

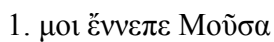

5. ع̈v $\theta^{\prime} \rightarrow$ Narración general $\rightarrow$

${ }^{239}$ Cf. Notopoulos, 1949, p. 16 y ss., donde se aduce el ejemplo de los kirguisos y la adecuación de su narración al público del momento. 
Así pues, el proemio en toda su extensión se articula en espiral en torno al concepto principal que da lugar al comienzo de la obra; la narración parte de ese concepto y se desliza con fluidez sin abandonar su objetivo, designado, insistimos, por el término clave, aunque se presenten digresiones, de modo que las dos estructuras se superponen de manera perfecta.

El examen de esta sección de las epopeyas, aunando la crítica compositiva de Parry y de quienes trabajaron en su estela con la aplicación de los más recientes estudios narratológicos, nos permite dudar del concepto de estructuración inorgánica, a la que nos referíamos al comenzar esta parte.

Los mecanismos puestos de relieve en nuestro estudio tendrán una supervivencia limitada más allá de la épica: la íntima ligazón entre forma y contenido dotaba a estas estructuras de una caracterización tal que especializaba sus usos para unas obras muy determinadas: hablar de la cólera, del hombre, astuto, que recorrió el mundo, suponía traer a la memoria un universo heroico cuya significación era ya parte de un marco literario muy determinado en época de Heródoto, y por ello solo se recurrirá a su empleo en circunstancias muy delimitadas, buscando además unas reminiscencias muy concretas que subyacen de manera clara en la configuración de la perspectiva literaria de las obras historiográficas y que están muy lejos del mundo que nos presenta Hecateo de Mileto. En definitiva, el universo de los primeros proemios en prosa, con una tendencia más «poética» y otra marcada por la aparición de la citada fórmula ó $\delta \varepsilon i ̃ v \alpha$

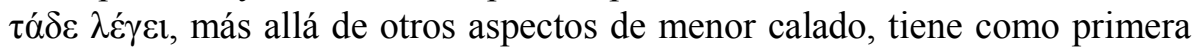
consecuencia la falta de esos recursos plásticos de la gran tradición literaria griega. Estamos ante dos tradiciones necesariamente paralelas que fomentarán y perfilarán la naturaleza reflexiva y literaria de la historiografía antigua, y cuya imbricación dará lugar precisamente al género literario que conocemos como historiografía. Una vez perfiladas estas constantes, podemos aproximarnos a la figura de Hecateo. 


\subsection{Hecateo de Mileto}

La tradicional denominación de Heródoto como pater historiae debida a Cicerón fue comúnmente admitida hasta la gran época de la filología alemana, en la que, con la figura de Eduard Meyer y después con la de Jacoby, se situó como princeps del género en Grecia a Hecateo. Seguramente, fueron criterios solo conceptuales los que llevaron a esta afirmación, porque, tanto el proemio como los textos más enjundiosos de las Genealogías se sitúan todavía en la más pura tradición de los primeros prosistas griegos conservados, lejos de las perspectivas artísticas que los antiguos exigían a la historiografía, como ha señalado recientemente Nicolai. ${ }^{240}$

\subsubsection{EL ESTILO DE HECATEO DE MILETO}

El rétor Demetrio, al hacer examen de los tipos de expresión, nos cita

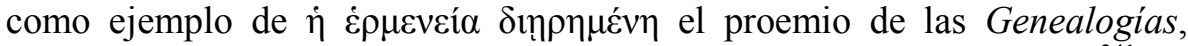
como texto con elementos sueltos y sin duda no unidos entre ellos. ${ }^{241} \mathrm{El}$ proemio presenta la estructuración habitual en los conocidos del período, con una introducción semejante a la que, como vimos, Diels y Wilamowitz propusieron para la obra de Demócrito, para pasar a una formulación

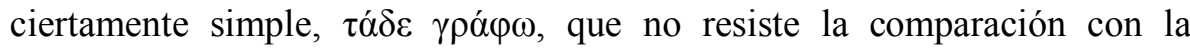
formulación, por ejemplo, de un autor como Protágoras. En cierta manera, parece segura la ya vieja afirmación de Haberle ${ }^{242}$ respecto a los discretos

${ }^{240}$ Cf. Nicolai, 1997, p. 143 y ss., especialmente p. 146 y ss.: «si può dire che Ecateo non ha mai goduto di una posizione particolare nel campo della storiografia: giudicato stilisticamente inferiore, egli non poteva contendere il titolo di padre della storia all' omericissimo Erodoto, ma veniva incluso nel vasto limbo dei precursori che scrivevano in modo disadorno».

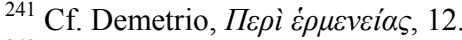

${ }^{242}$ Cf. Haberle, 1938, p. 22. 
usos poéticos de Hecateo en comparación con otros autores del periodo, algo que Lilja ${ }^{243}$ apoyó, y que a nuestro entender es correcta: la propia tradición antigua nos recuerda que, por norma general, se tenía a estos autores como no literarios, y ello los excluía de la tradición historiográfica. ${ }^{244}$ Estamos de nuevo ante la oposición entre oral y escrito, pero en un estadio de desarrollo de la prosa no oral, como veremos, aún muy temprano.

Y es que más allá de esta consideración, la observación de Demetrio es clara: dejando atrás la oposición que el rétor presenta entre el estilo de Hecateo y el de un Isócrates o un Gorgias, y teniendo en cuenta las observaciones que hicimos respecto a la primitiva consideración aristotélica, comprobamos la ausencia de esos elementos de cohesión propios de la cultura oral y que hacen de esta obra una clara creación escrita, lo que se ve apoyado por el uso de expresiones personales relativas a la opinión del autor, ${ }^{245}$ en un nítido posicionamiento respecto a la anterior tradición, como señaló Tozzi. ${ }^{246}$ Tras la afirmación inicial, se abre una oración introducida por $\gamma$ ó $\rho$, un uso muy común en los proemios de este carácter, salvo por el caso de que incluso en esta frase aparece la $\delta$ ó $\xi \alpha$ particular del autor, concepto que, por otra parte, se manifiesta a lo largo de la obra, a la vista de los fragmentos conservados, según apunta Tozzi, ${ }^{247}$ lo que perfila esa importancia conceptual que caracteriza a los proemios.

Respecto al empleo de $\tau \varepsilon \ldots$... $\alpha$ í, Lilja advirtió de su uso enfático ${ }^{248}$ y lo

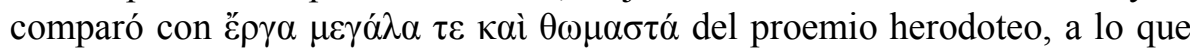

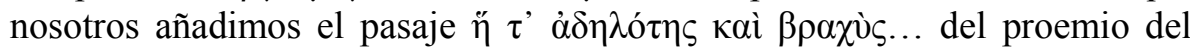
Sobre los dioses de Protágoras, o el pasaje del proemio de Filolao antes

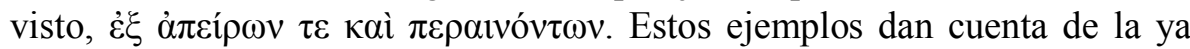
conocida naturaleza de fuerte unión que presenta esta estructura, pero no creemos que pueda argumentarse ninguna conexión entre los diferentes ejemplos.

${ }^{243}$ Cf. Lilja, 1968, pp. 23 y 32.

${ }^{244}$ Cf. Nicolai, 1997, p. 143 y ss. Como señala el propio Nicolai, es en la Suda donde a

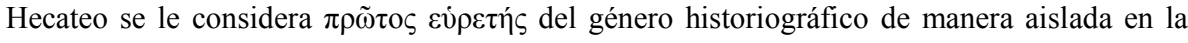
Antigüedad.

${ }^{245}$ Cf. West, 1991b, p. 145, en referencia a la no universalidad de la obra de Hecateo, asimilada a unas esferas reducidas, como indicó Turner; cf. además FrGrHist, 1 F 1, Komm.

${ }^{246}$ Cf. Tozzi, 1964, p. 106.

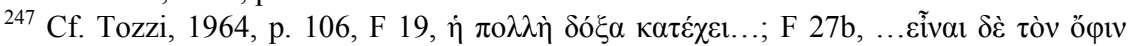

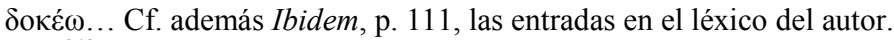

${ }^{248}$ Lilja, 1968, p. 23, nota 40. 
Aun a pesar de la poca extensión del proemio, podemos distinguir tres partes, en una forma que hemos de tener presente, principalmente porque tendrá cierta fortuna en la futura historiografía:

1) Fórmula introductoria.

2) Afirmación y $\delta o ́ \xi \alpha$ personal.

3) Justificación de la afirmación y $\delta$ ó $\xi \alpha$ personal.

La configuración del proemio de Hecateo nos lleva por momentos al mundo de la prosa y los proemios antes explorados, dejando atrás los recursos de mayor complejidad observados en la épica. Ello, unido al carácter paradigmático del texto como la mejor justificación de la denominación de pater historiae, hace necesario que los datos derivados del análisis se pongan en clara relación con el estudio meramente intelectual del mismo.

Se ha de insistir además en que la naturaleza de los rasgos que estamos describiendo lleva claramente a señalar la publicación de esta obra de modo escrito y no por medio de una performance oral, como apuntamos en el examen de los proemios en prosa, si bien ello no implica la imposibilidad de lecturas a viva voz, como señaló Corcella. ${ }^{249}$ El perfilado de estas ideas será mucho más nítido en el estudio de Heródoto.

\subsubsection{EL PENSAMIENTO DE HECATEO}

El análisis del fragmento conservado se ha de hacer con la seguridad de que no estamos ante un texto excesivamente mutilado: la comparación con otros proemios de la época nos ha demostrado que seguramente nos falte la justificación de la afirmación inicial, pero tenemos la certeza de que estamos ante el pensamiento completo de Hecateo.

Este pequeño fragmento ha despertado voces opuestas que lo han convertido en el inicio del pensamiento racional aplicado al pasado -entendido este término en el sentido más laxo que podamos aplicarle-, o que defienden lo contrario, sin que esta segunda postura conlleve una definición que vaya más allá de la simple negación de la primera.

\footnotetext{
${ }^{249}$ Cf. Corcella, 1996, p. 300 y ss.
} 
La necesidad de articular el pensamiento historiográfico en una progresión culminante ${ }^{250}$ que detenga su evolución en Tucídides hacía imprescindible crear una serie de pasos intermedios entre la épica y el primitivo Heródoto. Esta evolución situó a toda la generación de logógrafos, como los clasificó Creuzer, ${ }^{251}$ en el espacio que llevaba al historiador de Halicarnaso, y a Hecateo en la proedría de todos ellos.

Por un momento hemos de olvidarnos de la posterior construcción de Jacoby que hacía de Hecateo el predecesor inacabado de Heródoto, ${ }^{252}$ y valorar en realidad qué se esconde detrás de su definición como un racionalista, dado que precisamente esta afirmación se ha convertido en la justificación del título de pater historiae.

El positivismo de buen cuño, con Eduard Meyer y de Sanctis a la cabeza, consideró la afirmación con la que se abre el proemio como una declaración de intenciones en lo que se refiere a la racionalización del mito. ${ }^{253}$ Esta tendencia ha sido matizada de maneras muy diferentes, de modo que Fertonani hablaba incluso de la simple aplicación del método de la verosimilitud, ${ }^{254}$ es decir, de la reconsideración del pasado mítico en atención a su congruencia o incongruencia, sin que ello suponga la negación del mito o de la divinidad, ${ }^{255}$ en una obra en la que lo teogónico es escaso. ${ }^{256}$ Sea como fuere, Fertonani se sitúa en una línea que parte de la idea apriorística de considerar a Hecateo un historiador con métodos de

${ }^{250}$ Cf. Starr, 1968, p. 3, «Also implicit in my use of the Word "awakening" [sc. en el título del libro] is a firm belief that history did not suddenly emerge as a simple reflex to Athenian pride in empire, the jubilation of the Greeks over their almost miraculous defeat of the Persian onslaught, or any other single characteristic of fifth-century society». Era éste un camino además de absoluta falta de sentido histórico, cf. p. 9.

${ }^{251}$ Cf. Creuzer, 1845, p. 265 y ss. Cf. Lendle, 1992, p. 10, y Bertelli, 2001, p. 94.

${ }^{252}$ Construcción que se benefició de la indefinición que presentaba en la Antigüedad la figura de Hecateo, que, como señalaba Nenci, 1955, p. XXIII, pasa de logógrafo a geógrafo, o a historiador según las épocas y los contextos.

${ }^{253}$ Cf. de Sanctis, 1933, p. 1: «Non corre dubbio che, affermando così solennemente i diritti della ragione a fronte de la tradizione, Ecateo ha fondato la scienza storica». Cf. también Lasserre, 1976, p. 115, quien resume el asunto en una mezcla de empirismo, racionalismo y crítica histórica.

${ }^{254}$ Cf. Fertonani, 1952, p. 20.

${ }^{255}$ Para la unión de estos aspectos cf. Gehrke, 2011, p. 45.

${ }^{256}$ Cf. Fertonani, 1952, p. 20. 
historiador, ${ }^{257} \mathrm{y}$, si bien la conclusión es en cierta manera extraña, no es del todo ajena a la que, a nuestro entender, es la vía para la comprensión de Hecateo. El propio Fertonani afirma que «resulta che il "racionalismo" di Ecateo consiste nella presa di posizione della ragione di fronte ad una supina accetazione del mito». ${ }^{258}$

Esta afirmación es fruto de una paradoja como es el hecho de que el arranque de la historiografía racional se haga con una valoración de los antiguos mitos. ${ }^{259}$ De este modo, el racionalismo, o verosimilitud, se funda únicamente sobre su propia esencia metodológica, que es aplicada con criterios de historiador a un material que no es compatible con esos medios, de ahí la necesidad de defender el valor metodológico de Hecateo, ${ }^{260}$ dado que el contenido se mantiene dentro de la tradición mítica.

Más allá de todas estas interpretaciones, más determinadas por su inclusión en un sistema que trata de explicar una evolución ideológica que al propio autor, a nuestro entender, es necesario tener presente que, al menos en este estadio, se han de tomar en consideración las dos obras del autor, que necesariamente constituyen una unidad de pensamiento. A pesar de que aunando ambas tengamos un cuerpo relativamente grande de fragmentos, parece complicado determinar los contornos del pensamiento de Hecateo, ya que será una constante la tendencia a desarrollar las ideas expuestas de forma en cierta manera criptográfica en el proemio en el cuerpo de la obra.

Dado este problema, parece interesante determinar los contornos ideológicos que determinan la aparición de la obra $\mathrm{y}$, en definitiva, identificar el motivo que lleva a Hecateo a la redacción de sus obras. En este sentido, creemos que una idea que ya hemos explorado en el ámbito formal ha de ser tenida de nuevo en cuenta, la inclusión de las obras que nos ocupan dentro de un género muy heterogéneo, del que desde Creuzer se trató de aislar a los logógrafos de manera intencionada. Esta separación, basada únicamente en la naturaleza temática, no permite ver la realidad que supone la cercanía intelectual de Hecateo con los habitualmente denominados

\footnotetext{
${ }^{257}$ Cf. Fertonani, 1952, p. 20. Esta idea lleva aparejada la también apriorística de considerar la labor del historiador como la salvaguarda del pasado, cf. p. 29, «Con un tale procedimiento si tentava di salvare la saga eroica transformandola in storia».

${ }^{258}$ Cf. Fertonani, 1952, p. 27.

${ }^{259}$ Compatibilidad de mito y religión con la historia se puede ver también en Starr, 1968, p. 17.

${ }^{260}$ Paradoja que llevó a Nenci, 1955, p. XXIV, a señalar la existencia de un necesario fondo histórico en los mitos, cosa que complica aún más el idealizado paso del mito al logos.
} 
presocráticos, con los que entra en concurrencia e, incluso, en conflicto. Nenci nos recordaba que la obra de Hecateo gozó, a tenor de los contactos entre diferentes autores en su época, de una rápida difusión, ${ }^{261}$ dado que Heráclito lo incluye en una lista en la que están presentes Hesíodo, Pitágoras y Jenófanes. ${ }^{262}$ Tras este primer periodo de difusión, que, aunque amplia, ha de considerarse dentro de los límites propios de la época, asistiremos ya en época clásica a un relativo abandono de estos autores, siendo precisamente Hecateo, de manos de Heródoto, uno de los mejor conocidos. ${ }^{263}$ Parece interesante, dada esa hetereogeneidad, explorar las razones por las cuales, más allá del contenido, Hecateo no es un presocrático.

La creación de un sistema unificado y consistente de pensamiento por parte de autores como Heráclito es, simplificando quizá en exceso, una de las razones por las que se asume, sin ningún tipo de dudas, su pertenencia al ámbito filosófico. Sin embargo, y en lo que se refiere a Hecateo, los fragmentos conservados no ofrecen pautas para la reconstrucción de un sistema como el que veremos en futuros autores historiográficos. En este sentido, el fragmento heracliteo explorado por Nenci es fundamental: ${ }^{264}$

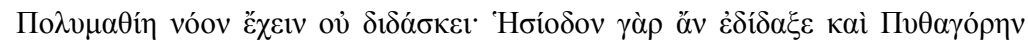

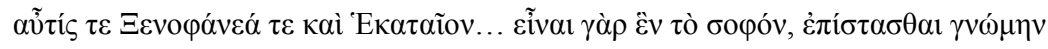

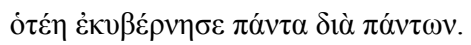

El propio Nenci ${ }^{265}$ consideraba que estábamos ante un ataque a la falta de $\lambda$ ó $\gamma$ o $\varsigma$ en la obra de Hecateo, a la acumulación organizada de saberes al modo tradicional de un Hesíodo en los Erga, y seguramente deba ser ésta la interpretación del proemio de Hecateo. Gitti ${ }^{266}$ afirmaba que la intención de Hecateo no era decir la verdad, sino que el proemio era la declaración de un método: «delle cose che io tratto $(\gamma \rho \alpha ́(\varphi \omega)$ e che espongo nella mia opera

${ }^{261}$ Cf. Nenci, 1949, p. 110.

${ }^{262}$ Cf. Heráclito, DK 22 B 40 y 41. Cf. además Kirk, Raven y Schofield, 1987, p. 266 y ss.

${ }^{263}$ Cf. Pearson, 1939, p. 9, para consideraciones generales.

${ }^{264}$ Cf. Heráclito, DK 22 B 40 y 41: «El saber sobre muchas cosas no enseña a tener juicio: pues no enseñó a Hesíodo, ni a Pitágoras, ni a Jenófanes ni a Hecateo [...] pues una sola cosa es la sabiduría, el conocimiento del diseño que gobierna todo por medio de todo».

${ }^{265}$ Cf. Nenci, 1949, p. 116.

${ }^{266}$ Cf. Gitti, 1952, p. 391. 
( $\tau \alpha \dot{\delta} \delta \varepsilon$ ) io dó l'interpretazione che mi sembra la vera». Si bien el propio Gitti, seguramente por la fecha de la publicación de su trabajo, trata de suavizar esta afirmación, ${ }^{267}$ estamos, simplemente, ante la interpretación del proemio de Hecateo en términos de subjetividad. En la misma línea, von Fritz daba con una de las líneas clave de la interpretación de los proemios historiográficos y de la historiografía misma al afirmar: «Die Geschichte und die beschriebende Geographie haben es unter allen Wissenschaften am eigentlichsten mit dem ganz Individuellen zu tun». ${ }^{268}$

Esta tendencia interpretativa en la que el individuo goza de una posición central es fundamental para comprender la conexión existente entre el diseño que la antropología nos ofrece del saber tradicional histórico y la aparición del género en la Antigüedad. La idea de von Fritz, ${ }^{269}$ quizá en una línea más tradicional, que daba cuenta de la transmisión del pasado por medio de la poesía esconde en cierta manera la idea tradicional de transmisión del saber histórico, y la oposición a esa individualidad tiene unas consecuencias que, a nuestro juicio, no son las que habitualmente se defienden.

Guarda especial relación con este último aspecto la posible crítica a la religión. Más allá de planteamientos ilustrados modernos que separan religión y razón, y que subyacen en las afirmaciones habituales de quienes tratan de compatibilizar el tratamiento de narraciones mitológico-religiosas y el modelo racional habitualmente atribuido a Hecateo, ${ }^{270}$ ha de tenerse presente la función que estas obras desarrollarían en el contexto histórico en el que vieron la luz.

Para este aspecto, creemos que la estricta función social que asignamos a los géneros tradicionales al comienzo del presente estudio ha de ser tenida también en cuenta en el análisis del pensamiento. Obviamente, ello tiene como primera consecuencia que la habitual oposición de subjetividad, entendida como una autoafirmación con tintes políticos casi aristocráticos, ${ }^{271}$ se ha de ver sustituida por una idea de alejamiento de las tradiciones sancionadas, no precisamente en un intento de salvarlas de un olvido que no

\footnotetext{
${ }^{267}$ Así, trata de defender todavía la privilegiada posición como racionalista de Hecateo, cf. Gitti, 1952, p. 391.

${ }^{268}$ Cf. von Fritz, 1967, p. 6.

${ }^{269}$ Cf. von Fritz, 1967, p. 25

${ }^{270}$ Cf. e. g. de Sanctis, 1933, p. 13; Gitti, 1952, p. 392. Cf. también de manera clara Fertonani, 1952, p. 27.

${ }^{271}$ Así, Pearson, 1987, p. 97.
} 
es tal. ${ }^{272}$ Más allá de la simple idea de una sistematicidad racional de los elementos presentados por la tradición, algo que seguramente tiene su origen en afirmaciones como las de Hesíodo acerca de la capacidad de las musas para decir mentiras semejantes a verdades, ${ }^{273}$ parece difícil pensar en una sistematización real del contenido de las Genealogías, y en la aplicación sistemática de un $\lambda$ ó $\gamma o \zeta$, en palabras de Heráclito, a la narración contenida en la obra. En este sentido, es realmente interesante la observación de Gitti, ${ }^{274}$ quien advertía que Genealogías y Periégesis se contradicen. Este hecho, que podría parecer circunstancial, es fundamental si tenemos presente la necesaria unidad de pensamiento y obras propia de esta época. ${ }^{275}$ En todo caso, la simple idea de un racionalismo unificador requeriría de una actuación sistemática que difícilmente puede ser aplicada a lo que los fragmentos nos revelan. En último término, cuando Fowler afirmaba ${ }^{276}$ que «Hecataeus [...] simply gave his solutions to particular problems and implicitly defied his readers to prove him wrong», no se alejaba demasiado de la realidad de la obra. Si a ello unimos además la dificultad para definir un concepto claro de mito en oposición a razón, ${ }^{277}$ la interpretación del proemio de Hecateo adquiere un sentido muy diferente al habitual.

El proemio de Hecateo no es historiografía, no responde al diseño de un modelo de comprensión de la realidad, pero en tanto que presentación de las

${ }^{272}$ Cf. Fertonani, 1952, p. 29: «Con un tale procedimento si tentava di salvare la saga eroica transformandola in storia». Cf. Canfora, 1972, p. 10 y la sección relativa al siglo IV para el mantenimiento oral de la historia hasta épocas tardías.

${ }^{273}$ Cf. Hesíodo, Teogonía, 27. El propio Pearson, 1987, p. 98, conecta el proemio de Hecateo con este pasaje. Para lo tradicional del denominado «sueño de Hesíodo», cf. West, 1982, p. 158 y ss.

${ }^{274}$ Cf. Gitti, 1952, p. 396. Las contradicciones, que afectan a la geografía de Sicilia y a la narrativa de Heracles son estudiadas por Pearson, 1987, p. 45 y ss., quien en p. 98, les resta importancia. Sea como fuere, y más allá de problemas de cronología, lo importante es la existencia de lagunas en la narración relativa a Heracles, que probablemente ocupaba todo un libro.

${ }^{275}$ Lo que ha causado algún problema de asignación de fragmentos a una u otra obra; cf. para todo ello Caspari, 1910, p. 238. No entramos, claro está, en el estéril debate sobre la autenticidad de la Periégesis.

${ }^{276}$ Cf. Fowler, 2001, p. 146.

${ }^{277}$ Cf. Most, 1999, p. 25 y ss. Hartog, 1999, p. 184, observaba también que en el propio proemio Hecateo emplea el verbo $\mu v \theta \varepsilon i \tau \alpha l$, que Gitti, 1952, p. 390, entiende como "proclamar", lo que se aleja de la semántica del término, relacionada con "contar" más que con "hacer público". 
opiniones personales y no sometidas al modelo tradicional imperante ${ }^{278} \mathrm{y}$, lo más importante, gracias a su determinación de dos de los ejes fundamentales que habremos de tener presentes en estadios posteriores del género, podemos considerarlo sin lugar a dudas un precedente necesario.

El trabajo geográfico de Hecateo es fundamental para su tiempo, ${ }^{279}$ como lo es la apertura de los intereses etnográficos, que se han de entender en íntima relación con su pensamiento historiográfico. ${ }^{280}$ Lo importante no es la determinación de un pensamiento racional, o la inexistente separación entre mito e historia, ${ }^{281}$ sino el emparejamiento solidario de dos ejes interdependientes, ${ }^{282}$ en contra de lo que pensaba Jacoby, tiempo y espacio, que determinarán el futuro ámbito de actuación de los historiadores. Hecateo no es, pues, el padre de la historiografía, ${ }^{283}$ dada la falta de un $\lambda$ ó modelo intelectual que articule su obra, ${ }^{284}$ pero presenta ya el escenario en el que se articulará el pensamiento de los autores posteriores. Si hablábamos en otra sección de que estamos ante un género heterogéneo que dará lugar a la historiografía cuando acoja recursos literarios orales, ahora, en lo relativo al pensamiento, hemos de señalar que es en el seno de ese mismo género heterogéneo donde aparecerán los primeros condicionantes que darán lugar a la historiografía.

${ }^{278}$ Así, ya de Sanctis, 1933, p. 14.

${ }^{279}$ Cf. Heidel, 1943, p. 262 y ss. Tambien Jaeger, 2000, p. 345.

${ }^{280}$ Cf. Heidel, 1943, p. 264.

${ }^{281}$ Así, erróneamente, Heidel, 1943, p. 265.

${ }^{282}$ Así Strasburger, 1968a, p. 418.

${ }^{283}$ Cf. Nenci, 1951, p. 53. Recientemente cf. Nicolai, 1997, p. 143 y ss., en términos estilísticos.

${ }^{284}$ Idea en cierto modo expresada por Nenci, 1951, p. 55: «[...] l'interesse di Ecateo è rivolto all' accetamento di una versione sola. Egli crede perciò nella realità del fatto anche miracoloso, anche inverosimile, puiché unívocamente testimoniato». Esta idea recoge en último término mucho del autor como simple transmisor selectivo, quizá enfatizada por el

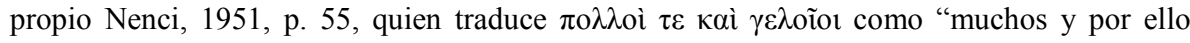
ridículos", lo que en cierta medida falsea el texto. 


\subsubsection{CONTEXTO LITERARIO Y SOCIAL DE HECATEO}

Los datos examinados insisten en la idea de que Hecateo pertenece todavía a un mundo no asimilable a lo que entendemos como género literario historiográfico. Esa unión con idéntica importancia de lo literario y lo reflexivo comparece en la obra de Hecateo de forma ciertamente desigual, al menos por lo que podemos colegir de los pocos fragmentos de suficiente enjundia conservados.

Hecateo se sitúa en un mundo cultural prodigioso, nacido al calor de una fuerte efervescencia cultural que cristaliza en lo que tradicionalmente se conoce como el milagro jonio, pero hemos de insistir en la necesaria moderación a la hora de examinar estas ideas, en ocasiones fuertemente ligadas a ambiciones más propias de la crítica moderna que a los tiempos de la remota especulación intelectual griega. Hay un abismo que separa a Hecateo de lo que podría ser una narración oral en prosa, y todavía falta mucho para llegar al refinamiento literario perfectamente engrasado de, por ejemplo, una epopeya. Nada hay en el proemio, cuya importancia en este aspecto nunca está de más recordar, que nos haga presentir un desarrollo estructural de peso literario semejante al que se puede observar en Heródoto, y ello es seguramente la mejor razón para convertir a Hecateo en el máximo representante de la prehistoria de la historiografía griega. Es su fuerza intelectual la que nos lleva al escenario prodigioso de la polémica casi agonal de los presocráticos, a una literatura que poco a poco adquiere importancia ante los ojos del moderno y que necesariamente, dadas sus limitaciones formales, comparece en ambientes y contextos muy diferentes a los que habitualmente se asumen para el mundo de la literatura arcaica y clásica griega. La incipiente prosa griega no oral tiene en su haber el origen de la reflexión individual y en su debe la dificultad de difundir esos mensajes meramente individuales y subjetivos que tan poco tienen que ver con la denominada enciclopedia tradicional. La opinión de Hecateo sobre los mitos, la reflexión sobre los dioses de Protágoras o las disquisiciones sobre la ả $\rho \chi \eta ́$ son cuestiones que, sin rozar lo irreverente o subversivo, tienen poca cabida en ámbitos literarios como los que presenta la literatura oral. El desajuste es claro, y estamos ante una tendencia que se separa de manera nítida incluso 
de la prosa oral, cualquiera que fuese su naturaleza precisa, ya que los datos que la antropología comparada nos ofrece sitúan, una vez más, esta prosa junto a la poesía oral. El nuevo renacer de la prosa conlleva necesariamente la armonización de los recursos que pudiesen heredarse de una tradición centenaria, como era la de la poesía y la prosa oral griega, con los retos que se imponían en los nuevos contextos y con las nuevas ideas. Y ello no es precisamente poco, dado que dibujará, quizá por tiempo limitado, un tipo de literato de perfiles realmente seductores y de una influencia nunca lo suficientemente valorada. Los círculos literarios en los que se moverán estos autores, siempre marcados por esa fuerza innovadora en lo que a las ideas se refiere, son una realidad que conoceremos mejor en tiempos de Heródoto, pero seguramente constituyen la mejor prueba de que la separación entre la filosofía, la primitiva historiografía o la simple reflexión individual es una cuestión propia de clasificaciones modernas y no de la realidad del momento histórico que nos ocupa. ${ }^{285}$

Todo ello, en definitiva, tiene una conclusión más que clara en lo que se refiere a la imposibilidad de hacer de Hecateo un pater historiae: estamos ante una tradición de reflexión seguramente tan antigua como el mundo mismo, pero el tránsito de la simple reflexión a la literatura exige un paso que todavía no tenemos presente. De este modo, y como veremos en Tucídides, la reflexión gana la carrera a la forma artística, que tiene que crearse no desde la nada, sino con el difícil reto de adaptar la tradición oral a un mundo paralelo que necesariamente está llamado a integrarse en el gran teatro literario griego.

Sim embargo ni siquiera el que fue interpretado como el catecismo fundacional de la historiografía griega puede, a nuestro entender, pasar por tal: la $\delta$ ó $\xi \alpha$ de Hecateo puede estar dotada de todo el valor transgresor que se quiera -sobredimensionado, en todo caso-, pero no constituye, a decir verdad, un elemento rector de los planteamientos de la obra como para situarnos ante una Weltanschauung lo suficientemente poderosa como para constituir el inicio de nada. Se trata, pues, de un predecesor llamado a palidecer ante el empuje y la fuerza de Heródoto, pero necesario para entender el desarrollo posterior del género.

${ }^{285}$ Un momento en el que la variedad de narraciones que por temática pueden ser denominadas historiografía es más que amplia. Para todo ello cf. Lasserre, 1976, p. 119 y ss. Creemos que es difícil, a partir de lo conservado, hablar en estos casos de historiografía, al menos como género literario. 



\section{HÉRODOTO, PADRE DEL GÉNERO LITERARIO HISTORIOGRÁFICO}

\subsection{Publicación de la obra: fechas y contexto}

Como hemos señalado, el género historiográfico no es un género tradicional, ni está ligado a una performance de carácter público que nos lleve a una cultura oral. Sin embargo, la aparición sistemática de elementos estructurales y narrativos en la obra de Heródoto que nos remiten a los recursos empleados por la literatura oral ha hecho que se dé casi por segura la concepción oral de la obra, aunque se admita después su escritura. Sin embargo, Goldhill ${ }^{286}$ nos ponía sobre aviso del muy diferente contexto de representación de la obra de Heródoto y sus predecesores, observación que necesariamente ha de ser examinada atendiendo al momento aproximado de aparición de la obra de Heródoto.

Jacoby fue el iniciador de los modernos ${ }^{287}$ estudios relativos a la fecha de «publicación» de la obra herodotea, ${ }^{288}$ proponiendo el año 430 como término post quem y los años finales de la década de los veinte como ante quem para su «publicación», ${ }^{289}$ partiendo del análisis de los pasajes de la literatura de la época en los que se rastreaban reminiscencias o parodias de las Historias, así como prestando atención a las omisiones de acontecimientos históricos conocidos por otros autores.

${ }^{286}$ Cf. Goldhill, 2002, p. 12, si bien las afirmaciones en exceso «retorizantes» han de ser, a nuestro entender, tomadas con prudencia.

${ }^{287}$ Anterior al de Jacoby fue el trabajo de Kirchhoff, 1878, quien proponía una fecha relativamente alta, entre el 449 y el 442, para la composición de, al menos, los libros I a III, con el capítulo 119 del libro III como el último redactado en la primera estancia en Atenas, cf. pp. 7, 10 y 14. Por su parte, los libros centrales son de datación incierta, en tanto que los tres últimos se sitúan en la segunda estancia en Atenas, entre el 430 y el 428, año de su muerte, cf. p. 22 y ss.; resumen, en p. 47 y ss.

${ }^{288}$ Cf. Jacoby, 1913, col. 231 y ss. Ya Röse, 1879, p. 1, proponía una fecha en torno al 425. Nótese que la idea de una obra no terminada es fundamental para el razonamiento de Jacoby, idea hoy superada. Cf. Porciani, 2005, p. 1 y ss. para una crítica reciente.

${ }^{289}$ Del año 426 a. C. hablaba Powell, 1939, p. 77. 
En el ámbito inglés, fue Wells quien pocos años después de la publicación del artículo de Jacoby desarrolló la investigación a este respecto, preludiando el futuro trabajo de Powell, en línea con los estudios analíticos de Kirchhoff, ${ }^{290}$ aparentemente sin conocer la propuesta de Jacoby. Partiendo de la peligrosa idea de que un autor es parodiado cuando es un clásico o cuando acaba de publicar su obra, ${ }^{291}$ añade el matiz de que Heródoto en persona no era el objeto de las parodias aristofánicas, sino su obra, lo que ha de ser tenido en cuenta, dado que aleja al de Halicarnaso del ideal de sabio sofístico o socrático. ${ }^{292}$ En lo que se refiere a la parodia en Acarnienses (425), reduce su peso como prueba ${ }^{293}$ al tiempo que señala con especial énfasis la presente en Aves (414). Ello hace que retrase la fecha de la muerte de Heródoto hasta pasado el año 414, y piense en una redacción tardía del libro IV, dadas las referencias al oráculo de Bacis en Aves, 962. ${ }^{294}$

Más recientemente, y abandonando la opción de valorar los silencios de la obra herodotea, como hiciera Wells, Fornara retomó el análisis de las referencias de otros autores, de nuevo las parodias aristofánicas, para rebajar la fecha al mismo año que Wells, dado que prácticamente sigue a este autor, salvo por el hecho de que expresa una mayor confianza en el uso de estos textos como prueba. ${ }^{295}$

Como respuesta a Fornara, Cobet publicó en 1977 un amplio y documentado artículo en el que defendía la fecha propuesta en su día por Jacoby de manera concluyente. ${ }^{296}$ Más allá del análisis, a nuestro entender en ocasiones dudoso, que incorpora a Eurípides y Sófocles, y que admite

${ }^{290}$ Un análisis, el de Powell, sustentado en el estudio de las referencias internas de la obra para establecer la cronología interna de las diferentes secciones; cf. Powell, 1939, p. 2 y SS.

${ }^{291}$ Cf. Wells, 1923, p. 169: «The parodies of Aristophanes then render it likely that an autor, who is quoted or referred to, if he is no an established classic, had recently published his work», lo que es más propio de un sistema editoral moderno.

${ }^{292}$ Cf. Wells, 1923, p. 171.

${ }^{293}$ Cf. Wells, 1923, p. 173: «But it will be at once obvious that the majority of them might have been familiar to an Athenian audience from many other sources, and so by themselves they prove nothing».

${ }^{294}$ Cf. Wells, 1923, p. 178; en contra, Bauer, 1878, p. 171 y ss., quien propone una fecha temprana, los años cuarenta, para el libro en cuestión.

${ }^{295}$ Cf. Fornara, 1971b, p. 27.

${ }^{296}$ Cf. Cobet, 1977, p. 25: «Die Datierung der Publikation von Herodots Darstellung der Perserkriege in die erste Hälfte des Archidamischen Krieges, zwischen 430 und 426, erscheint also gut gesichert». 
influencias en el Edipo en Colono, del 404, ${ }^{297}$ parece interesante separar claramente la influencia que pudiera ejercer Heródoto de la de los autores dramáticos, cuyas obras representadas en sucesión imprimían una dinámica cultural más rápida de lo que podría pensarse, en contra de lo afirmado por Wells. ${ }^{298}$

Cuatro años después, Fornara presentó la contrarréplica al artículo de Cobet, que poco aporta salvo observaciones concretas a las ideas ya propuestas, y aborda la relación del pasaje de Acarnienses, versos 426 y siguientes, con el rapto de las mujeres del proemio, concluyendo que se debe pensar en un ámbito polémico más amplio y por ello no concluyente, ${ }^{299}$ habida cuenta de que la narrativa de Helena tiene una gran tradición. Esta idea, en apariencia trivial, es un buen ejemplo, a nuestro entender, de lo complejo de los escenarios literarios en los que nos ubicamos, una complejidad que nos ha de hacer abandonar un optimismo quizá excesivo en el empleo de estos indicios.

En contestación no directa a la contrarréplica de Fornara, Evans publicó un breve trabajo en 1987 en el que volvía a la fecha propuesta en su día por Jacoby, basándose en las referencias a Decelia de IX 73, 3, retomando así el análisis de Todd, ${ }^{300}$ un análisis que presupone una inviolabilidad de Decelia, que fue atacada en el 427 con la desaparición de Arquídamo. ${ }^{301}$ Dado que Heródoto estaba por aquel entonces en Turio, idea -permítasenos indicarlodifícil de defender o de rebatir, es necesario pensar, según este autor, en el transcurso de unos años para que la noticia llegase a Heródoto, lo que nos da una fecha cercana a la de finales de los años veinte, como la propuesta por Jacoby, ${ }^{302}$ pero, a nuestro entender, y más allá de los problemas de localización del autor o una excesiva tardanza en la transmisión de las noticias, la mayor dificultad se plantea quizá a la hora de dar por sentado que IX 73, 3 fue de lo último en ser escrito por pertenecer al final de la obra.

En nuestra opinión, toda la polémica suscitada y bien razonada se debe a una perspectiva metodológica que parte de un modelo de publicación ajeno al mundo de Heródoto. Se ha de tener en cuenta que es posible que Heródoto

\footnotetext{
${ }^{297}$ Cf. Cobet, 1977, p. 20; Jebb, 2004, p. 61.

${ }^{298}$ Cf. Cobet, 1977, p. 7.

${ }^{299}$ Cf. Fornara, 1981, p. 153 y ss.

${ }^{300} \mathrm{Cf}$. Todd, 1922, p. 35 y ss.

${ }^{301}$ Cf. Tucídides, III 26, 3.

${ }^{302}$ Cf. Evans, 1987, p. 227 y s.
} 
realizase lecturas de su obra en determinados círculos sin que esta estuviese completada, al tiempo que es imposible determinar hasta qué punto detalles concretos, como pudieran ser los de la muralla en Aves, se podrían filtrar a la sociedad ateniense simplemente como detalle aislado, o incluso sin proceder de la obra de Heródoto, en tanto que los silencios son quizá un camino todavía menos fiable.

Todo ello nos lleva prácticamente a Kirchhoff, que, en un trabajo ya clásico, dispuso los cimientos de un tipo de análisis de la obra y de su publicación perfectamente incompatibles con la misma. La idea de una puesta por escrito de materiales y de una organización editorial de la obra en un sentido moderno son ajenas al mundo antiguo. ${ }^{303}$ Este criterio lleva a Kirchhoff a crear una cuestión herodotea, con incluso la sugerencia de lagunas en diferentes partes de la obra, ${ }^{304}$ en lo que es un proceso lento de demolición de la obra de difícil justificación, máxime por las pocas certezas que puede ofrecer como resultado.

Por contra, la postura seguida entre otros por Röse en un trabajo antiguo, y que recoge un pensamiento contrario al de la crítica de fines del siglo XIX, es realmente avanzada, al señalar que el sistema de publicación de libros de la época no hacía necesaria una edición como tal, ${ }^{305}$ en una idea que supera incluso el avance que años más tarde supondría el planteamiento por parte de Powell acerca de la posible recitación de la obra como algo poco probable. ${ }^{306}$ Sea como fuere, la seguridad de las críticas en Aristófanes, aun a pesar de que estas no tuviesen procedencia directa de la obra del de Halicarnaso, dan cuenta de que el universo intelectual de Heródoto se situaba en un ámbito ajeno al mundo tradicional ateniense, dirigiéndose así a una determinada audiencia, lo que apunta, una vez más, a un escenario diferente a los habituales de la literatura oral.

En este mismo sentido y recientemente, Stewart Flory planteó las dificultades que presentaría una obra en prosa como la Heródoto para

${ }^{303}$ Cf. Kirchhoff, 1878, p. 1 y ss., en las que expone los criterios a emplear, a saber, la recopilación de notas, la definición de un marco de pensamiento, y la organización del material en términos de edición. Esta idea se recoge en parte en Jacoby, 1913, cols. 361 y ss. Cf. la crítica reciente de este último en Rösler, 2002, p. 83 y ss.

${ }^{304}$ Cosa que creemos fuera de lugar; cf. Kirchhoff, 1878, p. 6 y ss.

${ }^{305}$ Que, obviamente, el texto de Hérodoto no presenta, como tampoco resiste la crítica desde esta perspectiva, cf. Röse, 1879, p. 6 y ss. y p. 9.

${ }^{306}$ Lo que devolvía a Heródoto a una publicación en términos de libro, cf. Powell, 1939, p. 31 .

Monografias de Filología Griega, 22. ISSN 1136-0860 
ganarse una audiencia. El autor reconocía como un hecho la menor popularidad de las obras en prosa de gran extensión -piénsese que Flory no lo indica, pero Teopompo realizó un epítome de la obra, lo que demuestra este hecho- ${ }^{307}$ frente a las obras poéticas, dado que las últimas eran más fáciles de aprehender. ${ }^{308}$ En nuestra opinión, esta idea debe ser retomada y analizada de nuevo, pues sabemos que las expresiones literarias de las culturas orales necesitan de recursos que van más allá de los simples recursos estructurales para facilitar su memorización, o, en caso contrario, esas obras no gozarían de gran extensión. ${ }^{309}$

A este respecto y de manera reciente, Porciani ha retomado el análisis de las alusiones antes vistas para reducir de manera concluyente su significación: ciertamente, podría incluso pensarse en un tercer texto en el que se hubieran apoyado tanto Heródoto como el otro autor, o incluso en alguna narración oral popular, tan defendible e indefendible como las reminiscencias de Aristófanes. ${ }^{310}$ Por otra parte, Porciani introduce un concepto muy interesante para el estudio de la difusión de las obras en prosa de la época, como es el de texto definitivo, ${ }^{311}$ es decir, el momento en el que el autor deja de trabajar en la obra, que sustituye al concepto de publicación y que, aun siendo igual de imposible de localizar en el tiempo, es más acorde con la realidad de la difusión de las obras en este periodo y su naturaleza, el mayor condicionante para su extensión y divulgación.

La obra de Heródoto tiene una extensión importante, que se organiza como es sabido por medio de la aplicación sistemática de recursos de sobra

\footnotetext{
${ }^{307}$ Teopompo, 115 F 1-4, obra primera del autor, como señala Jacoby, com. ad loc., p. 354 y ss. En esta época, las obras de Heródoto y Tucídides se asimilaban a niveles superiores de educación, como apunta su estudio en los círculos de Isócrates, en oposición a las líneas tradicionales de educación, asimiladas con Platón, de manera quizá errónea. Ello no implica, a nuestro entender, una excesiva popularidad, como indica respecto a los epítomes Momigliano, 1984b, p. 114. Cf. Marrou, 1985, p. 113 y ss. Después de esta época, con la llegada del poético alejandrinismo, la historiografía será aún más un genero para escogidos, cf. p. 224. Para este fenómeno en época de Séneca, cf. Nicolai, 1992, p. 54.

${ }^{308}$ Cf. Flory, 1980, p. 16. Cf. también Flory, 1987, p. 16: «[...] Herodotus must have aimed at a relatively small and elite audience of readers».

${ }^{309}$ Cf. Vansina, 1985 , p. 15 y ss.

${ }^{310}$ Cf. Porciani, 2005, p. 2 y ss., para un análisis crítico, y especialmente p. 11. Dumbar, 1995 , p. 595, reduce en la nota de su comentario a Aves el pasaje a simplemente una reminiscencia probable.

${ }^{311}$ Cf. Porciani, 2005, p. 11 y ss.
} 
conocidos como la Ringkomposition, ${ }^{312}$ o recursos narrativos como el empleo de estilos progresivos de narración, herencia de la primera prosa, y que permiten la organización de pequeñas narraciones, pero no goza de recursos mecánicos que faciliten esa labor de presentación oral de la obra, como puede ser el ritmo, el verso, la música o la construcción mecánica al modo de los poemas épicos, es decir, falta la microestructura. ${ }^{313}$ A este respecto, no está de más recordar cómo Rosalind Thomas afirmaba al estudiar el fenómeno de las tradiciones orales en Atenas que «though it is widely held that people in oral societies have extremely long memories, even that is not certain, they do have to have better devices or mechanisms for remembering». ${ }^{314}$

Esta idea, a la que ya hemos hecho referencia antes dentro de un marco antropológico general y aquí aplicada al tiempo y el lugar en que se encuadra Heródoto, hace muy complicado pensar en una oralidad rigurosa de la obra herodotea, cosa que no excluye las posibles lecturas en voz alta, ${ }^{315}$ como era habitual en la Antigüedad hasta tiempos tardíos, pero imposibilita plantearse la figura de Heródoto como un aedo en prosa, cosa que ya vio con gran genialidad Pohlenz, al dar cuenta del tono oral de ciertas partes, con empleos como los antes vistos, pero dudando seriamente de tal naturaleza respecto a otros pasajes. ${ }^{316}$ Ello nos recuerda que es necesario pensar que las Historias

${ }^{312}$ Cf. Beck, 1971, passim.

313 En este sentido, Johnson, 1994, p. 249 y ss., da cuenta de la existencia de la asociación de ideas y de referencias cruzadas dentro del texto, pero solo estos rasgos no permitirían la expresión oral de la obra, sino, en todo caso, su unidad; falta, pues, la microestructuración a la que antes hacíamos referencia.

${ }^{314}$ Cf. Thomas, 1989, p. 4.

315 Cf. Jacoby, 1913, col. 226 y ss. Flory, 1980, p. 22, habla de la posibilidad de memorizar pequeños libros en prosa para su posterior lectura, lo que, obviamente, sería el camino de vuelta de las antiguas narraciones de carácter tradicional, dado que partiríamos de obras no tradicionales que son expuestas como tradicionales. Lógicamente, la lectura de una obra como la de Heródoto llevaría largo tiempo, y Flory, defendiendo un carácter elitista de la misma, afirma que «The Histories must have seemed an even longer and more difficult book to them than it does for us», pero, a nuestro entender, el problema reside en el círculo en el que se leyera, y sabemos de lecturas de obras no precisamente populares en casas de las élites atenienses, como atestigua Diógenes Laercio, IX 54, para Prótagoras y su obra Sobre los dioses, por lo que el problema sería determinar en qué esfera se realizarían esas lecturas. Resulta difícil determinar dónde se leyeron las Historias, pero lo que parece seguro es que no se hacía ante un auditorio como el de la tragedia, ya que no es una obra por completo tradicional, y desde un concurrido «salón» de prohombres hasta la lectura individual hay un espacio que no es fácil delimitar.

${ }^{316}$ Cf. Pohlenz, 1961, p. 208 y ss., especialmente p. 210. 
fueron concebidas desde un comienzo como obra escrita, idea ya apuntada por Pearson, ${ }^{317}$ pero aún resta por examinar un último problema, y es que esta afirmación parece entrar en contradicción con los testimonios antiguos.

La tradición antigua, principalmente Luciano y sobre todo Plutarco, ${ }^{318}$ nos presenta a un Heródoto haciendo lecturas públicas y recibiendo fuertes sumas de dinero por ello. Más allá de la inquina del de Queronea por el historiador, nos parece interesante seguir la línea trazada de manera magistral por Erbse en el análisis de esos testimonios, buscando esclarecer qué personaje nos presentan ambos autores, con total independencia del tiempo en que fuera creada esa imagen. ${ }^{319}$

El Heródoto de Plutarco y de Luciano, concluye Erbse, es un sofista, ${ }^{320}$ semejante a Hipias o a cualquiera de los que pululan por las obras platónicas, a partir de cuyas caricaturas nos atreveríamos a afirmar que Plutarco construyó su demonio personal: la defensa de la cultura tradicional es representada por la negativa del beocio Aristófanes a pagar a un Heródoto que trataba de perturbar a los jóvenes, ${ }^{321}$ lo que nos lleva de manera sorprendente a un ambiente plenamente platónico, con una imagen estereotipada de la sofistica que debemos precisamente a este filósofo, uno

${ }^{317}$ Cf. Pearson, 1939, p. 8; la idea de un autor «cortesano» no nos seduce. En contra Havelock, 1994, p. 63 y ss.

${ }^{318}$ El resto de pasajes pueden verse recogidos y comentados en Chaniotis, 1988, p. 290 y ss.

${ }^{319}$ Cf. Erbse, 1979a, p. 142. Más recientemente, Johnson, 1994, p. 232 y ss., ha analizado el significado de à $\gamma \omega ́ v i \sigma \mu \alpha$ en Tucídides, I 21, concluyendo que su significado no es "recitación oral", sino "composición popular". Sea como fuere, no nos parece en exceso desencaminada la propuesta, si bien popular nos lleva irremediablemente a un contexto oral, y lo más sencillo parece, como el propio autor indica, no asumir el prejuicio de una referencia a Heródoto, cf. Johnson, 1994, p. 239, que no deja de ser, por otra parte, la opinión habitual, cf. e. g. Canfora, 1999b, p. 122 y ss.

${ }^{320}$ Cf. Erbse, 1979a, p. 141 y ss. El Heródoto de Luciano es sin lugar a dudas un Hipias o un Gorgias redivivo, con sus lecturas en Olimpia, si bien Luciano, como indica Erbse, hace a Heródoto el iniciador de la tradición de estas lecturas, cf. Luciano, Heródoto, 3; el problema es que la Helena de Gorgias es un discurso retórico asequible para su recitado, la obra del de Halicarnaso no. Cf. también Johnson, 1994, p. 242.

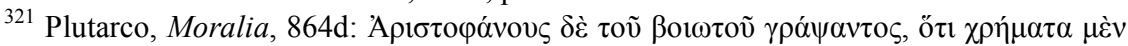

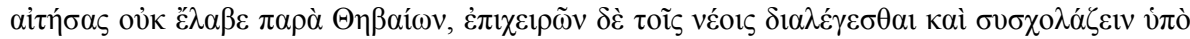

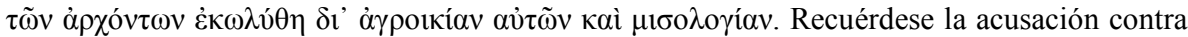
Sócrates. Cf. Erbse, 1979a, p. 140 y ss. Piénsese en el paralelo de Platón, Hipias mayor, 285d y ss., en el que Hipias da cuenta de que a los espartanos solo les interesaban las sagas; no era en esta época la historia lo que más peligroso parecía a las facciones más tradicionales. 
de los mentores intelectuales de Plutarco. Ello nos permite poner seriamente en duda las noticias antiguas acerca de esas lecturas públicas, que responden al diseño de una imagen idealizada y endemoniada al tiempo del intelectual peligroso y codicioso.

Teniendo presente este hecho, las posibles dificultades que puede presentar el pensar en el empleo sistemático y no ocasional de recursos de carácter oral se ven superadas gracias a los avances en la delimitación del espacio oral en la literatura griega, que han venido en los últimos años a frenar un «panoralismo» que terminó por confundir los, eso sí, confusos márgenes de un proceso que tanto ha revolucionado el estudio de la literatura. Bakker razonó de forma adecuada la necesidad de distinguir entre conceptos como oral, literario, transcripción y escrito. ${ }^{322}$ Distingue así el autor un concepto «oral», referido a la forma, a los recursos empleados en la configuración de la obra literaria -piénsese en el empleo de estructuras anulares, estilos propios, etc.-, frente al concepto de literario, que recoge los recursos propios de una producción al modo de un Plutarco, por poner un ejemplo claro. Por su parte, el concepto de «transcripción» ${ }^{323}$ hace referencia a la puesta por escrito de obras con el empleo de recursos de carácter oral, y, finalmente, la idea de escrito alude a la escritura como tal de, continuando con el ejemplo, una vida plutarquea. A pesar de ello, cabe preguntarse si el autor piensa, como nosotros creemos, que entre el concepto de transcripción y escrito hay lugar precisamente para la escritura de obras con ligeros rasgos orales, como el caso que nos ocupa. De este mismo modo, Thomas se pronunciaba a favor de una concepción de la oposición oral-escrito de un carácter difuso y poco delimitado, ${ }^{324}$ lo que daría margen para nuestra propuesta.

Todo ello permite al autor afirmar tajantemente que «the orality of a discourse is perfectly compatible with writing», ${ }^{325}$ delimitando así dos planos superpuestos, uno referido a la caracterización formal de la obra, oral

\footnotetext{
${ }^{322}$ Bakker, 1999, p. 30: «We might speak of oral as the conception that underlies a discourse, and oppose this quality not to written but to literate».

${ }^{323}$ No creemos sostenible la idea de Pascucci, 1981, p. 302, acerca de un desarrollo de la «transcripción» como un simple proceso restringido a unos pocos que se dedicarían a transcribir las obras anteriores, dado que ello convertiría la escritura en un fenómeno casi funcional.

${ }^{324}$ Cf. Thomas, 1989, pp. 2 y 9.

${ }^{325}$ Cf. Bakker, 1999, p. 31. 
o literaria, y otro referido a la performance de la obra. De este modo, tenemos un esquema como el siguiente: ${ }^{326}$

\begin{tabular}{|l|l|l|c|}
\hline RECURSOS & Oral & Oral & Literario \\
\hline CONTEXTO & $\begin{array}{l}\text { Público } \\
(\text { Teatro...) }\end{array}$ & Lecturas privadas & Lecturas privadas \\
\hline TIPOLOGÍA & Oral & Transcripción & Escrito \\
\hline
\end{tabular}

Ello nos lleva a uno de los problemas ya tratados, pero desde otra perspectiva: si antes hacíamos alusión a la fuerte dicotomía establecida por Lord, ahora hemos de abordar un aspecto que, perfectamente visible en esta parte de nuestro estudio donde la oralidad ocupa la posición privilegiada, será sometido a una negación general en etapas futuras. Las teorías románticas acerca de las sociedades tradicionales han dibujado una imagen idealizada de dos tipos de sociedades, la tradicional y la moderna, con relaciones de carácter excluyente. Los avances de las escuelas sociológicas nos han permitido romper con esa visión, y hoy debemos dar por sentado que la oralidad es un fenómeno transversal en el tiempo, que por su especial carácter es más difícil de observar y que convive, sea en superioridad de condiciones, como en el periodo de Heródoto, o subordinada en lo que a los ambientes sociales se refiere, a la cultura literaria. Una vez más hemos de desechar la idea de una progresión continua, una errónea idea de progreso que impediría asumir la presencia de rasgos orales propios en el Nuevo Testamento, ${ }^{327}$ o que dificultaría la comprensión de las narraciones populares comunes a todas las sociedades.

Todo ello ahonda en la idea de que la obra de Heródoto fue concebida como escrita, lo que es fundamental para la interpretación del incipit de la obra: este tenía una función clara en la literatura tradicional oral, con el ruego a las musas o la vertiente utilitaria de los proemios trágicos o líricos

${ }^{326}$ Cf. Bakker, 1999, p. 31. Ampliamos el esquema propuesto por Bakker para dar cabida también a las obras orales, lo que nos lleva a deshacer cierta ambigüedad que presenta su estudio: ¿solo las obras puramente orales se escriben? A nuestro entender, hay un segundo estadio.

${ }^{327}$ Cf. Blass, 1905, p. 275 y ss.; López Eire, 1985, p. 55 y nota 165. 
-que contextualizaban la obra-, pero, una vez que el escenario es otro, esa función referencial respecto al contexto es muy diferente. ${ }^{328}$

Habida cuenta de todo ello, cabe preguntarse por el contexto, al menos aproximado, en que se desarrolla una obra como la de Heródoto. La producción libraria hace impensable algo así como una lectura individual, ${ }^{329}$ ajena al mundo antiguo, $y$, dado que parece imposible pensar en lecturas públicas, aunque aún se mantiene esa idea entre los críticos, ${ }^{330}$ solo resta que la lectura seguramente fuera en grupo y, obviamente, en voz alta, pero esto no es un contexto «oral» en el sentido estricto del término, ${ }^{331}$ que hemos de reservar para festivales o representaciones públicas, $\mathrm{y}$, como los contextos oficiales ${ }^{332}$ no dan cabida a este tipo de obras, otro ha de ser el lugar donde se sitúa la historiografía.

Recientemente Collins ${ }^{333}$ ha trazado las líneas de la que pudo ser una de las grandes tensiones literarias del siglo $\mathrm{V}$ a. C. Este autor contrapone las representaciones públicas de los rapsodas a lo que podríamos denominar ambiente simposiaco, resaltando la importancia de este último como lugar de innovación. Así, señala las variaciones de hexámetros épicos que se convierten en pentámetros por medio de juegos y variaciones muy afines al citado ámbito, en una tendencia que llega hasta Ovidio y los versos iniciales del primer libro de Amores. Ampliando una vez más el espectro, cabe reflexionar sobre la oposición que venimos presentando entre ámbitos

${ }^{328}$ La postura de Rösler, 2002, p. 82 y ss., de considerar la obra de Heródoto como resultado de la puesta por escrito del material recogido en su labor de logógrafo ante el temor de que desapareciera a su muerte es, a nuestro entender, difícil de apoyar, principalmente si se tiene en cuenta que ese material logográfico sí se transmitía de generación en generación. Además, esta propuesta cierra en falso el problema de la diversidad de temas, afirmando simplemente que el deseo de perpetuar el material es la causa de que encontremos muy diferentes elementos dentro de la obra, aunque hay que reconocer que es capaz de superar la simple reutilización de lecturas propuestas por Jacoby, cf. Rösler, 2002, p. 83.

329 A lo largo del siglo v los libros eran preciadas posesiones de las élites culturales griegas, piénsese en Eurípides o en Alcibíades, lo que reduce el ámbito de los libros a determinadas clases. Cf. Kleberg, 1995, p. 53 y ss., con testimonios antiguos.

${ }^{330}$ Como por ejemplo Vignolo Munson, 1993, p. 27; Hunter, 1982, p. 227.

331 Como señala acertadamente Fowler, 2001, p. 105: «the simple fact of being read aloud does not make a literate work oral».

${ }^{332}$ La idea de un Heródoto leyendo su obra en un certamen musical se debe a Escalígero, quien interpretó así el pasaje de san Jerónimo, Chronographia, O1. 83, 4, Herodotus cum athenis libros suos in concilio legisset honoratus est. Cf. Kirchhoff, 1878, p. 11, y recuérdese lo dicho acerca de esta interpretación en línea con la de Erbse del Heródoto plutarqueo.

${ }^{333}$ Cf. Collins, 2005, p. 135 y ss. 
literarios orales, con el teatro y las composiciones poéticas para festivales, de muy marcada formalidad, y el ámbito simposial, ajeno a esos ambientes y normas y que ha de entenderse en una forma más amplia que la tradicional, ${ }^{334}$ con sus muy rigurosos tiempos repartidos entre comensales, ${ }^{335}$ cercana a la imagen que nos presenta Platón de modo paradigmático. ${ }^{336}$ Los propios testimonios, ajenos al estricto estudio del escolio ático nos permiten advertir cómo era este un lugar en el que la literatura se desarrollaba de manera natural, y habitualmente elevada, ${ }^{337}$ con composiciones que rebasan quizá la extensión adecuada para el respeto de la dinámica canónica de desarrollo del simposio, pero que difícilmente se ubicarían en otro ambiente. Sabemos de narraciones históricas como las que hizo Cimón sobre el reparto de unos esclavos tomados en Sesto y Bizancio, ${ }^{338}$ y Platón nos aporta una imagen clara de lo que debió ser la forma de esos ambientes, los denominados simposios socráticos, ${ }^{339}$ en los que la rígida imagen del simposio convencional se disuelve: era, pues, un ambiente en que ciertos sectores sociales podían desarrollar una actividad literaria paralela a la «oficial» presente en los espacios de la polis, superando así el localismo de géneros como la tragedia, ${ }^{340}$ y que en el ámbito político, recuerda Collins, llegará a la abierta confrontación con la oficialidad. ${ }^{341}$

${ }^{334}$ Para la cual cf. Reitzenstein, 1893, p. 3 y ss., con examen de los testimonios.

${ }^{335}$ Cf. Bowie, 1986, p. 33, pero vid. nota siguente.

336 Cf. e. g. Platón, Parménides, 127a, y Protágoras, 314b; Gorgias, 449b, donde Sócrates pide al sofista brevedad para favorecer el método mayéutico, aunque quizá deba ser conectado con el reparto exacto de tiempos que Bowie, 1986, defiende para los discursos del Banquete.

${ }^{337}$ Obviamente, como señala Reitzenstein, 1893, p. 11, había muy diferentes niveles,

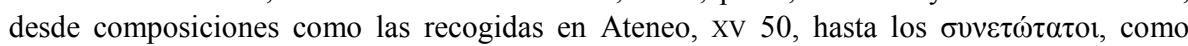
Alceo o Píndaro.

${ }^{338}$ Cf. Plutarco, Cimón, IX 2-3; Hug, 1932, col. 1273.

${ }^{339}$ Cf. Hug, 1932, col. 1274.

${ }^{340}$ Cf. Asheri, 2007, p. 4 y ss. Al igual que ocurrirá con Tucídides, el examen atento de la obra de Heródoto demuestra un carácter panhelénico sustentado por datos que superan el ámbito ateniense.

${ }^{341}$ Cf. Collins, 2005, p. 145. A este respecto, no se sostiene la propuesta de «festivales», sin más precisión, propuesta por Marincola, 2001, p. 23: ¿qué festival, hecho tradicional, acogería al nuevo género? Diferente es pensar en que las concentraciones como las que se pudieran producir en Olimpia fuesen un buen lugar para lecturas de la obra, pero siempre fuera del «circuito oficial», como están los simposios, propuestos también por Marincola. 
Ya el propio Reitzenstein ${ }^{342}$ en su análisis del escolio y del epigrama daba cuenta del carácter marcadamente abierto e innovador de estos géneros, en los que aparecen rasgos de la fábula, la máxima, y de la tragedia y la comedia, hasta incluso el exceso. ${ }^{343}$ Es esta una imagen que choca con la idea de la estricta formalidad que presenta el ambiente literario tradicional, que solo a fines del siglo $\mathrm{V}$ a. C. empezará a resquebrajarse en autores como Prátinas, ${ }^{344}$ el propio Eurípides o Aristófanes. Así, podemos tener ante nosotros un escenario de producción literaria que favorecerá la extensión de obras no tradicionales que se irán gestando como géneros en el ambiente mixto de oralidad y sociedad escrita de la Atenas del siglo V a. C. De este modo, si hemos de buscar un lugar donde una obra que recoja la experiencia del autor, sus opiniones personales, o una visión particular del mundo cuya ligazón con la sociedad no llegue al grado de un género como la tragedia, ese ha de ser el simposio, como ha sugerido Marincola recientemente. ${ }^{345} \mathrm{~A}$ nuestro entender, y habida cuenta de la naturaleza escrita de la obra herodotea, y sus dimensiones, puede pensarse en lecturas en grupo al modo de las que Diógenes Laercio ${ }^{346}$ nos transmite, facilitadas además por la plasticidad propia de la obra, que permitiría la narración de elementos aislados del resto, ${ }^{347}$ como señaló Fowler, ${ }^{348}$ en unas divisiones que Cagnazzi ${ }^{349}$ hábilmente rastreó bajo la posterior y distorsionadora división en nueve libros, divisiones con marcas propias y entidad por sí solas, ${ }^{350}$ al modo de la narración de Cimón antes señalada, o al modo de los mitos presentes en los simposios socráticos, y que, en último término, se equipararían a los usos de la épica y la posibilidad de elegir el tema a cantar.

La ausencia de una división originaria de la obra en libros, como sí harán autores posteriores, da cuenta de la dificultad de pensar en una distribución libraria de una obra que, tal y como está constituida, ${ }^{351}$ no puede

\footnotetext{
${ }^{342}$ Cf. Reitzenstein, 1893, pp. 18 y ss. y 105.

${ }^{343}$ Cf. Reitzenstein, 1893, pp. 34 y 43.

${ }^{344}$ Cf. Pickard-Cambridge, 1997 , p. 53 y ss., especialmente p. 55.

${ }^{345}$ Cf. Marincola, 2001, p. 23.

${ }^{346}$ Cf. Diógenes Laercio, IX 54 (= Protágoras, DK 80 A 1).

${ }^{347}$ Cf. Marincola, 2001, p. 23.

${ }^{348}$ Cf. Fowler, 2001, p. 107.

${ }^{349}$ Cf. Cagnazzi, 1975, p. 385 y ss., para la división en nueve libros, con testimonios; desarrollo de los $\lambda$ ó $\gamma$ or, en p. 389 y ss.

${ }^{350}$ Cf. Cagnazzi, 1975, p. 387 y ss.

${ }^{351}$ El paralelo más cercano es la epopeya, cuya extensión y forma oral impiden la presencia de divisiones formales, aunque se encuentren, claro está, pasajes en los que la 
concluirse que fuera escrita pensando en rollos de papiro con vistas a su venta. ${ }^{352}$ Baste recordar, a modo de ejemplo, que Eurípides, en cuya casa se leyeron algunas obras de Protágoras, según cuenta la tradición, representa quizá el paradigma del anfitrión de estas lecturas y de quien, en último término, generaría incluso copias privadas para su biblioteca. ${ }^{353}$

Thomas ha señalado ${ }^{354}$ de manera muy estimulante la necesidad de devolver al siglo $\mathrm{V}$ a. C. a un Heródoto relegado por norma a un ambiente cultural mucho más arcaico que el que realmente lo acogió: la búsqueda incesante de vínculos intelectuales con los presocráticos llevó a esa distorsión que aún hoy se mantiene. En este mismo sentido, Stewart Flory nos indica que, a pesar de la imagen tradicional que tenemos de Heródoto, la naturaleza de su obra y su pensamiento era bastante selecto, ${ }^{355}$ quizá más tradicional, diríamos, que el de Protágoras, pero que entronca con la tradición aristocrática simposiaca más pura, lo que respalda esta ubicación, que, por la $\pi$ oıкı $\lambda i^{356}$ de la forma y por la naturaleza intelectual que mencionamos, corresponde a esta tradición, en la que Turner precisamente acierta a situar la aparición de la obra escrita, con presencia real o no del autor en la lectura, ausencia superada, según vimos, por el esquema de comienzo de las obras antes expuesto, y que podemos vislumbrar ejemplificado en el Parménides de Platón. ${ }^{357}$ No es posible ubicar este tipo de obras en un ambiente público al uso habitual, donde sería mal recibida, lo que se ve probado por las burlas de Aristófanes a las innovaciones de Eurípides, que precisamente se sitúa en ese proceso de entrada del ámbito

acción parece tomar un descanso. A pesar de todo, si bien sabemos por la cerámica que en torno al primer cuarto del siglo $\mathrm{V}$ a. C. se empleaban rollos de papiro para Homero, cf. Irigoin, 2001, p. 18 y ss., dudamos si se asumiría la edición continua de una obra como la de Heródoto por parte del mercado librario incluso sabiendo que el público era infinitamente menor frente al de Homero, que era texto escolar. Creemos que la respuesta es no.

${ }^{352}$ Cf. Irigoin, 2001, p. 21 y ss., que habla de un tratamiento «quirúrgico» sobre la obra de Heródoto en época alejandrina, para facilitar su acomodo en un soporte usual. Después de Tucídides, los historiadores asumirán de manera personal la división de sus obras, cf. ibidem. Cuál fue el criterio seguido para la división de la obra es una pregunta sin respuesta, dado que la extensión es variable y no se ajusta ni a la longitud de un rollo de papiro ni responde a criterios formales o de contenido de la obra; cf. Asheri, 2007, p. 11.

${ }^{353}$ Cf. Kleberg, 1995, p. 55.

${ }^{354}$ Cf. Thomas, 2000, p. 6.

${ }^{355}$ En contra, Fowler, 2001, p. 108

${ }^{356}$ Asegurada además por el conocimiento y uso de toda la literatura generada en torno a las guerras médicas, cf. Pohlenz, 1961, p. 192.

${ }^{357}$ Cf. Turner, 1995, p. 38 y ss.; cf. Platón, Parménides, 127 y ss. 
literario simposiaco en el tradicional, ${ }^{358}$ que terminará por ser una realidad en la crisis de fines del siglo V a. C., con la persecución de estos intelectuales y su huida a cortes extranjeras, así como en el paradigmático juicio a Sócrates. ${ }^{359}$

Todo lo expuesto hasta el momento apunta a una convivencia clara de un ámbito escrito y otro oral, claramente separados, a pesar de las críticas de quienes defienden, como Havelock, un ámbito plenamente oral, o quienes creen en una Atenas ampliamente libraria. ${ }^{360}$ Esa distinción apunta, en nuestra opinión, básicamente a la necesidad de distinguir dos niveles de desarrollo cultural, el primer nivel es político en el sentido etimológico de la palabra, relacionado con las esferas públicas y por ello cultuales de la polis. Tragedia, comedia y épica poseen unos ámbitos de representación claramente demarcados y sancionados en los que tradicionalmente se desarrollan desde tiempos plenamente orales. Paralelamente a este ámbito, la escritura facilita el desarrollo de una esfera cultural presente de manera clara desde el arcaísmo cultural griego que asociamos, como venimos defendiendo, a un ambiente simposial en un sentido amplio, en el cual las estrictas normas de la oralidad dan paso a una mayor laxitud que permite desarrollos literarios de todo tipo: ${ }^{361}$ parodias, juegos o, simplemente, literatura no conocida, con un desarrollo del pensamiento ajeno y destructor en ocasiones del propio sistema social, y que se nos muestra difuminado porque su mejor conocedor fue en parte su mayor verdugo, Platón. Este determinó nuestra visión de todo este ámbito cultural con su crítica a los sofistas, y terminó incluso por condenar el ámbito urbano o tradicional, poniendo de manifiesto esos trasvases entre un mundo y otro. ${ }^{362}$

Estas ideas se muestran consonantes con la imagen más generalizada de un desarrollo de la escritura en este tiempo, asumida dentro de unos límites claros que apuntan a una moderación en su extensión en la Atenas de la época, ${ }^{363}$ lo que, por otra parte, nos permite aunar las dos propuestas, la que

\footnotetext{
${ }^{358}$ Piénsese sin ir más lejos en el ejemplo que podría ser el paralelo entre Sobre los dioses de Protágoras y la invocación a Zeus en Troyanas, 886, en comparación con el himno a Zeus del Agamenón de Esquilo.

${ }^{359}$ Cf. Thomas, 2000, p. 12.

${ }^{360} \mathrm{Cf}$. Turner, 1995, passim.

${ }^{361}$ Lo que responde a una idea de cosmopolitismo que Aly, 1927, p. 92, defendía incluso para la lengua de Heródoto.

${ }^{362}$ Cf. Havelock, 1994, p. 49 y ss.

${ }^{363}$ Cf. Harris, 1989 , p. 54 y ss. 
defiende un gran desarrollo de la escritura ante la necesidad de justificar un nivel cultural y de conocimiento literario elevado, y la que se opone a esta idea: estamos hablando de ámbitos diferentes, y un ateniense ajeno al mundo escrito podía tener un inmenso conocimiento de la literatura oral.

Por todo ello, la interpretación literaria de la obra se deberá hacer teniendo en cuenta el ámbito de realización de la misma, así como la naturaleza intelectual elevada y la menor severidad en las formas literarias propias de los ámbitos tradicionales, lo que dará lugar a juegos de reminiscencias y ecos de todo tipo, acordes con el nivel del público y con la formación literaria del historiador. ${ }^{364}$

Recapitulando lo hasta ahora expuesto, y en lo que se refiere a la fecha de escritura de la obra, los datos formales que aquí nos ocupan solo nos permiten constatar su ubicación en un ámbito cronológico que se extiende prácticamente a lo largo de las décadas que se suceden desde los años cincuenta del siglo $\mathrm{V}$ a. C. hasta los años treinta, es decir, una fecha ligeramente superior a la propuesta tradicionalmente por Jacoby. Los paralelos formales y las reminiscencias que vamos a ver y que están en consonancia con el escenario definido para la divulgación de la obra solo tendrían sentido cuando fuesen un elemento actual y no de mero anticuarismo.

\subsection{Heródoto, I 1-5: pautas estilísticas}

Fue Denninston ${ }^{365}$ quien indicó la especial configuración del primer periodo del proemio de Heródoto: el orden de las palabras viene determinado

${ }^{364}$ Cf. Verdin, 1977, p. 55 y ss., para el asombroso conocimiento literario de Heródoto, que no se reduce a las escasas citas directas, y que se puede observar en sus comentarios y juicios, que constantemente nos recuerdan que el conocimiento era incluso directo y vivo.

${ }^{365}$ Cf. Denninston, 2000, p. 7. Cf. además Asheri, 2007, p. 7 y ss. Señala el autor lo raro de la formación de este proemio, que no se acoge a la configuración habitual de los proemios en prosa. El tratar de defender que es obra de un editor nos parece inconsistente, ya que sólo se fundamenta en criterios librarios muy posteriores, y en el testimonio de Focio, Biblioteca, Codex 190, 148b, quien nos habla de un tal Plesirroo, un autor de himnos que sería responsable del comienzo de la obra. Como toda noticia curiosa o anécdota, puede tener cierto fondo lógico, y una posible reminiscencia poética ha de ser tenida en cuenta. Cf. además, 
por algún criterio que consideramos ya irrecuperable, por cuanto no parece atender, como veremos, a criterios habituales de la ordenación de los elementos en la frase.

La especial importancia de la posición inicial era un fenómeno que se observaba ya, según vimos, en la configuración de la épica, y la sustitución del término clave por el nombre del autor ha dado lugar a una tendencia que trata de resaltar la importancia del autor como pieza clave en la configuración del proemio; pero, a pesar de ello, la estructura responde a un criterio, a nuestro entender, mucho más profundo.

Parece difícil trazar una línea entre los ejemplos conservados de comienzos de obras en prosa y el inicio del proemio herodoteo, por cuanto la estructuración de este último responde a algo muy diferente, lo que quizá llevó a Drexler ${ }^{366}$ a hablar de nuevo de título. $Y$ es que podemos afirmar sin dudas que la fórmula presente en los proemios conservados del siglo $\mathrm{V}$ a. $\mathrm{C}$. responde a un patrón que aparece incluso en Tucídides, pero al que es ajeno Heródoto, con lo que ello supone respecto a la habitual idea de evolución lineal del género.

La temática de la obra y, más en concreto, el proemio, dan cuenta de dos términos, dos conceptos claves en la configuración del mismo, el concepto de $\kappa \lambda \varepsilon ́$ ó y el de $\mu \nu \eta ́ \mu \eta$. Estas dos ideas tienen, más allá de las posibles conexiones con la épica, género que recoge esta idea de profundo carácter antropológico, una fuerte ligazón con los fenómenos de la muerte y sus manifestaciones, tan emparentadas con la historia. Mantuvo en su día Koenen $^{367}$ la semejanza entre el comienzo de la obra herodotea y los epitafios mortuorios, si bien la intención defendida por este autor no se refería a la organización del periodo, sino a fenómenos relativos a la creación del lenguaje escrito y sus recursos, en conexión con la idea del objeto parlante, con el ejemplo paradigmático de la copa de Néstor, lo que

Asheri, 2007, p. 1 y ss. Recientemente, Johnson, 1994, p. 246, parece respaldar a esa idea de separación del inicio de la obra del resto del proemio, cosa que es falsa, como trataremos de demostrar.

${ }^{366}$ Cf. Drexler, 1972, p. 3.

${ }^{367}$ Cf. Koenen, 1993, p. 95 y s., y Moles, 1999, p. 8, quien defiende además la naturaleza epistolar y epigráfica de Hecateo y una red de influencias y paralelos entre Hecateo, Heródoto y Tucídides que nos parece por completo insostenible, y que Moles no llega a respaldar con pasajes concretos. En la misma línea puede verse Bakker, 2002, p. 30. 
determinaba que el libro asumiese el significado expresado por el deíctico. ${ }^{368}$ A nuestro entender, a esta idea se ha de sumar la de que la estructuración del periodo inicial de la obra responde en cierta manera a la organización de los epitafios, y por extensión a la de la épica, dado que estos tres tipos de composición literaria guardan fuerte semejanza, por cuanto su finalidad es común: velar por el mantenimiento de pasado como referente para la comunidad. Es esta una idea que Pohlenz apuntó en el terreno conceptual de

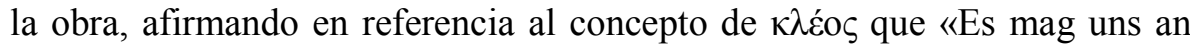
die gleichzeitigen Grabepigramme erinnern, die in gleicher Schlichtheit den Tod fürs Vaterland feiern»». ${ }^{369}$

La estructuración nombre + patronímico $+\sigma \tilde{\eta} \mu \alpha+$ deíctico es una formulación habitual en la configuración de los epitafios, con las variaciones pertinentes según necesidades métricas, y con ejemplos ya desde los primeros tiempos. Así, en el repertorio de Peek ${ }^{370}$ se recogen hasta casi sesenta ejemplos de esta tipología, quizá la más simple de las presentes, lo que da una idea clara de su popularidad, siendo interesante además el hecho de que la organización de los periodos y su construcción en aquellos que superan el simple verso se realiza con el empleo -artificial- de mecanismos de carácter épico semejantes a los antes vistos.

Como ejemplos, podrían citarse el hallado en Atenas y fechado en el siglo VI a. C., ${ }^{371}$ cuya naturaleza hexamétrica favorece la modificación de los elementos según los sabidos mecanismos.

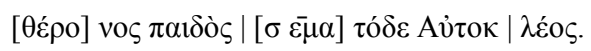

Frente a esta configuración, de carácter simple, aparecen composiciones de mayor complejidad, y cuya configuración poco a poco se mezcla con la del ejemplo anterior, con referencias al concepto de $\mu \nu \eta \dot{\mu \eta}$ o $\kappa \lambda \varepsilon \dot{\delta}$, , y

\footnotetext{
${ }^{368}$ Fowler, 1996, p. 69, nota 61, indicaba la posibilidad de referir a su vez ese deíctico al autor, ahondando en la idea de la importancia de la subjetividad, pero, a nuestro entender, está fuera de lugar por completo, dado que dos palabras antes hay una referencia al autor.

${ }^{369}$ Cf. Pohlenz, 1961, p. 92.

${ }^{370}$ Peek, 1988.

${ }^{371}$ Peek, $n^{\circ} 63$ (IG I² 990).
} 
configuraciones de carácter literario, todo ello en extensiones mayores que el simple verso: ${ }^{372}$

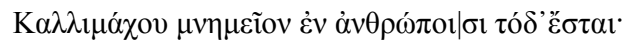

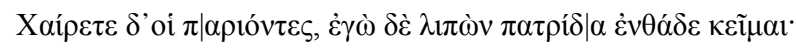

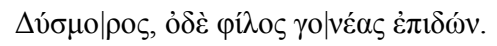

La relevancia formal de la tradición de los epitafios viene refrendada por una motivación intelectual profunda que se demuestra en uno de los episodios más importantes de la obra herodotea, en la escena programática de Solón y Creso, fundamental por muchos motivos, y en la que aparece lo que podríamos considerar como un epitafio narrado. Así, cuando Creso pregunta a Solón quién ostenta la primacía en dicha, ${ }^{373}$ dice este: ${ }^{374}$

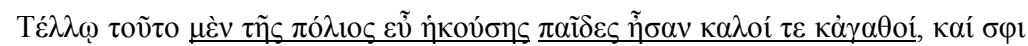

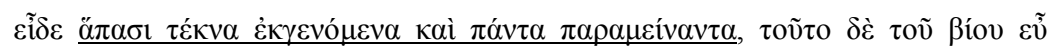

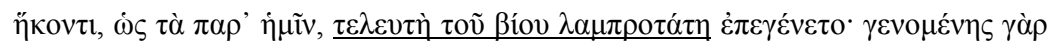

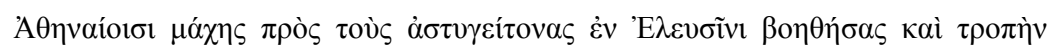

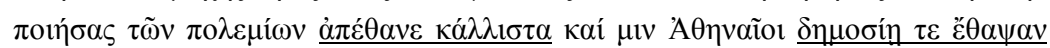

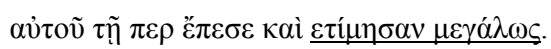

Esta breve narración da cuenta, como decimos, de un pequeño epitafio en el que se recogen de manera clara los principales elementos que se presentan en estos. Así, aparece el tema de la supervivencia de los hijos, ${ }^{375}$ el tema de la muerte por la patria, ${ }^{376} \mathrm{y}$ la consideración que esta expresa por los caídos. Contrapunto a los valores que manifiesta la moral tirteica, ${ }^{377}$ los

\footnotetext{
${ }^{372}$ Peek, $n^{\circ} 83\left(\mathrm{IG}\right.$ II/ III ${ }^{2} 3,2$ n $\left.^{\circ} 11780\right)$.

${ }^{373}$ Cf. Lloyd, 1987 , p. 26, para la correcta interpretación de la significación de la muerte de Telo y la de Cleobis y Bitón.

${ }^{374}$ Heródoto, I 30.

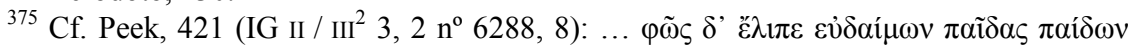

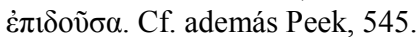

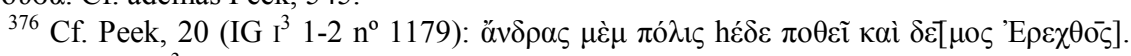

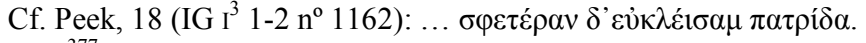

${ }^{377}$ Cf. Tirteo, Fr. 1 West. Cf. Jaeger, 1960, p. 79 y ss. 
epitafios no eran el fin ${ }^{378}$ sino el principio de la futura gloria del caído, que permanecía vivo en el recuerdo de la comunidad, formando ya parte de las genealogías del lugar, y añadiendo así futuro a la historia. ${ }^{379}$

Seguramente, la pieza clave de este razonamiento nos la proporcione el propio Heródoto al introducir en su obra los epitafios de los caídos tras la batalla de las Termópilas. ${ }^{380}$ Uno de los tres, el del adivino Megistias, ${ }^{381}$ es el único que es realmente un epitafio, como señaló Page: ${ }^{382}$

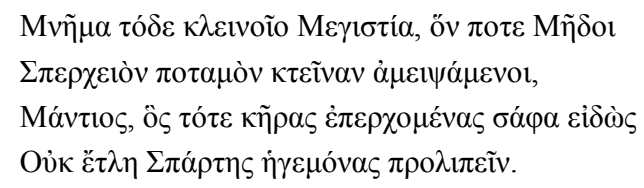

La lectura atenta de este epitafio atribuido a Simónides habrá hecho al lector rememorar sin duda a Homero, tanto por el destinatario, un adivino

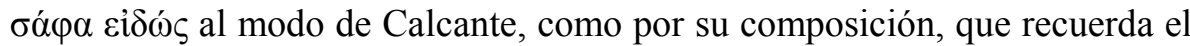
de los proemios homéricos. ${ }^{383}$ No cabe duda de que la mayor elaboración de este epitafio responde en gran manera a su carácter homérico, y también seguramente por el hecho de ser su destinatario un adivino.

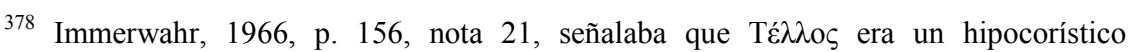

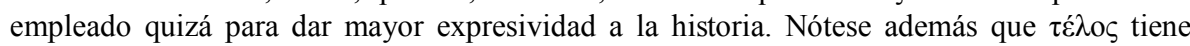
como sentido más propio el de final completo, lo que da mayor peso si cabe a esa idea, cf. Chantraine, 1999, s. v., y quizá haga dudar de la real existencia del personaje, que defiende Jacoby, 1956b, p. 275, y también Immerwahr.

${ }^{379}$ Cf. Vansina, 1985, p. 24.

${ }^{380}$ Citemos, aunque sea en nota, el muy complejo poema 26 PMG, del cual se discute hasta su naturaleza, para lo cual cf. Degani y Burzacchini, 1980, p. 316 y ss., con un estado de la cuestión hasta la fecha que poco ha variado. No nos atrevemos siquiera a asegurar que el comienzo mismo del poema sea el primer verso de lo conservado, pero, un examen detenido del mismo nos permite observar cómo a partir de los versos 1 y 5 se construye una estructura semejante a la que observamos en los poemas que vamos a estudiar.

${ }^{381}$ Cf. Heródoto, VII 228; Peek, 94 (= Antología griega, vII 677).

${ }^{382}$ Cf. West, 1991a, p. 287 y ss., donde se discute la opinión de Page, considerada válida. Para la cuestión de la autenticidad de las inscripciones citadas por Heródoto cf. Pritchett, 1993, p. 160 y ss.

${ }^{383}$ Cf. West, 1991a, p. 288, nota 44, para más paralelos épicos, como Mérope, Ilíada, II 831 y ss.; Thomas señaló la especial significación del oficio de adivino en lo referente a la tradición funeraria, cf. Thomas, 1989, p. 105. 
Tenemos el término clave del que hablaba van Groningen, $\mu v \tilde{\eta} \mu \alpha$, su

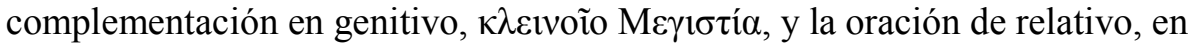
tanto que la naturaleza métrica de los dísticos favorece la repetición de esta estructura en el segundo par de dísticos, lo que hace que tengamos el elemento apositivo y la oración de relativo de nuevo. En definitiva, estamos ante una evolución del esquema compositivo que estudiamos en el proemio épico y que da cuenta de su más clara adaptación a un género eminente y exclusivamente escrito de manos de un gran poeta.

Es el deíctico el que nos pone sobre aviso de que estamos en un plano de presentación de la obra muy distinto al de los poemas homéricos: es una obra escrita, que fue grabada ${ }^{384}$ y que por ello no pertenece a la órbita de la tradición oral, ${ }^{385}$ en consonancia con lo dicho en el apartado anterior:

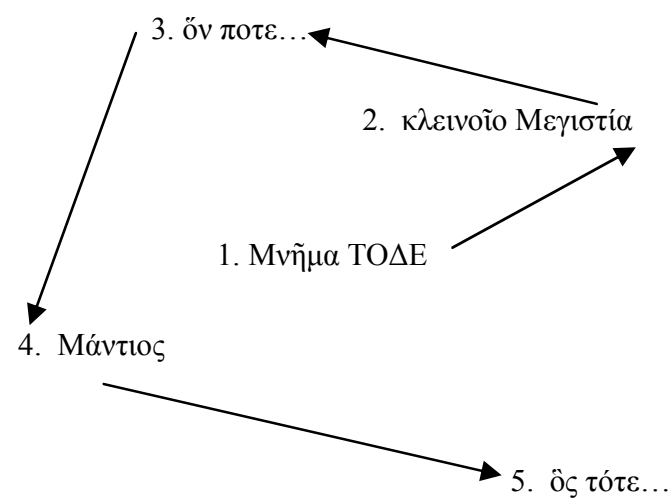

Quizá la concepción moderna de la muerte nos haga cuestionar la pertinencia de estos paralelismos, pero la función misma de los muertos en las sociedades tradicionales nos permite asumir que la épica, la cultura

${ }^{384}$ Cf. Heródoto, VII 228.

${ }^{385}$ Cf. Koenen, 1993, p. 96, para el caso de Heródoto. La discusión sobre si Heródoto visitó el paso de las Termópilas nos es ajena, pero ello ha dado lugar a Page a considerar estos epigramas como elementos propios de una tradición oral, y que fue así como Heródoto los conoció. Los argumentos sobre la posible presencia de Heródoto en las Termópilas rozan en ocasiones lo peregrino, y realmente la solución es, a nuestro entender, otra: el epitafio es por su misma naturaleza escrito; si se copió, memorizó o visitó, esto no afecta a su «performance» escrita. Cf., sin embargo, West, 1991a, p. 288 y ss., y en contra, las ideas de Thomas sobre la tradición oral, que van más allá del recurrente y difuso concepto anterior, cf. Thomas, 1989, passim, y ya antes Pohlenz, 1961, p. 190 y ss. 
literaria de los epitafios y la obra herodotea comparten rasgos que al oído de un antiguo le llevarían rápidamente a un conjunto de ideas que versan sobre el honor, el recuerdo, la gloria, la ciudad y la sucesión generacional, elementos presentes en las Historias. ${ }^{386}$ La función de la que hablaba Denninston, y con la que comenzábamos el capítulo, apunta, a nuestro entender, a una reminiscencia para el lector relativa a la organización del periodo, que remite a la cultura de los epitafios, y con ello a la cultura de los muertos.

Sin embargo, en lo referente al incipit de Heródoto, las opiniones han sido variadas y profundamente razonadas. La mayoría de esos juicios se han referido a la ligazón sintáctica del último periodo. Tres han sido las posibilidades de interpretación propuestas.

La primera de ellas analiza el periodo $\tau \dot{\alpha} \tau \varepsilon \ldots \dot{\alpha} \lambda \lambda \hat{n} \lambda$ oı $\sigma$ como un objeto dependiente del verbo «implícito» en $\dot{\alpha} \pi$ ó $\delta \varepsilon \xi 1 \varsigma$, propuesta defendida por Stein, Pagel, Jaeger, Krischer y Bakker. ${ }^{387}$ Esta propuesta se topa con la dificultad que implica el hecho de tratar de hacer presente en Heródoto una construcción más propia de un gramático moderno que de la mentalidad del autor y de su sintaxis, y que además ensombrece en gran manera la perfecta intelección del texto, al construir una estructura paralela para salvar el problema, argumento que ya apuntó Drexler. ${ }^{388}$

La segunda posibilidad propone considerar un anacoluto en el inicio de la obra herodotea: así, Pohlenz ${ }^{389}$ creía que aíín no pertenece a la oración final, al igual que $\alpha \lambda \lambda \lambda \alpha$, y por ello pensaba en una relación vaga de los elementos. No es fácil sostener esta propuesta, habida cuenta de que implica un proceso de ruptura de la lógica del pensamiento ${ }^{390}$ y parece difícil que se presente en el comienzo mismo de la obra.

La tercera posibilidad es considerarlo un periodo dependiente de la frase final, lo que también es difícil, pero es una afirmación que fue respaldada

\footnotetext{
${ }^{386}$ Cf. López Eire, 2005, p. 61 y ss.

${ }^{387}$ Cf. Stein, 1962, I p. 1; Pagel, 1927, p. 5 y nota 9, en la que indica que esta es la postura de Werner Jaeger, director de la tesis de Pagel. Respecto a Krischer, 1965, p. 159 y ss., y Bakker, 2002, p. 6 y ss., no encontramos la posible explicación de cómo se relacionan los diferentes elementos, y sólo aparece una vaga «referencia» de un término al otro por medio del paralelo, a nuestro entender correcto, con la épica.

${ }^{388}$ Cf. Drexler, 1972, pp. 4 y 7.

${ }^{389}$ Cf. Pohlenz, 1961, p. 4, nota 2.

${ }^{390}$ Cf. Schwyzer, 1959, p. 704.
} 
por Drexler. ${ }^{391}$ El estudioso restaba importancia a los problemas que Erbse veía en la relación entre las negaciones de los períodos, ${ }^{392}$ y partiendo de la consideración de $\alpha i$ ín $\nu$ y ó $\lambda \lambda \alpha$ como nominativos, ${ }^{393}$ el emparejamiento con ह̌py $\alpha$ era, según el autor, prácticamente necesario. Dudamos, como decimos, de la pertenencia de este periodo a la oración final, cuyo orden sería algo

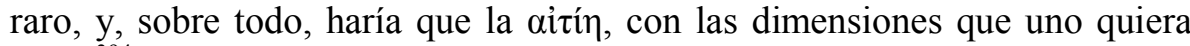
darle, ${ }^{394}$ fuese objeto de exaltación casi heroica.

Lo hasta ahora analizado en relación con la fraseología de los epitafios y la epopeya nos lleva a considerar, a diferencia de Hummel, que pensaba en un añadido posterior de la frase final, ${ }^{395}$ que, simplemente, esa frase final es ajena a los recursos literarios antiguos: las características ya expuestas de los géneros tradicionales hacía que en su propia naturaleza estuviese su finalidad, por lo cual esa frase no estaría presente si el género de la historiografía fuese tradicional. Como señalaba Erbse, ${ }^{396}$ esa frase dejaba claro cuál era el cometido del autor, cosa que, como decimos, se da por sabida en otros géneros tradicionales. Así, la propia novedad del género hace que ese elemento sea absolutamente necesario, en contra de las ideas defendidas por Hommel ${ }^{397}$ y criticadas ya por Erbse. ${ }^{398}$ El hecho no evita que ese período sea un aparte en la configuración de la frase, lo que hace que en nuestra interpretación la podamos aislar entre paréntesis para una mejor comprensión. Esto da cuenta de la naturaleza no oral del proemio, cuya configuración presenta ciertamente una estructuración más laxa que la de un poema homérico. Se trata, en definitiva, de un elemento de distorsión intencionada de un modo de composición ya conocida, como lo puede ser la variación métrica de un hexámetro, lo que nos lleva de nuevo al ambiente literario antes señalado. Hay, sin duda alguna, una gran distancia entre los primeros proemios en prosa antes explorados y el de Hérodoto, pero detrás de toda la tramoya literaria del de Halicarnaso, podemos observar los

${ }^{391}$ Cf. Drexler, 1972, p. 8.

${ }^{392}$ Cf. Erbse, 1958, p. 217.

${ }^{393}$ Cf. Drexler, 1972, p. 9, para ejemplos de esta expresión en nominativo en Heródoto.

${ }^{394}$ Cf. Drexler, 1972, p. 11, quien resta valor a esta expresión como referida a un marco intelectual, apunta a un «Bezeichnung des Inhalts».

${ }^{395}$ Cf. además Asheri, 2007, p. 9, quien habla de «a sort of appendix». Las posibles dudas acerca del uso de $\omega \varsigma$ se ven resueltas al observar los paralelos ofrecidos por Thomas, 1888, p. 28

${ }^{396}$ Cf. Erbse, 1958, p. 214; Erbse, 1992, p. 123.

${ }^{397}$ Cf. Hommel, 1981, p. 284 y ss.

${ }^{398}$ Cf. Erbse, 1992, p. 124 y ss. 
mismos condicionantes. Con todo ello, la estructura se muestra más clara, y no andaba errado Erbse al hablar de la importancia de $\alpha \dot{\pi}$ ó $\delta \varepsilon \xi 1 \varsigma$, como también hacía Stein, pero no es necesario hablar de un verbo sobrentendido. Recordemos el epitafio homerizante: si colocamos en posición central el término clave, rápidamente vemos cómo el desarrollo del pensamiento se construye en espiral en torno a ese concepto, dependiendo todos los elementos de dicho término, como ocurría en Homero y en Simónides, en oposición, además, a lo que era la tendencia habitual en los proemios de la prosa de la época, dejando constancia clara de que su obra iba a tener un gran peso literario:

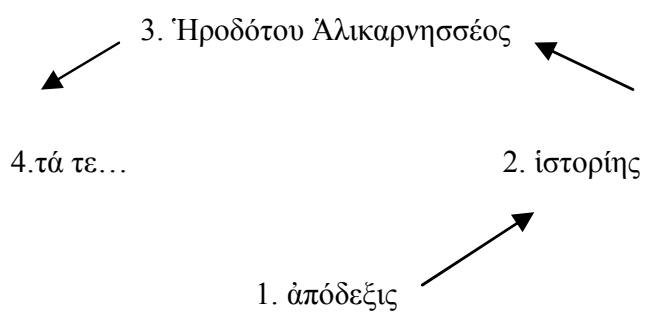

$\mathrm{H} \Delta \mathrm{E}$

Según este esquema, se debe desechar la idea de Erbse de considerar el

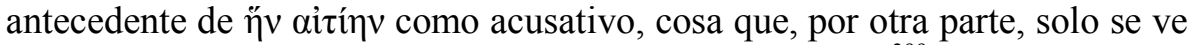
apoyada por la paráfrasis del texto, según indicó Drexler: ${ }^{399}$ el relativo lo es, pero no el antecedente, que a todas luces tiene que ser un nominativo, como corresponde, por lo demás, a una oración nominal como la presente. Ello se ve reforzado si tenemos en cuenta que la intencionalidad al expresarse así es clara, dado que ese detenimiento de la oración nominal se opone al dinamismo de los proemios homéricos, con su invocación a la musa. Por ello el periodo tiene que ser una aposición a $\dot{\alpha} \pi$ ó $\delta \varepsilon \xi 1 \zeta$, construcción nominal acorde con la estructura de los proemios homéricos y los epitafios, y que incide además en la idea de acumulación y detención del pensamiento en la tradición de los proemios poéticos, lo que, por otro lado, hace que este recurso tenga una presencia reducida en los pasajes narrativos, dada su poca capacidad de avance. ${ }^{400}$

\footnotetext{
${ }^{399}$ Cf. Drexler, 1972, p. 7.
}

${ }^{400}$ Cf. Webster, 1941, p. 390. 


\subsubsection{HERÓDOTO EL NARRADOR: EL RAPTO DE LAS MUJERES}

La parte analizada da paso a las famosas narraciones de los raptos y finalmente a un capítulo de tono programático, cuya naturaleza ejemplifica dos de los más importantes estilos narrativos de la obra de Heródoto. Ello hace que de nuevo, en pocos capítulos, podamos observar una mixtura de «estilos» que nos recuerda en parte a la variedad platónica, pero con la particularidad de que en este caso el ensamble de los mismos es tan perfecto que resulta difícil tratar de aislar las diferentes variedades.

El primer capítulo se abre con un periodo que inicia un estilo indirecto que abarca hasta el final del mismo, en un empleo narrativo característico de la prosa arcaica: ${ }^{401}$ recogiendo los conceptos expuestos en el examen del estilo de la prosa arcaica, podemos distinguir un mínimo de cuatro elementos clave $^{402}$ cuya repetición caracteriza el uso de la «retórica oral» en el relato. Así, en el comienzo mismo del relato se presenta el término Фoívikas, que será recogido y adjetivado a lo largo del texto hasta un total de diez veces: en primer lugar, se emplea un pronombre que recoge el nombre empleado al

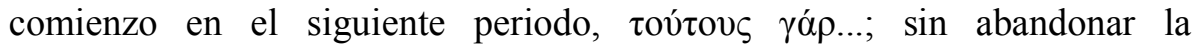
referencia, se utiliza el estilo participial ${ }^{403}$ para incluir información acerca

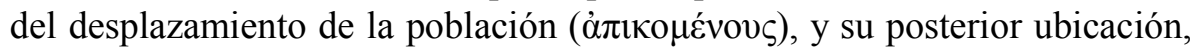

${ }^{401}$ A este respecto, Slings, 2002, p. 55, realiza un examen de la narrativa herodotea con el empleo de una terminología innovadora que se sustenta en principios como los de repetición, unión, ampliación, anáfora y otros más que ya fueron utilizados en el estudio de la prosa por los autores antes citados en el examen de la misma. La principal novedad de este trabajo es el querer asumir que la naturaleza de este estilo parte de la lengua oral, entendida como la lengua conversacional, la parole de Saussure. Pero parece imposible que tengamos que entender así la literatura oral, dado que ello supondría colocar a Heródoto a improvisar una conferencia grabada -en este caso escrita- al vuelo.

${ }^{402}$ Cf. Long, 1987, p. 40 y ss., para un análisis de la narración con este enfoque, si bien el autor se centra únicamente en términos con la misma raíz, lo que es, a nuestro entender, un fallo, debido a la defensa de unas connotaciones mágicas en los términos, cf. p. 12 y ss., lo que deja fuera del análisis los pronombres. Esto supone, dentro del esquema antes ofrecido para el análisis de la prosa arcaica, un error de comprensión incompatible incluso con propuestas de análisis como las de Fränkel o Norden.

${ }^{403}$ Participios que pueden dar lugar a grupos coordinados de expresión acumulada, cf. Lamberts, 1970, p. 36 y ss. 
con un empleo que da cuenta de en qué modo tiene cabida la subordinación

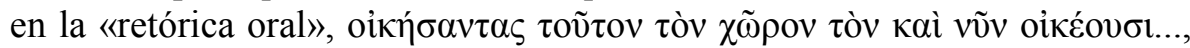
donde la semántica del participio es recogida por el verbo del periodo subordinado relativo, hecho muy frecuente incluso en Tucídides, ${ }^{404}$ de modo que la mayor extensión del periodo se supera en lo relativo a la cohesión del texto por medio de una referencia semántica.

El siguiente periodo se abre de nuevo con un participio referido al

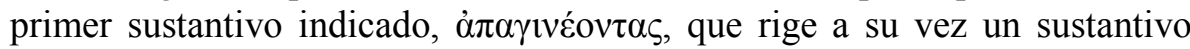
que será el segundo elemento clave del texto, фортía. Por su parte, el verbo principal, un infinitivo dependiente del primer verbo, rige el complemento que da entrada al tercer elemento clave, $\dot{\varepsilon} \varsigma$ 'A $\rho \gamma o \varsigma$. La referencia a Argos da lugar a la aparición de un pequeño inciso en la narración, cuyo único periodo está perfectamente unido al anterior por medio de la repetición ilativa, tan

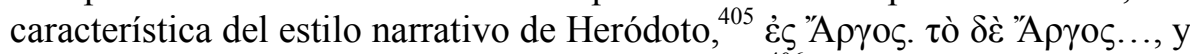
que se presenta en menor medida en Tucídides. ${ }^{406}$ El último periodo de la primera parte de la primera narración termina con una suerte de

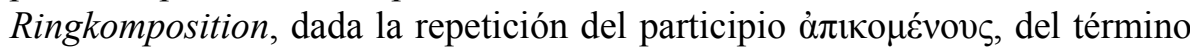

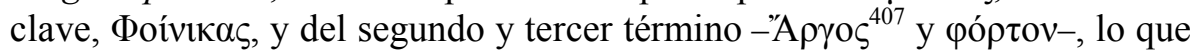
cierra la estructura del texto con todas las digresiones e informaciones proporcionadas poco a poco, con esa lentitud de que hablaba Aristóteles, pero que permite, como insistimos, la supervivencia oral de textos de este tipo.

La ruptura de esta narración en dos partes viene confirmada por el comienzo del siguiente periodo, en el que la construcción adjetival participial se rompe por el empleo del segundo periodo subordinado de la narración, que de nuevo es conectado semánticamente con el anterior texto,

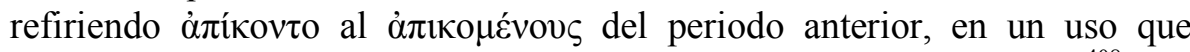
Müller, con buen juicio, considera como característico de Heródoto. ${ }^{408}$ Esa

${ }^{404}$ Cf. Müller, 1980, p. 89 y ss. con tabla 16, cuyos datos son contundentes en cuanto a los porcentajes respecto a otro tipo de subordinadas, para lo que hay que recordar la especial capacidad de cohesión de este tipo de oraciones.

${ }^{405}$ Cf. Müller, 1980, p. 51 y ss.

${ }^{406}$ Cf. Müller, 1980, p. 70 y ss., con tabla 10.

${ }^{407}$ Cf. Johnson, 1994, p. 252, para la naturaleza oral del empleo de la repetición de este término.

${ }^{408}$ Cf. Müller, 1980, p. 29. Nótese que el caso presente rompe la regla de que la frase principal es por lo general breve, habida cuenta de que incluso la estructura se encuentra desarrollada en sintagma adverbial más oración relativa, en un uso ya visto de desarrollo 
variación se ve completada por el empleo de un participio absoluto en el que

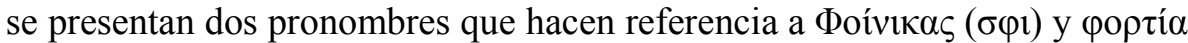
$(\pi \alpha ́ v \tau \omega v)$, sin que todavía se haya presentado la oración principal. Esto se debe a que esta se reserva para la presentación del último término clave, que

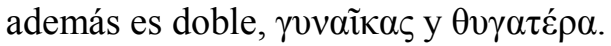

A continuación aparece un pequeño inciso, en el que se encuentra un

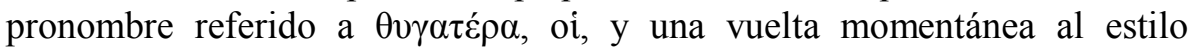

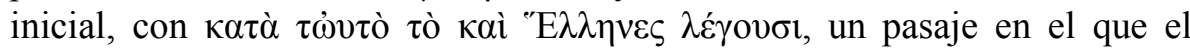
narrador se hace presente, por lo que es ajeno al desarrollo del texto.

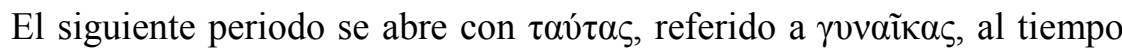
que aparece de nuevo el segundo término clave, poptí $\omega v$, que presenta un periodo subordinado que acoge, en la línea de lo que venimos defendiendo,

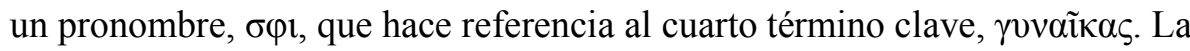
siguiente oración comienza con la repetición del primer término clave ya muy lejano, Фoívikas, y termina con un pronombre que recoge el cuarto término, av่นás. El penúltimo período se inicia con la repetición ilativa ya

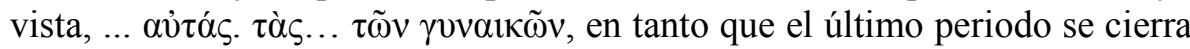
con dos adjetivaciones participiales, $\dot{\varepsilon} \sigma \beta \alpha \lambda \mathrm{o} \mu \varepsilon \dot{v} \mathrm{vov}_{\varsigma}$ y $\dot{\alpha} \pi \mathrm{o} \pi \lambda \dot{\varepsilon} \mathrm{ov} \tau \alpha \varsigma$, con lo que queda concluida la narración.

Este rápido análisis nos ha demostrado la perfecta obra literaria que es esta pequeña narración, cuya configuración oral es aplastante: la sistematización de los empleos de tan solo cuatro términos clave permite la configuración del texto y hace, por otra parte, que la demora en el progreso del mismo sea muy grande, según vimos. Así, todo ello puede resumirse del siguiente modo:

Primera parte
1) Фoívikas.

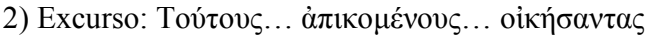

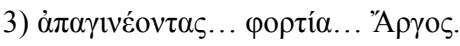
4) Excurso: 'A

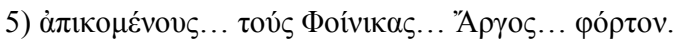

semántico que Norden, 1956, p. 168 y ss., definía como «Relativstil». Cf. Además Johnson, 1994, p. 253. 
Segunda parte:

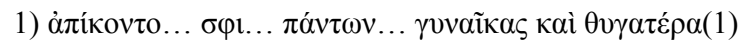

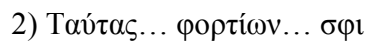

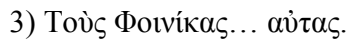

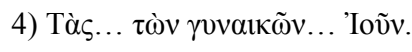

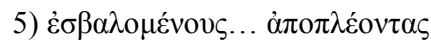

Tras una pequeña transición, que después analizaremos, aparece un nuevo $\lambda$ ó ${ }_{0} \varsigma$ de mayor brevedad, respecto al cual el propio Heródoto expresa la dificultad que supone la escasez de las fuentes. En solo un punto del capítulo 2 tenemos de nuevo tres elementos clave, dada la desaparición de la justificación comercial que daba cuenta del motivo de ese primer viaje. Así,

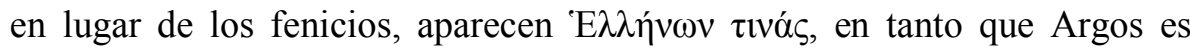

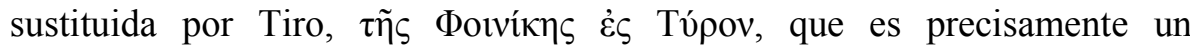
complemento de un participio, $\pi \rho \circ \sigma \sigma \chi o ́ v \tau \alpha \varsigma$, dependiente del primer término clave, en tanto que el verbo principal, un infinitivo propio de un estilo

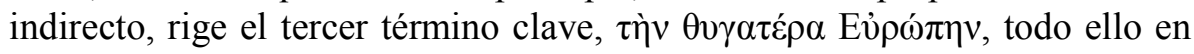
una sola frase.

Tras otra frase, que de nuevo dejaremos para el final, comienza el primer $\lambda$ ójo $\varsigma$ de la segunda parte, de mayor complejidad que el anterior. Se inicia otra vez con el primer término clave, "E $\lambda \lambda \eta v \alpha \varsigma$, repetido al comienzo del segundo periodo por medio del participio $\kappa \alpha \tau \alpha \pi \lambda \omega \dot{\sigma} \sigma \alpha \nu \tau \alpha \varsigma$, que a su vez introduce el segundo término clave, Ko $\chi \chi i^{\delta} \delta \alpha$, en esta ocasión doble, como vimos en el primer $\lambda o ́ \gamma o \zeta$ con el caso de las mujeres e Ino. Tras la introducción de la enumeración que contiene el término clave, y dada la extensión de la misma, se introduce un elemento que recoge la narración, $\dot{\varepsilon} v \tau \varepsilon \tilde{v} \theta \varepsilon v$, con la aparición acto seguido de otro participio dependiente del

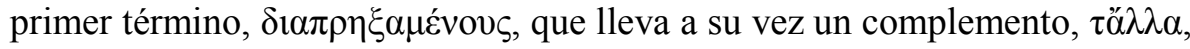

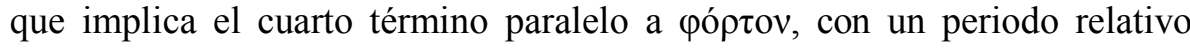
dependiente. Finalmente, esta parte concluye con el tercer término, $\theta v \gamma \alpha \tau \dot{\varepsilon} \rho \alpha$, que lleva aparejado el sustantivo $\beta \alpha \sigma \lambda \lambda \dot{\varepsilon}$ os, doblete del segundo término clave, dependiente todo ello de $\alpha \rho \pi \alpha ́ \sigma \alpha$, con lo que se cierra la primera parte.

La segunda parte, al igual que en el primer $\lambda$ ó $\gamma \circ \varsigma$, se abre con la

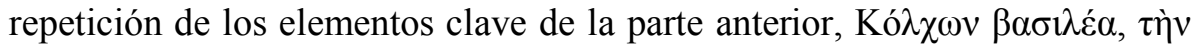
"E $\lambda \lambda \alpha \dot{\alpha} \delta \alpha, \theta v \gamma \alpha \tau \dot{\varepsilon} \rho \alpha$ y el concepto de $\alpha \rho \pi \alpha \gamma \tilde{\eta} \varsigma$ y con un participio, uso 
habitual en Heródoto para iniciar una frase. ${ }^{409} \mathrm{El}$ segundo periodo comienza

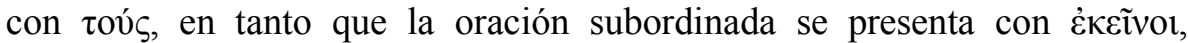
referido a Kó $\lambda \chi \omega v$, mientras que $\sigma \varphi \mathrm{l}$ se refiere a "E $\lambda \lambda \eta v \alpha \varsigma$, y reaparece $\dot{\alpha} \rho \pi \alpha \gamma \tilde{\eta} \varsigma$, cerrándose la narración con una frase conclusiva. Con todo ello, el esquema es:

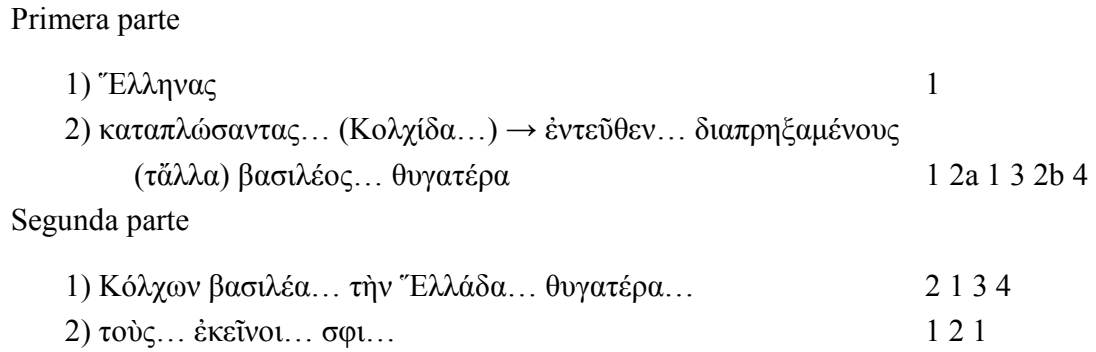

Si bien la estructura parece algo más compleja que en el caso anterior, ello se debe únicamente a que la narración se concentra en una menor extensión, dado que la estructuración es semejante.

El último $\lambda$ ó $\gamma o \varsigma$ se refiere ya a la generación de la guerra de Troya, siendo precisamente el primer elemento clave $A \lambda \hat{\varepsilon} \xi \alpha v \delta \rho o v$, del cual depende un participio que rige un elemento transversal en la conformación del texto,

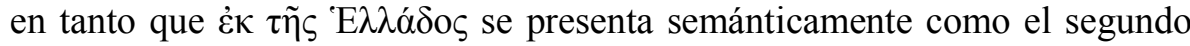

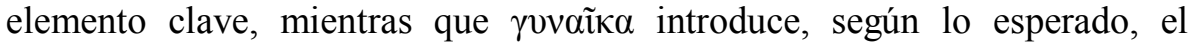
tercero, seguido de $\dot{\pi} \pi \sigma \tau \tau_{\alpha} \mu \varepsilon v o v$ que introduce un elemento de importancia no solo estilística, en tanto que toda esta primera parte se cierra con

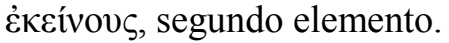

De nuevo la segunda parte se inicia con un participio absoluto, reconocido como uno de los usos más habituales de Heródoto para iniciar una nueva parte de la narración, ${ }^{410} \dot{\alpha} \rho \pi \alpha ́ \sigma \alpha v \tau o \zeta ~ \alpha v j \tau o \tilde{\text {, }}$, referido al primer elemento, y que rige $\left.{ }^{E} \mathrm{E} \lambda \dot{\varepsilon} \mathrm{\eta}\right\rangle$, el tercero. El periodo principal se abre con

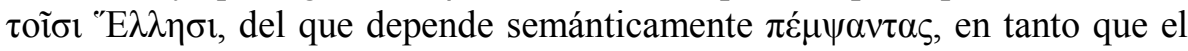
verbo principal rige $E \lambda \dot{\varepsilon} v \eta \nu$. El último periodo, que podríamos considerar

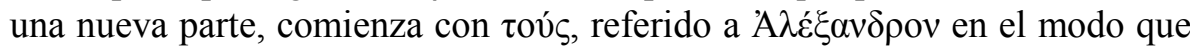
hemos visto en otros casos, mientras que de nuevo con un participio absoluto

${ }^{409}$ Cf. Müller, 1980, p. 28 y ss.

${ }^{410}$ Cf. Müller, 1980, pp. 28 y ss. y 74 y ss. 
se introduce la referencia a los griegos, al tiempo que ese participio introduce un $\tau \alpha \tilde{\tau} \tau \alpha$ que recoge todo lo antes narrado. ${ }^{411}$ Por su parte, $\sigma \varphi \imath$ se refiere de nuevo a $A \lambda \hat{\varepsilon} \xi \alpha v \delta \rho o v$, y los participios introducidos por $\dot{\omega} \zeta$ dependen de $\sigma \varphi \mathrm{l}$, en tanto que el dependiente de la oración de infinitivo se refiere a los griegos.

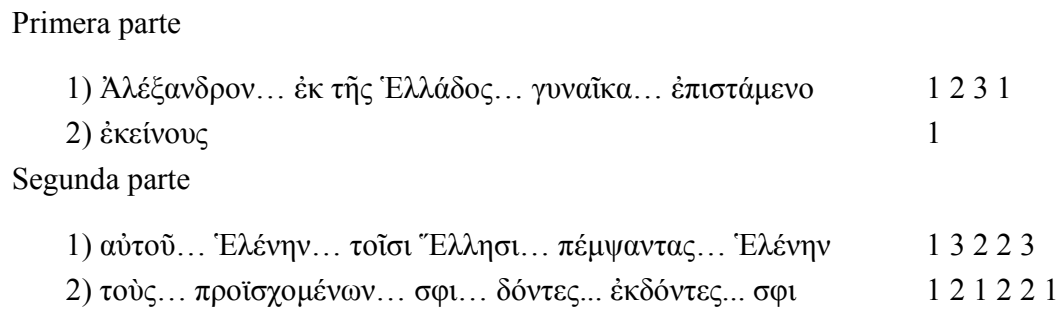

Junto a esta estructuración interna de cada pasaje, a lo largo de los tres últimos $\lambda$ ó or hallamos una serie de elementos de carácter transversal que unifican las diferentes narraciones. Elementos como $\mu \varepsilon \tau \grave{\alpha} \delta \delta \dot{\varepsilon} \tau \alpha \tilde{v} \tau \alpha$ introducen las tres narraciones últimas, mientras que la repetición en la tercera narración de la figura de Ío nos retrotrae a la primera. Algo parecido ocurre con la aparición de referencias a Medea en la última. Más importante es la repetición de dos palabras clave ${ }^{412}$ que unifican la totalidad de la

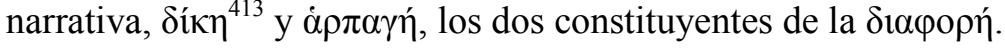

El capítulo 4 supone un cambio total de estilo: la funcionalidad de la narrativa oral con sus elementos clave repetidos, cuya finalidad de cohesión del texto hemos analizado, deja paso, todavía en estilo indirecto, a una prosa de una complejidad mayor que la del anterior, lo que hace imposible su asignación a un contexto puramente oral. La desaparición de la repetición ilativa ${ }^{414}$ de elementos clave permite las construcciones paralelas en las que, precisamente, se elimina aquello que por repetido es sobrante, como en el

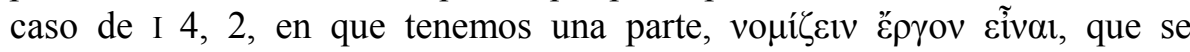

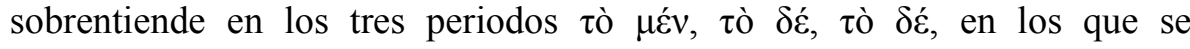

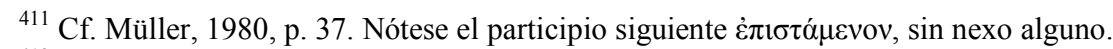

${ }^{412}$ Cf. Long, 1987, p. 41 y ss.

${ }^{413}$ Cf. ya Fehling, 1969, p. 255

${ }^{414}$ No creemos que la repetición presente en $\dot{\alpha} \rho \pi \alpha \sigma \theta \varepsilon 1 \sigma \varepsilon \dot{\varepsilon} \omega v \ldots . . \dot{\alpha} \rho \pi \alpha \sigma \theta \varepsilon 1 \sigma \varepsilon \dot{\varepsilon} \omega v$, señalada por Fehling, 1969, p. 130, se encuentre en un contexto de igual simplicidad que en otros casos, pero interesa ver cómo Heródoto se vale de recursos tradicionales en contextos nuevos. 
vislumbran paralelismos y reminiscencias semánticas, pero de una manera muy leve si lo comparamos con los tres relatos anteriores. En el siguiente punto, I 4,3 , justamente en una estructura $\mu \varepsilon \dot{v}-\delta \varepsilon ́$ observamos de nuevo la falta de esos elementos, y la ruptura de la ilación entre periodos con la consiguiente falta de cohesión en ellos.

El capítulo 5 se abre con una fórmula estructural que aparece por tres veces y que después veremos, en tanto que en I 5, 2 encontramos una breve narración paralela al $\lambda o ́ \gamma o \zeta$ inicial cuya conformación es por completo ajena

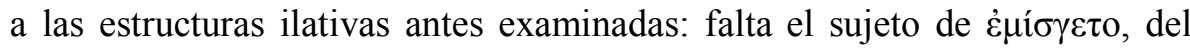
que dependen semánticamente los participios del siguiente verbo, principales y subordinados -compárese la aparición sistemática del elemento clave desde el principio en los anteriores casos-, y hemos de remontarnos tres líneas atrás para ver el referente 'Ioṽ $\varsigma$, de modo que observamos una ligera desviación del uso tan riguroso de esos recursos en los anteriores relatos,

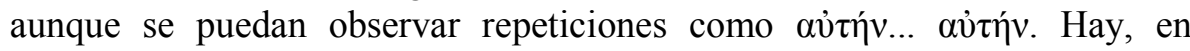
definitiva, un rasgo que hace esta pequeña narración muy diferente a las anteriores: frente al mantenimiento escrupuloso del estilo indirecto en los $\lambda$ ó $\gamma o 1$, en este caso la introducción de una oración dentro de ese estilo indirecto con $\omega \varsigma$ es la causa de dicha ruptura, y ese empleo irregular se debe a la introducción, muy sutil, del juicio del autor. El empleo de esa modalidad de estilo indirecto por parte de Heródoto frente a los usos regulares permite al autor introducir su juicio, al igual que ocurría en el desarrollo del capítulo 4 con todas las reflexiones de los persas acerca de las tradiciones antes expuestas.

Todo ello responde a la mayor complejidad de aquellos pasajes, no excesivos pero quizá más abundantes de lo que parece a primera vista, en los que Heródoto muestra su opinión o juicio, o, simplemente, en los que no se atiene a los mecanismos narrativos o descriptivos tradicionales, ${ }^{415}$ cuya propensión a una mayor complicación de la expresión ${ }^{416}$ responde a un escenario no oral en el sentido estricto en el que venimos empleando el

\footnotetext{
${ }^{415}$ Cf. para estos últimos Müller, 1980, p. 83 y ss.; Fränkel, 1960b, p. 51 y ss.; en p. 52 afirma: «Das technische Problem dieses Stiles lag in der Auswahl, Anordung und Verbindung der vielen einzelnen Wirklichkeitsstäubchen». Lo que de nuevo nos pone sobre aviso de la necesidad de tener siempre presente el problema de la cohesión para la conservación del texto. Long, 1987, p. 45, no advierte este cambio de estilo precisamente por reducir su análisis a la repetición de palabras con la misma raíz, lo que no es raro en textos no orales.

${ }^{416}$ Cf. Müller, 1980, p. 101 y ss. 
término. ${ }^{417}$ La dualidad de recursos orales y ajenos a esta esfera es la que da lugar a la articulación general de la obra por medio de clavijas estructurales o la tradicional Ringkomposition, propia de la más pura tradición oral ${ }^{418}$, no asimilables a un solo estilo, ${ }^{419}$ como indicaba Immerwahr, ${ }^{420}$ y que se combinan con pasajes a nivel de fraseología que no responden a esa estricta retórica oral y que, una vez más, hacen difícil que la obra se pudiese presentar en un escenario puramente oral. Müller decía a este respecto: «Verschiedene stilistische Eigenheiten resurtieren zum Teil auch daraus, dass Herodot nich nur für Leser, sondern auch für Hörer geschrieben hat». ${ }^{421}$ Esta afirmación en su dualidad expresa la clave no solo de la obra sino también del momento cultural, y sintetiza bien los resultados que se derivan de los datos observados. Y es que, si tenemos presente que la constitución de un texto puramente oral requería de manera continua esos recursos observados en los $\lambda$ ó $\gamma o 1$, parece difícil determinar como contexto de la obra herodotea uno oral, y, a nuestro entender, es esta la única vía segura para determinar la naturaleza del contexto de la obra. ${ }^{422}$

La muy criticada propuesta de $\mathrm{Nagy}^{423}$ acerca de la consideración de la labor herodotea como la de un $\lambda$ ó 1 los a partir de los paralelos homéricos, tanto en forma como en pensamiento, es errada en sus conclusiones pero no en su planteamiento. Heródoto se situa al final de una tradición poética oral, como creemos haber demostrado, y también de una larga tradición oral en prosa. Son los $\lambda$ ó $\gamma 101$ los representantes de este modo de literatura oral para nosotros perdida, como indica en parte Nagy, ${ }^{424}$ pero Heródoto no es uno de ellos. Esto se debe a la distancia formal que existe entre el necesario rigor en

${ }^{417}$ Fundamentales son las indicaciones a este respecto de Vignolo Munson, 2001a, p. 17 y passim.

${ }^{418}$ Cf. Fränkel, 1960b, p. 71; Beck, 1971, p. 4 y ss.; van Groningen, 1958, p. 51 y ss.

${ }^{419}$ Cf. Beck, 1971, p. 6.

${ }^{420}$ Cf. Immerwahr, 1966, p. 15, hablaba de dos niveles de estructuración, uno superior y otro inferior más complejo, en el que precisamente hemos de situar los aspectos que indicamos.

${ }^{421}$ Cf. Müller, 1980, p. 107.

${ }^{422}$ Recientemente Scott, 2005, p. 4, afirmaba que «We do not know if the work was published in parts or as a whole, orally or in writing, either in his lifetime or alter his death».

${ }^{423}$ Cf. Nagy, 1987, p. 175 y ss. Cf. crítica de Lang, 1987, p. 203 y ss. Destructiva en exceso es la puesta en cuarentena del propio empleo del término por parte de Fehling, 1989, pp. 8 y, especialmente, 52 .

${ }^{424}$ Cf. Nagy, 1987, p. 181. La idea de que el paralelo entre el aedo y el $\lambda$ ó $\gamma 10 \varsigma$ es el ser guardianes de la fama es simplemente cerrar el espectro arbitrariamente; ambos son garantes, a nuestro entender, de la enciclopedia tradicional. Cf. también Murray, 2001, p. 34. 
la aplicación de los recursos orales que ha de tener presente un $\lambda$ ó 1 io y la labor de Heródoto, que juega con esos recursos y los concentra en las narraciones de las pequeñas novelas y cuentos que aparecen a lo largo de la obra y que, no hemos de olvidar, tienen un origen popular, lo que las convierten seguramente en fiel reflejo de la obra perdida de los prosistas orales de la Grecia arcaica. Pero el hecho mismo de que estas narraciones supongan elementos fácilmente aislables dentro de la obra es la mejor señal de que Heródoto se encuentra un paso más allá de los $\lambda$ óyıo y de sus narraciones, que inserta dentro de su obra como elementos con entidad propia y diferenciada del total de su creación historiográfica.

Sostenía $\mathrm{Ong}^{425}$ que fue necesario el surgimiento de la escritura y la transición de las etapas orales a las escritas para la aparición de la historiografía, y, en general, de las ciencias. A partir de lo expuesto en cuanto al empleo de la «retórica oral» en los $\lambda$ ó desaparición de los recursos propios de la misma de los juicios del autor sobre lo que nos cuenta, podría parecer que es así, pero, a nuestro entender, ello solo quiere decir que esos juicios eran incompatibles con una transmisión literaria que permitiese su supervivencia más allá de una generación. La eclosión producida en la época dorada de Jonia está claro que se relaciona con la escritura, y ello a su vez significa que, antes de la aparición de la escritura, la distribución y supervivencia de esos juicios era un fenómeno muy limitado, inexistente si hablamos de literatura al modo herodoteo o de los jonios.

\subsubsection{EL PROEMIO RETOMADO: HERÓDOTO POETA ÉPICO}

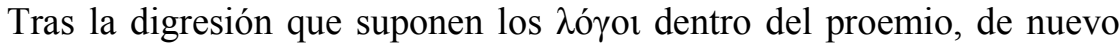
aparece la primera persona de forma contundente marcando el inicio de un «proemio» al modo habitual de los existentes en la prosa del siglo $\mathrm{V}$ a. C. Veíamos como característico de estos proemios el empleo de esa primera

${ }^{425}$ Cf. Ong, 1982, p. 14 y ss.: «[...] without writing, human consciousness cannot achieve its fuller potentials, cannot produce other beautiful and powerful creations. In this sense, orality needs to produce and is destined to produce writing. Literacy, [...] is absolutely necessary for the development not only of science but also of history, philosophy, explicative understanding of language itself»». 
persona, así como la aparición de un verbo -el elemento dinámico-, cuya evolución desde la invocación a las musas es clara y, sobre todo, el uso de $\pi \varepsilon \rho i ́$, presente en Filolao en Protágoras, o en La república de los atenienses del Pseudo Jenofonte, y que incluso podíamos rastrear en los «títulos» de las obras de los presocráticos. ${ }^{426}$ Pero, en el caso de Heródoto, ha de notarse, sin embargo, el fuerte tono polémico, que nos recuerda a Protágoras y su Sobre los dioses: ${ }^{427}$

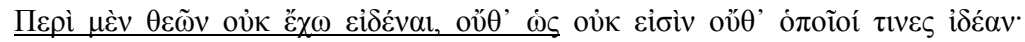

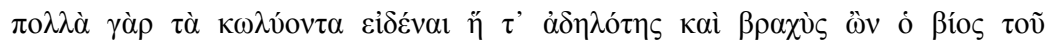
$\dot{\alpha} v \theta \rho \omega ́ \pi$ ov.

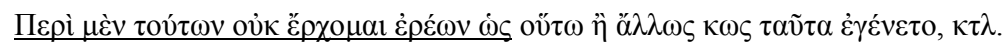

Interesante es señalar la expresión oṽ $\tau \omega$ ì $\partial \lambda \lambda \omega \omega \varsigma$, que nos recuerda, de manera simplificada, a una formulación que se presentará como plenamente

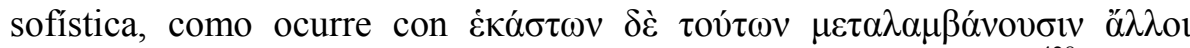
$\alpha \ddot{\lambda} \lambda \omega v \not \alpha \lambda \lambda \omega \varsigma$, poliptoton llevado al extremo de parodia en Platón, ${ }^{428}$ y cuya significación conceptual es muy alta. Nótese además que hemos excluido el pronombre personal $\dot{\varepsilon} \gamma \omega \grave{\delta} \delta$ : se trata de un elemento ajeno al desarrollo del periodo, como demuestra la aparición de una correlación posterior $\mu \varepsilon v^{\prime}-\delta \varepsilon,{ }^{429}$ y cabe preguntarse si en el caso de Protágoras ocurriría lo mismo, aunque la pérdida de texto nos impide emitir juicios contundentes al respecto. La respuesta a esta pregunta y la posición tan fuerte de $\dot{\varepsilon} \gamma \omega ́$ puede tener su origen en el examen de un fragmento de localización incierta ${ }^{430}$ de Hipias,

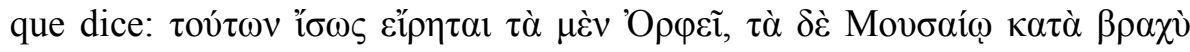

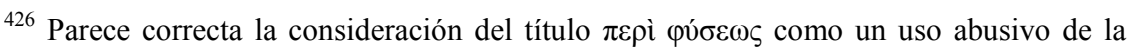
Antigüedad a la hora de dar título a unas obras que quizá no lo tuvieron, pero no hemos de desechar la idea de que no fuera el título, sino el incipit de las obras -tenemos los ejemplos citados-, de modo que expresase el contenido de esa obra. La repetición haría que las diferentes obras constituyeran un todo crítico sobre el tema, creado a partir de las diferentes

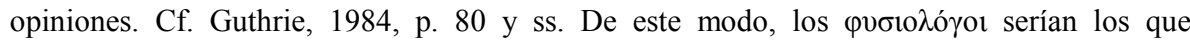
disertarían $\pi \varepsilon \rho \grave{~} \varphi v ́ \sigma \varepsilon \omega \varsigma$.

${ }^{427}$ Protágoras, DK 80 B 4.

${ }^{428}$ Cf. Platón, Gorgias, 448c, en boca de Polo. Cf. Untersteiner, 1967b, p. 83.

${ }^{429}$ Cf. Müller, 1980, p. 43.

${ }^{430}$ Cf. Untersteiner, 1967 b, p. 82, para un rápido examen de las posibles atribuciones,

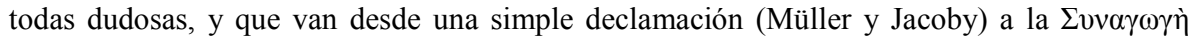
propuesta por Gomperz. 


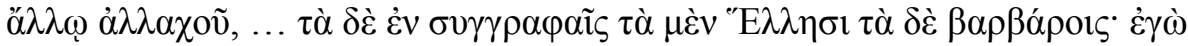

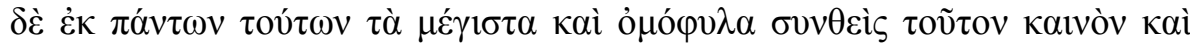

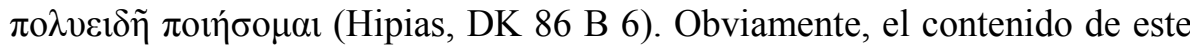
pasaje y el de Heródoto I 5 son muy diferentes, por cuanto diríamos que Hipias no plantea un método, pero los paralelos son muchos en el plano formal: la oposición algo confusa de fuentes distintas así como la fuerte contraposición aislada de lo anterior al pronombre personal son semejantes en ambos autores. Igualmente interesante es la aparición del término

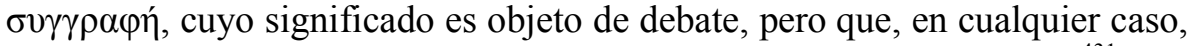
nos pone sobre aviso de la contextualización general de esta obra. ${ }^{431}$ Por desgracia, y esto es lo que realmente nos interesa, no sabemos nada del contexto del fragmento, y por ello no tenemos razones para defender que es esta la continuación habitual en la prosa de la época de comienzos como el de Protágoras. La caprichosa tradición nos priva de respuesta, pero al menos podemos afirmar que la expresión formal herodotea era habitual, y que no se reducía al uso del historiador. Si Hipias copió a Heródoto por ser aquel más joven, ${ }^{432}$ o si, simplemente, era un uso general, es algo que confesamos no poder resolver.

Más allá de esta pregunta sin respuesta, cabe destacar el hecho de que Heródoto se inscribe aquí en una corriente clara de polémica intelectual cuyo desarrollo en el siglo v a. C. está claramente demostrado. Pero, además, tras un periodo construido por medio del empleo de pronombres y participios al

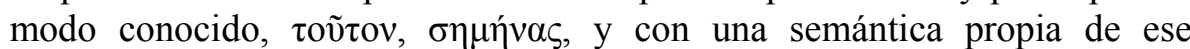

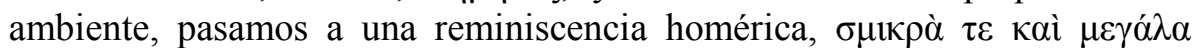

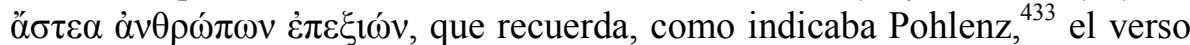

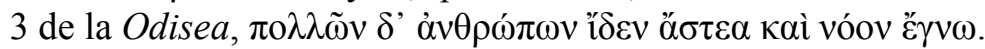

Sin embargo, desde esta reminiscencia homérica, la narración se retoma de una manera similar a la que presenta el proemio de Protágoras, con un periodo introducido por $\gamma$ ó $\rho$, que explica - al igual que en Sobre los diosesel porqué de esa afirmación, con construcciones paralelas que recogen una variatio en miembros paralelos. Es esta estructura de afirmación seguida de

${ }^{431}$ Cf. Untersteiner, 1967 b, p. 84, para las interpretaciones de este término, que van desde la simple obra de los poetas a la de los historiadores. Creemos que, simplemente, significa 'escritos', sin determinación expresa de la tipología de la obra.

${ }^{432}$ Hipias nació en torno al año 460 a. C., si bien Untersteiner rebaja la fecha al 443, cf. Untersteiner, 1967, p. 111. Sea como fuere, la cronología es en este caso de poca ayuda, dado que nuestro objetivo rebasa la simple comparación entre ambos autores.

${ }^{433}$ Cf. Pohlenz, 1961, p. 9. 
causa introducida por $\gamma$ ó $\rho$ algo que, además de en Protágoras, Filolao, y Hecateo, se presenta en Antifonte, ${ }^{434}$ en Gorgias, ${ }^{435}$ y en el propio Heródoto en los discursos. ${ }^{436}$

Ya en los orígenes mismos de la literatura griega, en Homero, aparece este tipo de expresión en los proemios, paralela a la muy conocida polaridad y analogía, claves en la configuración de la primitiva corriente cultural jonia. Antes de pensar en un carácter marcadamente retórico de este recurso, hay que tener presente su especial importancia en la configuración de las denominadas aretalogías de la literatura hímnica. ${ }^{437}$ Norden $^{438}$ advirtió su empleo casi formular en la exposición de las $\delta v v \alpha ́ \mu \varepsilon 1 \varsigma$ de la divinidad, justificación del ruego mismo. Obviamente, para comprender estos usos hemos de pensar en una disolución de las esferas que tradicionalmente aislamos, la religión y la filosofía, al menos en el plano formal, y a ello hemos de unir el uso repetido por Píndaro ${ }^{439}$ en contextos paralelos o desligados del uso propio de la aretalogía habitual, que permiten ver la versatilidad del recurso.

La simplicidad de este modelo causativo y justificativo hace que pensar en establecer una jerarquía de dependencias de uno $u$ otro género nos parezca insostenible: es más simple pensar en un modo de expresión generalizado en los estadios más antiguos de la literatura hímnica por ser la única generalizada, pero su presencia en los primeros discursos conservados, en Homero, ${ }^{440}$ en Gorgias y los demás autores, da cuenta de su popularidad como mecanismo de expresión de la causa en el primitivo estadio tradicional

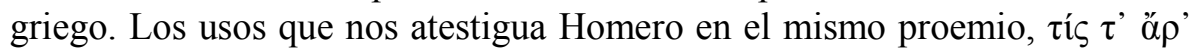

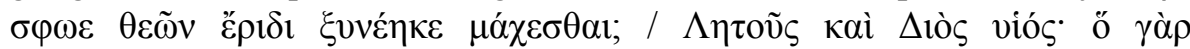

${ }^{434}$ En Contra la madrastra, Tetralogías, 1 y 2; Sobre la muerte de Herodes; Sobre el coreuta.

${ }^{435}$ En Defensa de Palamedes y en Encomio de Helena.

${ }^{436}$ Cf. I 31; 32; III 80 y ss.; VII 9; VIII 60, de modo más desarrollado, entre otros. Parece interesante indicar el hecho de que los rasgos gnómicos señalados en este pasaje por Fehling, 1969 , p. 305 y ss., se repiten solo en los discursos.

${ }^{437}$ Cf. Himno a Apolo, 20; Himno a Afrodita, 9, etc.

${ }^{438}$ Cf. Norden, 1956, p. 150 y ss., en especial p. 157.

${ }^{439}$ Cf. Olímpicas, VI 11; X 4; XII 4; XIII 6; XIV 6; Píticas, I 10; II 16; VII 9; VIII 7; X 11, etc.

${ }^{440}$ Cf. Munro, 2003, p. 316 y ss.; Denninston, 1960, p. 58 y ss. La diferencia entre el tipo confirmativo y el explicativo nos parece muy leve: a nuestro entender, el segundo es una evolución del primero, como veremos al analizar el proemio de Tucídides. 
$\beta \alpha \sigma 1 \lambda \tilde{\eta} \ldots . .,{ }^{441}$ o en versos siguientes, ${ }^{442}$ dan cuenta de que el modo de expresión causativo se emplea con total naturalidad en estadios primitivos de la cultura griega, en los momentos previos del milagro jonio.

Ya Lloyd alertó sobre la necesidad de evitar asociar la aparición de la causatividad con el surgimiento del citado movimiento, ${ }^{443}$ dado que es un fenómeno muy común en los estadios primitivos de los pueblos tradicionales, que, basados en su experiencia, someten los diferentes fenómenos a un sistema regular a partir de cuyos incumplimientos se sustenta el principio causal, ${ }^{444}$ sea el garante una divinidad, como en el caso anterior, o la propia responsabilidad humana, como en el proemio de la Odisea ${ }^{445}$ o estadios que podríamos definir como mixtos, presentes, según señala Lloyd, en Heródoto. ${ }^{446}$ En lo que a nosotros aquí nos interesa, se ha de destacar que el recurso de afirmación seguida de causa introducida por $\gamma \alpha$ ó $\rho$ es un recurso formalizado muy elemental que será empleado en los proemios de los prosistas hasta el siglo IV a. C. Los primitivos usos homéricos y de la súplica religiosa serán recogidos por los $\varphi v \sigma ı \lambda$ ó forma abundante, y después por los oradores, siempre desde una perspectiva plenamente estilística, como vimos que ocurría con los diferentes recursos de origen oral, que son reutilizados por autores inmersos ya en épocas confusas en cuanto a los usos orales.

Finalmente, el último periodo que pone fin al proemio, se inicia con un uso intensificador de la posición inicial, $\dot{\alpha} v \theta \rho \omega \pi \eta$ í $\nu$, término tan importante como mal entendido, así como con una ligera aliteración, غ̇ंt- en

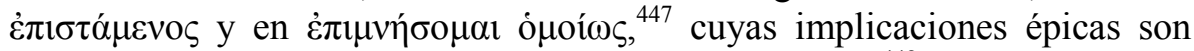
dudosas, a pesar de su aparición en la Ilíada y la Odisea ${ }^{448}$ pero que parecen

${ }^{441}$ Homero, Iliada, I 8 y ss. Kirk, 1985, p. 54, afirma: «an action that is to be so portentous deserves a divine cause».

${ }^{442}$ Cf. Ilíada, I 12.

${ }^{443}$ Cf. Lloyd, 1999, p. 48 y ss.

${ }^{444}$ Para después construir la interpretación causal del mundo como tal y no sólo de las excepciones; cf. Lloyd, 1999, p. 50.

${ }^{445} \mathrm{Cf}$. Odisea, I 6.

${ }^{446}$ Cf. Lloyd, 1999, p. 50, nota 214.

${ }^{447}$ Cf. Beck, 1971, p. 74, para ó $\mu$ oí $\omega \varsigma$ como elemento anular que recoge la ampliación introducida por $\gamma \alpha \dot{\alpha} \rho$.

${ }^{448}$ Dos son las apariciones del verbo compuesto en Homero, la primera en la Ilíada, en la

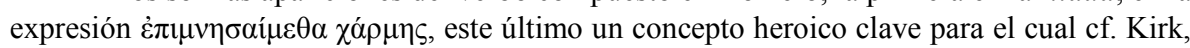
1985, p. 383. El problema se presenta por el hecho de que el verbo compuesto es minoritario frente al simple. 
confirmarse por su aparición en un fragmento de Arquíloco $^{449}$ de difícil interpretación pero de contexto claro, perteneciente al ciclo de Glauco y que pone en valor el ardor guerrero, al igual que en Homero, donde aparece en un monólogo de Menelao. De esta forma, con la referencia semántica a la $\mu \nu \eta \mu о \sigma v ́ v \eta$-cuyos vínculos con el concepto de $\kappa \lambda \dot{\varepsilon}$ os son de sobra conocidos- ${ }^{450}$ se cierra el proemio de manera clara, pero sin una ilación suficiente con la narración propiamente dicha. ${ }^{451}$

\subsection{La estructura proemial. Reminiscencias e innovaciones}

La publicación por Peter Parsons ${ }^{452}$ de un amplio fragmento de Simónides, además de la lógica expectación y quizá alguna desilusión por los muchos caminos sin salida abiertos, nos proporciona una pieza clave en la comprensión de la estructura general del proemio herodoteo, y, con ello, de los resortes estilísticos de historiografía antigua. La complejidad del texto es mucha, pero las cuestiones textuales han sido aparentemente resueltas por la publicación del mismo en la edición de West, en lo que a nosotros nos importa -dado que es el claramente referido al «comienzo» del poema-, como fragmento $11 \mathrm{~W}$.

La amplia labor crítica realizada sobre este texto nos permite afirmar sin reservas la existencia de una estructura clara de ese «principio», como lo denominaremos por ahora. Respecto a las posibles complicaciones relativas a la performance del poema, nosotros nos arriesgaríamos a asociarlo con un festival público conmemorativo ${ }^{453}$ de las guerras médicas, hecho ya señalado por Kowerski ${ }^{454}$ y que ha de ser tenido en cuenta para las posibles

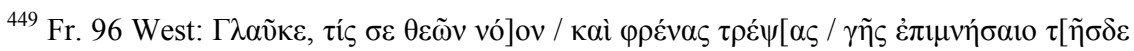

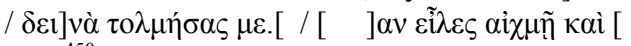

${ }^{450}$ Cf. Nagy, 1994, p. 95 y ss.

${ }^{451}$ Johnson, 1994, p. 246, señaló este hecho, si bien considerar el proemio un añadido es algo discutible, y no da cuenta de la naturaleza arcaica de ese corte.

${ }^{452}$ Cf. Parsons, 1992, Oxyrhyncus Papyri, XLIX, Nr. 3965.

${ }^{453}$ Idea generalmente admitida, cf. Boedeker, 1995, p. 220; igual y concluyente, Bowie, 2001, p. 60 .

${ }^{454}$ Kowerski, 2005, p. 120; el propio autor reconoce en sus conclusiones lo complejo del tema, y de sus palabras se desprende la idea clara de asociar este poema a la intencionalidad del epigrama funerario. A nuestro entender y según veremos, el complejo de composiciones
} 
conclusiones derivadas de nuestro estudio estructural. En este mismo sentido, Bowie ha apuntado, ${ }^{455}$ con las consabidas precauciones al tratar con obras fragmentarias, la diferencia de extensión entre el proemio del fragmento $11 \mathrm{~W}$ y el resto de las denominadas elegías narrativas, lo que es buen aviso en cuanto a la mayor complejidad formal de aquel.

A este respecto, tenemos la suerte de contar con estudios como el de Obbink y el del propio Kowerski, que más recientemente recoge la obra del primero. Así, las semejanzas establecidas entre lo que denominamos «principio» y un proemio épico del tipo que antes estudiamos son claras. Kowerski distingue hasta cuatro partes en el fragmento: la primera sería el incipit propiamente dicho de la composición, no conservado pero que tuvo que existir por las razones ya señaladas respecto a su funcionalidad en un mundo oral, y que daría paso a lo que Kowerski define como un himno a Aquiles ${ }^{456}$ cuya naturaleza y contenido exactos no es posible delimitar, y que a su vez nos llevaría a una fórmula de transición representada por $\dot{\alpha} \lambda \lambda \dot{\alpha} \sigma \grave{v}$ $\mu \dot{\varepsilon} \nu$ vข̃v $\chi \alpha \tilde{\rho} \rho \varepsilon,{ }^{457}$ muy habitual en los Himnos homéricos y cuya presencia en el fragmento, más allá de las cuestiones de género, nos importa porque establece la frontera entre dos partes diferenciadas del poema. ${ }^{458}$ Ello es así porque a partir del verso 19 se da paso a un nuevo tema de manera indiscutible, en el que se tratan las guerras médicas, sin necesidad, en lo que nos atañe, de determinar si se refiere a Platea, como todo parece apuntar. ${ }^{459}$

De esta manera, podemos afirmar que el poema se abriría de manera tradicional, para pasar a continuación a la exposición de una escena relativa a Aquiles, al igual que observamos en los Himnos homéricos, y, de modo especial, en los protohímnos, como los himnos a Afrodita, Ártemis, Atenea, Deméter, la diosa madre y otros, en los que se realiza después esa transición que daría paso a una narración -de la naturaleza que fuere-, como en el

del autor referidas a las guerras contra el persa deben, en cierto modo, ser consideradas cercanas en cuanto a su espíritu.

${ }^{455}$ Cf. Bowie, 2001, p. 57.

${ }^{456}$ Cf. Kowerski, 2005, p. 64 y ss., con examen de las evidencias; en contra, Boedeker, 1995, p. 219.

${ }^{457}$ Fr. $11 \mathrm{~W}$, v. 19. Bowie, 2001, p. 63 y ss., alerta además de la gran importancia de este pasaje para el planteamiento de las posibles influencias de la lírica en la creación de la historiografía; su desaparición en el plano formal también lo será.

${ }^{458}$ Cf. Bowie, 2001, p. 58.

${ }^{459}$ Cf. Boedeker, 1995, p. 219 y ss.; crítico en sus conclusiones Kowerski, 2005, p. 148 y ss. 


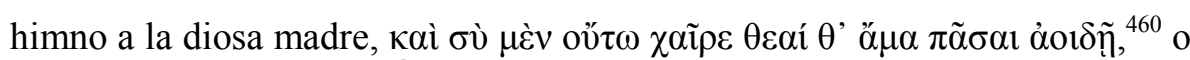
más claramente en el de Ártemis: ${ }^{461}$

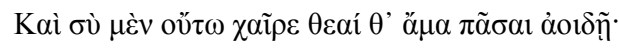

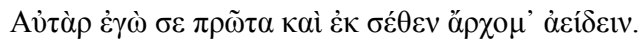

En el caso de Simónides la cosa es diferente e ingeniosa: si antes observamos la reforma de elementos homéricos en el epigrama al adivino, la tradicional estructura del himno permite al poeta reaprovechar el espacio inicial que sigue a la primera invocación y que recoge habitualmente la aretalogía de la divinidad para tratar el tema troyano y sus héroes; donde el autor tradicional comenzaba su narración de los hechos de la divinidad, Simónides sitúa su narración de los hechos de Platea y, en parte, crea formalmente el mito de las guerras médicas, conjugando pasado mítico y pasado cercano. ${ }^{462}$

Al margen de las consideraciones particulares que afectan al fragmento, su naturaleza proemial nos acerca de nuevo al que fue nuestro punto de partida, Homero, al tiempo que su tema nos permite dirigir nuestra atención a Heródoto. El empleo de estructuras homéricas para la expresión de hechos no épicos fue clave en la configuración del género naciente, $y$, en lo que se refiere a la estructura del proemio, más. ${ }^{463}$

Así, la organización del proemio herodoteo se realiza en virtud del empleo de recursos propios de la más pura literatura oral, como la Ringkomposition, ${ }^{464}$ y sobre una estructuración propia de la obra herodotea, que, por lo que podemos observar, es por primera vez empleada de esta

\footnotetext{
${ }^{460}$ Himno a la madre de los dioses, 6.

${ }^{461}$ Himno a Ártemis, 7-8.

${ }^{462}$ Cf. en este sentido la indicación de Hornblower, 2004c, p. 22.

${ }^{463}$ Citemos, aunque sea en nota, la propuesta ingeniosa de Pelliccia, 1992, p. 63 y ss., de
} ver en la estructura del proemio un priamel al modo sáfico y con claras conexiones con la Helena de Gorgias. Más allá del problema que conlleva basar la propuesta en unos

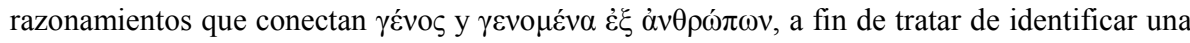
reminiscencia en el proemio que sustente el priamel en referencia a las Genealogías de Hecateo, esta estructura es por completo incompatible con la Ringkomposition que gobierna todo el proemio.

${ }^{464}$ Recursos que, como veremos, aseguran la autenticidad de la primera sección del proemio, en contra de la muy antigua opinión de La Roche, 1859, p. 282 y ss. 
forma por un prosista. Por desgracia, hemos tenido que trabajar con autores que la caprichosa transmisión nos ofrece mutilados, pero podemos asegurar que la formulación de la mayoría de los proemios presenta una conformación general constituida por una frase que desde Wilamowitz y Diels se considera como título de manera errónea; ${ }^{465}$ a esta sigue un razonamiento del tema, contenido habitualmente en el denominado «título», y seguramente un paso a la narración, como parecen indicar los tratados del Corpus Hippocraticum, como después veremos. ${ }^{466}$

La característica más patente del proemio homérico es precisamente la misma que la de la propia épica oral, la continuidad narrativa. Según hemos defendido, la naturaleza de esta literatura se sustenta en la cohesión de sus elementos, creando una cadena fuertemente enlazada en la que el paso de un eslabón al siguiente es clave, y se realiza de la misma manera que la configuración del verso homérico, por medio de la complementación, la repetición o la asociación.

En el análisis de la construcción de la frase hemos defendido la imposibilidad de considerar la obra de Heródoto como una obra oral en el estricto sentido del término, pero ello no impide que, de forma artificial, pueda el de Halicarnaso emplear este recurso de una forma cuyas implicaciones intelectuales no son pocas.

El examen del fragmento de Simónides 11W nos ha permitido observar la aplicación de los mecanismos homéricos a un tema que nos lleva a Heródoto, y con un metro que suavizaría las posibles repercusiones negativas de la aplicación de la estructura proemial épica a un tema que solo con el tiempo adquiriría ese tinte, probablemente ayudado por composiciones como esta. Seguramente, es solo con este precedente como se puede entender que Heródoto abandonase el uso ya establecido de los proemios en prosa para dar origen a una nueva estructuración que únicamente puede ser entendida si se tienen en cuenta lo especial del tema y las fuertes reminiscencias que podría presentar esta transgresión.

Antes hemos analizado los segmentos que componen el proemio así como su unidad individual. Esos elementos se unen de manera semejante a como lo hacían los inferiores y de forma paralela a los procesos observados

\footnotetext{
${ }^{465}$ Cf. Immerwahr, 1966, p. 63, quien señala en lo relativo a Heródoto que con el tiempo pudo tomar esa consideración, pero que en origen, desde luego, no lo fue. Recordamos una vez más la anécdota transmitida por Focio y remitimos al tratamiento antes realizado.

${ }^{466} \mathrm{Cf}$. apartado 5.5 . 
en la épica homérica. Así, la frase inicial, ajena a la numeración de las ediciones modernas, sustituye a la tradicional invocación homérica, ${ }^{467}$ en la que se observaban desarrollos complementarios referidos al término clave, y de igual manera tenemos en Heródoto la complementación de la frase apositiva que envuelve las oraciones finales. Esta unidad es compacta, completa por sí misma y con sentido completo, y supone el desarrollo a pequeña escala de toda la obra. ${ }^{468}$

En los proemios homéricos siguen dos relativos que determinan el punto temporal que da inicio a la narración ${ }^{469}$ de un excurso previo a la narración propiamente dicha de los poemas, ${ }^{470}$ con unos elementos correlativos, $\tau$ í $\zeta$ ¿ $v \theta$ ', que inician una retrospectiva sobre las causas de la futura narración. En

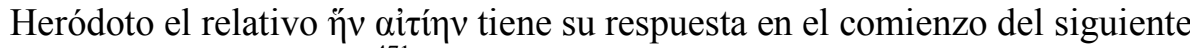

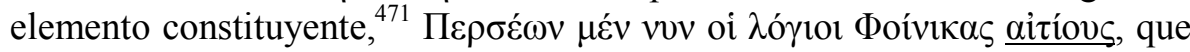
da inicio a la narración de esa retrospectiva ya presente en Homero, y que en Heródoto tiene un mayor desarrollo pero no complejidad; se recurre a la repetición de esa fórmula de enlace que nos mantiene en 1,1 hasta 5,3 , por

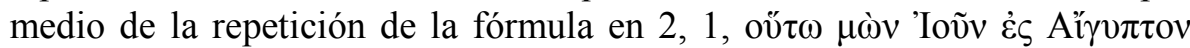

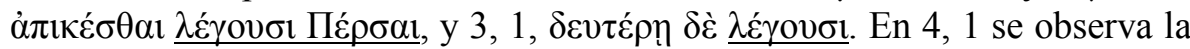

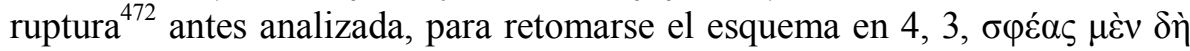

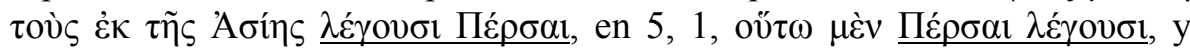

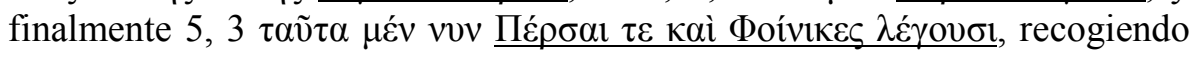

${ }^{467}$ Ilíada, I 1-6; Odisea, I 1-9.

${ }^{468}$ Cf. ya Maddalena, 1942, p. 25: «La molteplicità delle notizie non è fine dell' opera erodotea; fine è l'unità d'un quadro, di cui la molteplicità è la materia che costituisce le parti». Fundamental para la estructura es el trabajo de Cobet, 1971, que señaló la uniformidad de los excursos, cf. p. 44 y ss., cuya idea más sugestiva es sin duda la organización de esos excursos en torno a las ideas rectoras de la obra, cf. p. 179 y ss.

${ }^{469}$ Ilíada, I 7-52; Odisea, I 10-25.

${ }^{470}$ Cf. Lang, 1984, p. 3 y nota 5, quien en parte advierte dicha disposición. La función de estos proemios es la exposición de los precedentes cuyo conocimiento es necesario para la perfecta comprensión de la narración, es decir, la causa de lo que se va a narrar, lo que, por otra parte tiene importantes implicaciones, según veremos, en el plano intelectual. La representatividad de esta sección viene dada por su aparición incluso en las recreaciones de la épica helenística, como en Apolonio de Rodas, i 5 y ss.

${ }^{471}$ Cf. ya Stein, 1962, I, p. 2.

${ }^{472}$ Cf. Beck, 1971, p. 58, para una visión diferente, frente a nuestra interpretación de todo el capítulo cuarto como un bloque. 
así el excurso de 5,2, dado que este esquema se puede ampliar sin límites siempre que se mantengan las referencias al punto inicial de partida. ${ }^{473}$

Finalizada esta parte, se presenta una innovación de Heródoto, como ya observamos, y que consiste en la introducción de un segundo proemio del tipo habitual en la prosa y cuya conexión con la anterior narración se ve tenuemente mantenida por la correlación $\mu \varepsilon^{v}-\delta \dot{\varepsilon}$, que nada tiene que ver con los recursos hasta ahora vistos, lo que prueba la naturaleza ajena de esta parte de la estructura respecto al mecanismo homérico, y da además lugar a uno de los problemas más importantes en el plano estructural del proemio historiográfico, la continuidad entre el proemio y la narración.

El examen comparado de los proemios épicos y la estructuración del herodoteo presenta unas semejanzas muy claras que se acentúan si tenemos en cuenta el carácter plástico de las composiciones arcaicas; el esquema básico puede expandirse o reducirse manteniendo los elementos fundamentales que, como se puede observar, aparecen siempre. A pesar de ello, ha de tenerse en cuenta la presencia de elementos no correctamente integrados en el esquema, como las reflexiones críticas sobre los relatos de los $\lambda$ ó $\gamma$ to persas y el segundo proemio, lo que hace de este esquema algo diferente al del proemio homérico y supone la aparición de algo nuevo.

Véase el siguiente gráfico: ${ }^{474}$

${ }^{473}$ Cf. Beck, 1971, p. 12, con nota 40, si bien no da cuenta del hecho de que la Ringkomposition es «doble» al recoger tanto los relatos de los persas como el pequeño excurso sobre la variante fenicia.

${ }^{474} \mathrm{Se}$ indican con el símbolo $\uparrow$ los elementos que hacen referencia a un elemento inicial, señalado a su vez con $\downarrow$, y que unen el total del proemio, en tanto que [---] engloba elementos no integrados, y ø elementos que no presentan continuidad. 


\begin{tabular}{|c|c|c|c|}
\hline ILÍADA & ODISEA & SIMÓNIDES & HERÓDOTO \\
\hline 1. Invocación:ő $\varepsilon 1 \delta \varepsilon \downarrow$ & 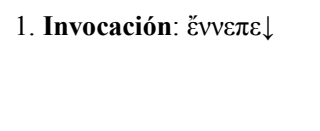 & & $\begin{array}{l}\text { 1.Presentación: } \\
\qquad \dot{\alpha} \pi \delta ́ \delta \varepsilon \xi 1 \varsigma \downarrow\end{array}$ \\
\hline $\begin{array}{r}\text { 1a.Complementación: } \\
\text { vv. } 1-5\end{array}$ & $\begin{array}{r}\text { 1a. Complementación: } \\
\text { vv. } 1-5\end{array}$ & & 1a. Complementación: \\
\hline $\begin{array}{l}\text { 1b. Concreción de la } \\
\text { causa: } \grave{\varepsilon} \xi \text { oṽ v. } 6\end{array}$ & $\begin{array}{l}\text { 1b. Digresión de la } \\
\text { complementación: } \\
\text { vv. } 6-9 \\
\text { 1c. Concreción: nueva } \\
\text { invocación: } \tau \tilde{\omega} v \dot{\alpha} \mu \circ \theta \dot{v} v\end{array}$ & & $\begin{array}{l}\text { 1c. Concreción: } \\
\eta ๊ v \alpha i \tau i ́ \eta v\end{array}$ \\
\hline $\begin{array}{l}\text { 2. Excurso: Causa. } \\
\text { Tís } \uparrow \text { v. } 8 \\
\text { 2a. Apolo y Crises. }\end{array}$ & $\begin{array}{l}\text { 2. Excurso: Causa. } \\
\tilde{\varepsilon} v \theta^{\prime} \uparrow \\
\text { 2a. Poseidón y Calipso }\end{array}$ & $\begin{array}{l}\text { 2. ¿Excurso? } \\
\text { Aquiles }\end{array}$ & 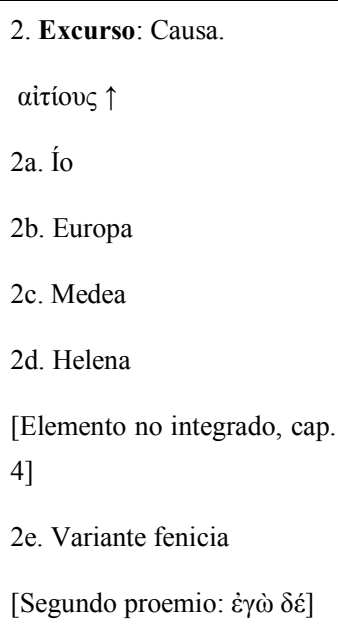 \\
\hline 3. Narración: & 3. Narración: & 3. Narración: & 3. Narración: \\
\hline 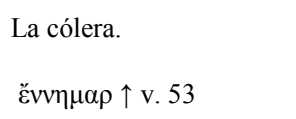 & $\begin{array}{l}\text { La asamblea. } \\
\text { Ěv } \theta \alpha \uparrow\end{array}$ & $\begin{array}{l}\text { ¿Platea? } \\
\chi \alpha \tilde{\mathrm{i} \rho \varepsilon} \uparrow\end{array}$ & $\begin{array}{l}\text { Ciro. } \\
\varnothing\end{array}$ \\
\hline
\end{tabular}




\subsection{El léxico proemial: precisión y unidad de la obra}

Contamos, afortunadamente, con todos los instrumentos necesarios para el correcto estudio del léxico de Heródoto en su proemio. ${ }^{475}$ Obviamente, nos interesa el examen de aquellos términos de especial significación para la obra de Heródoto y la configuración característica de su obra. Esta delimitación hace que los términos de mayor interés se concentren por razones obvias en la parte introductoria y en lo que denominamos proemio retomado.

El término $\dot{\alpha} \pi$ ó $\delta \varepsilon \xi 1 \varsigma$ aparece como tal por primera vez en Heródoto,

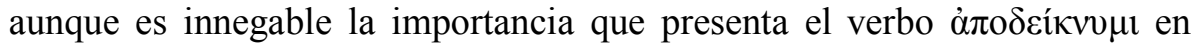
Homero, si bien la caracterización del término adquiere un sentido claro en la obra herodotea. La traducción propuesta por Powell en su léxico ${ }^{476} \mathrm{es,} \mathrm{a}$ nuestro entender, imposible, a la luz de la diferente perspectiva que tenemos hoy de la difusión de la obra de Heródoto: la complejidad de decidir el correcto significado del término pasa por la comprensión de los restantes usos que Heródoto hace del término. De los cuatro casos restantes, el

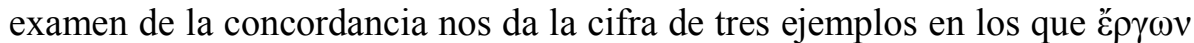
es el complemento del término en cuestión, ${ }^{477}$ lo que en cierta manera nos permite entrever posibles reminiscencias que llevan a pensar en un valor claro cercano a 'dar a conocer', con una idea de percepción exterior que hemos de tener presente, y que es compatible con el nuevo enfoque sobre la difusión de la obra. ${ }^{478}$ A este respecto, Bruno Snell en su tesis nos aportó una definición ciertamente interesante de las familias de $\gamma v \omega ́ \mu \eta$ y oĩ $\delta \alpha$ que es de especial valor aquí, dado que es la complementación del término la que define el valor de la voz ả $\pi$ ó $\delta \varepsilon \xi 1 \varsigma$, complementación realizada por un

475 Así, el léxico de Powell, 1977, cuya fecha de publicación original es 1938, y la concordancia de Schrader, 1996.

${ }^{476}$ Cf. Powell, 1977, s. v., quien traduce por 'publication'.

${ }^{477}$ La excepción es VIII 101.

${ }^{478}$ A este respecto, Bakker, 2002, p. 20, parece indicar que hemos de rastrear un sentido neutro en el verbo, sin una especialización clara de su semántica, lo que parece evidente,

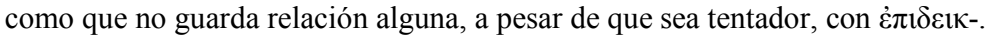




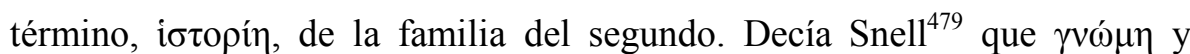
$\gamma \iota \gamma \nu \omega ́ \sigma \kappa \omega$ daban cuenta del ejercicio intelectual del individuo con el objeto, en tanto que oĩ $\delta \alpha$ y sus derivados hacían referencia al ejercicio interno y solitario del individuo respecto a su percepción, estableciéndose un orden temporal que responde a $\gamma \nu \omega ́ \mu \eta-\varepsilon i ́ \delta \eta \sigma i \varsigma,{ }^{480}$ de interactuación exterior, actuación interior, pasos a los que, añadimos nosotros, se suma un tercero

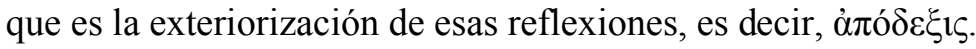

El término $\bar{\varepsilon} \xi i ́ t \eta \lambda \alpha$ es ajeno de nuevo a Homero, pero se puede rastrear en Esquilo, ${ }^{481}$ en Eurípides en pasajes elevados, ${ }^{482} \mathrm{y}$ en el propio Heródoto

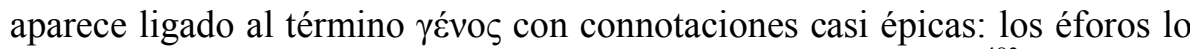
emplean ante el miedo de que se extinga el linaje de Eurístenes. ${ }^{483}$

$\Theta \omega \mu \alpha \sigma \tau \alpha ́$ es un término presente, a diferencia de los anteriores en una dualidad de significados clara ya en Homero, ${ }^{484}$ y que observamos también en Heródoto; $\theta \tilde{\omega} \mu \alpha$ es por igual el elemento causante de la admiración como la propia admiración, ${ }^{485}$ en lo que es un término clave en la configuración de la obra, precisamente porque su semántica no ha de reducirse a un elemento como tal: es, simplemente, un prodigio, algo que llama la atención, un fenómeno si se desea, de una naturaleza tan variable como se quiera pensar.

Para la comprensión de oĩ $\delta \alpha$ es necesario atender a la construcción del término, teniendo presente, eso sí, lo arriba indicado. Si bien no podemos hablar de normas sintácticas seguras, la propia naturaleza de la construcción, participial en este caso, y su origen determinan la semántica del verbo. De nuevo estamos ante un caso claro de primacía de la percepción, obviamente en el proceso anterior al expresado por oî̃ $\alpha$. Frente a los usos de infinitivo y

${ }^{479}$ Cf. Snell, 1992, p. 27 y ss.

480 El propio Snell, 1992, p. 30 y ss., indica lo tardío de este derivado, véase su formación, pero lo empleamos para poder establecer simplemente un paralelo con términos de igual categoría, y seguimos hablando de familias léxicas.

${ }^{481}$ Por primera vez atestiguado en el Fragmento 162 Radt (cf. Asheri, 2007, p. 73):

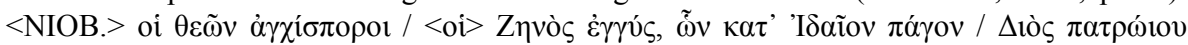

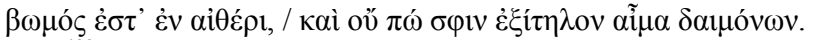

${ }^{482}$ Eurípides, 497 Nauck.

${ }^{483}$ Cf. Asheri, 2007, p. 73. Moles, 1999, p. 8, quien defiende la posible conexión de este uso con el ámbito de las inscripciones mortuorias, para lo cual cf. supra.

${ }^{484}$ Cf. Ebeling, 1963, S. V.

${ }^{485}$ Cf. Ebeling, 1963, s. v. Cf. además Momigliano, 1975, p. 25, quien al estudiar a Polibio habla de Heródoto como el historiador que siempre se maravilla, lo que constituye una pauta para la correcta interpretación del término. 
de nexo introductor, ${ }^{486}$ que dan cuenta de una certeza aún no cumplida, construida sobre una reflexión previa, en la mayoría de los casos referida al

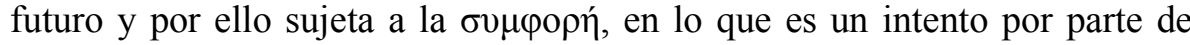
Heródoto de deslindar la percepción real de lo esperable, aparecen casos con participio que dan cuenta de una certeza secundada por ese empirismo. ${ }^{487}$ Como decimos, la propia construcción participial resalta la posición central del sujeto actuando, lo que apunta a esa vivacidad perceptiva de que hablamos. Así, en el proemio retomado aparece de nuevo la carga experimental del término iotopín, de manera que la rectitud semántica se mantiene de manera clara no solo en el proemio, sino a lo largo de toda la obra.

De igual naturaleza programática es el término aĩín, cuya presencia en la obra alcanza la cifra de cincuenta ejemplos, en tanto que el adjetivo ailtıo presenta un total de treinta y nueve ejemplos. ${ }^{488}$ De particular interés es el hecho de que en Homero no aparece el sustantivo pero sí el adjetivo, es decir, existe el causante pero no la causa como tal. En Sófocles tenemos ambos conceptos, con la particularidad de que el sustantivo ya ha desarrollado el sentido jurídico habitual, como en cierta manera ocurre con el adjetivo. ${ }^{489}$ Pero en Heródoto, además de los casos que Powell recoge en su léxico con un sentido cercano al judicial, ${ }^{490}$ nos parecen de especial interés los que incluye en el primer apartado de su entrada, con la traducción de 'reason why'. La naturaleza profunda del significado de este término es quizá más sencilla de lo que a primera vista pudiera parecer: más allá de un concepto tan rotundo como el nuestro de causa, parece adivinarse en muchos casos una semántica cercana a lo que entenderíamos por desencadenante, de modo que no pretende con ello Heródoto expresar un concepto de causalidad semejante al que podríamos hallar en Tucídides. Los datos casi se dividen a la mitad: por una parte, reconocemos el empleo del término de una manera cercana al concepto moderno de motivo, ${ }^{491}$ mientras que, por otra parte, la

${ }^{486}$ Cf. I 20; V 106, 4; III 69, 4; IV 155, 2; V 105, 1; VI 17; I 193, 4; III 71, 5, y VIII 78.

${ }^{487}$ Cf. Powell, 1977, S. V., y Schrader, 1996, S.V.: I, 131, 1; I 140, 2; II 12, 3; II 17, 1; II 23; II 122 , 2; II 150, 2; III, 61, 1; III 72, 1; III 72, 2; III, 115, 1; III 146, 2; IV 15, 1; IV 35, 5; IV 34, 1; IV 46, 1; IV 76, 6; V 92, ๆ 5; VII 26, 2; VII 159; VII 175, 2; VIII 214, 2; VIII 80, 1; IX 21, 2; IX 43, 1 ; IX 43,2 ; IX 84, 1, y IX 94, 2 .

${ }^{488}$ Cf. Schrader, 1996, s. v.

${ }^{489}$ Cf. Ellendt, 1835, S. v.

${ }^{490}$ Cf. Powell, 1977, s. V., e. g.: III, 63, 3; IV 133, 3; VII 214, 2, y IX 71, 3.

${ }^{491}$ Cf. IV 69, 2; VII 213, 3; IX 70, 4; III 119, 1; IV 80, 2; VII 133, 2, y VIII 116, 2. 
explicación que sigue a aitín parece en ocasiones pueril: ${ }^{492}$ encuentros fortuitos, desencuentros o narraciones pintorescas son el desarrollo de este concepto, como en III 1, 1, con la narración del desaire de Ámasis al rey persa, u otro desaire, como el de Polícrates a Oretes en III 122, 2. También se presentan hechos azarosos, como la pérdida de los regalos a Creso en I 70, 2, o discusiones, como en III 120, 2.

Volviendo al proemio, la polémica sobre el pasaje en cuestión es enorme, y ha de señalarse que lo que precisamente sigue al contexto en que aparece el término son narraciones de poca profundidad, al modo de las antes vistas. Heródoto no se desdice de ellas, simplemente no puede demostrarlas, pero su misma aparición hace que las considere como una aĩín plausible, de modo que, dentro de la subdivisión que hemos realizado en el primer subapartado de la entrada de Powell, creemos que la entrada del proemio se encuadraría dentro de la noción de desencadenante, no de causa, como señalaba Asheri. ${ }^{493}$

Para apoyar esta afirmación, parece interesante examinar un pasaje paralelo que hemos reservado. En el libro IX, Heródoto pone en boca de Mardonio un discurso, a nuestro entender, de carácter programático ${ }^{494} \mathrm{el}$

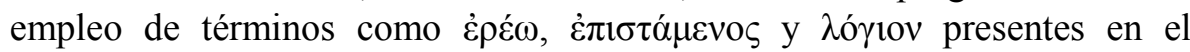
proemio, así como el pensamiento general del pasaje apuntan a unas similitudes muy amplias que nos facilitarán la comprensión de ese concepto. Mardonio expone en su discurso que un oráculo determinaba que los persas sucumbirían si asaltaban el templo de Delfos, y acto seguido afirma: $\tau \alpha$ v́ $\rceil \zeta$

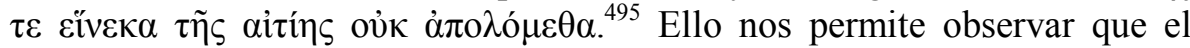
concepto de aitín se mueve, en efecto, en un esquema difícil de asumir fuera de la concepción general del mundo propia de Heródoto. Aitín no es una causa racional asumible como motor de explicación por Heródoto, como ocurrirá con otros autores, sino que representa un elemento de percepción sensorial: aitín viene definido como desencadenante porque es el elemento perceptible por el hombre de un esquema superior, de modo que la verdadera

${ }^{492}$ Cf. I 70, 2; I 75, 1; III 1, 1; III 30, 2; III 59, 1; III 120, 1; III 139, 1; III 122, 1, y IX 42, 3.

493 Cf. Asheri, 2007, p. 73, quien habla de «blame, offence, responsibility, etc», concretándolo en la figura de Creso, aunque cabría preguntarse si en ese caso no habría empleado simplemente aîtıos, utilizado hasta treinta y nueve veces, cf. Schrader, 1996, S. v., si bien la causa parece apuntar a que entre el sustantivo y el adjetivo e incluso tò aítıov hay gran diferencia léxica, dado que en estos usos parece seguir Heródoto a Homero.

${ }^{494}$ No causativo lo definía Hohti, 1976b, p. 73.

${ }^{495}$ Cf. IX 42, 3-4. 
realidad de esos planteamientos en exceso pueriles se ha de reinterpretar dentro de un esquema de mayor complejidad.

Tradicionalmente e incluso en la actualidad, ${ }^{496}$ se entiende que el término $\dot{\alpha} \kappa \lambda \varepsilon \tilde{\alpha}$ relaciona directamente a Heródoto con Homero, lo que tiene un gran fondo de razón pero empece nuestra correcta percepción del concepto en Heródoto. No cabe duda de la gran importancia que tiene el concepto $\kappa \lambda \dot{\varepsilon}$ os en Homero, ${ }^{497}$ pero también es innegable la trayectoria sufrida por el término en fechas posteriores a la hegemonía épica. Parecerá una obviedad señalar que la lírica posterior a Homero emplea profusamente este término, pero no es una idea que la crítica haya explicitado, si bien los datos son claros: solo en lo que se refiere al sustantivo, sin tener en cuenta el adjetivo ya presente en Homero, Píndaro nos presenta dieciocho ejemplos, ${ }^{498}$ Baquílides cuatro, ${ }^{499}$ y, lo que es más importante, Simónides presenta ejemplos claros en los poemas dedicados al enfrentamiento con el persa, como en la composición a los caídos en las Termópilas, ${ }^{500}$ o en los epitafios, como el de Megistias ya visto, con el adjetivo derivado, o el contenido en la Antología, VII 251, atribuido por la tradición a los muertos en las Termópilas, dato que Bergk puso en duda, dado que, al anteceder a este poema una composición a esos caídos, la atribución del segundo poema al mismo contexto que el primero es un error común. ${ }^{501}$ Sea como fuere, tenemos adaptado el concepto

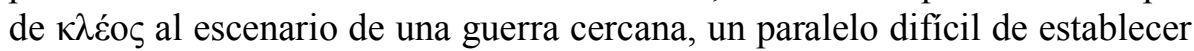
entre los poemas homéricos y los epinicios pindáricos, cuya moral es en parte semejante. El concepto agonal aristocrático ha extendido su ámbito de aplicación al fenómeno persa. En la tragedia, los usos se reducen de manera drástica en Esquilo, que solo lo emplea en el Agamenón ${ }^{502}$ mientras que Sófocles, excepción hecha de usos metafóricos relacionados con el mundo deportivo, lo emplea en cinco ocasiones, dos de ellas en Filoctetes, con claro

\footnotetext{
${ }^{496}$ Cf. Asheri, 2007, p. 73.

${ }^{497}$ El término exacto, $\dot{\alpha} \kappa \lambda \varepsilon \eta ́ \varsigma$, , tiene una presencia más discreta que el término positivo. Cf. Ebeling, 1963, S. v.

${ }^{498}$ Píndaro, Olímpicas, I 23; I 93; VIII 10; IX 101; X 21; X 95; Píticas, I 66; III 111; IV 125; V 73; Nemeas, III, 83; VII 63; VII 38; IX 39; Ístmicas, V 8; VI 25; VII 29, y Fr. 52.

${ }^{499}$ Baquílides, Ditirambos, III 80; Epinicios, IX 40; XIII 32, y XIII 50.

${ }^{500}$ Simónides, PMG 26.

${ }^{501}$ Cf. Bergk, 1882, p. 456 y ss. Bergk no duda de que el poema correspondía al conflicto con el persa, solo la correcta atribución, debido a la ausencia de unas referencias concretas que apuntaran a un poema grabado en el lugar exacto, un nuevo poema promovido por una ciudad, a diferencia del de Megistias.

${ }^{502}$ Cf. Wellauer, 1830, s. v. Agamenón, 487, 1098, y 1356. 
tinte homérico, como ocurre con el caso de Áyax. El ejemplo de Antígona puede interpretarse dentro de las referencias a las leyes no escritas, lo que en cierta manera es comprensible dentro del esquema de valores ancestral; finalmente, el caso de Electra es de difícil explicación, y nos lleva ya a otra época. ${ }^{503}$

Dentro de esta misma complejidad se ha de situar el caso de Eurípides, cuyo empleo del término aumenta progresivamente a lo largo de su obra.

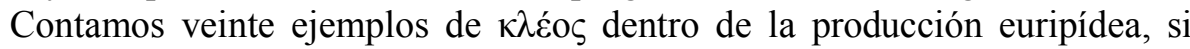
bien hay dos obras en las que la concentración de casos es grande, Helena e Ifigenia en Áulide, con cinco casos cada una, seguidas por los casos únicos de Ion, Bacantes, Orestes, Fenicias, Troyanas, Andrómaca, Electra y Hécuba, a lo que hay que sumar dos fragmentos. Todo ello dice poco, salvo que lo comparemos con los datos de los otros dos trágicos, lo que nos permite afirmar que en Eurípides se observa un mayor uso de este término, que, dado su peso semántico, tendrá que aportar datos de interés a su interpretación, especialmente combinado con los datos observados en Simónides, y el hecho de que el marco cronológico nos lleva ya a fechas muy tardías.

\subsection{Heródoto y su mundo reflexivo}

La interpretación del contexto cultural de la obra de Heródoto supone examinar algunos de los aspectos más complejos de la gran época de la Grecia clásica y superar el agravio comparativo que, de manera tradicional, se ha producido entre Heródoto y Tucídides. ${ }^{504}$

Criterios como la aplicación de un idealismo racionalista, ${ }^{505}$ sustanciado en el famoso paso del mito al logos, ${ }^{506}$ la aparición de un método empírico 985.

${ }^{503}$ Cf. Ellendt, 1835, s. v. Filoctetes, 251, 1331; Antígona, 498; Áyax, 756; Electra, 60,

504 Cf. e. g. Schadewaldt, 1991, p. 67, quien defiende que toda interpretación de Heródoto pasa por situar nuestra mirada en la conclusión que supone Tucídides. En contra, cf. e. g. Corcella, 1984, p. 104.

${ }^{505}$ Cf. e. g. Lloyd, 1975, p. 157.

${ }^{506}$ Cf. Schadewaldt, 1991, p. 69: «Die Tat Homers hat aber auch ihre innere, geistige Seite. Unter der Oberfläche des Mythos zeichnen sich schon die Fundamente ab, auf denen die spätere wirkliche, rationale und reale Geschichtsschreibung der Griechen mitberuht». Cf. además p. 73. Para la propuesta opuesta, cf. e. g. Saïd, 2007, p. 77, quien alerta de la 
de investigación, la concepción religiosa que impregna la obra así como la relación con la Atenas de su tiempo son las grandes cuestiones herodoteas que afectan a la cabal comprensión del proemio, y con él a toda la obra. ${ }^{507}$

El estudio de los aspectos formales de los proemios de la época nos ha permitido trazar los perfiles de un ambiente y de un género que poco tienen que ver con lo que tradicionalmente se ha pensado para la historiografía: la casi mítica figura de un Heródoto exponiendo su obra en público es una recreación de época tardía que responde al imaginario de un lector fiel de Platón. La figura de un Gorgias, quien podría responder bien al modelo construido por Plutarco, nos pone sobre aviso, más allá de los habituales rasgos comunes, ${ }^{508}$ de que Heródoto estaba muy lejos de ser un autor popular que gozara de un gran auditorio.

La más reciente propuesta de Nagy respecto a los $\lambda$ ó́roı se enfrenta, a nuestro entender, a unas dificultades formales que tienen como consecuencia la apertura de nuevas vías de apreciación de la obra herodotea: los denominados $\lambda$ ó ${ }_{1} 101$, presentes en el propio proemio de la obra (I 1, 1), responden a un paso anterior, paralelo a la tradición homérica, como señala Nagy, ${ }^{509}$ al que ocupa Heródoto. Ellos son los transmisores de las narraciones que recoge Heródoto, pero este no es un $\lambda$ ó $\gamma 10 \varsigma$, por razones de contexto y de contenido. En primer lugar, los $\lambda$ ó nosotros perdido- de la tradición literaria en prosa de los antiguos griegos, como también hemos perdido prácticamente sus narraciones, que podemos en parte intuir en la obra de Heródoto, ${ }^{510}$ quien las recoge incluso con rasgos estilísticos propios de la performance de esos $\lambda$ ó $\gamma$ ıol. Pero Heródoto puede hacer esto precisamente porque es ajeno a ese modo de actuar, porque se encuentra fuera de ese mundo tradicional que tiene como escenario propio

diferencia de conceptos entre Heródoto y nosotros, y p. 78, sobre la configuración de esa oposición con posterioridad a Heródoto, exactamente con Diodoro, cosa que nos parece que no se fragua en esos términos.

${ }^{507}$ Cf. Schadewaldt, 1991, p. 64.

${ }^{508}$ Cf. Nestle, 1966, p. 510 y ss. Defiende Nestle la aparición de semejanzas en las ideas panhelénicas de ambos autores y en el ideario religioso que poco peso tienen.

${ }^{509}$ Nagy, 1987, p. 175.

${ }^{510}$ Cf. Aly, 1921, passim. La observación de Waters, 1985, p. 76, de tomar con reservas la traducción de Powell, 1977, s. v., del concepto como 'versed in history' es digna de tenerse en cuenta en este sentido. 
los círculos populares y sociales públicos, ${ }^{511}$ completamente perdido para nosotros en su realidad formal, lo que hace que abordemos su análisis en el contexto cultural.

A todo ello se une el hecho de que Heródoto no es transmisor de los valores, criterios e ideas que impregnan el saber tradicional, como sí harían estos autores, cosa que sabemos por la antropología comparada. La creación y transmisión de la denominada enciclopedia tradicional recaía de manera clara en los $\lambda$ ó $\gamma 10$ y en Homero, en una idea claramente defendida incluso por Nagy. ${ }^{512}$

Esta posición de Heródoto nos permite afirmar sin problemas que no fue la redacción en prosa de sus obras lo que favoreció la aparición de lo que conocemos por historiografía. ${ }^{513}$ Ya hemos explicado las diferencias formales existentes entre la prosa de carácter tradicional y la empleada en determinados pasajes por Heródoto. Está claro que la utilizada por los $\lambda$ ó $\gamma 101$ sería más limitada en lo que a facilitar la expresión se refiere, pero no sería excluyente a la hora de llevar a término la exposición de ideas, cosa que sí ocurre en el caso de la temática y la finalidad de esas obras, o, lo que es lo mismo, con la posibilidad de la aparición de la historiografía.

Dada esta situación, ya defendimos la idea de insertar la figura de Heródoto en un ámbito simposial en sentido amplio. La existencia de una fuerte oposición excluyente entre un ámbito cultural tradicional en la época, principalmente en Atenas, dotada de una filosofía y una religión de carácter social, y otro privado reducido a pequeños grupos es una realidad conocida por los testimonios antiguos y que se ve confirmada por medio del examen del funcionamiento de las ideas de autores como el que nos ocupa.

Esta posición no oficial de dichos autores hace difícil tratar de conectar de manera clara la labor que desarrollaban con las diferentes corrientes y pensamientos de la época; la obra de Heródoto responde únicamente al pensamiento individual y personal de su autor, en el que pueden tener cabida muy diferentes influencias, pero nunca con un sometimiento a ninguna de ellas.

\footnotetext{
${ }^{511}$ Ya la crítica se pronunció claramente en lo que se refiere a la diferenciación de los $\lambda$ ó p. 866.

${ }^{512}$ Nagy, 1987, p. 184.

513 Cf. e. g. Schadewaldt, 1982, p. 27; Regenbogen, 1962, p. 63, para la habitual asociación de prosa y despertar intelectual.
} 


\subsubsection{LA METODOLOGÍA HERODOTEA}

Una de las principales líneas de interpretación del proemio ha sido el análisis de la metodología empleada, con el lastre que supone la comparación con un Tucídides que sí realiza breves reflexiones sobre este aspecto, mientras que en el caso de Heródoto no tenemos nada semejante, al menos de manera clara, dado que seguramente no serían, a ojos del autor y su público, de necesaria exposición. ${ }^{514}$

La idea defendida por Eduard Meyer y hoy ya clásica acerca del empirismo herodoteo responde a una de las construcciones más antiguas de la comprensión de la historiografía griega, que remonta a Creuzer. La existencia de una evolución desde «el toque de clarín en el aire puro de la mañana de la palabra henchida de noble razón y fría claridad», de que hablaba Gomperz en referencia a Hecateo y su proemio, ${ }^{515}$ hasta Tucídides en la configuración de un método semihistórico está de manera latente detrás de afirmaciones referidas a Heródoto como «über die Heroensagen, die Abstammung der Menschen von der Göttern, die Wunder der Mythengeschichte denkt er nicht anders als Hekataios und seiner Nachfolger» ${ }^{516}$ Esta afirmación responde a una idea clara de progreso que, independientemente de lo reprobable de la idea misma, da por sentado la existencia de una sólida tradición historiográfica, dotada de una metodología propia del historiador que va desde la perspectiva racionalista de Hecateo con su crítica subjetiva de tono racional- al empirismo herodoteo que sostiene su indagación en la experiencia personal, ${ }^{517}$ todo ello para crear una

${ }^{514}$ Cf. Jacoby, 1913, col. 468. Cf. crítica en Schrader, 1986, p. 667.

${ }^{515}$ Cf. Gomperz, 2000, p. 295 y ss. Jacoby, 1913, col. 470, alertaba también de que este empirismo había de ser entendido dentro de la corriente de pensamiento de la época, es decir, de la sofística. En este sentido, la propuesta de Pagel, 1927, p. 12, de hacer depender espiritualmente el proemio herodoteo de Hecateo es un buen ejemplo de esta idea.

${ }^{516}$ Cf. Meyer, 1899, p. 252.

517 «Nur was die Erfahrung lehrt, ist Wahr», Meyer, 1899, p. 252. El otro extremo de esta perspectiva puede verse en la afirmación de Armayor, 1985, p. 9, que podría servir de ejemplo de la denominada 'Liar school': «[...] the orthodox view of Herodotus as a simple-minded Greek tourist with a notebook is wrong. It has never been able to account for Herodotus transitional mixture of fact and fable, pilmagre and plagiarism». 
imagen continua y racional del pasado ${ }^{518}$ mantenida hasta nuestros días, y que permite superar la aporía que suponía la inclusión de material mítico en las obras de estos autores. ${ }^{519}$

Esta tendencia de análisis del $\tau$ òv $\delta \grave{\varepsilon}$ oĩ $\delta \alpha$ herodoteo (I 1,5$)$ responde a un juicio apriorístico acerca de la metodología empleada por Heródoto, y que trata de acercarlo de manera clara a la crítica positivista alemana. ${ }^{520}$ Sería el cambio de tema sobre el que trabajar el que llevaría a su perfección este método, de modo que el abandono del spatium historicum mítico presenciado en Tucídides será el que permitirá alcanzar la perfección en el género.

Esta propuesta, magistralmente sustentada en el esquema monumental sancionado por Felix Jacoby, ${ }^{521}$ flaquea en su estudio cuando tenemos

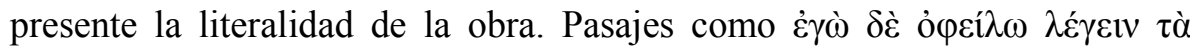

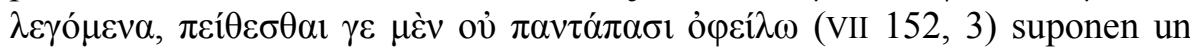
desafío claro en la adecuación del modelo a la realidad de la obra difícilmente superable, ya que, como señala Darbo-Peschanski, la preocupación de Heródoto tiene poco que ver con la crítica de fuentes. ${ }^{522}$

518 Cf. Schadewaldt, 1991, p. 65. El asumir que el hecho histórico es un fenómeno antropológico presente en todas las culturas, cf. p. 64 , es lo que obliga a la crítica tradicional a justificar la aparición del nuevo género por medio de la oposición de una imagen organizada del pasado, historiografía, y una irracional e inconexa, la idea de historia de las culturas tradicionales.

${ }^{519}$ Cf. e. g. Waters, 1985 , p. 4.

${ }^{520}$ Cf. Weber, 1976, p. 27: «Allenfalls verbindet Meyer den für Herodot behaupteten Empirismus noch mit gewissen Prinzipien die als Konstitutiv für der Historicismus und die historische Methode des 19. Jahrhunderts angesehen werden». Fehling, 1989, p. 58, proponía que era esta una fórmula que auguraba en teoría un cambio de fuente, lo que no nos parece tampoco sostenible. La idea de Flory, 1987, p. 50, de situar el comienzo de la época histórica con Giges no pasa de ser una excentricidad. Quizá un extremo opuesto pueda verse en estudio, muy erudito, de Payen, 1997, quien condena en p. 27 estos apriorismos para aplicar otros, si cabe, más alejados del mundo herodoteo, como es, por ejemplo, el tomar las vidas de los personajes como eje conductor de la obra, cf. p. 49 y ss., planteando peligrosamente modelos propios de perspectivas contemporáneas.

521 Cf. Jacoby, 1913, col. 470: «H[erodotos] huldigt einem vorsichtigen und etwas lahmen Empirismus, der nichts geben will, als was er selbt mit Augen gesehen oder von Augenzeugen bestätigt findet».

${ }^{522}$ Cf. Darbo-Peschanski, 1987, p. 119. Una visión más «tradicional», en Spath, 1968,

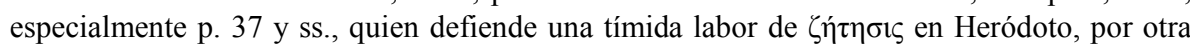
parte no incompatible con la postura anterior. En líneas generales sobre este aspecto cf. Schepens, 2011, p. 103 y ss. 
Ello se debe, además de a la clara contaminación de la metodología positivista, a un error de perspectiva que va mucho más allá de la actuación habitualmente asimilada como instrumento de este empirismo.

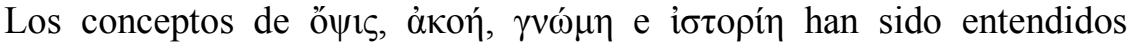
tradicionalmente como los elementos que configuran el método historiográfico herodoteo, ${ }^{523}$ englobados bajo el supraconcepto del empirismo. La problemática que presenta la interpretación de estos conceptos en la obra herodotea, y, con ella, la interpretación del que denominamos como proemio retomado (I 1,5$)$, pasa por la concentración de estos elementos en la parte inicial de la obra, en la denominada sección etnográfica.

Ello ha sido la causa de que Jacoby interpretara estos conceptos como propios de la etnografía y, en menor medida, de la geografía, ${ }^{524}$ dentro del esquema evolutivo general que hace de esas secciones de la obra historiográfica herodotea un paso previo a la labor propiamente histórica, verificada en la segunda mitad de las Historias, en camino hacia la perfección tucidídea. No hemos de olvidar, por otra parte, posturas como las de Regenbogen, que apostaba por una mezcla de elementos sin proponer evolución alguna, lo que es un planteamiento más cómodo y acorde con la obra. ${ }^{525}$ Esta tensión alcanza su mayor expresión en las conclusiones del excelente trabajo de Schepens, al sostener que la ö $\psi 1 \varsigma$ es el fundamento de la investigación histórica herodotea, o que, al menos, con el paso del concepto

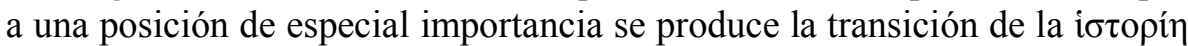
a la historia. ${ }^{526}$

${ }^{523}$ Cf. Verdin, 1971, p. 1 y ss. (nos valemos del resumen en p. 224).

${ }^{524}$ Cf. Jacoby, 1913, col. 468 y ss. Esta idea se apoya, como decimos, en el esquema general de comprensión de la obra herodotea que traza una evolución desde el geógrafo hasta el historiador, cf. col 352 y ss.: «H[erodotos] hat begonnen als Reisender wie Hekataios, mit der Absicht, eine Beschreibung der bewohnten Erde zu liefern wie Hekataios».

${ }^{525}$ Cf. Regenbogen, 1962, p. 68 y ss.

${ }^{526}$ Cf. Schepens, 1980 , p. 88 «Hérodote a été dès lors le premier à saisir l'importance

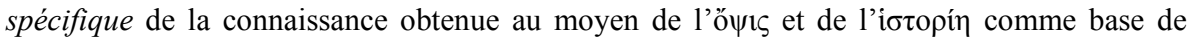
l'enquête historique». En ello se opone a la postura de Jacoby, 1913, col. 469, que defendía una ő $\psi 1 \varsigma$ moderada en Heródoto: «[...] seine Autopsie reicht doch nicht gerade übermässig weit». 
La dificultad que supone asumir como metodología histórica el empleo de un concepto que prácticamente está ausente de la obra, ${ }^{527}$ y que, sobre todo, no responde a la sistematicidad que cabría esperar, ${ }^{528}$ nos debe hacer pensar que, como mucho, podemos admitir que ese concepto posee simplemente un valor instrumental más. ${ }^{529}$ La naturaleza del tema histórico no es en manera alguna adecuada para la labor del í $\tau \omega \rho$, como ya señalaba Strasburger, ${ }^{530}$ y no es raro que incluso especialistas de la talla de von Fritz hayan caído en contradicciones por este motivo. ${ }^{531}$ A todo ello hemos de añadir un obstáculo más, como es el hecho astutamente indicado por Hellmann de que el objeto de interés de esa ő $\psi 1 \varsigma$ herodotea no se centra en

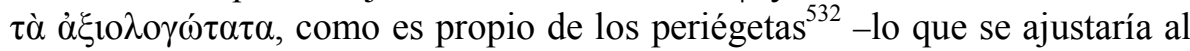
modelo de Jacoby, que propone las periégesis como origen del método-, sino en lo importante y en lo que no lo es, cosa que, como veremos, resultará fundamental para comprender los aspectos metodológicos.

Lo que es más interesante es el empleo que se presenta como mayoritario del término en la obra herodotea. El grueso de ejemplos se nutre de la acepción de 'aparición' en sueños, con la importancia que este aspecto tiene en el desarrollo de la obra herodotea. ${ }^{533} \mathrm{Si}$ este hecho es interesante, aún más nos parece su unión con el verbo oĩ $\delta \alpha$, en al menos diez casos, en todos los cuales la ő $\psi 1 \varsigma$ no se reduce a simple visión, sino que se emplea incluso en escenas espectrales. ${ }^{534} \mathrm{El}$ resultado de la visión es además indicado en todos los casos por medio de términos de $\delta$ ó $\xi \alpha$, no solo por el propio Heródoto, sino también por los personajes partícipes de la aparición, lo que resalta de nuevo la idea que venimos señalando. $Y$ es que creemos que ello es una prueba más del valor instrumental del concepto, que, se trate de una visión

${ }^{527}$ Schrader, 1994, S. V., cuenta un total de 79 ejemplos en la obra, de los cuales solo cuatro tienen el sentido técnico que nos ocupa: II 99, 1 (dos casos); 147, 1, y IV 81, 2.

${ }^{528}$ Cf. Darbo-Peschanski, 1987, p. 87.

${ }^{529}$ En contra de lo que defendía Nenci, 1953, p. 30, que lo consideraba el fundamento de la obra herodotea.

${ }^{530}$ Cf. Strasburger, 1982 , p. 860.

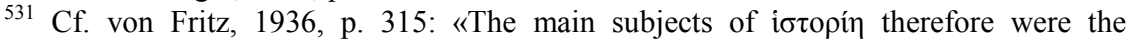
knowledge of foreign countries and remote ages, as this is the kind of knowledge which ultimately cannot be gained except from personal witnesses». Nótese lo difícil de estudiar hechos de tiempos remotos con un testimonio personal.

${ }^{532}$ Cf. Hellmann, 1934, p. 20.

${ }^{533}$ Cf. recientemente Hollmann, 2011, p. 75 y ss. También Hartog, 2003, p. 254.

${ }^{534}$ Cf. I 39, 1; 108, 1; 209, 1, y 3; II 139, 2; III 30, 2; 65, 2; 124, 1; v 55, 1; VII, 12, 1, etc. 
espectral o de las indagaciones de Heródoto, responde siempre a un paso previo a la actividad intelectual del individuo.

La ausencia de referencias claras a estos conceptos en el proemio no es excusa para su total eliminación de un posible marco metodológico, pero la realidad es tan simple como que necesitamos definir claramente cuál es la estructura intelectual en la que se asienta la parte más puramente histórica de la obra herodotea, y el lugar que ocupan estos conceptos en ella.

A nuestro entender, dentro de la obra de Heródoto han de distinguirse dos niveles claros en cuanto a la configuración del pensamiento del autor $y$, si se quiere, de su concepción historiográfica. Para esta división, hemos de partir del que es un apriorismo habitualmente extendido, y que no es otro

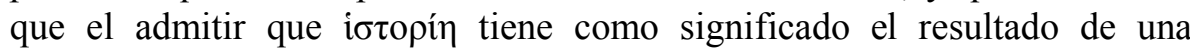
investigación, como indica, entre otros, Powell. ${ }^{535}$ De los ejemplos presentes del verbo en la obra herodotea, todos ellos aparecen en participio o en imperfecto, y delatan, por la habitual combinación de los primeros casos con verbos en forma personal, una semántica que más que a un resultado apunta a un proceso, significado que creemos que debe extenderse al proemio de la

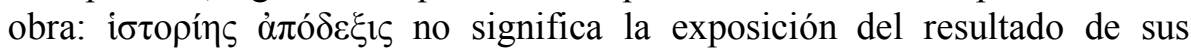
indagaciones, sino la exposición de la propia indagación.

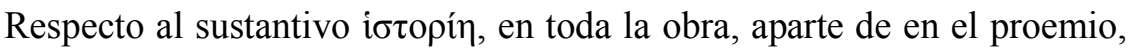

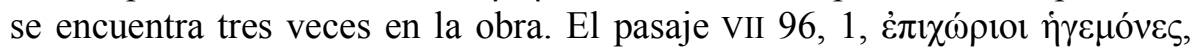

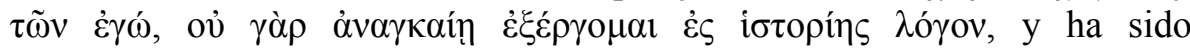
interpretado habitualmente como la primera aparición del término historia como tal, ${ }^{536}$ si bien ya Macan apostó por una interpretación del concepto en el sentido en el que proponemos: «I am not compelled by the necessity of my argument to give any account of my inquiries on that head». ${ }^{537}$

A nuestro entender, es este sentido dinámico ${ }^{538}$ y no conclusivo el único modo de entender la aparición en la obra de narraciones no correctamente verificadas, ${ }^{539}$ que el propio Heródoto cree falsas, o simplemente la aparición

${ }^{535}$ Cf. Powell, 1977, p. 174.

${ }^{536}$ Ya Schweighaeuser, 1816, VII, 96, traducía: «[...] praeerant duces ex popularibus: quorum ego nomina edere, quum nihil necesse sit ad historiae rationem, supersedeo».

${ }^{537}$ Cf. Macan, 1973b, p. 121.

${ }^{538}$ Ya Thomas, 2000, p. 225, parece apuntar a esta idea al considerar que la narración de las Historias asume a un tiempo la exposición y la demostración de las pruebas de esa exposición.

${ }^{539}$ Es decir, el acopio de materiales de que hablaba Verdin, 1974, pp. 53-76. 
de una información con la que el autor no opera. ${ }^{540}$ Estamos ante lo que podríamos definir como los telares de la historia, en los cuales tenemos acceso no a la imagen final y estática de la creación de una obra, como podemos observar en Tucídides, sino a la interactuación entre Heródoto y la realidad, que exige un paso posterior a la recolección de la información: «les logoi admis par Hérodote ne le sont pas en tant que discours vrais émanant d'instances véridiques. Nous verrons que ces logoi, eux aussi, autorisent une activité ultérieure: ils conditionnent le prolongement et l'achèvement de l'enquête dans le jeu des opinions et l'intervention du destinataire». ${ }^{541}$

El segundo caso, II 44, 5, un participio, sí tiene valor de conclusión, pero hemos de tener en cuenta que su carácter dinámico viene dado por el hecho de que poco antes encontramos el desarrollo de esa i $\sigma \tau$ opín en el examen de la antigüedad de Heracles y en el estudio del templo en Tiro.

Finalmente, en lo que se refiere al caso presente en II 99, 1, el locus classicus de la metodología historiográfica herodotea, no creemos, a

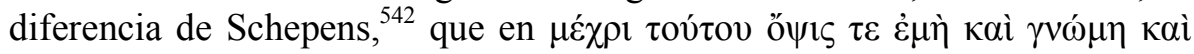

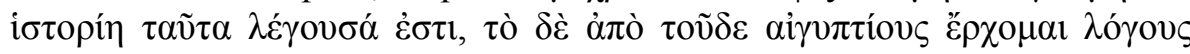

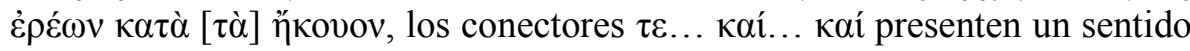
que desborda el meramente copulativo. Heródoto ha aplicado, simplemente, esos tres conceptos hasta el momento, lo que no implica que los tres formen un todo ${ }^{543}$ dado que metodológicamente el concepto de $\gamma v \omega ́ \mu \eta$ implica, como señaló Snell, un ejercicio intelectual que va más allá del simple empirismo. ${ }^{544}$

Con esto presente, y en lo que se refiere al proemio, las narraciones de los raptos de las mujeres no han de ser entendidas como una renuncia o una autoafirmación del autor que persigue abandonar modelos míticos, ${ }^{545}$ sino que estamos ante el proceso mismo de enjuiciamiento de la información por parte de Heródoto y el abandono de lo que no cree adecuado afirmar con

${ }^{540}$ Como señala acertadamente Darbo-Peschanski, 1987, p. 90 y ss.

${ }^{541}$ Cf. Darbo-Peschanski, 1987, p. 97.

${ }^{542}$ Cf. Schepens, 1980, p. 55.

${ }^{543}$ Así, Marincola, 1985, p. 13.

${ }^{544}$ Cf. Snell, 1982, p. 31 y ss. La problemática respecto a la reducción del significado en tiempos arcaicos del concepto de $\gamma v \omega ́ \mu \eta$ a inteligencia, que remonta a Bernays, 1885 , p. 87, nota 1, en referencia a Heráclito, parece superada, al decir de Snell, si asumimos simplemente que la referencia es tanto al órgano como al producto de ese órgano intelectual. Sea como fuere, supone siempre actuación por parte del individuo.

${ }_{545}$ Así, Gomperz, 2000, p. 295, y Reinhardt, 1989a, p. 151. 
seguridad. Se trata, en definitiva, de una aplicación previa del modelo intelectual herodoteo, como lo será también la arqueología tucidídea.

Es en este nivel de proceso dinámico en el que se desarrolla la actividad habitualmente considerada como historiográfica por parte de la crítica, que, por razones obvias, se muestra en su mejor desarrollo en aquellas secciones de la obra que recogen mayor número de elementos ajenos al mundo habitual de un griego. Marincola aportó en este problema luz a la dimensión que tratamos de explorar al confirmar que la aparición de Heródoto a lo largo de su obra se reducía a añadir precisiones o a dar cuenta del escaso resultado de sus indagaciones. ${ }^{546}$ En tal sentido, y teniendo en cuenta la problemática de esa perspectiva dinámica de la indagación, se comprende enseguida que será la naturaleza del tema historiado así como las posibles polémicas existentes en torno a él ${ }^{547}$ las que propiciarán la mayor o menor intervención del autor, que, en último término, responderá al grado de dificultad que presente esa labor.

\subsubsection{LAS INTERVENCIONES DEL AUTOR}

Es en esta misma línea en la que hay que tener en cuenta la propuesta de Dewald acerca de la «authorial voice» de Heródoto, ${ }^{548}$ que creemos incide en el sentido dinámico de la obra herodotea. De las cuatro categorías en las que clasifica las intervenciones del autor, ${ }^{549}$ por ahora nos interesan únicamente las tres primeras, por ser la última una recapitulación que engloba las restantes.

La primera de esas categorías, denominada «the onlooker», responde a la posición cero del narrador, a la simple contemplación del discurrir de los elementos, sin que el autor intervenga. Señala Dewald que esta situación

${ }^{546}$ Cf. Marincola, 1987, p. 121 y ss.

${ }^{547}$ Así lo considera Marincola, 1987, p. 123 y ss., razonamiento que creemos acertado, a pesar de las críticas de Fornara, 1987, p. 140, quien alertaba sobre lo peligroso de sustentar esta propuesta en debates polémicos indemostrables. Seguramente, el mayor problema para Fornara sea que parte de la consideración del libro II como un paso previo, casi iniciático de la labor historiográfica de Heródoto, cf. Fornara, 1971a, p. 23.

${ }^{548}$ Para la relación de este concepto con el proemio, cf. Dewald, 2009, p. 117.

${ }^{549}$ Cf. Dewald, 1987, p. 154 y ss. 
hace que el autor pase a una posición cercana a la que posee el propio auditorio, ${ }^{550}$ lo que, a nuestro entender, solo puede tener explicación si asumimos que ese carácter dinámico del que hablamos está incluso abierto a los presentes en la lectura de la obra.

Las dudas que en su día planteó Fornara respecto a la exitencia de un contexto polémico que propicie la aparición de lo que Dewald define como «the eyewitness investigator», ${ }^{551}$ tienen, a nuestro entender, poco sentido. La insistencia en la propia comprobación de los hechos, que tiene como resultado un determinado grado de certeza respecto a ellos, puede deberse a un carácter polémico de estos, o simplemente a que la afirmación de Heródoto toma tono de autoridad por ser la primera vez que se hace referencia a ese aspecto.

Pero, sin lugar a duda, es «the critic» la forma más interesante para nuestro estudio de la presencia del autor en la obra. ${ }^{552}$ Es, como señala la propia autora, una de las intervenciones más habituales dentro de la obra, y

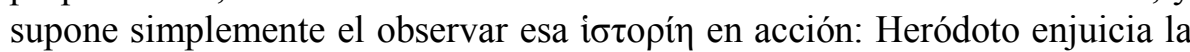
información recibida de manera positiva o negativa, dando cabida en su obra a aquel material que un autor como Tucídides simplemente rechazaría y no incluiría en su obra. ${ }^{553}$

\subsubsection{LAS VERSIONES DOBLES EN LA METODOLOGÍA HERODOTEA}

En este sentido, es un hecho aún defendido en fechas recientes la idea de que la inclusión de datos o narraciones que Hérodoto considera dudosos o simplemente falsos se debe a la necesidad de evitar que cayeran en el olvido, como hace Lateiner y recientemente Rösler. ${ }^{554}$ Los avances en el conocimiento de la transmisión cultural en el mundo tradicional que antes

${ }^{550}$ Cf. Dewald, 1987, p. 155.

${ }^{551}$ Cf. Dewald, 1987, p. 155 y ss.

${ }^{552}$ Cf. Dewald, 1987, p. 159 y ss.

${ }^{553}$ Lo que no implica que esos datos tengan una operatividad clara en el sistema herodoteo, como indica Vignolo Munson, 2001a, p. 83.

${ }^{554}$ Cf. Lateiner, 1989 , p. 83, quien en cierta medida presenta puntos de contacto con nuestra propuesta acerca de la no supresión de la iotopín como causa de la inclusión de esas narraciones. Cf. Rösler, 2002, p. 91. 
vimos nos permiten negar cualquier validez a esta afirmación. Lo realmente interesante y válido se conserva en la época dentro de unos círculos claros de cultura tradicional que no tienen necesidad alguna de la escritura como soporte para su conservación. Ello hace que la única razón para la inclusión de estos datos sea el carácter dinámico de la iotopín, carácter que justifica incluso la aparición de distintas versiones a pesar de que sean contradictorias. ${ }^{555}$

Esta nueva perspectiva nos permite dejar de centrarnos en los criterios empleados habitualmente para enjuiciar la metodología herodotea, y nos

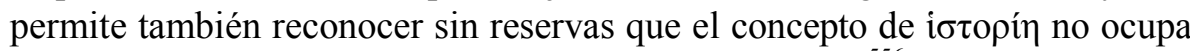

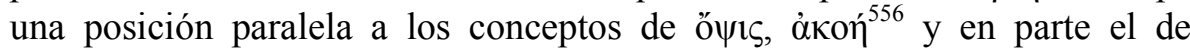
$\gamma v \omega ́ \mu \eta$, sino que, simplemente, hace referencia a la aplicación de estos en el desarrollo de la actividad del autor. En tal sentido, es interesante señalar que, además de la aparición de iotopín con verbos cuya semántica apunta al concepto de ảKoń -en al menos una ocasión (II 29, 1)-, se usa, en referencia

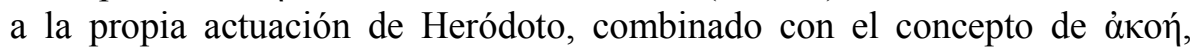

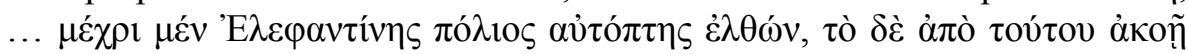

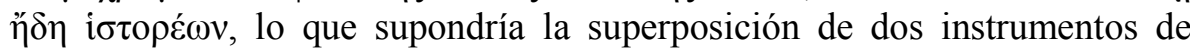
investigación, cosa por completo imposible, e incide en la idea hasta ahora

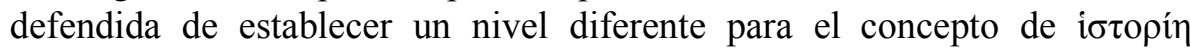
respecto al de los demás conceptos, que son meramente instrumentales.

Es en este sentido en el que hemos de analizar dichos conceptos, y ello ha de realizarse salvando algunos problemas, como puede ser el intento excesivo de ratificar una vinculación del concepto ö $\psi 1 \varsigma$ con el pensamiento

\footnotetext{
${ }^{555}$ Ha de entenderse la idea de doble versión en un sentido más concreto que el empleado por Spath, 1968. No consideramos que aspectos como la duplicidad de perspectivas en un personaje (cf. Spath, 1968, p. 56 y ss.) tengan la misma explicación que, por ejemplo, la presencia de dos informaciones contradictorias acerca de una cuestión concreta. Por lo demás, creemos que el buen trabajo de Spath se centra en exceso en las implicaciones que el empleo de fuentes tiene en este aspecto, cf. Spath, 1968, p. 31 y ss., lo que le impide percibir la causa última del procedimiento, cuya complejidad desborda nuestro objetivo. Sobre este aspecto y la polémica con la «liar school» cf. Pritchett, 1993, p. 10 y ss. No creemos que en la presentación de diferentes versiones haya un rasgo democrático, como señala Baragwanath, 2008 , p. 20.

${ }^{556}$ Según Schrader, 1994, S. V., los ejemplos de ảkoń en la obra herodotea se reducen a siete, que se extienden solo hasta el libro IV: I 38, 2; 171, 2; II 29, 1; 123, 1; 148, 6; IV 16, 1 y 16, 2. El concepto es, por otra parte, de difícil definición. Lateiner, 1989, p. 146, lo definía como «historical accounts depended on the reports and memories of others», lo que en

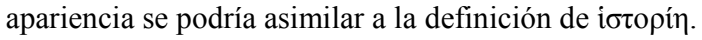


de Hecateo, y, a partir de esta influencia, tratar de establecer una dependencia y primacía de la geografía respecto a la historiografía, como señala Nenci, ${ }^{57}$ y que Jacoby asimilaba a la conocida evolución de la etnografía a la historiografía. ${ }^{558}$ Pero la realidad, como señala Schepens, es tan simple como que no tenemos ni una sola referencia al concepto en lo que conservamos de Hecateo, y tratar, como hace este autor, de defender una diferencia cualitativa del empleo del concepto entre los dos autores puede llevarnos a caer en especulaciones. ${ }^{559}$

En lo que se refiere exclusivamente a Heródoto, la mala interpretación de estos conceptos, así como un exceso de rigor en la valoración de los resultados obtenidos por el de Halicarnaso, han causado la depreciación de su obra hasta extremos realmente insostenibles. La postura de Sayce, nacida al amparo de los descubrimientos arqueológicos de finales del siglo XIX, puede ser tomada como el pistoletazo de salida de la moderna crítica negativa de la veracidad de Heródoto. Errores en ocasiones muy concretos y apuntados por un especialista moderno son el paso previo para la puesta en duda incluso de los viajes herodoteos. ${ }^{560}$ Poco más de una década después la corriente varió su sentido, y el importante estudio de Hauvette vino a presentar un análisis más sosegado de los hechos en una forma aún hoy modélica. La idea de un Heródoto viajero y no historiador, ${ }^{561}$ cercano al Solón que nos presenta el propio Heródoto, es seguramente más fiel a la verdad de los hechos que el intento forzado de hacer de Heródoto un historiador en términos modernos.

En íntima relación con la figura del viajero se halla un concepto de especial interés en la obra, tò $\theta \tilde{\omega} \mu \alpha$. Su definición fue abordada en un importante trabajo por Barth, y sus conclusiones apuntaban a que se trataba de un concepto plenamente etnográfico, casi técnico. ${ }^{562}$ La catalogación del término a lo largo de la obra llevó a Barth a determinar un uso exclusivo del

${ }^{557}$ Cf. Nenci, 1953, p. 29: «[...] la descrizione geografica è, per eccellenza, decrizione di cose viste $[\ldots] »$; «L'autopsia è entrata dunque nella storiografia per mediazione dei periegeti». Cf. también Nenci, 1954, p. XIV.

${ }_{558}$ Cf. Jacoby, 1913, col. 471.

${ }^{559}$ Cf. Schepens, 1980, p. 84.

${ }^{560}$ Cf. Sayce, 1883 , p. XXIV y ss.

${ }^{561}$ Cf. Hauvette, 1894, p. 29. Es interesante recordar también las palabras de Rollinger, 1993 , p. 182 y ss., quien señalaba que, en cualquier caso, es injusto valorar la diferente significación que un monumento pudiera tener para un antiguo o para nosotros.

${ }^{562}$ Cf. Barth, 1968, p. 94. 
sustantivo en los primeros libros, en referencia a elementos de tradición etnográfica, tales como animales, plantas u obras materiales, atendiendo a su divergencia de lo habitualmente presente en Grecia. ${ }^{563} \mathrm{La}$ principal causa para señalar esta separación entre una y otra parte de la obra se debe básicamente al hecho de que en las denominadas secciones históricas el término solo se presenta como adjetivo. ${ }^{564}$ A nuestro entender, esa dualidad es en realidad inexistente, y lo que ha de subrayarse es la continuidad del concepto. El hecho de que se haga referencia a elementos adjetivados en las secciones históricas es algo que indudablemente se debe a que en la segunda parte se adjetivan acciones de valor. En último término, creemos que ambas perspectivas forman parte de un todo que permite dibujar, como bien señaló Raubitschek, el horizonte social de un pueblo. ${ }^{565}$

\subsubsection{EL CONCEPTO DE ISTQP Y HERÓDOTO}

Es en este momento cuando debe analizarse la tendencia, más pronunciada en los últimos tiempos, de vincular la labor del historiador con la del $\iota \sigma \omega \rho{ }^{566}$ Ya Lateiner insistía en la naturaleza crítica de la labor del i $\sigma \tau \omega \rho$, dado que desarrollaba un trabajo de peritaje en situaciones de conflicto ${ }^{567}$ Recientemente, Darbo-Peschanski ha insistido en la ligazón del i $\sigma \tau \omega \rho$ con la historia, seguramente tratando de buscar un precedente en la epopeya para la historiografía, que no registra el término como tal. ${ }^{568}$

La propia naturaleza del î́ $\tau \omega \rho$ es seguramente la mejor refutación de los intentos de ligar la actividad del historiador con la de la figura judicial. Los propios testimonios antiguos, relativamente escasos, ${ }^{569}$ no perfilan

${ }^{563}$ Cf. Barth, 1968, p. 97 y ss., y 102 y ss. para los elementos materiales, juzgados según su tamaño, coste o belleza. En este mismo sentido, cf. Raubitschek, 1939, p. 221, para la misma idea.

${ }^{564}$ Cf. Barth, 1968, p. 104 y ss., especialmente p. 108.

${ }^{565}$ Cf. Raubitschek, 1939, p. 222.

${ }^{566}$ Presente de manera pionera en von Fritz, 1936, p. 315 y ss.

${ }^{567}$ Cf. Lateiner, 1989, p. 92.

${ }^{568}$ Cf. Darbo-Peschanski, 2007b, p. 41 y ss.

${ }^{569}$ Seguramente sea esta la causa de lo breve de las indicaciones presentes en una obra tan extensa como la de Lipsius, 1984, p. 10, que simplemente se limita a citar la figura del ī $\sigma \omega \rho$. 
precisamente una actividad crítica, lo que, por otra parte, viciaría la idea de juez imparcial. ${ }^{570}$ La figura de juez supone, por lo demás, una evolución a partir de casos como el de la Ilíada, XVIII 497 o XXIII 486, ${ }^{571}$ pero es difícil de explicar en casos como el de Hesíodo, Trabajos y días, 792, que parece hacer referencia, simplemente, a un hombre sagaz, si bien el pasaje presenta complicaciones, que, aunque no afectan a lo que a nosotros interesa, ${ }^{572}$ hacen del texto una prueba poco concluyente..$^{573}$

Es, pues, el '̌ $\sigma \tau \omega \rho$ un sujeto que por su integridad y mente despierta parece adecuado no para establecer una crítica, sino para simplemente constatar la realidad; $;^{54}$ de ahí la verdadera semántica de toda la familia léxica, que apunta no a una crítica orientada en una u otra dirección, ${ }^{575}$ sino a un contacto sin apriorismos entre individuo y realidad, cuya evolución puede apuntar a lo que conocemos como juez, pero que en un principio se trata simplemente de alguien que presta atención a un aspecto, un perito, como bien indicaba Hirzel. ${ }^{576}$ Será, pues, el contexto el que determinará el significado una vez más. ${ }^{577}$

${ }^{570}$ Una idea esta de juez imparcial que convive en la crítica con la del ǐ $\sigma \tau \omega \rho$ como un personaje prestigioso y recogedor del saber y la memoria de la comunidad, casi cercano a nuestro moderno «notario», cf. Fusai, 2006, p. 142. Sea como fuere, no hay diferencia de fondo entre ambas ideas.

${ }^{571}$ Cf. Wolf, 1950 , p. 88 y ss., para la interpretación de $̋ \sigma \tau \omega \rho$ como «Kenner der Rechts».

${ }^{572}$ Cf. Paley, 1883, p. 110. Las dudas afectan a la interpretación del acusativo como sujeto u objeto, si bien la semántica parece claramente alejada de la deriva de juez. West, 1982 , p. 357, es concluyente al indicar que no se hace referencia a un juez sino a un hombre sabio.

${ }^{573}$ Cf. un rico resumen de las diferentes propuestas en Fusai, 2006, pp. 191-195.

${ }^{574}$ Cf. para esta perspectiva Fusai, 2006, p. 44 y ss.

${ }^{575} \mathrm{Y}$ que favorece esa vinculación de la figura del $̂$ $\sigma \tau \omega \rho$ con el paso del mito al logos, cf. Fusai, 2006, p. 143.

${ }^{576}$ Cf. Hirzel, 1966, p. 65, si bien, como admite el propio Hirzel, ya pronto la deriva hacia el sentido de juez hace que el término se aleje de ese inicial significado: «Es sind Richter, in denen gewissermassen noch der Schöffe steckt». Cf. Hirzel, 1966, p. 71.

${ }^{577}$ Por esta razón creemos que la opinión de Darbo-Peschanski, 2007b, p. 50 y ss., que concluye en un significado claro del término como juez, es simplemente una traducción contextualizada, que difícilmente podremos aplicar más allá del pasaje homérico. En el caso

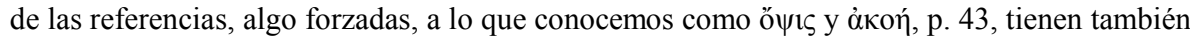
poco resultado más allá del pasaje concreto, dado que no pueden aplicarse a Ilíada, XVIII 496 y ss., donde la resolución del caso de asesinato difícilmente se podría beneficiar de la ő la òkoฑ́, al menos en el sentido que trata de darle Darbo-Peschanski. La idea defendida con posterioridad por la misma autora, Darbo-Peschanski, 1998, p. 143 y ss., relacionando el 
Si bien el posible desarrollo de la propuesta de Darbo-Peschanski nos parece difícil de sostener, lo que sí resulta interesante, por cuanto nos lleva a la propuesta antes vista de Marincola, es la idea de entender que el fruto de esa indagación es un hecho que tiene como objeto último su presentación ante el público. ${ }^{578}$

\subsubsection{SISTEMATICIDAD DEL MODELO HERODOTEO}

Sea como fuere, los datos al respecto de la metodología empleada por Heródoto parecen dibujar un horizonte con una sistematicidad más bien escasa. A todo ello hay que unir un hecho innegable al que ya nos hemos referido, como es la práctica desaparición de estos conceptos en la segunda parte de la obra, aunque realmente no observemos una profunda brecha entre ambas partes.

Para tratar de dar respuesta a este problema hemos reservado los dos

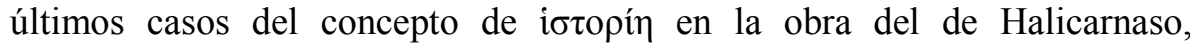
localizados en el libro II y referidos a los sacerdotes egipcios, ... है $\varphi \alpha \sigma \alpha \nu$

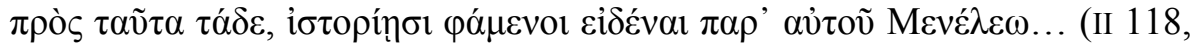

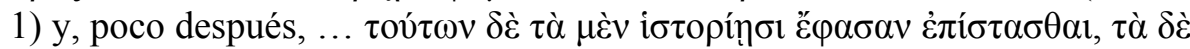

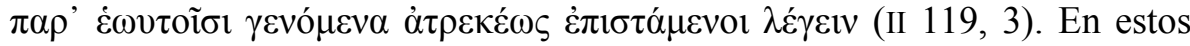
dos pasajes se hace patente, a nuestro entender, la existencia de dos niveles de actuación en la obra herodotea, $\mathrm{y}$, lo que es más importante, nos permite dar una explicación válida de la actuación de Heródoto para toda la obra.

En ambos casos aparecen dos conceptos clave del proemio herodoteo en

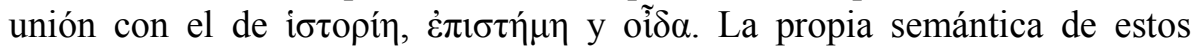
últimos nos lleva a un nivel de elaboración mayor de lo que hasta ahora hemos visto: frente a una actuación de tono empírico registrada en los conceptos de naturaleza instrumental hasta ahora abordados, ambos conceptos presentan un recorrido en la época de composición de la obra

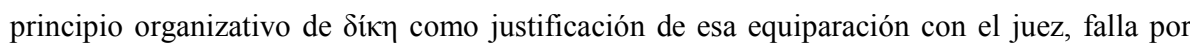
completo cuando observamos que Heródoto es observador de esos principios, no parte, para lo cual cf. infra.

${ }^{578}$ Cf. Darbo-Peschanski, 2007b, p. 67. Nótese además que este hecho invalida de nuevo las observaciones de la autora acerca de la definición del í $\tau \tau \omega \rho$ como juez, dado que no resuelve el litigio, sino que se convierte en un testigo que facilita información. 
herodotea lo suficientemente amplio y complejo como para tenerlos presentes en el análisis de la misma.

Es una vez más Snell quien nos pone sobre aviso del significado de oĩ $\delta \alpha$, cuyo valor guarda cierta semejanza con el de $\gamma \imath \gamma v \omega ́ \sigma \kappa \omega$, y la esfera de las percepciones, estableciéndose así una gradación causa-efecto entre lo percibido y lo comprendido, ${ }^{579}$ lo que nos lleva un paso más allá de la

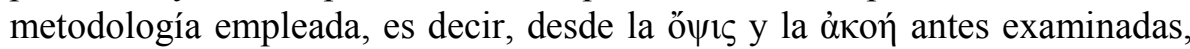
un paso que en muchas ocasiones, como ya señalaba Macan, no podemos reconocer, puesto que Heródoto solo nos deja ver su $\gamma v \omega ́ \mu \eta,{ }^{580}$ saltándose así uno de los pasos de la indagación. Ya Strasburger alertaba de que no eran criterios simplemente historiográficos los que fundaban esta falta de sistematicidad, ${ }^{581}$ y ello nos debe poner sobre aviso de que, en último término, nuestra comprensión de la obra no puede residir, simplemente, sobre unos conceptos que, a ojos de Heródoto, no gozan de la suficiente importancia como para hacer un empleo continuado de ellos.

Teniendo en cuenta que el verbo oĩ $\alpha$ se presenta con el concepto de

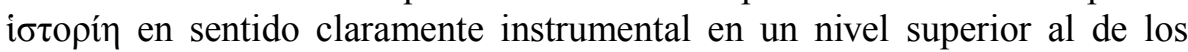
conceptos antes reseñados, hemos llegado a uno de los últimos peldaños de la escalera del discernimiento herodoteo. En este terreno aún es posible determinar niveles de precisión todavía mayores por medio del examen de la construcción sintáctica, como ya vimos, y todo ello nos lleva a pensar que oĩ $\delta \alpha$ hace referencia al objetivo mismo de la indagación herodotea, ${ }^{582}$ lo que parece verse refrendado por el el propio uso generalizado del concepto en la época, como bien recoge Snell. ${ }^{583}$

El verbo recoge una acción que va más allá del simple procesamiento de

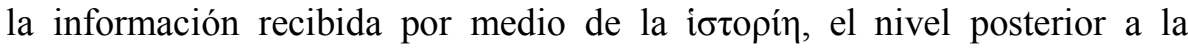

\footnotetext{
${ }^{579}$ Cf. Snell, 1992, p. 21 y ss.

${ }^{580}$ Cf. Macan, 1973a, p. CIV y ss., con notas 7 y 8 . Macan reconoce explícitamente la poca sistematicidad de Heródoto, cuyos intereses están muy lejos de los que la crítica actual desearía que hubiese tenido. El empleo en ocasiones de formulas de gran claridad sobre aspectos de su investigación, para las cuales cf. p. $\mathrm{CV}$, nota 1 , nos permite ver que detrás de los silencios de Heródoto se esconde un trabajo cuya complejidad o simplicidad es imposible de determinar.

${ }^{581}$ Cf. Strasburger, 1982, p. 861.

${ }^{582}$ Los casos en que el verbo se refiere al propio Heródoto se encuentran en una proporción elevada, como ya indicó Lateiner, 1989, p. 92, acompañado de av̉ ós, lo que puede ciertamente implicar polémica, como señala el autor, si bien es difícil de determinar.

${ }^{583}$ Snell, 1982, p. 23.
} 
simple examinación de los fenómenos, ${ }^{584}$ y de ello da buena cuenta el propio

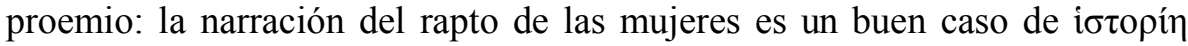

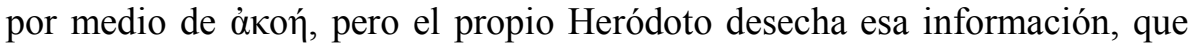
aparentemente queda en el nivel de la iotopín -de la simple indagación-,

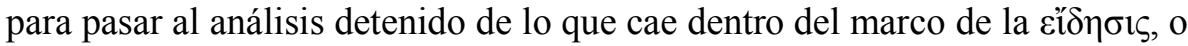
más bien de la $\gamma v \omega ́ \mu \eta$, el concepto con el que Heródoto hace referencia a la acción de oĩ $\delta{ }^{585}$ en un paso posterior a la simple aplicación de los

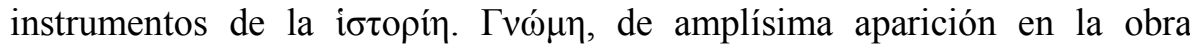
herodotea, con al menos ciento setenta ejemplos, ${ }^{586}$ tiene la particularidad de responder a una opinión en último término fundada sobre la actuación previa

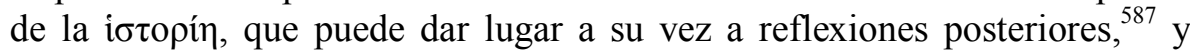

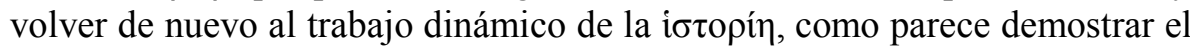
pasaje ya indicado de II 99, 1. Ejemplos como el de II 146, 1, pasaje en el que Heródoto expone su razonamiento acerca de los dioses, o el famoso pasaje de II 26 y ss., referido a las crecidas del Nilo, en el que a partir de datos debidos a la autopsia se construye un razonamiento que en último término depende de la $\delta$ ó $\xi \alpha$ personal e individual, ${ }^{588}$ confirman esta idea, cosa que demuestran pasajes como V 36,4 y 80,2 , en el que el manejo de las $\gamma v \tilde{\omega} \mu \alpha r$ se somete a la opinión individual, idea que tímidamente parecía recoger ya Lateiner ${ }^{589}$ y que señala Nicolai. ${ }^{590}$

Pero aún se puede avanzar más en la comprensión de la metodología

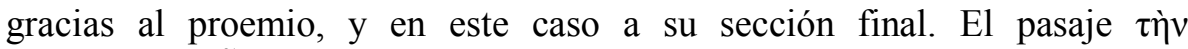

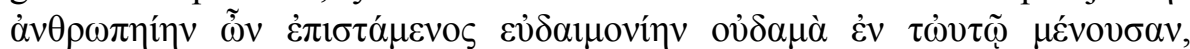

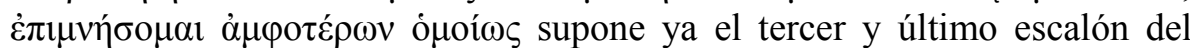

${ }^{584}$ Cf. Lloyd, 1975, p. 159.

${ }^{585}$ Cf. Snell, 1992, p. 30 y ss.

${ }^{586}$ Cf. Powell, 1977, s. v.

${ }^{587}$ Como por ejemplo en IV 15. Obviamente, como señaló Corcella, 1984, p. 111, es difícil establecer los límites entre lo que es empirismo y construcción herodotea, pero no era este el objetivo de Heródoto.

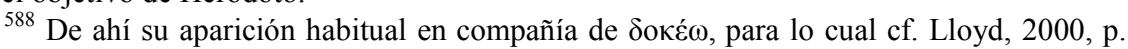

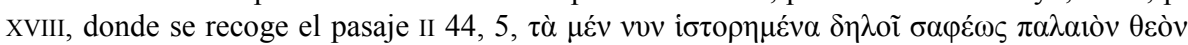

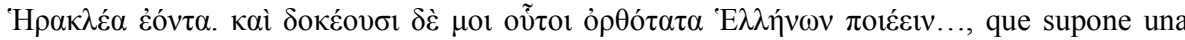
conclusión de ese proceso dinámico que antes señalábamos, con la aparición además del factor $\delta$ ó $\xi \alpha$.

${ }^{589}$ Cf. Lateiner, 1989, p. 190 y ss. Seguramente, este era el sentido de las palabras de Schadewaldt, 1982, p. 109: «was die Leute erzählen, und denn, was er selber weiss».

590 Cf. Nicolai, 2007, p. 17 y ss. La idea de Nicolai respecto a la falta de una Weltanschauung en la Antigüedad hasta la llegada del cristianismo depende seguramente de un exceso de rigor en la valoración de estos aspectos. 
universo conceptual herodoteo, su Weltanschauung, si se quiere, como señaló Regenbogen. ${ }^{591}$

Los datos recogidos y asimilados por la $\gamma v \omega ́ \mu \eta$ son ahora insertados en un sistema que los sustenta, ${ }^{592}$ más allá de la simple recolección empírica ${ }^{593}$ de los hechos, lo que hace que podamos hablar de convencimiento, ${ }^{594}$ de una puesta en movimiento de esos datos, válidos o no, como recuerda Corcella ${ }^{595}$ para integrar un conocimiento sustentado en esas actividades anteriores ( $\dot{\varepsilon} \pi i ́ \tau \tau \mu \alpha \iota)$, como parece indicar incluso el significado primario del verbo en Homero, según indicó Karl Meister, y que no es otro que el de 'sustentar(se), 596

Esta semántica hace que debamos entender el uso en el proemio y el que aparece, por ejemplo, en la narración de los sacerdotes antes vista como un paso más en el ejercicio intelectual del autor. Nótese, por otra parte, la

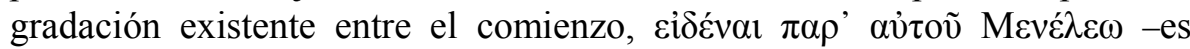

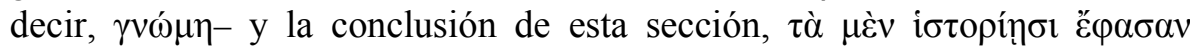

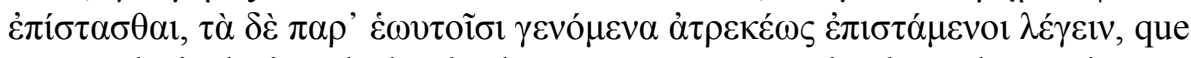
supone la inclusión de los hechos en un esquema intelectual superior, en último término el universo religioso tradicional de los egipcios. ${ }^{597}$

El concepto de $\dot{\varepsilon} \pi \imath \tau \eta \dot{\mu} \mu \eta$ en Heródoto se mueve, como indicamos, en una semántica que va del simple convencimiento a una concepción, dependiente de esta primera, que apunta a una creencia o intuición, en una organización

${ }^{591}$ Cf. Regenbogen, 1962, p. 90, indicando además la distancia existente entre este pensamiento y el de los periégetas.

${ }^{592}$ En este sentido, Corcella, 1984, p. 62, hacía referencia a la función de la $\gamma v \omega ́ \mu \eta$ en el estudio del futuro en términos que se amoldan fácilmente a lo que tratamos de exponer: «[...] la gnóme che, partendo dai data visibili del presente, formula certe aspettative per analogia (o per indirizione) risppetto al passato».

${ }^{593}$ En contra, a nuestro entender, de la reciente opinión de Stahl, 2012, p. 142, que veía en este concepto un sentido empírico.

${ }^{594}$ Cf. Stein, 1962, I, p. 5.

${ }^{595}$ Cf. Corcella, 1984, p. 101: «[...] base per l'indagine del passato sono i vari logoi, talora contradittori, che vengono giudicati dalla gnóme erodotea».

${ }^{596}$ Como corresponde a un término formado por غ̇ंí más ï $\sigma \tau \alpha \mu \alpha$, cf. Wackernagel, 1895, p. 20 y ss. Cf. además Snell, 1992, p. 81 y ss. Para este hecho, como nos recuerda Corcella, 1984, p. 88, es necesario que aún funcione el concepto de vó $\mu$ os en un sentido tradicional, de modo que ofrezca sustento al sistema.

${ }^{597}$ Obviamente, no nos importan en nuestro análisis las posibles vinculaciones reales de la narrativa con el posible ciclo de Busiris, o los contactos con narraciones griegas como la Odisea o incluso con la leyenda de Ifigenia. Cf. para ello Wiedemann, 1890, p. 440 y ss. 
de los elementos derivados de la ícopín en un marco superior, idea que ya apuntó Verdin con gran acierto. ${ }^{598}$ La historia del concepto, a pesar de las apariencias, responde a una evolución más bien compleja y tardía, al menos en lo que al sustantivo derivado se refiere, que no aparecerá hasta Baquílides. ${ }^{599}$ Pero lo más importante de los datos del término fue ya señalado con gran agudeza por Bischoff. El término tiene un valor programático que se reserva o para el propio Heródoto o para la figura del Warner,${ }^{600}$ lo que da una elevación programática al concepto que se ajusta a nuestra propuesta.

El análisis de este concepto, de gran uso en Heródoto, se ha de abordar, en lo que nos interesa y dejando atrás los dos pasajes antes examinados, a partir del propio proemio, exactamente desde un pasaje al que ya hicimos referencia -el falso proemio-, y a partir de la famosa narración de Solón y Creso, en lo que será un uso habitual en el género, el empleo de escenas en posiciones estructurales relevantes en la obra para allanar la comprensión de lo dicho en el proemio. ${ }^{601}$

En línea con esta escena, hemos de examinar previamente la importancia que presenta el breve discurso de Mardonio en este complejo sistema léxico: ${ }^{62}$

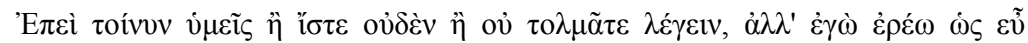

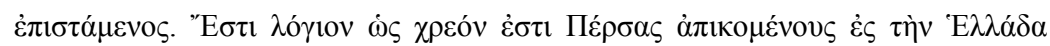

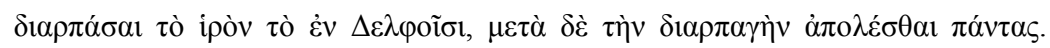

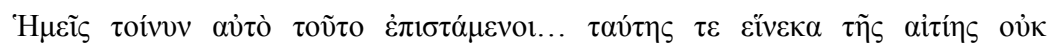
$\dot{\alpha} \pi \mathrm{o} \lambda \varepsilon \hat{\rho} \mu \varepsilon \theta \alpha$.

${ }^{598}$ Cf. Verdin, 1971, p. 202 y ss. Señala además el autor que es necesario asumir que, en cualquier análisis del juicio histórico herodoteo, se ha de tener presente el mundo religioso del historiador.

${ }^{599}$ Cf. Snell, 1992, p. 83.

${ }^{600}$ Cf. Bischoff, 1932, p. 39, con nota 1. Cf. además infra, para el tratamiento de Mardonio, y p. 76, para el uso de este término no por un Warner, sino por Amasis en la historia, también programática, de Polícrates. Para la función estructural del Warner, cf. Cobet, 1971, p. 103.

${ }^{601}$ Para este valor de la escena de Solón y Creso, cf. Gomme, 1954b, p. 80. Sobre el valor de este discurso, cf. Hohti, 1976b, p. 12.

${ }^{602}$ Cf. Heródoto, IX 42, 3. Cf. también IX 16, 2, y el comentario al respecto de Marincola, 1985, p. 23. 
Mardonio parece por sus palabras un alter ego de Heródoto. El empleo de ı̌ $\sigma \tau \varepsilon$ referido a la opinión de los demás queda atrás para hablar con una certeza que va más allá de la simple $\gamma v \omega ́ \mu \eta$, referida a la configuración de un

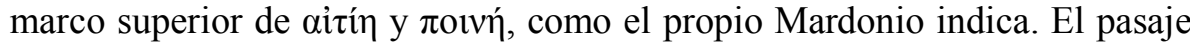
presenta, como ya indicó Macan, particularidades léxicas de especial interés. Aparte de la posible defensa de la posición del oráculo de Delfos en la guerra, ${ }^{603}$ nos interesa resaltar lo extraño no de $\chi \rho \varepsilon o ̀ v ~ \dot{~} \sigma \tau \imath$, sino de $\lambda$ ó $\gamma$ ıov, que, como señala Macan, difícilmente puede hacer referencia a un oráculo. ${ }^{604}$ Lo importante es que Mardonio, con su conocimiento de los fenómenos superiores, divinos, diremos por ahora, asume una posición muy diferente, que se resume de nuevo en la distinción entre los niveles de $\gamma v \omega ́ \mu \eta$ y $\dot{\varepsilon} \pi 1 \sigma \tau \eta \dot{\mu \eta}$.

Pero, como decimos, quizá la mejor prueba de la existencia de este doble nivel sea uno de los pasajes más famosos e importantes de toda la obra, la narración programática del encuentro de Solón y Creso. ${ }^{605}$ Es seguramente el hecho de que no se trata de una narración histórica la mejor prueba de que estamos ante una escena cuya importancia rebasa lo habitual en las narraciones herodoteas. ${ }^{606}$ Hellmann, en su trabajo sobre la escena, señaló tanto la importancia estructural de la misma, que abría el primer $\lambda$ ó su sentido programático y paradigmático: ${ }^{607}$ en el encuentro de Solón y Creso se nos presenta el marco teórico del posterior desarrollo de la historia de Creso, modelo que se repetirá a lo largo de toda la obra.

${ }^{603}$ Evidentemente, el discurso podría servir como buena justificación para su defensa, cf. Macan, 1973b, p. 634. En líneas generales, para Heródoto los oráculos permanecen ajenos a cualquier crítica, cf. Klees, 1965, p. 87.

${ }^{604}$ Cf. Macan, 1973b, p. 684. Como bien señala Macan, la referencia solo puede ser a un texto en prosa, como atestigua, añadimos nosotros, el uso del término a lo largo de la obra. Cf. Powell, 1977, p. 209, quien ya advierte: «prophecy, oracular or otherwise.» En este mismo sentido se pronuncia Crahay, 1956, p. 336 y ss.

${ }^{605}$ La importancia de este pasaje ha sido puesta de relieve por muy diversos críticos, $\mathrm{cf}$. e. g. Hellmann, 1934, passim; Defradas, 1972, p. 217: «... Hérodote a placé ce dialogue au début de son livre pour y exprimer l'essentiel de sa philosophie de l'histoire»; Solsem, 1974, p. 5. La postura un tanto peregrina de Waters, 1985, p. 113, de negar esa importancia nos parece fuera de lugar.

${ }^{606}$ Cf. von Fritz, 1967, p. 217 y nota 29. La problemática reside en un desajuste claro en la cronología de los dos personajes que impide su posible encuentro.

${ }^{607}$ Cf. Hellmann, 1934, p. 14 y ss. 
Solón es el primer Warner de la obra herodotea, y ya desde Bischoff sabemos que por boca de estos personajes se expresa el pensamiento que rige la obra herodotea ${ }^{608}$ y que además la sucesión de los mismos llega a adquirir tintes estructurales. ${ }^{609}$

La mezcla de ideas presentes en el relato, que se mueven desde lo que se puede adscribir a Solón y lo que remonta a tradiciones muy diversas, ${ }^{610}$ es un rasgo más que nos invita a examinar con detalle lo allí narrado, dejando por un momento a un lado el trasfondo religioso, objeto habitual de estudio. Respecto a la cronología, que Jacoby creía diferente para proemio y escena de Solón y Creso, el propio Hellmann mostraba su desacuerdo, basándose en la íntima relación entre ambas partes, ${ }^{611}$ cosa que creemos segura y que vamos a retomar en aras de reafirmar la relación de ambos pasajes. El asunto de las fechas exactas es complejo, pero podemos adelantar que dada la unidad de ambas secciones y su carácter programático, las dos han de responder a los primeros pasos de la composición.

De nuevo hallamos algunos de los términos que hasta ahora hemos venido examinando. Así, Creso pregunta a Solón en los siguientes términos:

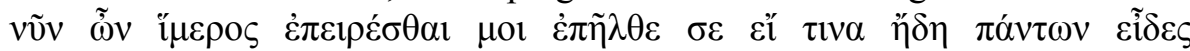

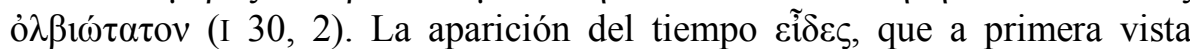
podría causar problemas, dada su clara diferenciación respecto a la semántica del perfecto, se ve solucionada si atendemos a las indicaciones de Snell, quien constata la aparición de eĩoov con valor de perfecto en la Odisea y en el caso de Heródoto. ${ }^{612}$

Superada esta dificultad, es interesante constatar cómo la conversación se mueve, sin que lo sepamos, en dos niveles diferentes, el de Creso, que

\footnotetext{
${ }^{608}$ Cf. Bischoff, 1932, p. 17 y ss.: «Herodot hat überhaupt die Eigenheit, Sentenzen, Überlegungen und Urteile, die ihn sicher persönlich wertvoll scheinen und am Herzen liegen, nicht selbst zu verkünden, sondern sie irgendjemand in den Mund $\mathrm{zu}$ legen, der in der Geschichte entweder ohnein eine Rolle spielt oder sogar eben erst durch einen solchen Ausspruch sich eine Rolle spielt darin verschafft». Cf., también en esta línea de Sanctis, 1936, p. 4. Sobre el desencadenamiento de males cuando no se atienden las indicaciones del Warner cf. Huber, 1965, p. 53.

${ }^{609}$ Cf. Bischoff, 1932, p. 49.

${ }^{610}$ Cf. von Fritz, 1967, p. 218 y ss., para un examen de las posibles fuentes de las que se nutre la narración. A nuestro entender, no es necesario determinarlas con exactitud, por cuanto responden con total seguridad a la propia persona e ideario herodoteo, como después veremos.

${ }^{611}$ Cf. Hellmann, 1934, p. 23 y ss.

${ }^{612}$ Cf. Snell, 1992, p. 27 y nota 1, con ejemplos.
} 
todavía se encuentra en la mera intelección de los hechos -es decir, la $\gamma \nu \omega ́ \mu \eta-$, y el de Solón, que, trasunto del propio Heródoto, piensa en algo muy distinto a las simples apariencias, moviéndose en el ámbito de la $\dot{\varepsilon} \pi \iota \tau \eta \dot{\mu \eta}$. Estamos ante un camino, si se quiere, iniciático, en el que Solón trata de conducir a Creso hacia la oopía que este atribuye al griego, como

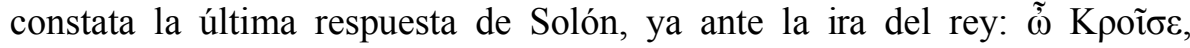

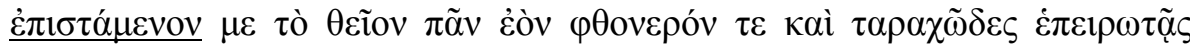

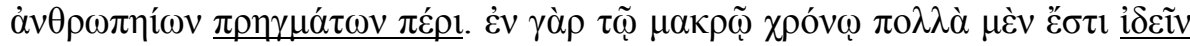

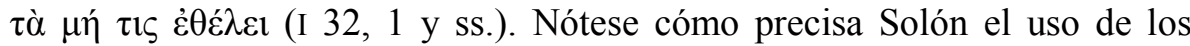

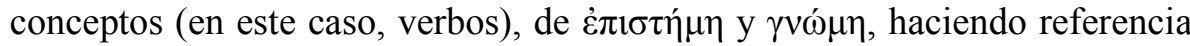
con el primero a un universo conceptual religioso y con el segundo,

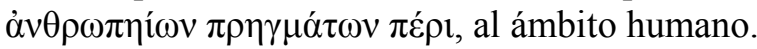

Por si a Creso no le quedaba suficientemente claro, Solón precisa un

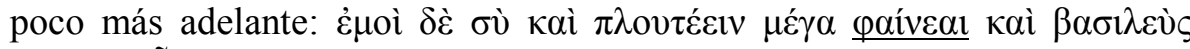

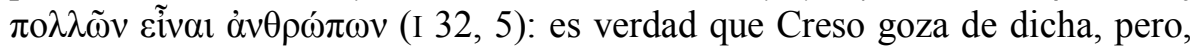
precisa Solón, solo en apariencia.

Todo ello nos reafirma en la idea de que en el seno de la obra herodotea es posible registrar al menos tres niveles de actuación. El primero de ellos, asimilado a un empirismo de mayor moderación que el presentado por Meyer, es un estadio, simplemente, instrumental, representado por los

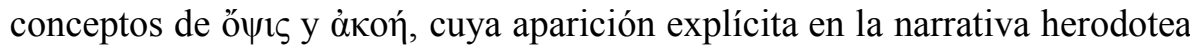
depende de la naturaleza misma de la información transmitida, como en parte la crítica más reciente ha advertido y ya hemos visto ${ }^{613}$ Este estadio

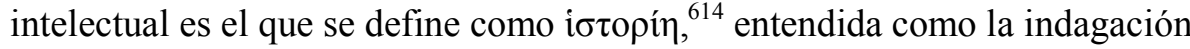
por medio de esos instrumentos, y es el paso previo para la $\gamma v \omega ́ \mu \eta$, sustantivo referido a la actividad implicada por el verbo oĩ $\delta \alpha,{ }^{615}$ que supone

${ }^{613}$ Cf. Gutschmid, 1893, p. 145 y ss., para un repertorio aún de utilidad de las diferentes fuentes herodoteas. A nuestro entender, el fundamento de este tipo de listas queda invalidado en el momento en que observamos que Heródoto no hace un empleo sistemático de las referencias, al tiempo que la inclusión arbitraria de ejemplos en exceso indeterminados reduce en gran medida su valor.

${ }^{614}$ En este sentido, disentimos de la propuesta de Müller, 1981, p. 311 y ss., quien deja

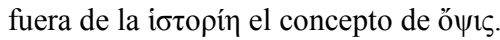

${ }^{615}$ Es interesante recordar, como hacen Cartledge y Greenwood, 2002, p. 355, que «It is noteworthy that, even in relation to stories for which he cannot vouch, Herodotus does not relinquish his authorial guarantee altogether». el hecho es más fácilmente comprensible si 


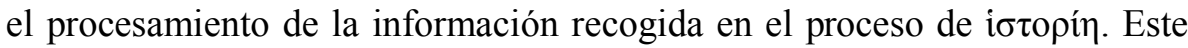
segundo paso es previo a la creación de la Weltanschauung, que viene

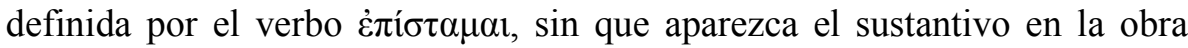
herodotea, dado que la definición que tenemos por habitual de este concepto es más bien tardía, ${ }^{616}$ lo que no excluye que sea un pensamiento relativamente común en el mundo arcaico.

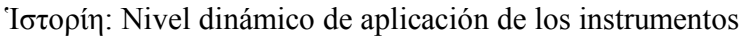

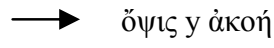

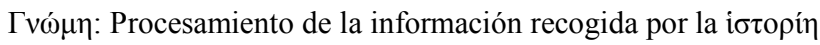

en aras de su sistematización

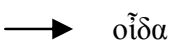

$\dot{\varepsilon} \pi \imath \tau \tau \eta \dot{\mu \eta: ~ I n c l u s i o ́ n ~ d e ~ l a ~ r e a l i d a d ~ e n ~ u n ~ s i s t e m a ~ c o m p l e j o ~ s u p e r i o r ~}$

$\rightarrow \quad$ ò̀ $\theta \varepsilon \tilde{o v}$

Como señalan Cartledge y Greenwood, Heródoto en ocasiones, especialmente en lo que se refiere a la geografia, aporta conjeturas en cuya afirmación emplea el verbo oĩ $\delta \alpha$, es decir, según lo que hasta ahora hemos defendido, llega a la $\gamma \nu \omega \dot{\mu \eta}$ sin pasar por el nivel instrumental. ${ }^{617} \mathrm{La}$ problemática de este caso se ve resuelta si aplicamos lo que ya hemos dicho y añadimos un aspecto fundamental en Heródoto, el principio de simetría: habida cuenta de que el nivel de $\dot{\varepsilon} \pi \iota \tau \eta \dot{\mu} \mu$ dibuja un tablero claro de la

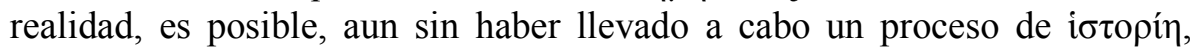
llegar a la certeza de la $\gamma \nu \omega ́ \mu \eta$ reconstruyendo esa información a partir de la trama presentada. De este modo, se puede pasar fácilmente de la inducción a la deducción.

Estos tres niveles, que van más allá de la habitual interpretación en términos historiográficos del método herodoteo, tienen cierto encaje en la tradición literaria griega, dentro de una combinación de elementos viejos y

asumimos la existencia de esa diferente nivelación, y la posición de la ő $\psi 1 \varsigma$ en un mero nivel instrumental.

${ }^{616}$ Seguramente, una de las primeras definiciones, todavía muy poética, de este concepto, la encontramos en la primera mitad del siglo IV a. C. de manos de Licofrón, DK 83 B 1, quien

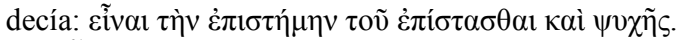

${ }^{617}$ Así por ejemplo en IV 15, 1 y ss., cf. Cartledge y Greenwood, 2002, p. 361. 
nuevos en el pensamiento heleno. ${ }^{618}$ No hemos de ser excesivamente optimistas a la hora de esperar un perfecto engranaje de estos elementos en una corriente o teoría determinada, pues ya señalamos que la naturaleza última de esta explicación es de carácter plenamente personal.

Empezaremos por Arquíloco. En el fragmento $128 \mathrm{~W}$ encontramos referencias al «ritmo» que regula la naturaleza humana, cuyo conocimiento

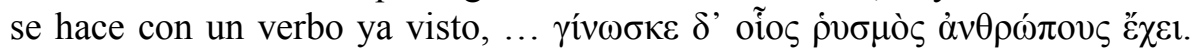
Ha de señalarse la particularidad del empleo del verbo del que procede el derivado $\gamma v \omega ́ \mu \eta$, el fruto de la acción de ese verbo, al tiempo que $\rho v \sigma \mu o ́ s$ asume el significado del término abstracto del nivel de la $\dot{\pi} \imath \sigma \tau \eta \dot{\mu \eta}$, excesivamente complejo para una época tan antigua. Más allá del interés que suscita el empleo de términos con una semántica semejante a la de Heródoto, hemos de destacar la conciencia por parte del poeta de la existencia de una variación sistematica en los fenómenos que le rodean. ${ }^{619}$

Ya vimos en el examen de los aspectos formales la importancia del fragmento proemial del $\Pi \varepsilon \rho \grave{~} \theta \varepsilon \tilde{\omega} v$ de Protágoras, en el que observamos la aparición del verbo oĩ $\delta \alpha$. Como ya señaló la crítica, con este término nos movemos en un abanico semántico relativo a lo sensible, ${ }^{620}$ como en el caso de Heródoto, y hemos de tener muy presente este empleo, que aparece también en Eurípides y en Esquilo, para la comprensión del pensamiento religioso de Heródoto, como ya indicó Burkert. ${ }^{621}$

Mucho más complicado y por ello más cercano a Heródoto ${ }^{622}$ es el

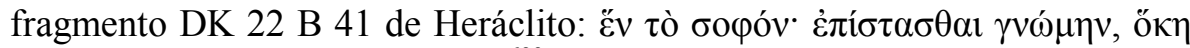

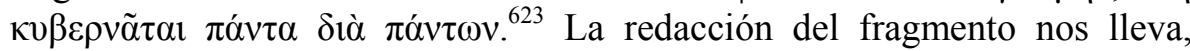

${ }^{618}$ Así, Müller, 1981, p. 317.

${ }^{619}$ Así, Schroeder, 1918, p. 324 y ss. La relación entre el concepto y el ámbito musical, señalada por el autor, hace difícil pensar que tras el concepto no se esconda algo en cierta manera sistemático, si bien las dudas de Wehrli, 1931, p. 14, nota 2, y Pfeiffer, 1928, p. 140, nos parecen acertadas: que exista una variación no implica que detrás se esconda una idea sistemática, lo que además se ve apoyado, como señala Wehrli, por el hecho de que hasta tarde no habrá siquiera una puesta en conexión de las diferentes ideas que tienen que ver con este concepto.

${ }^{620}$ Cf. Untersteiner, 1971a, p. 79. Cf. además Nestle, 1966, p. 275 y ss.

${ }^{621}$ Cf. Burkert, 1990, p. 26.

${ }^{622}$ Para esta relación, cf. los apuntes de López Eire, 1990, p. 76 y ss.

${ }^{623}$ El fragmento presenta complicaciones textuales que parecen hoy salvadas. Diels leía

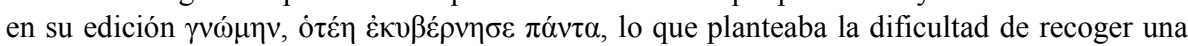
forma de relativo no conocida en los textos conservados, dato que confirmamos con una búsqueda informática. La lectura aquí ofrecida fue propuesta por Vlastos y aceptada por Kirk 


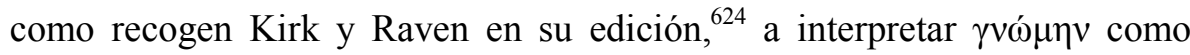

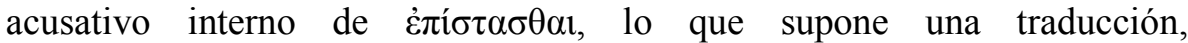
excesivamente literal para evidenciar la idea que tratamos de aportar, cercana a «comprender con el fruto de una reflexión cómo todo es gobernado por todo».

En este pasaje tenemos la explicación teórica de los conceptos que tratamos de defender en Heródoto de manera contundente, pero no podemos negar la problemática que presenta su interpretación, que deja muy atrás la propia edición de Diels-Kranz. La más reciente edición de Kahn edita ya sin

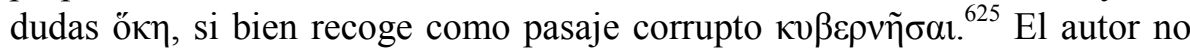
se decanta por ninguna de las dos posibilidades que se presentan, $\varepsilon \kappa \nu \beta \varepsilon \rho v \tilde{\sigma} \sigma \varepsilon$ o $\kappa \nu \beta \varepsilon \rho v \tilde{\alpha} \tau \alpha 1$, esta última la elección de Kirk y Raven. ${ }^{626}$ El propio Kahn nos alerta de la relación de gradación existente entre este fragmento y el que se constituye -diríamos nosotros- como paso previo al

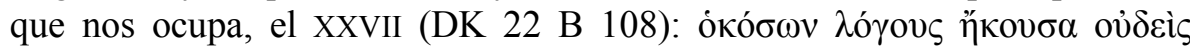

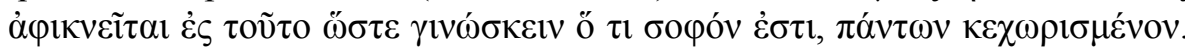

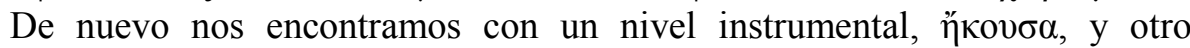
reflexivo con el verbo

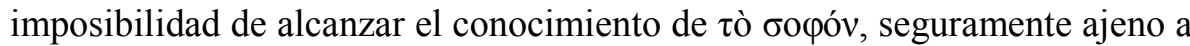

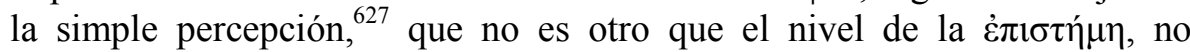
definido en el propio Heródoto y que, por cierto, Heráclito tampoco define.

El tercer estadio de esa definición y acercamiento al concepto de

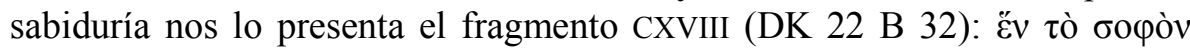

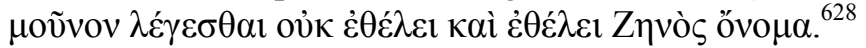

Interesante es también recordar el fragmento LV (DK 22 B 78): $\tilde{\eta} \theta$ os $\gamma \grave{\alpha} \rho$

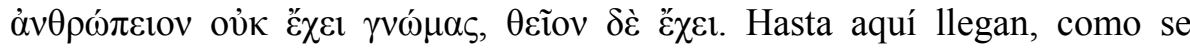
puede observar, las posibles semejanzas con Heródoto, dada la negación al

y Raven en su edición, y goza del beneficio de emplear una forma ő́ๆ que sabemos que usó el propio Heráclito, cf. Fr. DK 22 B 117.

${ }^{624}$ Kirk, Raven y Schoefield, 1987, p. 295 y ss.

${ }^{625}$ Cf. Fr. LIV, Kahn, 1987, p. 54.

${ }^{626}$ Cf. Kahn, 1987 , p. 170 y ss.

${ }^{627}$ Cf. Kahn, 1987, p. 115.

${ }^{628}$ Respecto a la posibilidad de combinar este fragmento con el DK 22 B 41, cosa con la que no estamos de acuerdo, puede verse Mondolfo, 1971, p. 215 y ss. En lo que se refiere al empleo de Znvós en lugar de la forma $\Delta$ iós, no creemos, a diferencia de lo que propone el citado autor, que deba pensarse en un juego etimológico con el infinitivo $\zeta \tilde{\eta} v$, reconstruido sobre un pasaje de Platón, Crátilo, 396a y ss. Cf. también Kahn, 1987, p. 267. 
individuo de la posesión de la $\gamma v \omega ́ \mu \eta$, medio para alcanzar ese conocimiento, sea cual sea la interpretación del fragmento DK 22 B $41 .{ }^{629}$

Como indicamos, a pesar de las semejanzas observadas, la conformación del pensamiento heracliteo nos lleva a un filósofo y no a un simple бoфós. Hechos como el asumir una posición predominante de la divinidad, o,

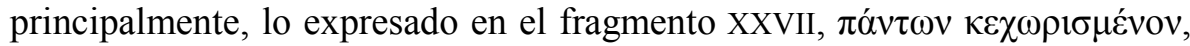
definido por Jaspers como uno de los grandes pasajes transcendentales de la filosofía, supone el abandono de cuanto implica la obra herodotea para alcanzar un pensamiento puro aislado. ${ }^{630}$

Todo ello nos debe poner sobre aviso de la existencia de un sistema en la obra de Heródoto que transciende la simple utilización de unos instrumentos para la consecución de las informaciones que presenta, lo que no supone que tengamos que abandonar al historiador para pensar en el filósofo, sino la aparición de ese $\lambda o ́$ yos que faltaba en Hecateo. El ejemplo de Arquíloco nos permite constatar que, con un mayor o un menor grado de desarrollo y complejidad, pensamientos de este tipo no eran extraños en un ambiente que, como ya indicamos en el análisis de los recursos formales, transciende las habituales fronteras entre géneros trazadas en el siglo $\mathrm{V}$ a. C. A este respecto, el reciente trabajo de Thomas viene a insistir en dicha idea ${ }^{631}$ y manifiesta la dependencia e independencia al tiempo que muestra Heródoto respecto a las diferentes polémicas e ideas presentes en su época. ${ }^{632} \mathrm{~A}$ pesar de lo interesante del trabajo de Thomas, en ocasiones creemos se excede al tratar de situar a Heródoto en polémicas que seguramente conocería, pero que no le afectarían demasiado. Tratar de vincular modelos muy concretos al mundo intelectual herodoteo para demostrar su ubicación en el final del siglo V a. C. es excesivo y además innecesario. ${ }^{633}$

${ }^{629} \mathrm{La}$ interpretación de este fragmento es seguramente de mayor complejidad de lo que pudiera parecer. Kahn, 1987, p. 173, interpreta el fragmento atendiendo a un fuerte valor de Ě $\chi \varepsilon 1$, que pone en relación con la teoría del eterno fluir, lo que haría que solo la divinidad pudiese asumir una $\gamma v \omega ́ \mu \eta$ permanente. Sea como fuere, la realidad es que estamos muy lejos del sistema herodoteo.

${ }^{630}$ Cf. para todo ello Heidegger, 1987, p. 36, quien se pronuncia en contra de esta idea.

${ }^{631}$ Cf. Thomas, 2000, p. 21: «It is increasingly clear that there are few demarcations between the various groups who may be categorized by modern scholars as Presocratics, natural philosophers, sophists, doctors...»

${ }^{632}$ Cf. e. g. Thomas, 2000 , p. 149.

${ }^{633}$ La idea, que mueve toda la obra de Thomas, 2000, p. 5, estaba ya presente, por otra parte, en el estudio clásico de Pohlenz, 1961, p. 187 y ss. 


\begin{tabular}{|c|c|}
\hline Tiempo & 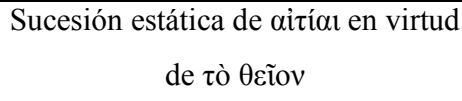 \\
\hline Espacio & Sistema geométrico de paralelos \\
\hline Nivel fenomenológico & 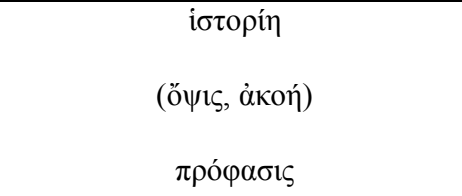 \\
\hline Nivel de comprensión del autor & $\begin{array}{c}\gamma v \omega ́ \mu \eta \text {-oĩ } \delta \alpha \\
\alpha i \tau^{\prime} \eta\end{array}$ \\
\hline 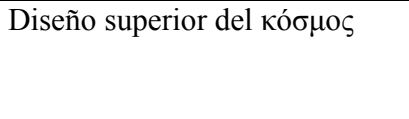 & 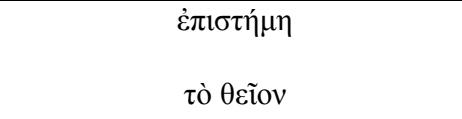 \\
\hline
\end{tabular}

\subsubsection{EL DISEÑO DEL MUNDO HERODOTEO}

La interpretación de los datos aportados por la iøtopín y su posterior procesado por medio de la $\gamma v \omega ́ \mu \eta$ son el paso previo a su inclusión en un sistema que no por muy estudiado está exento de problemas, y que incluso ha sufrido su total negación. ${ }^{634}$ La comprensión del marco general en el que Heródoto inserta sus datos para comprenderlos pasa ${ }^{635}$ para nosotros, por la necesidad de unificar y aunar todos los elementos que se dan cita en su obra.

Como hemos venido señalando, la importante teoría de Jacoby sobre la formación del pensamiento historiográfico entre los griegos ha tenido como consecuencia la división en dos de la obra herodotea. Ante esta perspectiva, basada principalmente en argumentos referidos a los conceptos

${ }^{634}$ Posturas como las antes vistas que privilegiaban el análisis de los conceptos instrumentales son las causantes de afirmaciones como las de Collingwood, 1970, p. 30, que apuntaban a un mero interés por los datos por parte de Heródoto.

${ }^{635}$ Ya von Fritz, 2004, p. 22, señalaba la contraposición del simple marco individual y subjetivo y el marco divino metafísico, en el que esos datos adquirían valor. 
instrumentales antes estudiados, parece difícil trazar una línea de pensamiento de manera continua en la obra del de Halicarnaso. Estudios como el de Fornara han supuesto el desarrollo hasta las últimas consecuencias de una propuesta que deja muchos aspectos de la obra herodotea en el tintero. ${ }^{636}$

La comprensión del marco conceptual profundo en el que se inserta la

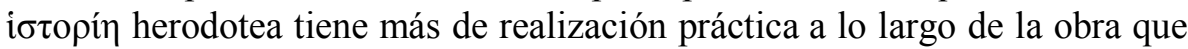

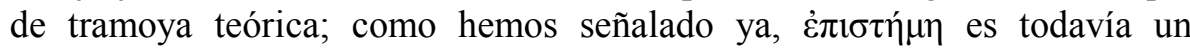
concepto por desarrollar en el mundo griego, y en Heródoto adquiere unos perfiles de escasa continuidad.

El pasaje del proemio herodoteo que supone nuestro punto de partida es

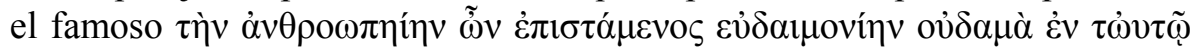

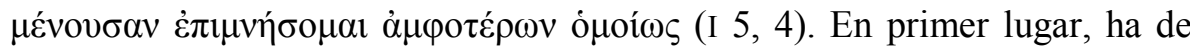
notarse que la esfera en la que se inserta el pensamiento es la humana, aun a pesar de que el término tenga de manera inexplicable menos predicamento que su correspondiente en la obra de Tucídides. Obviamente, ello se deriva del hecho mismo de que nos movemos en la comprensión de fenómenos de la esfera de la percepción humana, como ocurre en el tratado de Protágoras, lo que en ocasiones ha llevado a pensar en un sistema amoral ${ }^{637}$ en el de Abdera, si bien, a nuestro entender, estamos ante la simple y sincera imposibilidad de dar cuenta del exacto funcionamiento de las cosas, lo que lo acerca a Heródoto.

La idea de cambio derivada de la variación de la situación humana y la conciencia que Heródoto tenía de esta ha sido uno de los motivos que llevó a defender la existencia de una concepción del tiempo que por primera vez abandonaba la idea del tiempo circular, propio de las culturas primitivas. ${ }^{638}$ Así, la existencia, en palabras de Châtelet, de un vector orientado desde el pasado al presente es la idea fundamental del historiador. ${ }^{639} \mathrm{La}$ aplicación de esta idea (incluso dentro del marco definido por Jacoby) por parte de autores

${ }^{636}$ Cf. Fornara, 1971a, p. 1 y ss., en especial p. 23, para la comprensión del libro II como un texto iniciático en el desarrollo de la historiografia herodotea.

${ }^{637}$ Así, Corcella, 1984, p. 15 y ss.

${ }^{638}$ En relación con la importancia de este concepto en el nacimiento del pensamiento histórico, cf. Starr, 1968, p. 64 y ss., quien data la aparición de la conciencia de tiempo en el 500 a. C. Cf. para ello p. 69. No hace falta decir que no compartimos esta idea.

${ }^{639}$ Cf. Châtelet, 1978, p. 5 y ss. 
como Dorati ${ }^{640}$ da cuenta de la extensión de una teoría por completo insostenible. La aparición de algo cercano a la idea de progreso en la Antigüedad es un hecho que se retrasa hasta los tiempos de san Agustín.

Pero, sin duda alguna, es la idea de la existencia de una ruptura en la concepción del tiempo mítico, asimilado al ciclo del eterno retorno, el principal problema de la concepción del tiempo en Heródoto, y, con ello, de la interpretación del pasaje antes referido.

El estudio de Vidal-Naquet acerca del tiempo en el mundo griego sancionó la división en dos de la concepción del mismo, una asimilada a lo divino y otra a lo humano, sin que pueda trazarse una división clara en los primeros pasos del mundo griego, en los que se combinan evoluciones lineales -como la organización de la Teogonía - con ideas del tiempo que apuntan a una ausencia clara de esa linealidad, coexistiendo ambas perspectivas sin mayor problema ${ }^{641}$ en lo que es una representación insuficiente para el estudio de Heródoto. ${ }^{642}$ Los intentos posteriores de Darbo-Peschanski de adaptar este sistema a Heródoto han supuesto la vuelta incomprensible, quizá por otra vía, a la división entre mito y logos: la separación entre tiempo de dioses y tiempo de hombres, ejemplificada en la famosa elección de Creso como inicio de la obra ${ }^{643}$ supone la separación entre los personajes humanos y los heroicos, ${ }^{644}$ es decir, la vuelta a la tendencia interpretativa clásica de tintes racionales. ${ }^{645}$ Este hecho implica además asumir el abandono total de la esfera de lo divino por parte de

${ }^{640}$ Cf. Dorati, 2000, p. 92, con la oposición entre narración-tiempo y descripciónatemporal, que, obviamente, responde una vez más al binomio etnografía-historia.

${ }^{641}$ Cf. Vidal-Naquet, 1991, p. 140 y ss.

${ }^{642}$ Cf. también en este sentido van Leyden, 1962, p. 170; por su parte, Harrison, 2002, p. 203, da con la clave de la distinción: es tan simple como que Polícrates no se opone como historia a mito, sino como humano a dios. La idea de Fornara, 1971a, p. 12, «The causes of the Persian War do not lead back to an unjust act by Croesus, as simple reflection should serve to convince, except to one who is both the master of Lydian history and desirous of including it», nos parece alejada de toda realidad propia de la obra.

${ }^{643}$ Cf. Darbo-Peschanski, 1987, p. 24. También, Finley, 1979b, p. 22.

${ }^{644}$ O simplemente falsos, como propone Wardman, 1961, p. 139 y ss., quien defiende

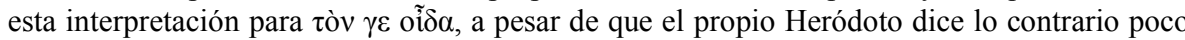
antes. Igualmente, no nos parece acertado sustentar, como hace Maddalena, 1942, p. 11 y ss., la elección de Creso como el primero que impuso tributo a los griegos, lo que se acerca demasiado a una explicación histórica en términos modernos y no se ajusta a la realidad del universo herodoteo.

645 Defendida de manera paradigmática e influyente en este aspecto concreto por Momigliano, 1984d, p. 153. 
Heródoto, algo que, a pesar de los intentos de la autora, el propio texto desmiente ${ }^{646}$ Heródoto habla de lo divino en una esfera elevada de reflexión y también lo hace, en menor medida, de los dioses concretos. No hay, pues, una ruptura al modo tucidídeo del ámbito divino y el humano, o al menos no existe en el modo que la escuela francesa persigue, porque tampoco había necesidad de ella.

El estudio de los líricos nos proporciona una imagen aún confusa del tiempo, representado simplemente por la sucesión del mismo, como se observa en el fragmento que ya vimos de Arquíloco. ${ }^{647}$ La ubicación del famoso tiempo del eterno retorno responde para Vidal-Naquet a una construcción intelectual de mayor calado que la que podría corresponder al mundo tradicional, idea que se ve apoyada además por el hecho de presentar el estadio homérico una imagen muy confusa del tiempo, ${ }^{648}$ de modo que correspondería a los presocráticos, y con ellos, a Heródoto, ejemplificar de manera clásica el modelo magistralmente estudiado por Eliade. ${ }^{649}$

Esta definición necesita, en primer lugar y antes de abordar el estudio de Heródoto, de algunas precisiones. La idea del eterno retorno, a nuestro entender, responde a una concepción que va más allá de la simple sucesión de hechos. La especial vinculación de lo agrario y lo religioso en los mundos tradicionales hace que la vida y la muerte, el ciclo natural de las estaciones, se asimilen a la propia realidad de un cosmos vivo. Ello explica que sea imposible retrasar hasta tiempos tan lejanos esta concepción, si bien no hemos de negar toda la razón a Vidal-Naquet. Seguramente es en el siglo V a. C. cuando la concepción cíclica del tiempo adquiere una significación filosófica, como ocurrirá con la aparición de la idea de progreso cristiano y su posterior elaboración reflexiva con san Agustín. ${ }^{650}$

Con esta puntualización hemos adelantado algunas de nuestras ideas sobre el tiempo en Heródoto, dado que creemos que solo es comprensible, al igual que ocurría con el diseño general, si lo ubicamos en la época que le corresponde. La muy debatida cuestión acerca de la aparición de una idea de

\footnotetext{
${ }^{646}$ Cf. Darbo-Peschanski, 1987, p. 25 y ss. Esta idea tendrá como consecuencia además la división en tres del esquema de comprensión del mundo.

${ }^{647}$ Cf. Vidal-Naquet, 1991, p. 142 y ss. A nuestro entender, el empleo del término  deducirse de lo dicho antes.

${ }^{648}$ Cf. Fränkel, 1960a, p. 2 y ss.

${ }^{649}$ Cf. Vidal-Naquet, 1991, p. 145 y ss.

${ }^{650}$ Cf. e. g. Momigliano, 1969, p. 21.
} 
progreso en los historiadores, al modo presente en Châtelet y que hemos negado, ha dado paso recientemente a propuestas que en cierta manera moderan ese exceso. El error que reside en considerar que la idea de causalidad supone un modelo de tiempo en términos de progreso bebe todavía de ideas trasnochadas de la antropología que hoy hemos superado. ${ }^{651}$

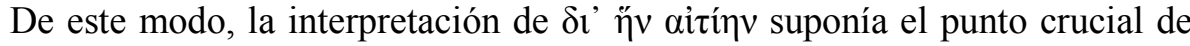
ordenación del tiempo, cosa que puede ser rechazada, simplemente, con una lectura detenida del comienzo de las epopeyas homéricas, que presentan con gran nitidez un principio de causalidad que no está muy lejos de Heródoto.

Hunter propuso situar la línea divisoria en lo que se refiere al gran cambio en la comprensión del concepto de tiempo entre Tucídides y Heródoto. De este modo y recogiendo ideas de Vidal-Naquet, ha propuesto para Heródoto la diferenciación entre generaciones míticas y humanas, siendo el ámbito de las segundas el de interés para Heródoto. ${ }^{652}$ Este sería el paso previo a la futura aparición del progreso en Tucídides. Sin embargo, hay un matiz que añadir a estas afirmaciones. Si bien las expresiones parecen apuntar a la configuración de un paso adelante hacia la definición de un spatium historicum asociado a lo humano y con ello a lo empírico y lo racional, ${ }^{653}$ la realidad de los datos nos presenta, como ya señaló van Leyden, una imagen muy diferente. ${ }^{654}$ Más allá de la cronología concreta de cada uno de los reinados y períodos, cuya suma constituye un modelo esclarecido por Strasburger ${ }^{655}$ y que no se diferencia demasiado de la primitiva cronología que puede presentar una narración histórica

${ }^{651}$ Cf. Lévy-Bruhl, 1972, p. 17 y ss.: «comprobaron [Sc. los exploradores] entre los primitivos una decidida aversión por el razonamiento, por aquello que los lógicos llaman las operaciones discursivas del pensamiento».

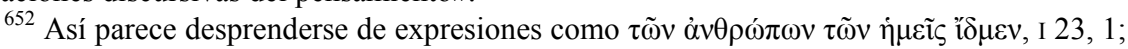
94, $1 ; 142,1 ; 178,2 ;$ III 94, 2, etc.

${ }^{653}$ Cf. Hunter, 1982, p. 19.

${ }^{654}$ Cf. Murray, 2001, p. 20.

${ }^{655}$ Strasburger, 1956. La opinión crítica de den Boer, 1967, p. 30 y ss., de dar especial importancia a los arcontes como método de datación cae en el error de partir de una imagen de la lista arcontal apoyada en la reconstrucción de los años de tiempos modernos. La lista de arcontes no se diferencia demasiado de las dataciones tradicionales y dibuja, en último término, una cronología relativa, que reside también en la datación de los vencedores olímpicos, cuya no conservación dentro de modelos tradicionales apunta precisamente a esta idea. Los vencedores serían recordados de manera aislada y regional, y la labor de Hipias sería seguramente la unificación de esas listas locales, con apoyo, claro está, de los testimonios que pudiesen existir en los propios santuarios. 
tradicional, ${ }^{656}$ la definición de los límites temporales de la obra de Heródoto no viene perfilada por el abandono de los temas que nosotros denominaríamos míticos, sino por un espacio que permita desarrollar la

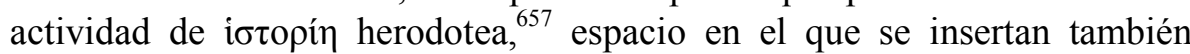
aspectos míticos, siempre y cuando a estos se les puedan aplicar los instrumentos antes reseñados. ${ }^{658}$ Estas coordenadas cronológicas, que difícilmente pueden ofrecer un panorama menos ruinoso que el reconstruido por Strasburger, en el que los sincronismos son simplemente testimoniales ${ }^{659}$ nos dibujan una concepción del tiempo que dista mucho de un modelo universal y unificado como el que en parte veremos en Tucídides. La reciente afirmación de Cobet abogando por defender la aparición de la figura de Creso como una fecha concreta ${ }^{660}$ entra en conflicto claro con la perspectiva empleada por Heródoto, dado que lo menos importante en Creso es el conocimiento exacto de algo semejante a un año. No existe un marco general que permita asumir algo más que una referencia concreta en el pasado. ${ }^{661}$

De esta manera, podemos ver definido un primer nivel de organización de los hechos que no responde a un esquema general, universal y válido para todos los fenómenos históricos, sino que estos adquieren su lugar de manera individual en un esquema constituido, simplemente, a partir de dichos

\footnotetext{
${ }^{656}$ Aun a pesar de las opinión de Strasburger, 1956, p. 131, que consideraba la cronología como uno de los datos que apoyaban la idea de un Heródoto padre de la historia, como también pensaba Finley, 1979b, p. 17, en un exceso de complejo científico. Sin embargo, las narraciones tradicionales eran capaces ya de admitir organizaciones del pasado por medio de la sucesión de los diferentes jefes tribales.

${ }^{657}$ Como ya indicaba van Leyden, 1962, p. 175.

${ }^{658}$ Como sucede, e. g. con Heracles, cf. Heródoto, II 43, 4, y van Leyden, 1962, p. 174 y Ss.

${ }^{659}$ Cf. Strasburger, 1956, p. 157 y ss. Los sincronismos no dibujan un esquema general, sino que responden a la unión de dos acontecimientos, sin que pueda avanzarse más allá; cf. Momigliano, 1969, p. 32 y ss., quien ve correctamente la importancia de estos sincronismos como puentes entre las diferentes culturas y escenarios.

${ }^{660}$ Cf. Cobet, 2002, p. 395: «For Herodotus, Croesus is an empirically well-documented point of departure, both temporally and in terms of the meaningful historical process which leads up to the only anchor date he offers at a particularly significant moment in the course of the events he wants to save from oblivion».

${ }^{661}$ De este modo se pronuncia Rhodes, 2003, p. 64 y ss.
} 
elementos. ${ }^{662}$ Sin embargo, el propio Heródoto nos indica por voz de Creso -una vez sometido a la catarsis que la muerte de su hijo y la pérdida de su imperio supuso, y que le permitió comprender las palabras de Solón- la verdadera significación del tiempo, del tiempo transcendental del que en parte hablaba Vidal-Naquet. Hace referencia el rey Creso, convertido ya en

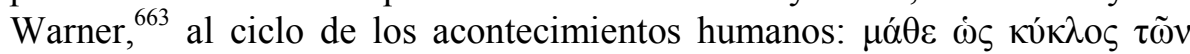

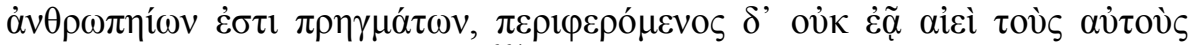

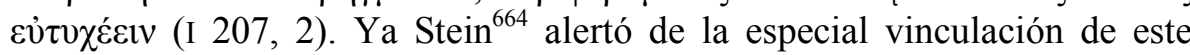
pasaje con I 5, y la importancia del mismo reside en la definición de una concepción transcendente del tiempo que, como advirtió Momigliano, poco tiene que ver con la idea del eterno retorno, a pesar de lo tentador del pasaje. ${ }^{65} \mathrm{La}$ definición clásica de la idea del eterno retorno expuesta por Eliade se sustenta básicamente por la adopción del arquetipo como modelo de repetición que persigue actualizar, mantener y purificar la realidad. ${ }^{666}$ Esta dinámica, presente en el mundo griego, responde a unos esquemas sociales que poco tienen que ver con la posición de Heródoto. Pero más allá de esta idea, de por sí importante y que después desarrollaremos, ha de destacarse que la propia definición del hombre en la obra herodotea rechaza por completo la idea del eterno retorno asimilada a las concepciones

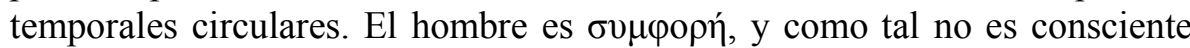
de la realidad profunda del devenir del mundo, lo que imposibilita por completo la idea de repetición, que sí hallaremos, a pesar de lo extraño que

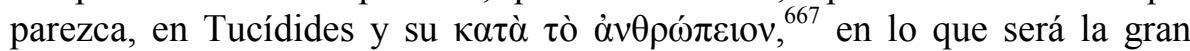
diferencia en lo relativo al tiempo entre Heródoto y Tucídides. ${ }^{668}$ Ya Immerwahr alertó de lo engañoso de la concepción temporal herodotea, que atenta precisamente como decimos contra el principio de regularidad,

${ }^{662}$ Cf. en este sentido el trabajo, de necesaria lectura conjunta con el de Strasburger, de den Boer, 1967, p. 31, quien pone en valor la importancia de los particularismos cronológicos como elemento fundamental en el sistema herodoteo.

${ }^{663}$ Cf. Bischoff, 1932, p. 43.

${ }^{664}$ Stein, 1962, I, p. 262.

${ }^{665}$ Cf. Momligliano, 1969, p. 25.

${ }^{666} \mathrm{Cf}$. Eliade, 2005, passim.

${ }^{667}$ Hellmann, 1934, p. 51, comprendió perfectamente este hecho al afirmar: «Er sagt niemals so muss es geschehen und so wird es immer wieder geschehen, sondern so geschieht es sehr oft und kann es wieder geschehen».

${ }^{668}$ A diferencia de la idea paradigmática de oposición entre tiempo mítico y humano en Heródoto y solo humano en Tucídides, para lo cual cf. Hunter, 1982, p. 93 y ss. 
fundamental en la imagen cíclica del tiempo, ${ }^{669} \mathrm{y}$ en este mismo sentido, la idea de Meier, que indica que el foco de atención herodoteo se sitúa en el proceso de cambio, ${ }^{670}$ ha de ser tomada con precaución, dado que es precisamente por medio de los sucesos concretos como se puede llegar a ese nivel superior.

De este modo, Heródoto construye un modelo superior no perceptible ni comprensible para el ser humano que se manifiesta de manera clara por

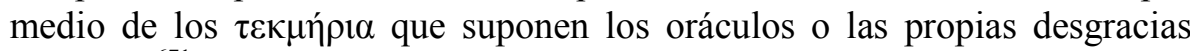
humanas. ${ }^{671}$ La narración de los hechos acaecidos no puede ser tomada como modelo exacto, arquetipo, diría Eliade, de lo que va a ocurrir, como sí pasa con Tucídides, sino que, simplemente, permite percibir la ejemplificación misma de ese orden ajeno al individuo. Con todo esto nos encontramos dentro del concepto arcaico de $\alpha \dot{\mu} \mu \chi \alpha v^{\prime}$ í en la concepción del individuo y de su situación en el mundo, concepto de amplio uso en el mundo de la lírica arcaica, ${ }^{672}$ si bien Heródoto va un paso más allá, y supone, en último término, la culminación de la reflexión sobre el mismo.

Antes dábamos cuenta de la especial importancia de la diferenciación de los pasos de recolección, procesado y comprensión de la información en Heródoto, teniendo en cuenta además la importancia que a la vista de esta interpretación del mundo adquiere lo fenomenológico, como en cierta manera indicó Gray. ${ }^{673}$ Sin embargo, el hombre no puede llegar a someter ese orden, al que Heródoto denomina $\tau$ ò $\theta \varepsilon i \tilde{o v},{ }^{674}$ y que poco tiene que ver

\footnotetext{
${ }^{669}$ Cf. Immerwahr, 1966, p. 150 y ss. Concluyente es en su examen de esta posibilidad al afirmar: «He is not a cyclical historian».

${ }^{670}$ Cf. Meier, 1987, p. 46.

${ }^{671}$ En este sentido, nos parece fundamental la observación de Gould, 2004, p. 94, acerca de la naturaleza fenomenológica de la religión en Heródoto, idea que él extiende a toda la religión griega. El concepto denominado «the uncertainty principle», definido por el autor como «the action of divinity is not revealed: it can only be inferred from the outward signs of that activity and these signs are almost never so unambiguous as to allow the inference to be certain», es fundamental no solo para comprender el mundo reflexivo de Heródoto, sino su metodología. Sobre los aspectos funcionales de muchos hechos de historicidad dudosa, cf. Waters, 1985, p. 34.

${ }^{672}$ Cf. Wehrli, 1931, p. 2 y ss. Poco más puede añadirse a la importancia del concepto en lo referido a la labilidad del ser humano a lo dicho por Fränkel, 1993, p. 23 y ss.

${ }^{673}$ Gray, 2001, p. 20: «His treatement of these [supernatural occurrences] indicates that he is receptive to them, though he strongly prefers not to give an opinion about them or to describe the gods in action». Mucho más contundente se muestra Hollmann, 2011, p. 13.

${ }^{674}$ Cf. e. g. I 32, 1; II 55, 2; III 40, 2; 42, 4; VI 69, 4; VII 16, $\gamma 2$; 137, 2; VIII 65, 2, y 94, 2.

De gran interés son los pasajes en los que se asume esa función fenomenológica del concepto
} 
con las divinidades conocidas. El mundo arcaico había conocido ${ }^{675}$ diferentes explicaciones para esa $\sigma u \mu \varphi \varphi^{\prime}{ }^{676},{ }^{6}$ pero, en el caso de Heródoto, el razonamiento se incluye dentro de una concepción del mundo que supone un paso más en su comprensión.

Al igual que ocurría en la épica, y como señala Lloyd-Jones, el hombre es de nuevo el responsable de esos cambios, ${ }^{677}$ lo que supone tender puentes entre ambas esferas. La constatación de la evidencia de una realidad rectora

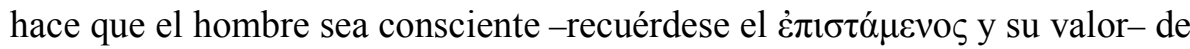
ese marco superior que se mueve, permítasenos la imagen, a semejanza de una balanza, en la que la carga de uno de sus platillos rompe el equilibrio. Es esa idea de equilibro la que regula la interpretación de los hechos en la obra herodotea, y se construye a partir de las evidencias presentes, que se mueven, como decimos, por medio de unos esquemas que Heródoto trata de reconstruir, aunque en ocasiones no sean pocas las contradicciones. ${ }^{678}$

La geografía herodotea y su estudio nos han deparado una auténtica obsesión por los paralelismos de todo tipo; ${ }^{679} \mathrm{y}$, lo que es más importante, la concepción de los fenómenos geográficos como elementos fronterizos, cuya transgresión depara el infortunio, ${ }^{680}$ añade peso a esta idea. De este modo, la descripción geográfica adquiere un papel importante incluso en lo que se

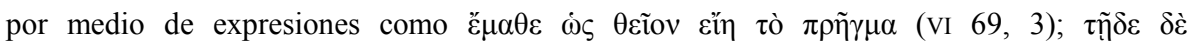

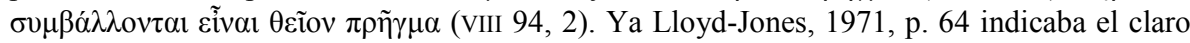
contraste entre Homero y Heródoto en lo que se refiere a la atribución de un determinado fenómeno a un dios concreto, algo imposible en la obra herodotea.

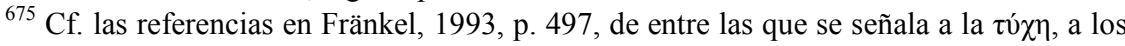
dioses o simplemente al destino como responsables de esos cambios en la vida del ser humano.

${ }^{676}$ Causante de la $\dot{\alpha} \mu \eta \chi \alpha v i ́ \alpha$, cf. Dodds, 1985, p. 40 y ss.; cf. también Fränkel, 1960c, p. 27 y ss.

${ }^{677}$ Cf. Lloyd-Jones, 1971, p. 63. Cf. también Lateiner, 1989, p. 35. La idea de Pagel, 1927 , p. 15, de hacer depender la idea de culpa de Hecateo es insostenible por la falta de textos claros de este autor, y se mantiene únicamente gracias a la idea de dependencia de Heródoto del citado autor. Esta tendencia épica no solo en lo formal la señalaba en ámbitos hispanos Alsina, 1981, p. 35.

${ }^{678} \mathrm{O}$ al menos múltiples tonalidades, como indica Gomperz, 2000, p. 302, en el análisis de la teología herodotea, que cimentó el estudio de la obra del de Halicarnaso hasta no hace demasiado en estos asuntos. Hohti, 1976a, p. 47, alertaba ya de lo cambiante de ese mecanismo rector.

${ }^{679}$ Cf. Tozer, 1897, p. 78 y ss. Para el fenómeno de la analogía en líneas generales cf. Hollmann, 2011, p. 31 y ss.

${ }^{680}$ Cf. Redfield, 1985, p. 103 y ss. 
refiere a la simple narrativa histórica de la parte final de la obra, dado que los paralelismos y los elementos geográficos delimitan un tablero físico que

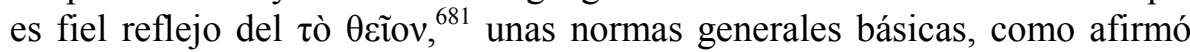
Gomperz. ${ }^{62}$

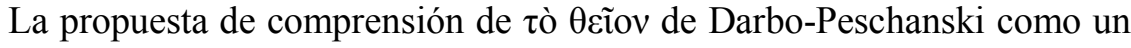
conglomerado de tres niveles diferentes de justicia es consecuencia directa de defender la existencia de una división entre dioses y hombres en la obra herodotea que no existe. De este modo, el concepto único rector se divide en manifestaciones de justicia entre dioses y hombres, así como entre hombres

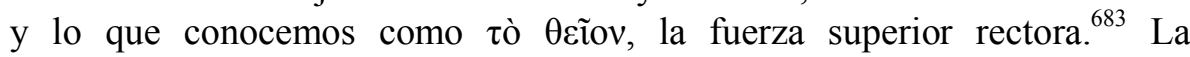
inconsistencia que antes señalamos en lo referido a la división entre tiempos de dioses y de hombres se mantiene en la negación de un carácter sacro a la justicia. ${ }^{684}$

El enfrentamiento entre griegos y persas dibuja una idea, ya presente en Esquilo, conforme a la cual las transgresiones comienzan desde el paso del Halis, ${ }^{685}$ se suceden en cadena y dan lugar a su natural regulación. La superación de esos límites y los excesos por parte de los hombres son corregidos en la búsqueda del estado inicial de cosas. A pesar de opiniones recientes que niegan la importancia de este aspecto en el conflicto con el persa, ${ }^{686}$ la realidad del propio texto confirma rotundamente la importancia del concepto de transgresión en el ataque persa, en el que un importante

\footnotetext{
${ }^{681}$ Que responde a las necesidades de diseñar un marco superior al simple ámbito griego, para lo cual cf. Redfield, 1985, p. 106.

${ }^{682}$ Cf. Gomperz, 2000, p. 303. De este modo, lo local necesariamente queda atrás para dar paso a una concepción universal que supera lo panhelénico y que trata de dar respuesta a un universo que rebasa las fronteras de Grecia.

${ }^{683}$ Cf. Darbo-Peschanski, 1987, p. 72.

${ }^{684}$ Cf. Darbo-Peschanski, 1987, p. 73: «Mais il est non moins important de remarquer qu'il n'y a pas hégémonie de l'explication religieuse, soit que le système judiciarie lui-même se trouve remplacé par de nouvelles grilles de lectures de faits, soit que la justice surnaturelle ne fournisse qu'une explication parmi d'autres».

${ }^{685}$ Cf. Immerwahr, 1966, p. 158, quien señala la importancia del cambio de planes de Creso, de un modelo, si se quiere, defensivo a otro expansionista, como inicio de sus males. Lateiner, 1989, p. 129. Fisher, 1992, p. 352.

${ }^{686}$ Cf. Scullion, 1987, p. 196. Acertada nos parece la idea de Mikalson, 2002, p. 187 y ss. La propia conclusión de la obra, con la eliminación del puente que unía Europa y Asia, ha de ser entendida como una superación de esta transgresión, a diferencia de lo que piensa Waters, 1985 , p. 5, que apunta a la apertura de un nuevo ciclo histórico, en concreto el inicio del Imperio ateniense, que poca significación tiene para lo narrado por Heródoto.
} 
ceremonial precede a una minuciosa descripción de esa transgresión. ${ }^{677}$ Los hechos no se ordenan respecto a un principio de causalidad -ya indicamos que el concepto de airín no implica causa ${ }^{688}$ sino retribución o, mejor, igualación de los hechos- ${ }^{689}$ de modo que toda acción conlleva otra que, más que castigar, cosa que sí diría Esquilo, regula el desorden que ha producido la anterior, lo que abre un marco que supera en ocasiones lo moral, siempre dentro del ámbito de la culpabilidad humana ${ }^{690}$ Este sistema de compensaciones queda patente en el suceso de los embajadores enviados por el rey persa y su posterior asesinato, para el cual Heródoto no encuentra compensación, dado que la única posibilidad parece ser la destrucción de la ciudad, si bien esa no parece ser la causa (airín). ${ }^{691}$ Es seguramente esta necesidad de determinar fehacientemente la cadena de compensaciones la que lleva a Heródoto a dejar atrás el examen de los famosos raptos de las mujeres del proemio. ${ }^{692} \mathrm{La}$ interpretación tradicional que hacía la crítica de este silencio en términos racionales y de abandono del mito ${ }^{693}$ responde más

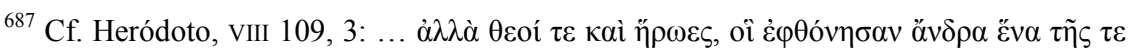

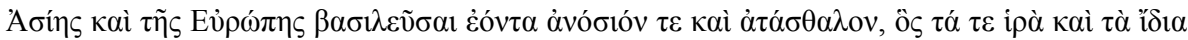

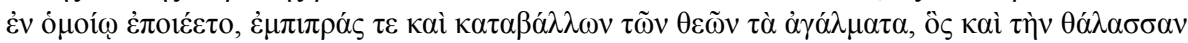

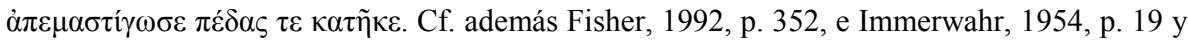
SS.

${ }^{688}$ La idea de Darbo-Peschanski, 2007a, p. 28, de considerar que el concepto supone una judicialización del mundo no deja de ser la aplicación de una explicación metafórica al término que puede producir malentendidos.

${ }^{689} \mathrm{La}$ expresión «reaction» de Immerwahr, 1966, p. 307, creemos que puede llevar a engaño, por cuanto parece apuntar a causalidad.

${ }^{690}$ Cf. Schadewaldt, 1982, p. 119.

${ }^{691}$ La propuesta de How y Wells, 1912b, p. 179, de encontrar la justificación de la destrucción de Atenas como compensación de la quema de Sardes, v, 102, nos parece probable pero difícil de defender.

${ }^{692}$ La opinión de Hommel, 1981, p. 281, de querer aplicar el concepto en el proemio sólo al rapto de mujeres y no a Creso no nos parece acertada, dado que todo responde al mismo modelo de pensamiento.

${ }^{693}$ Cf. de Romilly, 1971, p. 317 y ss. Es posible incluso encontrar restos de este pensamiento en Lloyd-Jones, 1971, p. 59, cuando afirma: «Herodotus is able both to indicate the infinite length and complication of the causal chains formed by successive aggressions and revenges, and to draw the distinction between the remote past dealt with by poets and the historical period wich was to be his own subject». Cf. también Lateiner, 1989, p. 35. No nos cabe duda de que, si Heródoto hubiese podido establecer la red de conexiones entre los raptos y Creso, habría narrado esas secciones. No hace falta que digamos que la idea de Bernardette, 1969 , p. 210, de que la negación de estos raptos daba cuenta de la negación del mundo divino por parte de Heródoto es incompatible con lo antes afirmado. 
bien a la imposibilidad de establecer de manera fiable el modelo de compensación desde esas generaciones.

Solo en este sentido se puede afirmar que hay algo parecido al tiempo cíclico en Heródoto, pero esto no ha de llevarnos a engaño; la realidad dibujada por Heródoto no es la realidad única, sino una construcción realizada por medio de los fenómenos desprendidos de ese esquema; no se

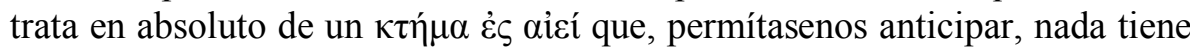
que ver con la metodología, sino con la consideración de un tiempo cíclico en los fenómenos humanos.

La acumulación de transgresiones responde a una concepción que no pertenece al ámbito de lo religioso, lo que facilita la inclusión de los muchos y muy variados ejemplos presentes en Heródoto, ${ }^{694}$ siendo sin duda el mayor el de la oposición entre griegos y bárbaros, la gran demostración de su pensamiento. La impresión que la guerra causó en Grecia, la verdadera magnitud que pudo adquirir a los ojos de los griegos fue lo que determinó este nuevo modo de ver el mundo que se extendió desde el enfrentamiento entre griegos y persas al resto de la realidad. Como muy bien señala Lateiner, los patrones que determinan la existencia de límites, los primitivos meridianos que Tozer veía en las descripciones geográficas de Heródoto, se extienden a todos los ámbitos del mundo y de la realidad. ${ }^{695}$

En este esquema general, la pregunta clave afecta a la posición de los dioses, a los que se suele atribuir en el reparto de esas compensaciones la responsabilidad, asimilada a la envidia ( $\varphi$ Óvvo $\varsigma$ ) de los dioses. ${ }^{696} \mathrm{Sin}$ embargo, ya Lateiner nos alerta de que la motivación última de la aparición de esa envidia es la actuación humana ${ }^{697}$ si bien la postura de este último es excesiva. El concepto, por lo demás, es de larga tradición en época arcaica ${ }^{698}$ y con un origen claro en los mecanismos de perpetuación de la imagen ideal del mundo, del famoso eterno retorno. La necesidad de mantener el estado habitual de cosas requería un concepto que hiciese

${ }^{694}$ La idea de Harrison, 2002, p. 115 y ss., de pensar en un sistema divino como tal es quizá llegar más allá de lo que la evidencia facilita; los dioses no son actores principales en estos designios, y su actuación en los acontecimientos humanos es más bien restringida, cf. Lateiner, 1989, p. 65, porque, como después veremos, su papel es otro.

${ }^{695}$ Cf. Lateiner, 1989, p. 127 y ss.

${ }^{696}$ Así, de Romilly, 1971, p. 315 y ss., si bien la propia autora deja entrever lo ambiguo del asunto.

${ }^{697}$ Cf. Lateiner, 1989, p. 197.

${ }^{698}$ Cf. Homero, Ilíada, IV 55; Odisea, I 346; vi 68; IX 149; 381, etc. 
referencia a esta idea, ${ }^{699}$ no exclusivamente aristócrático, ${ }^{700}$ a pesar de que habitualmente se asimilase la tiranía como un ejemplo de ese exceso a compensar por el $\varphi \theta$ óvo $\varsigma$, dado que aparece también en la tragedia en plena época clásica.

La propia definición del concepto, como una fuerza superior, ${ }^{701}$ nos pone sobre aviso de que la delimitación de su relación con los dioses es algo de gran complejidad, como lo es la definición misma de esos dioses en Heródoto.

La prueba de fuego para el espíritu religioso herodoteo pasa por un primer reconocimiento de la existencia de dioses en otras culturas; ${ }^{702}$ el convencimiento de una existencia de los mismos en pie de igualdad con los dioses griegos es el primer paso para la aparición de una serie de cuestiones que afectan de fondo a los aspectos implicados en la consideración del mundo espiritual herodoteo, y, con ello, a la interpretación del proemio.

Los intentos por ver en Heródoto atisbos de un monoteísmo primitivo se ven presionados por la evidencia que supone el hecho de que lo que más parece importar en el Heródoto etnógrafo es el rito. ${ }^{703} \mathrm{~A}$ este aspecto tampoco parecen ayudar los datos recogidos por Jones, que arrojaron como interesantes conclusiones la extensión de un empleo no muy riguroso de $\theta \varepsilon$ ć a lo largo de muy diferentes épocas, lo que, francamente, dificulta el pensar en un cierto avance hacia un monoteísmo en el sentido actual del término. ${ }^{704}$

Sin embargo, la posición de Heródoto, y con esto volvemos a la interpretación antes dada de oĩ $\delta \alpha$, es cercana en cierta manera no solo a la de Protágoras y su conocimiento objetivo de los dioses, ${ }^{705}$ sino a una constante en la reflexión religiosa del pensamiento presocrático en general, como es su

\footnotetext{
${ }^{699}$ Ya Günther, 1824, p. 6 y ss., pese a lo temprano de la fecha, apuntaba en cierta manera a esta idea.

${ }^{700}$ Rasgo demostrado por Píndaro, Olímpica, VIII 55; Pítica, I 85, e Ístmica, VII 39.

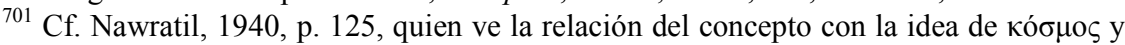

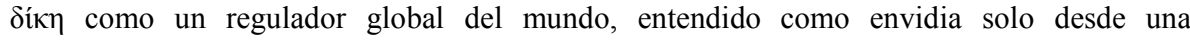
perspectiva humana.

${ }^{702}$ Cf. Linforth, 1926, p. 2.

${ }^{703}$ Cf. Linforth, 1926, p. 8; más recientemente Mora, 1985, p. 123 y ss., y Burkert, 1990, passim.

${ }^{704}$ Cf. Jones, 1913, p. 252 y ss., con abundantes ejemplos.

${ }^{705}$ Que no creencia, que sería vouí̧દıv, cf. Werner Müller, 1967, p. 145 y ss. Además, Linforth, 1928, p. 201.
} 
clara escisión de lo ritual, o, mejor dicho, social. ${ }^{706}$ Esta idea, que permite alejar la concepción religiosa profunda de Heródoto de su interés por lo ritual, entendido como un instrumento, o más bien, como una simple manifestación de un supraconcepto, nos lleva a una pregunta a la que no podemos aportar respuesta firme. Sabemos del especial interés de los pitagóricos por lo ritual gracias a Isócrates, y seguramente no sería osado tratar de ver semejanzas entre el manejo de lo ritual por parte de Heródoto y esta escuela, pero toda afirmación es difícil de sostener ante lo escaso de los testimonios. ${ }^{707} \mathrm{Ya}$ desde Tales asistimos a una interpretación del culto, entendido éste como fenómeno social, como demuestra la naturaleza de los procesos por $\dot{\alpha} \sigma \varepsilon ́ \beta \varepsilon 1 \alpha,{ }^{708}$ que dan cuenta de una especial vinculación de lo político y lo estatal, en una sociedad sin estamento sacerdotal de importancia, que apunta a una extensión de lo divino que traspasa la frontera de lo cultual. ${ }^{709}$

Es en este sentido en el que ha de ser entendido el interés por el culto de Heródoto, aspecto con el que guarda especial relación la consideración de los dioses y su equiparación en las diferentes culturas. ${ }^{710}$ Los intentos de Linforth de tratar de dar respuesta a los fundamentos sobre los que se sustentan estas equiparaciones dieron poco resultado, ${ }^{711}$ de manera que la polémica se ha mantenido hasta fechas recientes. De entre las diferentes posturas, y dejando atrás el importante trabajo de Burkert, que se adentra en complicadas valoraciones acerca de la definición del concepto de övo $\mu \alpha,{ }^{712}$ la postura clásica de Stein, ${ }^{713}$ retomada por Lloyd, parece la más plausible y la que más se ajusta al pensamiento general de Heródoto. Considerar que a iguales conceptos se equiparan iguales nombres es seguramente lo más

\footnotetext{
${ }^{706}$ Cf. Babut, 1974, p. 5 y ss. Una excepción clara es Heráclito, DK 22 B 5, para lo cual cf. Babut, 1974, p. 27 y ss.

${ }^{707}$ En este sentido cf. Babut, 1974, p. 20.

708 Los procesos por impiedad fueron, en líneas generales, escasos y debidos mayoritariamente a intereses políticos. Cf. Lipsius, 1984, p. 358 y ss.

${ }^{709}$ Cf. Aristóteles, Sobre el alma, 411a7. Cf. además Babut, 1974, p. 17.

${ }^{710}$ Para los datos concretos de los paralelos entre los diferentes dioses, cf. el útil cuadro de Linforth, 1926, p. 6 y ss.

${ }^{711}$ Cf. Linforth, 1926, p. 15 y ss.

${ }^{712}$ Cf. Burkert, 1985, p. 125 y ss. Scullion, 1987, p. 198 y ss., parece indicar lo mismo al apuntar que övo $\mu \alpha$ presenta un significado diferente al habitual, pero la realidad es tan simple como que la existencia de un interés por la semántica de los términos en el siglo $\mathrm{V}$ está tan probada como su aparente ausencia en Heródoto.

${ }^{713}$ Stein, 1962, II, p. 8.
} 
simple ${ }^{714} \mathrm{y}$, en último término, entronca con una tradición que hace que la denominación de la divinidad sea algo sometido a duda. Ya desde el Agamenón de Esquilo hallamos la aparente incapacidad de dotar a la divinidad de una denominación correcta, si bien es fácil asimilar un nombre a un concepto. ${ }^{715}$ Esta idea es la que posibilita el intercambio fácil de nombres entre divinidades asociadas a diferentes cultos, reconocidos precisamente por su vinculación a ese lugar, templo o celebración, como demuestran las palabras de Creso en referencia al Apolo griego. ${ }^{716}$ De este modo, se incide una vez más en la importancia de lo fenomenológico, y con ello en el culto exterior, como paso previo a la comprensión de la divinidad, en muchas ocasiones dificil de aislar de manera concreta en lo que a su personalidad se refiere, lo que provoca la aparición del ambiguo $\theta \varepsilon o ́ s$, presente, como decimos, en toda la Antigüedad y que en ocasiones funciona como un singular colectivo que enmascara la simple ignorancia de la divinidad concreta. ${ }^{717}$

De esta forma, la idea de los dioses se disuelve en una fenomenología que crea un tejido divino sustentado por los fenómenos cultuales, en detrimento de la denominada mitología, que se esconde tras el concepto de $\tau \alpha \grave{~} \theta \varepsilon i ̃ \alpha$, dado que esa mitología supone el establecimiento de un orden claro pero poco fundado entre los diferentes dioses, que no es en absoluto objeto

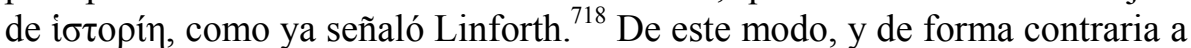
lo que pensaba de Ste. Croix ${ }^{719}$ sí existe una sistematicidad en el hecho religioso herodoteo, pero ha de ser diferenciado de nuevo del simple nivel fenomenológico. ${ }^{720}$

Dentro del proceso de definición del panteón divino -que pasa por el culto a dioses indeterminados, el posterior reconocimiento de dioses diferenciados, y, finalmente la plena caracterización de los mismos- ${ }^{721}$ el

${ }^{714}$ Así, Waters, 1985, p. 101.

${ }^{715}$ Cf. Esquilo, Agamenón, 160 y ss.

${ }^{716}$ Cf. Heródoto, I 87 y ss.; cf. además Linforth, 1926, p. 22.

${ }^{717}$ Cf. Linforth, 1928, p. 222.

${ }^{718}$ Cf. Linforth, 1924, p. 272 y ss., en especial p. 282.

719 Cf. Ste. Croix, 1977, p. 139. La idea defendida en p. 142 en referencia al desentendimiento de Heródoto de los niveles superiores de operación del concepto de destino a favor de las divinidades objeto de piedad no nos parece en absoluto sostenible.

${ }^{720}$ Es decir, el non plus ultra de que Sourdille, 1910, p. 10, hablaba para los silencios herodoteos.

${ }^{721}$ Cf. Linforth, 1924, p. 284, y Heródoto, II 50-53, lo que supondría, como señala Linforth, que los griegos tomaron sus dioses de los egipcios en el paso 2-3. 
fallo para Heródoto se produce precisamente en el paso segundo, en el que, transponiéndolo a términos herodoteos, operaría la iotopín, basándose en los aspectos propios de esa investigación, con el consiguiente paso a la غ̇ंı y a la creación posterior de una mitología. Dado que Heródoto es incapaz de sustentar los pasos propios de su investigación, apuesta, simplemente, por no pronunciarse sobre esos aspectos.

Todo esto tiene como consecuencia la apertura de un escenario que, como decimos, está presente ya desde Tales de Mileto. La indefinición de la divinidad permite la creación de un supraconcepto regulador ${ }^{722}$ que nada tiene que ver con el monoteísmo, sino que simplemente responde a la evidencia del simple desconocimiento de la denominación de esa divinidad. ${ }^{723}$ Ello facilita, como también lo hacía la superación de los dioses concretos, la aplicación de ese concepto de manera universal ${ }^{724}$ a todo el mundo conocido sin mayores problemas por parte del autor, con un abanico de denominaciones cuya extensión da cuenta de lo poco importante del nombre, y que seguramente ha de ser situado en una fecha tardía de la vida de Heródoto. ${ }^{725}$

No parece, pues, que los dioses tradicionales se encuentren sometidos a esta fuerza, como sí lo parecen estar en el caso de la Ilíada al destino, ${ }^{726}$ sino

\footnotetext{
${ }^{722}$ Que, a nuestro entender, unifica los tres tipos de explicación histórica propuestos por de Romilly, 1971, p. 334, la religiosa, la de encadenamiento y la política.

${ }^{723}$ Ya Nilsson, 1967, p. 763, afirmaba: «Es ist sehr unrichtig in dem Abstraktum des "Gottlichen" einen Monotheismus, auch nur einen in Werden befindlichen zu sehen. Herodot war eben so guter Polytheist wie irgendeiner seiner Zeitgenossen. Dies Abstraktum ist das Residuum, das, in dem Glauben an ein übernatürliches Eingreiffen Wurzenland, übrig bleibt, nachdem das persönlich Eingreifen der Göttern ausgeschalttet worden ist [...] Der Mensch braucht ein Gott, an dem er sucht in seinen Nöten und Sorgen werden Kann, dem er sein Herz ausschütten kann, auf den er hoffen und von dem er Hilfe und Trost erwarten darf». En definitiva, una elevación de un concepto general en la sociedad. Cf. en este mismo sentido Legrand, 1932, p. 131.

${ }^{724}$ De modo que, como indicaba Sourdille, 1910, p. 12 y ss., los misterios de la religión egipcia, por ser los de la cultura más antigua, adquirían cierta connotación universal, y desvelarlos, cf. p. 19, sería desvelar la esencia de la religión. Sobre la presencia de elementos de carácter universal en los diferentes dioses, cf. Bichler, 2001, p. 87. Es interesante señalar cómo este fenómeno se produce en términos semejantes con los oráculos, dado que Heródoto da cabida a procedimientos oraculares ajenos al mundo griego, cf. Klees, 1965, p. 46.

${ }^{725}$ Ya Linforth, 1924, p. 292, alertaba de lo impactante de la experiencia viajera de Heródoto para sus ideas religiosas, que, obviamente, se verían pronto orientadas por la senda de los filósofos.

${ }^{726}$ Recuérdese el pasaje clásico de Zeus y Sarpedón, Homero, Ilíada, XVI 432 y ss.
} 
que simplemente ambos, tanto los dioses como el supraconcepto, responden a una misma naturaleza divina que puede o no verse delimitada e identificada, estando además esta idea particularmente arraigada en ciertos ámbitos del mundo griego. La especial importancia y desarrollo de un pensamiento teológico desligado de los cultos tradicionales, sin la negación de estos, responde a unas esferas que, a pesar del respeto manifestado, poco tienen que ver con la faceta social del culto, al menos en sus más avanzadas evoluciones. ${ }^{727}$

\subsubsection{LA IRREFRENABLE FUERZA DE LOS HECHOS: EL DENOMINADO SEGUNDO PROEMIO}

Ya desde Jacoby, y teniendo en cuenta la división trazada por la crítica entre los seis primeros libros y los tres restantes, se han considerado los capítulos 7 a 18 del libro VII como un segundo proemio. ${ }^{728}$ Los citados pasajes suponen una suma de discursos indirectos y de narración que poco tienen que ver con los recursos propios no ya de Heródoto únicamente, sino de toda la estructura proemial del siglo $\mathrm{V}$ a. $\mathrm{C}$.

Pero lo que sin duda es innegable es la especial importancia que tiene el contenido del pasaje, que nos atreveríamos a considerar uno de los más importantes para la comprensión del pensamiento, ${ }^{729}$ en este caso claramente

\footnotetext{
${ }^{727}$ En este sentido, es interesante observar la diferencia de fondo entre el himno a Zeus de Agamenón, 160 y ss., y el de Eurípides en Troyanas, 886, dado que el primero hace referencia a una religiosidad tradicional y el segundo a la definición de ese concepto de divinidad escondida, definición que Heródoto, claro está, no aborda.

${ }^{728}$ Cf. Fornara, 1971a, p. 38, y especialmente Hagel, 1968, p. 84 y ss., que en último término no ofrece justificación alguna a su defensa de un paralelismo entre I 1-5 y VII 8-18. Sobre la estructura, cf. Frisch, 1968, p. 13.

${ }^{729}$ Sobre el acomodo de los sueños a los planteamientos que venimos defendiendo en torno a la religión en la obra herodotea, cf. Frisch, 1968, p. 49. El estudio de Löffler, 2008, al partir de modelos de interpretación de la actuación humana ajenos a Heródoto y a la Antigüedad, aporta ideas que tienen muy difícil convivencia con la crítica herodotea de todo tiempo y lugar: si Heródoto tan apenas conoció una imagen del individuo en términos modernos, díficilmente podría aplicar patrones de decisión en sus personajes propios de las ciencias sociales modernas.
} 
ateniense, de todo el siglo $\mathrm{V}$ a. C., y el último gran desarrollo programático del contenido del proemio. ${ }^{730}$

En el discurso de Artabano hallamos de nuevo muchas de las ideas señaladas hasta el momento: ${ }^{731}$ los conceptos y el pensamiento desarrollado de manera paradigmática en la narración de Creso o de Polícrates, o incluso de la expedición contra los escitas del padre del propio Jerjes, fluyen ahora de manera clara y fácil. ${ }^{732}$

La estructura de los tres discursos es de carácter agonal, lo que habremos de tener presente para futuras valoraciones. En esa estructura, el discurso central, el de Mardonio, es, simplemente, una anilla entre las dos exposiciones principales, la del propio Jerjes y la de Artabano.

Comenzando por el primero, observamos rápidamente, y más si tenemos presente todo lo dicho por Heródoto hasta el momento, que sus palabras apuntan, precisamente, a los excesos de transgresión que se han ido exponiendo a lo largo de la obra, con la particularidad de que ahora los límites superados son mayores, dado que Jerjes no solo va a cruzar las

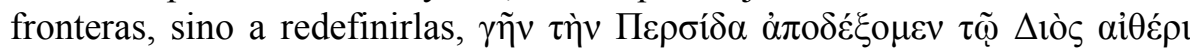

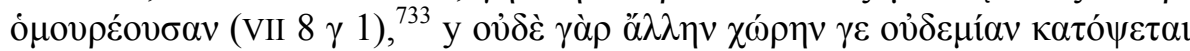

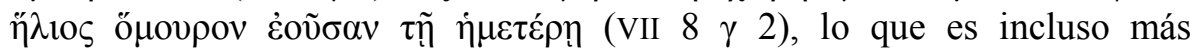
relevante que el subyugar el Helesponto, ${ }^{734}$ que supone, simplemente, la trasgresión de una de esas fronteras, no su modificación. ${ }^{735}$

${ }^{730}$ Fisher, 1992, p. 377, llegaba a hablar de una pseudo tragedia al modo sofocleo, lo que será interesante tener presente en el análisis del ambiente de desarrollo de la obra herodotea. No vemos rasgo oriental alguno en esta escena, ide que proponía Baragwanath, 2008, p. 249. Recientemente Rutherford, 2012, p. 24, ha incidido en la vinculación de esta escena con el encuentro de Solón y Creso, en línea con esa naturaleza programática del pasaje que nos ocupa.

${ }^{731}$ Cf. Hagel, 1968, p. 10 y 20 y ss.; Frisch, 1968, p. 13 y ss.; Solsem, 1974, p. 11.

${ }^{732}$ Cf. Hagel, 1968, p. 62 y ss. De entre las propuestas de Hartog, 2003, p. 33, sobre la interpretación de los escitas en la obra herodotea, creemos que es esta la opción acertada.

${ }^{733}$ Cf. How y Wells, 1912 b, p. 129 , con referencias a VII 56, 2, donde se hace ya patente

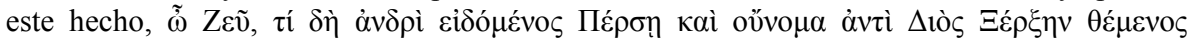

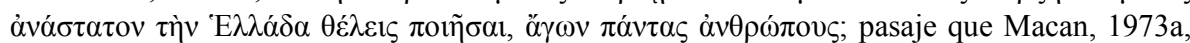
p. 78 pone en relación con VII 203, 1 y ss., en el que los lacedemonios dejan claro que no se trata de un dios, sino de un hombre. Cf. además Bischoff, 1932, p. 55, y Bichler, 2001, p. 17.

${ }^{734}$ Von Schelima, 1931, p. 25, señalaba la importancia que tenía, principalmente en Asia Menor, el culto a los ríos. Para la función del río como frontera natural y religiosa, cf. p. 29 y Vignolo Munson, 2001a, p. 11. En defnitiva, toda la campaña persa se entenderá, como señala 
Pero lo que seguramente causa mayor impresión en el lector es la existencia a lo largo del debate agonal de un doble nivel, el referido a los datos meramente estratégicos de la propuesta y el referido a la significación profunda del planteamiento. ${ }^{736}$ Es esta la causa de la existencia de una primera sección en el discurso de Artabano de tintes plenamente estratégicos, a la que sucede una segunda, que es la que nos interesa, y que

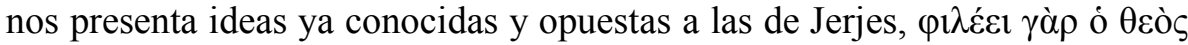

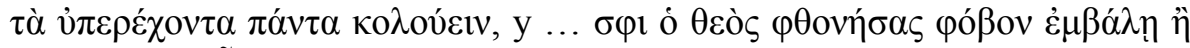

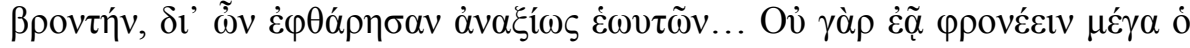

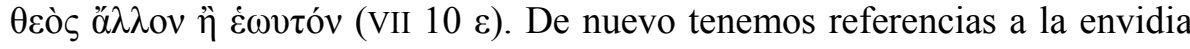
divina, que no es necesario que Heródoto explique, y, lo más importante, al

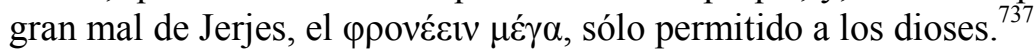

Interesante es también examinar el uso de los términos señalados antes.

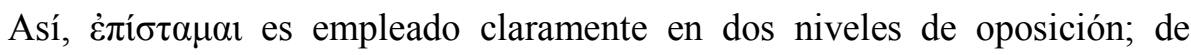
nuevo ocurre lo que ya vimos en la escena de Creso y Solón, con la particularidad de que en el caso presente también Jerjes y Mardonio usan el verbo, pero con una semántica errada que, en comparación con las palabras de Artabano, pone en evidencia clara el fallo de comprensión de la realidad por parte de los dos personajes. Dos veces usa el término Jerjes, y lo hace con una semántica banal, alejada de lo profundo del concepto hasta ahora visto, ${ }^{738}$ como es el caso también de Mardonio, ${ }^{739}$ quien hace patente que

Payen, 1997, p. 83, como un continuo avance, lo que subraya esa idea de transgresión. Para la idea de transgresión, cf. los apuntes de Hartog, 2003, p. 78.

${ }^{735}$ Que es la idea defendida por Esquilo en Persas, 50, cf. Macan, 1973b, p. 12; Hagel, 1968, p. 6.

${ }^{736}$ A nuestro entender, este doble nivel invalida propuestas como las de Evans, 1991, p. 35 , quien apunta que el desastre persa fue un hecho simplemente de elección humana. Por otra parte, la idea de Shimron, 1989, p. 53 y ss., de la poca validez de los oráculos y sueños, sustentada en que los sueños solo confirman el deseo humano (para lo cual cf. Huber, 1965, p. 59), cae en el error de no considerar que de lo que está hablando aquí Heródoto es del concepto de inevitabilidad de los designios del destino. Cf. así Huber, 1965, p. 38 y ss., especialmente p. 51, para el cumplimiento inexcusable de los oráculos. Recientemente se suma a esta postura Hollmann, 2011, p. 94 y ss.

${ }^{737}$ Cf. Hagel, 1968, p. 12.

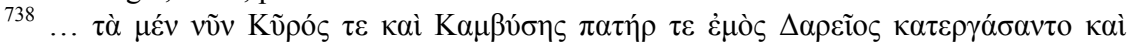

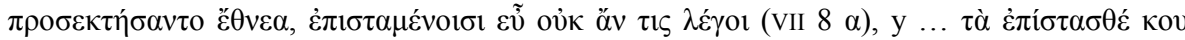
$\pi \alpha ́ v \tau \varepsilon \zeta($ VII $8 \beta 3$ ).

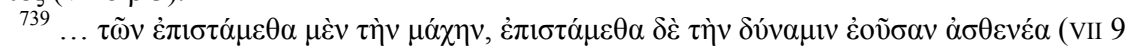
$\alpha 1)$.

Monografias de Filología Griega, 22. ISSN 1136-0860 
ambos personajes se mueven en ese nivel estratégico al que antes hacíamos referencia y no en el del conocimiento profundo del universo.

En cambio, el discurso de Artabano, curiosamente, omite este término,

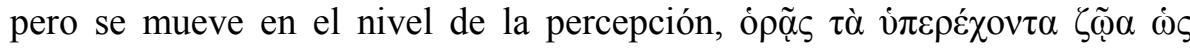

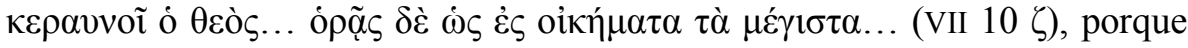
ante las palabras de los dos primeros no hay cabida para dar cuenta de un nivel superior fuera de su comprensión.

Sin embargo, y esto es lo interesante, el término aparece de manera contundente en la intervención de Artabano tras la escena del sueño, como señaló Bischoff: ${ }^{740}$

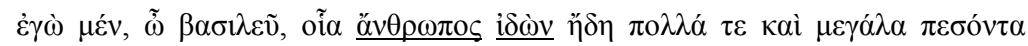

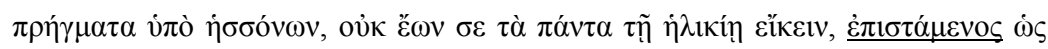

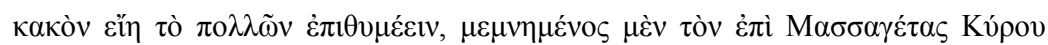

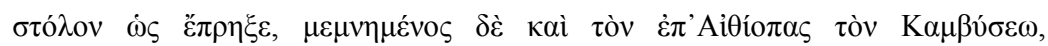

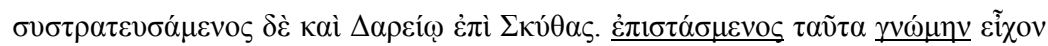

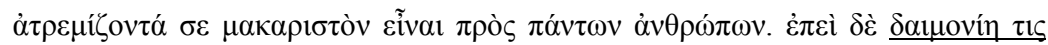

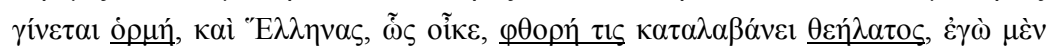

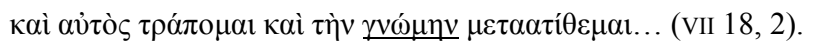

Con este pasaje se hace claramente evidente cómo tenemos un desarrollo de los conceptos vistos en el proemio, al tiempo que nos permite ir un paso más allá en su interpretación. ${ }^{741}$ Ya Hagel negaba un especial peso en la configuración de esta escena a los poemas homéricos, ${ }^{742}$ y no creemos estar muy desencaminados si pensamos en un género y ambiente más cercano, y que en parte podemos intuir en el estudio de Hagel: la tragedia. ${ }^{743}$

${ }^{740}$ Cf. Bischoff, 1932, p. 60.

${ }^{741}$ Para una interpretación histórica de la expansión persa, cf. Evans, 1991, p. 15 y ss., quien afirma en p. 19: «vengeance served more as an alleged cause than a real one [...]» Cf., sin embargo, Corcella, 1984, p. 167 y ss., para una interpretación del expansionismo persa como un hecho estructural del universo herodoteo.

${ }^{742}$ Cf. Hagel, 1968, p. 34 y ss.

${ }^{743}$ Las indicaciones de Fohl, 1913, p. 5, que inciden en la importancia de la tragedia en el diseño de las diferentes escenas herodoteas han de ser valoradas de un modo que no priven a Heródoto de su pensamiento propio. A nuestro entender, cuando Fohl, 1913, p. 84, afirma que 
Seguramente, el centrarse en los Persas de Esquilo haya favorecido el oscurecimiento de la importancia que adquiere en la presente obra la responsabilidad humana, ejemplificada en este pasaje. La aparición, que se expresa ante los que saben en términos muy claros, afirma: oü $\tau \varepsilon \dot{\varepsilon} \varsigma \tau$ tò

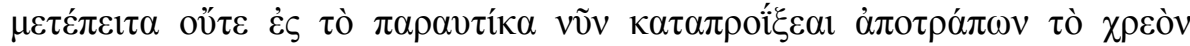

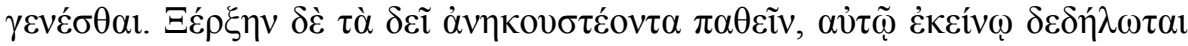
(VII 17, 2).

El punto clave para la comprensión de este aspecto no es siquiera la tragedia contemporánea de Sófocles, que creemos, como después veremos, que participa del mismo mundo de ideas. La representación en el año 458 a. C. de la trilogía conservada de Esquilo significó la sanción de un modelo de responsabilidad humana que poco tiene que ver con Heródoto y mucho con la política y el pensamiento de la Atenas de su tiempo. ${ }^{744}$ Las Euménides

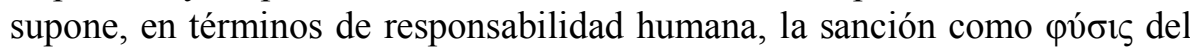
concepto de vó $\mu \varsigma \varsigma$, del diseño artificial de un modelo de responsabilidad humana y del destino adaptado a las necesidades de la democracia ateniense, actuando sus tribunales como equiparables a la sanción divina.

Obviamente, el modelo de Esquilo presenta una moderación muy alejada de los excesos posteriores, pero en parte supone la asimilación de convenciones humanas a la esfera de lo divino. ${ }^{745}$ La línea trazada entre los delitos y castigos en Agamenón, en una sucesión arcaica que nos lleva a Solón, ${ }^{746}$ se detiene por intervención del nuevo orden legal: el hombre es capaz de delimitar la responsabilidad humana, de interrumpir la sucesión de compensaciones de una manera que choca por completo con los supuestos de la moral y la religión tradicional, y con ello, dada la naturaleza eminentemente aristocrática de las instituciones que respaldan esos procesos, con una determinada parte de la sociedad.

La solución al dilema trágico planteada por Esquilo no responde a estructuras propias de la moral arcaica, y ello supone una transgresión

Heródoto participa del arte trágico, hemos de tener muy presente que ambos universos, el herodoteo y el trágico, participan de un mismo legado poético y cultural.

${ }^{744}$ Por su parte, Dodds, 1985, p. 41 y ss., traza en apariencia un paralelo entre Heródoto y Esquilo que rápidamente el propio autor define de manera clara, separando tajantemente ambos mundos.

${ }^{745}$ Dodds, 1985 , p. 50 y ss., denominaba este paso como una interpretación más elevada del mundo de los démones que conducía a una justicia racional, lo que, a nuestro entender, es perfectamente válido, como veremos.

${ }^{746}$ Sucesión que supone tiempo, en contra de lo que opina Starr, 1968, p. 99. 
también de los esquemas trazados de manera tradicional, por cuanto vulnera el principio de orden estático del mundo. Más allá de las posibles implicaciones políticas de la obra, quizá todavía no resueltas, ${ }^{747}$ lo innegable es que la solución a la que se llega supone un ataque contra la moral tradicional en lo que a la concepción de la justicia se refiere.

La crítica ha atendido tradicionalmente al plano estrictamente legal del problema, pero lo que nos interesa es señalar la evolución que recorre la trilogía de Esquilo, desde el propio Agamenón, en el que ya Fränkel inisitía en señalar la importancia de lo legal, en términos todavía morales y religiosos $^{748}$ que se acercan al plano herodoteo. Así, Podlecki alertaba de la importancia de versos como

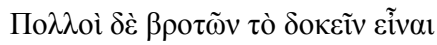

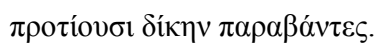

(Agamenón, 788-789)

Estas palabras adquieren especial relevancia en atención a lo visto en Heródoto: Jerjes y Mardonio atienden a las apariencias que les son favorables para transgredir los límites, ${ }^{749}$ pero en la Orestía pronto desaparece este mundo, que da paso a la bajada a la tierra de la justicia en la última de las obras, ${ }^{750}$ en lo que es seguramente la escenificación de una nueva justicia urbana perfectamente consecuente con el mundo de la $\pi$ ó $\iota \varsigma,{ }^{751}$ pero que, aunque no aparezca con claridad en Esquilo y en sus

${ }^{747}$ Cf. Podlecki, 1999, p. 83 y ss., para un rápido examen de las propuestas. La idea de

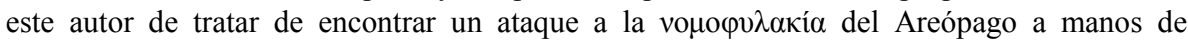
Pericles en un espacio de tiempo comprendido entre el año 462/61 y el 458 nos parece interesante pero relativa al desarrollo político.

${ }^{748}$ Cf. Fränkel, 1974, ad loc., y Podlecki, 1999, p. 64.

${ }^{749}$ En este sentido, la idea de Bodei Giglioni, 2002, p. 40, de un determinismo divino como responsable de la expedición de Jerjes es quizá posible en ambientes orientales, pero por completo imposible en Heródoto, como muestra el desarrollo del doble plano. Acertada es por ello la afirmación reciente de van Wees, 2002, p. 346: «No historian could have done more to assign a share of responsibility for war to the Greeks»».

${ }^{750}$ En este sentido, es interesante señalar las palabras de Sommerstein, 1989, p. 22, que nos recuerda el mantenimiento del marco divino aun a pesar de que el ejercicio de la justicia haya pasado a los hombres de manera clara.

${ }^{751}$ Cf. Esquilo, Agamenón, 1412, en referencia a Clitemnestra, tras matar a Agamenón:

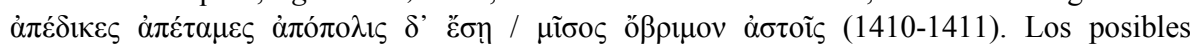
problemas textuales en $\dot{\alpha} \pi$ ó $\pi$ o $\lambda 1 \varsigma$, para lo cual cf. Fränkel, 1974, p. 665, no afectan a la interpretación del texto. 
críticos, supone la negación del esquema trazado por Heródoto, en un nivel humano que se superpone al divino, a diferencia de lo que defendía Podlecki. La consolidación de las estructuras civiles democráticas y su posterior sacralización dentro del esquema urbano conllevaba indudablemente, no solo la reducción de las instituciones de carácter aristocrático, sino la negación del mundo de valores que sustentaba ese sistema desde los inicios mismos de la época arcaica. ${ }^{752}$ Es en este escenario en el que hemos de situar la problemática señalada en el texto herodoteo, como en cierta manera indicó Meier, ${ }^{733}$ teniendo en cuenta que la cronología corresponde a un arco de aproximadamente unos veinticinco años de diferencia, pero que, como veremos, responde en origen a una anterioridad incluso del problema herodoteo y a la subsistencia de las dificultades mismas que hemos trazado, y que se inserta en un marco muy complejo cuya importancia es fundamental para la comprensión de la parte inicial del proemio, y de la relación con Atenas de toda la obra.

Tradicionalmente, la interpretación de las Euménides ha pasado por la oposición entre $\delta i ́ \kappa \eta$ y $\theta \varepsilon ́ \mu 1 \varsigma$, la primera asimilada a los nuevos tiempos y a los dioses olímpicos, y la segunda a los dioses ctónicos. ${ }^{754}$ Ello suponía el situar a Esquilo en el mundo de Solón y de la $\pi$ ó́ enfrenta con la dificultad que supone el hecho de que $\theta \varepsilon \dot{\mu l \varsigma}$ solo aparezca una vez en las Euménides, y con un significado que poco tiene que ver con la semántica requerida para esa oposición. ${ }^{756}$ Ya Hirzel alertó del anacronismo

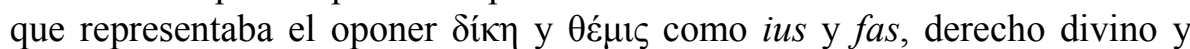
humano, ${ }^{757}$ y seguramente esta sea la razón por la cual la oposición ha de realizarse en las Euménides entre divinidades, porque todo el derecho es divino en la época. Que tras las Euménides se camufle una divinización del

${ }^{752}$ Cf. Dodds, 1985, p. 41 y ss.

${ }^{753}$ Cf. Meier, 1987, p. 53: «It is my opinion that there was a further factor, wich was that Herodotus felt that his idea of predetermined laws of nature in the world and of the limits of mankind were being called into question by all kinds of new and almost modern attitudes in contemporary Athens».

${ }^{754}$ Cf. Wolf, 1950, p. 412

${ }^{755}$ Cf. Wolf, 1950, p. 341 y ss.

${ }^{756}$ Se trata de la $\theta \varepsilon ́ \mu 1 \varsigma$ oracular, que, en opinión de Hirzel, 1966, p. 7, no guarda relación con la primitiva $\theta \dot{\varepsilon} \mu 1 \varsigma$, si bien creemos que esta nueva $\theta \dot{\mu} \mu 1 \varsigma$ es, simplemente, la evolución

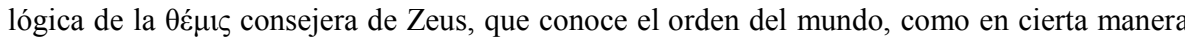
indicaba el propio Hirzel. Sobre la función de comunicación que ofrecen los oráculos todavía en el siglo v a. C., cf. Crahay, 1956, p. 343 y ss.

${ }^{757}$ Hirzel, 1966 , p. 158 y ss. 
derecho humano y urbano es una realidad que no necesita siquiera de esta oposición, que, por otra parte, es falsa. Ya desde Solón, como indica el propio Wolf, la idea de $\theta \dot{\mu} \mu 1 \varsigma$ había prácticamente desaparecido, ${ }^{758}$ seguramente por su carácter abstracto, asimilado a un principio regulador que pronto daría paso a la idea de esa $\theta \dot{\mu} \mu 1 \varsigma$ como esposa de Zeus, ${ }^{759}$ lo que haría que sus funciones pasasen a $\Delta i ́ \kappa \eta$.

Con todo ello, se hace patente que la realidad que nos plantea las Euménides pasa por la modificación de esa idea ancestral de derecho, regulada por leyes no escritas, no introduciendo leyes cívicas, sino tratando de modificar la imagen tradicional de la legalidad sagrada, de modo que, como indica Lloyd-Jones, $\varphi \theta$ óvo era un concepto que se podía evitar, ${ }^{760}$ a pesar de que afectara incluso a dinastías enteras. ${ }^{761}$

En esta evolución, desempeña un papel fundamental el antecesor directo de Heródoto en lo que a ideas se refiere, Solón. El modelo de justicia de Solón, expuesto en la famosa Elegía de las musas, es un ejemplo modélico de aquello que ataca el pensamiento del Esquilo en las Euménides. ${ }^{762} \Delta$ íkๆ es ya el único concepto clave a tener en cuenta en el mundo de la justicia, como señalábamos, un concepto de clara transcendencia religiosa -la que todo lo ve- ${ }^{763}$ y que se presenta como un concepto histórico, ${ }^{764}$ que es capaz de transcender el momento presente y proyectarse en el futuro. ${ }^{765}$ Este aspecto perfectamente asumido por la crítica y presente en Heródoto, ${ }^{766}$ conlleva otro que señala de manera clara Wehrli, y que es fundamental para la comprensión de Heródoto: «[...] bei Solon der Gott nicht persönliche Beleidigung, sondern jede Art von Unrecht rächt». ${ }^{767}$ Este concepto de justicia que persigue el delito y no al criminal responde a una idea más

${ }^{758}$ Cf. Wolf, 1950, p. 192. Señala además el autor el claro retroceso del concepto de $\theta \varepsilon ́ \mu 1 \varsigma$ en Teognis, en cuya obra solo aparece en una ocasión, v. 668.

${ }^{759}$ Cf. Hesíodo, Teogonía, 901, y West, 1982, p. 405 y ss.; Hirzel, 1966, p. 2 y ss.

${ }^{760}$ Cf. Lloyd-Jones, 1971, p. 68 y ss.

${ }^{761}$ Como ocurre en Heródoto, cf. Corcella, 1984, p. 165.

${ }^{762}$ Cuya dimensión histórica no pasa desapercibida, cf. Darbo-Peschanski, 2007b, p. 240 y ss.

${ }^{763}$ Cf. Solón, Fr. 13 W; Wolf, 1950, p. 192.

${ }^{764}$ Cf. Darbo-Peschanski, 2007b, p. 231 y ss.

${ }^{765}$ Cf. Solón, Fr. 13 W v. 29; Wolf, 1950, p. 194; Wehrli, 1931, p. 13.

${ }^{766}$ Ya Hellmann, 1934, p. 32 y ss., comprendió la función preparatoria de la narrativa de Giges, «Gyges interessiert nur, insofern das Schicksal des Kroisos dadurch bestimt wird», en lo que es una escena programática que se repite a lo largo de la obra.

${ }^{767}$ Cf. Wehrli, 1931, p. 13 y ss. 
abstracta de justicia que la habitualmente conocida; la deriva del interés desde el autor hasta el hecho incide en la existencia de un orden superior que ha de compensarse, a diferencia del habitual concepto de miasma sobre el individuo concreto. ${ }^{768}$ En el pasaje de Solón y Creso encontramos, como nos recuerda Hellmann, y será una constante en Heródoto, ${ }^{769}$ esta misma idea, ${ }^{770}$ «Massgebend ist allein der Tatbestand, nicht der Weg, wie der einzelne zur Tat gelangt: es nicht kommt darauf an, ob er Schuldig ist, sondern was er getan hat», si bien la referencia a la culpabilidad que apunta Hellmann no nos parece correcta.

De este modo estamos a las puertas de un proceso de sacralización abstracta de la justicia en el que, como señaló acertadamente Linforth, ${ }^{771}$ no hay todavía una sistematización suficiente; los conceptos aparecen sin insertarse en un marco general y, a pesar de todo, se presentan en relación con un diseño cuya culminación será la obra del propio Heródoto.

En este sentido, uno de los grandes continuadores del mundo espiritual homérico, y antecesor en este proceso del propio Solón, Semónides, dibujaba un escenario de mayor simplicidad que el de Solón, lo que nos permite valorar mejor el avance que supone este último. En el primero de los fragmentos leemos:

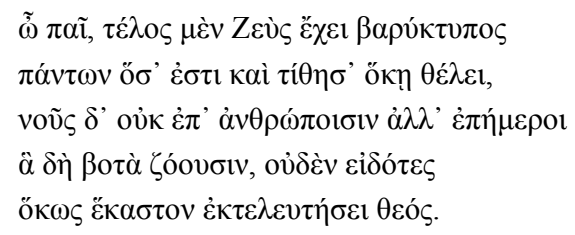

Estos versos, el mejor ejemplo de un concepto de $\dot{\alpha} \mu \eta \chi \alpha v^{\prime} \eta$ extremo, ${ }^{772}$ responden a una idea del hombre como incapaz de superar los designios de

\footnotetext{
${ }^{768}$ En este sentido se pronunciaba, quizá no con esta claridad, Pagel, 1927, p. 20, al

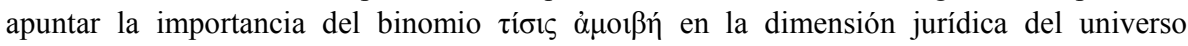
herodoteo.

${ }^{769}$ Cf. Schadewaldt, 1982, p. 197 y ss. Los paralelos entre Solón y Heródoto son una constante a lo largo de toda la obra, no solamente del famoso pasaje del encuentro entre Solón y Creso. Corcella 1984, p. 214, alertó incluso de las semejanzas personales.

${ }^{770}$ Cf. Hellmann, 1934, p. 32.

${ }^{771}$ Cf. Linforth, 1919, p. 109.

${ }^{772}$ Cf. Pfeiffer, 1928, p. 146. 
Zeus, que dispone (nótese el concepto de $\theta \dot{\mu} \mu 1 \varsigma$ enmascarado en el verbo y recuérdese lo dicho respecto a su desaparición) su vida sin que se muestre solución alguna. ${ }^{773}$

Sin embargo, la poesía aristocrática del siglo siguiente desarrolló un modelo, una vía para la superación de esa $\alpha \mu \eta \chi \alpha v i ́ \eta$. Autores como Teognis o Solón proponen de manera clara la virtud como vía para la superación del destino, como señaló Wehrli. ${ }^{774}$ El concepto de ö $\lambda \beta o \varsigma$, tan importante para la comprensión de Heródoto, se reserva en la Elegía de las Musas para los dioses ${ }^{775}$ pero de los hombres puede venir el reconocimiento, la $\delta o ́ \xi \alpha$. Esta idea de moral agonal pública, que reconoce el mérito de quien se mantiene dentro del lema délfico $\mu \eta \delta \grave{\varepsilon} v$ ó $\gamma \alpha v$, una de las ideas políticas fundamentales del pensamiento de Solón, ${ }^{776}$ responde a la imagen de una polis constituida

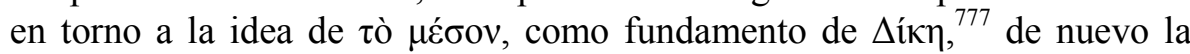
idea de no transgresión aplicada al funcionamiento de la ciudad, que reconoce al buen ciudadano, caracterizado en términos de moral aristocrática. ${ }^{778}$

A pesar de todo, y como venimos insistiendo, estas ideas no responden a un marco claro de sistematización, que tampoco era necesario en tiempos de Solón; las condiciones del momento favorecían más una simple unión de conceptos de carácter aristocrático que una reforma de gran complejidad, para lo que habrá que esperar a Heródoto.

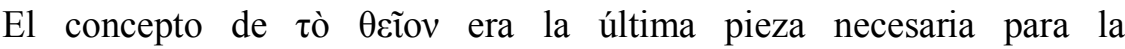
sistematización de un modelo de justicia religiosa asimilable a un modelo de comprensión del mundo. Para entender el proemio herodoteo, su concepto de aĩín, y la misma elección de Creso como comienzo de la obra, que a

${ }^{773}$ Cf. Wehrli, 1931, p. 8. También Pfeiffer, 1928, p. 139, «[...] eine Selbstbeherrschung gibt es nicht».

${ }^{774}$ Cf. Wehrli, 1931, p. 14 y ss.

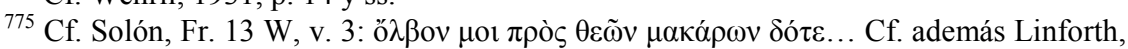
1919, p. 106.

${ }^{776}$ Cf. Wolf, 1950, p. 191

${ }^{777}$ Cf. Wolf, 1950, p. 197 y ss.

${ }^{778}$ Cf. Solón, Fr. 4 W, v. 4 y ss. No cabe duda de que el mayor desarrollo de esta

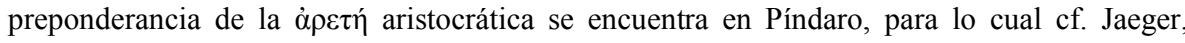
2000, p. 201 y ss. 
algunos decepcionó por su poco rigor histórico, ${ }^{779}$ es necesario asimilar el paso del foco de $\Delta$ íkๆ del individuo al hecho. De este modo, el sistema de compensación no depende del individuo y puede convertirse fácilmente en un sistema abstracto asimilable a todo el mundo conocido. La idea de sucesión en el tiempo, y, en resumidas cuentas, el concepto de justicia histórica al que hacía referencia Wolf, permite determinar el inmenso fresco herodoteo, con la particularidad de que la abstracción es ya total: iò $\theta \varepsilon i ̃ o v$ actúa por igual sobre la geografía, los animales ${ }^{780}$ y los hombres, de modo que, en definitiva, regula por completo el mundo ${ }^{781}$ lo que deja atrás incluso conceptos de tanta importancia en el mundo arcaico como el de ávó $\gamma \kappa \eta{ }^{782}$

Si bien quizá las afirmaciones de Legrand acerca de la poca altura de miras filosófica de Heródoto son excesivas, ${ }^{783}$ quizá aún marcadas por el pudor del historiador que trata de alejar cualquier tono ideológico que pueda contaminar la verdad de los datos, es innegable que el conocimiento literario de Heródoto, del que realmente solo podemos valorar una parte muy pequeña, ${ }^{784}$ es probablemente la clave para la comprensión de este inmenso fresco de ideas que tienen algo en común con gran número de autores, pero que al tiempo no depende en último término de ninguno. Seguramente por ello Heródoto sea historiador y no un filósofo o un poeta.

Para que Heródoto haya afrontado ese esfuerzo, es necesario asumir una explicación que pasa por el lugar en el que se desarrolla su obra.

${ }^{779}$ Cf. Bernardette, 1969, p. 212, y Bichler, 2001, p. 244, quienes plantean el proemio en términos historiográficos modernos. Esa elección tampoco supone, como propone Canfora, 1999a, p. 76 y ss., la continuación del «ciclo histórico» donde lo dejaron sus predecesores.

${ }^{780}$ Cf. Heródoto, III 108, pasaje en el que Legrand, 1932, p. 133, ve semejanzas con Protágoras; cf. Fisher, 1992, p. 353, y Hoffmeister, 1832, p. 16, para Heródoto I 189, en el que un caballo de Ciro muere víò v̋ßpıৎৎ al cruzar un río. Es interesante señalar además que esta

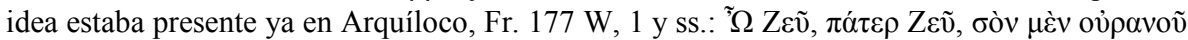

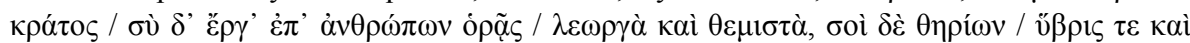
$\delta i ́ \kappa \eta ~ \mu \varepsilon ́ \lambda \varepsilon 1$, para el que cf. además Pfeiffer, 1928, p. 140. Los intentos de Waters, 1985, p. 103, de reducir este concepto a un préstamo anecdótico de los filósofos jonios, al no poder admitir bajo este concepto, entendido como una divinidad bondadosa, la idea de la envidia divina, supone forzar el modelo herodoteo.

${ }^{781}$ Cf. Pagel, 1927, pp. 29 y 33.

${ }^{782}$ Seguramente sea esta la causa por la que el excelente artículo de Vignolo Munson, 2001b, sobre el concepto de ảvó $\gamma \kappa \eta$ no parezca llegar a buen puerto. Será con Tucídides con quien el concepto recuperará valor, precisamente por presentar un universo conceptual opuesto al herodoteo.

${ }^{783}$ Cf. Legrand, 1932, p. 147.

${ }^{784}$ Cf. e. g. Legrand, 1932, p. 149 y ss. 


\subsubsection{EL CONCEPTO DE KAEOD. HERÓDOTO Y ATENAS}

La interpretación de la vinculación de Heródoto con Atenas es fundamental para la comprensión de los pormenores de la aparición del género historiográfico. Ya nos hemos referido a la importancia de lo formal para una vinculación del proemio herodoteo con una moral y escenario que poco tienen que ver con la definición habitual del espíritu democrático de la segunda mitad del siglo V a. C., y es precisamente en este marco donde se ha de abordar, una vez más, la vinculación de Heródoto con Atenas.

Fue Eduard Meyer ${ }^{785}$ quien sancionó la imagen de un Heródoto plenamente vinculado con el proyecto democrático radical de Pericles. La postura adquirió rango de verdad asumida con el apoyo de Jacoby, quien, no obstante, planteó la necesidad de rescatar al aristócrata que realmente era Heródoto ${ }^{786}$ que tendría difícil acomodo en el círculo pericleo. En línea con estas dudas, y ya en tiempos más recientes, Thomas indicó que la presencia de un intelectual en Atenas no suponía una ligazón de las ideas de ese autor con el ideario de la ciudad. ${ }^{787}$ Sin embargo, de una u otra manera, este supuesto, con los matices que uno quiera, se mantuvo hasta la aparición del importantísimo artículo de Strasburger, que puso seriamente en duda este aspecto, siguiendo, en último término, los planteamientos propuestos por Jacoby.

La realidad del texto presenta un solo pasaje referido a Pericles en toda la obra (VI 131,2), cuya ambigüedad causó ya problemas a la crítica, ${ }^{788}$ pese a que Jacoby afirmó tajantemente que no se trataba de un pasaje ambiguo, sino de un cumplido por parte de Heródoto a Pericles. ${ }^{789}$ La complejidad del pasaje se acentuó por la rápida extensión de la idea de Jacoby, ${ }^{790}$ si bien las

${ }^{785}$ Meyer, 1899, p. 198.

${ }^{786}$ Cf. Jacoby, 1913, col. 357 y ss.: «H[erodotos] ist auch nicht von vorherein etwa ein überzeugter Demokrat -wie hätte der adelige Mann das sein sollen».

${ }^{787}$ Cf. Thomas, 2000, p. 11 y ss.

${ }^{788}$ Cf. e. g. Legrand, 1932, p. 31.

${ }^{789}$ Cf. Jacoby, 1913, col. 238; igual opinion tiene Ehrenberg, 1954, p. 4.

${ }^{790}$ Cf. How y Wells, 1912 b, p. 119 y ss., si bien no se puede negar que presenta cierto tono escéptico. 
dudas nos parecen fundadas ${ }^{791}$ y el sentido negativo de la expresión claro. ${ }^{792}$ Para ello, baste con aportar el paralelo que supone precisamente un pasaje del Agamenón de Esquilo, en referencia a los peligros y ambigüedades del león: ${ }^{793}$

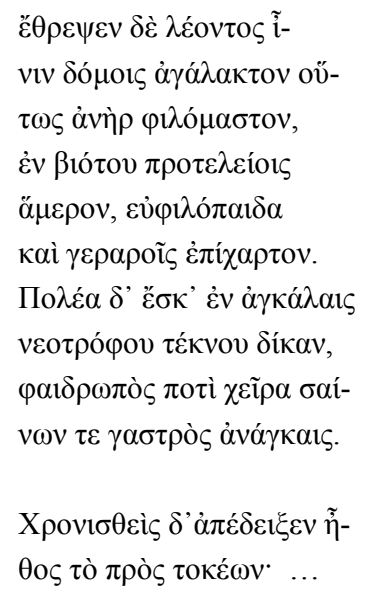

A pesar de lo evidente del pasaje, la realidad es que, como señala el propio Strasburger, es el resto de la propia obra lo que nos permite asegurar propuestas como la arriba indicada, ${ }^{794}$ si bien el artículo de Strasburger es tan rico e importante como poco concluyente. El análisis de los diferentes pasajes por parte de Strasburger nos deja una visión poco entusiasta de la democracia, ${ }^{795}$ al tiempo que los tiranos no obtienen un mal lugar, pero

${ }^{791}$ Así, prudentemente, Strasburger, 1955, p. 3.

${ }^{792}$ Contundente se muestran Fornara, 1971a, p. 53, y Waters, 1985, p. 110. Sin embargo, recientemente Scott, 2005, p. 430, sigue expresando sus dudas acerca del significado de la imagen. La estatua de un león en la tumba de Leónidas, cf. Heródoto, VII 225, 2, tiene, como señaló Clairmont, 1983, p. 118, clara función apotropaica: es un terrible guardián.

${ }^{793}$ Ya Focke, 1927, p. 29, con nota 46, y Gray, 1996, p, 373, alertaron de la importancia de este pasaje para la comprensión de la imagen en Heródoto, cf. infra y Gray, 1996, p. 386 y ss.

${ }^{794}$ La interpretación del sueño relativo a Pericles ha de realizarse de este modo, lo que permite, ahora sí, concluir con Strasburger, 1955, p. 597, que no se trata en absoluto de un panegírico.

${ }^{795}$ Principalmente, a partir del debate constitucional de III 80 y ss., cf. Strasburger, 1955, p. 588, si bien Asheri, Lloyd y Corcella, 2007, p. 473, se muestran menos optimistas a la hora de obtener opiniones de Heródoto de este pasaje. 
tampoco los libertadores de la tiranía, ${ }^{796}$ en unas conclusiones en las que se respira un intento de forzar los datos para otorgar a Heródoto la ansiada imparcialidad del historiador, una imparcialidad que parece esconder una cierta ambigüedad.

Trabajos posteriores han partido de una postura más moderada y por ello han ofrecido conclusiones más fundadas. El clásico trabajo sobre Sófocles y su relación con Pericles de Ehrenberg, salvando algunos detalles concretos y en lo que a nosotros nos interesa, tiene en la observación del autor acerca de la existencia de unas relaciones abiertas -más allá del fundamentalismo político- entre los diferentes personajes de la cultura de la época, unos planteamientos que nos parecen esenciales para la comprensión del mundo en el que se forja el pensamiento herodoteo. ${ }^{797}$

Por su parte, en el examen de la imagen del tirano en la obra herodotea, Gray ha aportado interesantes conclusiones acerca de la imagen del león y su relación profética con el futuro tirano. Casos como el de Cípselo (V 92 $\beta$ 2) son fundamentales para interpretar la imagen del león con un sentido claramente negativo. ${ }^{798}$ En este mismo sentido, la propuesta de Raaflaub de prestar atención a la posición estructural de la anécdota nos parece sumamente sugestiva: la referencia al león se hace como cierre de la narración que se iniciaba con el elogio del papel de los Alcmeónidas en la caída del tirano, lo que pondría en valor la posición de tintes tiránicos de Pericles, presente incluso en Sófocles, ${ }^{799}$ una perspectiva sobre la que ha avanzado con iguales resultados Vignolo Munson. ${ }^{800}$

Forrest ha señalado con buen juicio la importancia de discernir claramente criterios políticos de criterios sociales en la determinación de las relaciones políticas en Atenas: cercanía o amistad entre las grandes figuras de la época no implica un fundamentalismo político que impida relaciones entre personajes de creencias e ideas muy diferentes: la tríada Heródoto amigo de Sófocles y Sófocles amigo de Pericles es una ecuación difícil de mantener, ${ }^{801}$ principalmente porque -y esto es lo importante- Pericles era un

${ }^{796}$ Cf. Strasburger, 1955, p. 594 y ss.

${ }^{797}$ Cf. Ehrenberg, 1954, p. 157 y ss. Cf. también Fohl, 1913, p. 17 y ss.

${ }^{798}$ Cf. Gray, 1996, p. 367.

${ }^{799}$ Cf. Raaflaub, 1987, p. 225, nota 10.

${ }^{800}$ Vignolo Munson, 2001a, p. 52 y ss.

${ }^{801}$ Así, Forrest, 1984, p. 3, nos recuerda la especial relación de Sófocles con ámbitos de influencia de Cimón, e incluso la crítica abierta de Pericles que nos transmite Ion de Quíos, FGrHist, 392 F 6. 
Alcmeónida poco habitual, alejado seguramente de los esquemas propios de la gran familia ateniense ${ }^{802}$ más cercana al ideal del círculo en el que se movía Heródoto: «They were the old guard. It was Athenian polite society, enormously civilised, tremendously cultivated, intellectually way out ahead of its time [...] fundamentally hostile to the new society, to Periklean society $[\ldots] \gg{ }^{803}$

Seguramente, esta cita sea la clave para la comprensión de la postura de Heródoto y del ambiente en el que se desarrolla la obra y el proemio, y además, para la comprensión del nacimiento de una necesidad que llevase a la creación de la historiografía. La obra está claramente vinculada a Atenas, y lo que únicamente es dudoso -como señaló acertadamente Fornara- es el intento de vincular a Heródoto con el ideal pericleo. ${ }^{804}$

Hemos insistido ya de manera repetida en el hecho de que la sociedad ateniense, como cualquier sociedad primitiva, contaba con sus mecanismos para el recuerdo del pasado, lo que invalida propuestas como la de Rösler, que veía en la obra de Heródoto un simple paso para la conservación ${ }^{805}$ de $\tau \grave{\alpha}$ $\gamma \varepsilon v o ́ \mu \varepsilon v \alpha$. En este mismo sentido, creemos necesario recordar una vez más que las divisiones entre etapas etnográficas e historiográficas dentro de la obra herodotea están fuera de lugar en lo que al proemio se refiere y en la interpretación de la finalidad de la obra. ${ }^{806}$

La realidad es que algo ocurrió a mediados del siglo $\mathrm{V}$ a. C. en Atenas en lo que afecta a la conservación del pasado, $\mathrm{y}$, en último término, con el concepto de $\kappa \lambda \varepsilon ́$ os.

La muerte y todo lo que la rodea es un aspecto fundamental para la comprensión de los mecanismos de recuerdo y de construcción del pasado en la Antigüedad. La prohibición por parte de Solón de los enterramientos en exceso suntuosos de la aristocracia ateniense supuso, como bien ha señalado

${ }^{802}$ Cf. Forrest, 1984, p. 4.

${ }^{803}$ Cf. Forrest, 1984, p. 10 y ss.

${ }^{804}$ Cf. Fornara, 1971a, p. 45.

${ }^{805} \mathrm{O}$, incluso, la obtención de beneficios presentes, idea de Corcella, 1984, p. 187 y ss., que encaja bien en nuestros planteamientos. En este mismo sentido, Defradas, 1972, p. 211.

${ }^{806}$ Cf. Bernardette, 1969 , p. 154, quien cree, a nuestro entender de manera errónea, que $\tau \alpha \grave{~ \gamma \varepsilon v o ́ ~} \mu \varepsilon v \alpha$ se refiere a los bárbaros únicamente en los libros I-V. 
Thomas, un paso clave en la creación de impedimentos para la conservación en un modo correcto de los sistemas tradicionales de memoria. ${ }^{807}$

La relación de este hecho con el desarrollo progresivo de la mentalidad e instituciones de la democracia ateniense es una realidad que ni siquiera pasó por alto Cicerón, quien recuerda que el ritual tradicional pasó a ser controlado por la democracia. ${ }^{808}$ De este modo, el recuerdo del pasado desde la perspectiva familiar quedaba limitada a la esfera de la democracia, «so the aristocratic families lost their authority to glorify the family through praise of an individual as his funeral Praise was now in the state's hands». ${ }^{809}$

Teóricamente, el paso de estos mecanismos de memoria desde la esfera aristocrática del clan al seno de las nuevas instituciones democráticas no tiene que provocar la pérdida del pasado y su recuerdo, y realmente no lo hace, dado que la propia ciudad desarrolla mecanismos de recuerdo, pero la caracterización de dichos mecanismos es tal que difícilmente pueden parecer suficientes a ojos de las grandes familias atenienses.

El muy importante trabajo de Jacoby sobre los funerales de Estado en Atenas nos permite acercarnos con mayor seguridad a los orígenes de esta institución ateniense cuyo nacimiento es realmente problemático. ${ }^{810} \mathrm{La}$

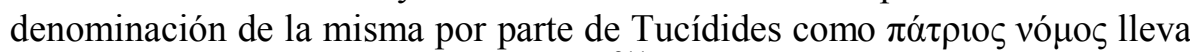
implícita la idea, como Jacoby señala, ${ }^{811}$ de que se trata de una institución ancestral en la ciudad, lo que difícilmente puede adaptarse a su clara ligazón con el sistema democrático. Seguramente, una definición ajustada del mecanismo es cosa imposible, ya que, a nuestro entender, estamos de nuevo ante un caso de superposición de instituciones culturales democráticas sobre

${ }^{807}$ Cf. Thomas, 1989, p. 105. Todo ello ha de entenderse, claro está, dentro de las tensiones generadas entre los modelos aristocráticos de la virtud y los nuevos modelos urbanos, cf. Heinimann, 1980, p. 37 y ss.

${ }^{808}$ Cf. Cicerón, De legibus, II 65: «[...] nec de mortui laude nisi in publicis sepulturis, nec ab alio nisi qui publice ad eam rem constitutus esset dici licebat. Sublata etiam erat celebritas uirorum ac mulierum, quo lamentatio minueretur; <auget $>$ enim luctum concursus hominum». Cf. Thomas, 1989, p. 102.

${ }^{809}$ Cf. Thomas, 1989, p. 104. Cf. también Morris, 1992, p. 144: «[...] in the fifth century the state funerals took away the right of heroic burial, even grom its richiest citizens»».

${ }^{810}$ El reciente trabajo de Bravo, 2006, p. 109 y ss., supone una agresión al texto tucidídeo que nada aporta respecto al estudio de Jacoby. Para las dudas respecto a los datos literarios, cf. Stupperich, 1977, p. 3 y ss.

${ }^{811}$ Cf. Jacoby, 1956b, p. 263. La solución salomónica de proponer un ritual ancestral ampliado después con un discurso causaba ya problemas al propio Jacoby, en lo que podía ser un simple juego retórico, para lo cual cf. p. 265, nota 10. 
las ancestrales, como sucede con la tragedia, lo que causa incongruencias de contenido y falsea además la cronología, que, por interés de la sociedad, adopta el marco más antiguo como el propio de la nueva institución, un hecho que, desde una perspectiva antropológica, es más común de lo que pudiera parecer. ${ }^{812}$

Sea como fuere, la fecha propuesta por el propio Jacoby, un arco temporal situado en la mitad de la década de los años sesenta del siglo $\mathrm{V}$ a. C., basándose en la aparición por este tiempo de la primera lista de caídos, creemos que ha de ser valorada como un dato aproximado, que la crítica más reciente apoya de una u otra manera, ${ }^{813}$ y a ello hemos de sumar un dato interesante, como es la aparición de ese sentimiento de colectividad en los Persas de Esquilo, del año $472,{ }^{814}$ que se verá sancionado, como señala Jacoby, por decreto, de modo que todos los caídos serán recordados como héroes sea cual sea su origen. ${ }^{815}$

A nuestro entender, el origen del discurso fúnebre solo es comprensible en un contexto democrático lo suficientemente avanzado como para haber desarrollado ya los mecanismos que llevan a la consideración de la colectividad como un individuo, dado que -insistimos- creemos que estamos ante la readaptación del sistema empleado en el culto tradicional al individuo muerto por parte de la familia a un contexto de identidad única asimilada a la ciudad. ${ }^{816}$ En este sentido, los estudios de Loraux han sido concluyentes: la ciudad se apropia de los caídos en oposición al sentimiento familiar arcaico. $^{817}$

De este modo, la historia y el recuerdo del pasado empiezan a girar de manera clara en torno a la ciudad como centro que otorga su significado a

${ }^{812}$ Cf. Vansina, 1985 , p. 59 y ss.

${ }^{813}$ Cf. Jacoby, 1956b, p. 268. La inscripción tenida en cuenta para esta datación es IG I ${ }^{2}$ 928. Loraux, 1981, p. 80 y ss., se decanta, simplemente, por la década de los sesenta como fecha aproximada.

${ }^{814}$ La idea de colectividad en el enfrentamiento contra el persa ha sido destacada por Podlecki, 1999, p. 8 y ss.

${ }^{815}$ Cf. Jacoby, 1956, p. 289.

${ }^{816}$ Por otra parte, no está de más señalar que la idea de Porciani, 2001, p. 127 y ss., de considerar el discurso fúnebre como un paso en la evolución del género tiene poco que ver con lo que decimos. En este sentido, la propuesta de Ziolkowski, 1981, p. 48 y ss., quien ve este discurso como sutituto del treno, adquiere especial sentido.

${ }^{817}$ Cf. Loraux, 1981, p. 45. Cf. Thomas, 1989, p. 197: «[...] this public funeral ceremony seems to be the counterpart of the aristocratic funerals curbed by legislation». 
ese pasado: se crea una identidad única, la de los atenienses, que se muestra al exterior, ${ }^{818}$ al tiempo que, como atestiguan los oradores, la tradición familiar empieza también a girar en torno a la ciudad. El interés por poseer un ancestro que hubiera desarrollado una labor democrática es prueba para Rosalind Thomas de la influencia que la nueva idea de recuerdo del pasado tiene sobre los antiguos sistemas de recuerdo, ${ }^{819}$ pero, en lo que nos interesa, da cuenta de la progresiva creación de un nuevo modelo de pensamiento histórico.

La caracterización de este nuevo tipo de memoria es especialmente interesante para la comprensión del pensamiento herodoteo. Frente a las tradiciones familiares, que asocian individuo y acontecimiento de manera solidaria -dado que lo importante es quién realizó la acción, y esta se verifica en un contexto determinado y con un marco ideológico concreto-, los esquemas reformados por la democracia para el recuerdo del pasado hacen imposible el recuerdo de individuos concretos. Así, estos se disuelven en la colectividad de la ciudad, lo que dificulta a cualquier nivel el recuerdo individualizado al modo aristocrático, y además provoca que el contenido de ese recuerdo sea limitadísimo, un contenido hecho a medida de la ciudad, ${ }^{820}$ recogiendo unos valores fundamentales explicitados en una serie de lugares comunes de gran imprecisión histórica, ${ }^{821}$ que terminan por eliminar nombres y referencias concretas. ${ }^{822}$ Los pocos testimonios que tenemos de la oración fúnebre ateniense nos dejan una imagen más o menos clara de la problemática que presenta este tipo de recuerdo, monolítico y que falsea los datos históricos en aras de la creación de un espíritu cívico.

En dicho escenario, poco propicio para el recuerdo histórico aristocrático, en el que incluso se observa la adaptación de este a los nuevos modos democráticos, podría entenderse que la formación del llamado mito de Maratón recogiese en parte el espíritu aristocrático ya perdido. Sin embargo, los estudios de Thomas nos han puesto sobre aviso de que la ecuación que asimila Maratón a espíritu aristocrático y Salamina a espíritu

${ }^{818}$ Cf. Loraux, 1981, p. 102 y ss.

${ }^{819}$ Cf. Thomas, 1989 , p. 108.

${ }^{820}$ Cf. Anderson, 2003, p. 197 y ss., con especial referencia a la reforma de la historia de los tiranicidas y el «extraño» olvido de Clístenes por parte de la nueva democracia.

${ }^{821}$ Cf. Loraux, 1981, p. 158: «Dans l'excurs historique de l'oraison funèbre, on me trouvera donc pas le déroulement d'une continuit, mais la mise en scène répétitive et exemplaire d'une seule et même areté».

${ }^{822}$ Cf. Thomas, 1989, pp. 202 y 214: «the deceased were not commemorated by name». 
democrático es algo difícil de defender cuando se profundiza en este aspecto, ${ }^{823}$ y las afirmaciones de Schrader, ${ }^{824}$ que propone situar el nacimiento de ese mito en el siglo IV a. C., insertándose de este modo en un contexto general de falsificación del pasado, inciden también en la imposibilidad de emplear esa imagen mítica como la idea de pasado del periodo que nos ocupa.

Sin embargo, creemos que la tradición patriótica basada en rumores que Thomas cree advertir de manera subterránea en el siglo V a. C., de carácter abierto y en la que se insertarían incluso narraciones como la del prodigioso sueño de la madre de Pericles, ${ }^{825}$ podrían responder a un modelo no asimilado todavía al escenario público ateniense.

Estos intentos por nuestra parte de buscar un modelo aristocrático de pensamiento se deben al hecho de que el concepto fundamental del proemio

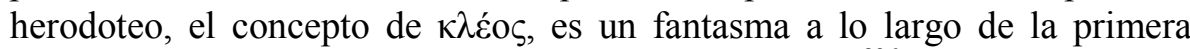
parte del siglo V a. C. Ya hemos efectuado en otra parte ${ }^{826}$ un breve recorrido por los usos del concepto, que ahora vamos a tratar de completar.

El caso de Esquilo es un buen ejemplo de la modificación semántica del

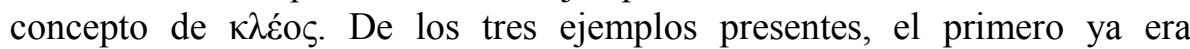
recogido por Wellauer en su léxico bajo el significado de 'rumor', en tanto que los dos restantes responden a una semántica lo suficientemente ambigua como para ser definidos en el mismo léxico como 'fama', 'gloria', si bien creemos que la semántica de al menos uno de ellos responde de manera clara

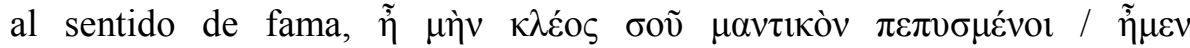
(Agamenón, 1098-1099), pero tiene unos tonos homéricos que lo invalidan como ejemplo.

Más interesante es el caso ya señalado de la Antígona de Sófocles, relacionado con el ámbito que nos ocupa, y que reservaremos por ahora. Es solamente con Eurípides con quien el concepto reaparece con fuerza, pero hemos de atender a la cronología tardía de las obras en las que se encuentra el concepto, lo que de nuevo invalida estos ejemplos para nuestro examen.

En el esclarecimiento de tales conceptos es de gran ayuda la epigrafía, que nos acerca a un panorama de inmensa riqueza que nos ayudará a obtener

${ }^{823}$ Cf. Thomas, 1989, p. 224.

${ }^{824}$ Cf. Schrader, 1981, p. 19 y ss.

${ }^{825}$ Cf. Thomas, 1989, p. 198.

${ }^{826} \mathrm{Cf}$. apartado 3.4 . 
interesantes conclusiones. El riguroso formalismo de la expresión de las listas de caídos en la guerra nos permite asumir como constantes los rasgos que se observan en unos pocos documentos, y, lo que es más importante,

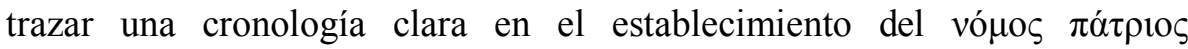
ateniense.

El completo estudio epigráfico y arqueológico de Clairmont nos facilita acercarnos a un universo que tenía como centro de acción el camino que se extendía desde el Dípilon a la Academia. A los lados de esa calle se situaban

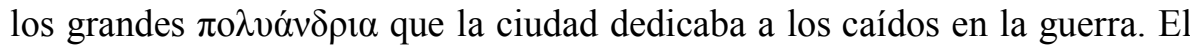
estudio de las evidencias arqueológicas de época arcaica ha permitido observar la inexistencia de una cultura de funeral público a los combatientes caídos, que eran honrados por sus familias. ${ }^{827}$ Es con la llegada del medo cuando la dinámica habitual se transforma, no con la aparición de la democracia. Las honras a los caídos ante el persa presentaban un carácter panhelénico y transcendental que dificultaba tanto la conmemoración individual como, simplemente, el entierro en la urbe. Pronto los acontecimientos del 479 se vieron en este sentido como una unidad que se solapaba con los de Maratón, seguramente de ahí la menor repercusión en estos primeros años de la batalla del 485 , con una perspectiva que pronto superaría el marco de las guerras médicas. El momento de verdadero auge de los $\pi 0 \lambda v o ́ v \delta \rho ı \alpha$ se produce con la hegemonía de Cimón: entre los años 476 y 450 se configura la tradición de honra común a los caídos, ${ }^{828}$ de la mano de un aristócrata, lo que nos hace asumir que estamos, simplemente, ante el

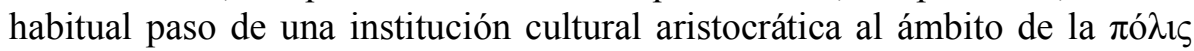
democrática. De esta época es el monumento al general Meandrio, de en torno al 469 , cuyo texto dice: ${ }^{829}$

${ }^{827}$ Cf. Clairmont, 1983, p. 7 y ss.: «The burials described in Homer and the vase paintings depicting some of the core actions are public affairs only in as far as the male community is involved [...] what is lacking in both instances is the involvement of the city as a governamental institution». Cf. además Ecker, 1990, p. 344 y ss., para las connotaciones homéricas de este pensamiento y del sentido de los monumentos. Stupperich, 1977, p. 213 y

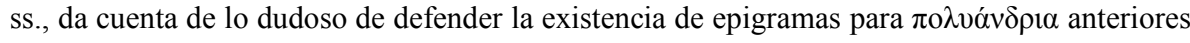
al enfrentameiento con el persa.

${ }^{828}$ Cf. Clairmont, 1983, p. 124 y ss. Merrit y Wade-Gery, 1950, p. 109 y ss. proponían como fecha para el primer funeral público el 465 a. C. Cf. también Strasburger, 1968b, p. 503.

${ }^{829}$ Clairmont, 1983, p. 154 (= MDAI (a) 1926, 26-28, $\mathrm{n}^{\circ} 1$ ). 


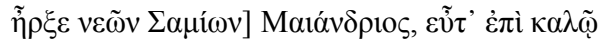

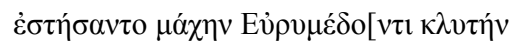

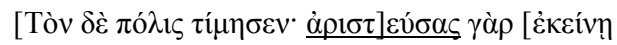

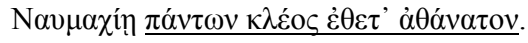

Este epígrafe individual, descubierto en Samos (recordemos la importancia del lugar para Heródoto), nos muestra cómo en la época cimoniana el ideal panhelénico aristocrático estaba aún vigente. El concepto

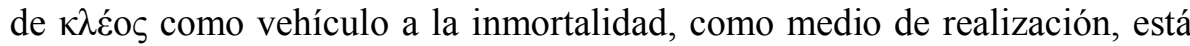
plenamente operativo, en el modo en que precisamente lo empleará Heródoto.

Los caprichos del destino nos han privado de textos que nos sirvan para ilustrar de manera clara la situación del momento en Atenas, pero el epígrafe recogido como IG I $\mathrm{I}^{3} 503 / 504$, posterior al 480 , lo que nos sitúa como pronto a mediados de la década de los setenta, dice: ${ }^{830}$

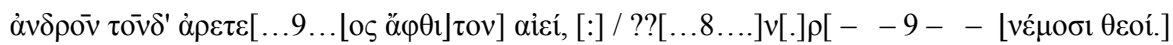

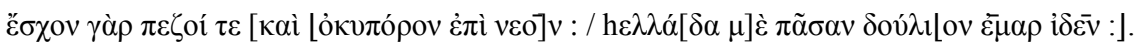

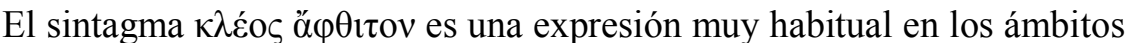
tradicionales aristocráticos, ${ }^{831}$ lo que seguramente conceda valor a esta reconstrucción. Ello nos permite apostar, con las debidas reservas, por la extensión del modelo aristocrático a los ambientes democráticos en una coexistencia de registros no segura pero al menos posible: por lo que

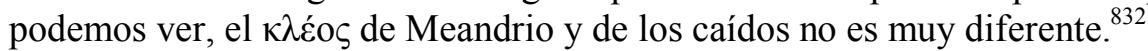

Como señala Clairmont, es con el inicio del periodo pericleo con el que la estructura tímidamente observada en el periodo de hegemonía de Cimón

\footnotetext{
${ }^{830}$ Como indica Maltomini, 2006, p. 103 y ss., este documento no pudo ser empleado por Jacoby en su análisis, pero tampoco implica, en lo que a las tesis del estudioso se refiere, novedad alguna.

${ }^{831}$ Cf. e. g. Homero, Ilíada, Ix 413; Íbico, 1, 47; Teognis, 246-247; Safo, 44, 4. Cf. además Ecker, 1990, p. 190 y ss.

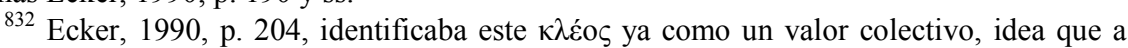
nuestro entender, ha de ser puesta en duda; cf. para ello Simónides PMG 26, que demuestra

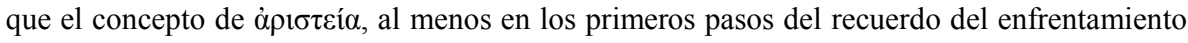
con el persa, era una realidad.
} 
obtiene su sanción: los monumentos se multiplican por los muchos enfrentamientos sostenidos por la ciudad, y las estructuras y fórmulas empleadas en la honra a los caídos terminan por fraguar ${ }^{833}$ entre los años 449 y 431, con una doble particularidad de especial interés.

Señala Clairmont ${ }^{834}$ que la tendencia observada en el periodo anterior de honrar a los caídos en las guerras con el persa se acentúa, debido, en nuestra opinión, a la cercanía temporal que hacía que los partícipes en la guerra estuvieran aún vivos y fueran testigos de primera mano. Ello tiene como consecuencia una cierta fosilización y -añadimos nosotros- la fácil utilización de ese pasado, como señaló Loraux, demostrada por ser precisamente solo a estos caídos a los que se tributaban este tipo de homenajes. La modificación de ese pasado fue, pues, pronto una realidad.

La epigrafía ha sido más fructífera en este periodo que en el anterior, y nos ha permitido observar que, además del encabezamiento (con un deíctico y una fórmula estereotipada $)^{835}$ y de los nombres de los caídos por tribus sin referencia al patronímico, ${ }^{836}$ el monumento se cerraba con un no menos formalizado epigrama que es realmente interesante, dado que nos permite observar la segunda gran transformación del periodo.

Cronológicamente, los dos primeros epigramas datan del año $447 . \mathrm{El}$ inventariado como IG I ${ }^{3} 1162$, perteneciente a un $\pi 0 \lambda v \alpha ́ v \delta \rho 1 \alpha$ ateniense, dice:

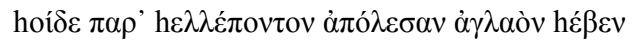

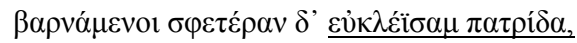

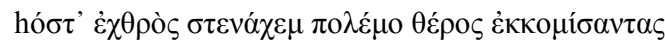

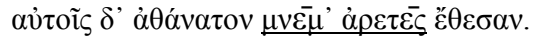

A este hemos de sumar otro posterior, de en torno al año 432, IG I3 1179 :

${ }^{833}$ Cf. Clairmont, 1983, p. 158 y ss.

834 Cf. Clairmont, 1983, p. 158: «The almost complete lack of commemorative monuments and votive offerings in this as in the previous period forms a strong contrast to the period of the Persian Wars. And rather than celebrating contemporary events dedications made in this (449-431) and the previous period hark back to the decade from 490 to 480 ».

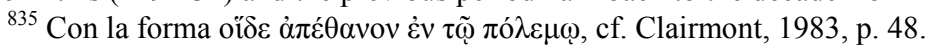

${ }^{836}$ A pesar de lo que indica Pausanias, como bien refiere Clairmont, 1983, p. 30. Solo aparecen en Mantinea y Corinto, cf. Clairmont, 1983, p. 52. 


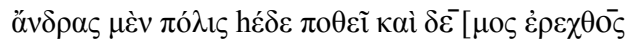

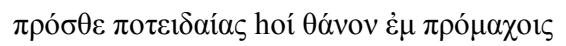

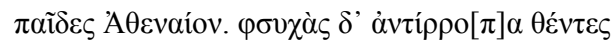

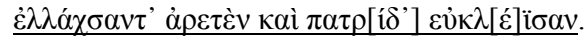

Más allá de las semejanzas con los más conocidos epigramas funerarios griegos ${ }^{837}$ es de destacar la gran diferencia conceptual existente entre estos epigramas y el ideario presente en Simónides, que después veremos.

La idea recogida en estos epigramas supone una reorganización del sistema moral de à que observamos en época cimoniana. La àpetí es el objetivo de los ciudadanos, no un medio, como era en el modelo tradicional, en tanto que el objetivo es dotar de $\kappa \lambda \varepsilon ́$ ó a la ciudad, lo que supone una clara modificación de un sistema que estaba todavía vigente. ${ }^{838}$

Se constata, así, el desplazamiento del modelo de realización personal aristocrático del ámbito ateniense, transformado en un sistema de servicio exclusivo a la ciudad: ${ }^{839}$ imágenes como la ofrecida por la narración de Solón y Creso sobre Telo son ya pasado. ${ }^{840}$

Pero aún hemos de ir más allá: la aparición de manera contundente de este modelo en un arco temporal que asegura que no es un hecho aislado nos ha de hacer preguntarnos por el modo en que se rendirían esos homenajes y conmemoraciones a los muertos en las guerras médicas, $y$, apoyados en estas evidencias, así como en la naturaleza antes señalada de la oración fúnebre, hemos de pensar que serían objeto de la misma distorsión que presentan estos epígrafes.

La realidad de los hechos presentados por estos datos parecen extenderse hasta finales del siglo $\mathrm{V}$ a. C., momento en el que se empieza a observar la aparición de enterramientos individuales privados en el espacio anteriormente reservado a los $\pi 0 \lambda v o ́$ vo $\rho 1 \alpha,{ }^{841}$ lo que, habida cuenta de los

\footnotetext{
${ }^{837}$ Para un examen de la caracterización de estos epigramas, cf. Stupperich, 1977, p. 12 y ss.

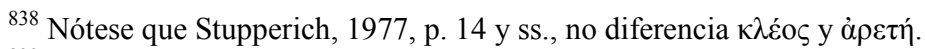

${ }^{839}$ Cf. Stupperich, 1977 , p. 214, quien recuerda que los epigramas tienen poco de democráticos, al menos en origen.

${ }^{840}$ Como reconoce Clairmont, 1983, p. 8, quien señala el carácter heroico del funeral de Telo.

${ }^{841}$ Cf. Clairmont, 1983, p. 40. 
conflictos desarrollados en estas fechas en el ámbito político, permite concluir la relativa vitalidad del modelo y su vinculación concreta con el modelo democrático.

Todos estos datos adelantan un vacío del término que, en líneas generales, se corresponde con la aparición y máximo desarrollo de ese concepto de memoria histórica democrática, e interrumpe un ciclo iniciado con los poemas de Simónides sobre las guerras con el persa.

La importancia de este autor en lo que nos ocupa reside en que, precisamente, se sitúa en el marco aproximadamente anterior al que estamos tratando en el recuerdo de las guerras médicas, como acertadamente indicó Wilamowitz. ${ }^{842}$

Como ya señalamos, la importancia del concepto de $\kappa \lambda \dot{\varepsilon}$ o $\zeta$ en la obra de este autor es más que reseñable y nos permite además vincular el concepto al ámbito aristocrático en el que se mueve Simónides. El ciclo de poemas simonideo y su naturaleza panhelénica hacen que difícilmente no se piense en el contexto antes indicado de la crisis causada por la radicalización de la democracia en tiempos de Efialtes y el papel que desempeñó Cimón y la alianza con Esparta. A los caídos en las Termópilas se refiere el poema más

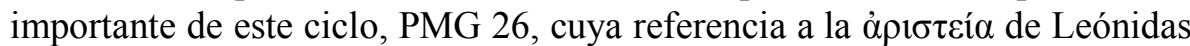
se hace en los siguientes términos: ${ }^{843}$

$\ldots \mu \alpha \rho \tau \nu \rho \varepsilon \tilde{i} \delta \dot{\varepsilon} \kappa \alpha i ̀ ~ \Lambda \varepsilon \omega v i ́ \delta \alpha \varsigma$,

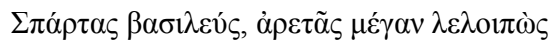

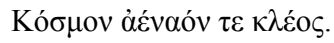

Seguramente sea este el ejemplo más conocido del ciclo al que en parte nos referimos en el análisis formal, pero no el único. La colección de epigramas relativos a las guerras médicas, de cuya exacta adscripción a Simónides en ocasiones se duda, nos ofrece cuatro ejemplos más, en

${ }^{842}$ Cf. Wilamowitz, 1985b, p. 137: «Pindar gehört zu Bakchylides und Aischylos, Simonides zu Anakreon, Ibykos zu dem Lokrer Stesichoros».

${ }^{843}$ Nótese además que el propio poema pone de relieve la valía personal de Leónidas, sea cual sea el valor de кaí, para lo cual cf. Degani y Burzacchini, 1980, p. 321. Sea este intensivo o equivalente al etiam latino, los tres versos finales se oponen a los seis primeros, dedicados a todos los caídos. 
ocasiones referidos a individuos concretos. ${ }^{844}$ Más allá de los poemas de Simónides relativos al enfrentamiento con el persa, hallamos el concepto además en poemas no pertenecientes al ciclo de las guerras en una época no excesivamente distante de la que nos ocupa, en los poemas referidos al tiranicidio en Atenas. ${ }^{845}$

Estas referencias concretas nos abren el camino hacia una imagen aristocrática de la sociedad y del pensamiento que se adapta bien a todo lo hasta ahora propuesto. No hemos de olvidar que el propio Simónides, en los fragmentos de sus trenos, nos presenta referencias claras a conceptos que hemos visto en la obra herodotea. Así, el fragmento PMG 16 es seguramente el equivalente en verso del discurso de Solón a Creso: ${ }^{846}$

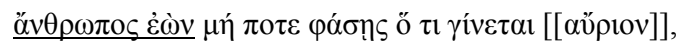

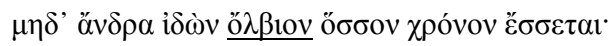

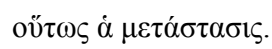

La importancia de la aparición en Simónides no solo de un concepto de pasado histórico de tintes aristocráticos -el fragmento pertenece al treno por los Escópadas-, en cierta manera cercanos a los presentes en Heródoto, sino también del mundo espiritual del que se nutre Heródoto para la configuración de su universo de ideas nos lleva a confirmar, teniendo presente lo indicado en el análisis formal del proemio, la ligazón de éste con el mundo simonideo. ${ }^{847}$ Todo ello nos reafirma en la idea de que el desarrollo de la moral democrática comenzó a ensombrecer ese mundo que hasta entonces había sido el sustento ideológico de las instituciones atenienses.

${ }^{844}$ Cf. PMG VI, VII, IX, XX. Cf. además el epigrama LXII, no perteneciente al ciclo de los enfrentamientos con el persa, sino a un ámbito bélico siracusano, para lo cual cf. Bergk, 1882, p. 470.

${ }^{845}$ Cf. PMG 896. Ya Page en su edición de los epigramas, p. 8, alertaba en referencia al poema I de Simónides sobre la posible repetición de un modelo anterior en este poema, lo que sin duda alguna es verdad.

${ }^{846}$ Cf. Weir Smyth, 1899, p. 320, para la idea del paralelo entre la escena de Solón y Creso y este fragmento. Cf. además Buchholz, 1909, p. 57, para paralelos en Teognis, 159, Eurípides, 553 Nauck. Cf. además Wehrli, 1931, p. 3.

${ }^{847} \mathrm{La}$ naturaleza, si se quiere, panhelénica de Simónides queda refrendada por los abundantes testimonios que la propia Antigüedad nos brinda sobre sus relaciones con prácticamente todos los centros de importancia de la época. Cf. Geffcken, 1927, col. 187 y ss. 
El Marmor Parium nos confirma la muerte de un prácticamente centenario Simónides en el año 468 a. C., lo que, sumado a otros datos, hace que viviera el enfrentamiento con el persa a una edad muy avanzada. ${ }^{848} \mathrm{La}$ comprensión que del suceso tuvo Simónides, entendiendo siempre que es simplemente un representante de una moral generalizada, es seguramente la primera que los griegos tuvieron tras el conflicto, y por ello responde a la readaptación continuista de los patrones existentes ya antes de las guerras con el persa.

Probablemente, la mejor prueba de lo que tratamos de exponer sea de nuevo el encuentro entre Solón y Creso. Hellmann advirtió que en la historia de Telo e incluso en la de Cleobis y Bitón hallamos la imagen del $\pi$ o $\lambda i ́ \tau \eta \varsigma^{849}$ en un sentido tradicional. Este aspecto nos pone sobre aviso de una cuestión de especial interés en lo que se refiere a la relación de Heródoto con Atenas. El ejemplo de Simónides nos recuerda que, salvando detalles, la moral aristocrática anterior al auge de la Atenas posterior a las guerras médicas no era muy diferente de la existente en otros ámbitos de Grecia, lo que seguramente favorecerería las relaciones no solo políticas, sino culturales, en toda Grecia. La llegada de la democracia a Atenas supuso un doble proceso en el que se propició, por una parte, gracias a la consabida política imperialista, una extensión del ideario, y, por otra parte, un aislamiento de la misma que en cierta manera nos resulta inabordable debido a la posición central que ocupa la propia cultura ateniense en el mundo griego.

Centrándonos ya en la obra herodotea, la importancia que adquieren los

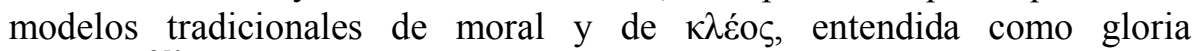
personal, ${ }^{850}$ queda demostrada cuando observamos la aparición de $\grave{\alpha} \rho\rceil \tau \varepsilon i \alpha^{851}$ al modo tradicional de manera sistemática tras las batallas, salvo en el caso de Maratón, para lo que basta con recordar lo antes indicado.

Este examen de los nombres ${ }^{852}$ es, sin duda, lo más opuesto que puede haber a la memoria de tono democrático que en el momento de la redacción de la obra herodotea debía triunfar en Atenas. El recuerdo de genealogías completas $^{853}$ que transcienden el ámbito ateniense -como la de los reyes

${ }^{848}$ Cf. Wilamowitz, 1985b, p. 137 y ss. Geffcken, 1927, col. 186.

${ }^{849}$ Cf. Hellmann, 1934, p. 40 y ss.

${ }^{850}$ Cf. Degani y Burzacchini, 1980, p. 322, para Simónides PMG 22, verso 9.

${ }^{851}$ Cf. Legrand, 1932, p. 55 y ss.

${ }^{852}$ Cf. Heródoto, VII 226 y ss.; VIII 93, y IX 71-89, la más extensa y minuciosa de las tres.

${ }^{853}$ La supuesta invención de estas genealogías por parte de Heródoto señalada por Fehling, 1989, p. 181 y ss., responde a la imposición a la obra herodotea de criterios de 
espartanos, ${ }^{854}$ con el caso paradigmático de Leónidas, definido por Macan como el non plus ultra de los patronímicos, y que constituye seguramente el mayor honor tributado en la obra, ${ }^{855}$ seguido de cerca por el tributado a Leotíquidas $-{ }^{856}$ tiene unas implicaciones que van más allá de la momentánea referencia al personaje y su pasado. ${ }^{857}$ Ello es así porque las relaciones existentes entre las diferentes familias atenienses ${ }^{858}$ y Esparta hacen que esa genealogía sea solo una de las caras del sistema de referencia cronológico, que se completaría con el miembro de cada familia que se adaptaría a ese determinado antepasado espartano.

Immerwahr indicó de manera clara la reforma que también sufre el

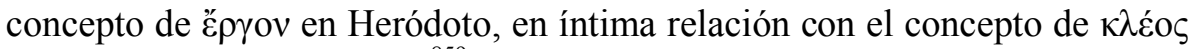
y el recuerdo del pasado. ${ }^{859}$ De esta manera, los ह̌ $\rho \gamma \alpha$ señalados en el proemio son el vehículo del que se vale Heródoto para alcanzar el recuerdo de ese pasado, en una caracterización física que engloba tanto a acciones como a elementos materiales, ${ }^{860}$ a diferencia de lo que ocurría en Homero, que hace que el hogar de estas ideas deba buscarse en un escenario muy diferente: «Basically, this conception is a phenomenon of the period Herodotus writes about, especially the period of the Persian Wars, and accordingly the closest parallels occur in Pindar and in inscriptions of the first half of the fifth century». ${ }^{861}$ De nuevo hemos de recordar lo indicado en el análisis formal del proemio para valorar la idea de Immerwahr de situar el origen remoto de estas ideas en el mundo funerario, ${ }^{862}$ lo que es un argumento más para la valoración de la estructura del proemio, originado

análisis histórico moderno, y no afecta tanto a la «verdad» de lo que dice Heródoto como a la comprensión de la significación de esas genealogías.

${ }^{854} \mathrm{Y}$ que muy difícilmente justificarían una postura proateniense radical, como señaló Schadewaldt, 1982, p. 151 y ss. El propio Legrand, 1932, p. 27, ya alertó de lo adaptable de la narración herodotea a diferentes auditorios.

${ }^{855}$ Cf. Heródoto, VII 204; Cf. Macan, 1973a, p. 304 y ss.

${ }^{856}$ Cf. Heródoto, VIII 131. La idea de Macan, cf. nota anterior y Macan, 1973b, p. 560 y ss. de defender estas genealogías como un estrato antiguo de la composición herodotea parece fácilmente solucionable si atendemos al contexto y al momento de clímax de las escenas que nos ocupan.

${ }^{857}$ En este sentido, las indicaciones de Stupperich, 1977, p. 216 y ss., respecto a la ausencia de patronímico en los $\pi \mathrm{o} \lambda v o ́ v \delta \rho 1 \alpha$ cobran una especial significación.

${ }^{858}$ Cf. el breve examen de Hart, 1982, p. 1 y ss.

${ }^{859}$ Cf. Immerwahr, 1960, p. 269 y ss.

${ }^{860}$ Y no solo res gestae, como señalaba Canfora, 1972, p. 74.

${ }^{861}$ Cf. Immerwahr, 1960, p. 272.

${ }^{862}$ Cf. Immerwahr, 1960, p. 273. 
todo ello en un mundo en el que Simónides y Píndaro cantaban un modelo

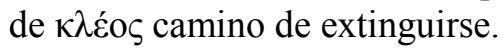

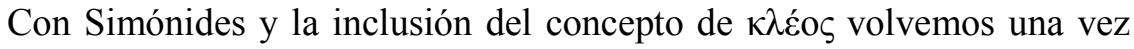
más al modelo soloniano que antes estudiamos; el paso de las guerras

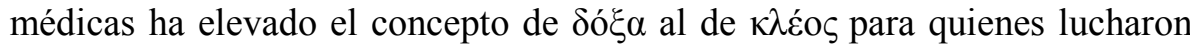
contra el invasor, incluso en las implicaciones formales de las composiciones literarias, pero el avance de la democracia supuso la caída de todo ello, y es precisamente esto ante lo que reacciona Heródoto.

Con estas observaciones tenemos la última de las grandes cuestiones que afectan a la interpretación de los condicionantes generales de la obra herodotea examinada. Nada hay en el proemio herodoteo que nos hable de pasos racionales hacia el $\lambda$ ó $\gamma o \varsigma$, ni de afanes de rescatar del olvido el pasado sin más.

La ubicación de Heródoto en el universo conceptual jonio es algo que fue planteado ya en el trabajo de Schwartz acerca de la supuesta sofística jonia que, entre otros aspectos, permitía justificar el rapto de las mujeres como un aspecto nacido en dicho ámbito, ${ }^{863} \mathrm{y}$ fue esta una idea retomada $\mathrm{y}$ desechada sin que parezca tener hoy mayores repercusiones. Nestle en un artículo de $1911^{864}$ devolvió de manera clara a Heródoto al ambiente sofístico ateniense, pero a comienzos de los años veinte Howald recuperó la idea de Schwartz de manera más fundamentada, alegando que las ideas políticas de Heródoto y su formación literaria no encajaban bien en la Atenas de su época. ${ }^{865}$ Obviamente, estas ideas solo pueden ser defendidas con una imagen en exceso simplista de la vida política y cultural de Atenas.

A pesar de esta apreciación errónea, es interesante destacar las ideas de Howald acerca de la procedencia oriental, o al menos no ateniense, de elementos como narraciones o fábulas ${ }^{866}$ lo que le permite justificar la naturaleza jonia de la obra herodotea, ${ }^{867}$ si bien por nuestra parte hemos de señalar que la facilidad que tienen esos elementos para viajar y readaptarse es enorme, y parece innegable asignar su conocimiento a la formación inicial del propio Heródoto, quien readaptaría posteriormente esos elementos en su

${ }^{863}$ Cf. Schwartz, 1891, p. 9 y ss.

${ }^{864}$ Cf. Nestle, 1911, p. 244 y ss.

${ }^{865}$ Cf. Howald, 1923, p. 123.

${ }^{866}$ Cf. Howald, 1923, p. 125 y ss.

${ }^{867}$ Cf. Howald, 1923, p. 127: «Nirgends so zu Hause war wie in Ionien». 
obra, en lo que será una constante en los muchos historiadores desplazados de su lugar de origen.

Lo que nos interesa es la adscripción ideológica de la obra y el lugar en el que apareció, y la necesidad que se vio resuelta con la redacción de la misma. En este sentido, la obra herodotea y su proemio responden a un ambiente plenamente conocido por los fragmentos conservados de los denominados presocráticos y por la nunca suficientemente valorada imagen que nos ofrece Platón del ambiente cultural del siglo V a. C. en Atenas. Decimos Atenas porque es innegable la importancia que la ciudad desempeñaba por este tiempo en el mundo griego y en su desarrollo intelectual, y, si bien todo apunta a pensar en que la itinerancia en la vida de Heródoto fue una constante durante sus famosos viajes -e incluso no sería descabellado pensar que lo fue también después, a pesar de que las noticias que poseemos se reducen a Turios-, seguramente es Atenas el lugar clave para el nacimiento de la idea de redactar una obra en los términos que

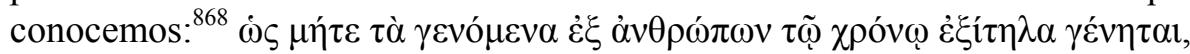

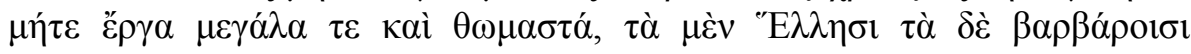

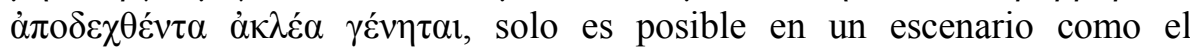
ateniense, en el que los modelos tradicionales de recuerdo del pasado habían quebrado.

Hemos de reconocer que nuestro escaso conocimiento de la actividad intelectual y cultural en otros lugares de Grecia es seguramente la causa de que nos centremos en Atenas, dado que el imperio fue una realidad temprana, y con él, la extensión de la democracia y sus consecuencias. A pesar de ello, parece fácil asumir que la combinación de abandono del pasado y de la existencia de este en términos tan gloriosos como el de las guerras médicas solo era algo presente en Atenas.

Es probable que los movimientos políticos de oposición a la democracia vividos en toda Grecia en el último cuarto de siglo deban ser interpretados como un movimiento de oposición contra la Atenas imperialista, pero a primera vista parece innegable que, si hemos de buscar un grupo social que auspiciara esas revueltas, no ha de ser otro que el que nos ocupa.

868 Sobre la idea de posibles redacciones anteriores de secciones, o de trabajos específicos en determinados $\lambda$ ó nada podemos saber de ellos, pero es innegable que la imagen que tenemos de la obra, en virtud de la interpretación del proemio que hemos presentado, es absolutamente unitaria. 
La existencia de clases elevadas, no exclusivamente las más grandes familias, sino el grueso de la clase social acomodada -fácilmente reconocible por el desempeño de las labores al frente de la democracia ${ }^{869}$ e instalada desde hacía tiempo en Atenas- ${ }^{8}{ }^{870}$ molestas con el sistema político, es una evidencia ya de antaño reconocida por la crítica, pero lo que no ha sido admitido con tanta facilidad es la existencia necesaria de una oposición cultural entre esas clases elevadas y la cultura institucional democrática que, por otra parte, auspiciaban económicamente.

La gran tradición cultural y literaria aristocrática existente de manera general en Grecia y en particular en Atenas se vio reducida a ambientes simposiales, en los que los temas habituales de esta clase se veían cultivados. Desde los escolios sobre los tiranicidas a temas elegiacos, pasando por lo más avanzado de la filosofía, en gran manera heredera, como hemos visto, de la tradición poética arcaica, tenían una gran vitalidad fuera de los círculos urbanos y en clara oposición a ellos. ${ }^{871}$ Este tipo de literatura no solo representaba una manera de pensar o de hacer arte, sino que comprendía toda una teoría y cultura de un proyecto de clase política que poco a poco desbordaba los escasos márgenes en que se movía el grupo más o menos cerrado de las élites griegas, no sólo atenienses, y terminaba por impregnar la cultura estatal - no en vano estos círculos pagaban y elegían a los poetas trágicos y cómicos-, como ejemplifica el caso de Sófocles y, de manera más clara, el último Eurípides. Obviamente, el panorama que los datos nos

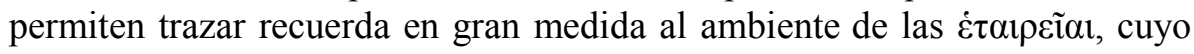

${ }^{869}$ Idea que según Beloch, 1914a, p. 162, hemos de extender al resto de las democracias.

${ }^{870}$ Cf. Beloch, 1914b, p. 131, lo que sin duda alguna facilitaría esos contactos. La posibilidad de reconstruir los diferentes partidos políticos de época tiránica y anterior a ésta, y de tratar de identificar sus relaciones con el marco que nos ocupa parece remota, pero es evidente que junto a las grandes familias que encabezaron la reforma democrática apoyadas en las nuevas fortunas del sector de la costa, se ha de situar el grupo de aristócratas encabezados por Iságoras, que representan la más rancia aristocracia ática. Como señala el propio Beloch, 1914a, p. 164, pronto los sectores no aristocráticos nacidos del comercio se sumarían al ideal aristocrático tradicional conforme avanzaba el proyecto democrático, de modo que la ampliación de la distancia entre los moderados y los radicales tuvo como consecuencia el reagrupamiento de estos sectores bajo la égida de las grandes familias y sus ideales.

${ }^{871}$ Cf. Calhoun, 1913, p. 24 y ss. Señala además el autor, p. 26, con referencias, que estas reuniones se realizaban en casas privadas de manera más o menos discreta, lo que incide en la idea examinada en la parte de análisis formal del proemio, en relación con las anécdotas acerca de las lecturas de Protágoras, tan cercano a Heródoto en su proemio, en casa de Eurípides. 
origen parece vinculado a instituciones de gran antigüedad ligadas a ambientes bélicos, ${ }^{872}$ y que están presentes en Atenas de manera continuada y activa a lo largo de finales del siglo VI y todo el V a. C. Dentro del complicado mundo de las ideas políticas y el juego de poder en el siglo $\mathrm{V}$, lo único que parece seguro, al menos por la naturaleza de las ideas defendidas, su elevación, y la relación segura con personajes como Sófocles, es que, aun no arriesgándonos a hablar de la existencia de un grupo en el que Heródoto fuera invitado, todo parece apuntar a que la línea conservadora moderada, la única que goza de una continuidad y un prestigio claro a lo largo de todo el siglo V, es el mejor escenario para estas ideas. ${ }^{873}$ Ideas que son, a pesar de todo, moderadas, $\mathrm{y}$, lo más importante, de gran continuidad y profundidad, alejadas de todo partisanismo $\mathrm{y}$, en último término, de una actividad agresiva, lo que reduciría la imagen de grupo cerrado, lejos de juramentos y de un secretismo solo necesario en conspiraciones. ${ }^{874} \mathrm{La}$ imagen de Heródoto y Sófocles es lo suficientemente moderada como para obtener respeto en cualquier ámbito de la sociedad ateniense, precisamente el sector del que hablamos, casi mimetizado en el continuo vaivén de la política ateniense. En definitiva, un grupo conformado por personajes lo bastante prestigiosos y poderosos como para no incurrir ni en conspiraciones ni en tretas judiciales, pero sí para asumir responsabilidades en el poder cuando fuese necesario, como ocurrió con Sófocles.

Pero limitar la vinculación de Heródoto al ambiente ateniense es, como decimos, simplificar el escenario cultural de la Grecia del momento. La naturaleza viajera de estos personajes, presente no solo en el propio Heródoto incluso después de sus grandes viajes, sino después de su llegada a Atenas, es una constante que observamos tanto en los sofistas, como incluso en los propios trágicos, que frecuentaban las cortes de los grandes personajes de la época, lo que nos recuerda que las relaciones de antiguo existentes entre estas clases no habían caído en el olvido. Ello seguramente facilitaría el movimiento de estos personajes, y también de sus obras, que en el caso de

${ }^{872}$ Cf. Calhoun, 1913, p. 10 y ss.

${ }^{873}$ Cf. Calhoun, 1913, p. 19; Busolt, 1904, p. 314, en referencia a Cimón: «Die Lakonerfreundschaft und das Parteiinteresse Kimons und seiner Hetairie ging nicht so weit, wie die anderer oligarchischer Hetairien, welche mit dem Feinde konspirierten und wohl dessen Sieg wünschen», lo que nos recuerda además que contactos con Esparta no es sinónimo de extremismo.

${ }^{874}$ Cf. Calhoun, 1913 , p. 34 y ss. 
Heródoto tendría seguramente buena acogida en cualquier ambiente aristocrático. $^{875}$

En el aspecto cronológico, es realmente complicado aventurar una fecha exacta para la obra. En otro lugar adelantamos algunos datos a los que ahora hemos de sumar lo que la antropología y la evolución del sistema cultural ateniense nos permiten aventurar. Señalábamos antes la importancia de las Euménides del año 458, y ahora hemos de añadir un hecho que ha recibido

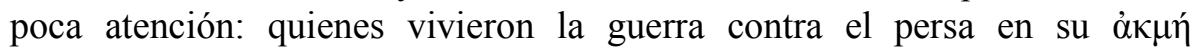
probablemente habrían fallecido en esos años, lo que elimina la generación implicada en el conflicto, como ejemplifica, por otra parte, el propio Esquilo, que luchó en Salamina y murió en el año 456.

Sabemos por los estudios de Vansina y Thomas que la memoria en estos casos puede ser realmente frágil: quienes contaran con una edad suficiente como para vivir con conciencia los acontecimientos de aquellos años extenderían sus días aproximadamente hasta el año 435, que se corresponde, a grandes rasgos, con el límite propuesto habitualmente por la crítica para la obra, y además se ajusta bien con la fecha propuesta por Jacoby y Loraux para la institución de la oración fúnebre en Atenas. Tratar de descender a detalles concretos parece complicado por lo poco fiable de los datos estudiados en el examen formal y lo flexible de lo que ahora nos ocupa, pero, habida cuenta de que sería a finales de los años cincuenta y comienzos de los cuarenta cuando se crearía en Atenas una reacción contra el fenómeno democrático debido al fallo de los sistemas tradicionales de recuerdo del pasado, y que Heródoto no lo desarrolla, sino que simplemente proporciona una estructura intelectual en respuesta, nos situamos fácilmente entre los años 447 y 443 , propuestos para la estancia de Heródoto en Atenas, donde parece necesario que se fraguase el pensamiento de su obra y apareciese la necesidad que llevó al de Halicarnaso a redactarla, quizá ya en los años

${ }^{875}$ Lo que, por otra parte, daría solución al problema del tono poco ateniense de determinados pasajes, cf. Jacoby, 1913, col. 350. Cf. además Focke, 1927, p. 32, en este mismo sentido. 
treinta. ${ }^{876}$ Desde esta fecha aproximada, las redacciones posibles, las ampliaciones y las variaciones pueden extenderse hasta el final de su vida. ${ }^{877}$

\subsection{La finalidad de la obra herodotea}

Seguramente, no haya nada más difícil que señalar el porqué de la labor literaria de un autor, y no parece además que la respuesta a esta pregunta facilite en gran medida la comprensión de su obra, pero, cuando se trata del iniciador de un género, el beneficio derivado de ese esfuerzo es, en el menor de los casos, un acercamiento al origen mismo de dicho género.

Responder simplemente, como ha hecho a menudo la crítica, que la aparición de la obra herodotea se debía a la necesidad sentida por su autor de conservar el recuerdo del pasado es asumir que los mecanismos de las sociedades tradicionales habían dejado de funcionar en la Grecia del momento, cosa que los avances en la antropología y en el análisis literario no permiten afirmar con tanta rotundidad.

El análisis de los rasgos formales del proemio, su ubicación en un ambiente ajeno a lo colectivo, así como la poca vinculación demostrada por Heródoto con la ciudad democrática nos llevan a dibujar un panorama que permanecerá latente a lo largo de los siglos siguientes. Heródoto escribe su historia desde una perspectiva panhelénica, simplemente porque los mecanismos ancestrales de realización personal de la aristocracia eran en cierta manera comunes a toda Grecia, como reacción a la deriva que presentaba la memoria del pasado en la Atenas que tuvo oportunidad de visitar en la década de los cuarenta. Los profundos cambios políticos y sociales escondían la negación o simplemente la transformación de un modo de entender la realidad propio de las clases aristocráticas que, en lo que se refiere al recuerdo del pasado, en la etapa moderada dirigida por Cimón, y

${ }^{876}$ Como señalaba Fowler, 2003, p. 307. En todo caso, asumir sin más que la estancia en Atenas y la influencia sofística son datos interdependientes de la cronología, como hace Dihle, 1962, p. 213, es, a nuestro entender, complicado.

${ }^{877}$ Nótese además que esta cronología coincide con la propuesta por Heinimann, 1980, p.

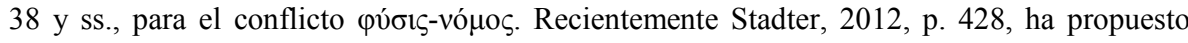
como fecha límite el 428 a. C., si bien es difícil, como decimos, fijar un límite inferior claro. 
seguramente tras la estela de ese pasado glorioso de las guerras médicas, había sido readaptado como moral democrática, de una manera moderada que, con la llegada de la democracia radical, perdería su sentido original.

Entender que la historiografía suponía para Heródoto el mismo ejercicio existencial que podía suponer para un Mimnermo cantar el irreversible destino humano es el primer paso para asumir la comprensión del modelo herodoteo. Hemos señalado lo mucho de tradicional, la suma de torrentes de cuño arcaico que se dan cita en el proemio de la obra herodotea, pero para su perfecta ubicación en el mundo del siglo $\mathrm{V}$ a. $\mathrm{C}$. hemos de ir un poco más allá. Ya no vale la simple vuelta a las ideas y los modos de pensar del pasado; la nueva realidad social y política de Grecia, con un panatenismo que nos ciega incluso a los modernos, imponía una reestructuración del pensamiento que diera cabida a los nuevos horizontes del universo de los griegos, que se adaptara a las nuevas fronteras físicas y morales que definía un mundo conocido de antaño pero que en el conflicto con el persa interaccionaba por primera vez de manera contundente con los griegos. La victoria, por inesperada, encontró explicación en un mundo regulado por una trama basada de manera poco ortodoxa en ideas conocidas de antaño por los griegos, pero que tomaron nuevo significado en la mente de Heródoto.

Seguramente, lo que diferenciaba la obra del de Halicarnaso de las muchas narraciones anecdóticas también referidas al pasado es la aplicación sistemática y consciente de un diseño personal y subjetivo de organización de la realidad, íntimamente asociado a los elementos recordados. El modelo propuesto por Simónides, readaptación del modelo tradicional aristocrático, dio paso a un modelo que asumía para la propia $\pi$ ó $\lambda \iota \varsigma$ la gloria de ese pasado, dejando sin modelo de realización personal a las antiguas clases aristocráticas en los ámbitos democráticos de la época.

Probablemente, lo menos importante en esa labor sea el motivo del recuerdo del pasado -el de concepto $\kappa \lambda \varepsilon \dot{o} \sigma \varsigma$ es, ciertamente, un aspecto importante, pero no el único-; lo que cuenta es la perspectiva y función aplicada al mismo, en lo que, sin duda alguna, el proemio es la pieza clave.

Comprender el proemio de la obra herodotea, y con él los primeros pasos del pensamiento historiográfico, nos ha de llevar a conclusiones muy distintas a las tradicionalmente mantenidas acerca de este aspecto. La narrativa historiográfica no nace como un instrumento que permita abordar un conocimiento del pasado en el modo que podemos hacerlo hoy desde una perspectiva moderna. Heródoto, y con él la primera obra historiográfica, son 
el resultado de un aluvión de influencias e ideas que se desarrollan en los ambientes arcaicos de raigambre aristocrática a lo largo de los siglos anteriores. No importa tanto el recuerdo de los hechos como tales -ya hemos insistido en que los griegos contaban con recursos suficientes para recordar lo acaecido-, sino el diseño de un modelo que permite reconstruir y actualizar los hechos históricos, si bien estos solo cobran sentido si son comprensibles, si permiten al autor obtener un sentido que explique y justifique la realidad.

La importancia del recuerdo, del concepto de $\kappa \lambda \varepsilon \dot{\delta} \varsigma$, ha de ser entendida dentro de la compleja situación de descomposición de los modelos culturales aristocráticos acaecida a lo largo de la época en Atenas. Hemos de tener presente que la condición crítica, o, si se prefiere, de carácter polémico de la historiografía va a ser una constante mantenida hasta el último de los historiadores, y las variaciones surgidas del largo espectro cronológico del género harán que el hilo conductor que señale el recorrido del pensamiento historiográfico grecolatino sea más una obra continuamente inacabada que un perfecto fresco. La dialéctica entre los diferentes autores, asumida tradicionalmente como un simple tópico, es precisamente la verdadera esencia de un género que actúa, en último término, como depósito de las inquietudes de una época. 


\section{ANTÍOCO DE SIRACUSA, EL HERÓDOTO OCCIDENTAL}

Además de los proemios de los dos grandes historiadores, en esta época solo conocemos un proemio histórico más, el de Antíoco de Siracusa, del que además poco sabemos, pero cuya situación cronológica entre Heródoto y Tucídides parece segura. ${ }^{878}$ Esta posición nos permite trazar puentes interpretativos entre ambos autores, y tomar clara conciencia de lo que supuso para la creación del género historiográfico la labor de Heródoto.

En lo que nos interesa, Dionisio de Halicarnaso nos transmite el que es a todas luces el proemio de la obra menor de Antíoco, Sobre Italia, ${ }^{879}$ de un solo libro, según propone Jacoby, ${ }^{880}$ y cuyo comienzo es:

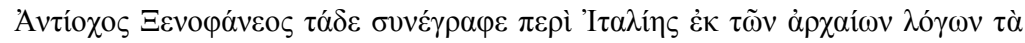

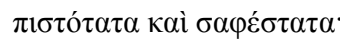

La formulación de este incipit no solo es claramente semejante a la de Hecateo, sino que está en consonancia con los usos habituales de la prosa de la época: presencia del nombre y el patronímico del autor, así como la expresión $\pi \varepsilon \rho \grave{~ ' I ~} \tau \alpha \lambda i ́ n \varsigma$ ya conocida, todo ello empleado en una frase que preludia, todavía con poca continuidad, el cuerpo de la obra.

${ }^{878}$ Ya Wölfflin, 1872, p. 20, presentó a Antíoco como fuente de la narrativa siciliana de Tucídides; Wilamowitz, 1884, p. 442, hablaba de la fecha de publicación de la gran obra de Antíoco como «wahrscheinlich kurz vor der attischen Expedition nach Sizilien»; cf. además Wilamowitz, 1985, p. 27 y ss.: «So kurz nach dem Tode des Herodotos, dass er ihn nicht mehr benutzt haben kann, schreibt Antiochos von Syrakus nicht etwa bloss die Chronik seiner Heimat, sondern die Archaeologie des neuen Hellas». En la misma línea, Columba, 1889, p. 89, sitúa la obra en los años 420-415. Cf. recientemente Pearson, 1987, p. 11.

879 Título, por lo demás, reconstruido, cf. Jacoby, FGrHist, III b, Noten, p. 290, casualmente, aunque ningún crítico lo señale, por el mismo procedimiento por el que se

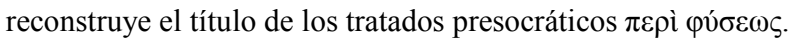

${ }^{880}$ Cf. Jacoby, FGrHist, III b, Komm., p. 487; más recientemente, Vattuone, 2007, p. 191. 
Si nos atenemos a los fragmentos, y si nos limitamos simplemente al texto herodoteo, difícil es hablar de manera segura de un conocimiento de Heródoto por parte de Antíoco, aun a pesar de las afirmaciones de Jacoby. ${ }^{881}$ Solo hay un fenómeno de carácter estructural que nos lleva a la recién iniciada tradición historiográfica, aunque, dada la escasez de obras en prosa conservadas, no podemos delimitar claramente si se trata de algo propio de los proemios historiográficos, pero sí afirmar que es una constante que se repetirá hasta Tucídides.

El fragmento en cuestión, F 2, nos es transmitido por Dionisio de Halicarnaso en sus Antigüedades romanas, ${ }^{882}$ pero no es su obra historiográfica la que ahora nos interesa, sino su faceta como crítico literario, en concreto sus estudios sobre Tucídides y su proemio, que adelantaremos brevemente.

En Sobre Tucídides, XX, 1, Dionisio demuestra claramente que la Ringkomposition es un fenómeno ajeno ya por completo a su sensibilidad. ${ }^{883}$

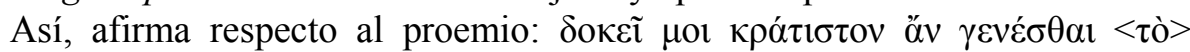

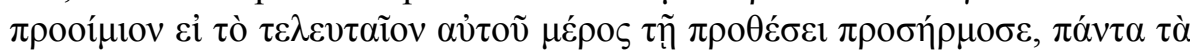
$\dot{\varepsilon} v \mu \varepsilon ́ \sigma \omega \pi \alpha \rho \alpha \lambda u \pi \omega ́ v . . .$, a lo que sigue una versión del proemio que, salvo algunos retoques, ${ }^{884}$ supone la exclusión de la denominada Arqueología, precisamente por esa falta ya de sensibilidad ante un recurso oral.

En el caso del fragmento del proemio de la obra Sobre Italia, el

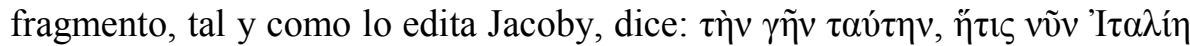

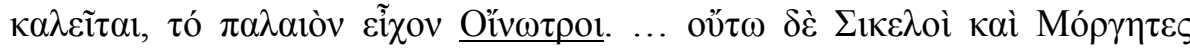

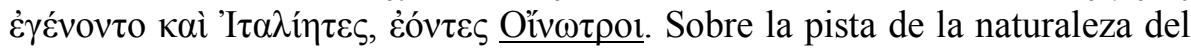
pasaje excluido por Jacoby, relegado a un tipo menor como testimonio, dado que es un resumen explicativo del topónimo, y puesto que lo que tenemos al final del fragmento es una vuelta al punto de inicio, es decir, una Ringkomposition, podemos afirmar que estamos ante una estructura conocida. Lo interesante es que esta pseudoarqueología se presenta en su espíritu intelectual como paralela de la que aparece en Heródoto entre I 1, 1

${ }^{881}$ Cf. Jacoby, FgrHist, III b, Komm., p. 486: «[...] er es geschrieben hat mit der bewussten Absicht die von Herodot in der Geschichte des griechischen Volkes gelassene Lücke auszufüllen». Igual pensamiento en Jacoby, 1949, p. 118. Cf. además Jacoby, FGrHist, III b, Noten, p. 289, nota 7. Dover, 1968, p. 362 y ss.; para el estudio contrario, el del conocimiento de Antíoco en Atenas cf. también de Sanctis, 1957, p. 13 y ss.

${ }^{882}$ I $12,3$.

${ }^{883}$ Sobre esta idea cf. Katičič, 1957, p. 181

${ }^{884}$ Cf. Aujac, 2002, p. 153. 
y 5, 1: a la afirmación inicial del proemio sigue un excurso de naturaleza probatoria, o no, como en el caso de Heródoto, que permite asentar las bases sobre las que se sustenta la afirmación principal y con ello el recorrido posterior de la obra, lo que, como señala Vattuone, ${ }^{885}$ nos acerca en gran medida a Tucídides y su proemio quien sin duda conocía a Antíoco.

Es de especial interés el empleo del vocablo $\sigma v v \varepsilon ́ \gamma \rho \alpha \psi \varepsilon$, que tanta importancia tendrá en el género. En el presente caso, el valor preposicional

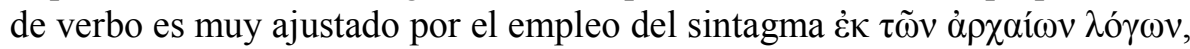
una indicación que permite poner en cuarentena la afirmación del escoliasta a Tucídides:

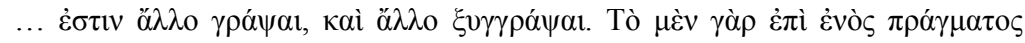

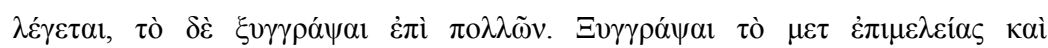

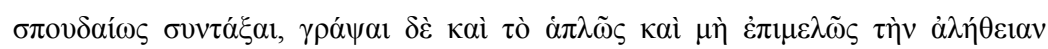
$\dot{\alpha} v \varepsilon v \rho \varepsilon \tilde{i} v$.

Está claro que de estas dos definiciones, por temática, la primera se puede asociar al uso de Antíoco, y la segunda al de Tucídides, en tanto que el intento de Doxopatro, ${ }^{886}$ recogido por Poppo y Stahl ${ }^{887}$ en su comentario

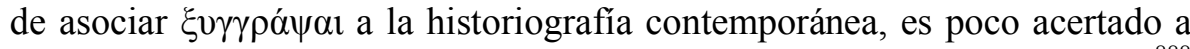
la vista del ejemplo de Antíoco; por su parte, la afirmación de Shilleto, ${ }^{888}$

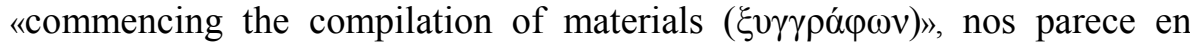
parte errada, dado que no es tanto de recogida de materiales de lo que se habla como de su puesta por escrito: son dos partes de una misma acción, pero no semejantes, y a esa recogida apuntan $\sigma u ́ v-$ y $\dot{\varepsilon} \kappa$.

Todo ello, aparte del abandono de la estructura de pensamiento que

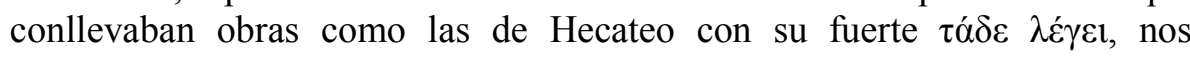
conduce, como decíamos, a resaltar el uso propio del verbo en Antíoco y a dejar atrás las muy especulativas afirmaciones de los rétores antiguos. Las implicaciones intelectuales que se quieran atribuir al verbo son en el presente

${ }^{885}$ Cf. Vattuone, 2007, p. 191 y ss.

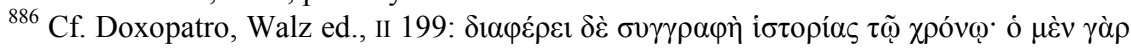

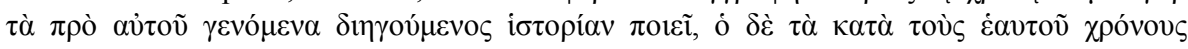

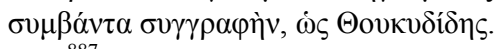

${ }^{887}$ Cf. Poppo y Stahl, 1886, p. 58 y ss.

${ }^{888}$ Cf. Shilleto, 1872 , p. 1. 
caso muy suaves, dado que el preverbio oúv- se presenta en un uso propio todavía. Hablar de una traducción ${ }^{889}$ aquí del verbo como 'escribir la historia ${ }^{890}$ es desaconsejable; simplemente, estamos ante un término propio de la labor del autor. ${ }^{891}$ A pesar de todo y de esa distancia apuntada, sin Antíoco sería difícil entender a Tucídides: «Antiochos ist noch weniger ohne Herodot denkbar als Thukydides $» .{ }^{892}$

La labor de interpretación de los fragmentos de la obra de Antíoco se ha centrado fundamentalmente en su estudio como fuente de la narrativa siciliana de Tucídides. En líneas generales, estamos ante una obra que se constituye como un paso más en la tradición que venimos trazando desde Hecateo y Heródoto, ${ }^{893}$ y que responde al trabajo del autor a partir de los $\lambda$ ó $\gamma$ iol, que le proporcionan las tradiciones locales, en un modo que perfila una obra que se acerca en gran medida a la mixtura de elementos presente en Heródoto y Hecateo ${ }^{894}$ Más allá de las propuestas que ven en el proemio un lugar retórico ${ }^{895}$ estamos ante el fragmento de un proemio que daba paso a una obra variopinta y rica en material, una auténtica despensa, quizá con orden cronológico, ${ }^{896}$ que revivirá en época de Augusto ante la necesidad de recabar materiales e información sobre el pasado más lejano de occidente. ${ }^{897}$

\footnotetext{
${ }^{889}$ Como proponía Loraux, 1986, p. 145.

${ }^{890}$ Cf. Schrader, 1997, p. 109.

891 Cf. Hornblower, 1987, p. 8, nota 2, quien recoge esta naturaleza «técnica»y no
} literaria del término. No entendemos el probably que Hornblower añade al uso de este verbo por parte de Antíoco, y menos las elucubraciones sobre el título de la obra. Cf. Hornblower, 1991, p. 5.

${ }^{892}$ Cf. Jacoby, FGrHist, III b, Komm., p. 486 y ss. Más prudente es Vattuone, 2007, p. 191, quien se decanta por considerar simplemente una red de influencias sin tratar de abordar quién influye a quién.

893 Walbank, 1968-1969, p. 478, hablaba con toda propiedad del Heródoto occidental, dentro de una tradición en la que Hipias se presenta como un antepasado de difícil ubicación aunque aceptemos su existencia, como demostró de Sanctis, 1957, p. 2, quien lo caracterizaba como un autor de anécdotas, p. 8, lo que nos permite situarlo en el mundo de Hecateo.

${ }^{894}$ Los reparos de Luraghi, 2002, p. 72 y ss., a la hora de admitir una posible influencia herodotea en el método de Antíoco se deben a su decisión de situarlo cronológicamente antes que el de Halicarnaso, cf. p. 81. Más allá de que esta afirmación parece difícil de defender de manera rotunda, como ya vimos y el propio Luraghi hace, basta recordar el hecho de que estamos ante una metodología que desborda lo que habitualmente conocemos como historiografía.

${ }^{895}$ Así, Luraghi, 2002, p. 74.

${ }^{896}$ Cf. de Sanctis, 1957, p. 16.

897 Cf. Luraghi, 2002, p. 58. Ya Nissen, 1883, p. 7 y ss., hablaba de la obra como un posible depósito de material para redacciones posteriores. Cf. también Columba, 1889, p. 85. 
Columba ${ }^{898}$ aseguraba además esta naturaleza de la obra gracias a la citación por parte de Antíoco de autores que no pertenecen precisamente a los habituales en la cultura de la época, lo que nos acerca al paradigma herodoteo de un historiador bien versado en literatura.

Pero, a pesar de estos datos, si la obra delataba una imagen del mundo compleja como la presente en Heródoto o Tucídides, como parecen indicar los rasgos jonios de su geografía ${ }^{899}$ o ese aire de autoridad arcaica que el proemio inspira a Luraghi ${ }^{900}$ es un hecho que, ante la parquedad de lo conservado, queda ya fuera de nuestro alcance. ${ }^{901}$

Walbank, 1968-1969, p. 479, alertaba de lo engañoso de los fragmentos transmitidos por Estrabón, centrados geográficamente en Italia, y que reducen erróneamente la importancia de la obra sobre Sicilia.

${ }^{898}$ Cf. Columba, 1889 , p. 85.

${ }^{899}$ Así, Luraghi, 2002, p. 73. Ya de Sanctis, 1957, p. 10.

${ }^{900}$ Cf. Luraghi, 2002, p. 75: «Nel momento in cui lo storico non si atiene con coerenza all' opzione tucididea di astenersi dal passato più lontano, egli rischia di invadere un'area in cui vige un più antico e diviso concetto di autorità».

${ }^{901}$ Por ello, las consideraciones acerca de la labor crítica de Antíoco propuestas por Columba, 1889, p. 90, nos parecen excesivamente especulativas. 



\section{TUCÍDIDES}

\subsection{Publicación de la obra. La cuestión tucidídea}

Connor $^{902}$ se planteaba en la introducción a su obra sobre Tucídides la necesidad de tener presente la posible audiencia del historiador a la hora de interpretar su obra, si bien la realidad es que la crítica ha sido más rigurosa en el método de difusión de la obra que en este aspecto. Ya los primeros pasos de la cuestión tucidídea apuntaban a una publicación escrita muy semejante a la que puede tener un libro moderno; las diferentes cuestiones planteadas por los sabios del siglo XIX nos presentaban de manera inconsciente un manuscrito inconcluso, campo de batalla para la más ingeniosa y al tiempo culta filología, cuyos antecedentes se encuentran en la labor de los antiguos sobre el texto, quienes, por medio de leyendas y anécdotas, diseñaron el modelo que fue tomado en el planteamiento de la cuestión tucidídea.

Pero las premisas han de ser, a nuestro juicio, otras, en línea con nuestro acercamiento a Heródoto y la difusión de su obra. Defendimos ya la imposibilidad de pensar en una publicación de los escritos en esta época al modo moderno, tanto por la incapacidad del mercado librario de acoger la obra como por la naturaleza de la misma y su extensión, aspectos que por separado no serían concluyentes para la imposibilidad de la publicación, pero que unidos la impiden por completo.

Ya Lamb daba cuenta de la importancia que a este respecto tenía la aparición de elementos redundantes para alguien que proviniese de Atenas, ${ }^{903} \mathrm{y}$, más recientemente, el posible público de Tucídides se ha rastreado igualmente por medio del análisis del público potencial de la obra a partir de las referencias a aspectos que un ateniense consideraría superfluos, ${ }^{904}$ o de los que, a su vez, consideraría superfluos un espartano. ${ }^{905}$

${ }^{902}$ Cf. Connor, 1985 , p. 12 y ss.

${ }^{903}$ Cf. Lamb, 1914, p. 18 y ss.

${ }^{904}$ Cf. Ridley, 1981, p. 26 y ss. Como señala Ridley, p. 43, los detalles institucionales o de topografía elemental son ajenos al interés de un ateniense, si bien algunos detalles son de carácter polémico y afectan por igual a atenienses y no atenienes. En esta línea se expresaba ya Wilamowitz, 1877, p. 336 y ss. 
En resumidas cuentas, la configuración de la obra de Tucídides responde a una idea panhelénica clara, ${ }^{906}$ dado que la nivelación de contenidos se adapta a un horizonte que no se puede circunscribir a Atenas, como ocurría también con Heródoto, algo por otra parte comprensible por la naturaleza no tradicional del género, o lo que es lo mismo, ajena a los escenarios habituales de la literatura oral, siempre ligados a un territorio concreto. Más allá de estas reflexiones, es realmente difícil abordar la definición del público de la obra. ${ }^{907}$

La segunda dimensión relativa a la publicación ${ }^{908}$ nos lleva a uno de los temas más importantes de la filología griega en el siglo XIX, que se nos muestra, si hemos de hablar con sinceridad, como un callejón sin salida: ${ }^{909}$ la cuestión tucidídea. Sin embargo, la reciente publicación del último tomo del importante comentario de Hornblower ${ }^{910}$ ha demostrado una vez más un hecho innegable, como es que cualquier investigación seria sobre Tucídides ha de abordar este problema, por lo que recorreremos de manera crítica las diferentes posturas tratando de analizar todas las propuestas y desechando las que consideramos erróneas, para tratar después de analizar desde una nueva perspectiva el estudio de los proemios, fundamentales en el acercamiento al problema.

905 Cf. Ridley, 1981, p. 31 y ss. Cf. además p. 34 y ss. para aspectos de carácter panhelénico. De difícil aceptación nos parece la propuesta de Debnar, 2001, p. 221 y ss., de considerar una audiencia dentro de la propia obra, en concreto en lo que se refiere a los discursos: ello supondría una compleja e inseparable superposición de escenarios. Cf. la crítica de Greenwood, 2006, p. 68.

${ }^{906}$ Cf. Hornblower, 2004c, p. 33

${ }^{907}$ Cf. Greenwood, 2006, p. 8.

${ }^{908}$ En el caso de Tucídides, la naturaleza escrita de la obra parece clara, cf. Gentili y Cerri, 1983, p. 9 y ss., y Edmunds, 2009, p. 91 y ss.

${ }^{909}$ Breve recorrido, en Grundy, 1948, p. 397, nota 1; von Fritz, 1967, p. 567 y ss., y en Luschnat, 1970, col. 1183 y ss. Solo señalamos los aspectos más relevantes para el análisis de los proemios dado que un estudio profundo de la cuestión supondría prácticamente una dedicación completa al tema. De especial interés es la obra de Patzer, 1937, por recoger de forma crítica las principales intrerpretaciones de la cuestión hasta su tiempo. Cf. además los apéndices en p. 103 y ss., en que recoge los pasajes concretos que dan pie a la consideración de una redacción temprana y otra tardía. En ámbitos hispanos puede verse el resumen de Alsina, 1981, p. 325 y ss.

${ }^{910}$ Cf. Hornblower, 2008, p. 1 y ss. La supuesta nueva perspectiva, menos atenta al detalle que Hornblower defiende en esta introducción, se ve desbordada en el análisis del texto, en el que aún hay cabida para el análisis de, por ejemplo, «contradicciones». 
La publicación de la obra de Ulrich en 1846 supuso el inicio de la denominada cuestión tucidídea y, como decimos, con ella, de uno de los aspectos más complejos del estudio del historiador. El estado inconcluso de la obra fue causa de problemas y origen de disparatadas historias cuya creación respondía a la necesidad de dotar de explicación a ese estado. ${ }^{911}$ Con una técnica filológica casi matemática, Ulrich analizó las referencias presentes en la obra que le permitían determinar los diferentes estratos de composición de la obra. Centrándonos en los proemios, cuya importancia para la cuestión tucidídea es inmensa, Ulrich concluía que hasta el libro III, la obra fue escrita pensando en la guerra arquidámica, y que el estudio del proemio inicial ha de hacerse teniendo presente este hecho, puesto que desde el comienzo mismo del proemio nada nos hace pensar en otra cosa, habida cuenta de la imprecisión temporal y semántica: $\tau$ òv $\pi$ ó $\lambda \varepsilon \mu o v$ es para Ulrich excesivamente ambiguo, ya que no indica si se refiere al periodo de diez o al de veintisiete años. Ello será uno de los caballos de batalla de la cuestión, dado que en la época de redacción de la obra se distinguían claramente los dos periodos de la guerra como dos guerras diferentes. ${ }^{912}$

Partiendo, a su vez, de las referencias presentes en el segundo proemio, en el que sí aparecen indicaciones temporales, ${ }^{913}$ y las advertencias que el propio Tucídides da en el libro IV, Ulrich concluye con fineza que el tono polémico del segundo proemio solo puede sustentarse si con anterioridad se hicieron presentes datos que apuntasen a la continuidad de la guerra, pues esta se da por supuesta en V 26 de una manera que solo es comprensible si se asume por parte del público una continuidad en los hechos bélicos reflejada en el texto de la obra que permita esas afirmaciones. ${ }^{914}$

Es esta misma justificación polémica la que lleva a Ulrich a plantearse la idea de que, si Tucídides hubiese pensado desde el comienzo en una guerra de veintisiete años, no necesitaría justificarse, y seguramente habría

${ }^{911}$ Cf. Wilamowitz, 1877, p. 327 y ss., quien señala la vertiente novelesca de los datos de la Vita Marcellini, generados de una manera que recuerda los procedimientos habituales de configuración de estas vidas, en las que como señala el sabio, lo anecdótico sustituye al dato exacto y a la fecha; seguramente, más allá de lo novelesco, la fecha es exigida por el crítico moderno, no por el antiguo, quien no escapa, como indica Wilamowitz, 1877, p. 334, a la necesidad de establecer nexos entre las diferentes figuras de la Antigüedad, pero sin tanta precisión.

${ }^{912}$ Cf. Ulrich, 1846, p. 3 y ss.; en p. 9 y ss., analiza Ulrich los testimonios de la época acerca de la consideración de la guerra; también p. 68 y ss.; cf. además, p. 90 y ss.

${ }^{913}$ Cf. Ulrich, 1846, p. 17 y ss.

${ }^{914}$ Cf. Ulrich, 1846, p. 101 y ss. 
hablado de la duración total de la guerra desde el inicio, facilitando así una información que a ojos de Ulrich era fundamental. ${ }^{915}$ Ello, a su vez, le habría evitado el largo excurso justificativo de la importancia de la guerra que es el proemio, dado que su misma duración habría eliminado cualquier duda, ${ }^{916}$

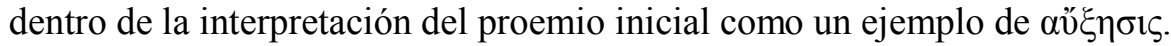

Teniendo en cuenta estos razonamientos, Ulrich propone unas fechas claras de redacción: los libros I, y con ello el proemio, ${ }^{917}$ II, III y la primera mitad del libro IV se habrían escrito entre el 421 y el 413, mientras que el resto se habrían escrito entre el 402 y el 396, ya en Atenas a la vuelta del exilio. ${ }^{918}$ Con todo ello, Ulrich inició el problema, pero, como señala Luschnat, no explicó el porqué de ese problema, ${ }^{919}$ más allá de la simple evidencia de la inconclusión de la obra.

En el año 1856 Poppo publicó un pequeño trabajo que contiene los principales rasgos de la crítica que se desarrollará, bajo una perspectiva unitaria, contra la interpretación de Ulrich. En lo que nos interesa, Poppo defiende que en I 1 Tucídides habla de la guerra entendida como los veintisiete años, ${ }^{920}$ de modo que el segundo proemio supondría la división en dos partes de una obra que en un principio el autor pretendía que abarcara la guerra arquidámica. ${ }^{921}$ La justificación de esta postura se realiza por medio del examen de la estructura general de la obra, en la que una narrativa circunscrita únicamente a los diez años iniciales sufriría en su elaboración

\footnotetext{
${ }^{915}$ Cf. Ulrich, 1846, p. 42 y ss.

${ }^{916}$ Cf. Ulrich, 1846, p. 111 y ss. y 130 y ss. Teniendo en cuenta esta doble redacción se asumiría la especial funcionalidad del segundo excurso sobre los tiranos atenienses, p. 134, respecto al que, desde una perspectiva más cercana a la nuestra, se podría hablar como de una narración polémica dentro de un contexto de difusión vivo.

917 Cf. Luschnat, 1970, col. 1201 y ss., con una valoración de la postura de Ulrich, teniendo en cuenta el problema que representará el capítulo I 23, que iremos, no obstante, analizando a lo largo del breve resumen.

${ }^{918}$ Cf. Ulrich, 1846, p. 138. Analizaremos detenidamente los pasajes clave para esta división en el estudio de la postura de Classen. Estos pasajes fueron examinados en fecha relativamente reciente en el artículo de Luschnat, 1970, col. 1195 y ss.

${ }^{919}$ Cf. Luschnat, 1970, col. 1185. Esta afirmación, quizá algo enigmática, responde, a nuestro entender, a la necesidad de dotar de una nueva perspectiva a estos acercamientos.

${ }^{920}$ Cf. Poppo, 1856, p. 1 y ss. La cuestión roza lo bizantino, por tratarse en todo caso de la defensa de uno u otro significado para tòv $\pi$ ó $\varepsilon \mu$ ov de manera contextualizada y -hay que decirlo- ${ }^{-}$sin mayor justificación que el propio hecho de sustentar con ello una $u$ otra propuesta.

${ }^{921}$ Cf. Poppo, 1856, p. 5 y ss. 
literaria. ${ }^{922}$ Las dificultades de sostener de manera rigurosa este esquema se hacen patentes si asumimos la realidad desigual de la composición de determinadas partes de la obra, como ocurre con el libro V, si bien hemos de reconocer que la idea más importante aportada por Poppo es la posibilidad de reelaboración de determinadas partes de la obra una vez iniciada la redacción de la segunda parte, cosa que se opone al excesivo encorsetamiento de una composición lineal, necesaria para sustentar la propuesta de Ulrich, quien, sin embargo, admite dos pequeñas reformas en lo relativo al elogio de Pericles y Arquelao, reformas que serán claves en las posteriores posturas de la crítica.

Seguramente, el más famoso de los unitarios fue Johannes Classen, quien defendió la unidad de la obra en sus Quaestiones Tucidideae, ${ }^{923}$ en las que se oponía a las ideas propuestas por Ulrich -ya para la época asumidas por la crítica- ${ }^{924}$ al tiempo que daba cuenta de la unidad y estructuración orgánica de la obra. La propuesta poco convincente a todas luces de basar el análisis de la composición de la obra en la comprensión del significado de ó $\pi$ ó $\lambda \varepsilon \mu \rho \varsigma$ es criticada con rotundidad por lo poco fiable de esta afirmación, principalmente si se tienen en cuenta las referencias temporales presentes a lo largo de los tres primeros libros y la primera parte del cuarto. Así, el análisis de II $1,{ }^{925}$ que Ulrich consideraba como ajeno a una guerra de veintisiete años, se presenta para Classen perfectamente unido con el final del libro I y el establecimiento de las causas verdaderas de la guerra; a todo ello se une el hecho de que $\xi v v \varepsilon \chi \tilde{\omega} \varsigma$ se presenta tanto aquí como en el final mismo de V 24, lo que, unido a su aparición en la Arqueología, así como en

922 Cf. Poppo, 1856, p. 48 y ss. En cierta manera, en Poppo se encuentra aún en germen la futura idea de un Tucídides trágico que desarrollará en un marco conceptual Cornford, con el famoso punto álgido en la expedición a Sicilia, lo que diseña un claro recorrido que no puede interrumpirse en el libro $\mathrm{V}$, si bien Poppo concluye en lo relativo al aspecto formal: «nos hanc huius historiae tanquam tragoediae in quinque actus divisionem sequi non possumus», precaución qen no tomarán en el estudio de esta interesante perspectiva en otros historiadores.

923 A la que, lamentablemente, no hemos tenido acceso. Como es habitual, dado lo raro de la tesis de Classen, recogemos sus ideas de los prolegómenos de su comentario en las ediciones anteriores a 1919, ya que en esta última Steup revisó las secciones relativas a la cuestión, si bien aporta información acerca de la postura de Classen y actualiza la bibliografía hasta la fecha. Cf. Classen y Steup, 1969 I, p. XXVI y ss. Por ello citaremos empleando la edición de 1879.

924 Cf. Classen, 1879, p. XXXIII y ss.

925 Cf. Luschnat, 1970, col. 1195 y ss., para un análisis en perspectiva del problema relativo al pasaje. 
otros contextos, garantiza su referencia a la guerra de veintisiete años. ${ }^{926}$ Del libro II analiza Classen también la propuesta de tomar el pasaje II $54^{927}$ como referido solo a la guerra arquidámica, dado que podría entenderse que Tucídides hace una referencia a una segunda guerra, cuando no habla más que de una eventualidad, ${ }^{928}$ y II 34,2 , el encabezamiento de la oración fúnebre, que Ulrich consideraba que solo podía referirse también a los primeros años de la guerra, cosa que Classen desmiente simplemente prestando atención al eventual de pasado con el que Tucídides lo expresa. ${ }^{929}$ Los dos principales pasajes en los que se apoya Ulrich en el libro III los rechaza Classen también por motivos lingüísticos: III $86,2,{ }^{930}$ en el que una referencia a los aliados de Esparta en Sicilia da pie a Ulrich para considerar el pasaje como anterior a la guerra en Sicilia, es desechado por emplear Tucídides un aoristo que puede perfectamente hacer referencia a un hecho pasado, ${ }^{931}$ en tanto que III 87,2 , en el que se afirma que la peste fue el hecho que más daño causó a Atenas, entra ya en el terreno de las especulaciones, aunque Classen lo sustenta con datos. ${ }^{932}$

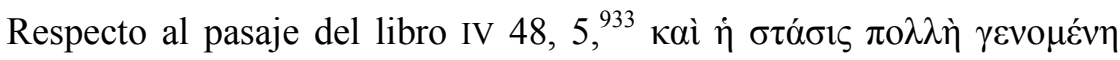

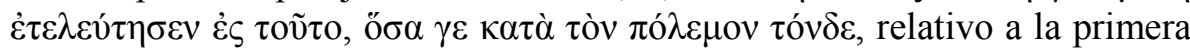
guerra de Corcira, concluye Ulrich, apoyándose en Diodoro, XIII 46, que fue escrito sin tener en cuenta que se contradice con la revolución que acontecería cinco años después, según Diodoro, lo que llevaría a interpretar el pasaje como referido únicamente al marco cronológico de la guerra arquidámica, aunque la contradicción desaparece cuando se tiene en cuenta que, como Classen señala, Diodoro confundió la cronología y retrasó la fecha del la revolución hasta el 410, dando lugar a una duplicación del acontecimiento y a un error en el que a este habría seguido Ulrich. ${ }^{934}$

${ }^{926}$ Classen, 1879, p. XXXV y ss. Los contextos son: I 11, 2; VI 26, 2; y VII $27,4$.

${ }^{927}$ Cf. Luschnat, 1979, col. 1196 y ss. La crítica desde una perspectiva gramatical de Classen parece innegable.

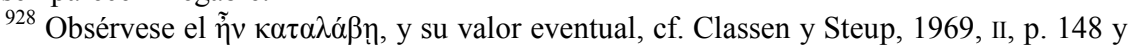
Ss.

${ }^{929}$ Cf. Classen, 1879 , p. XL y ss.

${ }^{930}$ Cf. Luschnat, 1970, col. 1199 y ss.

${ }^{931}$ Cf. Classen, 1879 , p. XLI.

932 Cf. Classen, 1879 , p. XLI y ss.

${ }^{933}$ Cf. Luschnat, 1970, col. 1200 y ss.

${ }^{934}$ Cf. Classen, 1879 , p. XLII y ss. No obstante, ha de señalarse que más que ante una confusión, podemos estar ante un doblete generado por la naturaleza analística de la obra de Diodoro, que necesita duplicar escenas para cubrir posibles lagunas. 
Finalmente, y lo que más nos interesa, trata Classen de los pasajes del libro I; en primer lugar analiza la opinión de Ulrich respecto a I $23,{ }^{935}$ que a ojos del analítico sería una justificación desmesurada y fuera de lugar si se refería al total de la guerra, con sus veintisiete años, teniendo en cuenta

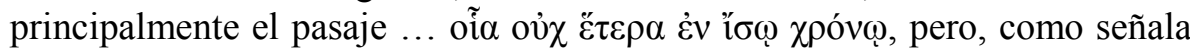
el ojo tan bien entrenado para la sintaxis de Classen y que tanto incomodaba a Wilamowitz, oĩ $\alpha$ no es ö $\sigma \alpha$, por lo que Ulrich confundió cantidad con importancia y creó un problema donde no lo había. ${ }^{936}$

El siguiente pasaje es I 10, donde de manera inexplicable Ulrich veía necesariamente un pasaje antiguo, dado que, a su entender, la comparación de las ciudades de Esparta y Atenas se tuvo que realizar cuando estas estaban en la cima de su poder, a lo que Classen apunta la idea que será, según veremos, general entre los críticos y que ve en este un pasaje tardío, escrito a la vista del desarrollo de la guerra ${ }^{937}$ del mismo modo que es incontestable el pasaje relativo a los muros en I $93,5 .^{938}$

Respecto a los dos proemios, ${ }^{939}$ Classen ofrece como solución la que será propuesta habitual entre los unitarios, el entender V 25, simplemente, como una inflexión interna justificada por la naturaleza perfectamente perceptible de las tres partes de la guerra, con lo que la conclusión es clara: Tucídides escribió toda su obra una vez terminada la guerra, y el segundo proemio no sería, en términos literarios, semejante al primero, ${ }^{940}$ lo que trataremos de refutar.

En 1873 publicaba su tesis Cwiklinski, en la que defendía, siguiendo las ideas de Poppo y en contra de lo opinado por Ulrich, que Tucídides sí revisó y alteró los primeros cuatro libros de su obra. ${ }^{941}$ En 1877 publicaba un extenso artículo en el que abordaba la segunda parte de la Historia,

${ }^{935}$ Cf. Luschnat, 1970, col. 1201 y ss.

${ }^{936}$ Cf. Classen, 1879, p. XLIV y ss., especialmente nota 52.

${ }^{937}$ Cf. Classen, 1879, p. XLVI. Una redacción temprana propone Gomme, 1950, p. 112 y ss.

938 Cf. Classen, 1879, p. XLVII y ss. Trata Classen también pasajes referidos a los discursos, así como las posibles conexiones de Heródoto con algunos pasajes de Tucídides, empleando para la publicación tanto una cronología alta como una idea de la misma que ya antes rechazamos y que ahora no tratamos, dada, por otra parte, su menor repercusión en la cuestión.

${ }^{939}$ Cf. Classen, 1879, p. XLVIII y ss.

${ }^{940} \mathrm{Cf}$. Classen, 1879 , p. LII.

${ }^{941}$ Cwiklinski, 1873, non vidi. 
concluyendo que la guerra de Sicilia no era considerada como una parte integrante de la guerra del Peloponeso $;{ }^{942}$ el segundo proemio, que considera previo a determinados pasajes de libros anteriores, algo que ya hacía Ulrich, ${ }^{943}$ no da constancia clara de la guerra en Sicilia, y la narrativa de esta tiene una «arqueología», lo que nos ha de poner sobre aviso de la posible naturaleza de esta parte. ${ }^{944}$ Todo ello, así como un concienzudo análisis en ocasiones excesivamente meticuloso, ${ }^{945}$ lleva al autor a considerar tres estratos en la obra, el primero del libro I al IV, el segundo compuesto por la narrativa siciliana, los libros VI y VII, y finalmente una parte sin elaborar, el libro V y VIII, ${ }^{946}$ lo que necesariamente nos lleva a un trabajo no lineal y a la exclusión de la narrativa siciliana de la obra.

Uno de los grandes unitaristas fue Eduard Meyer, quien expuso sus ideas de forma concisa en las famosas Forschungen zur alten Geschichte, de 1899. Haciéndose eco de los problemas que eran ya para la fecha auténticas encrucijadas de la filología moderna, ${ }^{947}$ su interpretación ${ }^{948}$ de los pasajes que habían dado lugar a la consideración de una posible revisión de la obra, concluía lo siguiente: «[...] dass das erste Buch, so wie es vorliegt, erst nach 404 geschrieben ist, ist in der That über jeden Zweifel erhaben», ${ }^{949}$ lo que trata de indicar lo inestable de muchos de los juicios emitidos por la crítica. Esta afirmación se extendía además a los cuatro primeros libros, $\mathrm{y}$, en lo que nos interesa, a la llamada Arqueología. ${ }^{950}$

\footnotetext{
${ }^{942}$ Cf. Cwiklinski, 1877, p. 30 y ss.

${ }^{943}$ Cf. Cwiklinski, 1877, p. 42, en referencia a II 65 y IV 81, 2.

${ }^{944}$ Cf. infra, para un análisis de esta idea realizado por H. Rawlings.

${ }^{945}$ Como puede serlo el tratar de adivinar si ó $\pi$ ó $\lambda \varepsilon \mu o \varsigma$ hace referencia en determinados contextos a la guerra de diez o de veintisiete años, una constante, como venimos indicando, dentro de la cuestión, o determinar sin más que pasajes como VII 18, en que se hace una comparación entre la guerra de Sicilia y la del Peloponeso, o VI 7, en que aparece uno de los famosos finales de año, son añadidos posteriores, dado que en este último caso hace referencia a un contexto ajeno a Sicilia, cosa incompatible con la idea de que esta narrativa constituye una unidad por sí misma. Cf. Cwiklinski, 1877, p. 77.

946 Cf. Cwiklinski, 1877, p. 83. Sobre la especial naturaleza política de los acontecimientos del libro v cf. Westlake, 2009, p. 298 y ss.

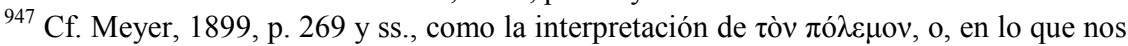
interesa, de la problemática que causaba la aparición de un segundo proemio, cf. p. 273 y ss.

${ }^{948}$ Cf. Meyer, 1899, p. 273; se trata de los pasajes ya vistos en el análisis de la postura de Classen, por lo que no repetimos de manera pormenorizada el análisis.

${ }^{949}$ Cf. Meyer, 1899, p. 280.

${ }^{950}$ Cf. Meyer, 1899, p. 283 y ss. 
Quizá la obra más importante después de la de Ulrich para la cuestión sea el libro que Eduard Schwartz publicó por vez primera en 1919, y que supone la quintaesencia de la corriente analítica, tanto por su meticulosidad como por su capacidad para destruir el texto. En lo que nos interesa, pues la complejidad e importancia del libro nos alejaría sobremanera de nuestro cometido, fue Schwartz el gran representante de la defensa, tras las huellas de Wilamowitz, de la figura de un editor de la obra tucidídea, que se habría encargado de nivelar el manuscrito incompleto del autor: todo aquello que por razones estilísticas no parecía lógico atribuir a Tucídides recaía en la mano de este editor. Así, en lo pertinente al segundo proemio y a la paz de Nicias, una de las secciones más problemáticas de la obra, Schwartz localiza secciones ajenas a la mano del historiador, prácticamente desde el final del libro IV,${ }^{951}$ dando por cierto lo que Ulrich apuntó de manera poco clara: Tucídides solo pretendía en un principio narrar los primeros diez años. ${ }^{952} \mathrm{La}$ conclusión que ofrece el análisis minucioso del sabio alemán es clara: el editor encontró una paz de Nicias simplemente bosquejada y la desarrolló de manera ajena a la tucidídea. ${ }^{953}$ Así, el segundo proemio sería obra del editor, que, partiendo de elementos y conceptos tucidídeos, habría creado una narración que sería incompatible con el resto de la sección. ${ }^{954}$

Muy importantes son las conclusiones acerca del primer proemio, dado que suponen la culminación de una tendencia analítica extrema cuyos detalles veremos cuando examinemos su estructura. ${ }^{955} \mathrm{El}$ análisis de Schwartz parte desde una interpretación retórica del mismo, viendo en la denominada Arqueología una $\alpha \mathfrak{v} \xi \eta \sigma \varsigma^{956}$ encaminada a resaltar la presente guerra en oposición a las anteriores, idea que más recientemente Woodman ha referido únicamente al primer párrafo. ${ }^{957}$ En lo que a la estructura se

${ }^{951}$ Cf. Schwartz, 1969, p. 33 y ss.

${ }^{952}$ Cf. Scwartz, 1969, p. 52; Luschnat, 1970, col. 1193.

${ }^{953}$ Cf. Schwartz, 1969, p. 45.

${ }^{954}$ Cf. Schwartz, 1969, p. 61 y ss. Además de falta de concordancia entre elementos de cuño tucidídeo, aspecto que es quizá más problemático para nosotros que para un antiguo, la línea general de la sección apunta a una falta clara de elaboración: Schwartz recuerda la ausencia de discursos, aun a pesar de que sea muy rica en datos.

${ }^{955} \mathrm{Cf}$. apartado 5.2 .

956 Cf. Luschnat, 1970, col. 1203 y ss., para un breve examen crítico de esta consideración del proemio, que nosotros rechazamos, cf. infra.

${ }^{957}$ Cf. Schwartz, 1929, p. 107. Crítica en Gomme, 1950, p. 89; Hornblower, 1991, p. 3, recupera la idea. Cf. además Woodman, 1988, p. 6. El centrar la idea únicamente en el primer párrafo es, a nuestro entender, referirla a la totalidad del proemio, dada la unidad del mismo. 
refiere, Schwartz sanciona la tesis defendida por Höpken, discípulo, como el propio Schwartz, de Wilamowitz, acerca de la presencia de dos estratos en la redacción del proemio, con un primer proemio del que solo quedaría I 23, 15. ${ }^{958}$ A ello habría que sumar la falta de unión de la primera frase con la siguiente: de manera incomprensible defiende Schwartz la falta de ligazón

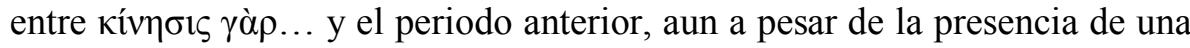
partícula de naturaleza coordinativa, si bien hay que recordar que la atención de Schwartz se centra solo en la exégesis conceptual, ${ }^{959}$ introduciendo por primera vez la perspectiva intelectual en la cuestión, el camino más seguro para obtener conclusiones. ${ }^{960}$ Sin embargo, aunque el propio Schwartz no lo supiera, dio con una de las claves compositivas del proemio al apuntar a la relación existente entre I 3, 1 y 20,1, si bien el autor defendía, por falta de desarrollo de los estudios estilísticos, la interpolación de toda la Arqueología ${ }^{961}$ por esa relación, Arqueología que respondería además únicamente a la guerra arquidámica, dado que para Schwartz una guerra de veintisiete años no necesitaría, al sumar más años que las anteriores, una $\alpha \tilde{v} \xi \eta \sigma ı \varsigma$ que justificara el tema. ${ }^{962}$

Finalmente, nos interesa destacar su postura contraria a la de Cwiklinski acerca de la naturaleza de la narración siciliana: frente a la idea de un proyecto externo después sumado a la obra, Schwartz concluye de manera contundente: «Nicht nur die historiographische Kunst des Thukydides hat die beiden sizilischen Bücher so mit dem fünften und achten verbunden... auch charakteristische mit der Unfertigkeit des Werkes zusammenhägende Mängel jener Bücher kehren im 6. und 7. Wieder». ${ }^{963}$ Para Schwartz la ignorancia de la guerra en Sicilia presente en el segundo proemio se debería a que el historiador no consideraba la guerra en Sicilia como estrictamente peloponesiaca, aunque -recuerda después- el segundo proemio no es de Tucídides. ${ }^{964}$ A nuestro entender, Schwartz está en lo cierto, si bien nos parece más sencillo afirmar que, dado lo incompleto de la parte final de la obra, la guerra siciliana está sobredimensionada al presentarse acabada en su redacción.

\footnotetext{
${ }^{958}$ Cf. Schwartz, 1969, p. 170.

${ }^{959}$ Cf. Schwartz, 1969, p. 178.

${ }^{960}$ Cf. Schwartz, 1969, p. 217 y ss. Patzer, 1937, p. 3 y ss., quien destaca esta postura y, según veremos, la desarrollará, cf. infra.

${ }^{961}$ Cf. Schwartz, 1969, p. 179.

${ }^{962}$ Cf. Schwartz, 1969, p. 175. En esto sigue además a Ulrich, según vimos.

${ }^{963}$ Cf. Schwartz, 1969, p. 209.

${ }^{964}$ Cf. Schwartz, 1969, p. 208 y ss. 
Siguiendo la estela de recuperación del interés en la cuestión tucidídea por parte de Schwartz, comenzó a publicar Pohlenz en 1919 sus Thukydidesstudien. Partiendo del examen del bloque de discursos de la asamblea en Esparta, Pohlenz recorre los detalles precisados por Schwartz, $\mathrm{y}$, como novedad, trata de afrontar el análisis de I 22 como clave de la composición de los discursos. Partiendo de una interpretación de este complejo pasaje que se resume en asumir que Tucídides reflejó con cierta libertad la $\gamma v \omega ́ \mu \eta$ general de lo que se dijo, ${ }^{965}$ detecta, a partir del análisis de los diferentes conceptos clave en los discursos (tales como la ideas relativas al modo de ser tradicional de los espartanos, ${ }^{966}$ o la presencia del concepto de $\sigma \omega \varphi \rho o ́ \sigma v v \eta)$, que la $\gamma \nu \omega ́ \mu \eta$ que desarrolla el historiador es la propia y no la de los oradores, pues responde a su interpretación de la guerra, posterior al 404 en muchos aspectos, y, por tanto, incompatible con el hecho de que esas ideas existiesen antes del fin de la guerra ${ }^{967}$ Por ello, teniendo en cuenta lo dicho respecto a la interpretación de I 22, la conclusión es clara: «Thukydides hat einen Wechsel in seinen darstellerischen Principien vorgenommen», por lo que «I 22 ist andrer Zeit als die Redeschlacht». ${ }^{968}$ Ello supone la distinción de dos grupos de discursos, ${ }^{969}$ el primero construido a partir de I 22, y el segundo ajeno a las ideas expresadas en el capítulo programático, correspondiendo estos a fechas posteriores al $404 .{ }^{970}$ Sin entrar en el análisis de la crítica de los discursos de manera detenida, diremos que Pohlenz considera los discursos de Nicias en el conflicto siciliano como tempranos, ${ }^{971}$ lo que supone una datación concreta de la narrativa siciliana, aunque con dudas, lo que nos interesa para el análisis del segundo proemio, y que ese plan inicial fue modificado ante la necesidad del historiador de describir los fundamentos de su visión propia. ${ }^{972}$

\footnotetext{
${ }^{965}$ Cf. Pohlenz, 1965, p. 233 y ss.

${ }^{966}$ Sobre este aspecto recientemente cf. Debnar, 2001, p. 11.

${ }^{967}$ Cf. Pohlenz, 1965, p. 222 y ss.

${ }^{968}$ Cf. Pohlenz, 1965, p. 234. Recuérdese que Pohlenz centra gran parte de su análisis en
} el grupo de discursos de la asamblea del libro I.

${ }^{969}$ Respecto a esta idea, basta con remitir a las críticas de Grosskinsky, 1936, p. 76.

${ }^{970}$ Cf. Pohlenz, 1965, p. 237.

${ }^{971}$ Cf. Pohlenz 1965, p. 238 y ss.

${ }^{972}$ Cf. Pohlenz, 1965, p. 250 y ss. Obviamente, el análisis de los discursos es mucho más amplio y profundo de lo aquí reflejado, pero no entramos en profundidad por no ser nuestro objeto principal de estudio. Se puede ver también Patzer, 1937, p. 33 y ss., para una crítica de este método y resultados. 
La continuación del trabajo nos interesa más: trata Pohlenz del segundo proemio, V 25 y 26, analizando este segundo capítulo bajo los esquemas habituales del proemio en prosa. Ello se traduce en el reconocimiento de

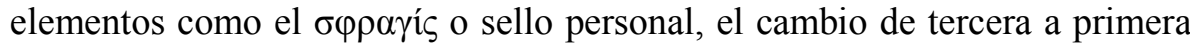
persona, o aspectos relativos al contenido, todos en línea con lo ya observado en el estudio de Heródoto. ${ }^{973}$ Además, el empleo de perfectos y de

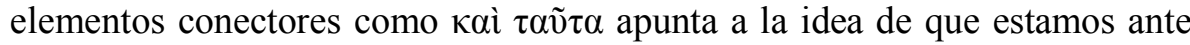
un proemio que no da inicio a una nueva sección: Pohlenz señala una idea general relativa a este aspecto, afirmando que el segundo proemio era necesario y el lugar ideal para el desarrollo de una perspectiva general de la guerra, con lo que podemos atisbar una idea muy clara de la función del primer proemio, desprendiéndose además de esta afirmación la necesidad de no separar el capítulo 25 del siguiente. ${ }^{974}$ Concluye Pohlenz que ambos capítulos son obra de Tucídides y no del editor, y que pertenecen al material posterior al $404 .{ }^{975}$

Patiendo del pasaje de Heródoto, VII 20, y apoyándose tanto en ideas de Schwartz como de Höpken, que después veremos, ${ }^{976}$ Pohlenz insiste en que el capítulo I 23 y la Arqueología presentan las mismas ideas, lo que supone que fueron escritas en momentos diferentes, dada la repetición. ${ }^{977}$ De igual manera, Pohlenz determina también que tras I 1, 2 existe una laguna no debida a la transmisión, un pasaje en el que se daría cuenta de los hechos acaecidos contra el persa, apoyando así las tesis de Schwartz al respecto, si bien este último apuntaba a la guerra de Troya como el tema del texto que faltaría. ${ }^{978}$

Respecto a la configuración de la Arqueología en relación con el resto del proemio, Pohlenz concluye que todo apunta a una redacción tardía de la misma, pero anterior al 404, como parece indicar I 10, 2, con lo que estaríamos ante un proemio referido a la guerra arquidámica. ${ }^{979}$

\footnotetext{
${ }^{973}$ Cf. Pohlenz, 1965, p. 255 y ss.

${ }^{974}$ Cf. Pohlenz, 1965, p. 257.

${ }^{975}$ Cf. Pohlenz, 1965, p. 265 y ss.

${ }^{976} \mathrm{Cf}$. apartado dedicado a la estructura del proemio.

${ }^{977}$ Cf. Pohlenz, 1965, p. 268 y ss.

${ }^{978}$ Cf. Pohlenz, 1965, p. 270 y ss. La transmisión textual no da pie a la consideración de esa laguna, que, más que textual, es un fallo en el sistema de razonamiento aplicado al texto, lo que nos pone sobre aviso de la deformación presente en algunos casos en estos estudios.

${ }^{979}$ Cf. Pohlenz, 1965, p. 274 y ss. 
Schadewaldt publicó en 1929, el mismo año de la reedición de la obra de Schwartz, el que fue el último gran trabajo de la corriente analítica, con una naturaleza en muchos casos contraria a los excesos de esta corriente. Dado el origen del libro en unas conferencias, Schadewaldt se centra únicamente en el análisis de la naturaleza de los libros VI y VII, en su contenido y, en menor medida, en sus aspectos formales, la causa que llevó a Cwiklinski a pensar en un origen de los mismos ajeno a la obra sobre el conflicto peloponesiaco. ${ }^{980} \mathrm{El}$ autor asume la función clave en la comprensión de la crisis de Atenas que presenta esta narrativa, lo que, además de fundamentos unificadores, da lugar a una datación posterior al 404. ${ }^{981}$ Esa unidad se ve reforzada por la posición paralela que presenta Alcibíades respecto a Pericles en la primera parte de la obra, lo que, en definitiva, respalda las ideas ya planteadas por Schwartz. ${ }^{982}$

En lo referente al proemio, y recogiendo ideas de Pohlenz, el autor defiende la pertenencia a los primeros pasos de la redacción de la obra de I 22 , dado que se observa rigurosamente en los primeros discursos de la misma. ${ }^{983}$ La datación temprana del primer proemio es la clave para comprender la posición que lleva a Schadewaldt a considerar el segundo proemio como el inicio de la conclusión de la parte relativa a los primeros diez años. ${ }^{984}$ Esas ideas dispersas respecto al proemio se ven unificadas en un largo apéndice en el que Schadewaldt examina aspectos formales que más tarde examinaremos y se posiciona en lo referente a la interpretación del mismo en la obra en la línea de quienes defienden una composición del mismo para la guerra arquidámica, basándose en la consideración de la imagen externa de Atenas y Esparta como engañosa. ${ }^{985}$ Para Schadewaldt esta afirmación solo es comprensible si se asume que en la narrativa Atenas seguiría siendo poderosa, es decir, durante la guerra arquidámica, pero Tucídides solo podría hacer esta afirmación si sabía de la futura caída, lo que supone por una parte que el pasaje fue escrito después del 404 pero sólo para los diez primeros años de la guerra. ${ }^{986}$ Ello se fundamenta además en la

\footnotetext{
${ }^{980}$ Cf. Schadewaldt, 1929, p. 3 y ss.

${ }^{981}$ Cf. Schadewaldt, 1929, p. 9 y ss.

982 Cf. Schwartz, 1969, p. 217 y ss. Schwartz señalaba la especial importancia de la figura de Pericles como motor de estructuración de la obra.

${ }^{983}$ Cf. Schadewaldt, 1929 , p. 25 y ss.

${ }^{984}$ Cf. Schadewaldt, 1929, p. 37.

${ }^{985}$ Cf. Luschnat, 1970, col. 1204 y ss.

${ }^{986}$ Cf. Schadewaldt, 1929, p. 60 y ss., pero cf. el apartado referido a la publicación, para el sentido de este tipo de indicaciones a partir del trabajo de Ridley, 1981.
} 
exclusión de datos relativos a Sicilia y a los fenómenos atmosféricos del capítulo I $23^{987}$-muy sólidamente afianzado en el proemio, según veremos-, y además en la existencia de un segundo proemio que, dado que Schadewaldt parte de criterios compositivos arcaicos, es de otra manera inexplicable. ${ }^{988}$

El trabajo de Patzer de 1937 supone el cierre, prácticamente, de la etapa clásica de la cuestión tucidídea y la apertura de una línea de análisis intelectual cuya cumbre se verá representada por Jacqueline de Romilly. Patzer analiza y desecha los pasajes que favorecían, a ojos de los críticos anteriores, un estadio temprano de elaboración dentro de la obra tucidídea, ${ }^{989}$ con lo que solo se sustentaría la postura de Ulrich en la ya desestimada antes por nosotros interpretación del término ó $\pi$ ó $\varepsilon \varepsilon \mu \varsigma, \mathrm{y}$, en lo que nos interesa, en el segundo proemio, que Patzer justifica como un elemento formal introducido por la larga duración de la paz de Nicias, ${ }^{990}$ como ocurría con la Pentecontecia.

En el análisis del primer proemio, Patzer rechaza las teorías de Pohlenz ${ }^{991}$ acerca de los posibles estratos en la composición de los discursos, determina que su composición fue posterior al año $404,{ }^{992}$ partiendo de la crítica de pasajes ya tratados como I 10 o $23,1-3$, y reconoce que, si se ha de admitir una fecha en torno al 421 , el proemio haría de igual manera referencia a toda la obra, dado que la Arqueología indica eso. ${ }^{993}$

En resumidas cuentas, el trabajo de Patzer apunta a una demolición de las teorías de Ulrich, si bien, como señala Luschnat, ${ }^{994}$ le falta una sistematización de los datos que permita dar unidad a su postura, cosa que sí alcanzarán los siguientes trabajos.

Solo tres años después las perspectivas eran muy diferentes, quizá porque los trabajos se realizaban ya fuera del ámbito alemán. En 1940 publica Finley su influyente y al tiempo torticero artículo sobre la unidad de

${ }^{987}$ Cf. Schadewaldt, 1929, p. 63 y ss.

${ }^{988}$ Cf. Schadewaldt, 1929, p. 64, nota 2.

${ }^{989}$ Cf. Patzer, 1937, p. 8 y ss., especialmente p. 15 y ss.

${ }^{990}$ Cf. Patzer, 1937 , p. 22 y ss.

${ }^{991}$ Cf. Patzer, 1937, p 34 y ss.

992 Cf. Patzer, 1937, p. 64 y ss. Remitimos a lo indicado en el examen de la obra de Schadewaldt, con quien coincide en gran medida: no hemos de olvidar que ambos son discípulos de Werner Jaeger.

${ }^{993}$ Cf. Patzer, 1937, p. 111 y ss.

${ }^{994}$ Cf. Luschnat, 1970, col. 1207. 
la obra de Tucídides. Impulsando el método de análisis de la obra de Tucídides desde una perspectiva conceptual, el norteamericano trata de demostrar la unidad de la obra de Tucídides desde un análisis del pensamiento que recorre la totalidad de la obra.

Partiendo de los resultados que, en líneas generales, hemos ido analizando y que rechazaban la antigüedad de la mayoría de pasajes tenidos por tales,${ }^{995}$ Finley analiza la continuidad del pensamiento a lo largo de la obra, y señala, entre otros conceptos, que las ideas programáticas defendidas por Pericles al comienzo de la obra se mantienen en el inicio del libro VIII, ${ }^{996}$ o que el análisis del poder marítimo de la Arqueología es parejo a la figura de Temístocles como personaje paradigmático de un espíritu que se presenta como caracterizador de los atenienses en la famosa asamblea del libro I y que reaparece en el último libro de la obra. ${ }^{997}$ Todo ello apunta, según Finley, a dos conceptos clave, el poder ateniense y la volubilidad del demos, señalada ya en la actuación de Pericles y resaltada en Sicilia y en el libro VIII. ${ }^{998}$ En consecuencia, se desechan estratos de diferentes redacciones y se considera la obra como una sólida unidad ${ }^{999}$ en la que el segundo proemio es solo un elemento que refuerza la continuidad de la obra. ${ }^{1000}$

A nuestro entender, la propuesta de Finley solo da respuesta a una de las dos perspectivas del problema, pues, aunque se mantenga un hilo conductor en la narrativa, ello no impide que la obra se haya redactado en diferentes momentos, o que Tucídides solo proyectase escribir la guerra arquidámica y después decidiese narrar, según el desarrollo de los acontecimientos, el resto del enfrentamiento manteniendo el pensamiento original. En resumidas cuentas, Finley retrocede en el problema a los primeros pasos del mismo, superando el hipercriticismo de Schwartz, que, al introducir la perspectiva intelectual sin dejar de lado los problemas de detalle de los diferentes pasajes, consiguió elevar la cuestión tucidídea un peldaño más en su dificultad.

Con la aparición en 1947 de la tesis de la gran helenista francesa Jacqueline de Romilly la cuestión tucidídea llega prácticamente a su fin y

${ }^{995}$ Cf. Finley, 1967a, p. 118 y ss. Citamos por la recopilación de artículos anteriores publicada por el autor en 1967.

${ }^{996}$ Cf. Finley, 1967a, p. 169 y ss.

${ }^{997}$ Cf. Finley, 1967a, p. 142 y ss.

${ }^{998}$ Cf. Finley, 1967a, p. 161.

${ }^{999}$ Cf. Finley, 1967a, p. 163 y ss.

${ }^{1000}$ Cf. Finley, 1967a, p. 169. 
agotamiento, fuera de los círculos alemanes y con una orientación muy diferente a la que marcó sus primeros pasos. De Romilly recoge la labor de Finley y lleva a cabo un análisis profundo de la génesis de la obra a partir del estudio de la evolución de la idea que tiene Tucídides del imperialismo. ${ }^{1001}$

Con el beneficio que supone el recoger toda la tradición crítica anterior, que había ya reducido sensiblemente los pasajes problemáticos, y a partir fundamentalmente del trabajo unitario de Patzer, de Romilly defiende la existencia de conceptos e ideas presentes en toda la obra y que proporcionan un punto de apoyo sólido para el análisis de su composición. Así, antes de examinar la principal de esas ideas, el imperialismo ateniense, determina la naturaleza antigua de conceptos como la $\dot{\alpha} \lambda \eta \theta \varepsilon \sigma \tau \alpha \dot{\tau} \eta \eta \pi \rho \operatorname{s\rho } \alpha \sigma 1 \varsigma,{ }^{1002}$ que recorre de manera clara el libro I, lo que impide la defensa de este concepto como tardío y agregado con posterioridad, y dota de unidad a todo el libro I, que deja de ser un gran centón para presentarse como un elemento cohesionado por dicha idea, ${ }^{1003}$ a excepción de la Pentecontecia, añadido posterior solo comprensible desde la profunda construcción intelectual que supone el análisis del imperialismo ateniense. ${ }^{1004}$ Ese imperialismo se construye como un pensamiento monolítico y sin fisuras ni diferentes tendencias que puedan hacer pensar en distintos estratos, sustentado además en la talasocracia, como pone de manifiesto la Arqueología, ${ }^{1005}$ algo que después examinaremos.

El análisis del imperio responde además a la sucesión de figuras individuales en la obra, recorrido que se inicia con Pericles, como ejemplo positivo de la valoración del imperio: poder y prudencia son las claves que determinan el imperialismo defendido por Tucidídes ${ }^{1006}$ y que se manifiesta en el estadista, ${ }^{1007}$ con su afán por una guerra defensiva y su absoluta conciencia acerca de la necesidad de asumir que el poder ateniense se

${ }^{1001}$ Cf. Luschnat, 1970, col. 1208.

${ }^{1002}$ Cf. Luschnat, 1970, col. 1209 y ss., para un análisis sistemático de este aspecto en la obra de la helenista, así como de la significación general de la obra.

${ }^{1003}$ Cf. de Romilly, 1951, p. 25 y ss.

${ }^{1004}$ Cf. de Romilly, 1951, pp. 36 y 290.

${ }^{1005}$ Cf. de Romilly, 1951, p. 56 y ss., especialmente p. 63.

${ }^{1006}$ Vogt, 2009, p. 227.

${ }^{1007}$ Cf. de Romilly, 1951, p. 99 y ss. 
sustentaba únicamente en el mar, como se puso en evidencia en la Arqueología. ${ }^{1008}$

Solo con esta imagen presente se puede comprender la figura de Cleón,

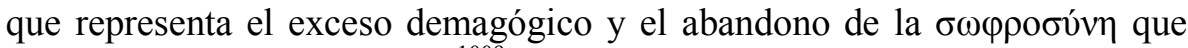
conformaba el ideal pericleo, ${ }^{1009}$ como también será antitética la posición de Alcibíades y la actuación en Sicilia, donde no fallará el proyecto, sino los líderes. ${ }^{1010}$

Pero si hay una parte de la obra donde es evidente la unidad del concepto de imperialismo, es la relativa a los discursos. Así, la asamblea del libro I supone un monumental estudio del imperialismo ateniense en su estadio inicial, un bloque homogéneo, como señalaba Pohlenz, y necesariamente posterior al 404, como también lo es el debate en Melos, en el que se rastrean reflexiones acerca del futuro de la guerra, y que, en último término, ofrece un marco de pensamiento solo comprensible después del fin de la guerra, suponiendo el segundo discurso una evolución más brutal del primero. ${ }^{1011} \mathrm{Y}$ es que, como señala de Romilly, el pensamiento de Tucídides respecto al imperialismo se construye en torno a tres reglas que señalan una evolución progresiva del análisis y la comprensión del fenómeno por parte del historiador: una primera ley referida a la «necesidad del imperio», que implica la imposibilidad de renunciar a él una vez adquirido; ${ }^{1012}$ una segunda ley referida a la ambición humana, siempre deseosa de más, ${ }^{1013}$ y una tercera ley, ajena al mundo intelectual griego a diferencia de las anteriores -que se asemejan a la $\dot{\alpha} v \alpha ́ \gamma \kappa \eta$ y a la $\ddot{\beta} \beta \rho ı \varsigma^{-}$, y que se asimila a la importancia que posee la naturaleza humana en el desarrollo de la obra, ${ }^{1014}$ con todo lo que esto conlleva para las ideas del autor. Estas tres leyes suponen, como decíamos, un esquema gradual, de modo que las dos primeras aparecen en

\footnotetext{
${ }^{1008}$ Cf. de Romilly, 1951, p. 104 y ss. Para la Arqueología como referida únicamente al poder ateniense y no al espartano, cf. Luraghi, 2011, p. 190.

${ }^{1009}$ Cf. de Romilly, 1951, p. 137 y ss., especialmente p. 165.

1010 Cf. de Romilly, 1951, p. 172 y ss. Unos líderes que, en el caso de Pericles, simplemente paralizaban una acción de este calado, cf. Cornford, 1907, p. 45.

${ }^{1011}$ Cf. de Romilly, 1951, p. 221 y ss.; p. 231 y ss.; p. 242.

1012 La denominada «nécessité politique», en la que 'necesidad' traduce el concepto de

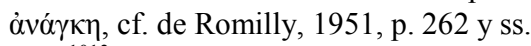

${ }^{1013}$ La desmesura de la hybris, cf. de Romilly, 1951, p. 268 y ss.

${ }^{1014}$ Cf. de Romilly, 1951, p. 280 y ss.
} 
partes «antiguas», mientras que la tercera solo se encuentra en las tardías, lo que permite observar la evolución del pensamiento de Tucídides. ${ }^{1015}$

Con este análisis, de Romilly diferencia de manera clara aquellas secciones que se presentan como tardías, es decir, posteriores al fin de la guerra, que son: la Pentecontecia; ${ }^{1016}$ la segunda parte del discurso de los atenienses en el libro I; en el II, la oración fúnebre, el último discurso de Pericles y su elogio; en el cuarto, ciertos pasajes relativos a Brásidas, el discurso de los melios, y algunos pasajes en el relato de Sicilia referentes a Alcibíades y al imperialismo, cuyo análisis requería del desarrollo completo de la guerra, cuyo resultado final acentuó si cabe la admiración del historiador por Pericles. ${ }^{1017}$

El análisis de de Romilly supone a nuestro entender el cierre de la ya sin salida cuestión tucidídea: ${ }^{1018}$ partiendo del análisis de un concepto clave en la obra, la helenista francesa fue capaz de dar fundamentos sólidos a una cuestión apoyada en ocasiones en afirmaciones o indicios poco fiables, al tiempo que dejaba atrás la trampa que suponía el unir el concepto de la obra como una unidad y la existencia de diferentes estratos de composición. Para esto último, cualquier propuesta siempre será dudosa si no se inserta dentro de un esquema sólido.

\subsubsection{LA CUESTIÓN HOY:}

\section{UNIDAD Y SENTIDO LITERARIO DE LA OBRA}

Libres ya del inmenso aparato crítico relativo a la cuestión tucidídea, pasaremos a examinar la posición de los proemios en la obra y su importancia para la composición de la misma, sin esperar soluciones en exceso brillantes, dado lo complejo del problema.

\footnotetext{
${ }^{1015}$ Cf. de Romilly, 1951, p. 284 y ss.

${ }^{1016}$ Cf. de Romilly, 1951, p. 286.

${ }^{1017}$ Cf. de Romilly, 1951, p. 291, en una idea que recoge la postura de Schwartz, cf. supra.

1018 Los posteriores trabajos, de perspectiva diferente, o de menor importancia por sumarse a las posturas analizadas, los indicaremos en el desarrollo de nuestra aproximación. 
Que la obra debía iniciarse con un proemio es algo claro, y que lo hace de una forma habitual y en nada ajena a los usos de la época parece también claro, a pesar de las ideas de Schwartz al respecto, quien, como Höpken, ${ }^{1019}$ pensaba en I 23 como un proemio antiguo en el que se presentaban elementos habituales en los proemios, cosa que es por completo falsa, dado que no aparece un $\sigma \varphi \rho \alpha \gamma i ́ s$ ni referencias al planteamiento de la obra. Tucídides encabeza su obra con un proemio general y único referido a toda

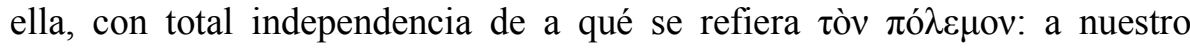
entender, es indiferente qué designa Tucídides con esa expresión, dado que, tanto si hiciese referencia al total de la guerra como solo a los diez primeros años, se habría expresado igual: en ambos casos se trataba de la guerra entre atenienses y lacedemonios, fuese esta de una u otra duración.

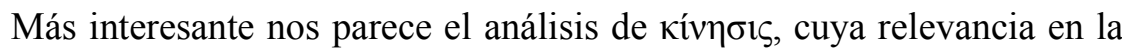
estructura del proemio analizaremos después. El término, es obviamente, de una semántica más importante para el proemio que el anterior: la explicación de la unidad de la Arqueología reside en esta idea, y nos atreveríamos a asegurar que la de gran parte de la obra. Es, a nuestro entender, el concepto clave del proemio, al modo que vimos en la épica y en Heródoto. La aparición de este término, de carácter más general al tiempo que menos técnico, es lo que asegura que la temática de la narrativa tucidídea transcienda una perspectiva únicamente política o militar: solo así podremos comprender secciones como el largo excurso que sigue al segundo proemio.

Respecto a la unidad y posición del proemio y su justificación, la idea de $\alpha$ $\xi \eta \sigma ı \varsigma$ nos parece fuera de lugar, dado que el proemio pone de relieve únicamente valores concretos de importancia para la guerra presente, lo que, dado su valor específico, impide la comparación con anteriores guerras de un modo que llevase a ese intento de amplificatio: la guerra presente fue la mayor conmoción porque, en lo que a Tucídides interesa, que es el imperialismo marítimo -recordemos la propuesta de de Romilly-, nunca estuvieron estos Estados en tal posición, sin entrar en efectivos concretos, ni con tantos nexos de unión entre los diferentes Estados, lo que no ocurría en guerras anteriores.

Por otra parte, hay un error de fondo en la consideración del proemio como un elemento retórico asimilado a la amplificatio, que ya en parte

${ }^{1019}$ Cf. Schwartz, 1969, p. 249 y ss. Véase además la sección relativa a la composición del proemio. 
señaló Connor. ${ }^{1020} \mathrm{El}$ error consiste en hacer del proemio un medio, como lo es en la retórica, que se vale de este elemento para ganar una causa o captar la atención de la audiencia, y ello provoca un serio trastorno en la interpretación de la obra. Si el imperialismo y todo lo que conlleva es un medio, Schwartz nos tendría que decir con qué fin se emplea ese recurso, pregunta que, por supuesto, es imposible en un contexto decimonónico, pero que quizá Hornblower debería plantearse al recuperar la idea. ${ }^{1021} \mathrm{Y}$ es que, a nuestro entender, el imperialismo es el fin mismo, es la idea que hace del proemio la cabeza que organiza el resto de la obra, lo que impide que se convierta en recurso: mucho se cuidaría un Antifonte de confundir la inocencia de un encausado con los posibles medios para defenderla.

Que su redacción es «antigua» lo demostró de Romilly en su análisis; Tucídides sabía muy bien lo que quería exponer, aunque no lo hiciera en exceso patente, ${ }^{1022}$ y la Arqueología da las pautas -como ocurría en Heródoto con el encuentro entre Creso y Solón- de la comprensión de la perspectiva del autor, conviertiéndose así en un elemento codificador de la obra. ${ }^{1023}$ Es imposible determinar si Tucídides puso materialmente por escrito la Arqueología y con ello el proemio ${ }^{1024}$ al inicio de la redacción de la obra, pero sí aseguramos que esas ideas estaban presentes desde el principio en la mente del autor, ${ }^{1025} \mathrm{y}$, si hemos de arriesgarnos y recurrir a los indicios que la composición literaria arcaica nos ofrece, y Tucídides actuó conforme a los usos de la época, este redactó el proemio al comienzo de su labor, cosa que además parece confirmar la fuerte estructuración del libro I. ${ }^{1026}$

${ }^{1020}$ Cf. Connor, 1985, p. 20, quien afirma que carece por completo de los medios habituales de expresión retórica de los proemios.

${ }^{1021}$ Cf. Hornblower, 1991, p. 3. Es algo que, por otra parte, nos permite rechazar sin complejo alguno cualquier posible relación de la historiografía con la oratoria epidíctica; si Cicerón, las une, debemos preguntarnos qué fin asignaba él a la historiografía.

${ }^{1022} \mathrm{Se}$ ha de recordar la interesante idea señalada por Mabel Lang respecto a la direccionalidad del proemio herodoteo, que no apuntaba al final mismo de la obra, sino a algunos aspectos no centrales de ella, cf. Lang, 1984, p. 3. Tucídides concebía su obra como algo muy diferente a la interpretación de Ulrich, que trabajaba desde la interpretación moderna tanto de la historiografía como del conflicto.

${ }^{1023}$ Cf. esta idea de manera algo primitiva ya en Taeger, 1925, p. 15.

${ }^{1024}$ Las pruebas de la unidad del proemio las reservamos para el análisis estructural, cf. infra.

${ }^{1025}$ Recuérdese lo dicho en esta línea por de Romilly, cf. supra.

${ }^{1026}$ Por medio de la consabida Ringkomposition, como concluye Katičič, 1957, p. 196. Fundamentales para el estudio del material de este libro son los apuntes de Badian, 1993, p. 130 y ss., especialmente referidos a la manipulación del contenido. 
Es también esa composición arcaica la que nos permite explicar el brusco paso desde el final del capítulo I 23 a la narrativa propiamente hablando. La composición en prosa del siglo $\mathrm{V}$ nunca solucionó el problema que suponía el unir las diferentes secciones de la obra, como ya vimos en Heródoto y vemos ahora en Tucídides. Los recursos de unión y cohesión de los diferentes elementos formales, creados como pequeñas secciones de un

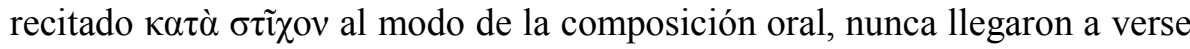
desarrollados en estas etapas iniciales de la prosa compleja y no oral de época clásica. La perfección homogénea de un poema épico viene sustentada por el recitado continuo que permite el paso claro de una parte a otra sin solución de continuidad, creando tiradas de miles de versos sin pausa alguna, por medio del empleo de recursos fosilizados que no tienen sitio dentro de la prosa que nos ocupa. A diferencia de la Ringkomposition, presente de manera formal y principalmente conceptual en el proemio, el empleo de figuras de repetición a nivel estructural, como las que se encuentran entre el canto I y II de la Ilíada ${ }^{1027}$ (las divisiones son alejandrinas, pero no sin sentido), tendrían difícil acomodo en Heródoto y peor en Tucídides, lo que se debe en último término al paso de unos esquemas de composición orales a la aparición de una prosa pensada para ser escrita únicamente.

\subsubsection{EL SEGUNDO PROEMIO}

Más complicado es el caso del denominado segundo proemio: la naturaleza programática de los proemios así como los aspectos formales que los convierten en el medio de inicio de una obra hacen difícil en una época de transición como en la que escribe Tucídides el empleo de más de un proemio. $^{1028}$

1027 Cf. Ilíada, I 609 y ss.: Zev̀ $\delta$ ' $\pi \rho$ ò

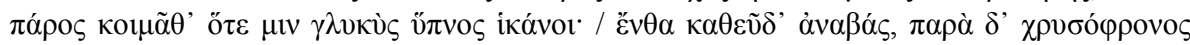

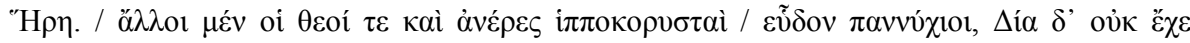

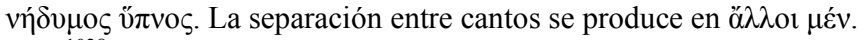

${ }^{1028}$ Reflejemos, aunque sea en nota, nuestro rechazo de la propuesta de Canfora, 1970, p. 42 y ss., de ver en este segundo proemio algo «ajeno» a Tucídides: su sentido e importancia argumental en la obra son esenciales para entender toda la obra. 
La postura de Pohlenz ${ }^{1029}$ y otros de considerar este segundo proemio como una inflexión sin más en la narrativa es difícil de sostener si

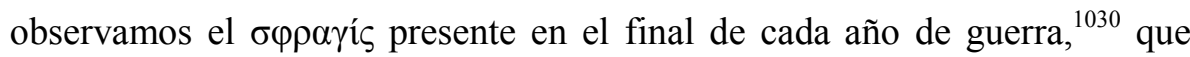

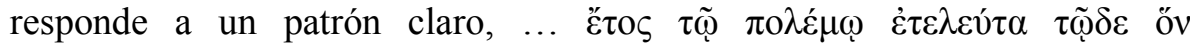

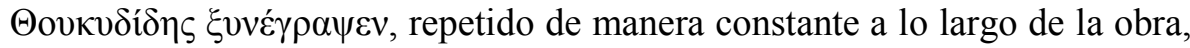
salvo, precisamente, en el final de la guerra de los diez años, en V 24, $\tau \alpha \tilde{\tau} \tau \alpha$

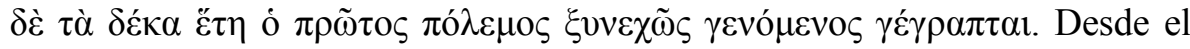
propio tiempo verbal, la denominación de primera guerra así como el adverbio $\xi v v \varepsilon \chi \tilde{\omega} \varsigma$, referido, como señalan Stahl y Gomme a la continuidad de la guerra y no a la labor de escritura, ${ }^{1031}$ plantean problemas a la hora de aceptar la postura que trata de hacer de este elemento uno más dentro de la obra, simplemente porque no lo es.

A ello ha de unirse que es junto con el proemio inicial el único lugar en

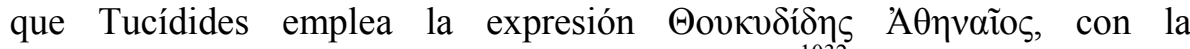
importancia que tiene el $\sigma \varphi \rho \alpha \gamma i$ s en los proemios, ${ }^{1032}$ y el hecho no menos importante que es la presencia de materia programática en el capítulo $\mathrm{V} 26$. Todo ello nos lleva a pensar que estamos ante un verdadero proemio, lo que nos obligará a demostrar su naturaleza como tal y las repercusiones que esto tendrá para la conformación de la obra.

Reservando las cuestiones estructurales internas del proemio para otra sección, ${ }^{1033}$ creemos que Tucídides redactó su obra con la guerra arquidámica como un punto clave de la articulación, no como un final: la idea de la guerra como un total de veintisiete años es algo tardío, pero sin embargo, no es de extrañar que Tucídides admitiera la existencia de dos guerras, simplemente por la obviedad de los hechos, lo que justificaría la

${ }^{1029}$ Cf. supra.

${ }^{1030}$ Nos causa dudas la propuesta de Canfora, 1970, p. 18 y ss., de ver en estas marcas cesuras de carácter ecdótico: a nuestro entender, nos encontramos todavía en una etapa en que la naturaleza si se quiere torrencial de las composiciones literarias hace innecesarias estas divisiones -véase el caso de las composiciones homéricas que Canfora aduce en p. 20-, al menos como algo normativo. Creemos que se trata de una pauta polémica, sin más, dentro de la obra, un asomarse del autor sosteniendo esa importancia de lo subjetivo que aparece ya desde el proemio. La famosa división en trece libros sería, de este modo, una división más dentro de las posibles; para los datos de esta organización cf. Canfora, 1970, p. 51 y ss.

${ }^{1031}$ Cf. Poppo y Stahl, 1879, p. 55; Gomme, 1956, p. 696 y ss.; Luschnat, 1970, col. 1191 y ss. Nótese además la posición del adverbio. Sorprendentemente, Hornblower, 1991, no dice nada al respecto.

1032 Cf. Hornblower, 2008, p. 46.

${ }^{1033}$ Cf. apartado 5.2. 


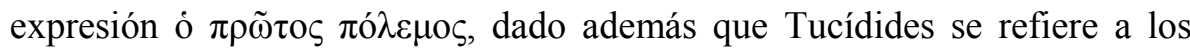
veintisiete años no como ó $\pi \delta ́ \lambda \varepsilon \mu o \zeta$, entrando así en el debate estéril de Ulrich, sino como $\tau \grave{\alpha} \xi u ́ \mu \pi \alpha v \tau \alpha$ (V 26, 1), lo que, a nuestro entender hace pensar en más de una guerra, idea que, por otra parte, era la habitual en la época.

Así, que Tucídides asumió desde el comienzo la segunda parte de la guerra como una guerra es algo claro, lo que parece más difícil es que asumiera la paz que medió entre ambas partes desde un comienzo como una etapa de actividad bélica, dado que ello requería valorar de manera profunda la significación de las maniobras diplomáticas por medio de terceros que llenan el libro $\mathrm{V}$, así como la verdadera significación de los combates en Mantinea y Epidauro. ${ }^{1034}$ Asumir la significación de un suceso como el de Melos, que pasó desapercibido en la época, como demostró de Romilly, ${ }^{1035}$ supone de nuevo actuar desde una perspectiva global que queda muy lejos de los primeros diez años de la guerra y de una fecha temprana de redacción, dado que son estos algunos de los episodios más importantes para la determinación de la articulación general de la obra y de los conceptos que la estructuran: el diálogo de los melios supone una idea de imperialismo difícilmente perceptible desde una fecha temprana, lo que, obviamente, quiere decir que pensamos en una redacción general tardía.

En lo formal, se han de desechar las opiniones que apuntan a $V 25$ y 26 como una unidad: ${ }^{1036}$ V 26 es el comienzo del proemio, y V 24 el final de la primera parte, por lo que la posición de V 25 es complicada. A nuestro entender, es simplemente una clavija o elemento estructural que facilita la unión de ambas partes, de ahí las dificultades formales que causa, ${ }^{1037}$ pero la unidad de las diferentes partes parece, a nuestro entender, clara.

Westlake propuso considerar V 25 y 26 como dos posibles opciones para un segundo prólogo conservadas, sin que el historiador decidiera cuál de las dos era la definitiva. ${ }^{1038}$ La premisa de la que partía para esta consideración

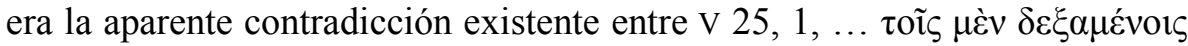

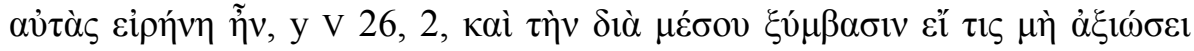

\footnotetext{
${ }^{1034}$ Como reconoce Tucídides, v 26, 2.

1035 Cf. de Romilly, 1951, p. 237 y ss., quien recuerda que el hecho fue más causa de mofa que de consternación, como lo demuestra Aristófanes, Aves, 186.

${ }^{1036}$ Así, Pohlenz, 1965, p. 257.

${ }^{1037}$ Respecto a v 25, cf. Gomme, Andrewes y Dover, 1970, p. 5.

${ }^{1038}$ Cf. Westlake, 1972, p. 15, proponiendo una cronología reciente para el capítulo 26.
} 


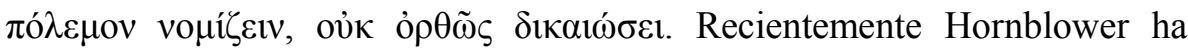
apoyado esta idea ${ }^{1039}$ y ha disculpado la supuesta contradicción recurriendo a una teórica corrección al ritmo de la composición de la obra, pero la solución es tan simple como leer detenidamente el texto.

$Y$ es que, a nuestro entender, estamos de nuevo ante un exceso de labor crítica como los que desarrollamos y rechazamos antes, porque lo que Tucídides dice en el primer pasaje, y citamos el pasaje completo, es: $\tau$ oĩ $\mu \tilde{\varepsilon} v$

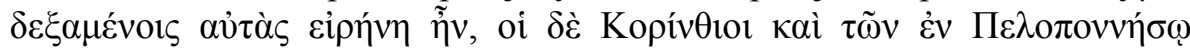

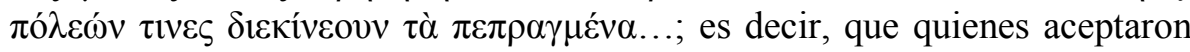
el tratado estaban en paz, pero había excepciones, lo que lleva al historiador a considerar que no fue un periodo de paz: Westlake y Hornblower se sitúan, simplemente, en la óptica de los contemporáneos de Tucídides, y no tienen en cuenta la visión particular del autor.

Asumida, pues, la unidad de estos capítulos y su pertenencia al proyecto final, el carácter de clavija de V 25 se ve apoyado por la repetición

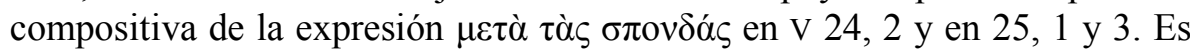
más, nos arriesgamos a sostener que el pequeño resumen presente en $\mathrm{V} 25$ es un puente entre esta primera guerra y la segunda, ${ }^{1040}$ pues tiene un largo recorrido, por lo que posteriormente será el contenido de la narrativa de los diez años de paz; la breve narrativa de $\mathrm{V} 25,1-2$ se presenta como algo diferente a una guerra manifiesta, dado que, concluye Tucídides, $\check{\pi} \pi \varepsilon \imath \tau \alpha$

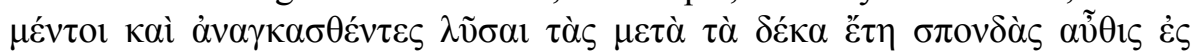

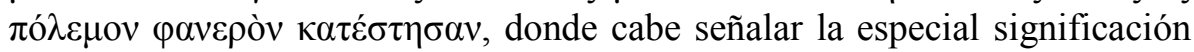
de términos como $\alpha \tilde{v} \theta 1 \varsigma$, que nos hace pensar en dos guerras, $\mathrm{y}$, principalmente, en el calco clarísimo de esta expresión respecto al final del

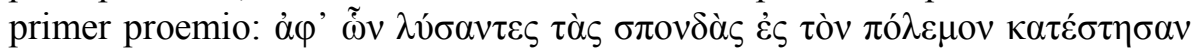
(I 23, 6). Sin embargo, aquí no comienza la narración, sino que se sucede un proemio que defiende, como contenido programático propio del mismo, la

${ }^{1039}$ Cf. Hornblower, 2008, p. 41 y ss.

1040 Véase, por ejemplo, el comienzo del libro II y III de Heródoto, que engloban la

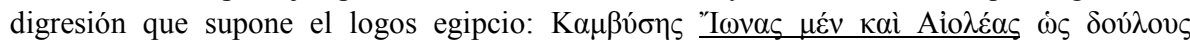

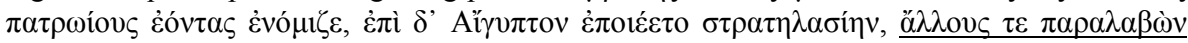

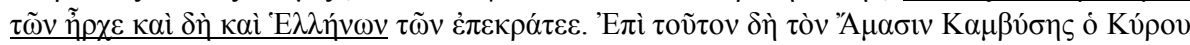

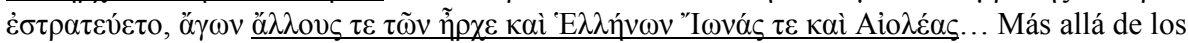
paralelos claros, parece interesante señalar la intención de indicar la meta a conseguir en la narración. Aquí se trata de un caso claro de Ringkomposition, pero en Tucídides es un paso más en la evolución de la estructura arcaica, no hay paralelo verbal, pero sí indicios de lo que se va a narrar. 
narración del periodo de paz unido al de la segunda guerra, lo que nos lleva a considerar el significado de $\tau \alpha \tilde{\tau} \tau \alpha$, al comienzo de $\mathrm{V} 26$, parejo al de V 24, 2 , con sentido anafórico, lo que a su vez nos lleva a considerar el significado del presente en el capítulo 26 como referido al breve resumen del tiempo de paz del capítulo anterior. A todo ello se ha de sumar la presencia de un кaí adverbial, hecho que da idea de la intención de éste segundo proemio, «ha escrito también esto...», hasta la caída del Imperio ateniense. La unidad es innegable.

Se nos plantean dos posibilidades: que Tucídides no hubiese asumido desde el inicio la narración de la paz de Nicias como una realidad bélica perteneciente al esquema general del enfrentamiento, idea que ya hemos tanteado; o, lo que nos parece más interesante, que Tucídides defendiese con decisión esta idea frente a un ambiente polémico que opinaba lo contrario. La segunda opción es la que presentaría mayores facilidades para comprender la función del proemio y la continuidad con el resto de la narración, dado que adquiriría una funcionalidad semejante a la presente en el primer proemio y permitiría explicar la reaparición de un esquema como tal en esta segunda parte.

Así, tras exponer a grandes rasgos sus ideas de carácter polémico y su experiencia personal, pasamos a la narración como tal en V 27, con la particularidad, no señalada habitualmente por los comentaristas, y menos recogida aún por los traductores, de presentar un $\gamma \alpha$ ó solo justificable si tenemos en cuenta el carácter polémico del proemio, constituyéndose toda la narración de la paz de Nicias en una suerte de excurso probatorio del segundo proemio, que no acertamos a limitar en su final, si bien no resultaría imprescindible un nuevo proemio justificativo que estableciera ese final, pues para la guerra decélica no sería necesario un nuevo proemio, o, lo que es lo mismo, una nueva justificación, dado que todavía tendría validez el

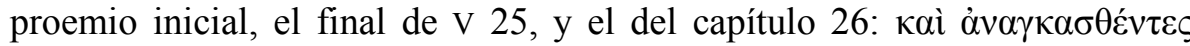

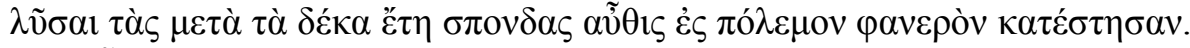

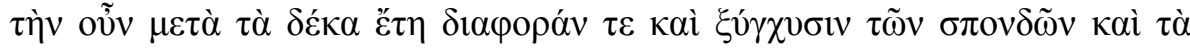

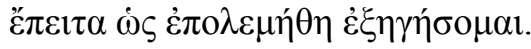

Respecto a la cuestión de si el segundo proemio nos permite aportar algún dato respecto a la composición de la obra, hemos de señalar que el proemio no responde a una nueva obra, dado que la continuidad entre las tres secciones está asegurada, continuidad basada en criterios arcaicos de 
composición ${ }^{1041}$ que impedirían el percibir cualquier brecha estructural si es que existiese. Tucídides presenta un proemio en tono marcadamente polémico con el fin de justificar la narración de la paz de Nicias como un periodo de guerra: aducir el perfecto $\gamma \dot{\varepsilon} \gamma \rho \alpha \pi \tau \alpha^{1042}$ como prueba de que V 24 supone el cierre claro de una sección es insostenible, debido a su aparición en un pasaje que poco tiene que ver con el final de una sección como es $\mathrm{V}$ 20, 3: en este contexto se hace referencia a la obra ya escrita desde la perspectiva de la propia obra, como ocurre, precisamente, en el segundo proemio, a diferencia de lo que sucede en el primero, en el que el autor se sitúa fuera de esa perspectiva. ${ }^{1043}$

Todo ello hace imposible fundamentar algún cambio en la configuración de la obra a partir de este pasaje, o tomarlo como testimonio de que Tucídides haya retomado su obra, ${ }^{1044}$ dado que el segundo proemio en su estado presente no responde a la intención de escribir algo diferente a lo anterior, o de modificar los criterios expuestos en el primer proemio: simplemente, persigue justificar la narración de las tres secciones de la guerra como un todo.

Así, si atendemos a la naturaleza primariamente polémica de los proemios historiográficos, pronto asumiremos cuál es la función del mismo. Ya hemos indicado que los testimonios antiguos nos confirman la idea de que la concepción de la guerra como una unidad era algo propio de Tucídides; a este respecto, es interesante la conclusión de Grundy, quien, tras reseñar los testimonios, afirma que la unidad de la guerra no era defendida ni por sus contemporáneos ni por sus sucesores. ${ }^{1045}$ Tanto la guerra arquidámica como la segunda guerra, o incluso el conflicto siciliano, eran considerados como entidades independientes, lo que, por otra parte, no es de extrañar si asumimos que los contemporáneos tendrían incluso decretos para dar testimonio de la conclusión de las diferentes guerras, como el propio Tucídides prueba.

${ }^{1041}$ Como los presentes en la conclusión de la Ilíada y que entroncaban este poema con la narración de las amazonas. En último término, es un recurso que observamos en el final del proemio de Heródoto y el comienzo de la narración, y que ya señaló Fränkel, 1960b, p. 83.

${ }^{1042} \mathrm{O}$ incluso como prueba de que la obra quedó completa, como quería Müller-Strübing, cf. Luschnat, 1970, col. 1112.

${ }^{1043}$ Cf. Poppo y Stahl, 1886, p. 59; Hornblower, 2008, p. 45.

${ }^{1044}$ Así, Westlake, 1972, p. 13.

1045 Cf. Grundy, 1948, p. 391 y ss., quien recoge los testimonios aportados ya desde el comienzo de la cuestión por Ulrich, 1846, p. 9 y ss. 
El estudioso inglés verifica que en los primeros años del siglo IV a. C. la opinión general bascula hacia un mayor peso del segundo conflicto frente a la guerra arquidámica, obviamente por el resultado de la segunda, y el propio Aristófanes, en la Paz, del 421, defiende una guerra, asimilable a la arquidámica, de un total de trece años, lo que nos lleva a la batalla de Leucime del 434, ${ }^{1046}$ mientras que Platón no solo diferencia las dos guerras, sino que incluso considera en el cómputo la primera guerra peloponésica, la del 459 al $446,{ }^{1047}$ y lo mismo ocurre con los oradores del siglo IV a. C. ${ }^{1048}$ Solo la dependencia más o menos directa de la opinión de Tucídides por parte de los historiadores de periodos posteriores hará triunfar la opción de Tucídides de considerar la existencia de una sola guerra, lo que lleva a Hunter, apoyándose en Grundy, a tantear una posible justificación del segundo proemio en estos términos, ${ }^{1049}$ cosa que creemos haber demostrado.

Teniendo presente este carácter innovador y polémico de la opción elegida, y habida cuenta de la naturaleza de los proemios como elementos de presentación de ideas polémicas, ${ }^{1050}$ no cabe duda de que el proemio presente en $\mathrm{V} 25$ es un proemio como tal, pero no un proemio desde la óptica moderna, que considera la especialización de esta sección en iniciar una obra literaria: simplemente, supone el establecimiento de un eslabón más en la cadena del pensamiento tucidídeo que persigue la defensa de una idea personal. Así como la narración de la historia se fundamentaba en la percepción por parte de Tucídides de la grandeza de la guerra, la narración de la paz de Nicias tiene como sustento la opinión vertida en el segundo proemio, y ello justifica la aparición de un $\gamma \alpha$ á cuya función es introducir la justificación de esa idea polémica, la propia narración de los hechos. ${ }^{1051}$

Obviamente, esto nos llevaría a una posición unitaria, y rápidamente nos saldría al paso la pregunta ya planteada por Ulrich en torno al porqué de la

${ }^{1046}$ Cf. Aristófanes, Paz, 990 y ss.

${ }^{1047}$ Cf. Platón, Menéxeno, 242e.

${ }^{1048}$ Cf. Grundy, 1948, p. 393, nota 5, para los testimonios.

1049 Cf. Hunter, 1977, p. 278.

${ }^{1050}$ Dover consideraba que la aparición del segundo proemio se debía a que el primero solo era válido para la narración de las guerras entre atenienses y espartanos, lo que dejaría fuera la narración de la paz de Nicias, lo que nos parece difícil de sostener, si bien Dover ya tenía suficiente con atacar la postura excéntrica de Canfora, cf. Gomme, Andrewes y Dover, 1981, p. 433 y ss.

${ }^{1051}$ Sobre la especial naturaleza de esa narración y la importancia del proemio en ella, cf. Rood, 1998, p. 87. 
falta de delimitación de la guerra en el primer proemio. ${ }^{1052}$ A nuestro entender, la respuesta a esta pregunta pasa por el mismo proemio inicial y su contenido: en él no se señala que se vaya a narrar la guerra por estar también integrada por los tiempos de la denominada paz de Nicias y la posterior guerra, sino que el interés de la misma parte del hecho de que ambos contendientes estaban en su máximo apogeo y de que fue una auténtica conmoción para el mundo conocido. Parece poco convincente el afán de precisión semántica de los críticos al tratar de buscar en Tucídides definiciones o denominaciones concretas cuando era uso general de la época el no usarlas. ${ }^{1053}$ El propio desarrollo de la narrativa es el que introduce en cada ocasión la puntualización concreta, y no nos cabe duda de que una observación cuantitativa en torno a la guerra en el primer proemio está fuera de lugar, como demostró Classen. ${ }^{1054}$

Como antes anticipamos, seguramente la pregunta fundamental a este respecto sea cuál es el final del excurso comenzado tras el denominado segundo proemio, ${ }^{1055}$ y la respuesta sería tan simple como afirmar que el fin de la narración de la paz de Nicias, pero no existe un tercer proemio que retome la narrativa, $\mathrm{y}$, si bien parecería lo más fácil el afirmar que simplemente pertenece a esas secciones que quedaron por escribir, la respuesta es más simple y quizá más segura si partimos del análisis estructural y de la caracterización de la composición arcaica que vimos desarrollada sobre el proemio homérico o el herodoteo.

Desde el mismo catálogo de las naves del canto II de la Ilíada sabemos que en la composición arcaica oral el torrente narrativo podía modificarse o,

${ }^{1052}$ Cf. Grundy, 1948, p. 415 y ss.

1053 A modo de ejemplo, compárese Grundy, 1948, p. 391 y ss., en la que da cuenta del caos existente en la época a este respecto, y p. 415 y ss., en la que se echa de menos la aparición en Tucídides de esas denominaciones.

${ }^{1054}$ Classen, 1879 , p. XLIV y ss., especialmente nota 52, respecto a oĩ $\alpha$.

${ }^{1055}$ La propia paz de Nicias y su conclusión es un problema sin aparente resolución que pasa en la actualidad por la modificación del texto transmitido, variando el periodo de seis a siete años, una propuesta de Krüger, quien actúa a su vez siguiendo a Acacio, cf. e. g. de Romilly, 1973, p. 189; en contra, Hornblower, 2008, p. 48, quien se basa en gran manera en la postura de Gomme, Andrewes y Dover, 1970, p. 6 y ss., y señala que vi 105 es difícilmente datable al detalle, pasaje que, como a Hornblower, nos parece el más lógico; el propio

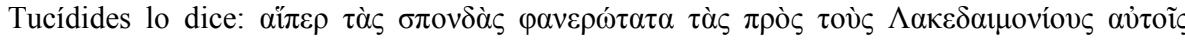
Ě $\lambda v \sigma \alpha v$. Insistimos en que una fuerte marca de la reanudación de las hostilidades es más importante para nosotros que para Tucídides, que asume todo el periodo como una unidad. La idea de la imprecisión de las fechas puede verse ya en Poppo y Stahl, 1879, p. 57. 
simplemente, redirigirse con facilidad, de modo que el desarrollo de la narración podía verse enfocado hacia temas que supusieran una digresión clara, algo habitual y que en el caso del catálogo se realiza por medio de la introducción de una fórmula de entrada especial, un proemio, que permite al autor reforzar tanto la unidad de lo recién introducido como las ideas que ello puede aportar.

Si esos inicios tienen entidad de proemio, ha de destacarse que la propia naturaleza, si se quiere, torrencial de la composición favorece el hecho de que no haya finales claros: la obra de Heródoto jamás tuvo ni podría tener una conclusión formal, ni las epopeyas antiguas, que terminaban cuando el aedo así lo quería, y se extendían, como demuestra el verso final de la Ilíada, cuando el autor lo deseaba. De este modo, las obras de configuración arcaica se asemejan a un continuo en el que pueden aparecer cuantos comienzos -o proemios- quiera el autor, para matizar, resaltar o adecuar la narración según las necesidades, pero esos comienzos siempre desembocan, sin fórmula de transición formal, en el desarrollo general de la narración, que es siempre única. ${ }^{1056}$

Por ello, el segundo proemio tucidídeo supone una marca que busca clarificar la postura polémica del autor ante la paz de Nicias, ${ }^{1057}$ y esa idea de continuidad conceptual expresada por Tucídides en lo concerniente a la guerra se reproduce formalmente en la narrativa de la obra, de modo que la justificación de ese segundo proemio, y con él el excurso explicativo, se funde sin solución de continuidad con el resto de la narración. Tucídides así veía la guerra, y defendía que los acontecimientos desde el 431 hasta la caída de Atenas conformaban un continuo; si hubiese añadido un final a la narración de la paz de Nicias y un nuevo proemio a la guerra decélica, esto tendría que verse causado, según venimos defendiendo, por una variación de la interpretación inicial o una opinión de carácter polémico, pero no por el inicio de un nuevo periodo, pues la continuidad se apoya en el empleo de las divisiones en inviernos y veranos, que no abandona. ${ }^{1058}$

${ }^{1056}$ Lo que nos lleva a confluir con las ideas de Marincola, 1985, p. 63, nota 9, quien defendía la existencia de un solo proemio por obra, cosa que, con las puntualizaciones señaladas, aceptamos.

${ }^{1057}$ Y no la capacidad del autor para esta labor, como quería Marincola, 1985, p. 65.

${ }^{1058}$ Como indica Tucídides, v 26, 1. Ha de recordarse que es este uno de los rasgos más propios de la obra de Tucídides, que encontraremos en sus imitadores del siglo IV a. C., a pesar del malestar de Dionisio de Halicarnaso, Sobre Tucídides, IX. 
A este respecto, es interesante observar el gran excurso que supone la Pentecontecia. Aquí sí hallamos marcas iniciales y finales, oi yà $\rho$

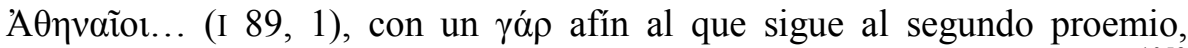
reconocido por Classen y Steup como marca de inicio de una digresión, ${ }^{1059}$ en tanto que la conclusión se señala por medio del enlace de la narración de la Pentecontecia con el punto cronológico en el que se encuadra (I 118, $2){ }^{1060}$ pero el caso es muy diferente. En la Pentecontecia no hay polémica abierta y clara, como demuestran los testimonios recogidos por Ulrich y recuperados por Grundy, y, lo que es más importante, su narración supone una brusca ruptura en el eje cronológico, ${ }^{1061}$ clave en la estructura de la obra, cuyo desarrollo lineal es paradigmático, ${ }^{1062}$ cosa que no ocurre en los capítulos que siguen al denominado segundo proemio.

Ello nos lleva a considerar que, como venimos defendiendo, el segundo proemio no supone una ruptura de la narración, como sí lo es la Pentecontecia, presente únicamente, más allá de las puntualizaciones respecto a detalles aportados por otros autores -que en ocasiones se nos escapan por lo escaso de los textos conservados-, para dar perspectiva a la idea del máximo grado de poder de ambos contendientes, es decir, la idea recogida por el proemio inicial.

La dificultad causada por el aparente estado de falta de revisión de los capítulos que restan hasta al menos la batalla de Mantinea es, seguramente, otra de las claves de nuestra propuesta. Como hemos visto en nuestro rápido examen de la cuestión tucidídea, la crítica se ha ocupado poco de este libro, seguramente partiendo de su supuesta redacción tardía, causada por la palinodia que llevó a Tucídides a reinterpretar la paz de Nicias como un periodo bélico, y es esta una carencia mantenida en gran medida hasta

${ }^{1059}$ Cf. Classen y Steup, 1963, I, p. 243

${ }^{1060}$ Cf. Hornblower, 1991, p. 194.

${ }^{1061}$ Cf. Gomme, 1950, p. 362 y ss. Gomme pensaba que la falta de fechas se debía a que se trataba de una parte sin revisar. A nuestro entender, Tucídides no perseguía narrar el periodo como si se tratase de una parte más de su obra, sino que es simplemente una serie de puntualizaciones a las narraciones ya existentes al respecto, y sobre todo, una narración de

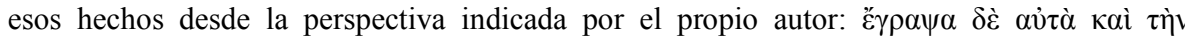

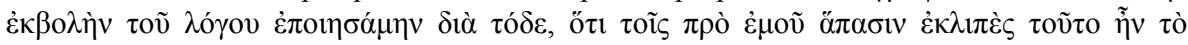

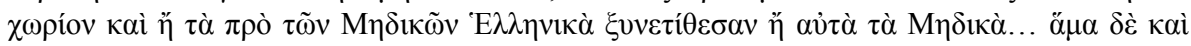

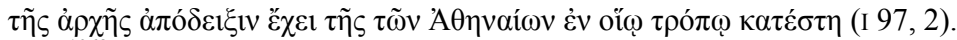

${ }^{1062}$ Cf. Hornblower, 2004d, p. 139 y ss. 
nuestros días. ${ }^{1063}$ El supuesto estado inconcluso pasa por la falta de discursos, y en menor grado por la narrativa poco lineal de los capítulos, especialmente hasta la batalla de Mantinea, una obra maestra de este tipo de narraciones y que cierra una sección a partir de la cual los problemas parecen, al menos en apariencia, superados hasta el diálogo de los melios, cuyo estado de conclusión está fuera de toda duda. Todo ello engloba una sección de la obra que Andrewes consideraba que podría ajustarse a la narrativa de esa paz falsa, dado que en los libros VI y VII asistimos ya a una narrativa bélica clara. ${ }^{1064}$ Además, no hemos de olvidar que es difícil, por no decir imposible, discernir con facilidad hasta qué punto no hemos de leer determinados pasajes de Tucídides con la vista puesta en obras que no han sido conservadas con el paso del tiempo, por lo que, como ya señaló Hornblower, ${ }^{1065}$ hemos de preguntarnos si muchos de esos fallos menores en la narración, los silencios, los énfasis en apariencia improcedentes, no han de ser entendidos en una perspectiva ya perdida para nosotros. El carácter polémico del pasaje puede ser, a nuestro entender, la clave para esa dificultad: más que una historia general y completa, una historia, hay que decirlo, soñada por los historiadores modernos, Tucídides buscaba defender su idea, y para ello solo hacía falta poner el acento en determinados aspectos de su narrativa, como las maniobras ocultas y las actuaciones bélicas.

La reciente aparición del excelente y documentado trabajo de Carolyn Dewald ha arrojado luz acerca de la organización estructural de la narrativa del periodo de paz. Señala la autora la clara distinción existente entre la organización de la narrativa arquidámica en lo relativo al detalle y aquellos aspectos que están vinculados con la temática de la narración. La falta de grandes escenas provoca la atomización de la narración en unidades de menor tamaño y simplicidad, ${ }^{1066}$ al tiempo que se mantienen los recursos estructurales generales que se emplearon a lo largo de toda la parte anterior, ${ }^{1067}$ lo que lleva a la autora a señalar la continuidad de la estructura

${ }^{1063}$ Cf. Hornblower, 2008, p. 2 y ss., para un estado de la cuestión. Salvo el caso del segundo proemio, y el lógico interés por los documentos, no hay pasajes de especial importancia para la polémica entre unitarios y analíticos.

${ }^{1064}$ Cf. Gomme, Andrewes y Dover, 1970, p. 9.

1065 Cf. Hornblower, 2004d, p. 155 y ss.

1066 Cf. Dewald, 2005, p. 121 y ss., con los datos estadísticos. El número de unidades narrativas de menos de 25 líneas se eleva al $80 \%$ del total, frente al $55 \%$ anterior, en tanto que el número de unidades simples pasa de un $20 \%$ a $43 \%$.

${ }^{1067}$ Cf. Dewald, 2005, p. 116 y ss. Se mantiene lo que nos parece más relevante, el propio Tucídides lo recuerda en $\mathrm{v} 20$, la división en años y estos en veranos e inviernos. 
general salvo en los detalles ya mencionados, ${ }^{1068}$ y nos permite dar más peso a la postura que presentamos.

La falta de discursos se puede ver justificada por la naturaleza del periodo, en el que las gestiones diplomáticas se realizaron de manera ajena al funcionamiento de las instituciones abiertas, en las que sí se presentan como pertinentes los discursos. Pero aún hay más: los temas expuestos no tenían, a nuestro entender, interés para la narración tucidídea, a diferencia de lo que ocurre con el diálogo de los melios, que corresponde ideológicamente, y por ello formalmente, al primer proemio, ${ }^{1069}$ con lo que obviamente asumimos un fuerte valor estructural de los discursos, incompatible por completo con la naturaleza de la narrativa: no olvidemos que el $\gamma$ ó $\rho$ hace de todo este pasaje un discurso funcional, de modo que la aparición de otro como tal sería introducir la valoración de Tucídides dentro de una valoración, lo que es por completo imposible, tanto como introducir un discurso en la Arqueología, o un discurso dentro de otro discurso.

En conclusión, trazar la línea que separa la paz de Nicias de la guerra decélica es imposible, y ello es así porque Tucídides perseguía precisamente esto. Es imposible señalar si el de Óloro pensó desde un inicio en la paz de Nicias como un periodo de guerra, lo que sí es claro es que desde V 24 hasta el final de la obra, más allá de los problemas que se acumulan a nivel de detalle, ${ }^{1070}$ la obra es una y escrita de manera continua, al menos hasta el libro VIII: ${ }^{1071}$ nada hay que nos lleve a pensar en variaciones de pensamiento, cuya linealidad debemos en gran parte a de Romilly, pero tampoco hay variaciones de tipo formal, y de una manera creemos más argumentada hemos de dar la razón a Classen: el segundo proemio solo es una inflexión -polémica, añadiríamos nosotros- en el continuo de la narración de la guerra, de modo que es el carácter personal y polémico del proemio el que más peso tiene en este caso. Tucídides quería expresar su opinión personal

${ }^{1068}$ Cf. Dewald, 2005, p. 143: « In V 25-VI 7 the narrative arrangement does not break away entirely from the Archidamian model». Y p. 156: «[...] books V-VIII are not merely imperfect sketches of something whose finished version would resemble books II, 1-V 24, but rather new kinds of narrative organization».

${ }^{1069}$ Cf. de Romilly, 1951, p. 240.

${ }^{1070}$ Insignificantes, como reconoce Andrewes, cf. Gomme, Andrewes y Dover, 1981, p. 376 y ss. en el libro v, y ni siquiera planteados en los libros VI y VII.

${ }^{1071}$ Que consideramos inconcluso, pues no hallamos razón para los fallos señalados por la crítica. 
sin romper la narrativa, y los medios de expresión que empleaba facilitaron la adecuación entre fondo y forma.

Antes de terminar, no podemos pasar por alto los aspectos cronológicos del problema. En el repaso al trabajo crítico sobre la cuestión hemos recogido las principales fechas propuestas, pero, aun a pesar de que en tiempos no muy lejanos ${ }^{1072}$ se han hecho estudios sólidos, antes de seguir cabe preguntarse por la forma en que Tucídides dio a conocer su obra. Tucídides no es Heródoto, parece que no hay cabida para cuestiones orales en su obra, pero olvidamos que son relativamente pocos los años que los separan, y que si, según vimos, Heródoto era un autor difícil, aún más lo es Tucídides. Ulrich, que ofrecía fechas concretas para la redacción de las diferentes partes, pensaba en un modelo de publicación de carácter moderno, pero no es osado considerar que el modo de distribución de la obra de Tucídides fuese idéntico al herodoteo. La propuesta de una primera redacción solo es comprensible si pensamos que la obra empezó a ser copiada y vendida, y que más tarde añadió el autor la segunda parte con las modificaciones en la primera parte, pero se nos hace difícil creer que en el siglo $\mathrm{V}$ a. C. se pudiera trabajar así.

Que la obra nació con vistas a un público muy reducido ${ }^{1073}$ es una tesis que ya hemos defendido con Heródoto, idea que en cierta manera está latente en la consideración alusiva, precisamente, del proemio, ${ }^{1074} \mathrm{y}$ es esto lo que impide suponer que pudiese realizarse un copiado masivo de la obra, por lo que habría que pensar en una difusión de la misma por medio de lecturas personales, trabajando seguramente con un manuscrito único, una de las claves para entender el porqué de la falta de título para las obras antiguas: las tragedias requerían título, como las comedias, al tiempo que las piezas corales se identificaban por el destinatario, pero en el caso de una obra como la de Tucídides, única, es simplemente la obra de Tucídides, su libro, como vimos que lo eran la multitud de tratados sobre la naturaleza asimilados simplemente a su autor.

${ }^{1072}$ Cf. Hunter, 1977, p. 294, quien propone una fecha de revisión posterior al 410, lo que da cuenta de que esta no es cuestión solo del siglo XIX.

${ }^{1073}$ Obviamente, no se ha de pensar en perspectivas idealistas que tengan en cuenta a las generaciones futuras de lectores, como planteaba Cornford, 1907, p. 3.

${ }^{1074}$ Cf. Luraghi, 2000, p. 231, lo que nos recuerda de nuevo que hemos de antender a la obra en un contexto mayor. 
Partiendo de esta forma de difusión, la escritura se entiende que responde a un borrador vivo: las modificaciones no se realizan sobre un texto ya publicado -lo que, por otra parte, nos abriría un mundo textual semejante al homérico-, sino sobre el original del escritor, y en todo este proceso no hemos de olvidar el importante papel que representa la memoria, dadas las dificultades que plantea el ámbito material en todo ello. Tucídides no podría localizar fácilmente un pasaje exacto, y seguramente tendríamos que pensar en una gestación de lo que después escribiría en la mente misma del autor, de modo que los supuestos borradores, recurso de una sociedad con fácil acceso a los medios de escritura, entran en contradicción con la metodología y los recursos antiguos.

Respecto a las posibles redacciones, propuestas incluso en tiempos no precisamente decimonónicos, ${ }^{1075}$ es peligroso trabajar con argumentos ex silentio (respecto a Tucídides no hay constancia alguna de ellas en la Antigüedad), si bien sabemos de casos como el del Hipólito de Eurípides, ${ }^{1076}$ noticia que en el caso de Tucídides no existe, pero sí tenemos información de que pronto causó cierta confusión a los antiguos el estado de la obra, lo que dio lugar al nacimiento de la leyenda de Tucídides, ${ }^{1077}$ innecesaria si para un antiguo hubiesen existido dos ediciones de la obra, que habrían servido para explicar la dificultad existente y habrían dado, sin duda alguna, un enfoque diferente al acercamiento a la obra por parte de los antiguos.

Con todo ello creemos que ha de tomarse en consideración la idea que Hunter y antes Grundy intuyeron para el segundo proemio, al tiempo que damos por superadas las dificultades que la redacción del primer proemio presenta, para lo que remitimos al capítulo relativo a la estructura. Los proemios de la obra son, sin duda alguna, ejemplos paradigmáticos de lo que era un proemio historiográfico en el siglo $\mathrm{V}$ a. C., un recurso formal polémico. ${ }^{1078}$

1075 Cf. Hunter, 1977, p. 283, quien además propone una redacción inversa, es decir, la segunda parte antes que la primera, lo que, aunque Hunter no lo diga, es la teoría de Cwiklinski, cf. supra.

${ }^{1076}$ Cf. las indicaciones de Barret, 2001, p. 18 y ss.

${ }^{1077}$ Cf. supra, apartado, 5.1, el análisis que Wilamowitz hizo de esas tradiciones.

1078 Aspecto de especial interés no solo para la configuración interna del género, sino para el diseño del panorama general literario de la época, cf. Thesleff, 1966, p. 103, en referencia a lo que denomina panfletos, nombre bajo el que se recoge una poco homogénea producción en prosa que va desde La constitución de los atenienses del Pseudo Jenofonte, al tratado Sobre el coro de Sófocles. 


\subsection{La estructura interna del proemio: unidad arcaica y razonamiento polémico}

El estudio de la estructura general del proemio nos lleva por un instante de vuelta a la cuestión tucidídea: la importancia de la posición y de la función de los proemios se ve desarrollada en el análisis de la estructura interna del proemio general. De nuevo las posturas de los críticos han generado teorías enfrentadas que se han plasmado en imágenes realmente distorsionadas del proemio.

Las ideas desarrolladas en el círculo de Wilamowitz ${ }^{1079}$ se recogieron en la tesis doctoral de Höpken, dedicada por completo al proemio general y que incluye ideas ya defendidas, como indicamos, por Schwartz y Cwiklinski, como la muy importante de escindir la Arqueología como un añadido posterior, pero anterior, claro está, a la segunda etapa de redacción de la

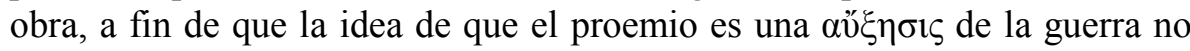
entrase en contradicción con la duración de la guerra, aunque, apoyando así a Schwartz frente a Cwiklinski, se defienda que en el proemio se conoce ya la etapa siciliana de la guerra, un argumento presentado quizá con poca solidez. ${ }^{1080}$

Tras el análisis del capítulo I 1, 1, Höpken determina con buen tino la unidad conceptual que supone I 2, 2 y siguientes, dado que «cognoscimus Thucydidem gravissimam sententiam in initio ponere et singulas explicationes aliam ex alia pendentes postea adserere», ${ }^{1081}$ lo que demuestra

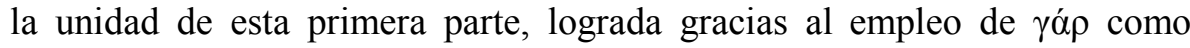
elemento de unión entre los diferentes segmentos, con una semántica explicativa. $^{1082}$

1079 Cuyo mayor representante fue Eduard Schwartz, con el trabajo ya indicado, que supone, a nuestro entender, la culminación de la labor emprendida por Wilamowitz en diferentes artículos.

${ }^{1080}$ Cf. Höpken, 1911, p. 6 y 10.

${ }^{1081}$ Cf. Höpken, 1911, p. 12.

1082 Cf. Höpken, 1911, p. 11: «Nam particula yó $\rho$ non causam addit sententiae antecedenti, sed explicationem». 
Pero los problemas comienzan con el examen posterior. Antes de entrar en la Arqueología, Höpken señala que con el capítulo I 22 termina lógicamente el proemio, y que lo esperado es ya la narrativa de la guerra, si bien encontramos de nuevo un capítulo proemial. La solución que propone sigue la idea general de Cwiklinski de considerar el capítulo en cuestión como perteneciente a un estadio anterior del proemio, que nada tiene que ver con I 1-22, sino que simplemente sería un esbozo de la primera intención del autor. ${ }^{1083}$

En lo que a la Arqueología respecta, el análisis estructural e interpretativo se mueve dentro de lo habitual: el segundo capítulo supone la afirmación de la debilidad de la población, mientras que el tercero desarrolla la argumentación de esa idea, y el cuarto parágrafo es una epanalepsis del capítulo segundo. ${ }^{1084}$

Con I 3, 5 se inicia la narrativa sobre Troya, a la que sigue una larga explicación relativa a la navegación, de I 4 a I $8,3,{ }^{1085}$ a cuyo término observa el autor una epanalepsis a I 3, 5, lo que nos devuelve al tema inicial, Troya,${ }^{1086}$ tema que es desarrollado hasta el capítulo I 13. El paso en el capítulo 13 a la narrativa de los tiranos y las guerras contra el persa llevan al autor a tratar la famosa duplicidad existente entre estos capítulos y el $23 .{ }^{1087}$

Además de las conclusiones ya expuestas, hay que añadir la consideración de que entre la redacción del capítulo 23 y el primero no hay gran diferencia de tiempo, lo que nos conduce a crear un tercer estrato y a situar la redacción del primer proemio entre el 421 y el $413,{ }^{1088}$ y la de la

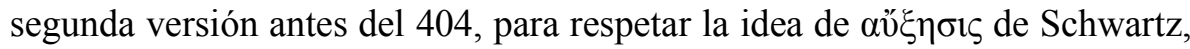
pero después del 413, cuando el ámbito persa había hecho acto de presencia y el desastre siciliano era una realidad. ${ }^{1089}$

\footnotetext{
${ }^{1083}$ Cf. Höpken, 1911, p. 18 y ss.

${ }^{1084}$ Cf. Höpken, 1911, p. 21 y ss.

${ }^{1085}$ Cf. Höpken, 1911, p. 26 y ss.

${ }^{1086}$ Cf. Höpken, 1911, p. 31 y ss.

${ }^{1087}$ Cf. supra, donde indicábamos su apoyo a la idea de que I 23 era un esbozo de un primitivo proemio general. Höpken pasa revista a las ideas de Herbst, que considera los capítulos 18 y 19 anotaciones no integradas en el texto, mientras que Steup habla de simples añadidos posteriores; cf. para todo ello Höpken, 1911, p. 47 y ss.

${ }^{1088}$ Dado que conoce los eclipses de sol, que tan dañinos fueron en Sicilia, pero no el eclipse lunar, por lo que tuvo que ser antes del final de la guerra en Sicilia, argumentación típicamente analítica. Cf. Höpken, 1911, p. 49.

${ }^{1089}$ Cf. Höpken, 1911, p. 49 y ss. 
El trabajo explicativo de Täubler publicado en 1927 es, a nuestro entender, de vital importancia porque examina de manera consistente el pensamiento del autor y el hilo que sigue en su desarrollo, y lo tendremos presente en nuestro estudio. Partiendo de la consideración del proemio como si de un discurso epidíctico se tratara, ${ }^{1090}$ Täubler reconstruye el pensamiento de Tucídides no considerando la Arqueología como un resumen de la historia anterior al conflicto, sino como una fundamentación de la futura narración de la guerra, a diferencia de lo que opinaba Meyer: ${ }^{1091}$ «Der grosse Gedanke, der die Darstellung des peloponnesischen Kriegs beherrscht, ist in der Archäologie entwickelt».${ }^{1092}$ La perspectiva del análisis se fundamenta, así, en una panorámica general de las circunstancias en que se desarrolla la guerra, no en la guerra como tal, lo que justifica la narración de aspectos no concretamente relacionados con ella. ${ }^{1093}$

Basándose únicamente en aspectos de la construcción lógica del proemio, Täubler analiza su estructura, dando cuenta del juego con elementos de pensamiento y argumentación, ${ }^{1094}$ encuadrándose todo ello en una división entre aspectos anteriores y correspondientes a la guerra de Troya, y posteriores a esta, respondiendo al esquema que ya vimos en Höpken, y que también presenta Gomme. ${ }^{1095} \mathrm{El}$ análisis que parte de estos fundamentos da lugar a unos esquemas de gran complejidad que en último término son susceptibles de crítica fundada, en primer lugar por no dar justa cuenta de los recursos formales empleados, y, en segundo lugar, por estar sometidos a la incertidumbre que arroja sobre los mismos el hecho de que se sustentan en criterios poco consistentes y no unificados a lo largo del proemio. A ello se une el desarrollo de paralelos entre la secciones relativas a los hechos anteriores y posteriores a la guerra de Troya, ${ }^{1096}$ lo que es

${ }^{1090}$ Cf. Täubler, 1927, prefacio.

${ }^{1091}$ Cf. Meyer, 1899, p. 281.

${ }^{1092}$ Cf. Täubler, 1927, p. 3 y ss. La cita, en p. 6. Cf. además p. 24. La idea no parece estar demasiado asumida cuando Luraghi, 2000, p. 230, afirma: «Its primary concern is not to convey rare information about the ancient history of Greece, but to show that Thucydides is right in maintaining that "his" war, the Peloponnesian war, is the greatest of all, definitely greater than any war of the past».

${ }^{1093}$ Cf. Täubler, 1927, p. 9.

${ }^{1094}$ Cf. Täubler, 1927, p. 13.

${ }^{1095}$ Cf. Gomme, 1950, p. 91 y ss.

1096 Cf. Täubler, 1927, p. 61 y ss. Cf. además p. 85, donde Täubler defiende esos paralelismos basándose en la línea de desarrollo que traza entre la guerra de Troya, las médicas y la del Peloponeso, aunque insistiera antes, cf. p. 9, en que la guerra no era la línea central del proemio, como sí hiciera Höpken, lo que rompe la solidez de su razonamiento. 
contrario a los mecanismos de composición tradicional que operan en la obra del historiador, según veremos.

Lo más importante, además del análisis estructural, es la consideración del proemio como un ejemplo formalmente hablando de un discurso epidíctico: ${ }^{1097}$ apoyándose en su análisis, Täubler distingue $\pi \rho o ́ \theta \varepsilon \sigma 1 \varsigma, \pi i ́ \sigma \tau \varepsilon ı \varsigma$ y $\alpha v \alpha \kappa \varepsilon \varphi \alpha \lambda \alpha i \omega \sigma ı \varsigma$, la primera asimilada a la primera frase, la segunda a la Arqueología, y la última a los capítulos finales, ${ }^{1098}$ esquema que el autor ve también dentro de la estructura de las $\pi i ́ \sigma \tau \varepsilon 1 \zeta$, con tesis, argumentación y resumen. ${ }^{1099}$ Es este un esquema que ya vimos en Heródoto, que intuímos en otros autores en prosa y que se rastrea en Homero, pero Täubler no acertó a perfilarlo hasta sus últimas consecuencias, ${ }^{1100}$ quizá por partir de una obcecación clara en el esquema retórico antes expuesto, impensable, por ejemplo, en Homero. ${ }^{1101}$

Con la publicación en 1929 del libro de Schadewaldt se cierra, prácticamente, según vimos, la corriente analítica. El libro trata el proemio partiendo de la idea de que, como tal, es, incluida la Arqueología, un elemento único ${ }^{1102}$ que persigue sustentar la afirmación de que con anterioridad no hubo un acontecimiento tan reseñable. ${ }^{1103}$ Siguiendo a Pohlenz, Schadewaldt recuerda que I 1, 2-21 forma una unidad como tal, al tiempo que desmiente la existencia de una laguna tras I 1, 2, como querían, Pohlenz, Schwartz y también Gomme, ${ }^{1104}$ demostrando la función de argumentación de la Arqueología respecto a ese pasaje, ${ }^{1105}$ y señala la evidente unión entre la Arqueología y los capítulos siguientes, basándose en la ya conocida fórmula anular. Más importante, a nuestro entender, es la

${ }^{1097}$ Cf. Täubler, 1927, p. 96 y ss., con examen de las ideas de Aristóteles y Dionisio de Halicarnaso sobre el proemio.

${ }^{1098}$ Cf. Täubler, 1927, p. 103 y ss.

${ }^{1099}$ Cf. Täubler, 1927, p. 105. Cf. además Maddalena, 1972, p. 8 y ss., quien recoge esta propuesta de manera continuada en su comentario.

${ }^{1100}$ Aunque sí examina tanto los anteriores proemios como los épicos, con referencias a la conclusión de los mismos, cf. Täubler, 1927, p. 107 y ss.

${ }^{1101}$ Idea que Schadewaldt, 1929, p. 50 sancionará: «Während Herodot die Grösse des Perserzuges nur behauptet und mit rhetorischen Mitteln zu überreden sucht, will Thukydides beweisen», con lo que queda clara la visión que de la retórica en uno y otro autor se presenta, cf. además p. 52.

${ }_{1102}$ Cf. Schadewaldt, 1929, p. 43.

${ }^{1103}$ Cf. recientemente Marincola, 1985, p. 62, nota 8.

${ }^{1104}$ Cf. Gomme, 1950, p. 92.

${ }^{1105}$ Cf. Schadewaldt, 1929, p. 46 y ss. 
sustentación en aspectos formales de la unidad del capítulo I 23 con los anteriores y por ello con el total del proemio, resaltando el paralelo entre I

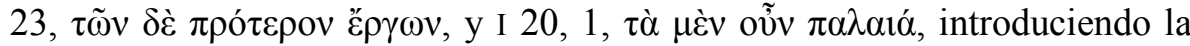
idea fundamental para la comprensión del proemio de que este presenta una caracterización compositiva propia del arcaísmo, ${ }^{1106}$ que permite, desde una perspectiva formal, plantear de manera sólida la unidad del proemio. Este será uno de los fundamentos de nuestro análisis.

La tesis de Fritz Bizer del año 1937 supuso un paso positivo en la superación de los excesos analíticos de los años anteriores. En un complejo diálogo con sus antecesores, Bizer considera el proemio como un caso de

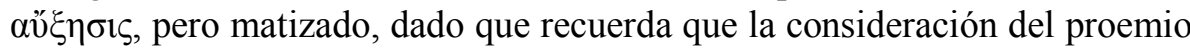
como un caso de este recurso retórico no es motivo para la negación completa de la sinceridad del autor. ${ }^{1107}$

En primer lugar, critica las posturas anteriores acerca de la consideración de V 26 como un fragmento del proemio principal mal colocado por el editor, idea defendida por Schwartz, ataque que sustenta en la poca solidez de argumentos basados en el significado de ó $\pi \delta ́ \lambda \varepsilon \mu o \zeta$, que Schwartz consideraba que indicaba en el primer proemio sólo la guerra arquidámica. Al decir de Bizer, si v 26 era una rectificación de esta imprecisión, el autor habría sido más claro en sus explicaciones, lo que ya apoyamos antes. ${ }^{1108}$

En lo que respecta al problema de una falta de texto propuesta por Pohlenz tras I 2, Bizer se opone a ello, si bien no está de más recordar que ya Höpken estableció ocho años antes el perfecto sistema de unión de estos primeros parágrafos, ${ }^{1109}$ a los que no hace falta un argumento que continúe la tesis, puesto que no es intención de Tucídides iniciar un razonamiento. En definitiva, se trata de una laguna a la que Pohlenz se ve empujado al asumir la inclusión de una cita herodotea en esta sección. ${ }^{1110}$

${ }^{1106}$ Cf. Schadewaldt, 1929, p 55 y ss.

${ }^{1107}$ Cf. Bizer, 1968, p. 9 y 22; es muy interesante esta observación, dado el prisma habitual con el que contemplamos la retórica, pero, a nuestro entender, en Schwartz y su

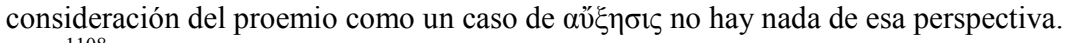

${ }^{1108}$ Cf. Bizer, 1968, p. 15; Schwartz, 1929, p. 176.

${ }^{1109}$ Cf. Bizer, 1968, p. 27, donde el autor asume también ese mecanismo compositivo para el proemio.

${ }^{1110}$ Concretamente, de VII 20, cf. Bizer, 1968, p. 19 y ss. 
Más importante es la idea del autor de considerar el proemio como un elemento formal unificado, superando en primer lugar el escollo que suponía

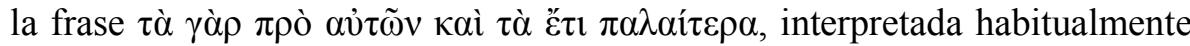
como referida a la guerra de Troya y a los enfrentamientos con el persa, lo que daba lugar a divisiones de la Arqueología como las que realizó en su tesis Höpken. Bizer considera, apoyándose en el propio texto tucidídeo, que el significado de estos elementos hace referencia simplemente al pasado de forma general, y que $\tau \grave{\alpha} \pi \rho o ̀ ~ \alpha \bigcup ̉ \tau \tilde{\omega} v$ es una fórmula que permite unir ese pasado a la guerra presente. ${ }^{1111}$

Esta idea es, a nuestro entender, fundamental para la comprensión del proemio, y más tarde la retomaremos. Su importancia estriba en la nueva interpretación a la que da paso, que permite a Bizer reconsiderar el contenido de la Arqueología: «Thukydides beurteilt die Grösse eines Krieges nicht nach seinen weltgeschichtlichen Folgen [...] sondern nach den Machtmitteln und der Machtstufe der dabei beteiligten Staaten». ${ }^{112}$

Ello supone superar el esquema de dos secciones hasta ahora visto, y dejar atrás la dificultad de introducir el capítulo 13 en la primera parte, como hizo Höpken, dado que el capítulo 12, como señala Bizer, implica un cierre,

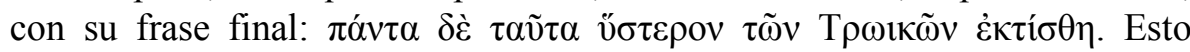
induce a Bizer a considerar que 1-19 es un elemento estructural único, en el que se trata solo de manera marginal las guerras, y que supone, en último

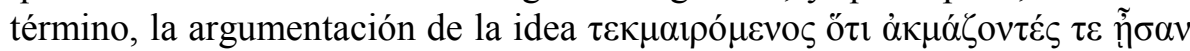

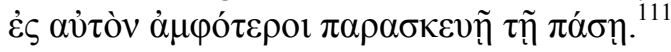

Sin embargo, Bizer aún considera, en línea con los analíticos, que I 23, 1-5 es un resto de un proemio anterior, señalando además su caracterización formal como propia de los proemios en prosa habituales, cosa que, según lo que hasta ahora hemos visto, es insostenible, así como lo es la supuesta incompatibilidad de su nuevo análisis de la Arqueología con el contenido del citado capítulo. ${ }^{1114}$

El artículo de Hammond publicado en 1952 aportó mayor solidez a las ideas de Täubler sobre los mecanismos de tesis, prueba y tesis; así, Hammond rastreó estos mecanismos hasta las más pequeñas unidades dentro

${ }^{1111}$ Cf. Bizer, 1968, p. 27 y ss.

1112 Cf. Bizer, 1968, p. 31. Recuérdense además las conclusiones a las que llegamos respecto a la función del proemio.

${ }^{1113}$ Cf. Bizer, 1968, p. 37 y ss., especialmente p. 43.

${ }^{1114}$ Cf. Bizer, 1968, p. 51 y ss. 
del proemio y señaló además la existencia de elementos de doble funcionalidad en las conclusiones de estas unidades, que dan cuenta de una naturaleza conclusiva e iniciadora a su vez de la siguiente unidad. ${ }^{115}$ Dada la muy flexible naturaleza de dichos elementos, Hammond analiza la Arqueología como constituida por ellos. Su análisis de I 3, 4-8, 4 parte del establecimiento de una unidad mayor de razonamiento en la que se articulan tesis menores en número de tres y que son introducidas por $\gamma \alpha$ ó $\rho$-que nosotros preferimos reservar para las argumentaciones- $-{ }^{1116}$ y da cuenta de que la estructuración de esta sección responde a esquemas composicionales propios de la estructuración anular. ${ }^{1117}$ Respecto a I 1, Hammond aporta al ámbito inglés las ideas que ya vimos desde Höpken sobre el desarrollo lógico de las primeras frases con el empleo del conector $\gamma \alpha \dot{\alpha} \rho$, en tanto que resuelve la dificultad de los capítulos I 20, 1-2 por medio de su referencia a I 1,3 y defiende su total integración en la Arqueología, en tanto que la parte correspondiente al denominado método queda separada. ${ }^{1118}$ Todo ello lleva a la idea de que el proemio tuvo que ser escrito de una sola vez, idea, como vimos, ya apuntada por Schadewaldt. ${ }^{119}$

En el examen de la significación de estos esquemas, Hammond nos recuerda su aparición en autores del siglo $\mathrm{V}$ a. C. y -lo más importante- su comparecencia fuera de contextos narrativos, si bien su análisis se reduce a Sófocles, Pseudo Jenofonte y Meliso, excluyendo de manera incomprensible el Corpus Hippocraticum. ${ }^{1120}$

De especial interés es el estudio de Erbse sobre el proemio tucidídeo publicado en 1970: ${ }^{1121}$ el trabajo queda lejos de los momentos de mayor vigor de la cuestión tucidídea, y la profundidad del pensamiento del sabio alemán es básica para la comprensión de su significación dentro de los estudios sobre el proemio. Ya antes, con el trabajo de Bizer, se alcanzó una

\footnotetext{
${ }^{1115}$ Cf. Hammond, 1952, p. 127 y ss.

1116 En lo que seguimos a Thesleff, 1966, p. 91 y ss., quien señala la importancia estructural de este elementos en la literatura «científica».

${ }^{1117}$ Cf. Hammond, 1952, p. 128, con nota 2, en la que presenta un esquema que quizá puede llevar a error ABCD:DCBA, dado que puede pensarse que no responde a un esquema lineal, si bien la idea es clara y acertada. Cf. además Connor, 1985, p. 29 y nota 29 en p. 30.

${ }^{1118}$ Cf. Hammond, 1952, p. 134: «These chapters, then, belong in thought and also in idiom of internal arrangement to the "Archaeology", if we may use that name for I 1-19»».

${ }^{1119}$ Cf. Hammond, 1952, p. 137.

${ }^{1120}$ Cf. Hammond, 1952, p. 138 y ss. Cf. además infra.

${ }^{1121}$ Reelaborado en los Kleine Schriften, por los que citamos. En ámbitos hispanos puede verse el análisis de Moralejo, 1981, p. 12.
} 
visión unitaria del proemio, defendida también por Gomme, ${ }^{1122}$ si bien con Erbse se logra una mayor profundidad en los argumentos a favor de ella, a nuestro entender por no necesitar ya defenderse de posturas de excesivo carácter analítico.

Como el propio Erbse indica, el objeto de su trabajo persigue, de manera poco convencional, interpretar el proemio como un elemento estructural unitario realizado en una sola fase de composición. ${ }^{1123}$ Para ello Erbse apunta, en línea con lo indicado por Taübler, la necesidad de partir de los esquemas argumentativos ${ }^{1124}$ que defienden la idea de narrar la guerra. ${ }^{1125}$ Esa justificación se ofrece por medio de esquemas argumentativos que, como hiciera Höpken, se desarrollan bajo dos tesis principales, asimilables a la guerra troyana y a las guerras médicas. ${ }^{1126}$ Dentro de estos dos apartados, y apoyándose en los recursos estilísticos empleados en el proemio así como en el hilo conductor del pensamiento, Erbse señala cómo la campaña militar troyana $^{1127}$ apunta al dominio del mar, desarollado a partir de I 4, al que sigue un largo excurso que se recoge con el empleo de una estructura anular en I 8,2 , que a su vez da lugar a un excurso sobre la piratería que se cierra en I 8,4 , construido todo ello por medio de un sólido esquema de argumentación. ${ }^{128}$ Después de esta primera sección se abre una nueva en la que se explora la significación de la guerra, I 9-11, en tanto que el capítulo

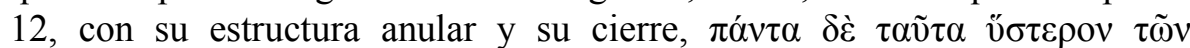

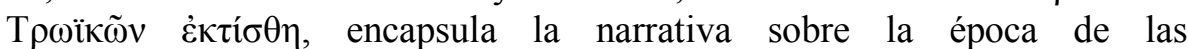
colonizaciones, ${ }^{1129}$ todo esto recorrido, claro está, por una idea principal: el conocimiento de los factores militares y políticos. Con todo ello, tenemos el fin de una parte del proemio.

${ }^{1122}$ Cf. Gomme, 1950, p. 89.

${ }^{1123}$ Cf. Erbse, 1979b, p. 246: «Es soll hier in sehr unkonventioneller Weise versucht werden, die Kapitel 1-23 des ersten Buches als endgültig ausgearbeiten text des Thukydides zu verstehen».

1124 Idea, por otra parte, presente también en Höpken y Bizer, aunque quizá sin la profundidad a la que apunta Erbse.

${ }^{1125}$ Cf. Erbse, 1979 b, p. 247 y ss.

${ }^{1126}$ Cf. Erbse, 1979 b, p. 252 y ss.

${ }^{1127}$ Sobre la importancia secundaria del enfrentamiento en Troya y su uso simplemente como ejemplo dentro de la argumentación general, cf. Tsakmakis, 1995, p. 37.

${ }^{1128}$ Cf. Erbse, 1979b, p. 253.

${ }^{1129}$ Cf. Erbse, 1979b, p. 256. Cf. Ellis, 1991, p. 352, quien también sigue un análisis por periodos históricos. 
La segunda sección, asimilada a las guerras médicas, se inicia en I 13 y se divide a su vez en dos secciones. La primera se extiende hasta I 15, 1 y tiene como tema el desarrollo de la navegación, mientras que desde I 15, 2 hasta I 17 se expone el desarrollo terrestre antes del conflicto con el persa. ${ }^{1130}$ Frente a esta sección, consagrada al periodo de las tiranías en Grecia, I 18-19 se centra en el desarrollo de Esparta y de Atenas hasta llegar a las guerras médicas, lo que supone la meta de lo expuesto en capítulos anteriores. ${ }^{1131}$ Los capítulos siguientes, dedicados prácticamente a la ejemplificación del método, suponen una defensa de la nueva consideración de las guerras médicas, sobredimensionadas en la Atenas del siglo V a. C., ${ }^{1132}$ en tanto que el capítulo I 23 representa una vuelta al final del capítulo I 19, antes del excurso del método, lo que implica la inserción del último capítulo escindido por los analíticos, y, con ello, la confirmación de la sólida estructura formal y conceptual que configura el proemio tucidídeo, uno y de una sola vez escrito. ${ }^{1133}$

En lo que a nosotros respecta, dejando al margen las ideas analíticas que hemos ido rechazando, el examen que realizaremos de la estructura del proemio seguirá muy de cerca los fundamentos expuestos por Erbse, si bien trataremos de abandonar la bipartición en guerra de Troya y guerras

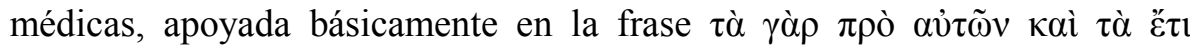
$\pi \alpha \lambda \alpha i ́ \tau \varepsilon \rho \alpha$, que llegó a ser marcada con una crux philologica en la edición de Classen y Steup y que, a nuestro entender, no quiere indicar nada más que una referencia general a la Pentecontecia y al pasado más remoto, ${ }^{1134}$ dado que en el desarrollo de la Arqueología no se atiene Tucídides a estos dos enfrentamientos como los ejes conductores del conflicto. La tradicional tendencia de la crítica $^{1135}$ de señalar la guerra como la clave para la comprensión de la obra empece en gran manera la perspectiva generada en el proemio para facilitar la comprensión general de la obra, que pasa por una

${ }^{1130}$ Cf. Erbse, 1979b, p. 259 y ss.

${ }^{1131}$ Cf. Erbse, 1979 b, p. 260 y ss.

${ }^{1132}$ Cf. Erbse, 1979b, p. 265.

${ }^{1133}$ Cf Erbse, 1979b, p. 265 y ss. Queremos resaltar que Erbse trata también aspectos plenamente históricos ajenos al interés de lo aquí examinado, como fuentes empleadas, que, al igual que ocurre con el aparato crítico de referencias a otros autores, suprimimos del análisis para aligerar la exposición.

${ }^{1134}$ Cf. el análisis de estos términos en la crítica a los datos sobre la variatio de Ros, apartado 5.3.1.

${ }^{1135}$ Cf. e. g. Gomme, 1950, p. 89. Hornblower, 1991, p. 5. 
serie de condicionantes que se presentan en su máximo desarrollo al comienzo de la guerra narrada por Tucídides.

Por ello nos decantamos por abordar la otra perspectiva, en parte apuntada por Erbse y desarrollada en mayor medida por Bizer, la de los

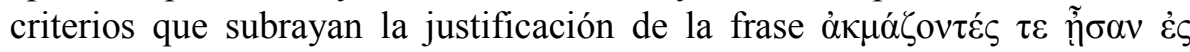

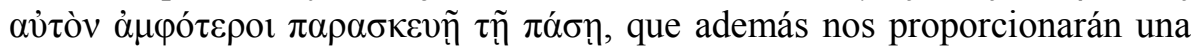
mayor unidad en la composición del proemio y dotarán a la misma del valor programático señalado por Hornblower -quizá de manera en exceso discreta, pero contundente-, al dar cuenta de la presencia de factores y conceptos en la Arqueología que se repetirán en el desarrollo de la obra. ${ }^{1136}$

Partimos, como ya vimos, de una frase inicial al modo de la herodotea, la de Antíoco y demás prosistas de la época, en la que se presenta como complemento la frase antes citada, y que es razonada por medio de una frase

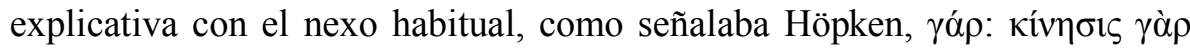

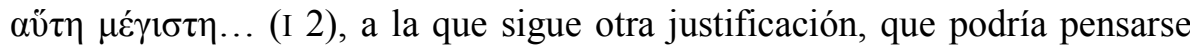
que rompe el hilo conductor de tesis-prueba, pero que responde, simplemente, a la plasticidad de una estructura arcaica en la que se pueden

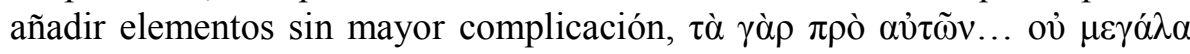

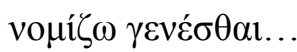

Esta idea de debilidad, una opinión personal, se ve sustentada por una justificación paralela a la presente en Antíoco y aún más visible en Heródoto, ${ }^{1137}$ que da inicio a un largo pasaje probatorio que se extiende desde I 2 hasta I 19. La primera sección la denominaremos «la población y sus movimientos», uno de los temas clave en la valoración de la guerra. ${ }^{138} \mathrm{Se}$

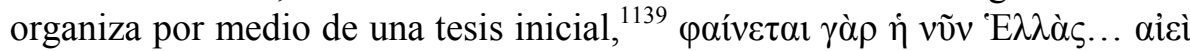

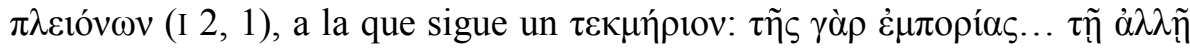
$\pi \alpha \rho \alpha \sigma \kappa \varepsilon v \tilde{n}$ (I 2, 2 ad finem). El examen de los criterios de debilidad de las

${ }^{1136}$ Cf. Hornblower, 1991, p. 7 y ss.

${ }^{1137}$ Cf. Heródoto, I 1, con el esquema antes expuesto que une el periodo inicial a la narrativa siguiente.

${ }^{1138}$ Cf. Hornblower, 1991, p. 8, quien da cuenta de la importancia de este concepto en relación con el Imperialismo ateniense, presentando el paralelo de Melos, aunque cabría hablar también de la importancia de los movimientos de población para la generación de recursos, como indica poco después Tucídides.

${ }^{1139}$ Cf. Täubler, 1927, p. 15, quien da cuenta de la doble naturaleza de este pasaje, tesis y elemento argumentativo al tiempo, a nuestro entender porque da inicio a la sección de doble manera, como tesis del primer razonamiento y como justificación de pasaje justamente anterior. 
poblaciones lleva a Tucídides a introducir un pequeño excurso relativo a la

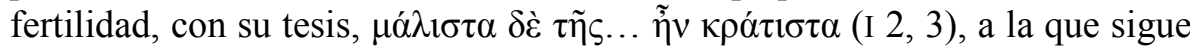

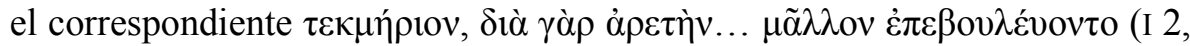
4). Este excurso, a su vez, y sin salir de la sección relativa a la población, se ve complementado por otro excurso relativo al caso del Ática, cuya tesis es

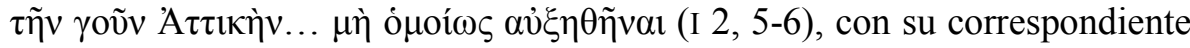

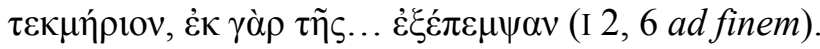

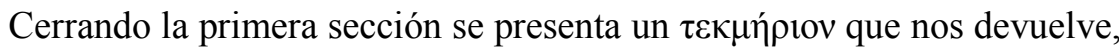
gracias al recurso de la composición anular, al punto inicial desde el que se

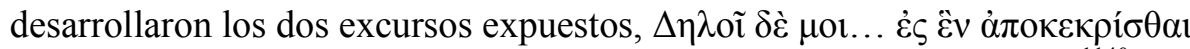

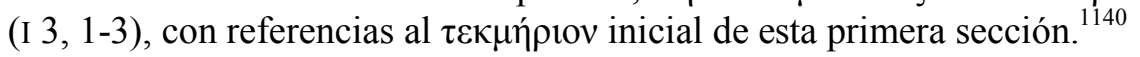

La articulación de las diferentes secciones en el interior del excurso probatorio se consigue mediante el empleo de pasajes mixtos, que presentan valores de conclusión del pasaje finalizado, al tiempo que actúan como tesis de la sección recién iniciada. La configuración de estas secciones dobles se realiza, sencillamente, por la acumulación de elementos de manera coordinada por medio de $\delta \varepsilon ́$ o $\mu \varepsilon ́ v$, de una forma muy característica en la composición arcaica y que se presenta, como señaló Fränkel, ${ }^{1141}$ en la primitiva prosa, principalmente en Heródoto. Así, finalizado el razonamiento acerca de la población, se pasa a la sección más extensa e importante por razones lógicas del proemio, la dedicada al mar, clave en el pensamiento de toda la obra y de manera programática aquí, como señaló Hornblower. ${ }^{1142}$

El pasaje se introduce con el nexo oũv, de carácter conclusivo: ${ }^{1143}$ oi $\delta$ ' oũv $\dot{\omega} \varsigma . . \theta \alpha \lambda \alpha ́ \sigma \sigma \eta \ldots \chi \rho \omega ́ \mu \varepsilon v o r ~ \xi v v \varepsilon \xi \tilde{\eta} \lambda \theta$ ov $(\mathrm{I} 3,4)$, donde aparece de nuevo el término clave en la valoración de la población y sus consecuencias,

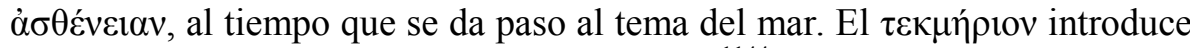

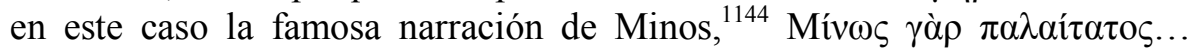

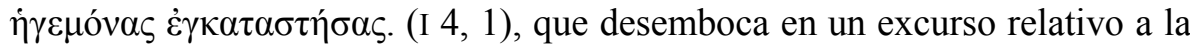

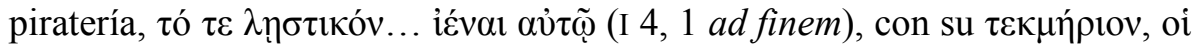

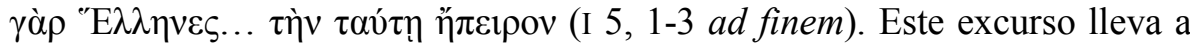
su vez un segundo excurso relativo a las armas, con su tesis, $\tau$ ó $\tau \varepsilon$

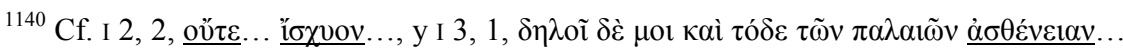
Cf. Täubler, 1927, p. 10 y ss.

${ }^{1141}$ Cf. Fränkel, 1960b, p. 83 y ss., con ejemplos abundantes tomados de Heródoto.

${ }^{1142}$ Cf. Hornblower, 1991, p. 3. Cf. incluso Gomme, 1950, p. 111, con menor énfasis.

${ }^{1143}$ Cf. ya Shilleto, 1872 , p. 5., y Stahl, 1886, p. 68.

${ }^{1144}$ Cf. ya Täubler, 1927, p. 33. 


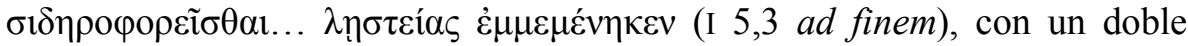

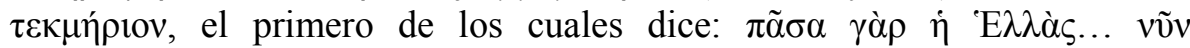

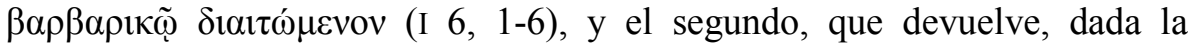

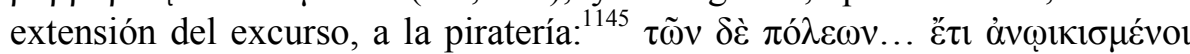
cioív (I 7 ad finem), al que sigue una tesis referida a la piratería, el famoso

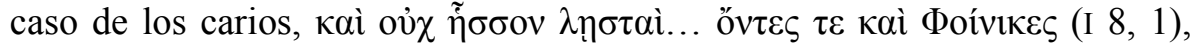

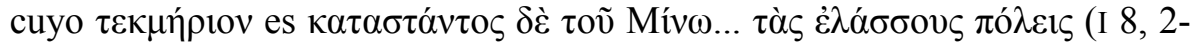
3 ), con referencias a Minos, con quien se iniciaba esta sección del apartado dedicado al mar, lo que nos advierte que aquí finaliza una sección y se inicia otra, ${ }^{1146}$ aún dentro de la relativa al mar, ahora centrada en la problemática de la guerra de Troya y los Nóstoi.

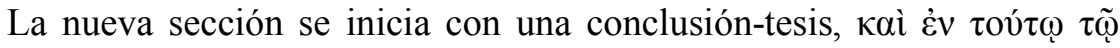

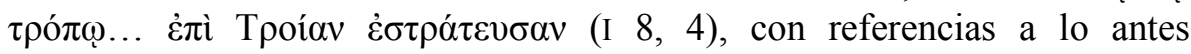
expuesto, «de esta manera», y a la futura guerra de Troya. El $\tau \varepsilon \kappa \mu \eta ́ p$ este caso es extenso, quizá por la necesidad de refutar a Homero, como

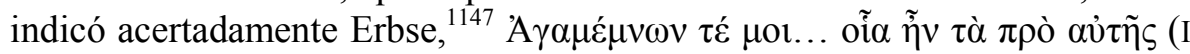
$9,1-4)$. En consonancia con este hecho, se introduce un excurso referido a la

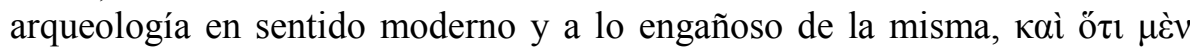

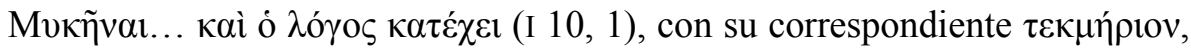

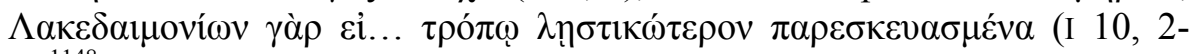
4). ${ }^{1148}$

El cierre de la sección dedicada a la guerra de Troya se realiza por la

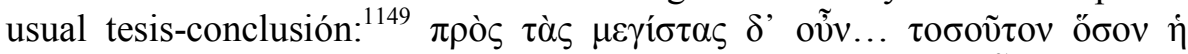

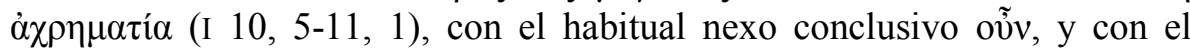
$\tau \varepsilon \kappa \mu$ ṕov justificando esa escasez de recursos, aspecto que va a ser el tema de la sección recién comenzada, dentro todavía del tratamiento de la guerra

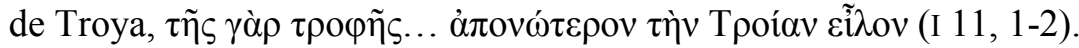

La siguiente sección dentro del tratamiento de Troya se centra en las

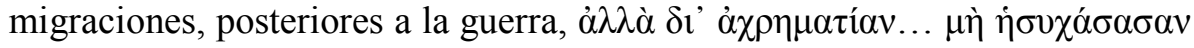

${ }^{1145}$ Cf. Hornblower, 1991, p. 28.

${ }^{1146}$ Cf. Hornblower, 1991, p. 29 y ss., quien señala además la aparición de conceptos clave que se encuentran a lo largo del excurso, si bien la expresión formal es ya de por sí concluyente, y en ocasiones tomar la simple repetición de un concepto como composición anular puede ser arriesgado. Ya Stahl, 1886, p. 78, daba cuenta del hecho.

${ }^{1147}$ Cf. Erbse, 1979b, p. 257 y ss., en referencia a I $21,1$.

${ }^{1148}$ Cf. Täubler, 1927, p. 49.

${ }^{1149}$ Cf. Täubler, 1927, p. 49, quien lo considera, simplemente, una tesis, lo que dejaría sin unión las diferentes partes. 
$\alpha \hat{\jmath} \xi \eta \theta \tilde{\eta} v \alpha 1$, funcionando esta frase como tesis-conclusión, en tanto que el

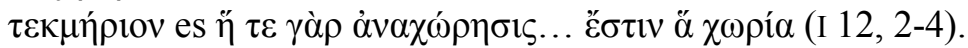

Después de los largos excursos internos de la sección relativa al mar, concretados en el tratamiento de la piratería, Troya, los recursos y las migraciones cada uno, dado lo flexible de la naturaleza de la estructura compositiva, dotada de excursos internos, se regresa al tema principal por medio de una tesis-conclusión que cierra el tema de Troya y actúa de forma

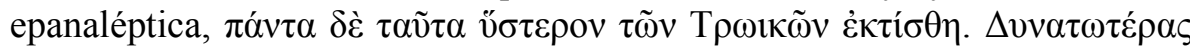

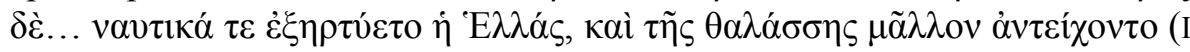
$13,1)$, con la unión simple coordinativa entre secciones diversas, enlazando la conclusión y la tesis, ${ }^{1150}$ y todo ello con su correspondiente $\tau \varepsilon \kappa \mu \eta ́ p เ o v$ referido al desarrollo de la construcción de barcos en Corinto, $\pi \rho \tilde{\omega} \tau 01 \delta \grave{\varepsilon}$

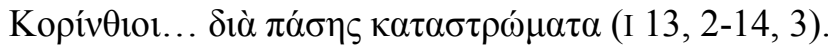

El final de esta sección, la más extensa del excurso explicativo, se realiza una vez más por medio de una tesis-conclusión cohesionada del modo antes visto, que cierra el tema marítimo y abre el relativo al imperio,

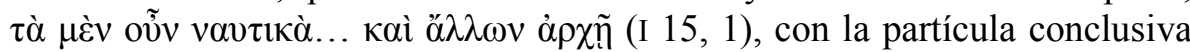

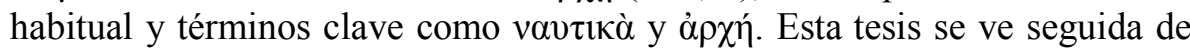

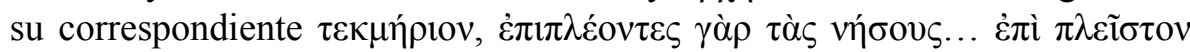

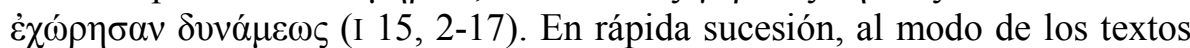
arcaicos, demorados en exceso en las secciones iniciales pero después con mayor rapidez en las finales, ${ }^{151}$ se pasa a una nueva tesis-conclusión que introduce el tema de las guerras médicas, oṽ $\tau \omega \pi \alpha v \tau \alpha \chi 0 ́ \theta \varepsilon v \dot{\eta}$ "E $\lambda \lambda \alpha \varsigma \ldots$

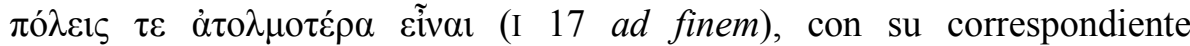

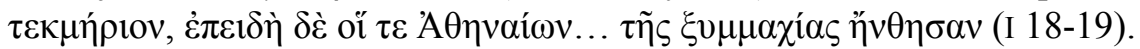

El final del excurso relativo a las guerras médicas supone también el cierre del excurso probatorio, como viera Täubler, ${ }^{152}$ con una fórmula, $\tau \grave{\alpha}$

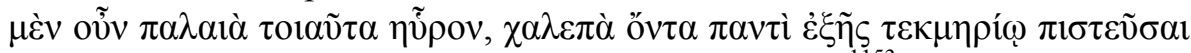

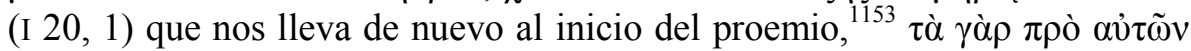

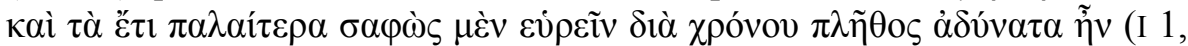
$3)$. Esta frase que nos conduce al inicio del proemio es además una tesis,

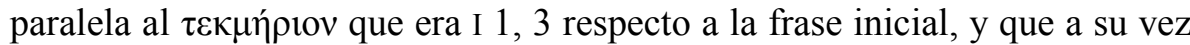

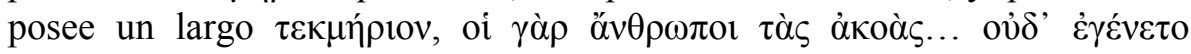

\footnotetext{
${ }^{1150}$ Cf. Fränkel, 1960b, p. 83 y ss.

${ }^{1151}$ Hornblower, 1991, p. 51, ya observó la mayor laxitud en la unión de estos capítulos.

${ }^{1152}$ Cf. Täubler, 1927, p. 89.

${ }^{1153}$ Cf. Täubler, 1927, p. 91; Maddalena, 1972, p. 75.
} 
$\pi \omega ́ \pi 0 \tau \varepsilon$ (I 20,3), extensión que favorece la aparición de una nueva tesis,

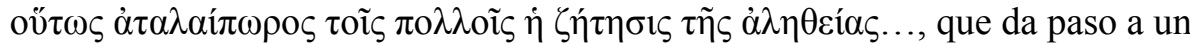

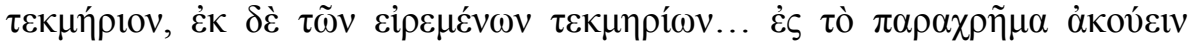

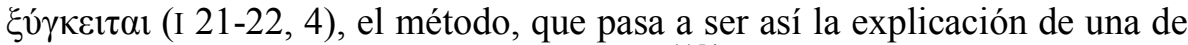

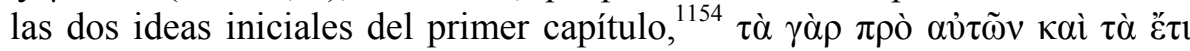

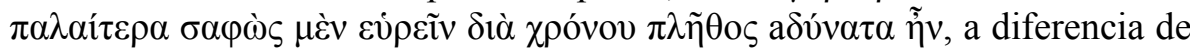
lo que opinaba Täubler, quien afirmaba que el capítulo del método no era ya argumentativo por estar desligado de la narración de la Arqueología; ${ }^{1155}$ lo que a nuestro entender no vio Täubler es que este capítulo se refiere al anterior, como es lo lógico en una obra construida con mecanismos orales, y no a la totalidad de la Arqueología.

Por último, el capítulo I 23 supone el resumen conclusivo de la primera

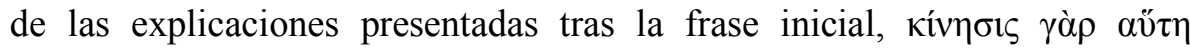

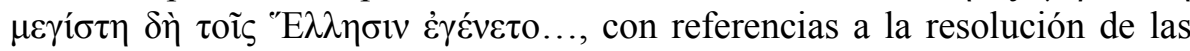

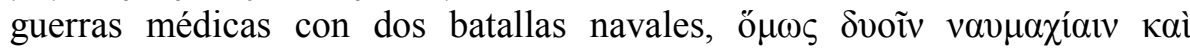

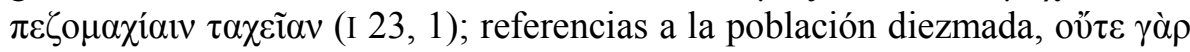

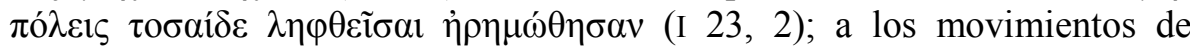

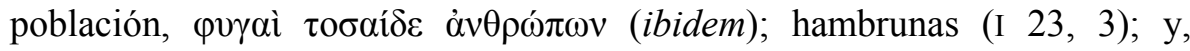

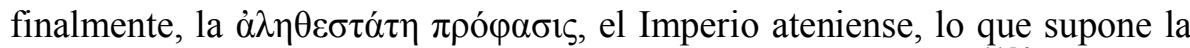
exposición de la última idea repasada en el excurso explicativo. ${ }^{1156}$

A grandes rasgos, se adivinan dos estructuras entrelazadas que parten del primer capítulo, en contra de la propuesta única de Gomme, ${ }^{1157}$ cruciales

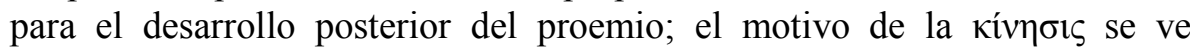
postergado en su exposición hasta I 23, dado que la sustentación del mismo

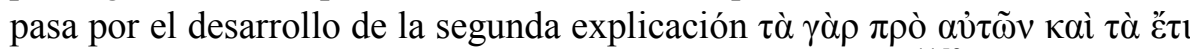
$\pi \alpha \lambda \alpha i ́ \tau \varepsilon \rho \alpha . .$. , que da inicio al largo excurso probatorio ${ }^{1158}$ en el que se

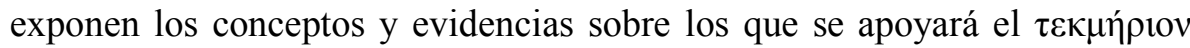

\footnotetext{
${ }^{1154}$ Así, Grosskinsky, 1936, p. 24, siguiendo a Schwartz y Schadewaldt.

${ }^{1155}$ Cf. Täubler, 1927, p. 91.

1156 Desde este punto, y por medio de una elaborada Ringkomposition se inicia el desarrollo estructural del libro I, cf. Katičič, 1957, p. 184 y ss.

${ }^{1157}$ Cf. Gomme, 1950, p. 89.

${ }^{1158}$ Es esta condición de excurso probatorio la que define la naturaleza de la denominada Arqueología, que no es, pues, un examen de la historia de Grecia, sino una argumentación. Ello invalida la consideración de la existencia de paralelos estructurales entre esta sección y la denominada Arqueología siciliana, lo que llevó a Rawlings, 1981, a proponer una bipartición de la obra estableciendo como inicios de esas dos secciones las dos arqueologías. Ya Grosskinsky, 1936, p. 17, decía: «Die sogenannte Archäologie lieferte den beweis für diese

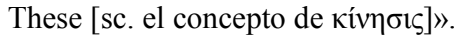




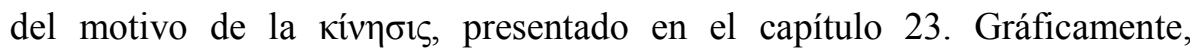
quedaría como indica el esquema.

\section{Proemio inicial}

Frase inicial: Presentación del autor y del tema.

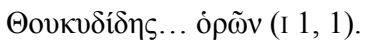

A Explicación de la frase inicial (1):

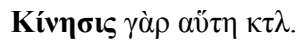

B Explicación de la frase inicial (2):

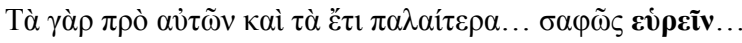

EXCURSO PROBATORIO. (I 2-19)

1. Población. (I 2, 1-3, 3).

1a. Fertilidad (I 2, 3-2, 4).

1b. El Ática (I 2, 5- 2, 6).

2. El mar. (I 3,4- 12, 4).

2a. Pirateria (I 4, 1-5, 3).

2aa. Armas (I 6, 1-6, 6).

2. $\tau \varepsilon \kappa \mu$ prov (I 7,1 ad finem).

2a. Piratería (I 8,1$)$.

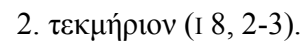

2b. Troya (I 8, 4-12, 4).

2ba. Arqueología (I 10, 1-4).

2bb. Recursos (I 10, 5- 11, 2).

2bc. Migraciones, (I 12, 1-4).

2. Poder naval (I 12, 4-14, 3).

3. Imperio (I 15-17)

4. Guerras médicas (17-19).

B Vuelta a la justificación de la frase inicial (2):

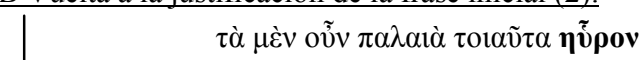

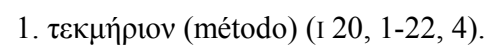

Conclusión general: Enlace de ambas justificaciones: a partir de los datos, difíciles de examinar (Sección B), podemos afirmar que fue la mayor conmoción (Sección A). (I 23)

La estructura es a todas luces plenamente arcaica, quizá más compleja que la vista en Heródoto, pero en último término no es otra cosa que una evolución de la estructura más sencilla del proemio herodoteo, dentro de la habitual flexibilidad compositiva arcaica, que los críticos analíticos no 
tuvieron posibilidad de comprender y por ello consideraron la llamada Arqueología como un añadido tardío a I 1 y 23, que obviamente responden a los extremos de la composición anular antes desarrollada, pero creemos haber demostrado de manera clara que, tanto por contenido como por forma, todo el proemio constituye un todo estructural en el que las ideas y los propios mecanismos compositivos dan una solidez a la estructura muy característica del periodo arcaico. ${ }^{159}$ A diferencia de lo que ocurría en el análisis de frase, Tucídides aún organiza su material por medio de recursos compositivos orales semejantes a los empleados por Heródoto. A este respecto, podemos decir que a nivel estructural observamos mecanismos semejantes en ambos autores que permiten hablar de la conformación, muy insegura todavía, del proemio historiográfico como una entidad estilística diferenciada, aún dentro de los esquemas propios de los tratados en prosa.

\subsubsection{EL SEGUNDO PROEMIO}

Menor atención de los estudiosos ha tenido la estructura del segundo proemio, si bien mucho de lo indicado en lo que al primero se refiere nos valdrá para el segundo.

El segundo proemio comienza con la presentación del autor y su intención, el narrar los hechos posteriores a la guerra de los diez años y el siguiente periodo, hasta la caída del Imperio de Atenas. Es, pues, esta una sección que se corresponde a la inicial del primer proemio, al tiempo que la complementa: es imposible entender la segunda sin la primera. En este caso se eliminan datos ya expuestos en la primera parte y se añade la intención de narrar la paz de Nicias, lo que introduce la estructura habitual de los

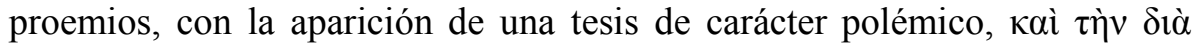

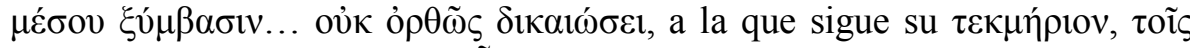

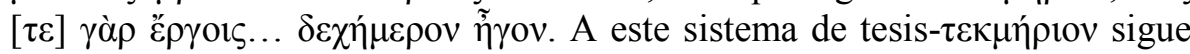

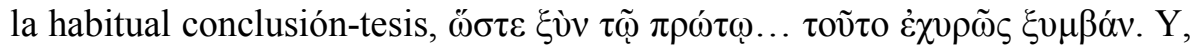

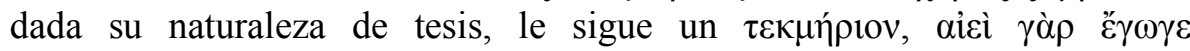

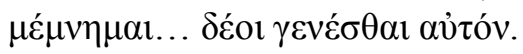

${ }^{1159}$ A nuestro entender, el minucioso estudio de Ellis, 1991, p. 350 y ss., establece reminiscencias no siempre acertadas, que terminan por llevar la Ringkomposition hasta el más pequeño fragmento del proemio, lo que dificulta el avance del pensamiento. 


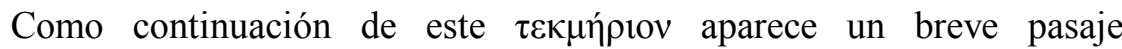
metodológico de carácter personal, opuesto en parte al anterior por un fuerte $\delta \varepsilon ́$, en el que el autor justifica con argumentos de primera persona lo que va a narrar, ausentes del primer proemio y que han de ser tenidos en cuenta en la interpretación del segundo. ${ }^{1160}$

Finalmente, se encuentra un elemento conclusivo que se asemeja al que ya observamos en Heródoto, introducido por la partícula habitual ỡv, $\tau \grave{v} v$

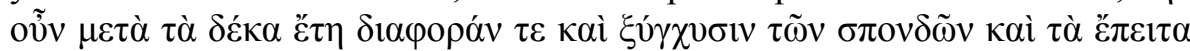
$\dot{\omega} \varsigma \dot{\varepsilon} \pi \mathrm{o} \lambda \varepsilon \mu \eta \dot{\theta} \theta \eta \dot{\varepsilon} \xi \eta \gamma \eta ́ \sigma o \mu \alpha l$, que permite el paso a la narración como tal de la paz de Nicias.

\section{Segundo proemio}

- Elemento inicial: referencia al autor y motivo de polémica.

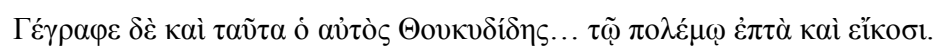

- Explicación de la frase inicial y tesis:

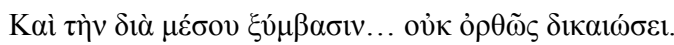

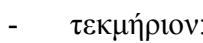

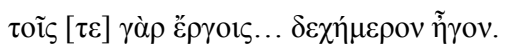

- Conclusión tesis:

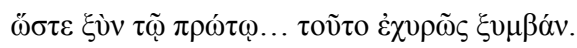

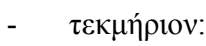

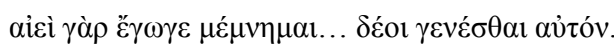

a) Segunda justificación personal: $\dot{\varepsilon} \pi \varepsilon \beta i ́ \omega v \delta \grave{\varepsilon} . . \mu \mu \tilde{\alpha} \lambda \lambda$ ov $\alpha i \theta \varepsilon \dot{\varepsilon} \sigma \theta \alpha$.

- Conclusión final:

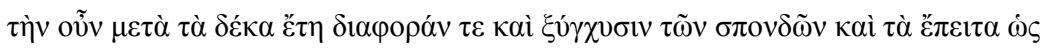
$\dot{\varepsilon} \pi \mathrm{o} \varepsilon \mu \mu \dot{\theta} \theta \eta \dot{\varepsilon} \xi \eta \gamma \eta \dot{\sigma o \mu \alpha l}$

\footnotetext{
${ }^{1160}$ Recuérdese lo indicado respecto a la polémica en torno a la verdadera duración de la guerra y a la división de la misma, una propuesta personal de Tucídides; de ahí la importancia de este argumento.
} 


\subsection{Pautas para una interpretación del estilo de Tucídides. Entre la exactitud y lo literario}

\subsubsection{LA INTERPRETACIÓN DEL ESTILO TUCIDÍDEO}

Tucídides pasa por ser para la crítica antigua ${ }^{1161}$ un gemelo en estilo de Heráclito y su oscuridad, y ello responde al abismo sustancial que se abre entre su prosa y la de cualquiera de los restantes autores de la época: nada aparentemente hay en común con Heródoto, y ni siquiera los oradores se le acercan en complejidad, lo que parece dar fin a una posible continuidad en el estilo de los primeros historiadores. El desentrañar el estilo de Tucídides en aquellas secciones de su obra donde alcanza grados de complejidad insospechados, como en el caso del proemio, pasa hoy por un juicio aséptico de su labor como escritor: la desmitificación de Tucídides como historiador acaecida en los últimos decenios puede hacer que se activen los juicios negativos de los autores antiguos, enmascarados por el fuerte reconocimiento que tuvo como historiador y no como escritor en el siglo pasado, pero la realidad es que fue ambas cosas, y de eso trataremos de dar cuenta.

Como siempre, Tucídides se enmarca en una época que aporta, por norma general, una caracterización de estilo a la que se han de sumar los

${ }^{1161}$ Los diferentes testimonios, más allá del habitual de Dionisio de Halicarnaso, pueden verse en Poppo, 1821, p. 86 y ss., y 1856, p. 53 y ss.; Ros, 1968, p. 2, nota 2; y Wille, 1968, p. 685 y ss. El propio Dionisio de Halicarnaso resume el estilo de Tucídides de la siguiente

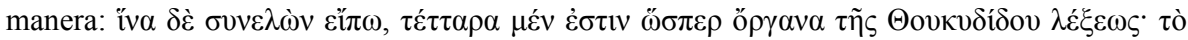

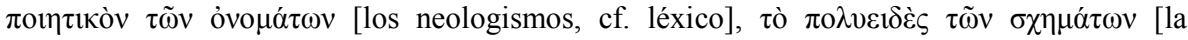

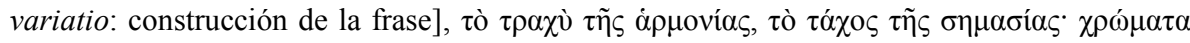

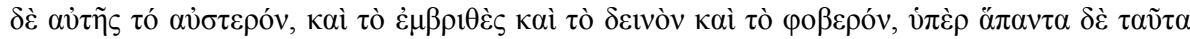

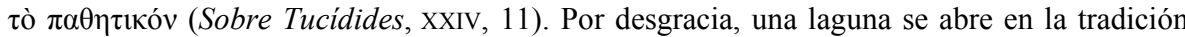
textual en el párrafo en el que Dionisio pasaba a analizar el proemio; sin embargo, cf. el apartado 4 sobre Antíoco de Siracusa, donde recogimos algunos apuntes estructurales de Dionisio sobre el proemio. 
rasgos personales del autor, ${ }^{1162} \mathrm{y}$, partiendo de este esquema tan sencillo, tendremos una pauta para la futura construcción de la imagen del estilo tucidídeo, en la que entran en juego muchos aspectos más, como puede ser la naturaleza misma del tiempo de redacción de la obra, sea cual sea esa fecha: unos pocos años por suerte no serán problemáticos. Son unos aspectos que dotan al estilo del historiador de una complejidad que se materializa en su posición dentro de la transición de la oralidad a la etapa escrita. En el caso de Tucídides, no hay el menor atisbo de duda de que su obra fue escrita y pensada como tal desde un comienzo, pero a estas alturas podemos asegurar que ese no es problema para determinar como orales algunos rasgos compositivos. En estos momentos, aun rebajando la fecha de composición de la obra de Heródoto, tenemos que contar con que la redacción de obras historiográficas posee el suficiente recorrido como para asumir la existencia de unos criterios claros de carácter compositivo y de elaboración de la frase, cuya existencia, más allá de laxos criterios formales, viene garantizada por la necesidad de unos medios que permitan al autor expresar sus ideas.

Es esa necesidad la que determina la naturaleza de su estilo, oscuro para la crítica antigua, que no hemos de olvidar que estaba compuesta por rétores y oradores, cuyo ideal literario perseguía fines muy diferentes. No cabe duda de que el fuerte y en ocasiones olvidado desarrollo de la actividad literaria en prosa que floreció a lo largo del siglo $\mathrm{V}$ a. C. tuvo que suponer la creación de medios de expresión técnica que favoreciesen la natural redacción de estas obras, que habitualmente recogemos bajo la denominación de filosofía presocrática, pero que abarca más de lo que aparentemente encierra esa afirmación. El carácter narrativo de la obra de Heródoto nos pone sobre aviso de sus conexiones con la tradición oral y sus narraciones, dada su posición como pionero en la redacción de este tipo de obras, pero, para cuando Tucídides desarrolla su labor, el tejido estilístico creado de manera general en el ambiente de la época tuvo que facilitar mucho su labor.

En tiempos modernos la crítica ha sido unánime en errores y ha disentido en lo correcto: a partir de datos de los antiguos, la crítica decimonónica creó fantasmas que han viciado la interpretación del estilo tucidídeo y han dado lugar a una imagen que aún hoy no ha sido desmontada, de suerte que la valoración estilística de su obra ha tenido una

${ }^{1162}$ Cf. Ros, 1968, p. 1 y ss., para una caracterización de ese estilo, no muy diferente de la que ofrece Dionisio de Halicarnaso y que recogimos en nota anterior. Los diferentes rasgos los estudiaremos a su debido tiempo. 
cuestión propia, aunque afortunadamente menor que la relativa a la composición.

Poppo, reaccionando contra la crítica de los antiguos respecto al estilo de Tucídides, realizó en los impresionantes prolegómenos de su comentario un análisis del estilo tucidídeo cuya principal finalidad era contradecir los juicios negativos de estos y resaltar la sublimidad del estilo del historiador. Ello hace que la metodología empleada para su descripción sea poco adecuada para el correcto análisis del estilo, ya que el fuerte tono polémico -en ocasiones con pruebas algo rebuscadas-distorsiona el análisis general.

El autor trata de demostrar la posición de Tucídides como escritor ático -tengamos presente la época del estudio-, dando cuenta de supuestas distorsiones, como desfases en la coordinación de número entre verbo y sujeto, ${ }^{1163}$ supuestos usos anómalos de los casos, o lo que es más interesante, un análisis de la variatio, ${ }^{1164}$ y de pleonasmos y usos léxicos, con un breve resumen de la caracterización dialectal del autor. ${ }^{1165}$ En resumidas cuentas, la idea del sabio es deshacer las críticas negativas sobre el estilo de Tucídides, lo que supone su inclusión en el ambiente literario de su época, si bien la excesiva perspectiva lingüística del autor y lo pedestre de esta invalida muchas de sus conclusiones, ya superadas por la crítica. Sin embargo, sus observaciones dejaron sentados unos principios que serán retomados por la crítica posterior.

El capítulo dedicado al estudio de la influencia de la poesía en Tucídides, concretado en el estudio de poetismos léxicos, parte de la premisa errada de que un historiador no puede admitir vocablos poéticos ni figuras estilísticas, e inicia una palinodia que tiene como conclusión que estos poetismos pertenecían ya al sustrato general de la lengua culta de la época, lo que demuestra que en ocasiones malas premisas llevan a buenas conclusiones. ${ }^{1166}$

${ }^{1163}$ Cf. Poppo, 1821, I 1, p. 93 y ss. Obviamente, la defensa está fuera de lugar, dado que en general Poppo trata de demostrar aspectos plenamente asumidos hoy por los lingüistas. La variación de género, examinada en p. 100 y ss., no ha de interpretarse como un defecto gramatical, sino como una cuestión léxica.

${ }^{1164}$ Cf. Poppo, 1821, I, 1, p. 134 y ss.

1165 Cf. Poppo, 1821, I, 1, p. 207 y ss., cuyos datos, a pesar de lo erróneo de la aproximación crítica, son cercanos a los propuestos por la crítica moderna. Cf. además Poppo, 1856, p. 56 y ss.

${ }^{1166}$ Cf. Poppo, 1821, I, 1, p. 250 y ss., especialmente 253. La moderna lingüística ha abordado esta cuestión del léxico por su importancia para la formación de la kotví, cf. López 
El análisis de lo que Poppo determina como estilo histórico es un excelente exponente de un ideal apologético de la figura de Tucídides, parejo al no muy alejado de la defensa de Heródoto por parte de Schweighäuser. En todo ello tenemos en parte la idea de Ranke acerca de la configuración de la narración en un modo que se acomoda de manera clara a la transmisión de la realidad, was es eingentlich gewesen war, lejos incluso de un influjo profundo de la retórica. La aparición de elementos de carácter patético, el empleo del presente histórico y, en definitiva, los rasgos antes descritos, apuntan a la necesidad de transponer la realidad pasada al presente. ${ }^{1167}$ Esta realidad monolítica del estilo historiográfico tiene su válvula de escape en la diversidad de detalle que se presenta según el tema elegido por el historiador, emparentando así el estilo de Tucídides con el de Salustio o Tácito, por narrar acontecimientos propios de épocas de crisis, inaugurando, por otra parte, una tendencia muy habitual en el análisis del estilo de los historiadores, ${ }^{1168}$ «cum moribus etiam dicendi ratio et ipsa lingua fit asperior», ${ }^{169}$ lo que, opuesto al ideal de Maratón, da una ecuación perfecta.

A pesar de lo remoto de la fecha, el transfondo y el concepto de historiografía que preside estas ideas se mantendrá hasta hace un par de décadas. ${ }^{1170}$

En el ámbito francés, Croiset publicaba en $1886^{1171}$ un comentario precedido de un pequeño estudio sobre el estilo de Tucídides. Su análisis parte de la idea de una prosa que experimenta un progreso ${ }^{1172}$ claro desde la

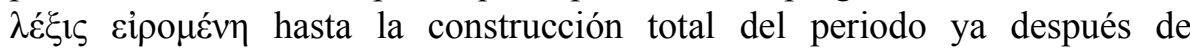

Eire, 1984, p. 245 y ss. Cf. además Poppo, 1856, p. 69 y ss., donde las conclusiones son más nítidas por eliminación del fárrago de datos del comentario: la obra de Tucídides poco tiene que ver con la poesía, a diferencia de lo que ocurría con Heródoto, o la de los latinos, con el apoyo de Quintiliano, x 1, 31 .

${ }^{1167}$ Cf. Poppo, 1821, I, 1, p. 273 y ss.

1168 Cf. Poppo, 1821, I, 1, p. 279 y ss. Bajo este epígrafe se acogen los anacolutos, la severitas y brevitas y, en definitiva, los elementos propios del sermo gravis. Cf. además Poppo, 1856, p. 76 y ss.

${ }^{1169}$ Cf. Poppo, 1821, I, 1, p. 293.

${ }^{1170}$ Cf. Woodman, 1988 , p. 197 y ss., en una polémica con uno de los más grandes expertos en Tucídides, K. Dover, quien separaba claramente historiografía de literatura, idea con la que comenzábamos esta exposición y que da cuenta de la muy diferente perspectiva de una generación a otra.

${ }^{1171}$ Recuérdese que, para hacer justicia al autor alemán, la primera edición de la obra de Blass que después examinaremos es de 1868.

${ }^{1172}$ Cf. Croiset, 1886 , p. 104 y ss. 
Tucídides, si bien ello no impide, a ojos del autor, la aparición de periodos incluso en Heródoto. Para Croiset es la retórica y la sofística el punto natural de partida para la creación del estilo de Tucídides: Antifonte, Pródico y, principalmente, Gorgias serían los autores a tener presentes: Pródico, con su distinción de sinónimos; Antifonte aportaría la nota oratoria, y Gorgias, sus consabidos recursos. ${ }^{1173}$ Deja para un lugar más discreto, a diferencia de Poppo, los aspectos plenamente lingüísticos para abordar las cuestiones de carácter léxico, en las que reconoce la deuda lógica de Tucídides con su época y su adaptación de nuevos términos con fines descriptivos y de precisión, con las lógicas innovaciones que tanto juego darán en кoเví, así como el fondo poético común que nos permite hablar de literatura. ${ }^{1174}$ Respecto a la frase, Croiset parte de la misma idea de precisión para determinar el importante papel desempeñado por las construcciones antitéticas en el estilo del historiador, pero rechaza usos estilísticos de pleno valor retórico, al modo de los empleados por un Demóstenes, con una austeridad muy característica, ${ }^{175}$ apoyada por una brevedad que camina pareja a la complejidad del pensamiento expresado, causante también del desorden, en ocasiones excesivo, de las palabras. A pesar de que el análisis del sabio francés es paradigmático de lo que será el estudio de estilo tucidídeo, caerá en el olvido ante el empuje de la escuela alemana.

Fue Blass quien determinó de manera clara el estilo tucidídeo con mayor influencia si cabe que Poppo, dadas las particularidades del análisis de este. Como es natural, dado que el análisis en cuestión se encuentra en el estudio de los oradores, el autor se centra precisamente en este aspecto de la obra. Blass define el estilo de Tucídides como la suma de influencias de la sofística y de la retórica, ${ }^{1176}$ introduciendo la consabida cuestión gorgiana ${ }^{1177}$ y dando cuenta de la importancia de los paralelismos y de la variación en el estilo del autor. ${ }^{1178}$ En líneas generales, el estudio de Blass fue tan influyente como deficiente, principalmente por el problema que causaba retrasar la generación de ese estilo a cuatro años después de comenzada la guerra. Dado que hoy podemos retrasar con facilidad el desarrollo de los $\sigma \chi \eta \dot{\mu} \mu \alpha \tau \alpha$

${ }^{1173}$ Cf. Croiset, 1886, p. 105 y ss.

${ }^{1174}$ Cf. Croiset, 1886, p. 107 y ss.

${ }^{1175}$ Cf. Croiset, 1886, p. 113 y ss. En p. 117 y ss. se encuentra un breve desarrollo de las cuestiones gramaticales también abordadas por Poppo, a cuyo análisis y crítica nos remitimos.

${ }^{1176}$ Cf. Blass, 1887, I, p. 203.

${ }^{1177}$ Cf. Blass, 1887 , I, p. 49 y ss.

${ }^{1178}$ Cf. Blass, 1887, I, p. 215 y ss. 
gorgianos mucho antes del consabido 427 a. C., ${ }^{1179}$ el desarrollo de la prosa en las últimas tres décadas del siglo $\mathrm{V}$ se nos muestra como una época de profunda evolución alejada de los mecanismos puramente orales, en los que sin duda creemos que han de situarse los recursos gorgianos. Como vio en su día Drerup, los $\sigma \chi \eta ́ \mu \alpha \tau \alpha$ gorgianos no son otra cosa que la acentuación y desarrollo de un recurso generalizado, a lo que añadiríamos nosotros, propio de la retórica oral. ${ }^{1180}$

Anterior en el tiempo a la segunda edición de Blass y poco conocido en los estudios sobre el estilo de Tucídides es el trabajo de August Nieschke, si bien sus ideas, publicadas en 1885 , se acercan proféticamente a la visión futura del estilo de Tucídides. La figura de Antifonte y su relación con el historiador es examinada de manera profunda con un amplio recorrido crítico, ${ }^{181}$ examen en el que se echa de menos trabajo sobre el texto antifonteo, dado que el autor llega a sus conclusiones, favorables a la influencia moderada sobre Tucídides solo a partir de los testimonios internos de la propia obra, en concreto el famoso pasaje de VIII $68 .^{1182}$ Más interesante nos parece la conclusión pionera de Nieschke acerca de la secundaria posición de Gorgias en la creación del estilo tucidídeo, y, por extensión, de la prosa ática; concluye de manera clara que los famosos $\sigma \chi \eta ি \mu \alpha \tau \alpha$ pertenecen al patrimonio de la poesía, principalmente homérica, y que por ello parece lógico pensar que Gorgias los tomó de esa fuente: «Haec omnia schemata mihi quidem multo ante Gorgiam partim poetae de industria ussurpasse partim casu quodam ad ea videtur delati ese». ${ }^{1183}$ Esta afirmación se apoya en un aparato erudito de referencias tomadas no solo de los poemas homéricos, sino también de Solón y Teognis, en el que se pone de manifiesto

${ }^{1179}$ Cf. Norden, 1958, p. 28, con el famoso ejemplo de la Medea de Eurípides. López Eire, 1997, p. 56: «[...] si bien Gorgias influyó decisivamente en la oratoria y en la retórica atenienses, afirmar que llevó la retórica a Atenas o que el arte llegó a esta ciudad de su mano no es en absoluto admisible».

${ }^{1180}$ Cf. Finley, 1967a, p. 70 y ss. La fina separación de estilos en Platón, presentada por Finley, p. 67, quien dota en el Simposio de un discurso excesivamente gorgiano a Agatón frente a los usos antitéticos de otros sofistas anteriores, es un buen razonamiento, siempre y cuando no estemos ante una parodia.

${ }^{1181}$ Cf. Nieschke, 1885, p. 3 y ss., donde se recogen, además de los testimonios antiguos con un examen razonado, las principales posturas de la crítica hasta la fecha; a partir de ella, recogemos nosotros en el presente trabajo las diferentes posturas.

${ }^{1182}$ Cf. Nieschke, 1885, p. 7 y ss. Nieschke se apoya en un estudio comparado del juicio sobre Antifonte y del que emite Tucídides sobre Pericles, algo, a nuestro entender, arriesgado; cf. p. 22 y ss.

${ }^{1183}$ Cf. Nieschke, 1885 , p. 37. 
que es imposible mantener la postura contraria. ${ }^{1184}$ La conclusión de todo ello es clara: «[...] pauca ex Antiphontis consetudine, multa cum ex poetarum studiis tum ex Homericis accepisse, at nihil Gorgiae acceptum rettulisse»». ${ }^{1185}$

Lamb publicó en 1914 un estudio sobre el estilo de Tucídides que se nos presenta muy diferente a lo que hasta ahora hemos visto. Sin entrar en detalles formales concretos, Lamb aborda la naturaleza general estilística de determinados pasajes. ${ }^{1186}$ La valoración de la prosa de la época responde de nuevo a la concesión de una gran importancia a la embajada gorgiana, ${ }^{1187}$ «It may be supposed that he was already able to write simple narrative, more concisely and weightily than Herodotus: but here was a device which would serve a higher artistic purpose [...]», ${ }^{1188}$ lo que en último término lleva de manera inexcusable a una mayor precisión lingüística y de pensamiento. Es en esta senda donde encontraremos, precisamente, el estilo que Tucídides empleará en partes como el proemio, en oposición a las partes narrativas en las que el estilo tucidídeo se acerca a Heródoto. ${ }^{1189}$

El análisis de la prosa, en líneas generales, lo aborda Lamb desde una perspectiva que recuerda a la de Norden pero acentuada: Lamb considera inexistente la prosa en los primeros pasos de la literatura helénica, y por ello aborda su configuración desde una perspectiva evolucionista que parte del

\footnotetext{
${ }^{1184}$ Cf Nieschke, 1885 , pp. 38-67.

${ }^{1185}$ Cf. Nieschke, 1885, p. 73.

1186 Así, bajo el epígrafe de lo trágico se recogen análisis que tocan de cerca el planteamiento de Cornford, 1907, p. 125 y ss., de forma negativa, y que dan cuenta de la conformación de la narración desde una perspectiva trágica, de modo que, tras un largo estudio del Decreto de Mégara difícil de explicar, se sucede un análisis de la narrativa de Pilos y el juego de la fortuna en la misma (para el cual cf. recientemente Rood, 1998, p. 36 y ss.); un análisis de las figuras de Cleón y Alcibíades como sujetos trágicos; y una valoración de las escenas posteriores al conocimiento del desastre de Sicilia. Sobre el sentido de la obra de Cornford, pueden verse los comentarios de Alsina, 1981, p. 50 y ss.

${ }^{1187}$ Cf. Lamb, 1914, p. 70 y ss.

${ }^{1188}$ Cf. Lamb, 1914, p. 71.

${ }^{1189}$ Cf. Lamb, 1914, p. 87 y ss., con una comparación del estilo de la narración sobre Temístocles y la de la stasis corciriana, perteneciente al estilo que Lamb analizó en el capítulo anterior, en la que las oposiciones son características: «always white and black, white and black». En la p. 91 y ss. se encuentra un análisis de la interpretación del estilo tucidídeo realizada por Dionisio de Halicarnaso, en la que Lamb trata de validar las ideas hasta ahora expuestas, lo que le lleva a desestimar la aparición clara de recursos «gorgianos» en la obra de los logógrafos, creando así un proceso evolutivo cuya pieza central sería Helánico, para el cual cf. supra.
} 
hexámetro, ${ }^{1190}$ que avanza hacia la perfección periódica, de la que se aleja Tucídides al generar pasajes de gran complejidad estilística en los que el estilo periódico se ve superado por la continua acumulación de elementos. ${ }^{1191}$ Heródoto, la prosa jonia en general y la hipocrática, así como la particular expresión de Heráclito, Anaxágoras o Demócrito son claves en la conformación de este especial estilo. ${ }^{1192}$

La cuestión de la retórica la aborda Lamb desde la configuración del estilo de Protágoras a partir de los escasos fragmentos y de las imitaciones tanto de Platón como de las semejanzas en Heródoto III 80 y ss., el debate constitucional, ${ }^{1193}$ de un modo que sigue en cierta manera las líneas trazadas por la filología alemana. Así, la retórica se abre paso de forma clara, sin que ello reduzca el genio del historiador, dado que este readapta los recursos de Gorgias a su elevación intelectual; «Thucydides' handling of formal prose might be summarily described as an attempt to bring the attractive and frankly poetic graces of Gorgias to terms with the sententious brevity and gravity of the early philosophers». ${ }^{1194}$ Resumiendo, el estilo de Tucídides sería una suma razonada de recursos de Protágoras, Gorgias y del ambiente de su época, ${ }^{1195}$ si bien la dificultad que supone la concreción de esas influencias se disuelve en una obra, a nuestro entender, poco dada a concrecciones y sí a mucha retórica hueca, acentuada en comparación con los estudios de Croiset o Blass, y que tuvo especial predicamento en ámbitos anglosajones.

Dando cuenta de esta complejidad, Finley, en un importante trabajo sobre el estilo del historiador, demostró, incidiendo en la idea de que no es necesario Gorgias para la aparición de fenómenos habitualmente ligados a su llegada a Atenas, que el estilo de Tucídides es plenamente consonante con el

1190 Cf. Lamb, 1914, p. 106. Cf. además p. 114 y ss. Recuérdense los datos a este respecto abordados en el examen de la prosa arcaica.

1191 Esa acumulación, como bien señala Lamb, 1914, p. 110 y ss., parte de elementos simples, como correlaciones, que se ven insertos en estructuras de mayor tamaño y complejidad.

1192 Cf. Lamb, 1914, p. 116.

1193 Cf. Lamb, 1914, p. 127 y ss. Pero cf. Shapiro, 2000, p. 98 y ss., quien ve una caracterización tradicional, diríamos agonal, del debate. En lo que se refiere a la realidad histórica de las dos versiones que se confunden en la narración herodotea, cf. Gschnitzer, 1977 , p. 24 y ss.

${ }^{1194}$ Cf. Lamb, 1914, p. 248 y ss., si bien, en línea con nuestra tesis, Lamb reconoce en los primitivos filósofos soportes poéticos muy válidos para su expresión, cf. p. 249 y ss.

${ }^{1195}$ Cf. Lamb, 1914, p. 305 y ss. 
de los autores en prosa. Finley decía que Tucídides y su estilo corren parejos a los sofistas, y que además es necesario asumir una continuidad ${ }^{196}$ que, superada la frontera que suponía la embajada gorgiana, da cabal explicación al estilo de la prosa de la época, una prosa que ha de ser asumida como panhelénica, dado que, a diferencia de lo que pensaba Blass, la comunicación entre los distintos puntos del mundo griego es una realidad necesaria para explicar semejanzas entre los diferentes autores de historiografía, como vimos con el caso de Antíoco y demostró Dover. ${ }^{1197}$

Como decíamos, lo más importante del trabajo de Finley es el dar cuenta de que fenómenos como las antítesis no son exclusivamente gorgianos, sino que responden a un fenómeno presente de manera general en la literatura ateniense anterior al $427{ }^{1198}$ Siguiendo las afirmaciones de Aly, Finley da un paso más al encontrar parecidos en la obra de Tucídides con lo que el primero definía como un vं

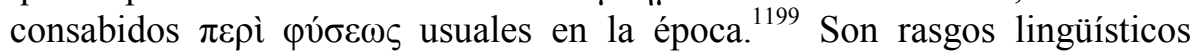
semejantes a los de Tucídides y el empleo moderado de recursos estilísticos los que caracterizan este tratado técnico, que, como tal, responde poco a la idea estilística que tenemos de dichas obras: el propio Finley alerta de la aparición en la obra de Antifonte de una riqueza estilística que nos aleja del tópico acerca de este tipo de obras y que se repite de manera clara, por ejemplo, en los tratados hipocráticos. A nuestro entender, en un estadio como el presente, no se puede asumir una labor literaria sin el empleo de recursos estilísticos, dado que estos no eran entendidos todavía como mecanismos retóricos como tales, sino como elementos orgánicos y funcionales.

Fue de nuevo Norden la voz autorizada que dio fuerza en las investigaciones posteriores al concepto de retórica en el análisis del estilo de

${ }^{1196}$ Cf. Finley, 1967b, p. 57 y ss. La propuesta de defender la antigüedad de estos recursos por su aparición en discursos tucidídeos anteriores al 427 a. C. es arriesgada, principalmente porque aún le queda por explicar de manera profunda la significación de I 22. Sin embargo, el razonamiento es contundente.

${ }^{1197}$ Cf. Finley, 1967a, p. 68 y el capítulo dedicado a Antíoco de Siracusa.

${ }^{1198}$ Cf. Finley, 1967a, p. 72; Luschnat, 1970, col. 1260. Para todo lo relativo a las figuras de repetición, claves en el estilo gorgiano, cf. Fehling, 1969, con una multitud de ejemplos incluso acomplejante. Puede verse un interesante panorama diacrónico en p. 90 y ss.

${ }^{1199}$ Cf. Finley, 1967a, p. 106 y ss. 
Tucídides. ${ }^{1200}$ Retórica y poesía parecen las dos claves en la configuración del estilo de los historiadores, pero se plantean serias dificultades si nos adentramos en detalle en el examen de esos criterios.

La retórica como tal es una creación tardía, al menos si entendemos por retórica la aplicación de unas reglas regulares con conciencia de ello para persuadir; pero, en último término, con una definición lo suficientemente abierta, hasta Homero habría empleado la retórica. ${ }^{1201}$ Siguiendo el hilo de las ideas trazadas en el análisis de la prosa, podemos afirmar que, al menos hasta la siguiente generación del autor que nos ocupa, la retórica como tal no funciona, sino que nos encontramos en una etapa de transición entre la retórica oral y la aparición de modelos como el isocrateo. Esta idea, defendida con gran polémica por Cole, ${ }^{1202}$ es consecuente con la visión de la prosa hasta ahora defendida. El cambio de modelo de una «retórica oral» a la retórica como tal sólo se puede producir cuando los mecanismos que definen la primera ceden ante los nuevos métodos de expresión, acordes con la nueva concepción de la comunicación, cosa que ocurrirá en tiempos de Platón. ${ }^{1203}$ Es también el mismo Norden ${ }^{1204}$ quien nos informa de la opinión general de la Antigüedad acerca de los paralelos con la sofística y con ello, nos atreveríamos a decir, con el ambiente intelectual de la época; la prosa tucidídea es comprensible por sí misma como fruto del momento de su redacción, sin necesidad de admitir deformaciones externas que hagan del historiador un autor retórico, dado que los elementos que estudiaremos se encuentran en gran medida en autores anteriores, y sus discursos no son

${ }^{1200}$ Cf. Norden, 1958, p. 95 y ss. En p. 81 y ss. se analiza la posición de la retórica en todo el género historiográfico, si bien la exactitud cronológica nos lleva al menos a retrasar la que es una polémica de tiempos de Polibio.

${ }^{1201}$ Cf. López Eire y Schrader, 1997, p. 28 y ss. A nuestro entender, es la definición que hacemos de retórica lo que imposibilita su aparición temprana, dado que la asimilamos a un modelo determinado reconocible en el siglo IV a. C.

${ }^{1202}$ Cf. Cole, 1991, p. 71 y ss. para Tucídides.

${ }^{1203}$ Así, Cole, 1991, passim y p. 94, para los problemas del mundo oral y escrito. A pesar de lo que pudiera parecer, expresamos nuestras cautelas en lo que se refiere al libro de Cole, por cuanto carece del aparato necesario de estudio de la primitiva prosa, lo que hace que en ocasiones sus razonamientos parezcan incompletos, al tiempo que el panorama cultural trazado en p. 80, con una cultura provincial ateniense y una global jónica dificulta la comprensión de un fenómeno que es general, y que bajo estos presupuestos volvería a la embajada gorgiana y su problemática para la comprensión de la prosa.

${ }^{1204}$ Cf. Norden, 1958, p. 96 y ss. Cf. además Schoell, 1890, p. 32 y ss., para parecidos entre Tucídides y La constitución de los atenienses, cuya prosa poco tiene que ver con modelos depurados de retórica. 
precisamente modelos retóricos, aunque empleen medios asimilados a lo retórico. $^{1205}$

\subsubsection{EL PROEMIO TUCIDÍDEO: PRECISIÓN Y EXPERIMENTACIÓN}

Sea como fuere, y aun sin necesidad de discutir acerca de la influencia de la retórica en Tucídides, que pasaría por una definición de la misma, tenemos suficientes puntos de apoyo en los autores de la época para valorar el estilo del proemio de Tucídides, y dilucidar en último término la configuración de la frase en relación con los antecesores en el género historiográfico.

El comienzo nos es ya conocido, pues se articula al modo del proemio de Antíoco y, en general, según el uso de los tratados en prosa, con nombre más verbo indicando la acción de la composición, pero, a diferencia de lo que ocurre con Antíoco, siempre que el texto editado responda a la realidad de lo escrito por Antíoco, Tucídides presenta un desarrollo de esta primera frase que recuerda al caso herodoteo por su extensión. Ya Blass encontró serias dificultades para definir este periodo, que denominó creciente, ${ }^{1206} \mathrm{y}$ posteriormente Ros determinó este como un ejemplo claro del estilo propio del autor, ${ }^{1207}$ si bien creemos que se puede ir un poco más allá. La

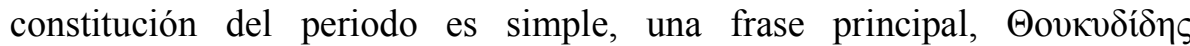

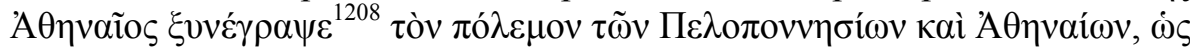

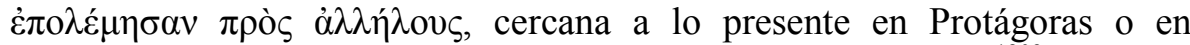
cualquiera de los proemios en prosa que examinamos, ${ }^{1209}$ con la particularidad de que, al igual que ocurría con Heródoto, la espiral de desarrollo de esta simple frase avanza de manera poco habitual, dependiendo p. 156.

${ }^{1205}$ De planteamientos arretóricos previos a una codificación habla Iglesias Zoido, 1995,

${ }^{1206}$ Cf. Blass, 1887, I, p. 224. Cf. además Croiset, 1886, p. 121.

${ }^{1207}$ Cf. Ros, 1968, p. 7.

${ }^{1208}$ Cf. las indicaciones acerca del término en el estudio sobre Antíoco de Siracusa.

${ }^{1209}$ Hornblower, 1991, p. 4, recoge la idea, que no apoyamos, acerca de la búsqueda de una mayor imparcialidad por medio del empleo de la tercera persona, explicable, a nuestro entender, como resto de un estadio mixto de expresión escrita y oral, que para esta época ya se presenta vacilante, como el propio Hornblower señala. 
los diferentes elementos del elemento clave de la oración principal,

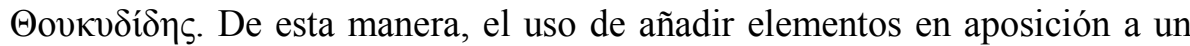
término clave inicial propio de la retórica oral alcanza su máximo desarrollo con Tucídides, con la misma particularidad que vimos en Heródoto: el añadido de un elemento ajeno al desarrollo de la frase que poco más tiene que un simple valor aclarativo, como señalan Classen y Steup y Hornblower, ${ }^{1210}$ pero que supone la interrupción drástica del desarrollo lineal de la expresión, algo tan difícil de valorar como segura es su existencia.

Fue Krüger ${ }^{1211}$ quien en su edición comentada dio de pasada con el paralelo que presenta este incipit con el del pitagórico Ócelo. Este misterioso personaje de datación muy tardía, ${ }^{1212}$ constituye el único testimonio completo del comienzo de una obra filosófica al modo arcaico, de aquellos tradados que denominamos genéricamente $\pi \varepsilon \rho i ̀ ~ \varphi v ́ \sigma \varepsilon \omega \varsigma$. A pesar de la datación tardía, podemos sospechar claramente que el autor trató de componer su obra como un tratado a imitación de los aparecidos en el siglo V a. C., como señaló Harder, ${ }^{1213}$ y ello nos permitirá, al igual que ocurría con Apolonio de Rodas para el estudio de la épica, obtener conclusiones fiables. Pero antes, veamos el texto:

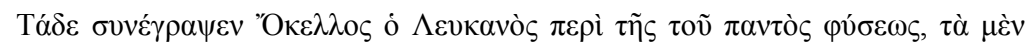

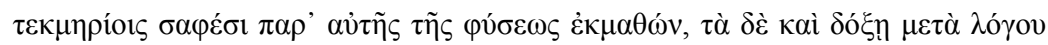

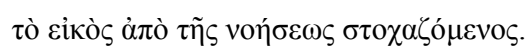

Aun siendo tardío, la conformación del texto es plenamente arcaica: ${ }^{1214}$ el deíctico, el verbo ya habitual, y la construcción preposicional con $\pi \varepsilon \rho i ́$, cuya aparición, por otra parte, asegura que el calco no es directamente de Tucídides, lo que nos llevaría a un planteamiento circular. Pero lo más importante es observar cómo, al igual que ocurre en Tucídides, el desarrollo

${ }^{1210}$ Cf. Classen y Steup, 1963, I, p. 2; Horblower, 1997, p. 5.

${ }^{1211}$ Cf. Krüger, 1860, p. 1.

${ }^{1212}$ Se le ha de situar en el siglo II a C., tanto por el terminus post quem que suponen las reminiscencias aristotélicas como por ser citado por Varrón; cf. para todo ello Beutler, 1937, cols. 2362 y ss., OCD, s. V. p. 1058.

${ }^{1213}$ Para el caso concreto del comienzo, definido como "Titel" por Beutler, 1937, col. 2364.

${ }^{1214}$ Nótese además la aparición de elementos conceptuales de considerable peso clásico

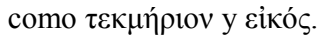


del texto se produce en espiral en torno al sujeto. Son los dos participios coordinados los que dotan de mayor contenido a la simple frase afirmativa.

Ello nos permite dar un paso más respecto a lo mantenido hasta el momento gracias al estudio de Heródoto y de Antíoco, y afirmar que la configuración del incipit historiográfico comparte su naturaleza con la de las obras en prosa del momento.

Pero hasta aquí llegan las semejanzas; al descender al detalle, la complejidad alcanzada en las primeras líneas de Tucídides supera lo hasta ahora visto. Cuatro son los participios dependientes en este caso del término clave, el doble, por ejemplo, que en el caso de Ócelo, con la particularidad de que son además elementos complejos también, y cada uno de ellos presenta a su vez variatio en su construcción, que, a nuestro entender, responde a criterios de precisión semántica: al igual que vimos con los usos de infinitivo y de oración subordinada en Heródoto y la capacidad de precisar semánticamente los usos que ello favorecía, la triple gradación que se presenta en las construcciones subordinadas sustantivas ha de ser examinada al detalle. El primer caso, un infinitivo dependiente de $\dot{\varepsilon} \lambda \pi i ́ \sigma \alpha \varsigma$, da cuenta de la inseguridad sobre el cumplimiento de la propuesta, en tanto

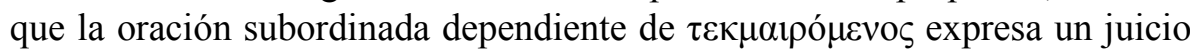
de valor. Finalmente, los participios dependientes de ó $\tilde{\omega} v$ responden a la constatación de un hecho, si bien todo ello es algo que ya tuvimos ocasión de ver en el proemio de Heródoto, quizá de manera menos clara.

La organización de todo este esquema es de gran complejidad, y la posición anómala de $\tau \varepsilon$ es quizá el menor problema. ${ }^{1215}$ Ya Croiset alertaba $^{1216}$ de la falta de simetría sintáctica del pasaje, si bien el crítico francés apuntaba a un uso habitual en Tucídides, simplemente una variatio; por su parte, Krüger daba cuenta ${ }^{1217}$ también de una variatio y aportaba el paralelo de un pasaje de Eurípides en apoyo de la interpretación del participio ó $\tilde{\omega} v$ coordinado con el pasaje introducido por ö $\tau$, criterio que siguen Poppo y Stahl en su edición. ${ }^{1218}$

La complicación parte del hecho de asumir una variación habitual en Tucídides pero de gran dificultad, lo que ha de verse justificado por algo más

\footnotetext{
${ }^{1215}$ Es un uso habitual la posición tardía; cf. Krüger, 1998, p. 1435.

${ }^{1216}$ Cf. Croiset, 1886, p. 144. Cf. además Classen y Steup, 1963, I, p. 3.

${ }^{1217}$ Cf. Krüger, 1860, p. 2. El paralelo es Eurípides, Hipólito, 280.

${ }^{1218}$ Cf. Poppo y Stahl, 1886, p. 60. El paralelo propuesto, IV 116,1 nos parece errado;

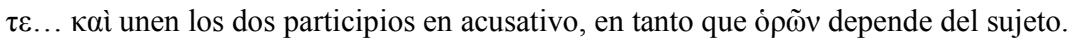


que por simples razones de variatio, como hacen los diferentes críticos, lo que, en último término, es no decir nada. Un examen rápido de la concordancia del texto tucidídeo nos revela un escaso uso del verbo $\tau \varepsilon \kappa \mu \alpha i ́ p o \mu \alpha 1$, con solo dos apariciones, además de la presente. ${ }^{1219}$ El caso del libro III ofrece también dificultades en su interpretación, por cuanto la habitual construcción con $\omega \varsigma$ o ö $\tau$ se ve sustituida por una construcción

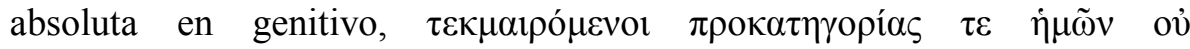
$\pi \rho \gamma_{\varepsilon v \varepsilon \mu \varepsilon ́ v \eta}$..., con la que se combina un acusativo absoluto, si bien esta variación no nos interesa por ahora, mientras que en el libro IV el ejemplo se

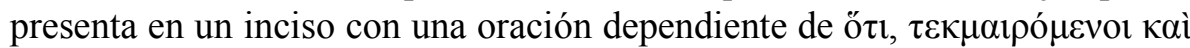

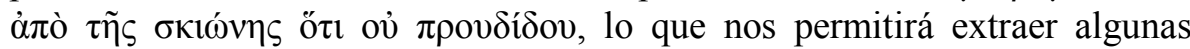
conclusiones. En el primer caso, del discurso que antecede al de los plateos se deduce con claridad perceptiva, como ocurría en el ejemplo esgrimido por Krüger, con un participio de semántica perceptiva, ${ }^{1220}$ que lo expresado es una realidad contundente propia de la percepción individual. Por otra parte, en el caso de los ejemplos introducidos por el nexo, lo expresado indica duda, pues en el libro IV se trata de una realidad por cumplir, y, en el caso que nos ocupa la gradación es clara, ya que la determinación del poderío ateniense es patente a lo largo de la obra. Sin embargo, el caso de Esparta es más complejo, mientras que las alianzas entre los diferentes implicados eran una percepción tan real como lo pudiera ser el conocimiento de las alianzas pactadas.

Pero, a pesar de ello, aún queda por justificar la aparición de un

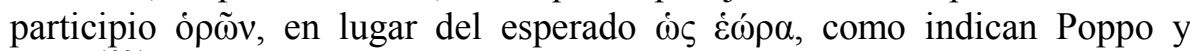
Stahl. ${ }^{1221}$ En este caso, no hay justificación léxica alguna para la aparición del participio frente a la construcción regular, dado que las consideraciones léxicas afectan a los elementos dependientes de ó $\tilde{v} v$, como hemos visto, y no al propio participio. Sin embargo, quizá podría apuntarse una causa de sentido compositivo comprensible si tenemos presente lo hasta ahora visto en los proemios en prosa de la época. La necesidad de articular un primer elemento de manera unitaria podría explicar la aparición de un participio en nominativo que nos llevaría de nuevo a la frase inicial, como hemos observado ya. No hemos de olvidar que el desarrollo del segundo participio dependiente del sujeto alcanza en este caso casi tres líneas, que aumenta en

${ }^{1219}$ Cf. Schrader, 1996, s. v. Los pasajes son III 53, 2 y IV 123, 2.

${ }^{1220}$ Cf. Además Jenofonte, Simposio, 8, 11; Platón, Critón, 44a6, con referencia a un sueño; opiniones con oración introducida con partícula, Teeteto, 192c4; $204 \mathrm{e} 1$.

${ }^{1221}$ Cf. Poppo y Stahl, 1886, p. 60. Cf. además Maddalena, 1972, p. 5. 
gran medida el número de elementos dependientes del mismo, y estos no presentan elemento alguno que acepte un participio en nominativo. La aparición de este elemento sería semejante a la estructura apositiva en Heródoto, si bien ahora la complejidad sería mayor, lo que nos pondría sobre aviso de la posición que en el desarrollo de los proemios en prosa ocupa Tucídides. De este modo, la variatio sintáctica adquiere una mayor dimensión en la formulación del pasaje, puesto que la riqueza expresiva empleada nos sumerge por completo en la metodología de Tucídides.

Y es que la variatio es una de las características más importantes del estilo de Tucídides: desde la publicación en 1938 del influyente estudio de Jan Ros, se puede considerar fehacientemente demostrada la frecuente presencia de este recurso en la obra de Tucídides. En lo que al proemio se refiere, Ros señala un amplio repertorio de ejemplos que trataremos de analizar y clasificar desde un punto de vista funcional. Como antes señalamos, y dada la naturaleza del estilo de Tucídides, creemos que este recurso ha de tener una funcionalidad que transcienda el simple empleo estilístico, que, por otra parte, no es incompatible con lo anterior, como indicamos en el análisis de la primera frase del proemio.

A este respecto, y aprovechando los amplios materiales que recoge Ros, en ocasiones demasiado generosos a la hora de dar cabida a casos de variatio, ${ }^{1222}$ trataremos de recorrer las diferentes manifestaciones del fenómeno en el proemio para dar con esa funcionalidad que sostenemos que es clave en la configuración del estilo tucidídeo.

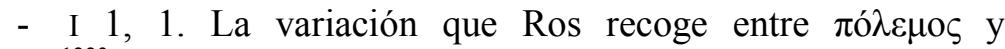

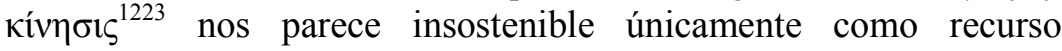
estilístico: la variación semántica es clara, y la ampliación de perspectiva en el segundo término es lo que permite dar paso a la Arqueología. Además, hemos de tener en cuenta esa precisión si queremos comprender el pasaje en toda su complejidad, debido al escaso uso que hace Tucídides del término, ${ }^{1224}$ y su carácter, tanto

${ }^{1222}$ No consideramos como caso de variatio la variación en tiempo o modo de verbos, dado que responden a un sistema dentro de la lengua de sobra conocido hoy y quizá no tanto en la época del estudio, lo que justificaría su importante posición en la obra de Ros, como tampoco incluimos las concordancias irregulares, al entender que responden a usos sancionados para la época y a una perspectiva no en exceso ajena a nosotros en la que prima el lexema sobre el morfema.

${ }^{1223}$ Cf. Ros, 1968, p. 101.

${ }^{1224}$ Cf. Bétant, 1969, s. v., y Schrader, 1996, s. v., que recogen únicamente tres ejemplos. 
por formación morfológica como por su elevada aparición en autores

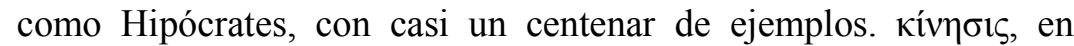
definitiva, se emplea para significar la totalidad de los aspectos que rodearon a la guerra y no únicamente esta. ${ }^{1225}$ Algo semejante ocurre

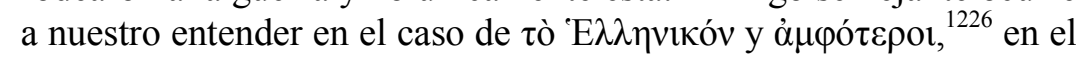
que el primer término, de nuevo uno de los típicos abstractos, tiene un ámbito semántico mucho más amplio que el segundo, lo que, seguramente, es la causa de la variación formal.

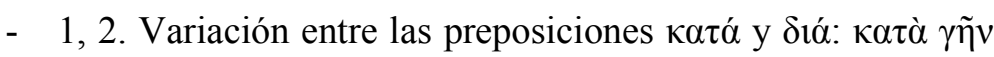

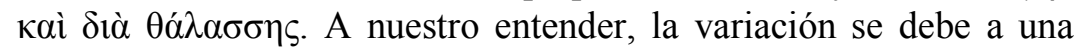
razón de precisión semántica, dado que los significados exactos de las preposiciones no son iguales. $\Delta$ ió con genitivo implica un concepto de extensión y movimiento, ${ }^{1227}$ como se observa en V 47 ,

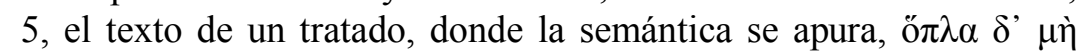

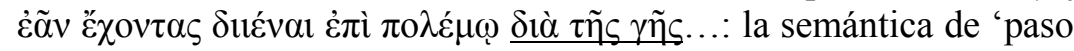
a través' es clara.

Variación entre construcción preposicional y sustantivo en

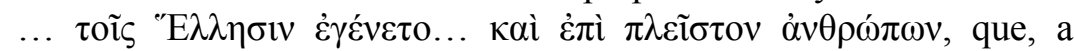
nuestro entender, responde de nuevo a una precisión semántica. A la semántica del dativo de interés se une en la construcción preposicional la semántica de perjuicio derivada del sentido inicial de la preposición, ${ }^{1228}$ aunque no ha de desestimarse el uso ya sancionado del sintagma غ̇ंì $\pi \lambda \varepsilon \tilde{\tau} \sigma \tau o v$, del que Schrader cuenta dieciocho ejemplos. ${ }^{122}$

- 2, 2. $\pi \alpha ́ \lambda \alpha$ y $\tau \grave{\alpha} \pi \rho o ́ \tau \varepsilon \rho \alpha::^{1230}$ un nuevo caso de precisión semántica, dado que el primer término tiene un sentido relativo a lo ancestral (las costumbres o el pasado más lejano), ${ }^{1231}$ en tanto que el segundo se refiere a un pasado más cercano; ${ }^{1232}$ variación en los

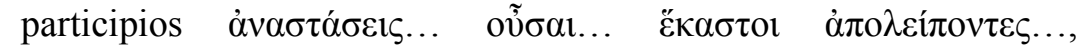

${ }^{1225}$ Cf. además lo indicado en el análisis de la cuestión tucidídea, apartado 5.1.

${ }^{1226}$ Cf. Ros, 1968 , pp. 148 y 156.

${ }^{1227}$ Cf. Crespo, Conti y Maquieira, 2003, p. 169.

${ }^{1228}$ Cf. Crespo, Conti y Maquieira, 2003, p. 173 y ss. Maddalena, 1972, p. 6, señala además la idea de progresión.

${ }^{1229}$ Cf. Schrader, 1996, S. v.

${ }^{1230}$ Cf. Ros, 1968, p. 110.

${ }^{1231}$ Cf. Schrader, 1996, S. v., especialmente I 2, 1; 5, 1; 6, 5; 13, 5; II 35, 3, y 54, 2.

${ }^{1232}$ Cf. Schrader, 1996, S. V., IV 114, 5 y VIII 50, 5. 
asimilable a un caso de exceso estilístico claro, y no a una intención expresiva, aunque ese exceso pueda asimilarse a un deseo de

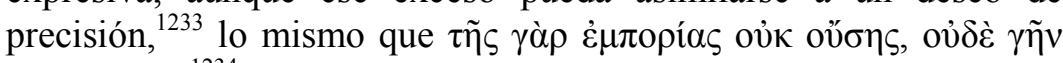

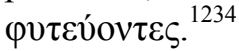

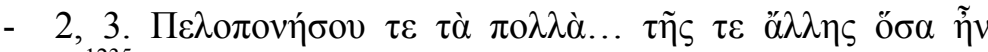
$\kappa \rho \alpha ́ \tau \tau \sigma \tau \alpha::^{1235}$ es difícil de justificar si no se trata simplemente de un recurso estilístico.

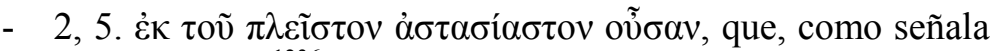
Ros, y antes Shilleto, ${ }^{1236}$ responde a una variación de la expresión

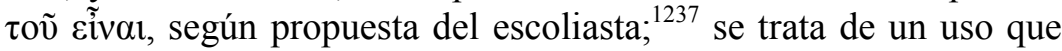
responde, pues, a un híbrido de construcción debido a una falta de consistencia entre la construcción del periodo principal y la del subordinado, representado por la construcción de $\tau$ oṽ más infinitivo, en este caso participio por necesidades sintácticas, en un uso que da cuenta del estadio de evolución de la prosa en que se encuentra Tucídides, con grados de experimentación quizá excesivos para nosotros.

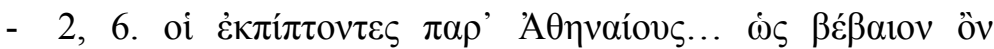

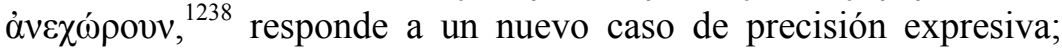

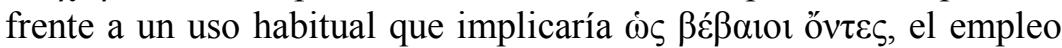
del neutro responde a una expresión abstracta que recoge más aspectos que los individuales, refiriéndose así a las circunstancias generales, y no solo a la integridad de los individuos. ${ }^{1239}$

- 3, 2-3. Variaciones entre el verbo simple $\kappa \alpha \lambda \varepsilon \tilde{i v}$ y sus compuestos: ${ }^{1240}$ responde de nuevo a un caso de precisión semántica por parte de Tucídides.

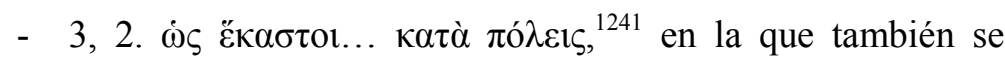
advierte un interés por precisar semánticamente la expresión: sección

${ }^{1233}$ Cf. Ros, 1968, pp. 165, nota 9, y 231, nota 8; cf. además nuestro análisis de esta

${ }^{1234}$ Cf. Ros, 1968, pp. 69 y 255.

${ }^{1235}$ Cf. Ros, 1968, p. 392.

${ }^{1236}$ Cf. Shilleto, 1872 , p. 3.

${ }^{1237}$ Cf. Ros, 1968, p. 69.

${ }^{1238}$ Cf. Ros, 1968, p. 220.

${ }^{1239}$ En parte así Classen, pero cf. Ros, 1968, p. 229 para diferentes interpretaciones.

${ }^{1240}$ Cf. Ros, 1968, p. 118. 
recuérdese lo dicho sobre los usos de esta preposición respecto a 1 , 2.

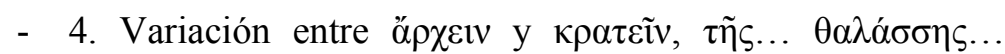

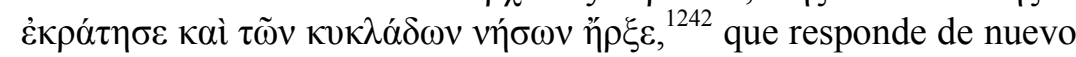

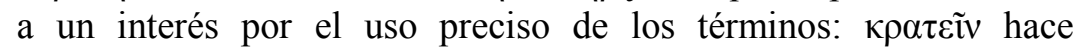
referencia al sometimiento como tal y ö $\rho \chi \varepsilon ı v$ al gobierno, con los matices que se quiera. ${ }^{1243}$

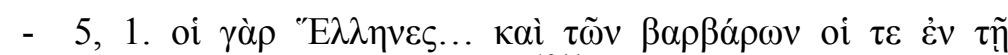

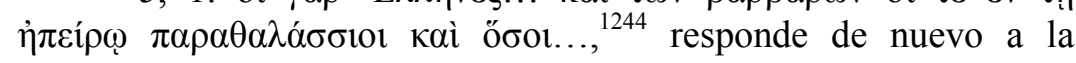
necesidad de precisar la expresión, lo que ocurre también con la

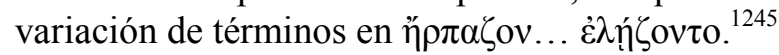

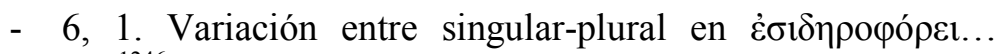

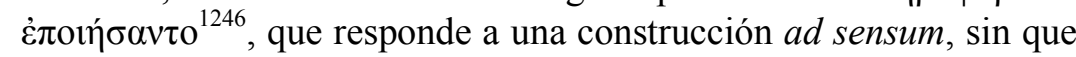
pueda explicarse desde un interés por ser preciso.

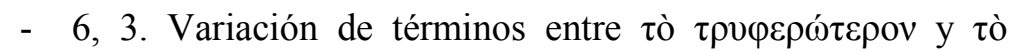

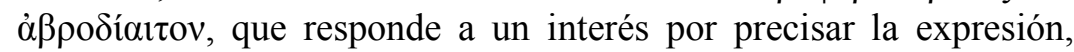

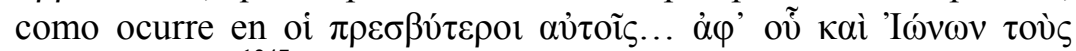
$\pi \rho \varepsilon \sigma \beta v \tau \varepsilon \dot{\rho} \rho \varsigma{ }^{1247}$

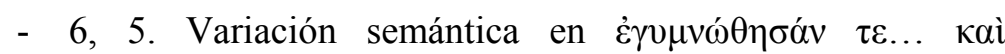
$\dot{\alpha} \pi \circ \delta \delta \dot{v} \tau \varepsilon \varsigma \lambda i \pi \alpha \mu \varepsilon \tau \grave{\alpha} \tau o \tilde{~} \gamma v \mu v \alpha ́ \zeta \varepsilon \sigma \theta \alpha 1,{ }^{1248}$ donde también se observa la necesidad de precisar la expresión, como lo demuestra la aparición de un complemento con el participio, al tiempo que la necesidad de recoger el verbo anterior con un complemento temporal apunta a la clara diferencia semántica entre ambos verbos.

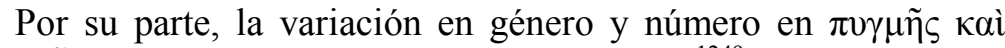

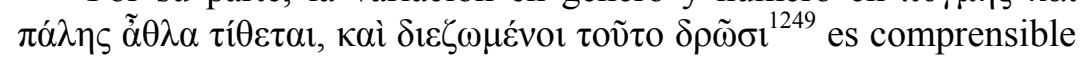

${ }^{1241}$ Cf. Ros, 1968, p. 185.

${ }^{1242}$ Cf. Ros, 1968, p. 124.

${ }^{1243}$ Cf. Bétant, 1969, s. v.

${ }^{1244}$ Cf. Ros, 1968 , pp. 157 y 392.

1245 Cf. Ros, 1968, p. 123 y ss. Cf. Bétant, 1969, s. v. El primer término responde a 'saquear' y el segundo a 'devastar'.

${ }^{1246}$ Cf. Ros, 1968, p. 213 y ss. Nótese, como indica el propio Ros, que hay una variante textual con el primer verbo en plural transmitida por vía indirecta y que recoge Hude.

${ }^{1247}$ Cf. Ros, 1968, p. 266.

${ }^{1248}$ Cf. Ros, 1968, p. 127.

${ }^{1249}$ Cf. Ros, 1968, p. 229 y ss. 
si se asume que Tucídides elige entre recoger con el anafórico los diferentes sustantivos o el periodo entero, como hace en este caso.

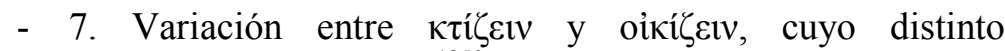
significado está fuera de duda, ${ }^{1250}$ mientras que la diferencia entre

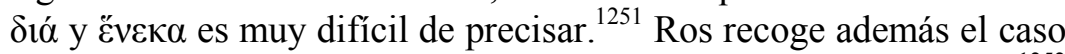

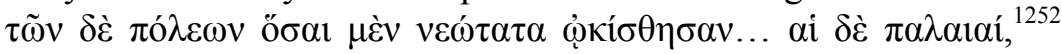
semejante al visto en 5,1 .

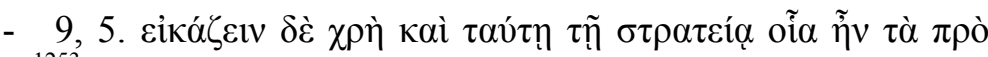
$\alpha \hat{\tau} \tau \tilde{\eta} \varsigma,{ }^{1253}$ que de nuevo responde a un uso abstracto del neutro, comprensible dentro del esquema general de conceptos del proemio.

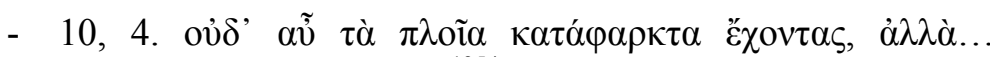
$\lambda \eta\rceil \sigma \tau \kappa \omega ́ \tau \varepsilon \rho o v ~ \pi \alpha \rho \varepsilon \sigma \kappa \varepsilon v \alpha \sigma \mu \varepsilon ́ v \alpha,{ }^{1254}$ que constituye otro caso de precisión sintáctica, al variar el adjetivo por un adverbio más participio.

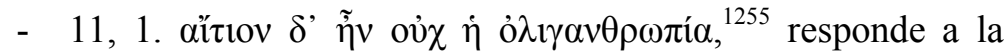
misma intepretación que 6, 5 .

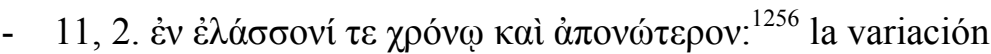
entre construcción preposicional y adverbio se puede asimilar también a necesidades de precisión expresiva.

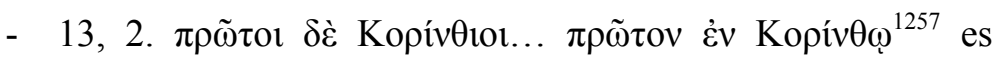
únicamente explicable como variación estilística, en tanto que

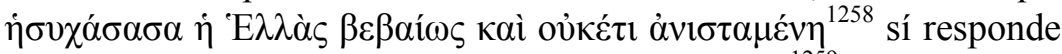
a un caso de variación léxica con afán de precisión. ${ }^{1259}$

${ }^{1250}$ Cf. Bétant, 1969, s. v. El primero es 'fundar' y el segundo 'habitar'.

${ }^{1251}$ Cf. Ros, 1968, pp. 126 (cf. además pp. 323 y 337) y 137.

1252 Cf. Ros, 1968, p. 392 . En p. 394 se examina un caso semejante: ह̌ $\varphi \varepsilon \rho o v ~ \gamma \grave{\alpha} \rho$

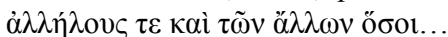

${ }^{1253}$ Cf. Ros, 1968, p. 231.

${ }^{1254}$ Cf. Ros, 1968, p. 162.

${ }^{1255}$ Cf. Ros, 1968, p. 226.

${ }^{1256}$ Cf. Ros, 1968, p. 164.

${ }^{1257}$ Cf. Ros, 1968, p. 107.

${ }^{1258}$ Cf. Ros, 1968, p. 144.

${ }^{1259}$ Cf. Bétant, 1969, S. v. El primer término puede asimilarse a 'tranquilidad interior', en tanto que el segundo se asimila a 'movimientos de población', 'migraciones' indica Bétant, como bien sugiere el contexto. 


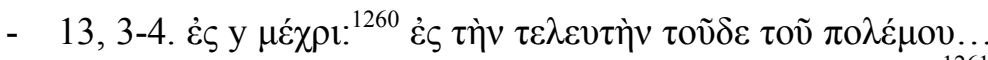

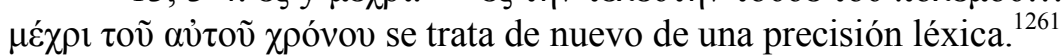

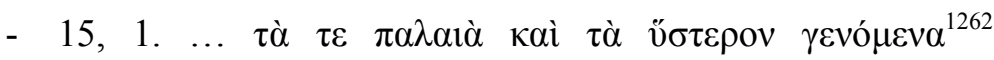
responde, una vez más, a una precisión léxica, para la cual recuérdese lo dicho en $2,2$.

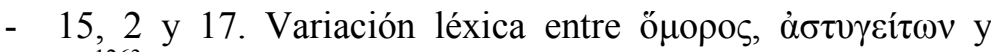
$\pi \varepsilon$ íou ç: $^{1263}$ un nuevo caso de precisión semántica, si bien Bétant recoge todos con el significado de finitimus. A nuestro entender, la diferencia semántica es clara entre ő $\mu о \rho о \varsigma$, que hace referencia a individuos de zonas limítrofes, ${ }^{1264}$ en tanto que ò $\sigma \tau v \gamma \varepsilon i ́ \tau \omega v$ responde al latín cives, simplemente 'ciudadano'. Finalmente, $\pi \varepsilon p$ óouко $\varsigma$ merece especial atención. Un examen de la concordancia y el léxico nos advierte de que este es el único caso en el que se emplea sin el sentido técnico de 'perieco', ${ }^{1265}$ lo que, unido al hecho de que se presenta en alusión a los tiranos, puede hacernos pensar en un sentido despectivo.

- 18, 1. vं parece tener explicación en ningún tipo de precisión semántica,

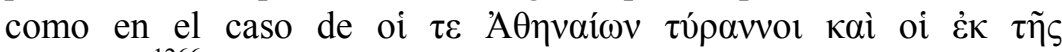

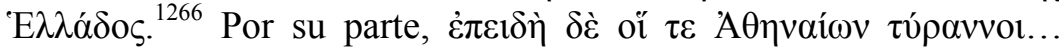

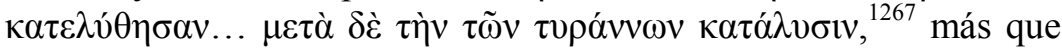
un ejemplo de variatio, sirve como muestra clara del desarrollo del léxico abstracto en Tucídides.

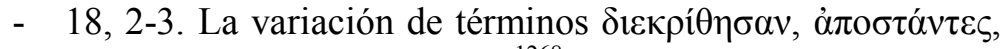
$\delta 1 \varepsilon v \varepsilon \chi \theta \dot{v} v \tau \varepsilon \varsigma, \delta 1 \alpha \sigma \tau \alpha \tilde{\varepsilon} \varepsilon v$ y $\dot{\chi} \chi \omega ́ \rho o v v^{1268}$ se explica de nuevo por precisión léxica.

${ }^{1260}$ Cf. Ros, 1968, p. 137.

${ }^{1261}$ Cf. Crespo, Conti y Maquieira, 2003, p. 170, con discusión de este pasaje, y p. 181.

${ }^{1262}$ Cf. Ros, 1968, p. 160.

${ }^{1263}$ Cf. Ros, 1968, p. 105.

${ }^{1264}$ Cf. Betánt, 1969, s. v., y Schrader, 1996, s. v., especialmente los ejemplos I 57, 5: عi

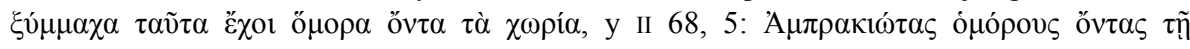

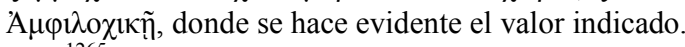

${ }^{1265}$ Presente en I 101, 2; III 92, 5; IV 8; 53, 2, y VIII 6, 4

${ }^{1266}$ Cf. Ros, 1968, pp. 107 y 174.

${ }^{1267}$ Cf. Ros, 1968, p. 401.

${ }^{1268}$ Cf. Ros, 1968, p. 127. 
- 18, 3. Variación de términos entre ó $\mu \alpha \_\chi \mu i ́ \alpha$ y $\mu \varepsilon \tau \grave{\alpha} \tau \tilde{\omega} v$ $\xi v \mu \mu \alpha ́ x \omega v,{ }^{1269}$ de nuevo por precisión semántica. ${ }^{1270}$ En cambio, el

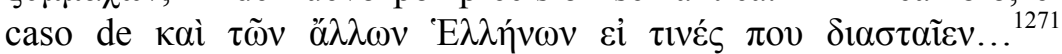
responde a un exceso gramatical que, de nuevo por tratar de afinar la precisión, pasa de la construcción de genitivo partitivo y oración relativa a un genitivo partitivo con una condicional, a fin de subrayar el valor condicional clave en el pasaje.

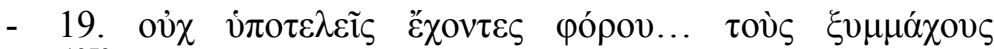

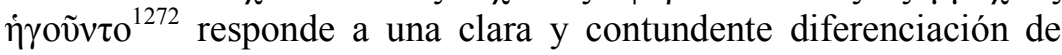
significado entre el carácter imperialista de lo primero y la concepción habitual de un aliado en el segundo, como demuestra el

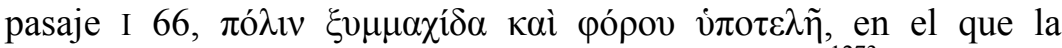
precisión añadida por el segundo adjetivo es evidente. ${ }^{1273}$

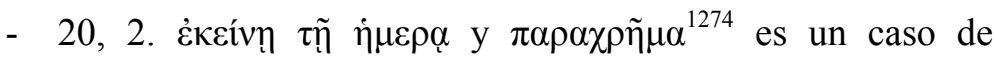
precisión léxica, en la que no se varía entre construcción preposicional y adverbio, sino que suman significados.

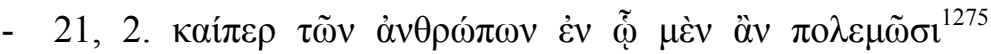
supone de nuevo un caso de necesidad de precisar, en este caso el carácter eventual de la expresión, que con el participio no estaría claro.

- 22, 2. $\tau \grave{\alpha} \delta^{\prime} \ddot{\varepsilon} \rho \gamma \alpha \tau \tilde{\omega} v \pi \rho \alpha \chi \theta \dot{\varepsilon} v \tau \omega v^{1276}$ supone un exceso semántico de precisión, en tanto que la variación entre participio y

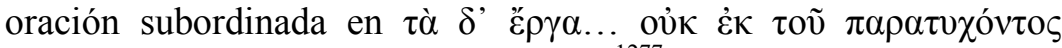

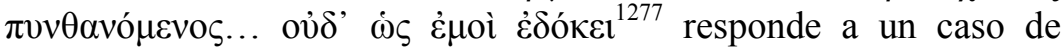
variación sin causa clara.

${ }^{1269}$ Cf. Ros, 1968, p. 102.

${ }^{1270}$ Nótese además que es un hápax, cf. Schrader, 1996, s. v., y Bétant, 1969, S. V.

1271 Cf. Ros, 1968, p. 397.

${ }^{1272}$ Cf. Ros, 1968, p. 130.

${ }^{1273}$ Cf. Bétant, 1969, y Schrader, 1996, s. V., para más ejemplos semejantes.

${ }^{1274}$ Cf. Ros, 1968, p. 173.

${ }^{1275}$ Cf. Ros, 1968, p. 418

${ }^{1276}$ Cf. Ros, 1968, p. 103.

${ }^{1277}$ Cf. Ros, 1968, p. 421. Es de señalar además la clara diferencia semántica de los términos empleados, cosa que Ros aparentemente no recoge. 


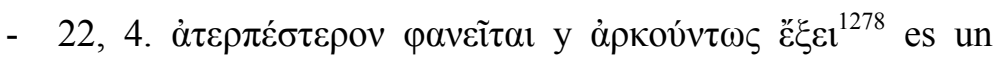
caso de precisión semántica en el que se observa la diferencia entre los verbos, con la clara especialización del primero, que, como veremos goza casi de sentido técnico.

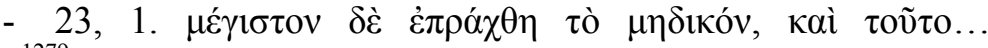
$\varepsilon \tilde{\sigma \chi \varepsilon v^{1279}}$ responde a la necesidad de expresar todo el conjunto de aspectos que se produjeron en el enfrentamiento contra el persa, lo que lleva al empleo del sustantivo neutro, de la pasiva, y al cambio posterior a activa al necesitarse una nueva precisión que obliga a que el sujeto sea un abstracto.

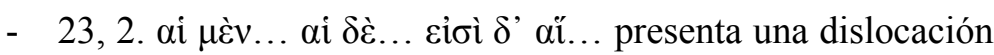
en el desarrollo habitual de la construcción debido a la necesidad de introducir una oración subordinada relativa, precisamente para poder expresar la idea del autor. Igual criterio se puede aplicar, quizá con

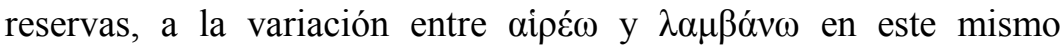

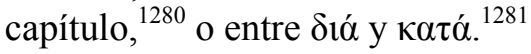

- 23, 5. Variación entre $\delta i \alpha ́$ y $\dot{\varepsilon} \kappa,{ }^{1282}$ a nuestro entender por los mismos motivos antes señalados respecto a la variación en

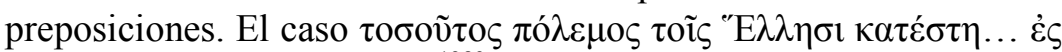

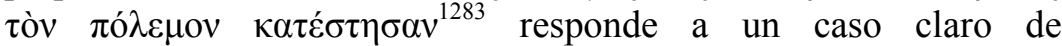
perspectiva, por cuanto en el primer caso se acentúa el concepto de guerra, piénsese en el adjetivo, mientras que en el segundo caso se señala la posición de los contendientes y sus acciones.

El examen detenido de los casos de variatio recogidos por Ros en el proemio, desechados aquellos ejemplos que no nos parecían propiamente variationes, nos permite ver que, en una gran mayoría de ejemplos, es posible aducir una funcionalidad claramente enfocada a una precisión léxica, que al lector, o incluso a los antiguos de épocas posteriores -dado que se

${ }^{1278}$ Cf. Ros, 1968, p. 184

${ }^{1279}$ Cf. Ros, 1968, p. 277.

${ }^{1280}$ En este caso es difícil determinar la diferenciación léxica entre aipé $\omega$, referido claramente a la toma por sitio de una ciudad, mientras que en relación con el segundo término podría pensarse en una toma pacífica, pero lo ambiguo del contexto complica el análisis, y es difícil no recordar el caso de Platea como máximo ejemplo al respecto.

${ }^{1281}$ Cf. Ros, 1968, pp. 116, 123 y 133 y ss.

${ }^{1282}$ Cf. Ros, 1968, p. 137.

${ }^{1283}$ Cf. Ros, 1968, p. 264. 
disfruta de un abanico de significados menores o simplemente se aspira a una menor precisión-, causa incomodo, lo que hace que la denominada variatio se entienda como simplemente un recurso estilístico, arrinconando el valor de exactitud que introduce. Esta variatio es solo comprensible desde una perspectiva en la que las estructuras tanto léxicas como semánticas están perfectamente creadas, lo que justifica la dificultad que crean a un lector -acostumbrado tanto a una gramática de manual o a la lectura de un modelo clásico de prosa al modo isocrateo- las fuertes rupturas de la conformación del texto. Así, baste observar la aparición de oraciones condicionales desempeñando la función de oraciones de relativo, lo que supera hasta las equivalencias más habituales, como pudiera ser la existente entre un adjetivo o una oración de relativo, medio empleado para favorecer la expresión precisa y exacta, que en el caso presente se lleva a extremos que no se repetirán en ese grado en ninguna otra etapa de la lengua griega.

\subsubsection{DESARROLLO DE LA FRASE}

En el proemio encontramos ejemplos del denominado estilo кaí. Si bien

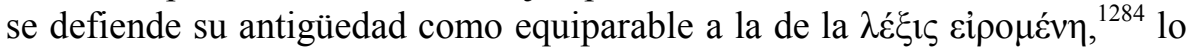
cierto es que en nuestro análisis de los proemios su aparición se retrasa hasta Tucídides, dada la particular naturaleza de este estilo, que, por otra parte, no se muestra precisamente en Tucídides en su forma más clara.

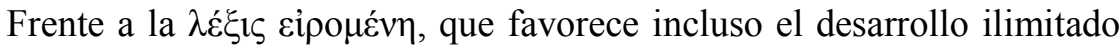
pero tedioso de los periodos, en el presente estilo se observa una limitación de su extensión, ${ }^{1285}$ aun entendiendo por estilo $\kappa \alpha i$ el empleo generalizado de nexos copulativos aparte de $\delta \varepsilon ́$. En líneas generales, la falta de repeticiones continuas como las observadas, por ejemplo, en Heródoto confiere al estilo кaí una rapidez notable en el desarrollo de periodos narrativos tanto en historiadores como en oradores, sus principales cultivadores en el presente

\footnotetext{
${ }^{1284}$ Cf. Trenkner, 1960, p. 1 y ss., para la defensa de esa antigüedad, si bien su mejor momento es solo observable en el desarrollo de la prosa ática.

${ }^{1285}$ Cf. Trenker, 1960 , p. 10 y ss. 
periodo, ${ }^{1286}$ si bien las observaciones de Trenkner a este respecto son algo confusas. ${ }^{1287}$

La aparición de este estilo en el proemio de Tucídides respalda lo hasta ahora dicho: su empleo se concreta en las narraciones, en las que es suficiente la simple acumulación de ideas, pero de un modo que se aleja de la especial sonoridad de las partes narrativas del proemio de Heródoto. Así, I 4 y 5, 1 son buenos ejemplos de lo dicho; la narración relativa a Minos, que bien pudiera expresarse en tonos míticos semejantes a los de Heródoto y los

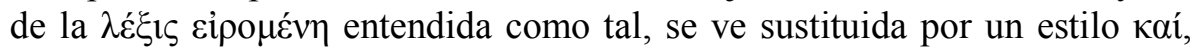
con una agilidad mayor que la presente en el caso del de Halicarnaso, a pesar

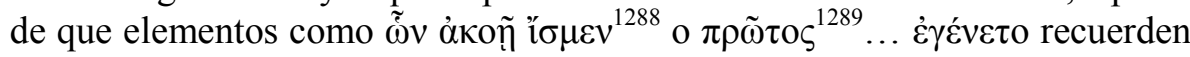
perfectamente a Heródoto. Además, estos incisos se insertan en pasajes de mayor sencillez narrativa, como los vistos, o como la narración de los inicios de la navegación corintia en I 13, 2-6, con abundante empleo de $\kappa \alpha$ y y una sencillez poco usual.

Otro ejemplo nítido es I 6, 3-5: las oraciones, de no mucha extensión se presentan sin un excesivo grado de complejidad, en ocasiones sin subordinación incluso, o con la aparición de elementos ya conocidos de la

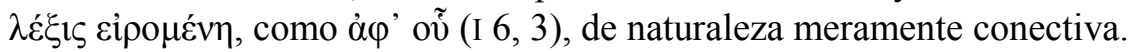

De igual manera, aparecen pasajes narrativos en los que el estilo кaí puro se combina con usos de $\delta \varepsilon$, todo ello en estructuras sintácticas de moderada sencillez. ${ }^{1290}$ Así, se presentan pasajes como I 15, 2-16, 1, o 20, 1$3,{ }^{1291}$ en los que $\delta \varepsilon ́$ se reserva para el desarrollo de la narración tras pausa fuerte -algo habitual-, ${ }^{1292}$ у каí coordina frases dentro de un período,

${ }^{1286}$ Cf. Trenkner, 1960, p. 2 y ss.

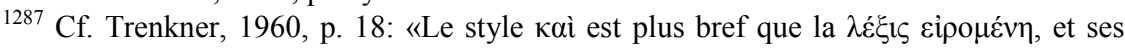
répétitions tautologiques [...] Hérodote manque parfois une hâte, il remplace les

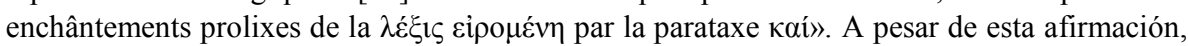
en p. 23 lo desmiente. A nuestro entender el estilo кaì representa el nivel oral narrativo hablado, cf. para ello Trenkner, 1960, p. 59, frente a los mecanismos literarios que suponen la

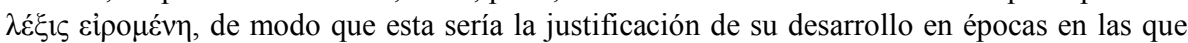
aún subsistían mecanismos orales pero estaban ya presentes medios de escritura, precisamente el escenario de Heródoto y Tucídides.

${ }^{1288}$ Cf. I 4,$1 ; 13,4$.

${ }^{1289}$ Cf. I 4, 1; 6, 3; 6, 4 .

${ }^{1290}$ Cf. además Ros, 1968 , p. 138 y ss., para ejemplos de variatio con nexos.

${ }^{1291}$ Nótese que además este pasaje concentra algunas de las pocas sententiae de la obra de Tucídides fuera de los discursos, cf. Meister, 1955, p. 13.

${ }^{1292}$ Cf. Denninston, 1960, p. 162 y ss.; Caballero López, 1997, p. 111. 
pensamos que respondiendo al criterio de considerar este segundo nexo como propio del nivel conversacional, mientras que el primero, por su

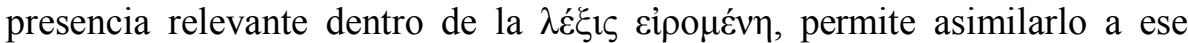
nivel estilístico y -lo que es más importante- a un marco de estructuración del período de un nivel superior que engloba al estilo кaí.

La aparente simplicidad del estilo kaí se ve pronto superada por el desarrollo de una complejidad en ciertos pasajes que, partiendo de esquemas simples de coordinación, hace un empleo profuso de participios absolutos $u$ oraciones circunstanciales que gravitan en torno a la oración principal sin excesiva unión, en unos usos ajenos a las corrientes gorgianas, y, en general, a toda la prosa de la época. ${ }^{1293}$

Probablemente, un caso paradigmático de todo aquello que puede ser considerado como opuesto a los planteamientos de la retórica es el parágrafo 2,2 . Seis líneas hay que esperar para alcanzar el verbo principal, que se demora por la presencia de participios dependientes del sujeto que a su vez llevan participios absolutos, que justifican por su parte los anteriores participios, generando así un grado de elaboración conceptual que explica de manera razonada, simplemente, las ideas observadas en la tesis inicial:

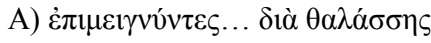

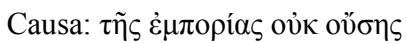

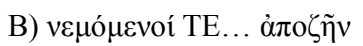
KAI $\pi \varepsilon \rho 1 o v \sigma i ́ \alpha \nu . . . ~ \varepsilon ̌ \chi o v \tau \varepsilon \varsigma$

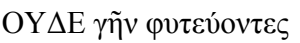

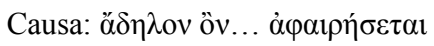

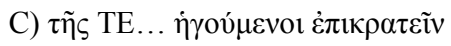

Oración principal: ov̉... $\alpha \dot{\pi} \alpha v i ́ \sigma \tau \alpha v \tau$,

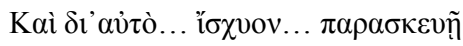

Otro ejemplo, quizá más sencillo, lo constituye I 8, 1, en el que la oración principal asume una posición central en torno a la que gravitan, de nuevo sin excesiva unión, un conjunto de oraciones subordinadas, que

${ }^{1293}$ Cf. Schmid y Stählin, 1948, p. 200. 
añaden información a una oración principal que no aporta información nueva alguna: ${ }^{1294}$

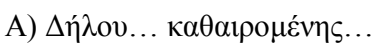
B) $\tau \tilde{\omega} v \theta \eta \kappa \tilde{\omega} v \dot{\alpha} v \alpha \iota \rho \varepsilon \theta \varepsilon \epsilon \sigma \tilde{\omega} v$

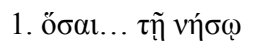

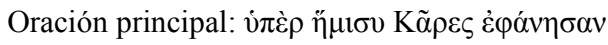

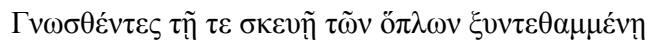

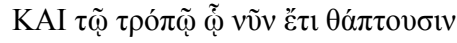

Así, podemos observar cómo la idea ya expresada es recogida de nuevo y ampliada, fundamentando el paso para un análisis del aparato circunstancial del hecho expresado, de modo que la información que a primera vista se nos presenta como fundamental adquiere una segunda posición frente a lo realmente importante, el análisis de los condicionantes del hecho.

Algo semejante ocurre en el complejo pasaje i 21, en el que una oración constituida por un periodo principal se ve amplificada por medio de simple coordinación y por el empleo de participios que se ven amplificados por medio de oraciones y elementos de todo tipo:

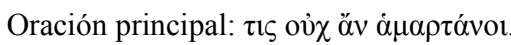

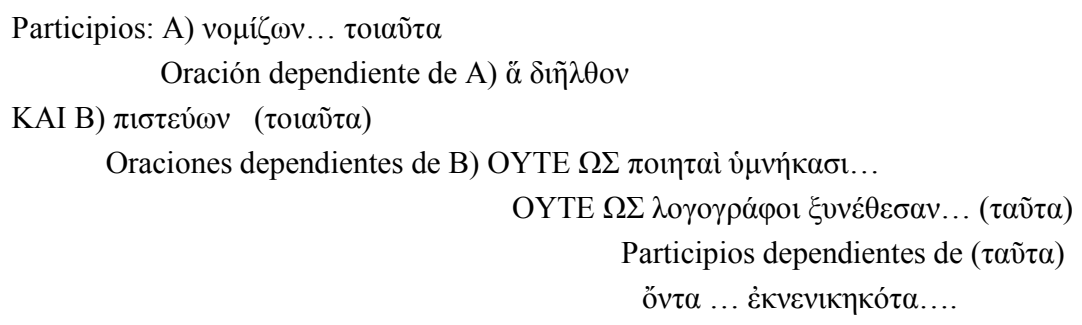

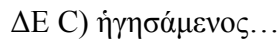

De nuevo se parte de principios de gran sencillez que se van complicando, simplemente, por el desarrollo de la estructura, siempre en un esquema general de coordinación sobre el que se construye el resto de la sección; no hay nada parecido a lo que encontraremos en el siglo IV a. C. dentro de la oratoria, ni en sus pasajes más complejos ni en los más simples.

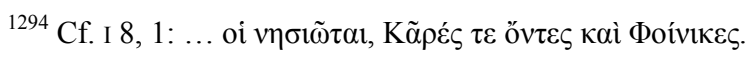


Otro tipo de expresión empleada por Tucídides en el proemio responde al uso de breves pasajes sin gran complicación que no responden a secciones de naturaleza narrativa, sino que se construyen como tesis afirmativas que constatan una realidad, a las que normalmente sigue un pasaje narrativo o

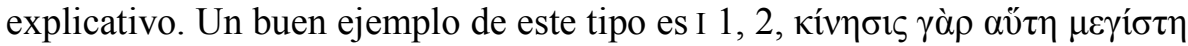

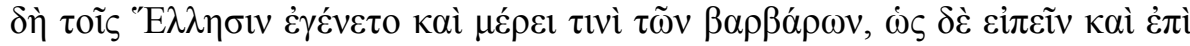
$\pi \lambda \varepsilon i ̃ \sigma \tau o v \dot{\alpha} v \theta \rho \omega ́ \pi \omega v$, en la que simplemente se presenta una afirmación que puede estar más o menos desarrollada, como ocurre en I 2, 1, donde el verbo

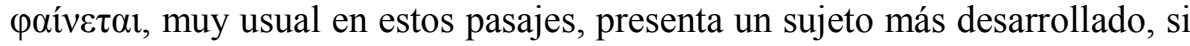
bien la unidad general se mantiene, a diferencia de lo que ocurría en los casos del desarrollo del estilo кaí.

Interesante es observar que estos pasajes -que denominaremos de tesispresentan una naturaleza estructural que señalamos en su momento y que se beneficia de esa sencillez. No es poco usual que aparezcan en varias ocasiones en pasajes de esta naturaleza nexos conclusivos, como oũv ${ }^{1295} \mathrm{o}$

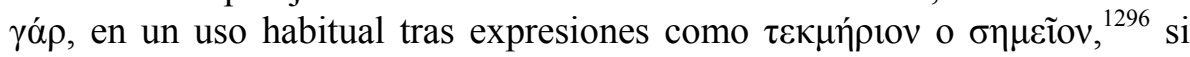
bien por norma general el término no se expresa. Este uso, a todas luces irregular respecto a lo recogido por Denninston, se comprende si asumimos el valor de clavija de los pasajes que denominamos de tesis, dado que son

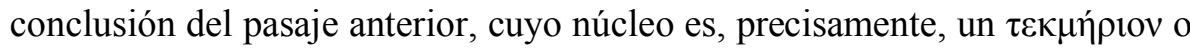
pasaje narrativo como los antes señalados, y a su vez son inicio de un nuevo

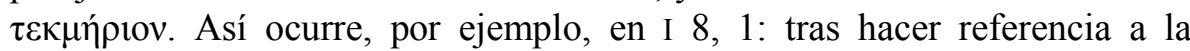
piratería y a los problemas que planteaba para la localización de las poblaciones, se concluye que los piratas eran isleños y carios, pues ( $\gamma \alpha \dot{\alpha} \rho)$ esos habitaban las islas, una idea a la que sigue un pasaje explicativo.

En lo que se refiere al complicado capítulo I 22, el denominado método, Günther Wille esclareció ${ }^{1297}$ la red compleja de paralelos existentes entre las secciones de su interior, que configuraban un esquema por completo desproporcionado, ajeno, diríamos, a los habituales equilibrios literarios de la época, aun incluso en la literatura de corte oral. Más allá de los motivos y paralelos conceptuales que respaldan el desequilibrio existente en el plano formal, parece interesante observar, cosa fácil gracias al esquema realizado por Wille, que la estructura general parte de nuevo, como vimos ya antes, de

${ }^{1295}$ Cf. I 3, 4; 15, 1. Cf. Denninston, 1960, p. 425 y ss.

1296 Cf. Denninston, 1960 , p. 58 y ss. Para un uso «regular», cf. Tucídides, I 8, 1:

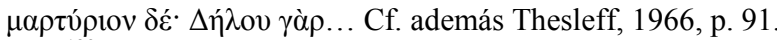

${ }^{1297}$ Cf. Wille, 1968 , p. 700 y ss. 


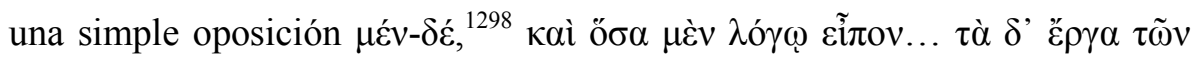
$\pi \rho \alpha \chi \theta \varepsilon \dot{v} \tau \omega v \ldots$, pero es la precisión semántica, precisión que, como ya señaló Gomme, es responsable del extraño ह̌ $\rho \gamma \alpha \tau \tilde{\omega} \nu \pi \rho \alpha \chi \theta \varepsilon ́ v \tau \omega v,{ }^{1299}$ la que lleva en la primera parte al empleo de la oración de relativo, que desencadena que, en lugar de un sintagma preposicional, se desarrolle el empleo de participios,

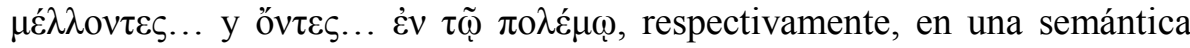
que, si se quiere, es más precisa en el primer caso, pero que -nótese el detalle- presupone el sintagma $\dot{\varepsilon} \nu \tau \tilde{\varphi}$ $\pi \mathrm{o} \lambda \dot{\varepsilon} \mu \omega$, dado que para recoger el último ejemplo deberíamos retroceder siete líneas y cambiar de capítulo, o recurrir a la semántica del infinitivo $\pi \mathrm{o} \lambda \varepsilon \mu \eta ́ \sigma \varepsilon \varepsilon v$, lo que deja claro que en esencia los conceptos son paralelos en esta sección.

Sin embargo, en las secciones siguientes disentimos de las opiniones de Wille: creemos que estas van más allá de lo que el propio Tucídides quiere indicar. Parece claro que, como indica Wille, los aspectos están invertidos, pero no por razones estilísticas, ni tampoco de contenido, ya que Tucídides dice precisamente lo contrario en cada una de las dos secciones, a pesar de las afirmaciones que la crítica ha presentado, con Gomme a la cabeza: ${ }^{1300} \dot{\omega} \varsigma$

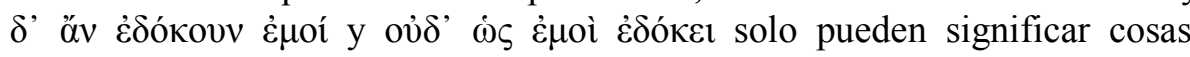
contrarias. Así, el esquema termina por romperse y no acepta paralelismo alguno; las ideas fluyen de manera lógica y, simultáneamente, cualquier intento de establecer un esquema estilístico parece imposible.

Sin embargo, si partimos de nuevo de los esquemas mínimos, se observará que la construcción del pasaje responde a la misma progresión desordenada antes observada, en la que una frase principal de gran brevedad, se ve desarrollada por medio de participios, oraciones comparativas o acusativos de relación que aparecen en forma de oraciones. En resumidas cuentas, la naturaleza formal del pasaje responde a los rasgos antes observados, sin que sea posible adivinar paralelismos. ${ }^{1301}$

${ }^{1298}$ Como señala Gomme, 1950 , p. 140 , nota 1, principalmente tras la confusión con $\dot{\omega} \varsigma$

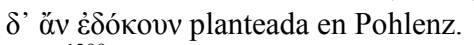

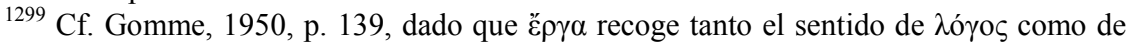
है $\gamma \gamma \alpha$. Ya Stahl, 1886, p. 115.

${ }^{1300}$ Cf. Gomme, 1950, p. 140 y ss.

${ }^{1301}$ Obviamente, con ello rechazamos la idea de Pelling, 2000, p. 117, quien veía cierta vaguedad en la expresión de este capítulo. 


\subsubsection{TUCÍDIDES EN LA ENCRUCIJADA DE LA PROSA GRIEGA}

La exposición de la caracterización general del estilo de Tucídides con la que comenzamos esta sección parece poco útil para la sección examinada. Los esquemas gorgianos o poéticos de lo que hemos denominado «retórica oral» y que Lamb y otros defendieron, así como la supuesta influencia retórica, parecen poco adecuados para el análisis de las diferentes secciones del proemio.

Los mecanismos que vimos en las secciones narrativas del proemio herodoteo y que son también observables en otras partes narrativas de la obra están ausentes incluso de las secciones del proemio de naturaleza plenamente narrativa, y es que, en último término, la narración pura es ajena a estos capítulos, aunque pudiera parecer lo contrario.

Decía Cole ${ }^{1302}$ que la prosa tucidídea respondía a un esquema que perseguía la expresión de ideas como primera intención, si bien ello no es disculpa para determinar un estilo diferente sin dar mayor respuesta al problema. El ya clásico estudio de Snell sobre la lengua de Heráclito, un autor que constituye, sin asumir complicaciones de cronología, el mejor exponente de una reflexión intelectual compleja en el ámbito de la retórica oral, nos pone sobre aviso de la perfecta adaptación de sus ideas a los esquemas de polaridad y analogía, y con ello, simplemente, a la dualidad de términos, ${ }^{1303}$ con un vocabulario de tonos fuertemente épicos. ${ }^{1304}$

Sin embargo, Snell y después Luschnat observaron la dificultad que plantea el empleo de este esquema con mecanismos de razonamiento que nosotros consideraríamos modernos: ${ }^{1305}$ las limitaciones que supone la aplicación de un esquema tan rígido como el que acogía tanto poesía tradicional como narrativa popular de naturaleza prototípica son claras, y determinan una forma de pensar por medio de opuestos muy habitual en toda la literatura griega, pero, en último término, lo que importa es que es posible

\footnotetext{
${ }^{1302}$ Cf. Cole, 1991, p. 73: «Attic prose of this period is a prose of information and ideas».

${ }^{1303}$ Cf. Snell, 1926, p. 356 y ss.

${ }^{1304}$ Cf. Snell, 1926, p. 357 y nota 1.

${ }^{1305}$ Cf. Snell, 1926, p. 360; Luschnat, 1970, col. 1260.
} 
expresar esos pensamientos, lo que no explica el porqué del estilo de Tucídides en el proemio, dado que podría haber utilizado simplemente dichos recursos. ${ }^{1306}$

A nuestro entender, la cuestión pasa por la observación de la presencia del estilo kaí como base de la prosa tucidídea: ${ }^{1307}$ frente a los usos tradicionales observados en un autor como Heródoto -o incluso, según decimos, en los presocráticos-, la prosa de Tucídides parte de un esquema ajeno a esos mecanismos, que toma como sustento el estilo coloquial hablado de la época, el estilo kaí, en detrimento de un uso cada vez más errático de las estructuras $\mu \dot{\varepsilon} v \ldots \delta \delta^{1308},{ }^{1308}$ e inicia su desarrollo como medio de expresión adecuado para sus intereses, como señaló ya Luschnat. ${ }^{1309}$ Observábamos antes cómo las partes explicativas del proemio se sustentaban en un estilo coordinativo simple que se veía desarrollado por el profuso empleo de participios y elementos subordinados que matizaban la idea expresada por la oración principal. Frente al caso de la «retórica oral», en la que se establecía un tedioso ritmo de repeticiones para dar pie a la introducción de una nueva circunstancia, poco adecuado para la expresión que necesitaban ya los modos de reflexión de la época, ${ }^{1310}$ el caso de Tucídides supone la superación de esos esquemas para la prosa literaria, al menos en parte. La construcción de la frase, el elemento más abierto a variaciones, permite el desarrollo de una nueva tendencia compositiva igual de poco satisfactoria -al menos, a ojos de quien parte de un modelo de perfección asimilado al siglo IV a. C.-, que la empleada por los primeros prosistas, dado que la desmesura en ocasiones de los recursos circunstanciales da pie a la aparición de una dificultad excesiva en secciones

${ }^{1306}$ A pesar de que, básicamente, y como señala Lüdtke, 1930, p. 5, el anacoluto se

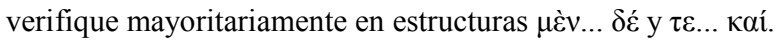

${ }^{1307}$ No está de más señalar claramente que, a nuestro entender, y a diferencia de lo que pensaba e. g. Trenkner, 1960, p. 74, el origen del estilo кaí no está en ámbitos folclóricos, sino en usos conversacionales, al modo de la idea de oral que tiene Slings, 2002. Ello se debe, como se podrá comprender a partir de nuestra intepretación de la literatura tradicional, al poco ajuste que presenta este estilo a las exigencias del mundo tradicional. Sin embargo, esto no es excusa para excluirlo del análisis de la primitiva prosa, dado que es perfectamente comprensible la aparición de rasgos de lengua conversacional en el momento en que los fuertes mecanismos de la «retórica oral» comienzan a retroceder.

${ }^{1308}$ Cf. Lüdtke, 1930, p. 25 y ss., para el anacoluto en estructuras de paralelismo, el caso más habitual de anacoluto, cf. p. 92.

1309 Cf. Luschnat, 1970, col. 1260 y ss., con referencias a la dificultad lógica de determinar no la esencia de la lengua, sino del estilo de la expresión coloquial de la época.

${ }^{1310}$ Cf. Luschnat, 1970, col. 1260. 
en las que el pensamiento de Tucídides va más allá de lo relativamente limitado de sus medios: el famoso capítulo del método, en el que la acumulación de elementos dificulta incluso el desarrollo del pensamiento, es un buen ejemplo.

Ello hace imposible que Tucídides sea un autor retórico en el sentido tradicional del término. La propuesta defendida por Blass, que lo incluye en su gran estudio interrumpiendo la línea de desarrollo de la oratoria, nos parece imposible de sostener, como también lo es el considerarlo ajeno por completo a la prosa de su época. Tucídides claro que recoge las influencias sofísticas de su época, ${ }^{1311}$ pero es difícil rastrearlas en las partes programáticas de su obra, pues, en lo que se refiere a la segunda mitad del siglo V a. C., tanto los sofistas como los oradores se mueven todavía dentro de los esquemas de la retórica tradicional, como lo demuestra el uso de recursos propios de ella. ${ }^{1312}$ Pero Tucídides crea algo nuevo, una prosa única que responde al intento claro de dotar de carta de naturaleza a la prosa hablada culta de la época de una forma todavía a nuestros ojos poco clara y muy compleja, y que incluso podemos rastrear en Heródoto.

Cabe preguntarse si este nuevo estilo, alejado de los recursos propios de una literatura oral, es propio de Tucídides o si es posible asumir que el ambiente literario culto de la época, que hemos asimilado a una esfera privada de la cultura griega, se movía en parámetros semejantes. La dificultad reside en este caso en la escasez de testimonios en los que apoyarnos, pero lo poco conservado de Protágoras autorizan a pensar en la posibilidad de que el estilo tucidídeo parta de ese nivel culto representado por un Protágoras, como apuntaba Aly, ${ }^{1313}$ si bien la escasez de textos solo nos permite advertir que, dejando atrás el famoso mito transmitido por Platón, ${ }^{1314}$ los textos disponibles dejan ya muy atrás los rasgos que vimos en Heródoto. A nuestro entender, y aun reconociendo lo arriesgado de nuestras afirmaciones, dada la falta de un elenco de textos sobre los que apoyarlas,

1311 Cf. Blass, 1887, I, p. 203. Cf. además Aly, 1929, p. 101, quien sitúa a Protágoras como paso intermedio entre Heródoto y Tucídides, si bien acertadamente concluye que ello no significa absoluta dependencia de Tucídides de Protágoras. Por otra parte, niega el supuesto gorgianismo de Tucídides de manera clara, cf. p. 171.

${ }^{1312}$ Cf. sin ir más lejos los estudios clásicos de Blass, 1887, I, p. 65 y ss., para Gorgias, y para Antifonte, cf. Aly, 1929, p. 168 y ss.

${ }^{1313}$ Cf. Aly, 1929, p. 179.

${ }^{1314}$ Cuyo estilo, por otra parte, es seguramente protagórico. Cf. Aly, 1929, p. 70 y ss.; Norden, 1956, p. 368 y ss., aunque han de tenerse presentes las indicaciones de prudencia de Thesleff, 1966, p. 98 y ss. 
pensamos que el caso de Tucídides es un ejemplo claro de la senda que tomó la prosa griega en la etapa de transición entre lo oral y lo escrito que antes presentábamos: la caída de las estructuras fuertemente cohesionadas de la «retórica oral» se produjo -no nos atrevemos a presentar primacías o relaciones de efecto-causa-, al tiempo que aparecía una necesidad clara de dar salida a unas nuevas formas de pensamiento de carácter profundamente abstracto $^{1315}$ y preciso que poca cabida podían tener en un marco tan duramente reglamentado como el expuesto respecto al estadio oral; el propio Heródoto es responsable de periodos poco organizados, casi caóticos, como los que hemos visto en Tucídides, y que responden a la necesidad expresiva del autor. En el caso de Tucídides, que parte de la facilidad que le ofrece el no tener presentes esas estructuras, salvo en el marco composicional de la obra, se puede ver que toma como punto de partida el nivel ático culto de la época, sobre cuya trama desarrollará de manera experimental un estilo propio que supondrá en ocasiones el sobrepasar incluso los límites que el propio estilo kaí ofrecía, con la consiguiente dificultad de comprensión.

Tucídides es, si se quiere, un autor de máximos, ${ }^{1316}$ un literato que emplea un nivel técnico de expresión muy elevado, y ello hace que en él veamos desarrollada hasta el exceso la estructura de lo que asimilamos como prosa «clásica» del siglo IV a. C. López Eire, en un importante trabajo sobre la lengua de Tucídides, advirtió de la importante posición de este autor para la futura koiné, ${ }^{1317} \mathrm{y}$, en lo que al estilo se refiere, es de destacar que el estilo кaí es la clave para la comprensión de esta situación del historiador; pero, como decíamos, la complejidad estilística de Tucídides poco tiene que ver con la elaboración de la prosa de la koiné, salvo si nos atenemos a ese núcleo originario de estilo coordinativo simple, momento en que la realidad nos sumerge de lleno en el futuro desarrollo de la prosa griega, en el que Tucídides es un experimento demasiado avanzado por su complejidad intelectual: la expresión del pensamiento corría pareja a las posibilidades que ofrecía una composición literaria encerrada en los requisitos que imponía la necesidad de organizar las ideas en forma tal que facilitase su memorización.

1315 Sobre la relación entre pensamiento abstracto y estilo, cf. las pinceladas de Parry, 1970 , p. 20, cuyo diseño general de la abstracción en la literatura griega no nos parece excesivamente ajustado a la complejidad del asunto.

${ }^{1316}$ Cf. Dover, 1973: «Thucydides seems constantly to expect us to understand a little more of his own process of thought than he has actually communicated to us in the written word».

${ }^{1317}$ Cf. López Eire, 1984, p. 245 y ss. 
Cuando surge el nebuloso periodo de transición entre lo oral y lo escrito, en el caso de las barreras que limitaban la expresión en la forma tan característica que observamos en un Ferécides, lo que era necesidad se muestra como opción, y los autores quizá siguieran pensando igual, o quizá no (la idea de Ong, acerca de la necesidad de la escritura para la aparición de determinados géneros solo nos parece válida si hablamos de composición literaria y no de simple pensamiento), ${ }^{1318}$ pero lo que sí tuvieron fue la posibilidad de experimentar y desarrollar un nuevo modo de expresión libre, que bascularía desde los tímidos pero reales pasos de Heródoto, quien ya genera pasajes sintácticos de dificultad, hasta el exceso contrario, el tucidídeo. Tucídides es, como decimos, y ya señaló López Eire, el eslabón clave para la creación de la expresión periódica y medida de un Isócrates, que caracterizará las etapas literarias posteriores y cuyas raíces hemos de buscar en la expresión oral culta de la época, único nivel estilístico libre de los recursos propios de la literatura oral. Sea como fuere y en último término, Tucídides parte de unos rasgos comunes que conducirán a la formación de la parataxis de la lengua común, ${ }^{1319}$ y esos rasgos, en una tensión que no será difícil encontrar en proemios posteriores, donde el nivel de complejidad del pensamiento es muy alto, se presentan de forma clara en el proemio.

\subsection{Hacia un léxico técnico de la historiografía}

El empleo del léxico en los proemios por parte de Tucídides responde a los mismos criterios que hemos defendido para su estilo. Dejando atrás los vocablos de uso más habitual, Tucídides despliega un auténtico repertorio de términos casi técnicos que favorecen la exactitud en la expresión y que garantizan así la correcta configuración de la ilación argumentativa. Schmid contabilizó 1787 hápax internos en toda la obra, de los cuales aparecían por primera vez en Tucídides cerca de $467,{ }^{1320}$ número engrosado prácticamente con términos abstractos y compuestos, lo que apunta en último término a una

1318 Sobre esa idea de una modificación del pensamiento gracias a la escritura, cf. Edmunds, 2009, p. 94.

${ }^{1319}$ Cf. López Eire, 1984, p. 254.

${ }^{1320}$ Cf. Schmid y Stählin, 1948, p. 186 y ss. 
necesidad de precisión semántica desmesurada que hace que muchos de esos términos no reaparezcan hasta fechas tardías.

Las vinculaciones de este vocabulario se mueven dentro de un abanico de autores reducido: ya Diener en su tesis de 1889 dio cuenta de la dependencia de Tucídides respecto a Heródoto en cuestiones de vocabulario $^{1321}$ y de lengua en general, dependencia lógica si nos atenemos a la cercanía temática de gran parte de las obras, a lo que ha de sumarse la influencia del Corpus Hippocraticum y de la tragedia, la primera por razones obvias de semejanza metodológica y la segunda por la importancia del género en la cultura ateniense. ${ }^{1322}$

Como decíamos, lo más destacable del léxico del proemio de Tucídides reside en la aparición de una terminología que podría denominarse «técnica» sobre la que se construye fundamentalmente la parte argumentativa de la Arqueología; la división antes vista entre tesis y argumentación se ve apoyada por la aparición continua de esos términos a los que nos referimos en virtud de la naturaleza de tesis o argumentación del pasaje.

Nos parece de difícil defensa la consideración de Ros, quien entendía la

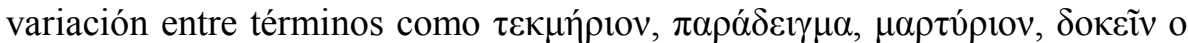

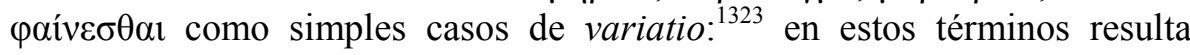
evidente la intención de Tucídides por conseguir una expresión muy clara y precisa, como veremos.

El caso de paívetal se puede rastrear en Heródoto, quien hace del término un empleo que responde a una semántica fenomenológica en el sentido etimológico de dicha voz, como demuestra un examen de la concordancia: ${ }^{1324}$ Heródoto usa de manera habitual -en referencia a su propia indagación personal- este término de igual modo que se presenta en Tucídides. Del casi centenar de ejemplos presentes en todo el Corpus Hippocraticum, nos interesan aquellos que de nuevo se acercan a los usos presentes en Tucídides, así como aquellos en que el término aparece en unión de otros presentes en el proemio y que después estudiaremos, como el

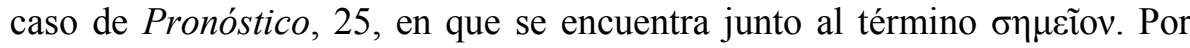
otra parte, la elevada cifra de apariciones del término se debe a la naturaleza

${ }^{1321}$ Cf. Diener, 1889 , p. 9 y ss.

${ }^{1322}$ Cf. Schmid y Stählin, 1948, p. 188.

${ }^{1323}$ Cf. Ros, 1968, pp. 99 y 120.

${ }^{1324}$ Cf. Schrader, 1996, S. v. Ejemplos semejantes a los presentes en el proemio, II 104, 4; IV 42,$1 ; 45,5 ; 53$, 4; V 9, 1; 10, 1; VIII 120, 1; II 58, 1 ; II 10, 1, y VII 129, 4. 
plenamente empírica de muchos de los tratados, como demuestra que se cuenten cerca de una treintena de ejemplos en Sobre las articulaciones.

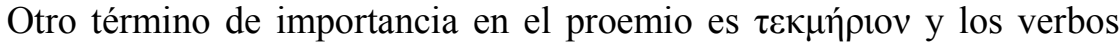
correspondientes, de los cuales Schrader contabiliza en su concordancia hasta dieciocho ejemplos, ${ }^{1325}$ de los que seis corresponden al proemio, lo que es, sin duda, una proporción elevada que, habida cuenta de lo fundamental del término -dado que, a diferencia del anterior, posee una semántica específica y referida a cuestiones programáticas-, nos permite aún más afianzar muchas de las ideas hasta ahora defendidas, debido a la importancia que para la historiografía posterior tendrá el término, como señaló Krüger. ${ }^{1326}$ Respecto a su semántica específica, Diller propuso ${ }^{1327}$ hace tiempo interpretarlo como 'saber por indicios, no por pruebas', apoyándose en pasajes como Heródoto, II 33, ${ }^{1328}$ o en la propia Arqueología, ${ }^{1329}$ dando cuenta así de un medio de apoyo para la posterior acción recogida por el verbo $\varepsilon i \kappa a ́ \zeta \omega$, idea que, por otra parte, ya fue presentada por Shilleto en su comentario, ${ }^{1330}$ si bien Hornblower ha expresado sus dudas acerca de que términos como el presente tengan una semántica específica y diferenciada. ${ }^{1331}$

El caso de zíkó es menos claro. Del casi centenar de casos recogidos por Schrader, solo cuatro se presentan en el proemio, ${ }^{1332}$ más uno en el denominado segundo proemio, si bien el elevado número de apariciones se debe a su presencia en los discursos, en un uso paralelo al del proemio y que fue estudiado ya con detenimiento. ${ }^{1333}$ Es probable que la distinción que

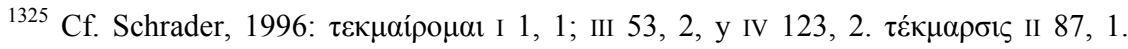

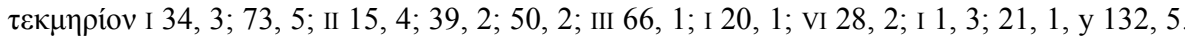
$\tau \varepsilon \kappa \mu \eta \rho і \tilde{~ I ~} 3,3 ;$ III 104, 6, у I 9, 4 .

${ }^{1326}$ Cf. Krüger, 1860 , p. 7.

${ }^{1327}$ Cf. Diller, 1932, p. 19 y ss.

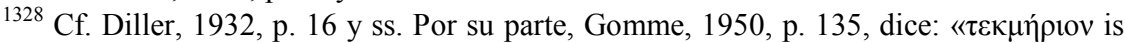
not evidence, but the inference drawn for evidence», lo que nos acerca quizá a lo que Diller

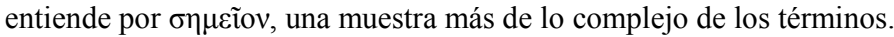

${ }^{1329}$ Cf. Diller, 1932, p. 21 y ss.

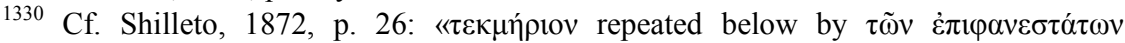

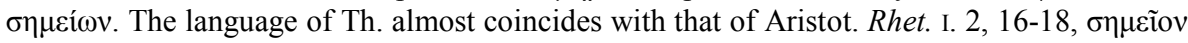
illative sign, from which one may draw an inference, admitting all grades of probability;

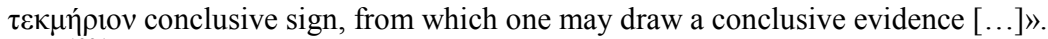

${ }^{1331}$ Cf. Hornblower, 1991, p. 25.

${ }^{1332}$ Cf. Schrader, 1996, S. v. Los pasajes del proemio son I 4, 1; 10, 3 (x2), y 10, 4.

1333 Cf. Sancho, 1996, p. 105 y ss.; Gommel, 1966, p. 19 y ss., para su uso en los

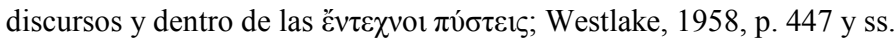


Westlake hace entre los casos que significan 'como es natural', 1334 y 'como parece lógico', pueda responder a los pasajes programáticos y a los discursos, respectivamente, idea que, por otra parte, parece sugestiva por cuanto aísla el uso concreto presente en el proemio respecto al concepto de Eìós habitual en la retórica del tiempo. Sin embargo, como decimos, recientemente se han expresado dudas sobre la distinción de Westlake, ${ }^{1335}$ ya que en otros autores los niveles de precisión bajan de forma insospechada y comprometen así la exactitud de la distinción.

Esquilo presenta un total de ocho ejemplos, ${ }^{1336}$ escasos frente a los diecisiete de Sófocles, ${ }^{1337}$ que aumentan de manera progresiva al acercarnos al final del siglo quinto, de modo que, excluyendo Edipo en Colono, por su particular naturaleza dentro de la producción y el ambiente literario, el uso del término cikós llega a su máximo desarrollo con Electra y Filoctetes, ambas con cuatro ejemplos.

Eurípides, cuya producción se sitúa cronológicamente al final de la del anterior, presenta un total de veinticuatro ejemplos, ${ }^{1338}$ repartidos de manera uniforme a lo largo de toda la producción, salvo en el caso de Medea, que acumula un total de cuatro ejemplos, lo que es interesante por la función prototípica de esta obra en la configuración del panorama retórico de la época. ${ }^{1339}$

En Aristófanes, los ejemplos llegan a veintidós, ${ }^{1340}$ con una acumulación de cinco ejemplos en Tesmoforias, cuatro en el tardío Pluto y tres en Nubes, de modo que de nuevo observamos el aumento progresivo del empleo del término en las obras de final de siglo.

\footnotetext{
${ }^{1334}$ Significado señalado ya por Krüger, 1860, p. 9; Westlake, 1972, p. 450.

${ }^{1335}$ Cf. Hornblower, 1991, pp. 22 y 33.

${ }^{1336}$ Los siete contra Tebas, 519; Agamenón, 575, 586; Euménides, 194; y cuatro ejemplos de fragmentos de difícil localización.

${ }^{1337}$ Traquinias, 56; 368; Áyax, 864, 1317; Antígona, 724; Edipo rey, 256; Electra, 540, 659, 1026, 1140; Filoctetes, 230, 361, 498, 763; Edipo en Colono, 342; y dos ejemplos en los fragmentos.

${ }^{1338}$ Ifigenia en Áulide, 501, 1400; Orestes, 539; Fenicias, 979; Ion, 557; Suplicantes, 41; Hipólito, 615, 1434; Heráclidas, 70; Medea, 345, 871, 909, 1386; y cinco ejemplos en los fragmentos.

${ }^{1339}$ Cf. Norden, 1958, p. 28 y ss.

1340 Acarnienses, 703; Nubes, 1374, 1418, 1439; Paz, 736, 761; Lisístrata, 1118; Tesmoforias, 582, 722, 839, 974, 1144; Ranas, 697, 1060; Asambleístas, 493; Pluto, 258, 662, $1122,1208$.
} 
Pasando a los prosistas, Antifonte llega a presentar, teniendo en cuenta la extensión del corpus, la elevada cifra de veintisiete ejemplos, ${ }^{1341}$ de los que once corresponden a Sobre la muerte de Herodes y siete a la primera Tetralogía.

Pero, sin lugar a dudas, el empleo más amplio del término عìcós se presenta en el Corpus Hippocraticum, con un total de cuarenta y nueve ejemplos, hecho lógico por la mayor extensión del mismo. ${ }^{1342}$ Cabe destacar un tratado del Corpus Hippocraticum, De aere, aquis et locis, con un total de veintidós ejemplos, ${ }^{1343}$ y cinco ejemplos en un solo capítulo, o de entre los antiguos, De prisca medicina con tres ${ }^{1344}$ o De diaeta in morbis acutibus con dos. ${ }^{1345}$ Se ha de señalar además la aparición lógica de este término en tratados tardíos relativos a aspectos tales como el tratamiento de lesiones traumáticas o de dolencias internas, lo que se deberá tener en cuenta para aportar una definición del término.

El caso de Heródoto es interesante: Eìkós no aparece como tal en la

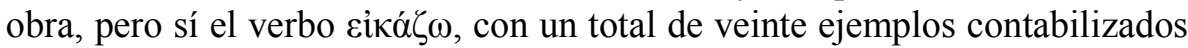
por Schrader, ${ }^{1346}$ de los que nos parecen especialmente interesantes los que se presentan en primera persona ${ }^{1347}$ y que recogen el parecer de Heródoto. A nuestro entender, es este un paso previo a la configuración del término zíkós como abstracto, y ha de ser tenido en cuenta para la delimitación cronológica del término.

${ }^{1341}$ Cf. van Cleef, 1895, s. v. Contra la madrastra, 2, 7, 11, 17, 18; Primera Tetralogía, I 2, II 5 (x2), 6, 7 (x2), IV 5; Segunda Tetralogía, IV 1; Sobre la muerte de Herodes, 4, 26, 27 , $28,43,48,49,50,63,73,74 ; \mathrm{y}$ tres ejemplos en los fragmentos.

${ }^{1342}$ Respecto al Corpus Hippocraticum, y sin entrar en complejidades de datación, para lo cual cf. el apartado siguiente, nos centraremos en aquellos tratados que son reconocidos por la crítica como más antiguos, a saber, De morbo sacro, De diaeta in morbis acutibus, De aere, aquis et locis y De prisca medicina.

${ }^{1343}$ Cf. I, IV, V, VI (x2), VII (x2), VIII, X (x5), XII (x2), XVI (x2) XXI, XXII, XIII y XXIV (x2).

${ }^{1344} \mathrm{Cf}$. III (x2) y xx.

${ }^{1345} \mathrm{Cf}$. VIII y IX.

${ }^{1346}$ Cf. Schrader, 1996, S. V., VII 49, 2; IX 17, 4; 32, 2; 45, 2; VIII 144, 5; II 106, 5; VII 162, 2 ; IV 133, 1; II 104, 2; VII 239, 2; I 34, 1; IX 34, 1; I 68, 4; IV 132, 1; 132, 2; II 69, 3; IV 31, 2; 111,$2 ;$ III 28, 3, y II 182, 1 .

${ }^{1347}$ Corresponden a las cuatro primeras entradas del listado en nota anterior. 


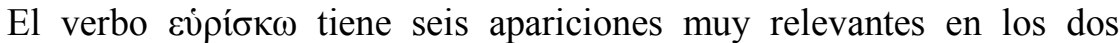
proemios: ${ }^{1348}$ con este verbo se hace referencia al resultado de las indagaciones de Tucídides en el desarrollo de su investigación.

El vocablo tiene una aparición muy numerosa en el Corpus Hippocraticum, incluso desde los tratados más antiguos, lo que nos pone sobre aviso acerca de la filiación del término, que, por otra parte, dado su alto índice de aparición, parece poco provechoso examinar con detalle.

En lo que al género historiográfico se refiere, es un término del cual Schrader cuenta en Heródoto hasta un total de ciento once ejemplos, de los cuales nueve se refieren al propio Heródoto y a su labor indagadora, ${ }^{1349}$ lo que ha de tenerse en cuenta junto al dato aportado por el Corpus Hippocraticum a la hora de obtener conclusiones relativas a este concepto.

E1 término $\pi \alpha \rho \alpha ́ \delta \varepsilon \imath \gamma \mu \alpha^{1350}$ aparece en una sola ocasión en el proemio, y Schrader cuenta hasta doce ejemplos en toda la obra, mayoritariamente en discursos. Fuera de Tucídides, es un término escasamente presente en otros autores: las pocas veces que se encuentra en Heródoto tiene un sentido completamente ajeno al que nos ocupa; ${ }^{1351}$ en el Corpus Hippocraticum se contabilizan cinco ejemplos, uno en De diaeta y cuatro en tratados tardíos; ${ }^{1352}$, y en Sófocles solo consta un ejemplo. ${ }^{1353}$

$\Sigma \eta \mu \varepsilon i ̃ o v$ aparece en diecinueve ocasiones, ${ }^{1354}$ de las cuales solo siete responden a la semántica que nos interesa. ${ }^{1355}$ De ellas, tres se localizan en el proemio, mientras que los restantes ejemplos se reparten dos en la oración fúnebre, y otros dos en una sección narrativa y en un discurso indirecto. Aparece el termino por primera vez para nosotros en Esquilo, con cinco

${ }^{1348}$ En I 1,$3 ; 20,1 ; 21,1 ; 22,3 ;$ v 26, 2 y 3 , a las que hay que sumar el ejemplo de v 20 , 3 , un pasaje programático que hace referencia al cómputo del tiempo.

${ }^{1349}$ Cf. Schrader, 1996, S. V., I 60, 3; I 105, 3; v 57, 1; VII 184, 1; 187, 2; VIII 30, 1; II 44, 3 y 4 ; y VII 28,2 .

${ }^{1350}$ Cuyo significado es 'prueba' (proof), no 'ejemplo', como señala Hornblower, 1991, p. 14.

${ }^{1351}$ Esos pasajes son, siguiendo a Schrader, 1996, S. V.: V 62, 3 y II 86, 2. En el primero se hace referencia a lo que en latín diríamos exemplum y el segundo a imago.

${ }^{1352}$ Exactamente, en De iudicationibus, XVI; De septimestri partu, IX; De articulis, x y De oficina medici, XVI.

${ }^{1353}$ Cf. Fr. 314, 78.

${ }^{1354}$ Cf. Schrader, 1996, S. v.

${ }^{1355}$ Es decir, la de signum, frente al significado técnico militar de 'señal', cf. Bétant, 1969, s. V. Son I 6, 2; 10, 1; 21, 1; 132, 1; II 41, 4; 42, 1, y IV 120, 3 (discurso indirecto). 
ejemplos, ${ }^{1356}$ en los que se rastrea ya de manera clara la semántica del término, a partir de la que también deriva el uso técnico antes visto.

Algo parecido ocurre con los siete casos que presenta Sófocles, concentrados en las tragedias más tardías, ${ }^{1357}$ en las que ya está perfectamente configurado el sentido usual del término, como ocurre en los catorce ejemplos de Eurípides, ${ }^{1358}$ concentrados, prácticamente, en las tragedias más tardías, o en los siete ejemplos de Aristófanes, repartidos de manera general en todas las comedias. ${ }^{1359}$

Pasando a los prosistas, el Corpus Hippocraticum ofrece cerca de doscientos ejemplos del término y del verbo relacionado, con los mismos elevados resultados en los tratados relativos a enfermedades traumáticas e internas, donde se superan con facilidad la treintena de ejemplos. En el caso de los tratados más antiguos, los resultados son más discretos, como los dos casos del Sobre la medicina antigua ${ }^{1360}$ un único ejemplo en Sobre los aires, aguas y lugares y tres en Sobre el régimen en las enfermedades agudas. ${ }^{1361}$ Por su parte, Antifonte presenta un total de diecisiete resultados, que van desde los casos únicos hasta la muy elevada cifra de nueve casos en Sobre la muerte de Herodes. ${ }^{1362}$ Es precisamente uno de los fragmentos de Antifonte, el 79 Blass-Thalheim, el que nos da una definición de este concepto:

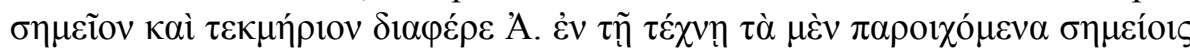

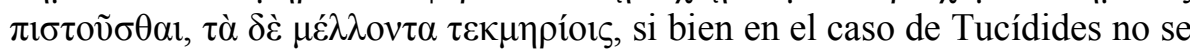
cumple; $\tau \varepsilon \kappa \mu$ ṕpıv y sus derivados son empleados en referencia a Homero y los datos que aporta respecto a la guerra de Troya en el proemio, pero Tucídides tenía muy claro que Homero era muy posterior a la Guerra de

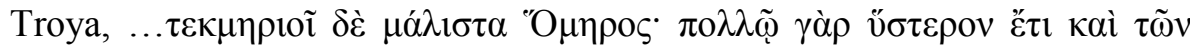

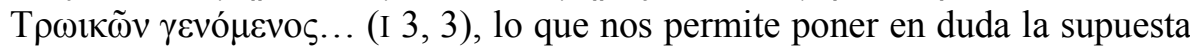

${ }^{1356}$ A los que habría que sumar uno de Prometeo encadenado, 842, que no consideramos como obra de Esquilo. Esos ejemplos son: Suplicantes, 218 y 506; Agamenón, 1355; y dos casos en los fragmentos.

1357 Antígona, 257 y 998; Edipo rey, 710 y 1059; Electra, 24 y 886; Edipo en Colono, 94.

1358 Hipólito, 925; Medea, 517; Electra, 575; Hércules, 714; Ifigenia en Táuride, $808 \mathrm{y}$ 822; Ion, 227, 329 y 349; más cuatro ejemplos de fragmentos y uno del Reso.

${ }^{1359}$ Caballeros, 952; Nubes, 369; Avispas, 585 y 690; Tesmoforias, 278 y 1011; Ranas, 933 (semántica dudosa; se refiere, simplemente, a una imagen); Asambleístas, 6.

1360 Cf. XVIII y XX.

${ }^{1361} \mathrm{Cf}$. X, y II y XIII, respectivamente.

1362 Cf. van Cleef, 1895, s. v., que actualizamos. Primera Tetralogía, II 5 y 8; Tercera Tetralogía, III 3; Sobre la muerte de Herodes, 14, 27, 28 (x3), 45, 81, 84 (x2); Sobre el coreuta, 2 y 43; y fragmentos. 
dependencia retórica de Tucídides respecto a Antifonte, al menos con una prueba sólida, dada la importancia del concepto en la retórica de Antifonte.

Por su parte, Diller, en el trabajo antes citado, otorga al término el significado de 'prueba' producida durante la investigación y que ayuda a su conclusión, ${ }^{1363}$ pero, como antes, hemos de señalar, en línea con lo que opina Hornblower, que es realmente complicado el establecer matices de significado en este grupo de términos, ${ }^{1364}$ y creemos que por ahora es de nuevo errado el ofrecer una posible definición concreta.

La expresión recorrido que parte de Homero, donde aparece en una expresión formular en

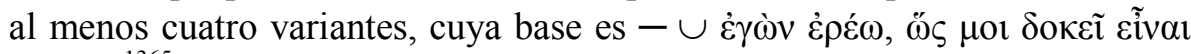
$\alpha$ $\rho ı \tau \tau \alpha,{ }^{1365}$ presente en la introducción de los discursos en la epopeya, y que reaparece, precisamente, en el proemio de Hecateo.

El uso de esta expresión alcanza en Heródoto su máximo desarrollo: apoyándonos en el trabajo de Schrader, que mejora al en este punto confuso léxico de Powell, ${ }^{1366}$ contamos hasta setenta ejemplos de la expresión, mientras que en lo que se refiere a la afirmación de Hornblower respecto a que su uso en Tucídides aumenta en gran medida en el último libro, ${ }^{1367}$ esos datos no concuerdan con los recogidos por Schrader, que indica que de un total de trescientos doce ejemplos sólo corresponden al libro VIII treinta y siete, lo que está un poco por debajo de la media de treinta y nueve ejemplos por libro. ${ }^{1368}$ Lo que sí es interesante es que en el proemio se recogen hasta un total de seis ejemplos, ${ }^{1369}$ y su uso en general se reduce a excursos del autor ${ }^{1370}$ o discursos.

\footnotetext{
${ }^{1363}$ Cf. Diller, 1932, p. 24. En este sentido parece emplearse en I 132, 1.

1364 Cf. Hornblower, 1991, p. 25, quien señala el uso, en referencia a la misma idea de

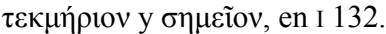

${ }^{1365}$ Cf. Ilíada, XIII 735; Odisea, XXIII 130. Variante con $\alpha$ 314; XIII 735. Cf. Odisea II 33; XIII 154.

${ }^{1366}$ Cf. Powell, 1977, s. v. § 4, en el que recoge cincuenta ejemplos, en los que observamos alguna ausencia, debido seguramente al complejo tratamiento semántico de varios de ellos.

${ }^{1367}$ Cf. Hornblower, 1991, p. 16.

${ }^{1368}$ Cf. Schrader, 1996, s. v.

${ }^{1369}$ Cf. Schrader 1996, S. v.: I 3, 2; 3, 3; 9, 1; 9, 3; 10, 1 y 10, 4 .

${ }^{1370}$ Como II 17,2 , o VI 55,3 .
} 
Respecto a $\delta \eta \lambda \tilde{\omega}$, encontramos sesenta ejemplos en toda la obra, de los cuales catorce responden a la semántica precisa empleada en el proemio, ${ }^{1371}$ es decir, aquella que no se presenta en primera persona referida al autor, sino como impersonal o con un sujeto ajeno a un individuo, lo que le da esa semántica de percepción sintomatológica.

Dos ejemplos recoge Wellauer en el léxico de Esquilo, ${ }^{1372}$ en tanto que Ellendt presenta tres ejemplos ${ }^{1373}$ para Sófocles con este significado concreto, en la mayoría de los casos con connotaciones religiosas. En Eurípides contamos quince ejemplos sin una clara evolución, salvo la aparición de cuatro ejemplos en Orestes. ${ }^{1374}$

Respecto a los prosistas, en los tratados más antiguos del Corpus Hippocraticum encontramos el mismo uso discreto, frente a la profusión en los restantes tratados de la especial temática y naturaleza ya indicada, que elevan la cifra a casi doscientos ejemplos, con una amplia preferencia por el empleo del adjetivo. Por su parte, los usos en Antifonte, en el que del total de doce ejemplos contados por van Cleef hemos de seleccionar cinco, ${ }^{1375}$ arrojan una cifra más bien baja.

Finalmente, respecto a Heródoto, Schrader contabiliza un total de cuarenta y siete ejemplos, en los que nos interesan dos variantes: la primera de ellas hace referencia a esa semántica sintomatológica a la que antes hacíamos referencia, y de la que contamos hasta once ejemplos. ${ }^{1376} \mathrm{El}$ segundo significado que nos parece de interés es el que hace referencia al propio autor y a su obra, ${ }^{1377}$ con expresiones del tipo $\dot{c} \varsigma \dot{\varepsilon} \mu$ ò $\delta \varepsilon \delta \eta ́ \lambda \omega \tau \alpha$, que permiten la perfecta articulación de la obra y, lo que es más importante, que muestran la consideración que el propio Heródoto tiene de su labor, no como

${ }^{1371}$ En este caso Bétant, 1969, S. V., es de poca ayuda por lo confuso de su clasificación. Los casos son: I 3 , 1; 5, 2; 9, 4; 10, 4; 11, 2; 13, 5; 10, 4 (x2); 126, 6; II 50, 1; III 104, 4 (x2); V 1,$1 ; \mathrm{y}[\mathrm{III} 84,2]$.

${ }^{1372}$ Cf. Wellauer, 1830, s. v. Persas, 511 y Coéforas, 834.

1373 Cf. Ellendt, 1835, s. v. Los ejemplos (actualizamos el número de verso) son Áyax, 55; Edipo rey, 77 y 1440.

${ }^{1374}$ Medea, 106 y 1197; Hipólito, 627; Electra, 65; Fenicias, 962; Orestes, 350, 734, 855 y 1129; más seis ejemplos en fragmentos.

${ }^{1375}$ Cf. van Cleef, 1895, s. v., III d 3; b 5; d 5; II g; v 70.

${ }^{1376}$ II 5,$2 ; 44,5 ; 106,4 ; 116,6 ; 117,1 ; 149$, 2; III 82, 4; IV 42, 2; v 78, 1; IX 68, 1, y I 57, 3.

${ }^{1377}$ I 106,$2 ; 192$, 1; II 101, 2; IV 36, 2; 81, 4; 99, 5; en pasiva, I 18, 2; II 9, 2; 51, 4; 145 , 2; III 159, 2; IV 129, 2; v 36, 4; VI 123, 2; VII 17, 2; 108, 1; 217, 2; IX 32, 2, y II 33, 1. 
simplemente narrativa, sino demostrativa, aunque esas demostraciones se sustenten en narraciones.

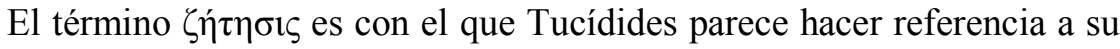
labor indagadora (I 20,3). Dentro de la propia obra del historiador, Schrader cuenta hasta tres ejemplos más aparte del ya citado, ${ }^{1378}$ que presentan en dos casos semántica judicial, mientras que el tercero (VIII 57, 1) tiene un sentido primario de búsqueda. En el resto de autores del siglo V a. C. los ejemplos son muy escasos; en el Corpus Hippocraticum los casos se reducen al empleo del verbo, con un ejemplo del sustantivo en Sófocles, ${ }^{1379}$ y ejemplos en general del verbo. Para terminar, respecto a Heródoto, Schrader cuenta hasta nueve ejemplos del sustantivo, cuya semántica responde al significado básico de búsqueda. ${ }^{1380}$

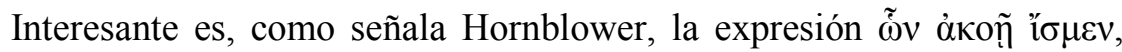
principalmente por su uso característico por parte de Heródoto. La propuesta de Hornblower de ver un enfrentamiento con Heródoto respecto a la intención de otorgar la primacía a Polícrates en el imperialismo marítimo nos parece plenamente acertada: ${ }^{1381}$ un examen de la concordancia nos revela que son cuatro las ocasiones en que Tucídides emplea la expresión, pero esta es la única en que utiliza el vocablo ákoń, de clara raigambre herodotea. Ha de notarse, finalmente, que de los tres casos restantes, dos se encuentran en el proemio ${ }^{1382}$ y corresponden a hechos casi míticos, lo que de nuevo confiere una especialización muy concreta al término.

Este examen nos permite llegar a conclusiones claras respecto al uso del vocabulario en el proemio tucidídeo que van más allá de las apuntadas en Heródoto. El léxico no es en exceso selecto -hemos señalado en la mayoría de los casos multitud de ejemplos en los autores del siglo V a. C.-, pero sí se observa una especialización progresiva de los términos, tanto en el desarrollo de sus usos en líneas generales a lo largo dicho siglo como en el propio Tucídides, que suele concentrar esos usos en el proemio o en los pasajes de carácter programático.

\footnotetext{
${ }^{1378}$ Cf. Schrader, 1998, S. V., VI 53, 2; VIII 57, 1, y 66, 2.

${ }^{1379}$ Cf. Traquinias, 55.

${ }^{1380}$ Cf. Schrader, 1996, s. v., v 21, 2; I 94, 6; II 44, 4; II 54, 2; IV 140, 1; v 92, $\delta 1$; VII 118, 1; VII 170, 1, y VI 47, 2.

${ }^{1381}$ Cf. Hornblower, 1991, p. 19 y ss.

${ }^{1382}$ Cf. Schrader, 1996, S. v.
} 
Este léxico no se reduce al abanico conformado por los términos presentes en el Corpus Hippocraticum, de modo que afirmar que este presenta una posición privilegiada en el empleo del léxico por Tucídides sería falso: muchos de los términos estudiados aparecen por igual en los trágicos y en Antifonte, y los usos en general nos llevan a un estadio de especialización conforme a lo esperado en la época, que nos hace pensar en un nivel culto alto de empleo del mismo que se ve potenciado conforme nos acercamos al fin de siglo.

De especial interés nos parece el hecho de que muchos de esos términos tienen ya un uso habitual en Heródoto, y con precisamente el mismo grado de especialización, lo que nos lleva a plantearnos la distancia habitualmente defendida entre la profundidad historiográfica de ambos autores. La utilización de un vocabulario técnico se desarrolla por igual en ambos autores, y simplemente se hace más patente en Tucídides, lo que no quiere decir que sea inexistente en Heródoto.

\subsection{Tucídides y la medicina hipocrática: aspectos formales}

Que la estructura presente en Heródoto y Tucídides responde en gran medida a los usos habituales de una prosa culta de la época lo asegura el Corpus Hippocraticum. Aun dentro de la dificultad que plantea la datación de las obras del corpus, entre los reconocidos como más antiguos hay un tratado cuya estructura ya analizó Aly y después van Groningen, ${ }^{1383}$ Sobre los aires, aguas y lugares, y que nos interesa. Como decimos, la crítica ha sido en cierta manera unánime en cuanto a la datación de este tratado -cuyas semejanzas con la perspectiva etnográfica herodotea son enormes- ${ }^{1384}$ y se decanta por una fecha en torno al 430 a. C., si bien Jouanna prefiere situarlo, simplemente, entre Heródoto y Tucídides, ${ }^{1385}$ detalles que no suponen obstáculo alguno para el trabajo a realizar.

${ }^{1383}$ Cf. Aly, 1929, p. 56 y ss.; van Groningen, 1958, p. 250 y ss.

${ }^{1384}$ Se ha defendido tanto que Heródoto influyó en el tratado como lo contrario; Jouanna, por su parte, se decanta más bien por la datación tardía del tratado, lo que impediría la segunda posibilidad, cf. Jouanna, 2003b, p. 82.

${ }^{1385}$ Cf. Jouanna, 2003b, p. 79 y ss. 
No contamos con una estructura inicial en el tratado que nos recuerde a lo hasta ahora visto, lo que justificó la exclusión de estos textos de nuestro análisis anterior. Es esta una ausencia fácilemente comprensible en una obra cuya autoría se asimila a una escuela, pero hemos de notar el hecho de que comienza también por el concepto clave, como vimos en el examen de la épica, lo que no es casual, como indica la dislocación del esquema sintáctico ya señalada por Jouanna. ${ }^{1386}$ A pesar de ello, el desarrollo del resto de la obra supone el último paso en la justificación de una estructura proemial consolidada a fines del siglo $\mathrm{V}$ a. $\mathrm{C}$.

Tras una sección inicial de tintes plenamente retóricos, ${ }^{1387}$ se inicia un apartado en que se desarrolla una tesis dividida en secciones que se organizan por medios narrativos conocidos, $\pi \rho \tilde{\omega} \tau o \nu \mu \grave{\varepsilon} v \ldots$, ह̌ $\pi \varepsilon ı \tau \alpha \quad \delta \dot{\varepsilon} \ldots$,

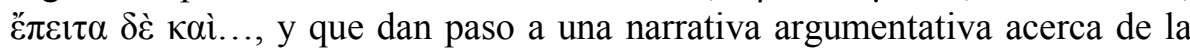
importancia de los fenómenos atmosféricos en la medicina, para comenzar después una sección de carácter justificativo precedida de una frase que

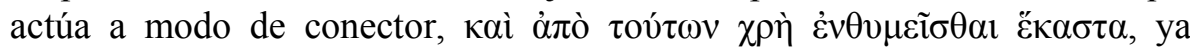
presente en I 2 , y I 4 , y que abre el equivalente a la sección del método de Heródoto, I 5, o la de Tucídides, I 21-22, si bien el contenido metodológico se ve reemplazado por la justificación acerca de la necesidad de atender a los principios antes enumerados. Terminada esta sección, tenemos una frase

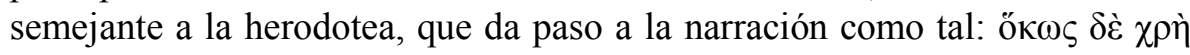

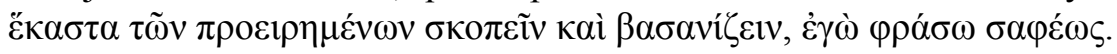

Una década más reciente parece ser el tratado Sobre la medicina antigua, ${ }^{1388}$ cuyo exordio fue objeto de estudio por van Groningen, ${ }^{1389}$ pero que -a nuestro entender- no responde a esquemas equiparables a los vistos en los historiadores. El comienzo del mismo sí es semejante: un elemento, en este caso una oración de relativo, desarrollada de manera muy compleja, de un modo que recuerda al empleo del estilo tucidídeo antes señalado, pero aún se rastrean ejemplos claros de estilos pertenecientes a la retórica oral que nos recuerdan a ambientes presocráticos. ${ }^{1390}$

${ }^{1386}$ Cf Jouanna, 2003b, p. 186, nota 2, con paralelos del propio corpus.

${ }^{1387}$ La fórmula $\pi \rho \tilde{o} \tau$ ov $\mu \grave{\varepsilon} v$... es usada hasta límites insospechados en la retórica del siglo V y IV a. C., y después parodiada incluso por Luciano, cf. e. g. Falaris, II 10, 11.

${ }^{1388}$ Cf. Jouana, 2003a, p. 84 y ss., y López Férez, 1988, p. 612.

${ }^{1389}$ Cf. van Groningen, 1958, p. 249.

${ }^{1390}$ Cf. Blass, I, 1887, p. 89; Aly, 1929, p. 61, nota 68, defiende, por su parte, que este estilo responde a un "pensamiento disciplinado», lo que no es incompatible con la defensa de un estilo. Cf. recientemente Jouanna, 2003a, p. 12. 
El tratado Sobre el régimen en las enfermedades agudas, cercano cronológicamente a los anteriores, ${ }^{1391}$ presenta una estructura muy reseñable para nuestro cometido. Van Groningen ${ }^{1392}$ en su análisis distingue dos grandes apartados, como en el caso anterior, uno polémico y otro explicativo, quizá asimilables en parte a los esquemas vistos en Tucídides en la estructura superior de demostración de la guerra. ${ }^{1393}$ Pero más interesante que esa estructura general del proemio, a nuestro entender poco acertada, es que en el mismo se observan mecanismos progresivos de construcción del proemio semejantes a los vistos en los historiadores. Así, el primer párrafo se construye por medio de repeticiones que articulan el avance del texto de

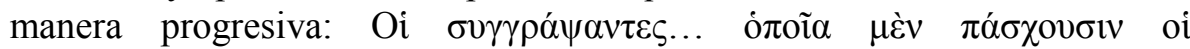

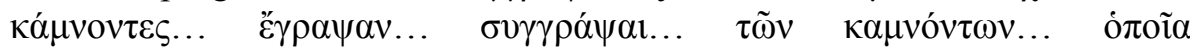

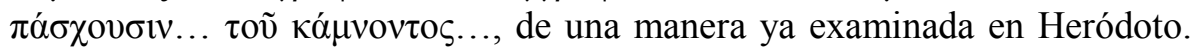
La transición al siguiente capítulo se realiza de nuevo de forma semejante a

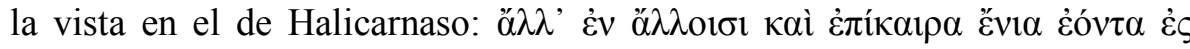

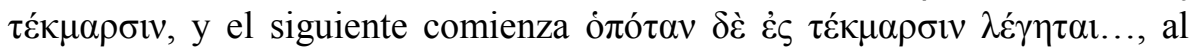
tiempo que podemos rastrear el sistema de tesis-argumentación en el desarrollo de este mismo capítulo. El autor expresa su rechazo a las tesis de

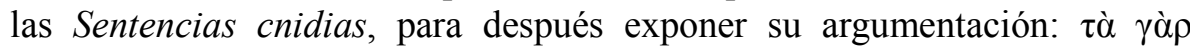

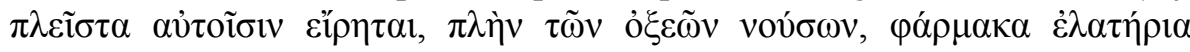

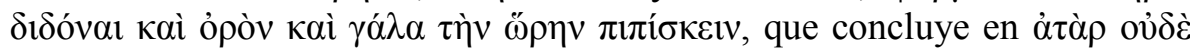

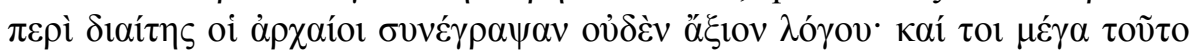
$\pi \alpha \rho \tilde{\eta} \kappa \alpha v$. Ello da paso a una nueva tesis, que contrapone la ausencia anterior a los excesos descriptivos en lo referente a los síntomas con una transición

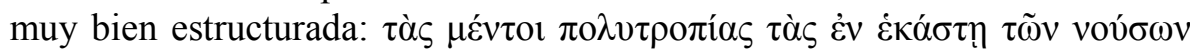

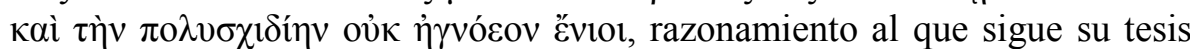

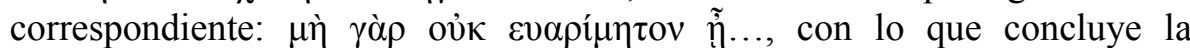
primera sección de las señaladas por van Groningen, para dar paso a la segunda, en cuya delimitación disentimos: van Groningen extendía esta segunda parte hasta el capítulo VI inclusive, ${ }^{1394}$ en tanto que Joly en su

\footnotetext{
${ }^{1391}$ Cf. Joly, 1972, p. 23.

${ }^{1392}$ Cf. van Groningen, 1958, p. 248.

${ }^{1393}$ Con ello nos referimos a la estructura iniciada con I 1,2 . Se ha de señalar además que Taübler, 1927, passim, analizaba la estructura interna de las secciones en virtud de oposiciones entre aspectos negativos y positivos, que quizá puedan presentarse como paralelos a estos aspectos formales del corpus, aunque nuestra opinión es que no, dado que el desarrollo lineal del pensamiento lo impide, siendo esta forma de articular el pensamiento pareja a los esquemas heracliteos antes examinados.

${ }^{1394}$ Cf. van Groningen, 1958, p. 248. 
edición extendía el proemio hasta el capítulo IX, ${ }^{1395}$ en ambos casos, a nuestro entender, sin excesivo éxito. Consideramos que el capítulo IV supone el final del proemio, con la exposición de la opinión del autor de Sobre la

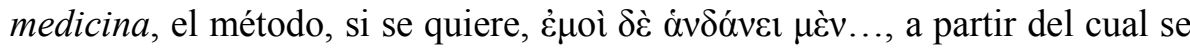
desarrolla la obra tomando como punto de partida esta consideración, que nos recuerda en gran medida a Heródoto I 5, con la misma transición de un tema general al personal, y con la desproporción habitual entre la parte inicial y la final, propia de la composición arcaica.

No es nuestro cometido valorar los proemios hipocrateos ni establecer cronologías aproximadas de los mismos, pero lo que sí podemos desechar es la afirmación tajante de Hammond sobre la falta de paralelos en el Corpus Hippocraticum antes vista. ${ }^{1396} \mathrm{El}$ examen de los hechos nos permite ver que los mecanismos de desarrollo y estructuración del pensamiento en las obras de los considerados como compañeros intelectuales de Tucídides se mueven, como señalaba Jouanna respecto Sobre los aires, aguas y lugares, entre Heródoto y Tucídides.

\subsection{De Hecateo a Tucídides: pensamiento y expresión en el mundo oral y en el escrito}

La polaridad y la analogía, señaladas por Lloyd como fundamento del desarrollo de una modalidad de pensamiento, se pueden observar de manera discreta en tratados como Sobre la medicina antigua, apoyadas, claro está, en recursos consonantes con ese modo de reflexión. No es casual que la conformación de los niveles de pensamiento en el ámbito literario se moviese en los primeros pasos de la literatura griega dentro de esos esquemas.

Lloyd en sus excelentes trabajos al respecto nos ha puesto sobre aviso de la importancia de los mecanismos de pensamiento basados en opuestos en las culturas tradicionales: ${ }^{1397}$ el autor no aborda aspectos formales, porque esa no era su intención, pero rápidamente el pensamiento pasa a recordar lo

\footnotetext{
${ }^{1395}$ Cf. Joly, 1972, p. 9.

${ }^{1396}$ Cf. supra, apartado 5.2.

${ }^{1397}$ Cf. Lloyd, 1987, p. 19 y ss.
} 
indicado por Vansina en su estudio y examinado por nosotros páginas atrás, y la conclusión de todo ello es la sustentación de manera simbiótica de los medios de expresión y de las ideas expresadas en estos autores, creando así un modo cultural perfectamente constituido y asimilable a estadios tradicionales y orales de las sociedades de todo tiempo y lugar. ${ }^{1398}$

A pesar de ello, el esquema no es tan claro, y pronto surgen los primeros problemas en el ámbito griego. Lloyd nos recuerda a este respecto, y precisamente en los ámbitos más antiguos del mundo heleno, Homero y Hesíodo, que en ambos autores la polaridad, aunque presente de forma discreta, no sustenta un universo conceptual claro: «the evidence clearly does not permit us to speak of any developed or systematic table of opposites in Homer or Hesiod». ${ }^{1399}$

La respuesta a este problema creemos que será fácilmente alcanzada si se tiene en cuenta lo indicado en el análisis de la constitución del proemio épico: la cohesión en esos casos no se alcanzaba por medio de estructuras polares, sino por los mecanismos propios del verso, que servían de garantes válidos para la estructuración del texto, lo que explicaría fácilmente la razón por la cual la épica griega permaneció ajena a los rasgos de un pensamiento que tanto los análisis de Lloyd como los de Vansina nos invitan a considerar como comunes a todas las sociedades antiguas.

El problema que a este respecto nos presenta el mundo griego es la pérdida de toda la primitiva prosa griega. Es en estos textos, así como en lo poco conservado de los primeros presocráticos, donde aún se respira el viejo pensamiento polar, que quizá debiéramos denominar simplemente tradicional; en el momento en que los textos empiezan a ser abundantes, los mecanismos de este pensamiento empiezan a gozar de poca vitalidad, lo que no impide que podamos seguir su último desarrollo, aunque tengamos que reconocer que es un pensamiento que, dada su claridad, nunca llegó a desaparecer del mundo griego, como tampoco desaparecen por completo los recursos orales, que, como hemos señalado, es posible rastrear incluso en época tan tardía como el cambio de era.

Lloyd reconce un caso interesante en un tratado hipocrático que hemos tenido presente en el estudio formal, Sobre la medicina antigua: en este

\footnotetext{
${ }^{1398}$ Cf. Lloyd, 1987, p. 31 y ss., para datos antropológicos a este respecto.

${ }^{1399}$ Cf. Lloyd, 1987, pp. 47 y 90 y ss., especialmente p. 92, donde se pone de manifiesto la flexibilidad de estos conceptos polares en la épica. 
tratado los ataques contra el pensamiento polar son furibundos, pero al tiempo, reconoce Lloyd, su autor hace un empleo claro de los medios asociados a él. ${ }^{1400} \mathrm{~A}$ nuestro entender, y teniendo en cuenta la ubicación cronológica del tratado, no es difícil concluir que el periodo nebuloso que Thomas señalaba en el ámbito formal para el paso del mundo oral al escrito ha de tenerse en cuenta también en el plano intelectual. Así, Lloyd defiende que el ataque a este tipo de pensamiento por parte de los hipocráticos se debe básicamente a que la polaridad se veía como un elemento deformante de la medicina, por una razón, y no menor, porque empíricamente es indemostrable, dado que se construye por medio de emparejamientos y no por medio de pruebas. ${ }^{1401}$

Por ello, cabe preguntarse cómo se mantuvo un sistema tan constrictivo durante tanto tiempo, y todo parece indicar ${ }^{1402}$ que se debía a factores ambientales, con opuestos como día y noche, y principalmente a razones clasificativas, porque no hemos de olvidar, y en ello nos ayuda la antropología, que los mecanismos intelectuales del mundo tradicional eran un medio para abordar la realidad que permitía tejer una cosmología global y enciclopédica, que, de manera paralela a la cohesión formal, brindaba un esquema encadenado y compacto de comprensión del mundo, «opposites provide simple and distinct reference points to wich other things may be related», ${ }^{1403}$ que se reflejaba, algo que no indica Lloyd, en la realización formal de la literatura de la sociedad.

Que no era la única forma de pensamiento parece claro a partir de lo indicado para Homero y la épica oral, que imponía un desarrollo del pensamiento progresivo, que no hay razones para desechar como coexistente con el polar, pero del que pocas huellas tenemos. No hemos de pensar que la expresión corriente y habitual, fuera del mundo poético-literario, responsable en las sociedades tradicionales de la cultura, fuera polar. Más allá de los mecanismos literarios, la existencia de un modo de expresión normal parece asegurada incluso por el futuro desarrollo de la prosa, sustentada, según indicamos, en el estilo кaí, cuyo origen coloquial ya aseguramos. Ello de nuevo nos lleva a la consideración antes hecha acerca de la postura de Ong sobre la necesidad de una literatura escrita como sustento para el desarrollo

${ }^{1400}$ Cf. Lloyd, 1987, p. 20.

${ }^{1401}$ Cf. Lloyd, 1987, p. 69.

${ }^{1402}$ Cf. Lloyd, 1987, p. 80.

${ }^{1403}$ Cf. Lloyd, 1987, p. 65. Para la denominada enciclopedia tradicional, cf. Havelock, 1994, p. 71 y ss., con el ejemplo de los poemas homéricos. 
de la historiografía y la filosofía. A este respecto, queremos de nuevo insistir en que no es que la aparición de la escritura favoreciese el desarrollo de esos modos de reflexión, sino que fue la única forma de que llegasen a nosotros, dado que son, por su propia naturaleza, difíciles de acomodar a un esquema formal, como el propio del mundo tradicional, que garantizara su supervivencia.

Teniendo esto presente, el desarrollo de los géneros denominados «científicos» en esa época de nebulosa se comprende rápidamente, al tiempo que se entiende la naturaleza del estilo de este primer periodo. Volviendo al tratado Sobre la medicina antigua, el ataque a los mecanismos polares se comprende enseguida desde una perspectiva que trata de buscar una expresión literaria ajena a los mecanismos ya obsoletos de la literatura oral. Pero ello no es óbice para que, dada la etapa de transición que supone esta época, se deslicen esquemas aún propios de esta forma de expresión, ${ }^{1404}$ aunque la perspectiva sea diferente.

Como hemos visto antes, el modelo polar imponía un esquema sobre la realidad, partiendo de una ilación de los diferentes aspectos de la misma que permitía crear una trama para su comprensión, pero las necesidades del pensamiento de la época parten en un sentido contrario, de la realidad al

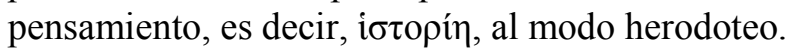

Sin embargo, es quizá Heródoto el autor que mejor representa este

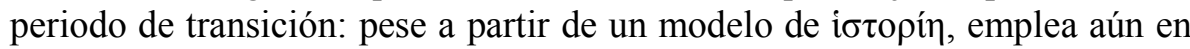
sus narraciones estructuras polares, como vimos en el proemio, en concreto en las narraciones sobre el rapto de las mujeres, al tiempo que sus reflexiones adoptan claramente unos esquemas de expresión cercanos a un nivel discursivo que en ocasiones cae en lo exagerado y que preludia el estilo tucidídeo.

Es precisamente Tucídides el exponente final de este proceso de nacimiento de una literatura no oral: en él aparece todo lo que más tarde veremos en el siglo IV a. C. y en su prosa, pero con las particularidades propias del historiador. Las lagunas son muchas, pero el recorrido es claro.

${ }^{1404}$ Cf. Lloyd, 1987, p. 69. 


\subsection{El universo intelectual de Tucídides}

Nuestra labor sobre el proemio a la obra de Tucídides, uno de los textos más importantes del género, pasa necesariamente por superar dos ideas falsas que han lastrado y lastran su perfecta comprensión, a pesar de que amplios sectores de la crítica se hayan pronunciado de manera razonada en contra de esos prejuicios.

Citando a una filóloga francesa, Tucídides no es un colega. ${ }^{1405} \mathrm{La}$ construcción del ideal de historiador científico moderno sobre Tucídides ${ }^{1406}$ tuvo como funesta consecuencia el verter sobre su figura y su obra rasgos que distorsionan la correcta interpretación de ambas. Precisamente, era el proemio, y con él la Arqueología, la página fundacional de la moderna disciplina, ${ }^{1407}$ lo que suponía que estos primeros pasos de la obra sancionaban el non plus ultra de la labor historiográfica, e implicaban el cierre, al menos en su forma canónica, del género en la Antigüedad. Pero, obviamente, esto no es en absoluto la realidad, y la primera de las trabas a superar será asumir que Tucídides no es el final del género, para establecer después las líneas de continuidad existentes entre el proemio de este autor y los de los autores posteriores, cosa no fácil dado el estado fragmentario de los autores helenísticos, que generan un vacío que comparte responsabilidad en la imagen distorsionada a la que estamos haciendo referencia.

El segundo de los prejuicios a superar es admitido por la crítica con más facilidad que el primero, $y$, a decir verdad, puede ser considerado como una consecuencia del anterior aún no eliminada. Jacoby en su importante trabajo de 1909 sancionó una evolución del género que situaba a Tucídides en su

\footnotetext{
${ }^{1405}$ Loraux, 1986. Cf. las indicaciones al respecto de Marincola, 2011, p. 2.

${ }^{1406}$ Cochrane, 1929 , p. 3, sienta las bases en el ámbito anglosajón de lo que será una idea mantenida de manera continuada: «[...] The truth is that Thucydides had the assured faith of a scientist because he was a scientist, because, in fact, he was inspired by contact with a department of positive science which in his day had succeeded in extrincating itself from the coils of cosmology, and which by means of a method adequate to the most rigid modern demands was already advancing to conclusions which were recognized as valid and immensely significant for human life». Excelentes observaciones sobre el no tan simple idealismo alemán pueden verse en Badian, 1993, p. 126 y ss.

${ }^{1407}$ Cf. Bayer, 1968, p. 183, quien hablaba de la Arqueología como una historia de Grecia en conceptos clave que preparaba al lector para la futura narración, y definía a Tucídides, p. 190, como «Anfang und Vorbild wissenschaftlicher Geschichtsschreibung».
} 
cumbre, reafirmando así ideas propias del siglo XIX. Para ello, y este es el segundo prejuicio, necesitó forzar la cronología de Heródoto a fin de crear una separación lo suficientemente grande entre Heródoto y Tucídides que permitiese defender una evolución realmente importante entre ambos autores que dejase a Tucídides aislado intelectualmente de su predecesor. ${ }^{1408}$ Hemos defendido una cronología más bien tardía para Heródoto, y, adelantando algunas de las ideas que expondremos a continuación, podemos afirmar que las diferencias entre ambos autores se deben más a la complejidad de los acontecimientos de finales del siglo $\mathrm{V}$ a. C. que a un mundo $\mathrm{y}$ una mentalidad opuestas. ${ }^{1409}$

\subsubsection{EL CONCEPTO DE KINH $I I \Sigma$}

La vuelta a unos planteamientos formales de carácter tradicional en lo que a la configuración del proemio se refiere -en línea con lo visto en Hecateo y Antíoco de Siracusa- nos pone sobre aviso de que la naturaleza de la obra tucidídea es plenamente polémica. En este sentido, es fundamental asumir la cronología de la manera más precisa posible: hemos de ser capaces de comprender la importancia que tiene el momento exacto en que se redactaron cada una de las secciones de los dos proemios, porque el fundamento último de una obra de este tipo no reside, aunque habitualmente lo olvidemos, en sus lectores futuros, sino en los presentes. ${ }^{1410}$ Con esto no

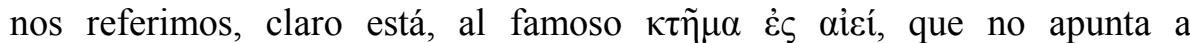
cuestiones metodológicas, sino a la verdadera dimensión del concepto de

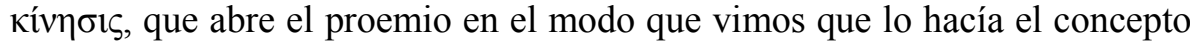
de $\mu \tilde{v} \theta$ o $\varsigma$ en el caso de Hecateo, en línea con lo que ocurría en los diferentes casos proemiales que analizamos en la sección referida al análisis formal. El

${ }^{1408}$ Cf. Cochrane, 1929, p. 15: «[...] Thucydides is the most scientific, as Herodotus is the most philosophic of Greek historians». Una ecuación que lo emparejaba además con Eurípides, cf. Nestle, 1948, p. 321: «Wie Euripides den Dichter, so könnte man Thukydides den Geschichtschreiber der griechischer Aufklarung nennen».

${ }^{1409}$ En este sentido, cf. recientemente Rood, 2006, p. 236.

${ }^{1410}$ Cf. Gomme, 1950, p. 149; Weidauer, 1954, p. 58 y ss., quien concluye afirmando la utilidad de la obra para el «Staatsmann», lo que es válido siempre que no sirva para reducir el valor polémico de la obra. Las indicaciones de Badian, 1993, p. 128, son a este respecto fundamentales. Recientemente ha perfilado esta paradoja Greenwood, 2006, p. 15. 
fundamento que lleva a escribir la obra a Tucídides es la toma de conciencia de la importancia de la guerra desde el minuto cero de la misma, en atención a la magnitud de los elementos en juego y en vista -no hemos de olvidarlode sus consecuencias.

La magnitud de este concepto ha de ser asumida no en su naturaleza física, tratando de ver la relación de su uso con el empleado en la definición de los terremotos, ${ }^{1411}$ sino en sus consecuencias políticas, que definirán además el escenario polémico del proemio. Nada hay aquí de recuerdo del pasado, sino la asunción por parte del historiador de la existencia de una coyuntura realmente compleja y única, ${ }^{1412}$ que va a dar lugar a unos resultados hasta ahora no vistos.

Obviamente y como venimos indicando, la cronología desempeña un papel fundamental en este proceso. Parece imposible solucionar este grave problema de la redacción de la obra de Tucídides, pero un buen punto de partida ha de ser la necesidad de considerar que el proemio fue escrito como texto fundacional del pensamiento que recorre la obra.

Sin embargo, Tucídides no evidencia, cosa que va a ser una constante en el género, el universo conceptual que le lleva a comprender este proceso. Una vez más, hemos de recuperar, a partir de la ejemplificación del mismo, el modelo que se proyecta sobre el total de la obra y que se razona en el proemio. Evidentemente, esto solo es posible si no vemos en la Arqueología un resumen de la historia anterior o un simple ensayo retórico acerca de la grandeza del momento que Tucídides se propone historiar. ${ }^{1413}$ Lo importante es asumir que, en el análisis de los hechos pasados tratados en la Arqueología, Tucídides pasa esos acontecimientos de manera intensiva por el tamiz creado para la redacción de su obra. ${ }^{1414}$ y ese tamiz es, como también ocurría en el caso de Heródoto, una mixtura de las diferentes ideas en boga en la época, un modelo ecléctico de planteamientos único y en muchos casos no excesivamente alejado de la metodología de Heródoto, por cuanto ambos autores suponen la existencia de un orden regulador de los

${ }^{1411}$ Como señala Luginbill, 1999, p. 3 y ss., lo que no debe pasar de ser un simple detalle expresivo.

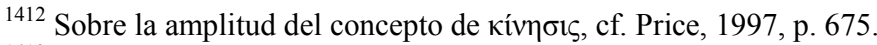

${ }^{1413}$ Así, Rood, 2006, p. 233. Un buen resumen de la idea que fue desmentida por Finley, 1967b, p. 167, se puede ver en Kallet-Marx, 1993, p. 21, nota 1, a quien remitimos en afán de brevedad.

${ }^{1414}$ O patrones generales, como indicaba Kallet-Marx, 1993, p. 27. 
acontecimientos, cada cual codificado en virtud de la propia experiencia personal del autor.

\subsubsection{LA SITUACIÓN DE LOS CONTENDIENTES: LA ПAPA $K E Y H$}

Las circunstancias que hacen de la guerra la mayor convulsión de la historia conocida parten de un término realmente complejo a la par que habitual en Tucídides: $\pi \alpha \rho \alpha \sigma \kappa \varepsilon v \eta{ }^{1415}$ A diferencia de lo que piensa Allison, ${ }^{1416}$ creemos que las dos apariciones en el proemio de este término, en I 1,1 y en I 19, 1, significan lo mismo. Considerar que el primero presenta una idea de resultado y el segundo de proceso supone asumir que el estado de $\pi \alpha \rho \alpha \sigma \kappa \varepsilon v \eta ́$ al comienzo de la narración es el resultado del proceso histórico desarrollado en la Arqueología, lo que es incompatible incluso con la esencia de los mecanismos de pensamiento anular, que exigen inexcusablemente la vuelta a la idea principal sin que esta sufra modificaciones.

La definición del concepto de $\pi \alpha \rho \alpha \sigma \kappa \varepsilon v \eta ́$, asumiendo ya de manera rotunda su unidad, responde, como bien indica Allison, a unos de esos términos abstractos que tan abundante aparición tienen en la obra de Tucídides y que son buen vehículo de su expresión, en ocasiones tan complicada. El análisis de la estructura nos ha permitido comprender que la posición ocupada por el término es, precisamente, el desencadenante de la Arqueología, lo que obviamente permite afrontar una definición más clara del mismo. No nos parece, por tanto, acertada la idea de quienes tratan de ver en este término el estado de pensamiento de los contendientes, ${ }^{1417} \mathrm{ni}$ mucho menos una definición que pase por una idea tan reducida como 'gente en armas'. ${ }^{1418}$ La definición de este concepto incluye una multitud de ideas

${ }^{1415}$ Cf. Immerwahr, 1973, p. 19 y ss.

${ }^{1416}$ Cf. Allison, 1989, p. 12

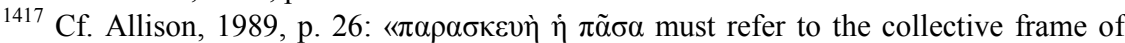

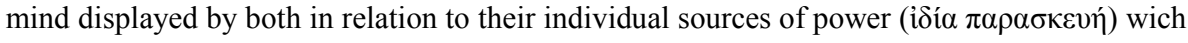
contributed to the increasing of tension in the political atmosphere».

1418 Cf. Tasolambros, 1979, p. 68 y ss. Tampoco parece correcta la consideración del concepto de $\chi \rho \eta \dot{\mu} \mu \alpha \tau \alpha$ como condicionante fundamental del poder, como indica Kallet-Marx, 1993, p. 23, dado que el concepto se engloba dentro de un sistema muy complejo. 
que conforman, en último término, los instrumentos de poder político que van a planear por la obra. ${ }^{1419}$ Ideas como los recursos materiales y la población, tan íntimamente ligadas (I 2, 1-3, 3), o el mar, con su especial importancia en el desarrollo de la guerra que nos ocupa (I 3, 4-12, 4), son las dos constantes sobre las que se sustenta un concepto lo suficientemente amplio como para no someterse fácilmente a una definición, como bien indica el pasaje ya apuntado por Allison, ${ }^{1420}$ en el que el empleo de un artículo neutro -cuya significación ya vimos- da cuenta de lo que tratamos

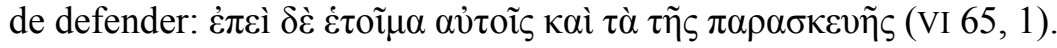

La especial intensidad con la que usa este término Tucídides en comparación con otros autores nos advierte de la importancia que desempeña el concepto en el pensamiento del autor. ${ }^{1421}$ Obviamente, a pesar de las reticencias que señalamos antes, creemos que en la definición del concepto no solo entra la dimensión plenamente material de las nociones indicadas, sino que, siguiendo a Allison -quien nos recuerda el amplio uso que hace del mismo Arquídamo en su discurso-, ${ }^{1422}$ podemos comprender que, en el escenario del debate en Esparta, no solo desempeñan un papel fundamental los conceptos plenamente materiales: el carácter individual de cada comunidad, háblese si se prefiere de carácter nacional, ${ }^{1423}$ forma parte de esta idea.

Tras este macroconcepto abstracto se esconde seguramente uno de los aspectos plenamente instrumentales del pensamiento tucidídeo. Con el concepto de $\pi \alpha \rho \alpha \sigma \kappa \varepsilon v \eta ́$ nos movemos en el campo de la simple evidencia, de la sintomatología de la obra tucidídea. Quizá suene extraño afirmar el parecido existente entre el rapto de las mujeres del proemio herodoteo y la sección que nos ocupa: del mismo modo que el sucesivo secuestro de las diferentes mujeres ejemplificaba $-o$ parecía ejemplificar- el sistema de compensación que estudiamos en el proemio herodoteo, ${ }^{1424}$ el análisis de la

${ }^{1419}$ En este sentido, la idea de Ober, 2006, p. 142, de ver en la diferencia de caracteres de Atenas y Esparta una de las causas de la futura convulsión nos parece interesante, siempre que no se limite a este aspecto el conflicto.

${ }^{1420}$ Cf. Allison, 1989, p. 43.

${ }^{1421}$ Cf. Allison, 1989, p. 28; Immerwahr, 1973, p. 31.

${ }^{1422}$ Cf. Allison, 1989, p. 46.

${ }^{1423}$ Así Luginbill, 1999, passim.

1424 Considerar, como hace Saïd, 2011, p. 66, que en estos raptos se ejemplifican conceptos clave nos parece forzar demasiado el texto. 
Arqueología tucidídea responde igualmente a la ejemplificación in nuce $e^{1425}$ de la metodología aplicada a lo largo de la obra, teniendo siempre presente que la intención primera del autor era, sin lugar a dudas, el razonamiento del

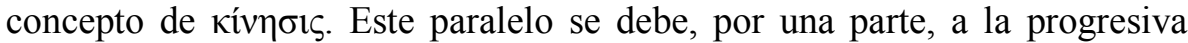
fosilización de las estructuras del proemio, y, por otra, a la semejanza

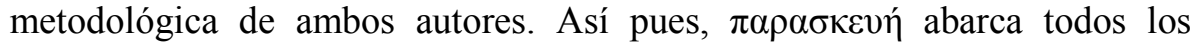
aspectos materiales, estratégicos y culturales que determinarán la actuación de los contendientes de un modo semejante al funcionamiento del concepto de aitín en Heródoto. ${ }^{1426}$

Y es que, más allá de las diferencias entre ambos historiadores, el acercamiento al conocimiento de los acontecimientos del pasado se realiza en un marco intelectual que responde a una metodología general semejante. La organización de los acontecimientos se orquesta en virtud de un modelo en cuyo primer escalón se sitúa el análisis de la $\pi \alpha \rho \alpha \sigma \kappa \varepsilon v \eta ́$, que como elemento se constituye en $\tau \varepsilon \kappa \mu \eta ́ p ı v$, en prueba o indicio para el paso a un segundo nivel de construcción intelectual de mayor complejidad.

\subsubsection{LA METODOLOGÍA DE TUCÍDIDES}

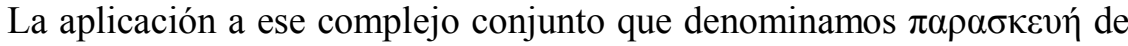
procedimientos de análisis presenta una sistematización diferente a la vista en Heródoto. La multiplicidad de términos no da cuenta en ningún caso de una jerarquización en ellos, sino de diferentes modos de afrontar la realidad, lo que delata que, frente al sistema triple herodoteo, Tucídides presentará un sistema de dos niveles.

Ya hemos defendido la idea de que los diferentes términos ofrecen una semántica muy determinada y precisa. ${ }^{1427}$ El propio hecho de que Tucídides emplee una semántica mucho más compleja y rica que Heródoto nos alerta de que los elementos en juego pasan la frontera de lo meramente material y fenomenológico, límite claro en el caso de Heródoto.

\footnotetext{
${ }^{1425}$ Cf. Connor, 1985, p. 7; Rood, 2006, p. 233 y ss.

${ }^{1426}$ Para este carácter previo del concepto, cf. Gomme, 1937, p. 120.

${ }^{1427}$ Cf. apartado 5.4.
} 


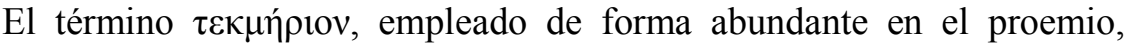
responde a una constatación que va más allá de la simple evidencia. Se trata de un análisis intelectual que supone un paso más incluso de lo que habitualmente podemos ver en el Corpus Hippocraticum, dado que hace referencia a un elemento probatorio que responde a una construcción intelectual del autor, muy lejos del conocido «was es eingentlich gewesen». ${ }^{1428}$

Esta dimensión del término como un acto reflexivo se puede ver en I 34, 3; 73, 5; II 87, 1; III 53, 2; IV 123, 2, etc. En la mayoría de los casos, como vemos que ocurre en el proemio, el término va asociado a una serie de ejemplos que preceden al empleo del mismo y que dan cuenta de la naturaleza reflexiva de este, que se refiere a la actuación sobre los elementos citados de manera previa a un nivel puramente intelectual: Tucídides reduce

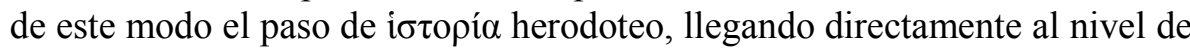
la $\gamma v \omega ́ \mu \eta$.

En este sentido, parece especialmente interesante su uso junto a los

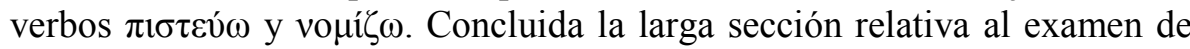

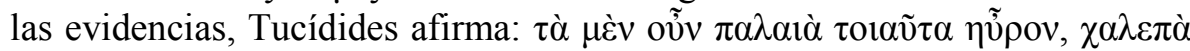

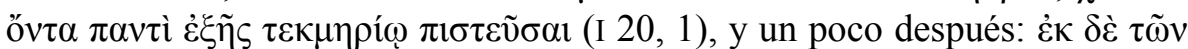

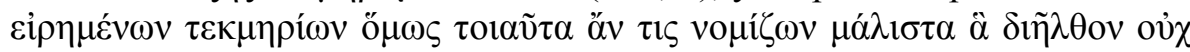

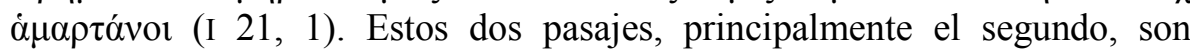

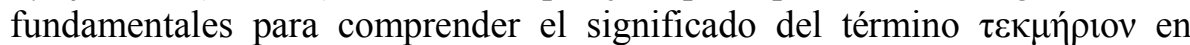

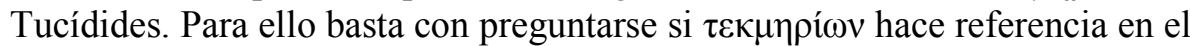
segundo caso únicamente a las simples evidencias presentadas en el desarrollo de la Arqueología, o si también se refiere a las reflexiones y razonamientos que Tucídides ha presentado a partir de esas evidencias. A nuestro entender, es obviamente la segunda de las opciones, y creemos que $\pi \alpha \nu \tau i ̀ ~ \varepsilon ̇ \xi \tilde{\eta} \varsigma \tau \varepsilon \kappa \mu \eta \rho i ́ \omega$ a lo que se refiere es, precisamente, a las lagunas que el hilo de la reflexión del autor plantea, como señala $\dot{\varepsilon} \xi \tilde{\eta} \varsigma$.

Para apoyar esta idea, las investigaciones sobre el uso arcaico del término y los de su familia léxica realizadas por Detienne y Vernant son de gran ayuda. Según dichos autores, $\tau \varepsilon ́ \kappa \mu \omega \rho$ no significa en el ámbito de la navegación simplemente el destino final, sino el desarrollo trazado hasta ese

${ }^{1428}$ Cf. Cochrane, 1929, p. 31: «[...] The scientific historian, as such, limits himself to the semeiology and prognosis of society, leaving to the political philosopher the task of constructing, on the basis of this prognosis, an adequate system of social therapeutics». 
objetivo. ${ }^{1429}$ Esa idea viene además confirmada por el léxico de la $S u d a$, que

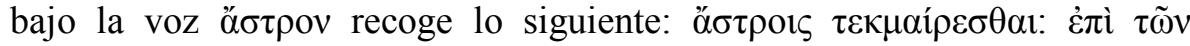

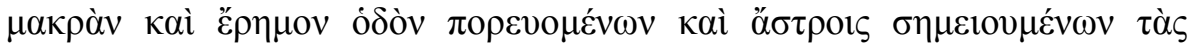
$\theta \dot{\varepsilon} \sigma \varepsilon 1 \varsigma \tau \tilde{\omega} v \pi \alpha \tau \rho i ́ \delta \omega v .{ }^{1430}$ Difícilmente, a la luz de la interpretación de los dos estudiosos y a la vista de la entrada de la $S u d a$, se puede afirmar que el

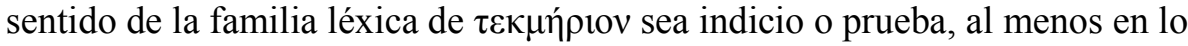
relativo al verbo. $\mathrm{Y}$ es que hemos de admitir que en lo que se refiere al sustantivo, y en concreto en su uso en discursos, parecen existir algunas dudas, si bien ya vimos con eíkós que es posible distinguir entre los usos presentes en los discursos y en las secciones programáticas. Sea como fuere, parece cierto que la interpretación del término ha de ser realizada en un campo muy diferente al que hasta ahora se le daba.

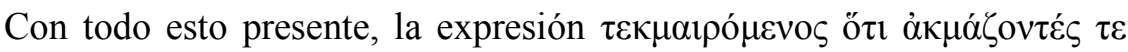

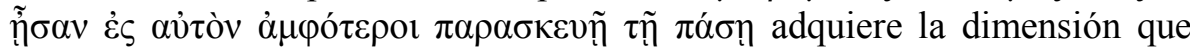
corresponde al desencadenante polémico del proemio: la narración de los acontecimientos de la guerra tiene su interés precisamente porque la valoración de los condicionantes de la misma es fruto de la reflexión del propio Tucídides, ${ }^{1431}$ no una simple observación patente a todos.

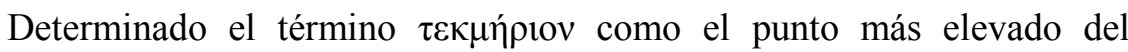
proceso del sistema reflexivo de Tucídides, el resto de conceptos se presentan, como ocurría en el caso de Heródoto, como elementos

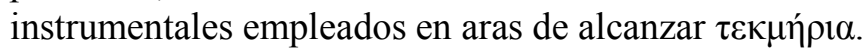

El concepto de عỉкós, como ya indicamos, tiene una aparición realmente limitada en el proemio, y no detectamos una semántica realmente técnica en el mismo, al menos en los casos proemiales, lo que sitúa a Tucídides en la línea de Heródoto, quien hace de él un uso relativamente reducido.

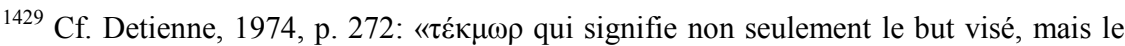
plan, le remède a une situation difficile, c'est una notion construite à la confluence de trois domaines distincts mais complémentaires: la navigation, l'astronomie, la divination. Dans le domaine de la navigation, $\tau \varepsilon ́ \kappa \mu \omega \rho$ est le terme du parcours, le point de l'horizon qui oriente la course du navire; dans l'astronomie élémentaire [...] le même mot designe la position des astres sur laquelle doit se régler la course du navire [...]» Cf. también Loraux, 1986, p. 146 y ss.

${ }^{1430}$ Suda, II p. 393 Adler. Cf. además el paralelo ofrecido por Grosskinsky, 1936, p. 71,

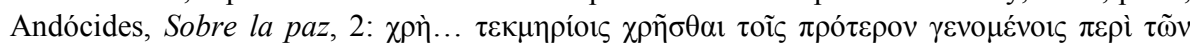
$\mu \varepsilon \lambda \lambda \operatorname{ó} v \tau \omega v^{\varepsilon} \sigma \varepsilon \sigma \theta \alpha 1$.

${ }^{1431}$ Así, Rood, 2006, p. 232. 


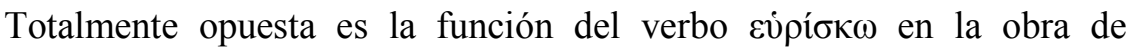
Tucídides. Su alto índice de aparición en el proemio da cuenta, como ya indicamos, de su especial importancia en la configuración del pensamiento del autor. El análisis de los datos nos permite ver que las apariciones en el proemio se sitúan en ambos extremos de la composición anular, lo que hace que tengamos que otorgar también a este término un sentido especializado. $\mathrm{Su}$ ausencia del cuerpo del razonamiento hace que estemos, dado que aparece en las fórmulas conclusivas, ante un término que, más allá de su semántica obvia, responde a una idea de acabamiento, de finalización de la

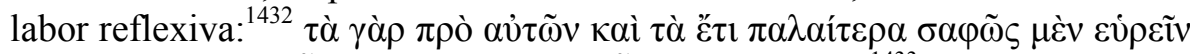

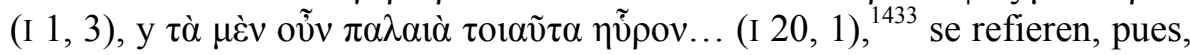
a un nivel diferente.

Finalmente, quedan como términos relativos a la labor plenamente

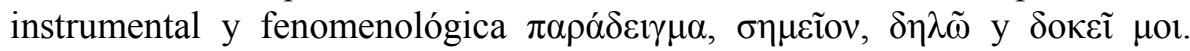
Respecto a todos ellos, ya vimos que su presencia en Tucídides no es nada excepcional, y que estamos simplemente ante términos de amplia aparición tanto en los autores de la época como en Heródoto. ${ }^{1434}$ En lo que se refiere a la semántica propia de cada uno de los términos, parece difícil señalar diferencias claras entre los cuatro. Ya defendimos, en contra de lo indicado por Hornblower, el significado de prueba para $\pi \alpha \rho \alpha ́ \delta \varepsilon(\gamma \mu \alpha$, y, en lo que

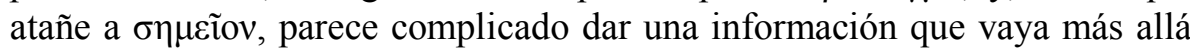
de la simple referencia a un hecho fenomenológico.

En cuanto a $\delta \eta \lambda \tilde{\omega}$ y $\delta$ $о \kappa \varepsilon \tilde{\imath} \mu$ o, responden a un tipo de evidencia referida a la opinión tanto del propio autor como de otros autores, respondiendo así a un segundo grupo de evidencias que apuntan a un concepto mucho más subjetivo.

Lo importante, más allá de la determinación de una traducción exacta de cada término, cosa realmente compleja y seguramente siempre deficiente, es dar cuenta de la sistematicidad presente en el pensamiento de Tucídides, que responde a cualquier cosa menos a un reflejo «científico» de la realidad. A grandes rasgos, estamos ante un sistema parecido al visto en el caso de Heródoto. La realidad es examinada a partir de las evidencias que se

${ }^{1432}$ En este sentido, Canfora, 1977, pp. 458 y 460.

${ }^{1433}$ Esta idea no es incompatible con la propuesta de Shrimpton, 1998, p. 77, de que

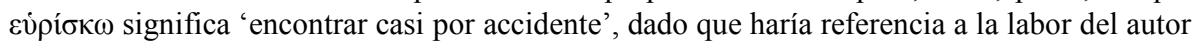
en general, no al método aplicado.

${ }^{1434}$ Cf. para Heródoto, Huber, 1965, p. 26 y ss. 
presentan al autor, sea por observación personal de los hechos, de las evidencias materiales o históricas a su disposición, o incluso por las observaciones de otro -en la Arqueología tiene un lugar especial Homero-, o gracias a las propias opiniones del autor.

Pero, si admitimos este como el último escalón del pensamiento de Tucídides, estamos privando al autor de lo más propio de su pensamiento. Todos estos elementos dan lugar a un primer nivel de comprensión, la $\varepsilon$ recogidos en el desarrollo de la actividad reflexiva que la Arqueología, por la necesidad de justificar la afirmación inicial, ejemplifica de manera brillante. Pero el paso fundamental, lo que hace que Tucídides represente un escalón más en el género historiográfico, es la $\tau \varepsilon ́ \kappa \mu \alpha \rho ı \varsigma$, que supone el dar forma personal y subjetiva a los datos que se han analizado, el generar $\tau \varepsilon \kappa \mu \eta ́ p ı$.

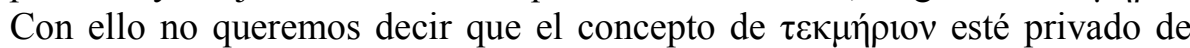
cierto sentido de prueba, pero no es una prueba neutra y «científica», sino que da cuenta de la argumentación realizada y codificada por el autor, la prueba de los hechos de la que habla el propio Tucídides (I 20, 1), y que separa la narración tucidídea de la de otros autores, ${ }^{1435}$ con un gran tinte polémico.

\subsubsection{CONTEXTOS DEL MODELO METODOLÓGICO TUCIDÍDEO}

La posible vinculación con la medicina hipocrática de la obra tucidídea es algo que se ha aplicado prácticamente a todos los aspectos de la obra. En lo que respecta a la metodología de Tucídides, a nuestro entender se impone la que será una constante en la labor interpretativa de la Historia en lo que se refiere al mundo hipocrático. Si bien es inegable la existencia de puntos de contacto, como bien ha demostrado Rechenauer, ${ }^{1436}$ por citar el trabajo sistemático más reciente, no podemos asumir que el modelo tucidídeo

${ }^{1435}$ Cf. Rood, 2006, p. 234.

${ }^{1436}$ Cf. Rechenauer, 1991, p. 216, donde aduce e. g. el innegable paralelo que supone

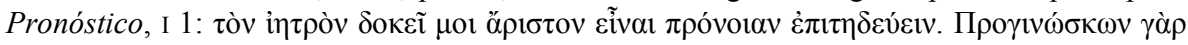

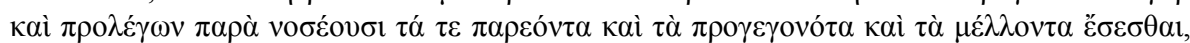

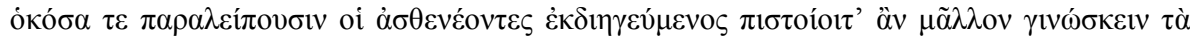

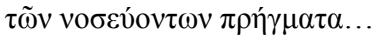


dependa en gran medida de la ciencia médica, ${ }^{1437}$ por cuanto muchos de sus métodos estaban ya presentes incluso en Heródoto y delatan un patrimonio común de la época. ${ }^{1438}$ Hussey demostró hace años los contactos existentes entre la teoría democritea de la $\pi$ ó $\lambda$ is y el modelo tucidídeo, en un modo parecido al que observamos en Heródoto. ${ }^{1439}$ Lo importante, más que una simple rotación de los elementos en juego a la hora de valorar las influencias, es tener presente la riqueza cultural del momento y lo inútil de limitar esa misma riqueza.

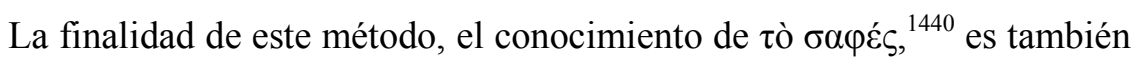
un buen medio para valorar la complejidad que se esconde detrás de la obra de Tucídides. Scanlon nos advirtió de los parecidos con el fragmento DK 68 B 34 de Jenófanes: ${ }^{1441}$

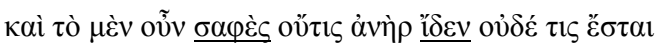

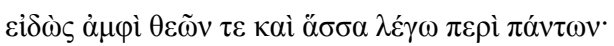

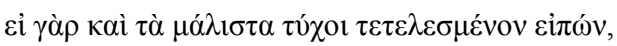

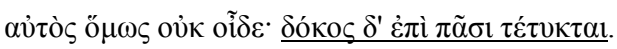

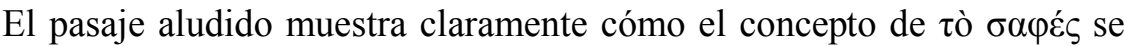
presenta en un nivel superior de comprensión de la realidad que va más allá de la simple observación empírica, y que nos recuerda lo visto en Heródoto. El mundo de la $\delta$ ó $\xi \alpha$ se supera para alcanzar un nivel superior, asimilado tradicionalmente a la divinidad, incluso en la época que nos ocupa por Eurípides. ${ }^{1442}$

Por ello, sin llegar al extremo difícilmente sostenible de negar la presencia de elementos hipocráticos en Tucídides, como defendía von

${ }^{1437}$ O que estos rasgos sean de aplicación de manera localizada en la obra, cf. Hornblower, 2011 a, p. 5.

${ }^{1438}$ Sobre la importancia del concepto de $\gamma v \omega ́ \mu \eta$ en la poesía como precedente tucidídeo, cf. de Romilly, 1990, p. 62.

${ }^{1439}$ Cf. Hussey, 1982, p. 120 y ss.; cf. Demócrito, DK 68 B 33, 119 y 191.

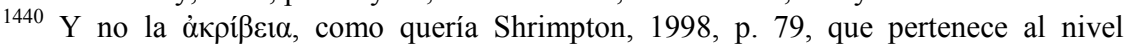
instrumental de la obra.

${ }^{1441}$ Cf. Scanlon, 2002, p. 133. Ampliamos el texto de Jenófanes que presenta el autor, dado que el último verso nos parece fundamental.

${ }^{1442}$ Cf. Scanlon, 2002, p. 135. 
Fritz, ${ }^{1443}$ hemos de asumir que la excesiva dependencia de la medicina hipocrática se debía a la imagen de un Tucídides científico que poco a poco la crítica ha ido suavizando, y que planteaba una innecesaria y distorsionada imagen de la obra del historiador, heterodoxo como todos los autores del genero.

Siguiendo con el razonamiento y las posibles influencias hipocráticas, la propia estructura del proemio nos lleva irremediablemente a examinar los

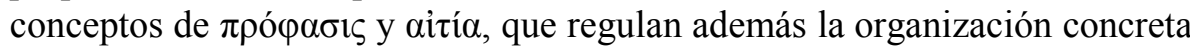
de la teoría antes examinada, constituyendo el segundo escalón de la triple organización intelectual de la obra tucidídea, en el nivel en el que se situaba la $\gamma v \omega ́ \mu \eta$ herodotea.

La cuestión no es fácil, y en pocos años se pasó de considerar que

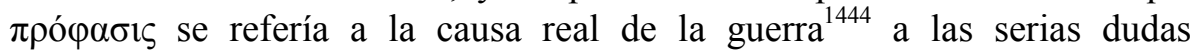
expresadas por Pearson y después por Kirkwood en dos trabajos contestados pocos años después por Sealey, quien consideró necesario volver a la idea inicial, ${ }^{1445}$ distinguiendo dos niveles de explicación, ${ }^{1446}$ idea que todavía ha de tenerse presente.

$\mathrm{Y}$ es que, a nuestro entender, el análisis de ambos conceptos se ha de orientar a su comprensión e inclusión dentro del sistema que estamos trazando hasta el momento, y no a proporcionar una simple traducción de ellos. Esta idea, que ya apuntó Rawlings, ${ }^{1477}$ se ha de sumar a la siempre olvidada indicación de Wilamowitz acerca de los peligros de apoyarse en la etimología para definir el significado de un término: las lenguas y sus palabras varían, y con ellas el significado de los términos, por lo que el estudio de ambos conceptos habrá de hacerse con especial atención al contexto en el que se presentan. ${ }^{1448}$

Hemos de tener en cuenta en el análisis de estos conceptos que nos movemos, más que en una simple revolución racional que requiere del empleo de términos precisos, en el complejo proceso de evolución de la lengua y la prosa al que ya hemos hecho referencia. Como advierte

${ }^{1443}$ Cf. von Fritz, 1967, p. 545

${ }^{1444}$ Cf. Gomme, 1950 , p. 152 y ss.

1445 Cf. Sealey, 1957, p. 9: "Thus the older view should be accepted: at I 23, 6 Thucydides states the true cause of the war, as he conceives it».

${ }^{1446}$ Cf. Sealey, 1957, p. 11.

${ }^{1447}$ Cf. Rawlings, 1975, p. 2

${ }^{1448}$ Así, Rawlings, 1975, p. 4 


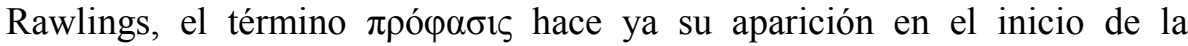
literatura griega, con Homero, pero hemos de asumir un muy largo recorrido del término, un recorrido prácticamente silencioso hasta finales del siglo $\mathrm{V}$ a. C. ${ }^{1449}$ La carga conceptual futura del término es posible rastrearla ya en los autores anteriores, incluso en Heródoto, donde desempeña una función adverbial que recoge, en cierta manera, futuros sentidos abstractos. ${ }^{1450}$

Pero más allá de estos casos, nos interesa observar la función que presenta en Heródoto en una serie de usos que el propio Rawlings analiza y que vienen a confirmar la aplicación continuada del concepto con un mismo sentido, el de excusa o justificación, ${ }^{1451}$ en todos los niveles de la obra herodotea, tanto humano como divino, ${ }^{1452}$ lo que se enmarca, como veremos, en un proceso de inversión de conceptos entre los dos autores.

El análisis de Rawlings incluye un planteamiento que nos cuesta aceptar: la idea de la existencia de dos términos homófonos, derivado uno de $\varphi \eta \mu$ y y otro de paív $\omega$, no tiene más apoyo que la deriva semántica ${ }^{1453}$ que parece adquirir el término en diferentes contextos. ${ }^{1454}$ Con este planteamiento, Rawlings propone la aparición en los escritos hipocráticos del término

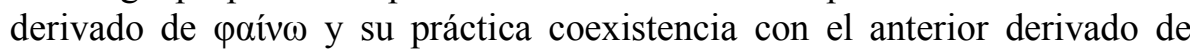
$\varphi \eta \mu$ í. La idea, que se apoya en la habitualmente defendida evolución del pensamiento ilustrado griego, tiene además este inconveniente. Ya señalamos en el análisis formal la clara continuidad existente en la literatura griega, continuidad que difícilmente admite este tipo de evoluciones. El hecho, sumado a que no existe apoyo lingüístico alguno para proponer tal

${ }^{1449}$ Cf. Rawlings, 1975, p. 22 y ss.

${ }^{1450}$ En cierta manera, Rawlings, 1975 , p. 25 , piensa lo contrario al afirmar: «[...] in Herodotus, Pindar, Theognis and Homer, the only early authors in whose work prophasis appears, its functions primarly as an adverb, is the subject of only a few sentences, and is not truly a concept in its own right». A nuestro entender, el sentido casi preposicional presente en pasajes como Heródoto, I 29, 2, tiene una fuerza semántica no muy lejana de la que veremos en autores más tardíos.

${ }^{1451}$ Cf. Rawlings, 1975, p. 32: «Prophasis is always an explanation, a justification for one's conduct, and it is frequently delivered to someone else». Este sentido de excusa es aceptado por Pearson, 1952, p. 220, en un trabajo ya polémico al poco de su publicación.

${ }^{1452}$ Cf. Rawlings, 1975, p. 31.

${ }^{1453}$ En este sentido, el análisis de los ejemplos hasta Heródoto de Nikitas, 1976, p. 31, quien da como significados «Ursache, Grund, Vorwand, und Anlass», parece apuntar precisamente a esta escasa diferencia semántica.

${ }^{1454}$ Así, Pearson, 1952, p. 206 y nota 7. 
distinción, ${ }^{1455}$ nos lleva a, por lo menos, no tomar como una cuestión apriorística esta diferencia etimológica. Además, el sentido de 'síntoma' de cuño hipocrateo ${ }^{1456}$ puede ser aplicado de manera clara a los usos herodoteos referidos a la divinidad, manifestada en sueños y bajo otros aspectos, principalmente si tenemos en cuenta lo que hemos expuesto antes respecto al universo intelectual herodoteo. ${ }^{1457} \mathrm{Y}$ es que, a decir verdad, la deriva semántica desde cualquiera de los dos campos al otro es algo fácil si no exigimos una precisión léxica excesivamente profunda, que, en último término, responde a un uso técnico propio de cada contexto.

Para el caso de Tucídides, I 23, 6, creemos que el primer punto que debemos tener claro es si nos movemos en un plano causal o en un plano fenomenológico, aspectos habitualmente relacionados pero no necesariamente semejantes. Con esto queremos decir que ha de precisarse si asumimos que el concepto pertenece al nivel de observación o de comprensión de la realidad. Si realmente el concepto entronca con el espíritu hipocrático, con los usos que Rawlings asumía como derivados de paív $\omega$, estamos ante un concepto que tiene relación con el escalón previo a la comprensión verdadera de la guerra. Esto es así por la fuerte naturaleza sintomática de los fenómenos referidos con este concepto, lo que Rawlings

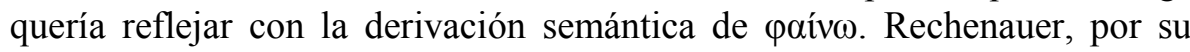
parte, nos permite avanzar en la definición del concepto al señalar la habitual oposición del mismo al adverbio $\dot{\varepsilon} \xi \alpha i ́ \varphi v \eta \varsigma,{ }^{1458}$ lo que necesariamente parece indicar un proceso observable ${ }^{1459}$ y no su causa, cosa que nos lleva a pensar en un aspecto fenomenológico del concepto, en contra de la idea de

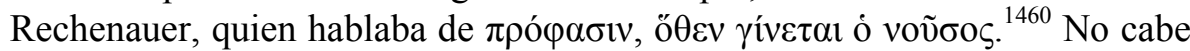
duda de que Tucídides, como todo personaje culto de su época, estaba al

${ }^{1455}$ Sealey, 1957, p. 3, planteaba que el resultado de * $\pi \rho 0-\varphi \alpha \nu-\sigma ı \zeta$ tendría que presentar alargamiento de la alfa. Sobre dicho aspecto ya Weidauer, 1954, p. 13, planteaba esta imposibilidad. Cf. también Rechenauer, 1991, p. 42 y ss.

${ }^{1456}$ Sentido que, por otra parte, Kirkwood, 1953, p. 41 y ss., nos recuerda que es mucho más complejo de lo que a primera vista pudiera parecer. Por lo demás, la consideración de que este sentido fenomenológico del término viene asegurado por la adjetivación habitual del

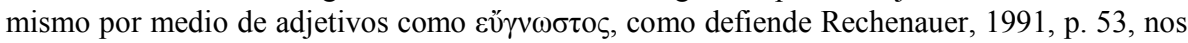
parece algo arriesgada.

${ }^{1457}$ Ya Kirkwood, 1952, p. 55 y ss.

${ }^{1458}$ Cf. Rechenauer, 1991, p. 57 y ss.

${ }^{1459}$ En este sentido, la idea de Wick, 1975, p. 177, de entender Tucídides I 23, 6: $\tau$ où $\varsigma$

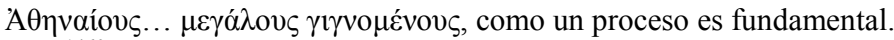

${ }^{1460}$ Rechenauer, 1991, p. 62. 
tanto de los escritos médicos, ${ }^{1461}$ que, como hemos señalado, no eran todavía un género excesivamente especializado, cosa que permitiría una fácil circulación de conceptos, que podrían ser manejados -esto es lo fundamental- con una gran libertad. ${ }^{1462}$

Importante, y realmente poco tenida en cuenta, es la posición dentro de la argumentación en que se encuentra la expresión. El análisis formal realizado nos permite afirmar que su situación responde al punto final de la evolución del pensamiento a lo largo del proemio. La rígida estructura del mismo demuestra que desde el comienzo de I 23 estamos ya muy lejos del análisis de los fenómenos que permiten a Tucídides construir su pensamiento. Teniendo esto presente, podemos afirmar que la idea de

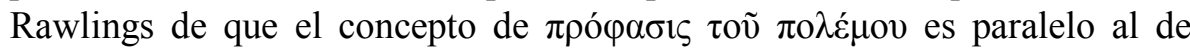

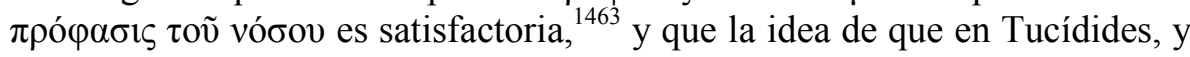
en concreto en el proemio, este concepto no tiene fuerza causal es correcta. ${ }^{1464}$ No estamos hablando de la causa última, sino de una «visible Vorphase», de un síntoma previo, ${ }^{1465}$ pero, y en esto disentimos de Rawlings, Tucídides no está haciendo el diagnóstico de la enfermedad que es la guerra, dentro de lo que sería una aplicación radical de la influencia de la medicina hipocrática. ${ }^{1466}$ Teniendo presente el nivel conceptual subjetivo que hemos planteado para la intepretación de $\tau \varepsilon \kappa \mu \alpha \iota p o ́ \mu \varepsilon v o \varsigma$ en el inicio del proemio, y recordando lo que el propio Tucídides nos dice acerca de la naturaleza del

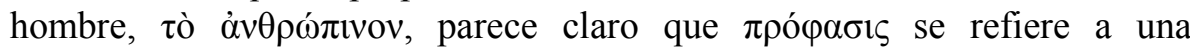
maniestación, a un síntoma, pero para nada relacionado con la simple observación hipocrática, sino perteneciente a ese nivel de interpretación intelectual que impregna el proemio y que tan lejos está del idealismo

${ }^{1461}$ Cf. Rawlings, 1975, p. 73.

${ }^{1462}$ Esta idea fundamental se la debemos a Parry, 1969, p. 111 y ss., quien dio cuenta del detalle no menor de la poca especialización del léxico de la plaga, cuyos supuestos términos técnicos son comunes en la literatura no especializada. En contra de esta idea, aunque sin avanzar demasiado, cf. Alsina, 1987, p. 3, nota 5.

${ }^{1463}$ Lo que no quiere decir, como pensaba Cochrane, 1929, p. 17, que sea un concepto necesariamente tomado de la medicina hipocrática.

${ }^{1464}$ Cf. Rawlings, 1975 , p. 78 y ss.

1465 Preferimos esta definición a la ofrecida por Page, 1953, p. 108, quien habla de «exciting phase», traducción propuesta por Cochrane, 1929, p. 17, y ya negada por Kirkwood, 1952, p. 41.

${ }^{1466} \mathrm{Cf}$. Rawlings, 1975, p. 79: «Thucydides is simply doing a diagnosis of the illness that was the war». 


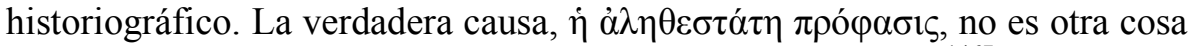
que un síntoma de la naturaleza humana en su desarrollo, ${ }^{1467}$ que rige el

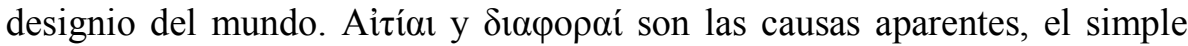
nivel fenomenológico, lo más cercano al famoso «was es eingentlich gewesen», los hechos constatables, que se oponen a lo que realmente importa en la obra de Tucídides y que es su mayor aportación a la historiografía, la afirmación de la existencia de un nivel superior de comprensión de la realidad que supone pasar de los simples hechos a la interpretación de los mismos. El rechazo de Kirkwood a considerar $\pi \rho o ́ \varphi \alpha \sigma ı \varsigma$ como la explicación del autor a la guerra, en la idea de que este concepto y aỉíal están al mismo nivel, es difícil de respaldar precisamente por la razón que el propio Kirkwood ${ }^{1468}$ propone, la existencia de una correlación $\mu \varepsilon \dot{v} \ldots \delta \delta \varepsilon^{1} .{ }^{1469}$ que determina un fuerte dualidad, la cual, a nuestro entender, apunta justamente a esa oposición a la que hacemos referencia. En esta misma línea se mueve la interpretación más reciente de

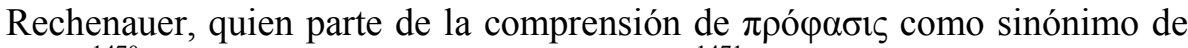
$\alpha i \tau i ́ \alpha,{ }^{1470}$ lo que, aplicado a la obra tucidídea, ${ }^{1471}$ permite salvaguardar la idea de objetividad de la obra del de Óloro, pero que lleva al citado autor a

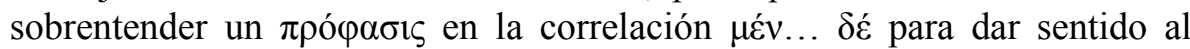
superlativo, cosa innecesaria, a nuestro entender, y que supone complicar un texto ya de por sí complejo.

De este modo, si nos atenemos a la intepretación propuesta, parece difícil mantener de manera rígida los hilos que habitualmente se trazan entre los autores del Corpus Hippocraticum y Tucídides, y es necesario replantearse la relación existente entre Heródoto y Tucídides. ${ }^{1472}$ Respecto al historiador de Halicarnaso, está claro que la semejanza en la construcción de los modos de entender la realidad acerca de manera drástica las figuras de ambos

${ }^{1467}$ En este sentido, hay que reconocer que la propuesta de Gomme, 1950, p. 153, de entender $\pi \rho o ́ \varphi \alpha \sigma ı \varsigma$ como causa psicológica no estaba muy lejos de nuestra propuesta. Weidauer, 1954, p. 18, dotaba al concepto de un valor durativo acorde con esta idea.

${ }^{1468}$ Cf. Kirkwood, 1952, p. 47.

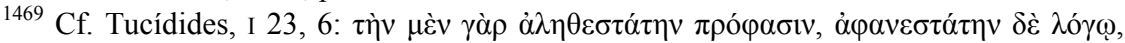

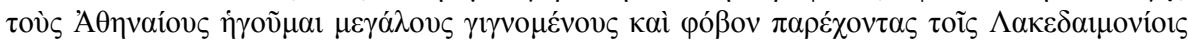

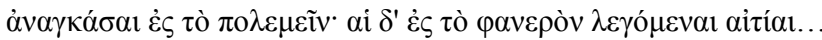

${ }^{1470}$ Cf. Rechenauer, 1991, p. 70 y ss.

${ }^{1471}$ Cf. Rechenauer, 1991, p. 83 y ss.

${ }^{1472}$ Cf. recientemente Foster y Lateiner, 2012, p. 2, nota 3, para la aparición de esos usos supuestamente técnicos de la descripción de la peste ya en Heródoto. Como señalan los propios autores, es este un hecho que ya señaló Poppo en su comentario. 
historiadores. La diferencia existente entre la doctrina del tò ỏv $\theta \rho \omega ́ \pi ı v o v$ y el modelo de construcción divina del universo de Heródoto es tan pequeña en sus planteamientos generales que resulta difícil no asumir la relación existente entre la causalidad humana herodotea y la aĩí $\alpha$ de Tucídides, y la

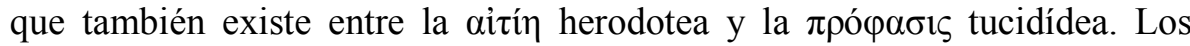
términos cambian, y una vez más hemos de tener presente que un mismo término puede adquirir significados diferentes en distintos autores, pero el paralelo es claro. En el caso de los dos últimos, estamos ante las manifestaciones, en ocasiones insignificantes a primera vista, de un orden superior subjetivo diseñado por el historiador, ${ }^{1473}$ de difícil comprensión a primera vista, pero que responden a un nivel mucho más complejo y elaborado que la simple causalidad comprensible para el ojo humano, la que

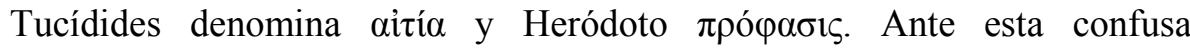
complejidad del uso de los conceptos, hemos de tener presente que su significado es el mismo. Seguimos insistiendo en que no es necesario hacer diferencias etimológicas, con la particularidad de que su significado depende

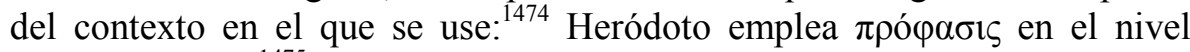

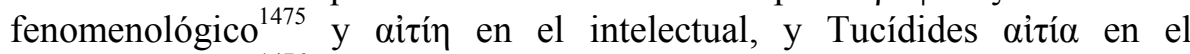
fenomenológico $^{1476}$ y $\pi \rho o ́ \varphi \alpha \sigma r \varsigma$ en el intelectual, lo que da lugar a diferencias técnicas en cuanto al uso de términos, pero no al océano que habitualmente se quiere abrir entre ambos autores en este aspecto. ${ }^{1477}$ Es verdad, como bien indican Rawlings y Page, que en Tucídides tenemos usos de $\pi \rho o ́ \varphi \alpha \sigma ı \varsigma$ que parecen asimilarse a un simple nivel fenomenológico o

${ }^{1473}$ Creemos que las observaciones de Malitz, 1982, p. 257 y ss., son fundamentales para entender este nivel de subjetividad plenamente ligada al rigor intelectual del autor y no entendida en términos de tendenciosidad.

${ }^{1474}$ Esta es la respuesta de Sealey, 1957, p. 2, a la aporía de los trabajos de Pearson y Kirkwood: "They have rightly emphasized the instances where $\pi \rho$ ó $\varphi \alpha \sigma \varsigma s$ means an explanation which is not genuine and they admit that it sometimes means a genuine explanation».

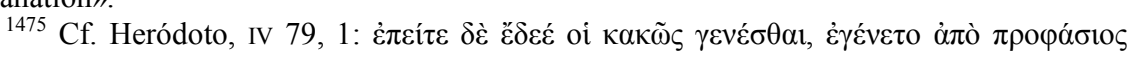
$\tau$ ๘oฑ̃ $\delta \delta \varepsilon \ldots$ y Pearson, 1952, p. 209 y ss.

1476 Obviamente, con esto rechazamos la idea de Pearson, 1952, p. 221, de considerar airía como 'acusación', cf. p. 222: «Thus we may say that when Thucydides directly contrasts prophasis with aitia he contrasts 'defence' or 'justification' with 'accusation' or 'grievance'», como también piensa Tasolambros, 1979, p. 184 y ss.

${ }^{1477}$ Cf., así, Rawlings, 1975, p. 94 y ss. 
sintomático, ${ }^{1478}$ y creemos que esta observación es correcta, dado que seguimos moviéndonos en el nivel de la $\tau \dot{\kappa} \kappa \mu \alpha \rho \sigma \iota \varsigma$. En tal sentido, los lectores modernos nos encontramos indefensos ante un texto de la complejidad del de Tucídides, pero teniendo presente, como antes indicábamos, la rígida estructura del proemio, está claro que un lector antiguo determinaba fácilmente a qué se refería el término. ${ }^{1479}$

Respecto a la diferencia existente entre el concepto de $\pi \rho o ́ \varphi \alpha \sigma r \varsigma$ en el proemio a la obra de Tucídides y el uso que hacen los autores del Corpus Hippocraticum, hemos de asumir que es claramente insalvable. Como ya advirtió Page, Tucídides conocía y empleaba el léxico de los autores del corpus, ${ }^{1480}$ pero ese material heredado es reutilizado y sistematizado de forma personal por el propio Tucídides ${ }^{1481}$ de un modo que recuerda a Heródoto y que se define como una de las características del género. ${ }^{1482}$

Esta propuesta tiene además la ventaja de que supera la complicada idea de un cambio de opinión por parte de Tucídides y la aparición de dos redacciones diferentes en I $23,6 .{ }^{1483}$ La redacción del parágrafo no es excesivamente clara para el lector, dado que la fuerte inversión presente en

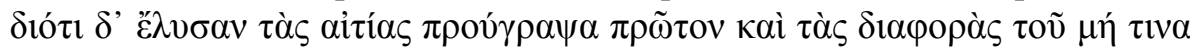

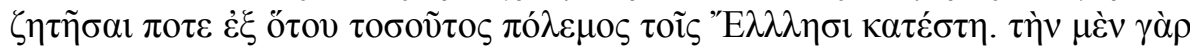

${ }^{1478}$ Cf. Page, 1953, p. 108. Se ha de señalar que, en contra de la opinión de Rawlings, Page defiende la unidad del concepto. Cf. también Pearson, 1952, p. 210, quien ve el paralelo entre este uso y el de Heródoto citado en nota anterior.

${ }^{1479}$ El propio Rawlings, 1975, p. 83, recuerda que la estructura del libro I se mueve precisamente entre las marcas que determinan esta diferenciación entre aíía y $\pi \rho o ́ \varphi \alpha \sigma ı s$.

${ }^{1480}$ Cf. Page, 1953, p. 97 y ss., para un completísimo análisis de los términos empleados en la descripción de la plaga.

1481 Para esta idea de insertar lo hipocrático dentro de los moldes de la obra, cf. Rechenauer, 2011, p. 242, en referencia a la peste acaecida en Atenas, y ya antes Alsina, 1987, p. 4.

${ }^{1482}$ Lo que haría que la idea de Hornblower, 2004c, p. 67, quien hablaba de Píndaro y Tucídides como médicos "amateur" tuviese que extremarse.

${ }^{1483}$ Así, Andrewes, 1959, p. 224 y ss. (Cf. p. 231: «This then is a hypothesis about the genesis of Thucydides' first book. It is no objection to it that the $\dot{\alpha} \lambda \eta \theta \varepsilon \sigma \tau \alpha \dot{\tau} \tau \eta \pi \rho \operatorname{\varphi q} \alpha \sigma \iota \varsigma$ was not a wholly new conception but one which had played a large part in his first draft -this is rather an advantage, in that his change of mind does not involve a complete break with all that he had ever thought before»). También ha sido esta idea defendida recientemente por Cawkell, 1997, p. 22. Ya Pohlenz, cf. apartado 5.1.1, con excelentes razonamientos, se manifestó en contra de la idea de Schwartz, como también lo hizo Weidauer, 1954, p. 47 y ss. 


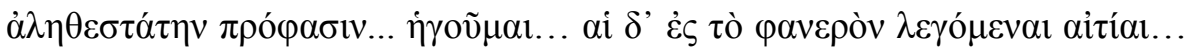
dificulta la comprensión del pasaje. A nuestro entender, la frase final de infinitivo es la clave: lo importante no es la $\dot{\alpha} \rho \chi \eta ́$-permítasenos adelantar un concepto polibiano- ${ }^{1484}$ que solo interesa a un cualquiera, $\tau i ́ v \alpha$, sino la motivación de la guerra, que viene precisamente introducida por el fuerte

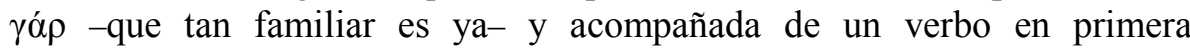
persona, ${ }^{1485}$ elementos que marcan los puntos álgidos del proemio. Es este conector junto con el $\delta \varepsilon ́$ posterior el que crea el marcado cambio de nivel en este breve pasaje, en el que la idea principal viene expresada por $\pi \rho o ́ \varphi \alpha \sigma ı \varsigma$, concepto que queda doblegado por la necesidad de referirse a las $\alpha \rho \chi \alpha i ́$-en sentido etimológico- de la guerra, presentes en esa posición por la deriva reflexiva a la que por la referencia al comienzo de la guerra se ve obligado el autor, lo que hace que el yó $\rho$, cuyo sentido solo es comprensible tras

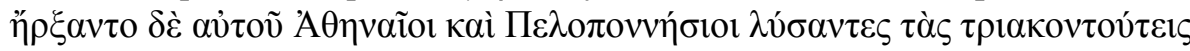

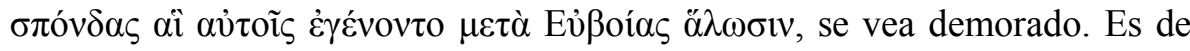
nuevo un bucle en el pensamiento de Tucídides, aún a caballo entre el mundo tradicional y el escrito, el que hace que pidamos al de Óloro lo que no nos dice, precisamente en la transición del proemio a la narración, uno de los puntos más complejos, estructuralmente hablando, de la obra. Del mismo

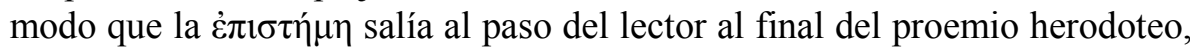

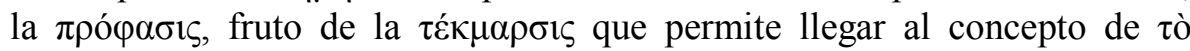
$\dot{\alpha} v \theta \rho \omega ́ \pi ı v o v$, aparece, dentro de los moldes arcaicos del proemio, al final del mismo.

\footnotetext{
${ }^{1484}$ Definido para el caso tucidídeo por Weidauer, 1954, p. 8, como «Ausgangpunkt».

${ }^{1485}$ Como bien ve Andrewes, 1959, p. 231, si bien disentimos de su idea de una doble redacción.
} 


\begin{tabular}{|c|c|c|}
\hline & Heródoto & Tucídides \\
\hline Tiempo & $\begin{array}{l}\text { Sucesión estática de aitíal en } \\
\text { virtud de tò } \theta \varepsilon i ̃ o v\end{array}$ & 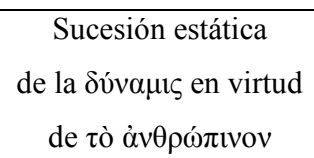 \\
\hline Espacio & $\begin{array}{c}\text { Sistema geométrico } \\
\text { de paralelos }\end{array}$ & $\begin{array}{c}\text { Escenarios de actuación } \\
\text { de } \pi \alpha \rho \alpha \sigma \kappa \varepsilon v \eta ́\end{array}$ \\
\hline Nivel fenomenológico & 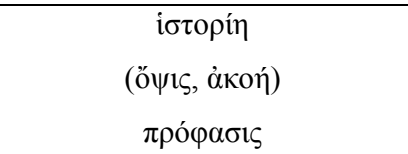 & $\begin{array}{c}\varepsilon \tilde{\rho} \rho \varepsilon \sigma 1 \varsigma \\
(\sigma \eta \mu \varepsilon i ̃ o v, \delta \eta \lambda \tilde{\omega} \ldots) \\
\text { Airía }\end{array}$ \\
\hline $\begin{array}{l}\text { Nivel de comprensión } \\
\text { del autor }\end{array}$ & $\begin{array}{l}\gamma \nu \omega \dot{\mu \eta \eta}-\text { oĩ } \delta \alpha \\
\alpha i \text { ín }\end{array}$ & 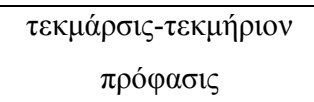 \\
\hline 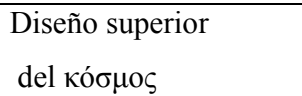 & 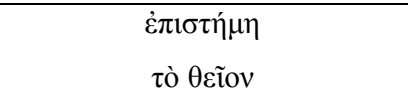 & 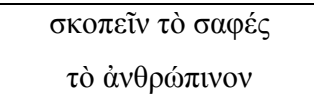 \\
\hline
\end{tabular}

\subsubsection{EL PODER POLÍTICO Y SUS CONSECUENCIAS}

La lectura del análisis del proemio de Heródoto deja bien claro que el afirmar que Tucídides es el creador de la historiografía política ${ }^{1486}$ es algo que debe ser precisado o analizado desde una perspectiva muy diferente. El naciente género historiográfico es una realidad que difícilmente puede desvincularse de la actividad política en su sentido más amplio. En el caso de Tucídides, el tema por historiar determina una senda que revela las diferencias existentes entre el autor que nos ocupa y Heródoto.

La habitual separación entre ambos autores se fundamenta en la falsa concepción de la obra de Heródoto como un simple medio para el recuerdo del pasado: esta idea hace que la naturaleza política de Tucídides gane una dimensión nueva que falsea la distancia existente entre ambos autores. ${ }^{1487}$

Así, Ober ${ }^{1488}$ ha trazado recientemente una línea de separación entre el universo de Telo el ateniense, paradigma del modelo expuesto en Heródoto,

\footnotetext{
${ }^{1486}$ Cf. e. g. Jaeger, 2000, p. 347.

${ }^{1487}$ Así, Ober, 2006, p. 132.

${ }^{1488}$ Cf. Ober, 2006, p. 137 y ss.
} 
y el mundo que se abría ante los ojos de nuestro autor y de la generación periclea. A nuestro entender, esta separación tiene un serio inconveniente, que se materializa ante nosotros cuando asumimos la verdadera significación del modelo de Telo el ateniense y lo que ya suponía en época de Heródoto. Además, la interpretación de la obra de Tucídides desde una perspectiva que trace una línea partiendo de la rehabilitación de la moral tradicional hasta Tucídides comete, según creemos, la incongruencia de poner al mismo nivel dos modos de hacer historia que guardan escasa semejanza. En Tucídides, como veremos, hay mucho de ese espíritu tradicional, muy reformado para la época, pero el hilo fundamental de interpretación empleado en la historiografía tucidídea tiene mucho que ver con el universo que gira en torno a la creación de la imagen ideal del pasado, sea a nivel de comunidad o de un grupo social menor, como pudiera ser un círculo oligárquico.

La comprensión de ese mundo reflexivo, del que emana el estudio de la

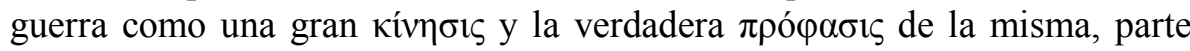
necesariamente de la época y las circunstancias exactas presentes en el tiempo en que se redactó la obra. La definición de Tucídides del marco de circunstancias políticas y con él la de la importante figura de Pericles es, simplemente, un factor más dentro de una imagen realmente compleja del momento.

Sin duda alguna, la realidad que le toca definir a Tucídides es una realidad social, una realidad política entendida en el sentido etimológico de la palabra: antes de pensar en una contraposición con Heródoto en términos de ateísmo y de diseño religioso, ${ }^{1489}$ hemos de pensar, una vez más, en el amplio espectro del género ante el que estamos, y lo realmente limitado del escenario elegido por Tucídides, un escenario materializado en la realidad política y urbana de una polis y sus relaciones externas. Difícilmente podemos encontrar un desarrollo profundo de un sistema con connotaciones religiosas ${ }^{1490}$ en una obra que únicamente se centra en estos temas, ${ }^{1491}$ lo que definitivamente, y en consonancia con el modelo de interpretación de la realidad que emplea Tucídides, cierra la puerta a esta vía de oposición.

${ }^{1489}$ Cf. e. g. Cornford, 1907, p. 72.

${ }^{1490}$ Las conclusiones de Marinatos, 1981, p. 56 y ss., apuntan precisamente a la negación de un tono crítico, centrado únicamente en las observaciones habituales de un pensador de la altura de Tucídides.

${ }^{1491}$ Los pocos pasajes en los que Tucídides trata de temas que podríamos denominar cercanos a la esfera religiosa, más que ambiguos, son, a nuestro entender, presentados desde una óptica que no permite aventurar rasgos religiosos. 
Todo este complejo diseño tiene, como ocurría con Heródoto, un elemento fundamental en torno al cual se elabora el conjunto en una red de tela de araña. Tò $\alpha \dot{v} \theta \rho \omega ́ \pi t v o v$, con su formación neutra abstracta, es un prodigioso término a medio camino entre la especulación humana de la tragedia, la discusión filosófica sofística y los nuevos horizontes que se van a abrir con Sócrates. La propia expresión de Tucídides en el proemio nos propone un sistema permanente que permite, precisamente, una construcción semejante a la vista en Heródoto. La realidad va a ser construida a partir de una serie de constantes que determinan no solo la naturaleza del hombre, sino también -y esto es lo importante- la actuación del mismo y la interacción que tiene con el ambiente que le rodea. ${ }^{1492}$ Asumir que el concepto que nos ocupa viene a significar, simplemente, 'naturaleza

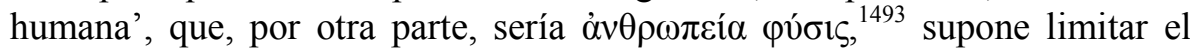
diseño tucidídeo, en contra de una perspectiva que recoge, como indicó Cogan, aspectos que traspasan lo meramente cultural. ${ }^{1994}$

Empezando por el individuo como elemento compositivo de la polis, Tucídides diseña una compleja anatomía del imperialismo. El diseño de este concepto se basa en un doble nivel de estudio desde una perspectiva universal dada por el concepto de tò àv $\theta \rho \omega ́ \pi ı v o v$, que favorece la afirmación polémica sobre la importancia de la guerra, ${ }^{1495} \mathrm{y}$ un nivel fenomenológico. La evolución trazada por de Romilly en lo que al imperialismo se refiere y que prácticamente es una verdad inamovible de los estudios tucidídeos, ${ }^{1496}$ responde claramente a un proceso de degeneración, o, mejor, a un alejamiento de una imagen estática ideal de lo que Tucídides consideraba como una realidad irrenunciable. Ya Woodhead indicó que el poder, a ojos de Tucídides -y como demuestra la aséptica Arqueología, diríamos-, es un elemento neutral, ${ }^{1497}$ que, a priori, no es ni bueno ni malo, lo que supone la

${ }^{1492}$ En este sentido, nos parece de gran mérito la propuesta de Patzer, 1937, p. 102, quien

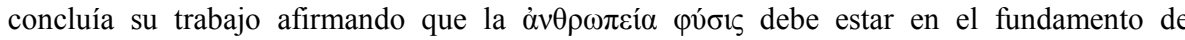
cualquier estudio sobre Tucídides, siempre que se asuma el valor práctico de la expresión,

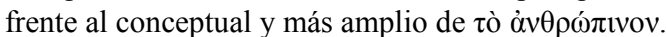

${ }^{1493}$ Como bien señala Cogan, 1981, p. 186.

${ }^{1494}$ Cf. Cogan, 1981, p. 189, si bien no creemos que se deba asimilar el concepto a la actuación de los Estados.

${ }^{1495}$ Cf. Allison, 1989, p. 15.

${ }^{1496}$ Cf. Cogan, 1981, p. 125 y ss., quien, de manera más simple, sanciona el esquema por medio del empleo de los discursos como elementos miliares de la evolución del pensamiento.

${ }^{1497}$ Cf. Woodhead, 1970, p. 14 y ss. Ello hace difícil hablar, como quería Taeger, 1925, p. 3, de una apologia del imperialismo en Tucídides. 
necesaria imbricación de este con otros aspectos de la vida de la polis para ganar esas calificaciones positivas o negativas. La idea de un poder neutro lleva inevitablemente aparejada la de un poder que fluye, ${ }^{1498}$ que hace que pase de unos a otros, sin que por ello podamos hablar de algo semejante a nuestra idea moderna de progreso: estamos, exactamente, ante la misma idea presente en Heródoto de degeneración de la situación dada, ante un sistema de vaivenes presente en la filosofía presocrática de manera contundente.

El ideario que subyace en la consideración de la causa de la guerra, la $\pi \rho$ óp $\alpha \sigma \iota \varsigma$, y que recorre de manera silenciosa toda la Arqueología es de una escalofriante tensión, casi trágica, diríamos, que se materializa en las palabras de Pericles. El imperio, fruto de la capacidad de Atenas, de su

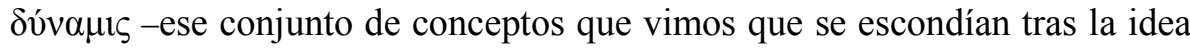
de $\pi \alpha \rho \alpha \sigma \kappa \varepsilon v \eta \dot{-}$, es, en palabras de Woodhead, la enseña de la ciudad próspera $^{1499} \mathrm{y}$, a nuestro entender, la aplicación práctica de esos medios. La Arqueología, ${ }^{1500}$ en la figura de Agamenón, desarrolla una pequeña imagen de lo que decimos. A ojos de Tucídides, la razón que llevó a la creación de la alianza contra Troya bajo el mando de Agamenón -quien era $\tau \tilde{\omega} v \tau o ́ \tau \varepsilon$ $\delta v v \alpha ́ \mu \varepsilon 1 \pi \rho o v ́ \chi \omega v-$, no fue tanto al juramento prestado como, precisamente, esa posición de poder absoluto. ${ }^{1501}$ Fue, pues, Agamenón el responsable de ponerse al frente de la flota también por este extremo: A $\gamma \alpha \mu \varepsilon ́ \mu v \omega v$

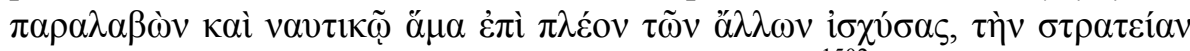

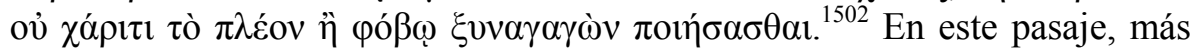
que ante un análisis de los datos históricos que Homero nos puede transmitir, ${ }^{1503}$ estamos ante la definición práctica del funcionamiento de los

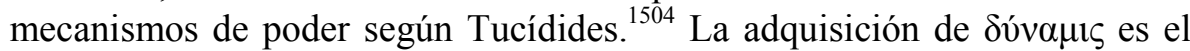
requisito previo para la creación de alianzas, cuya motivación es el $\varphi$ óßos, el

${ }^{1498}$ Cf. Woodhead, 1970, p. 13.

${ }^{1499}$ Cf. Woodhead, 1970, p. 37

${ }^{1500}$ Cf. Jaeger, 2000, p. 349: «En la narración de la guerra, los mismos principios [sc. de la Arqueología] aparecen más circunstanciados y menos compendiados y ocupan un lugar más amplio».

${ }^{1501}$ Cf. Tucídides, I 9, 1.

${ }^{1502}$ Cf. Tucídides, I 9, 3.

${ }^{1503}$ Como ha querido ver Pouncey, 1980, p. 9. No creemos lógica tampoco la opción de Cuscunà, 2005, p. 69, quien trata de indagar en las posibles fuentes en las que Tucídides se basa para refutar el juramento a Tíndaro como causa de la guerra de Troya, dado que la idea de poder es algo original de la obra tucidídea.

${ }^{1504}$ Estableciendo así una visión poco habitual que realza las relaciones de sometimiento y de manejo de poder en general, como indica Price, 1997, p. 667. 
temor a la acción del poderoso. Estos requisitos previos conducen a la expansión imperial por medio -en el caso de Grecia, en la que el mar desempeña un papel tan importante, como se señala en la propia Arqueología $-{ }^{1505}$ de la adquisición de una flota poderosa. Pero una condición básica del ejercicio en alianza de esa fuerza es la necesaria e indiscutible supremacía del miembro que ejerce el poder de manera unificada. ${ }^{1506} \mathrm{El}$

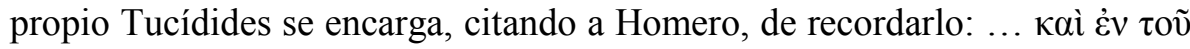

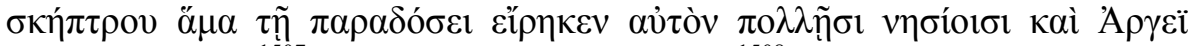
$\pi \alpha v \tau i ̀ ~ \alpha ́ v o ́ \sigma \sigma \varepsilon ı v . ~{ }^{1507}$ Como ya se ha señalado, ${ }^{1508}$ el leitmotiv del Imperio

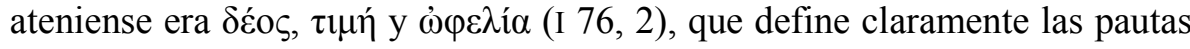
señaladas en la figura de Agamenón.

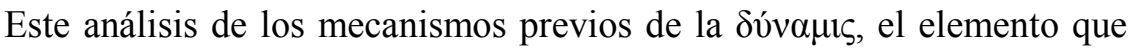
hace posible el imperialismo, traza una clara imagen de lo que el historiador entiende como los cimientos del poder que va a reflejar en su obra. Especialmente importante es también la idea, ya apuntada por Woodhead, de

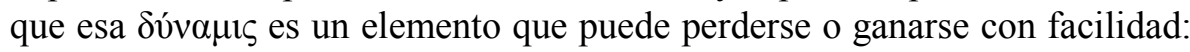
en resumidas cuentas, que el ejercicio del imperio es una acción sometida a

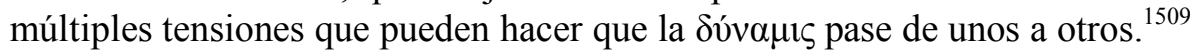
Es necesaria la estabilidad absoluta para el mantenimiento del poder, para evitar que cambie de manos. Una de las obsesiones de la Arqueología ${ }^{1510}$ y

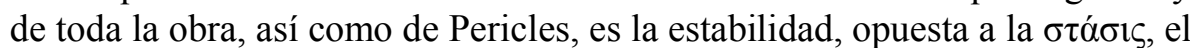
mayor mal que puede acechar a la comunidad. ${ }^{1511}$ Es esta una idea, por otra parte, plenamente arcaica, ${ }^{1512}$ como también es plenamente arcaica la tensión existente entre cambio y estabilidad, que tanto molesta al crítico moderno. ${ }^{1513}$ A nuestro entender, la propia Arqueología no nos presenta un modelo de evolución, dado que no diseña una línea de progreso, sino los

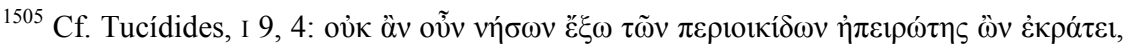

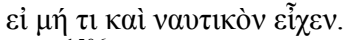

${ }^{1506}$ Así, Price, 1997, p. 670 y ss.

${ }^{1507}$ Cf. Tucídides, I 9, 4.

${ }^{1508}$ Cf. Crane, 1998, p. 64.

${ }^{1509}$ Cf. Woodhead, 1970, p. 38

${ }^{1510}$ Cf. e. g. I $2,2$.

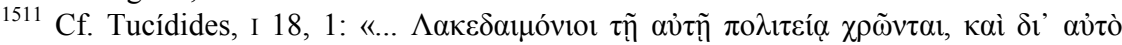

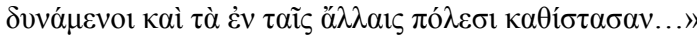

1512 Idea que, como señala Crane, 1998, p. 295, obsesionaba a los griegos desde la escuela milesia.

${ }^{1513}$ Cf. Crane, 1998, p. 301 
vaivenes de la gestión del poder a lo largo del pasado como ejemplificación explicativa de las ideas de Tucídides.

Obviamente, si la historia de Tucídides es una historia de una

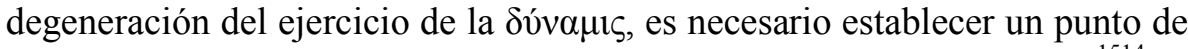
partida del mismo, y este no es otro que el que ya indicó Rengakos, ${ }^{1514}$ el primer discurso puesto en boca de los atenienses, que justifica y determina

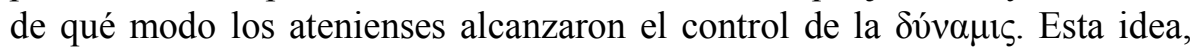
que se sustenta en los paralelos presentes entre el diseño de la Arqueología y el discurso, ha de ser perfectamente separada de la actuación posterior de Pericles. Esto es así porque tres son los estadios reconocibles en la concepción de la gestión del imperio por parte de Tucídides, estadios de clara raigambre tradicional: el alcance del estado de cosas, la perfección con el mantenimiento de la misma y, finalmente, su degeneración, estadio que es responsable de que en ocasiones se tengan imágenes engañosas del pasado, una idea que nos recuerda, una vez más, que Tucídides está abandonando ya el modelo tradicional. ${ }^{1515}$

De este modo, Tucídides asume que el primer escalón de su narrativa, el statu quo del imperio en el momento de su narración, es un elemento secundario que ha de ser narrado en la Pentecontecia, y que tiene un modesto lugar en la Arqueología (I 18, 3 y ss.), simplemente como regreso a la idea

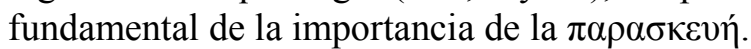

Lo complejo del proceso que lleva a esta situación de máximos es una cuestión solo latente en la obra de Tucídides. El proemio no tiene como finalidad la definición del modo en el que se alcanza ese estado de cosas, y la realidad, aunque parezca difícil asumirlo, es tan simple como que en Tucídides tenemos todavía un modelo triple de comprensión del pasado y de la realidad, del cual solo se nos manifiestan de manera clara los dos segundos pasos, el conflicto que distorsiona el estado perfecto de cosas y la decadencia.

${ }^{1514}$ Cf. Rengakos, 1984, p. 37.

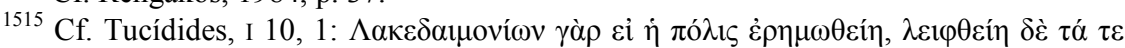

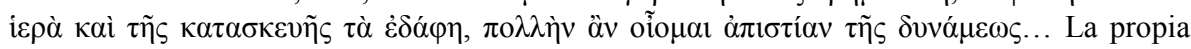
conciencia de que ese tipo de fenómenos pueden ser engañosos nos advierte de que Tucídides está ya a un nivel diferente. 


\subsubsection{EL CAPÍTULO DEL MÉTODO}

La justificación de la presencia del capítulo denominado del método ${ }^{1516}$ es seguramente una de las claves no solo del proemio sino de la constitución del género historiográfico. ${ }^{1517} \mathrm{Su}$ comprensión ha de ser abordada una vez más dentro de la diacronía que venimos trazando en el estudio del género, $\mathrm{y}$ teniendo muy presentes las necesidades que pueden haber dado lugar a su aparición.

En este sentido, el análisis estructural dejó claro que el denominado método no es otra cosa que la consecuencia directa de la afirmación inicial. ${ }^{1518}$ La idea de Tsakmakis de que el método era un medio retórico empleado por Tucídides para reafirmar el contacto con su público por medio de la defensa de la importancia de su material y el rechazo del de logógrafos y poetas ${ }^{1519}$ debe ser tenida en cuenta, pero en estos simples términos tiene poca valía, por cuanto no contempla una funcionalidad acorde con esa dependencia de la afirmación inicial.

Pensar en un criterio casi técnico de manejo de las fuentes y los datos es algo completamente fuera de lugar, porque no estamos hablando de una ciencia consolidada como tal: el intento de poner determinados conceptos en conexión directa con metodologías de autores anteriores es imposible, y lo realmente importante es asumir que por alguna razón Tucídides necesita precisar el manejo de los datos y su reconstrucción. Y esto lo hace no con un criterio que busque reflejar las cosas como fueron, sino con el desarrollo de

\footnotetext{
${ }^{1516}$ Fundamental en este sentido es todavía Grosskinsky, 1936, p. 15: «Kapitel 22 bringt dann die Angaben über die metodische Prinzipien, an die sich Th. bei der Darstellung dieses Krieges geschehens gehalten hat, und über Wesen und Zweck seines Werkes».

${ }^{1517}$ Un recorrido simple y efectivo por la diferentes propuestas, en Iglesias Zoido, 1989, p. 126 y ss., y 1995, p. 23 y ss., todo ello desde una perspectiva formal.

${ }^{1518}$ Cf. Grosskinsky, 1936, p. 18. Así también se pronunció en cierta manera Tsakmakis, 1998, p. 239, al afirmar: «Das sogenannte Methodenkapitel des Thukydides I 22, ist Teil eines kohärenten, sorgfältig durchstrukturierten Gedankengangs, der den Vorrang des peloponnesischen Krieges gegenüber allen Kriegen der Vergangenheit nachweisen und die für diese Erkenntnis notwendige Methode demostrieren soll». Téngase presente todo lo dicho en la sección relativa a la constitución formal del proemio. Cf. Schneider, 1974, p. 139.

${ }^{1519}$ Cf. Tsakmakis, 1998, p. 242. 
la narración de los acontecimientos bajo el amparo rector de la idea que organiza los hechos.

No creemos que sea casual el hecho de que Tucídides empiece por referirse a los discursos, que van a ser fundamentales en la articulación de su obra. Así, el concepto de $\dot{\eta} \alpha \alpha \kappa i ́ \beta \varepsilon 1 \alpha,{ }^{1520}$ tomado como la finalidad y la prueba clara de la intención de hacer una obra historiográfica en tono moderno por parte del de Óloro, no tiene un sentido que apunte a la veracidad o al apego a la verdad de lo dicho en este caso, ${ }^{1521}$ o a los ipsissima verba ${ }^{1522}$ sino a su exactitud, a la precisión, a la atención al detalle. En sintonía con este concepto ha de entenderse casi de manera

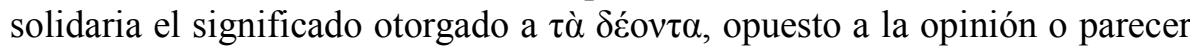

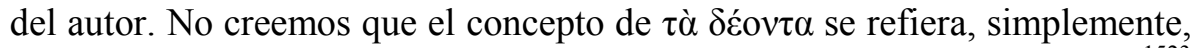
a las opiniones de cada uno de los oradores en la búsqueda de veracidad, ${ }^{1523}$ o que tenga un sentido únicamente retórico, como señalaban Finley y Hornblower con apoyo en Platón, ${ }^{1524}$ sino a esto y a mucho más. En contra de lo habitualmente mantenido, y siguiendo con las conclusiones que nos deparó el análisis formal de los proemios, creemos que poco o nada de retórico en el sentido habitual del término puede encontrarse en Tucídides en

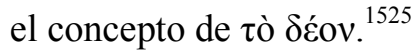

Dado que los discursos son el mejor vehículo de Tucídides para organizar el pensamiento que regula la totalidad de la obra, ${ }^{1526}$ pues son incluso elementos que presagian el futuro, ${ }^{1527}$ el concepto que nos ocupa recoge además referencias a los aspectos necesarios para el desarrollo del

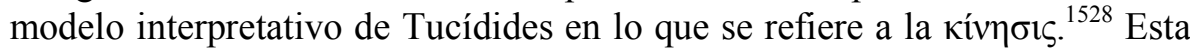

${ }^{1520}$ Cf. Tucídides, I 21, 1. Como bien señala Tsakmakis, 1998, p. 245, es esta la primera aparición del concepto en Tucídides.

${ }^{1521}$ Cf. Grosskinsky, 1936, p. 16: «Wie aber die Redner über die jeweils vorliegenden Dinge bei Zugrundlegung der Gesamttendenz des wirklich Gesprochenen nach seiner Ansicht am ehesten das Erforderliche gesagt haben könnten so ist es formuliert».

${ }^{1522}$ Así, Wilson, 1982, p. 99.

${ }^{1523}$ Cf. recientemente, Porciani, 1999, p. 123.

${ }^{1524}$ Cf. Finley, 1967b, p. 5; Hornblower, 1987, p. 46 y ss. El pasaje platónico en

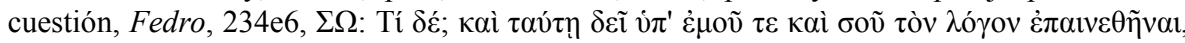

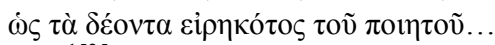

${ }^{1525}$ Cf. Connor, 1985, p. 273.

${ }^{1526}$ Sobre su valor paradigmático de un momento y situación, cf. Nicolai, 2011, p. 169.

1527 Cf. infra.

${ }^{1528}$ En este sentido, la idea de Tsakmakis, 1998, p. 248, acerca del concepto de $\delta$ ćov como no moral, sino eminentemente práctico, es compatible con lo que tratamos de defender. 
idea, en el fondo, no supone una transgresión de la habitual interpretación de $\tau \grave{\alpha} \delta$ śov $\tau \alpha$ como lo que en cada momento era preciso decir, sino que permite incluir la concepción de los discursos dentro del esquema del proemio. Todo ello nos lleva, por una ruta diferente, a la misma conclusión que alcanza Hornblower, que no es otra que la imposibilidad de ajustar a Tucídides dentro de un marco técnico riguroso en este aspecto: ${ }^{.529}$ de ahí los indicios en uno y otro sentido en lo que se refiere a la imposiblidad de enmarcar al autor y a sus discursos en un diseño retórico claro, y menos dentro de una terminología altamente técnica.

Tsakmakis notó ya la tensa dualidad en que se mueve este pasaje, en el que se analiza, por una parte, la necesidad de articular una respuesta coherente a lo que era preciso decir en cada momento y, por otra, la

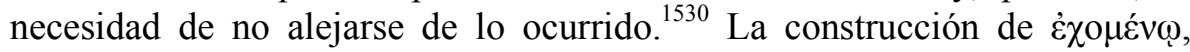
dependiente de $\dot{\varepsilon} \mu$ ó hace que esa necesidad se presente en referencia al concepto de $\xi v ́ \mu \pi \alpha \sigma \alpha \gamma \nu \omega ́ \mu \eta$, que no alude a la exactitud de cada discurso, sino a la realidad general y compleja ${ }^{1531}$ que diseñan todos los discursos, que

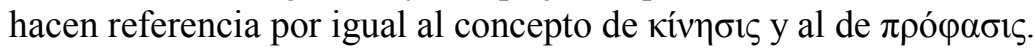

La especial imbricación de $\lambda o ́ \gamma o r$ y ěpya en la obra tucidídea hace que sea de especial interés la estructuración paralela de estos dos elementos que, como decimos, conforman la obra de Tucídides. ${ }^{1532}$ Ya Hunter en un estudio fundamental alertó de esa relación y, esto es lo novedoso, de cómo los discursos predicen muchos de los acontecimientos venideros. ${ }^{1533} \mathrm{La}$ tendencia a convertir «resultados o efectos en intenciones» ${ }^{1534}$ viene además

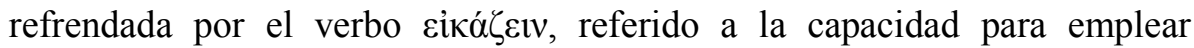
acontecimientos pasados en el futuro. ${ }^{1535} \mathrm{Ya}$ antes Pohlenz llamó la atención sobre este paralelo y sobre la significación de $\chi \alpha \lambda \varepsilon \pi$ óv en la sección referida a los discursos, con la particularidad de que la dificultad planteada en el examen de los mismos se debía fundamentalmente al paralelo existente entre

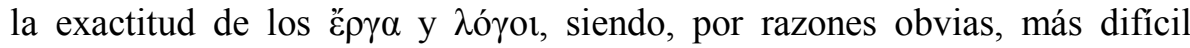

${ }^{1529}$ Cf. Hornblower, 1987, p. 50: «Thucydides in several areas stands at the frontier between the loose and the technical, the amateur and the professional».

${ }^{1530}$ Tsakmakis, 1998, p. 249.

${ }^{1531}$ Cf. Tsakmakis, 1998, p. 250. $\delta \varepsilon \dot{~}$

${ }^{1532}$ Cf. Grosskinsky, 1936, p. 24, quien hace especial hincapié en la correlación $\mu \varepsilon ́ v . .$.

${ }^{1533}$ Cf. Hunter, 1973, p. 13.

${ }^{1534}$ Cf. Hunter, 1973, p. 16.

${ }^{1535}$ Cf. Hunter, 1973, p. 92. 
reflejar la exactitud de los discursos. ${ }^{1536}$ Interesante es también el hecho señalado por Pohlenz ${ }^{1537}$ respecto a la naturaleza polémica del pasaje, acorde con el fuerte tono polémico de los proemios que venimos defendiendo. Los discursos adquieren en Tucídides un rango muy diferente al que tenían en Heródoto, y ello es así por la deriva política del siglo $\mathrm{V}$ a. C. y en especial de Atenas. A pesar de las reticencias de Grosskinsky, ${ }^{1538}$ que seguramente han de ser tenidas muy en cuenta, dado que nos recuerdan que no hemos de limitar nuestra interpretación de Tucídides a una simple oposición con Heródoto, creemos que el salto cualitativo viene determinado por una funcionalidad de los mismos. En definitiva, es esta nueva función la que genera la necesidad del pasaje, lo que no obsta para que deba entenderse en oposición a otros usos de los discursos. ${ }^{1539}$

Esta intepretación da lugar a una intervención directa ${ }^{1540}$ por parte de Tucídides en los discursos, cosa que la crítica difícilmente ha admitido. ${ }^{1541}$ Ello ha originado una fuerte distorsión sintáctica del pasaje, con el paso del participio $\dot{\varepsilon} \chi \mu \mu_{\varepsilon} \vee \omega$ a la frase principal de manera difícilmente justificable. ${ }^{1542}$ Grosskinsky, por su parte, opta por parafrasear el texto de un modo tal que hace que termine por decir algo semejante a la versión sintácticamente

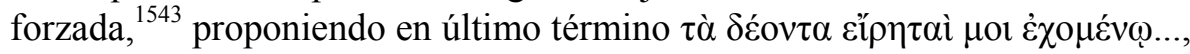
pues Grosskinsky insiste en el «wie» que necesariamente remite a oũ $\tau \omega \varsigma$, adverbio referido, a su vez, de manera clara a $\dot{\omega} \varsigma .{ }^{1544}$

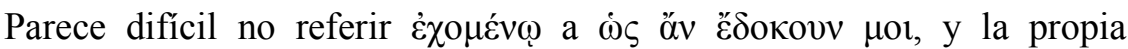

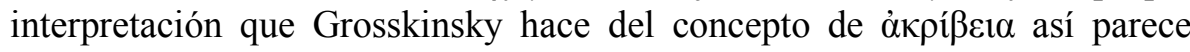

${ }^{1536}$ Cf. Pohlenz, 1965, p. 232: «Die bei den ع̌ $\rho \gamma \alpha$ notwendig zu erstrebende Exaktheit der

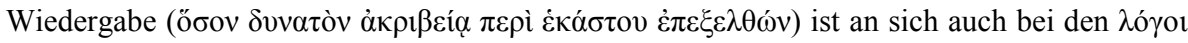

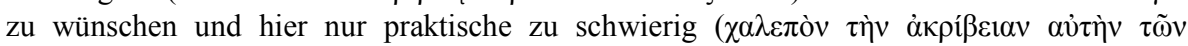

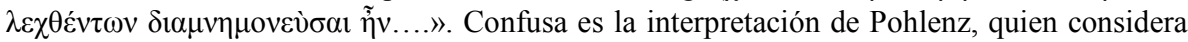

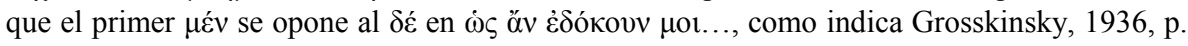
27, si bien esto no afecta a la idea de oposición.

${ }^{1537}$ Cf. Pohlenz, 1965, p. 232.

${ }^{1538}$ Cf. Grosskinsky, 1936, p. 27.

${ }^{1539}$ Así, Grosskinsky, 1936, p. 28.

${ }^{1540}$ Lo que sería una excepción, en cierta medida, a esa posición omnisciente del narrador tucidídeo, cf. Rengakos, 2011, p. 57.

${ }^{1541}$ Cf. e. g. de Romilly, 2005, p. 35 y ss.

${ }^{1542}$ Cf. e. g. el comentario escolar de Marchant, 1905, p. 68 y ss., quien, sin explicación defiende esta idea. Cf. Bicknell, 1990, p. 175.

1543 Cf. Grosskinsky, 1936, p. 31: «[...] wie mir scheint, für die Klarlegung des

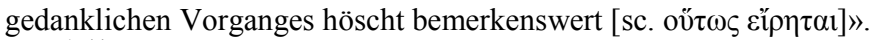

${ }^{1544}$ Ya Wilson, 1982, p. 99. 
indicarlo. Tradicionalmente, se ha entendido este concepto como referido al plano formal de los discursos, sin que para ello medie apoyo interpretativo alguno. La transcripción palabra por palabra de los discursos es algo que, teniendo en cuenta la fuerte tradición oral del momento y el grado de dependencia de la oratoria de este tiempo de modelos tradicionales, no supondría en último término un problema especialmente grave, ${ }^{1545} \mathrm{y}$, a nuestro entender, la pregunta que ha de plantearse es si tendrían sentido en la obra tucidídea unos discursos simplemente transcritos. Sabiendo que los discursos son además un elemento fundamental en la obra de Tucídides en lo que atañe a la configuración del pensamiento, parece tomar fuerza la idea de

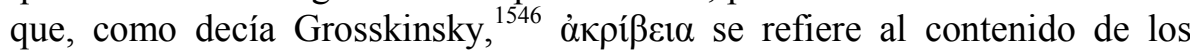
mismos. Grosskinsky creía que, partiendo de un fondo «histórico» de los discursos, Tucídides conducía el pensamiento de estos según su criterio, ${ }^{1547}$ disponiendo así una teoría objetiva de los discursos que se opondría a la de Heródoto. Esta contradicción, que lleva al autor a desdecirse de la condena de los planteamientos de Pohlenz, viene causada por la necesidad de respetar la verdad histórica del padre de la ciencia, ${ }^{1548}$ que se presentaría en una dualidad subjetiva y objetiva, resumida en «Gesamttendenz der jeweiligen Rede historisch, Wortlaut und Gedankenaufbau geistiges Eigentum des Thukydides». ${ }^{1549}$

A nuestro entender, no hay posibilidad de confusión si nos desembarazamos del bagaje positivista, $y$, en este aspecto, uno de los errores

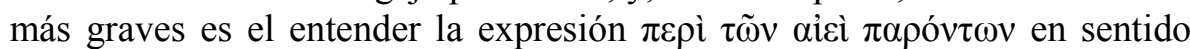
distributivo. ${ }^{1550}$ Con ella Tucídides no puede referirse, y seguimos con el esquema de interrogativos, al wann und wo. ${ }^{1551}$ Porque, además, esta

1545 Opinión contraria, comprensible por la época del trabajo, en Grosskinsky, 1936, p. 38

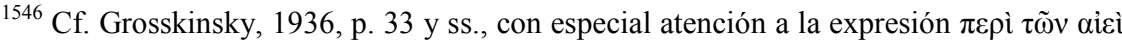
$\pi \alpha \rho o ́ v \tau \omega v$

${ }^{1547}$ Cf. Grosskinsky, 1936, p. 34: «[....] er zunäscht die Gesamttendez der betreffenden wirklich gehaltenen Rede zugrunde legte, dann aber -innerhalb dieses Rahmens- die Gedanken so entwickelte, disponierte und formulierte, wie nach seiner Ansicht eine wirksame Vertretung dieser Tendenz in der betreffenden Situation es erfordete». Nótese como «in der

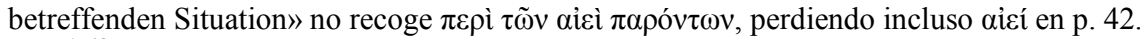

${ }^{1548}$ Cf. Grosskinsky, 1936, p. 35.

${ }^{1549}$ Cf. Grosskinsky, 1936, p. 36.

${ }^{1550}$ Cf. Bicknell, 1990, p. 174, sobre este error.

${ }^{1551}$ Así, e. g. Grosskinsky, 1936, p. 38. 
afirmación llevó a la gran pregunta acerca de la selección realizada por Tucídides entre la lógica multitud de discursos pronunciados. ${ }^{1552}$

Todo ello nos proporciona una imagen realmente poco cohesionada del pasaje, algo impensable en un autor como Tucídides, a tenor de lo visto en el análisis estilístico. Por eso parece interesante una vez más recurrir a la literalidad misma del texto en los puntos fundamentales para la comprensión

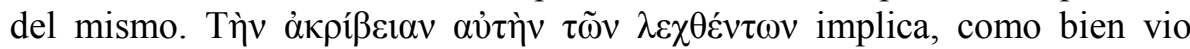
Grosskinsky, una referencia al pensamiento de los discursos, y ello es así por la extraña expresión $\tau \tilde{\omega} v \lambda \varepsilon \varepsilon \chi \theta \varepsilon ́ v \tau \omega v$. Obviamente, lo fácil hubiera sido decir $\tau \tilde{\omega} v \lambda \hat{\gamma} \gamma \omega v$, pero el análisis del léxico del proemio ya dejó claro que este tipo de expresiones conlleva una necesidad de claridad y precisión en la expresión. Por ello, creemos que $\tau \tilde{\omega} v \lambda \varepsilon \chi \theta \varepsilon \dot{\varepsilon} v \tau \omega \nu$ esconde un neutro plural,

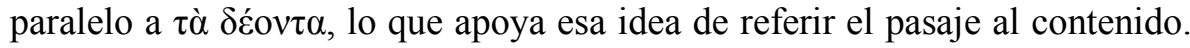

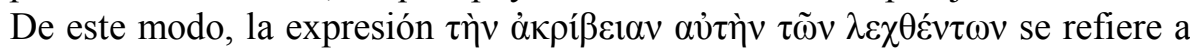
la necesidad de reflejar la exactitud de lo dicho, pero parece difícil considerar que fuese complejo para Tucídides recordar la esencia de lo dicho en los diferentes discursos.

En ayuda viene la segunda parte del pasaje relativo a los discursos, en la que ya hemos insistido sobre la necesidad de hacer depender sintácticamente

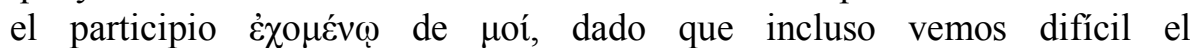

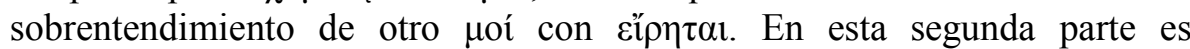
fundamental la comprensión de $\tau \tilde{\omega} v$ aízì $\pi \alpha \rho o ́ v \tau \omega v$, que ha de ser entendido,

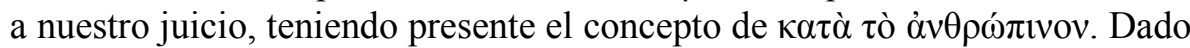
que no estamos ante un distributivo, creemos que la referencia a los aspectos siempre presentes ha de entenderse dentro del universo de constantes producidas por la reiteración de la naturaleza humana, lo que supone que necesariamente $\tau \grave{\alpha} \delta$ śov $\tau \alpha$ implique una referencia clara a la adaptabilidad de lo dicho a los condicionantes de la naturaleza humana, que, como veremos, regulan la totalidad de la realidad.

Teniendo esto presente, el análisis de la expresión $\dot{\eta} \xi v \mu \pi \alpha ́ \sigma \eta \gamma v \omega ́ \mu \eta \tau \tilde{\omega} v$ $\dot{\alpha} \lambda \eta \theta \tilde{\omega} \varsigma \quad \lambda \varepsilon \chi \theta \varepsilon \dot{\varepsilon} v \omega v$ adquiere unas connotaciones diferentes de las habituales. ${ }^{1553}$ El concepto de $\gamma v \omega ́ \mu \eta$ ya nos salió al paso en el estudio de

${ }^{1552}$ Cf. Classen y Steup, 1969, I, p. LIII; Pohlenz, 1965, p. 236, quien habla, siguiendo a Meyer, 1899, p. 385, de la creación de una unidad ideal de pensamiento por medio de la cual se englobaban los diferentes discursos.

${ }^{1553}$ Puede verse un buen resumen de las diferentes interpretaciones, traducciones o paráfrasis en Porciani, 1999, p. 124 y ss., al que remitimos en afán de brevedad. El propio 
Heródoto, y creemos que la semántica del mismo en Tucídides no está demasiado lejos de lo visto en el de Halicarnaso. Гvஸ́ $\mu \eta$ es el fruto de la actividad reflexiva en un primer estadio, y, posteriormente, una opinión o idea y, por extensión, un estado emocional, ${ }^{1554}$ pero ha de tenerse muy presente ese primer estadio, que necesariamente nos pregunta quién es el responsable de esa reflexión: en último término, si la $\gamma v \omega ́ \mu \eta$ es de Tucídides ${ }^{1555}$ o de los diferentes oradores. Si fuera este segundo caso el correcto, la expresión seguramente estaría en plural, $\gamma \nu \tilde{\omega} \mu \alpha$, en referencia al

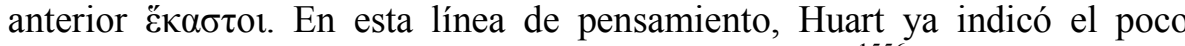
contenido emocional de este concepto en Tucídides, ${ }^{1556}$ lo que hace que primen los valores intelectuales, más propios de Tucídides que de los oradores en acción. A ello ha de unirse el hecho de que el concepto $\alpha \lambda \eta \theta \tilde{\omega} \varsigma$ nos lleva de nuevo a la esencia misma de la interpretación de la realidad por parte de Tucídides. ${ }^{1557}$ Esto hace que la $\gamma v \omega ́ \mu \eta$ haya de ser entendida como propia de Tucídides, y que a lo que se ajuste Tucídides sea al diseño general de los aspectos profundos de lo que realmente se quería decir en los discursos, o sea, a la justificación del desarrollo en los mismos de la teoría que va a guiar la totalidad de la obra. ${ }^{1558}$ El propio Tucídides, en uno de los

Porciani, 1999, p. 134, insiste en que este pasaje hace referencia a un intento de conseguir el mayor grado de fidelidad a la verdad, como defendía, creando casi una communis opinio, Gomme, 1937, p. 160.

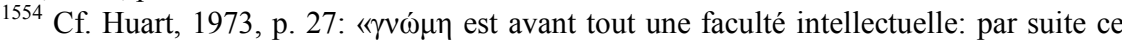
terme, même quand il signifie essentiellement état d'esprit, sentiment, n'abandonne jamais absolument tout rapport avec la notion de pensée [...]» Cf. también la interesante observación del propio Huart en p. 41: «la $\gamma v \omega ́ \mu \eta$ donne à l'homme la possibilité de voir clair, et par suite $[\ldots]$ lui offre le moyen de discerner son devoir [...]» Sin embargo, hemos de señalar que, a nuestro entender, Huart comete un error metodológico al analizar el concepto en virtud de las diferentes traducciones que parecen presentar los textos aducidos, cosa que le lleva a considerar que el concepto de $\gamma v \omega ́ \mu \eta$ en I 22,1 recoge un sentido diferente al que proponemos, cf. Huart, 1973, p. 118.

${ }^{1555}$ Así, Pohlenz, 1965, p. 222 y ss.

${ }^{1556}$ Cf. Huart, 1973, p. 70 y ss.

${ }^{1557}$ Cf. Tucídides, I 20, 3, en referencia a la necesidad de conocer la realidad profunda y

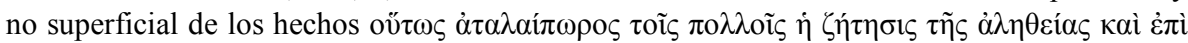

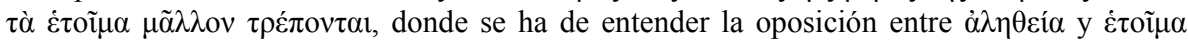
como una oposición entre lo aparentemente real y lo verdaderamente real, probado dentro de una sistematicidad como la que determina quién era el tirano en Atenas, que responde a

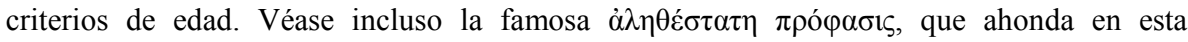
significación.

${ }^{1558}$ En este sentido, es interesante el paralelo que ofrece Eurípides, Ifigenia en Áulide,

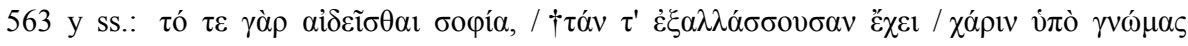


discursos puestos en boca de Pericles, empareja los conceptos al afirmar:

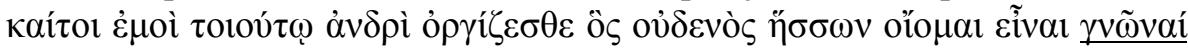

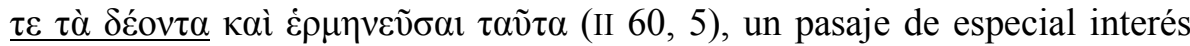
incluso para el examen de las motivaciones políticas de la obra. Tà $\delta \varepsilon ́ o v \tau \alpha$ es considerado como objeto de la acción del verbo asociado al concepto de $\gamma \nu \omega ́ \mu \eta$, de modo que necesariamente se constituye en objeto y resultado de la acción intelectual. ${ }^{1559}$

Además, el segundo proemio viene en nuestra ayuda para confirmar el sentido de $\gamma v \omega ́ \mu \eta$ propuesto, además en conexión con la obtención de la

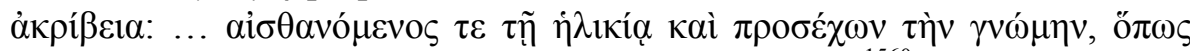

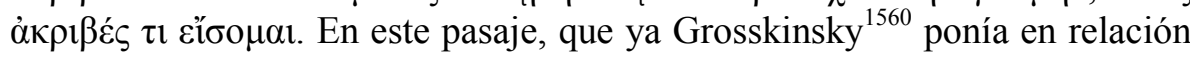
con el primer proemio, podemos observar cómo la percepción de Tucídides se ve limitada por la aplicación de la $\gamma v \omega ́ \mu \eta,{ }^{1561}$ el mecanismo de

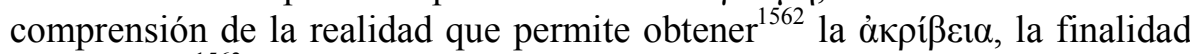
de la obra, ${ }^{1563}$ que una vez más parece ser cualquier cosa menos una contundente imparcialidad. ${ }^{1564}$

De este modo, quedan lejos las discusiones acerca de la literalidad o no de los discursos, así como de la selección o adaptación de los mismos a las circunstancias propias de cada momento. Lo que Tucídides nos dice es que es complejo desarrollar el hilo preciso del pensamiento de los discursos, y que, por ello, decide escribirlos como cree que expresarían los diferentes oradores los aspectos necesarios en lo que se refiere a los condicionantes universales de la realidad, teniendo presente el diseño total de comprensión de la significación profunda de lo dicho.

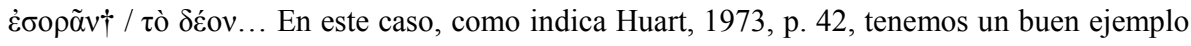
de la deriva moral del concepto, para lo que es importante observar el plural empleado.

${ }^{1559}$ Cf. Huart, 1973, p. 88.

${ }^{1560}$ Cf. Grosskinsky, 1936, p. 52. También Egermann, 1961, p. 447: «Der bereits zitierte

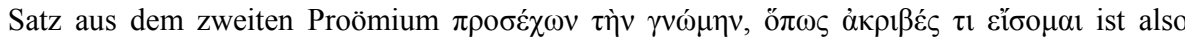
gleichsam eine gedrängte Inhaltsangabe und Rekapitulation dessen, was Thukydides auch im Programmkapitel des ersten Buches als historiographisches Ziel vorschwebt».

${ }^{1561}$ Cf., así, Huart, 1973, p. 71, si bien la traducción ofrecida es poco fiel a la literalidad del texto.

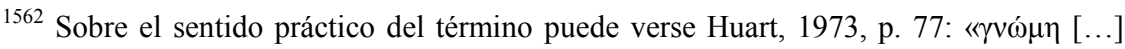
suggère l'activité de l'esprit quand elle s'applique à un état de fait: $\gamma v \omega ́ \mu \eta$ ainsi représente le jugement de l'homme aux prises avec le réel».

${ }^{1563}$ Así se pronunciaba Egermann, 1961, p. 440.

${ }^{1564}$ Ligada, como siempre, al concepto de verdad, cf. e. g. Pouncey, 1980, p. 12. 
De esta manera, sorteamos problemas creados no por el texto, sino por la necesidad de proyectar sobre él ideas ajenas a Tucídides, y adquiere un profundo sentido el capítulo 22, en relación con el desarrollo en los discursos del plan de interpretación de la esencia del imperialismo ateniense, una idea que, en último término, tenían en cierta manera ya en mente Eduard Meyer y Otto Regenbogen. ${ }^{1565}$

En lo que se refiere a los ह̌ $\rho \gamma \alpha$, la interpretación es paralela y diferente.

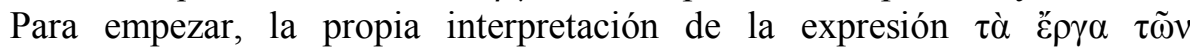
$\pi \rho \alpha \chi \theta \varepsilon ́ v \tau \omega v$ responde una vez más a esos intentos por precisar la semántica que venimos señalando. Tò $\pi \rho \alpha ́ \chi \theta \varepsilon v \tau \tau \alpha$ esconde de nuevo una semántica abstracta que poco tiene que ver con el significado altamente material de हैp $\alpha$. De este modo, la frase recoge de manera prodigiosa la materialidad de las acciones llevadas a cabo y la significación profunda, reflexiva, de ellas. Es precisamente aquí donde se puede ver el rigor tucidídeo, dado que las acciones en toda su significación no son reflejadas simplemente $\dot{\varepsilon} \kappa$

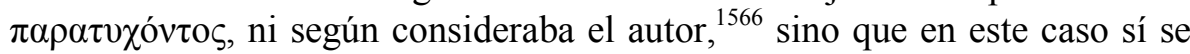

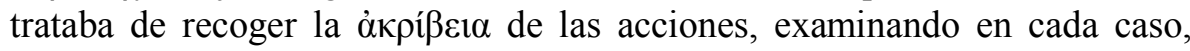

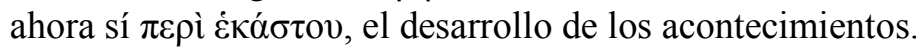

La idea de Pohlenz de que esta era una forma de desmarcarse por parte de Tucídides de la habitual subjetividad de los proemios en prosa ${ }^{1567}$ nos permite además poner, como también hace Grosskinsky, ${ }^{1568}$ este pasaje en relación con los proemios de Heródoto y Hecateo. La oposición que

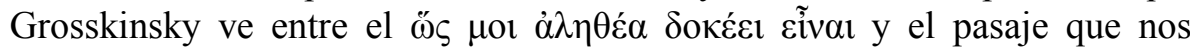
ocupa es ingeniosa, pero, a nuestro entender, no se corresponde con la realidad. ${ }^{1569}$ Si realmente existe una oposición es con la sección relativa a los

${ }^{1565}$ Cf. Meyer, 1899, p. 385: «Es ist zweifellos: keine Rede bei Thukydides entspricht der ephemeren, sondern nur der idealen Wirklichkeit, sie alle sind nicht Reden, wie sie gehalten sind, sondern, wie sie der jedesmaligen Situation entsprechend hätten gehalten werden können». Cf. Regenbogen, 1968, p. 25: «Für uns und unsere Betrachtung wird sich zeien, dass aus ihnen mit deutlicher Stimme Thukydides vornehmlich als der grosse politische Denker zu uns redet». Y p. 26: «Sie sind nicht etwa autentische Dokumente historischer Wirklichkeit und haben das zu keiner Zeit der für uns erfassbaren Entwicklung des Thukydides sein sollen».

${ }^{1566}$ En oposición a lo que ocurría con los discursos, cf. Bicknell, 1990, p. 174.

${ }^{1567}$ Cf. Pohlenz, 1965, p. 272.

${ }^{1568}$ Cf. Grosskinsky, 1936, p. 49 y ss.

${ }^{1569}$ Cf. Grosskinsky, 1936, p. 50. El propio autor dice: «Direkte Polemik mag also sehr wohl vorliegen, ob aber gegen Hekataios, ist zum mindesten fraglich». La consideración de

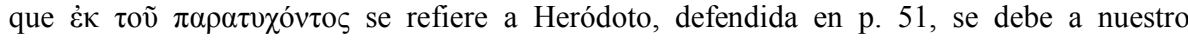


discursos del propio Tucídides, y lo que delata la comparación con los otros dos autores es, simplemente, el muy diferente modelo empleado a la hora de comprender la realidad narrada.

Pero esta idea de objetividad en lo que se refiere a los हैpya, defendida por Grosskinsky como una de sus conclusiones, ${ }^{1570}$ viene en parte desmentida por el paralelismo señalado por Pohlenz al que ya hemos hecho referencia y que el propio Grosskinsky amplía. ${ }^{1571}$ La unión solidaria de hechos y discursos hace que mucho de lo aplicado a los discursos transcienda a estos y afecte a los hechos. Si bien es innegable la narración aséptica de los hechos, ${ }^{1572}$ la organización de la tramoya intelectual en los discursos atraviesa necesariamente la organización y, sobre todo, la elección

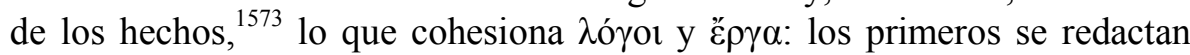
potenciando su función de reflejar las ideas rectoras de la obra, y los segundos son seleccionados con ese mismo fin.

En resumen, el denominado método lo es tal si entendemos por método la exposición de las directrices en virtud de las cuales Tucídides va a desarrollar su obra, y no un embrión del futuro modelo de estudio histórico. ${ }^{1574}$

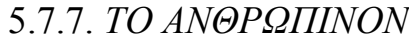

Obviamente, el denominado capítulo del método es la simple determinación de la forma de canalizar el pensamiento que recorre la obra, y para la comprensión de esas ideas hemos de volver una vez más al desarrollo del proemio y a la evolución del pensamiento del mismo, que

entender, a un exceso de rigor positivista y a la aplicación rígida del modelo de evolución del género propuesto por Jacoby.

${ }^{1570}$ Cf. Grosskinsky, 1936, p. 52.

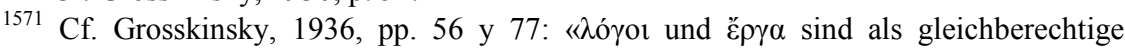
Glieder eines organischen Ganzen nebeneinander».

${ }^{1572}$ La idea de Janssens, 1999, p. 19, de que la intención de Tucídides es desmitificar la guerra tiene poco que ver con la creación de un modelo de interpretación de la realidad.

${ }^{1573}$ Cf. Loraux, 1980, p. 68

${ }^{1574}$ Para esta idea de método cf. recientemente Saïd, 2011, p. 62. 
inmediatamente nos conduce a la crítica del concepto de $\mu v \theta \tilde{\omega} \delta \varepsilon \varsigma$ y al

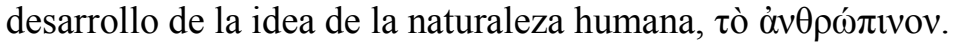

La definición correcta de este concepto es uno de los puntos fundamentales de la comprensión del proemio y de todo el complejo pensamiento historiográfico del siglo $\mathrm{V}$ a. C. ${ }^{1575}$

Como veremos, uno de los aspectos fundamentales del estudio de la realidad por parte de Tucídides se sustenta en la comprensión de la naturaleza del ser humano como ser constituyente de la sociedad. En este

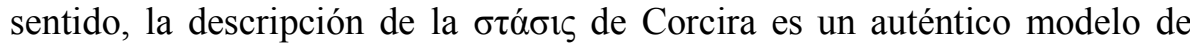
degeneración humana en lo que a la sociedad se refiere, y es precisamente en ella donde encontramos el concepto de $\varphi v ́ \sigma 1 \varsigma ~ \alpha \dot{v} \theta \rho \omega ́ \pi \omega v .{ }^{1576}$ El concepto, cuya cercanía con la medicina quizá ha sido excesivamente valorada, ${ }^{1577}$ presenta como primer problema su relación con el concepto de tò àv$\theta \rho \omega ́ \pi ı v o v$. La interpretación de $\varphi v ́ \sigma ı \varsigma ~ \alpha v \theta \rho \omega ́ \pi \omega v$ como «die notwendige Grund ${ }^{1578}$ nos parece acertada, pero creemos que la idea de relacionar en calidad de sinónimos ambos conceptos ${ }^{1579}$ ha de ser rechazada en favor de la interpretación de Stahl. ${ }^{1580}$ La propia interpretación de los términos neutros en Tucídides, así como el contexto general del proemio, apunta a un significado mucho más amplio de $\tau$ ò $\alpha \dot{v} \theta \rho \omega ́ \pi ı v o v$. A nuestro entender, el concepto contenido en la $\sigma \tau \alpha \dot{\sigma} \sigma \varsigma$ corciriana hace referencia, precisamente, a la descripción del factor humano como condicionante del progreso de los acontecimientos: el desmoronamiento de las virtudes individuales narrado desde III 82, 4 es un ejemplo de la degeneración de esos valores, entendidos estos dentro de un modelo constante, ${ }^{1581}$ pero que afecta únicamente al individuo. En este mismo sentido se ha de entender el famoso excurso sobre los tiranicidas. ${ }^{1582}$ La versión propuesta por Tucídides de los acontecimientos

1575 Finley, 1967b, p. 67, afirmaba «Thucydides himself expressly valued his work not for his accuracy (important as he thought accuracy to be) but for its exposition of recurrent social forces, and his judgment sets the order in which we too should appraise it».

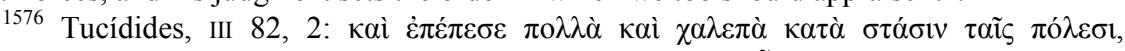

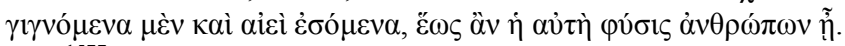

1577 El propio Rechenauer, 1991, p. 125, hace un limitado recorrido por la literatura

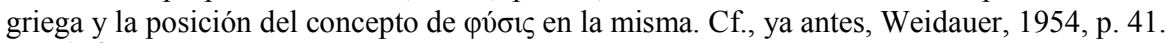

${ }^{1578}$ Cf. Rechenauer, 1991, p. 145.

${ }^{1579}$ Cf. Rechenauer, 1991, p. 158 y ss.

${ }^{1580}$ Cf. Stahl, 2003, p. 30, quien traduce «that which pertains to man», y que diferencia

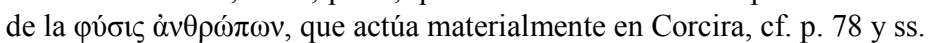

${ }^{1581}$ Así, Rechenauer, 1991, p. 151 y ss.

${ }^{1582}$ En este sentido, cf. Gomme, 1968, p. 374 y ss., quien indica los paralelos existentes. 


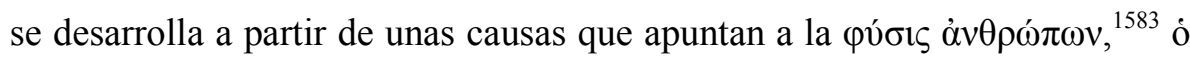

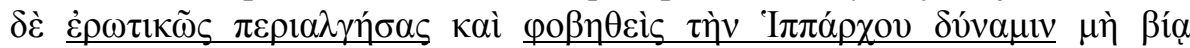

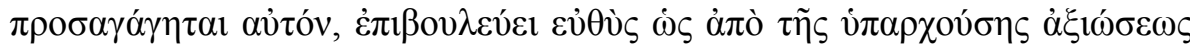

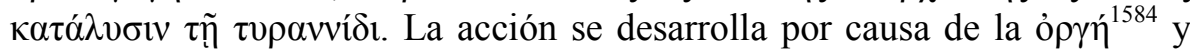
del $\varphi$ óßos, que tanta importancia tendrán en la obra como condicionantes a tener en cuenta.

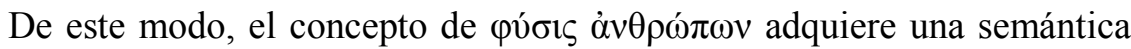
limitada a las pulsiones humanas, es decir, a la aplicación concreta de estos aspectos, en tanto que tò $\alpha \dot{v} \theta \rho \omega ́ \pi ı v o v$, con su valor de neutro abstracto, afecta a la totalidad de condicionantes a tener en cuenta por el estadista, como un concepto de carácter universal, ${ }^{1585}$ que va de lo general de los aspectos reflexivos a la exposición de lo particular en la narración. ${ }^{1586}$

\subsubsection{EL CONCEPTO DE TIEMPO}

Es esta misma concepción universal la que hace que en $\tau$ ò $\alpha \dot{v} \theta \rho \omega ́ \pi$ ivov resida además la concepción temporal de Tucídides, que ha dado origen a no poca polémica. Hunter ha sido la principal defensora de la idea de un Tucídides progresista en la concepción temporal, ${ }^{1587}$ y de que esta idea encontraba su mejor exposición precisamente en la Arqueología. ${ }^{1588}$ Para Hunter, frente a Heródoto, que tenía preocupación por el «tiempo de los dioses» y por «el tiempo de los hombres» por igual, Tucídides prestaba atención únicamente al tiempo humano, ${ }^{1589}$ en aparente línea con lo

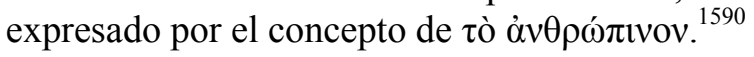

${ }^{1583}$ Cf. Tucídides, vi 54, 2 y ss.

${ }^{1584}$ Sobre este concepto en la $\sigma \tau \alpha \dot{\sigma} \sigma \varsigma \varsigma$ corciriana, cf. Rechenauer, 1991, p. 146 y ss.

${ }^{1585}$ En el que la experiencia, como había primado en la ciencia griega, desempeña un papel fundamental, cf. Hunter, 1973, pp. 141 y 182.

${ }^{1586}$ Cf. para este aspecto de Romilly, 1990, p. 65.

${ }^{1587}$ Cf. Hunter, 1982, p. 102.

${ }^{1588}$ Cf. Hunter, 1982, p. 42 y ss. También Crane, 1998, p. 128.

${ }^{1589}$ Cf. Hunter, 1982, p. 96 y ss.

${ }^{1590}$ Cf. Crane, 1998, p. 296. Por medio de este concepto, indica Crane, Tucídides trata de limitar el cambio. 
Este debate, del que Hunter es probablemente de los últimos capítulos a destacar, arranca en tiempos recientes con la opinión de Eldestein, quien defendía que la evolución de la idea de progreso registrada desde Jenófanes alcanzaba su perfección, precisamente, en la historiografía de finales del siglo V a. C., o lo que es lo mismo, con Tucídides. ${ }^{1591}$ Dodds defendía lo contrario, ${ }^{1592}$ es decir, que estamos ante la aplicación decididamente peligrosa de una idea moderna a un autor antiguo, como también denunció den Boer ${ }^{1593}$ en un trabajo que concluía con la negación de atisbo alguno de la idea moderna de progreso en la obra tucidídea ${ }^{1594}$ y la fundamentación, precisamente, de una concepción opuesta del tiempo histórico en el concepto

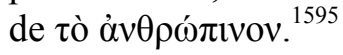

Lloyd-Jones nos alertó de la importancia de no empecinarnos con el concepto de progreso, y, evitar enmascarar lo permanente, concepto fundamental en la comprensión de la concepción religiosa y cultural de la etapa de la Antigüedad que nos ocupa. ${ }^{1596}$ Estas palabras demuestran que detrás de este debate se encuentra un prejuicio relativo a la configuración de la moderna historiografía que ya denunció Jaeger, y que exigía al padre de la historiografía moderna una concepción temporal acorde. ${ }^{1597}$

En último término, hay en la obra de Tucídides dos realidades de complejo ajuste, en cierta manera semejantes a las que indicó Crane, ${ }^{1598}$ si bien el autor perseguía más tratar de dar explicación a su defensa de la idea

${ }^{1591}$ Cf. Eldestein, 1967, p. 31: «It should now be clear that in the second half of the fifth century the bold thesis of Xenophanes had been considerably elaborated in political theory and in historiography even in regard to that aspect which is most essential for the concept of progress, its nearing on the future». Cf. también de Romilly, 2005, p. 42.

1592 Cf. Dodds, 1985, p. 11, sustentando su afirmación en el concepto de $\tau \varepsilon ́ \chi v \eta$ en Tucídides

1593 Cf. den Boer, 1977, p. 35 y ss.

${ }^{1594}$ Cf. den Boer, 1977, p. 38, con la conclusión de que lo que habitualmente se concibe como progreso no es tal. Un buen ejemplo de este tipo de interpretaciones erradas se puede ver en Crane, 1998, p. 135, quien interpreta la referencia al cultivo de la tierra de i 2, 2 como un ejemplo de evolución histórica y no un condicionante de la $\pi \alpha \rho \alpha \sigma \kappa \varepsilon v \eta ́$, seguramente pensando en periodos históricos de diseño moderno.

1595 Cf. den Boer, 1977, p. 53.

${ }^{1596}$ Cf. Lloyd-Jones, 1971, p. 159. Cf. también den Boer, 1977, p. 9.

${ }^{1597}$ Cf. Jaeger, 2000, p. 350: «Tucídides expresa repetidamente la idea de que el destino de los hombres y de los pueblos se repite porque la naturaleza del hombre es siempre la misma. Es exactamente lo contrario de lo que hoy denominamos, ordinariamente, conciencia histórica».

${ }^{1598}$ Cf. Crane, 1998, p. 303. 
de progreso en Tucídides. La literalidad del pasaje que nos ocupa es contundente:

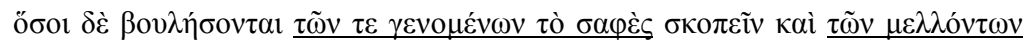

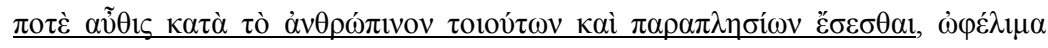

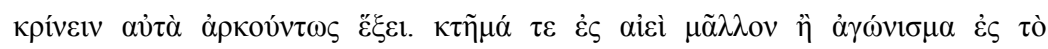

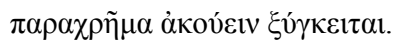

Tucídides está definiendo un patrón de repetición estático, al tiempo que la sucesión de ese patrón de funcionamiento de la realidad parece implicar un concepto de vaivén al modo herodoteo. En este sentido, la idea de de Romilly ${ }^{1599}$ de considerar que el concepto de $\chi \rho \varepsilon i ́ \alpha$ está detrás de la evolución del individuo en la Arqueología, como ocurría en el mito del Protágoras platónico, cae en el error de no tener presente la finalidad de estas narraciones. Ello es así porque la narración de la Arqueología no persigue superar esa $\chi \rho \varepsilon i ́ \alpha$, sino valorar la concentración de poder, ${ }^{1600}$ dejando en un plano meramente instrumental lo que en el mito de Prometeo es una finalidad. Sea como fuere, la idea defendida en Tucídides, más cercana a la

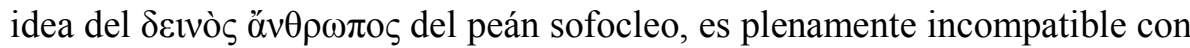
lo que de Romilly propone, que no se corresponde con la rígida estabilidad que nos señala el pasaje.

El doble movimiento hace que estemos casi ante lo que se conoce como tiempo agrario o circular, la continua repetición de una serie de patrones de manera sucesiva. Esta idea se encuentra en perfecto acuerdo, más bien, con una concepción temporal plenamente arcaica. A nuestro entender, el denominado progreso visto por algunos en la Arqueología ${ }^{1601}$ no es otra cosa que la progresión propia del tiempo histórico arcaico que podemos observar en los procesos de ü $\beta p ı \varsigma$ herodoteos, o en el primer estadio temporal que los antropólogos reconstruyen para las sociedades tradicionales, el que define los procesos que justifican el estado presente de cosas, ${ }^{1602}$ que no es sino la

${ }^{1599}$ Cf. de Romilly, 2005, p. 58 y ss.

${ }^{1600}$ De Romilly, 1956, p. 366 y ss.

${ }^{1601}$ Así, de Romilly, 2005, p. 56.

${ }^{1602}$ Esta idea no es incompatible con el pensamiento de Finley, 1967b, p. 89, de que el poder en la Arqueología no se presenta como un simple concepto maquiavélico, sino en su significación en la civilización. El poder es entendido por Tucídides como un elemento clave en esa progresión hacia el estado ideal de cosas presente. 
idealidad de la etapa central asimilada al presente o a un pasado cercano. Esa progresión y el estado ideal de cosas ${ }^{1603}$ se ven sucedidos por la convulsión que pone en peligro ese estado ideal, en un modelo de más fácil observación en el ámbito latino. Con esto no queremos decir que Tucídides sea un buen ejemplo de un modo de entender el tiempo de cuño plenamente tradicional, sino que más bien estamos ante una reforma de carácter fuertemente personal de esos esquemas, dado que, como veremos, uno de los signos de cambio respecto a los modelos tradicionales será la apuesta de Tucídides por la posibilidad de interrumpir la decadencia del modelo ideal, algo impensable en el mundo arcaico.

De este modo, el concepto de $\tau$ ò $\alpha \dot{\alpha} \theta \rho \omega ́ \pi ı v o v$ asume por una parte una semántica referida al tiempo de carácter regulador y estático, lo que nos permitirá abordar su exacta definición de manera más comoda. El concepto está, como indicó Finley ${ }^{1604}$ y ya vimos, en plena relación con la idea de $\tau \grave{\alpha}$ $\delta \varepsilon ́ o v \tau \alpha$ referida a los discursos, en un modo tal que es un elemento subordinado al concepto de $\tau$ ò $\alpha \dot{v} \theta \rho \omega ́ \pi ı v o v .{ }^{1605}$ No podemos pretender que Tucídides nos proporcione una definición clara del concepto, que, como buen abstracto, se verifica más en la exposición por medio de ejemplos que en una definición sistemática. Ello es así porque hemos llegado al nivel máximo del diseño de comprensión de la realidad de Tucídides, a un nivel

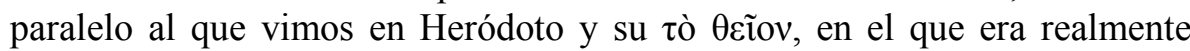
difícil definir los fundamentos que regían el orden de cosas. Es solo la $\dot{\varepsilon} \mu \pi \varepsilon 1 \rho i ́ \alpha$ la que determina el sucederse de los acontecimientos, que, al igual que ocurría en Heródoto, son los únicos medios para verificar la regularidad y, en el caso de Tucídides, el sucederse de los acontecimientos, de la relación solidaria entre acontecimientos y discursos. ${ }^{1606}$ Esta idea, como indica Finley, tenía consecuencias no solo para la definición del acontecer humano, sino también para la configuración del pensamiento antropológico del siglo $\mathrm{V}$ a. C., dado que el concepto de $\tau$ ò $\alpha$ v $\theta \rho \omega ́ \pi t v o v$ requiere necesariamente de una idea de la naturaleza humana estable e inmutable. Más allá del interminable número de consecuencias que este hecho depara

${ }^{1603}$ La idealidad de este estadio ha de entenderse en un sentido restringido, dado que, en nuestra opinión, los grandes discursos de la asamblea en Esparta han de ser entendidos como un repaso a esa idealidad, o momento culmen del proceso, cf. así Finley, 1967b, p. 121.

${ }^{1604}$ Cf. Finley, 1967b, p. 98.

1605 Finley, 1967b, p. 291, alertaba ya de que, se pensase lo que se pensase sobre la cuestión compositiva de la obra, era innegable que el concepto de $\tau$ ò òv $\theta \rho \omega ́ \pi ı v o v$ residía en el corazón mismo de la obra.

${ }^{1606}$ Cf. Finley, 1967b, p. 290 y ss. 
para la configuración de la futura revolución socrática, las consecuencias a nivel político y social son de primer orden. Si la naturaleza humana está predispuesta a la repetición inevitable de determinadas actuaciones, cabe preguntarse no solo por las consecuencias para el ordenamiento político que ello puede tener, sino también por la propia finalidad de la obra.

\subsubsection{TUCÍDIDES Y LA DIMENSIÓN POLÍTICA DE LA HISTORIOGRAFÍA}

La profunda dimensión política de la obra es una realidad innegable pero que conviene matizar. El desarrollo del análisis del proemio herodoteo nos ha de obligar, como ya indicamos, a replantearnos la primacía del análisis político-histórico habitualmente atribuida a Tucídides. ${ }^{1607} \mathrm{La}$ propia definición de la finalidad de la obra, aspecto sobre cuya importancia en la historiografía hemos insistido, es el punto de partida para el estudio de las implicaciones de la dimensión política en el proemio.

Todo el proemio nos ha venido perfilando las líneas maestras en las que se encuadra la naturaleza política de la finalidad de la obra tucidídea. Tanto

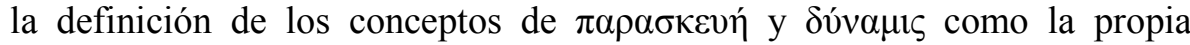
conformación de los discursos son fundamentales para la delimitación precisa de la naturaleza política de la obra del de Óloro.

El concepto de $\pi \alpha \rho \alpha \sigma \kappa \varepsilon v \eta ́$ nos lleva necesariamente al Imperio ateniense, y este a los discursos. Es sabido que Tucídides desarrolla una auténtica teoría del ejercicio del imperialismo por medio de sus discursos, con auténticos miliarios en el ciclo de discursos pericleos, en los discursos de Cleón y Diodoto, y en el diálogo de los melios. Poco más se puede añadir al magistral estudio de Jacqueline de Romilly, cuyas líneas maestras ya exploramos. Solo queda insisitir en la asunción del imperialismo como una realidad de la que Atenas no puede librarse sin más. Y esto es importante para adoptar un punto de partida necesario en la configuración del ideario

${ }^{1607}$ Así, cf. Strasburger, 1968a, p. 413: «[...] hätte er das Vertändnis für die politische Geschichte nicht erschlossen, dann bald ein anderer». En ultimo término, Strasburger parte de una idea de historiografía política y de un concepto de lo político sumamente limitado y de carácter extremadamente realista, muy diferente a nuestra interpretación. 
político de Tucídides. El primer gran fresco que constituyen los discursos pronunciados en Esparta es, a nuestro entender, una imagen estática ${ }^{1608}$ de los parámetros políticos que definen a los contendientes en materia de actuación política. Sin embargo, no hemos de buscar allí la definición política de Atenas a ojos de Tucídides, sino que hemos de recurrir a la oración fúnebre para obtener la imagen ideal ${ }^{1609}$ de lo que supone Atenas políticamente, entendido este término en un sentido etimológico.

Pero, antes de abordar el análisis de la imagen que tiene Tucídides de Atenas, hemos de señalar que la idea de que la guerra es inevitable es una

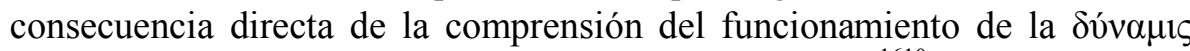
expuesto en la Arqueología, que se aleja de lo habitual ${ }^{1610}$ y que otorga un

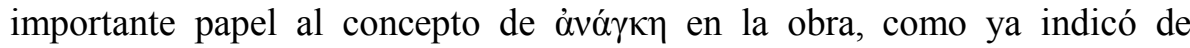
Romilly. Sin embargo lo realmente interesante no es la presencia en la obra de Tucídides de un concepto fundamental en el imaginario griego, sino la reacción ante el mismo en términos políticos, reacción que tiene especial vinculación con el diseño del tiempo histórico en la obra de Tucídides.

A nuestro entender, el plan propuesto por Pericles para ganar la guerra, sea una realidad histórica atribuible al estadista o una creación reflexiva del propio Tucídides, es un excelente ejemplo de una dinámica de tensiones que ya hemos tenido oportunidad de ver en Heródoto, y que, en último término, enmascara los entresijos del funcionamiento de la democracia ateniense a lo largo de las últimas cuatro décadas del siglo $\mathrm{V}$ a. C. La propia figura de Pericles es un ejemplo paradigmático de estadista, al tiempo que de un modelo de Estado diseñado para nosotros por Tucídides a través de los propios discursos puestos en boca de Pericles a lo largo de los libros I y II, fundamentales para la comprensión de toda la obra. ${ }^{1611}$

\footnotetext{
${ }^{1608}$ Sobre la progresión de esa imagen, especialmente en lo que se refiere a Esparta, cf. Debnar, 2001, p. 156.

${ }^{1609}$ Así, Bayer, 1968, p. 199. Para lo poco convencional de esta oración fúnebre cf. Ziolkowski, 1981, p. 9 y ss.

1610 Concepto que determina la perspectiva del pasado colonial y de las tradicionales

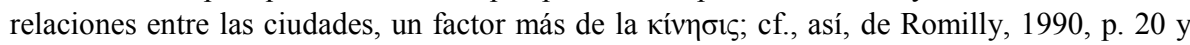
ss.

${ }^{1611}$ No es casual que se concentren en estos dos libros, como indicó Hornblower, 1987, p. 100 y ss., la mayoría de los términos técnicos que afectan a la comprensión de la obra, dado que es precisamente en ellos donde se configura, por medio de los discursos, el pensamiento que la recorre.
} 
El primer discurso pronunciado por Pericles a las puertas mismas de la guerra es el mejor ejemplo del desarrollo del pensamiento expuesto por Tucídides en la Arqueología y el proemio en general. En el comienzo mismo del discurso, Tucídides desarrolla un pensamiento en boca de Pericles que

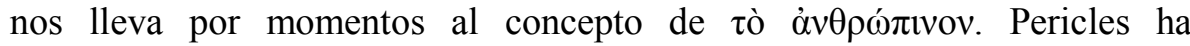
concebido un plan uniforme e inamovible para afrontar la futura guerra: $\tau \tilde{\eta} \varsigma$

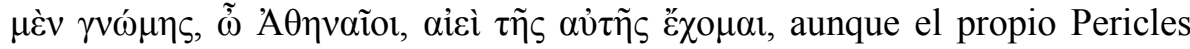

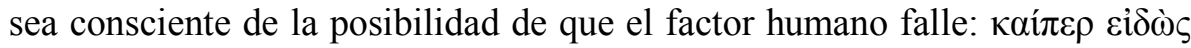

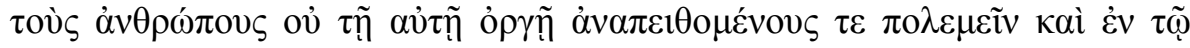

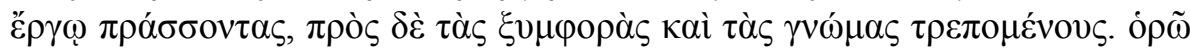

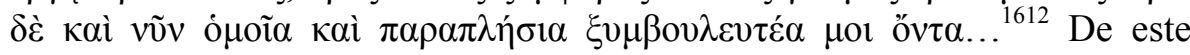
modo, Pericles está ejerciendo la máxima capacidad propia de los estadistas,

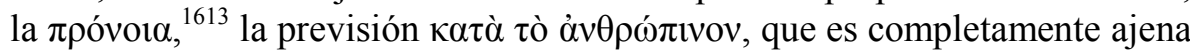

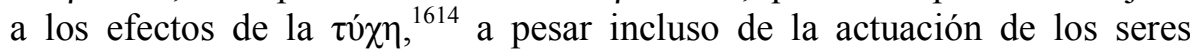

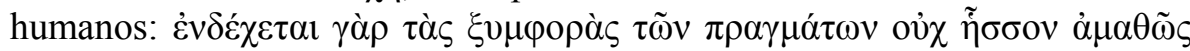

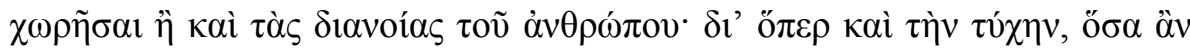

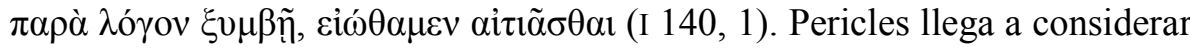
que es fundamental no correr riesgos de manera voluntaria, lo que incide en la idea de limitar el factor de riesgo humano en el devenir de la guerra:

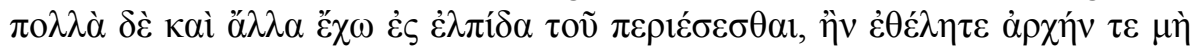

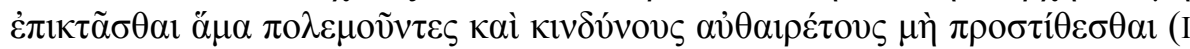

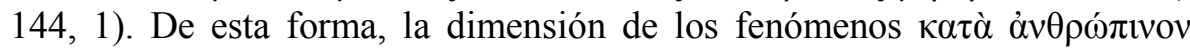
queda regulada de manera clara por Pericles, limitando una manera de

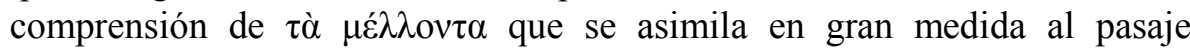
proemial I 22, 4.

Además, este aspecto fundamental de análisis del conflicto se ve apoyado por el desarrollo de un análisis de las $\pi \alpha \rho \alpha \sigma \kappa \varepsilon v \alpha i ́$ de ambos bandos en este primer discurso que recoge aspectos considerados en la Arqueología

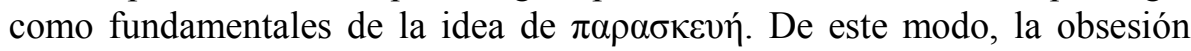
inicial de Pericles acerca de la escasez de recursos de los espartanos, todavía apegados al cultivo de la tierra -lo que ha de ser entendido como un impedimento a la hora de emprender acciones que requieran desatender los campos-, así como la necesidad de que una sociedad así organizada solo

${ }^{1612}$ Cf. Tucídides, I 140, 1, 1 y ss.

${ }^{1613}$ Sobre este concepto, cf. recientemente Greenwood, 2006, p. 33.

1614 Sobre esta caracterización de la $\tau u ́ \chi \eta$, cf. Herter, 1968, p. 262 y ss. Sobre la

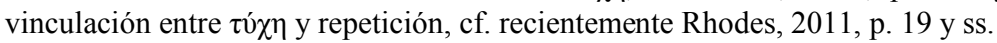


pueda embarcarse en guerras breves, ${ }^{1615}$ es un reflejo tanto de la importancia del cultivo de la tierra a pequeña escala en comparación con formas más desarrolladas de agricultura, que llevan aparejadas el comercio para los

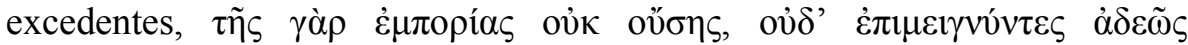

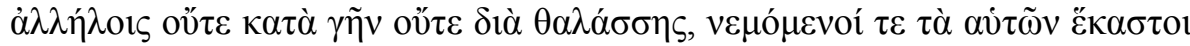

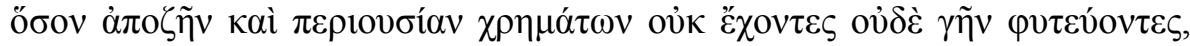
como del análisis global de las guerras anteriores: $\tau \tilde{\omega} v \delta \dot{\varepsilon} \pi \rho o ́ \tau \varepsilon \rho o v ~ \varepsilon ̌ p \gamma \omega v$

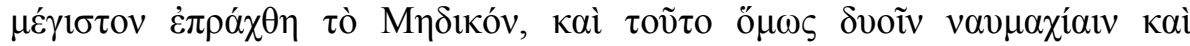

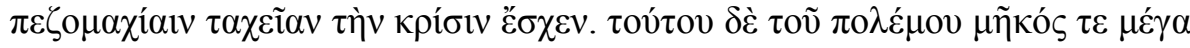
$\pi \rho 0 u ́ \beta \eta \ldots$

Como ya hemos señalado, una de las obsesiones de Tucídides es la concentración y los movimientos de población que derivan en el primer aspecto -entendidos estos como el medio más adecuado para la concentración de recursos-, y esta misma idea reaparece en referencia a los espartanos, con claras alusiones a los problemas que plantea la dispersión del

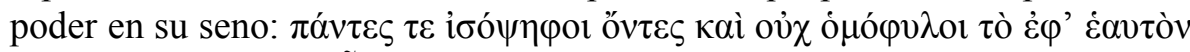

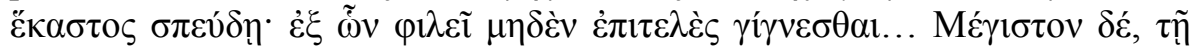

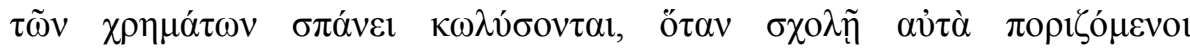

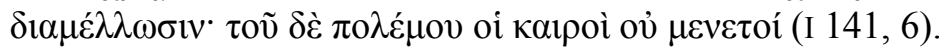

Sin embargo, lo más interesante es la amplia referencia a la fuerza naval como principio rector del desarrollo de la guerra (I 142, 4 y ss.). En el análisis estructural del proemio delimitamos una amplísima sección que determinaba la importancia que tenía el mar en el conflicto bélico (I 3, 4-12, 4). Al añadirse este último aspecto, la totalidad del análisis del concepto de $\pi \alpha \rho \alpha \sigma \kappa \varepsilon v \eta ́$ por parte de Pericles se convierte en un fiel reflejo de las ideas sobre las que el propio Tucídides ha diseñado su obra.

Este mismo discurso lleva, de una manera poco artística, el aviso de que hemos de completar la información que nos transmite con otro discurso:

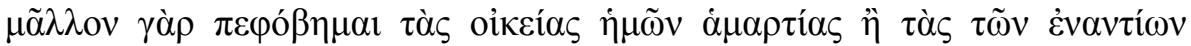

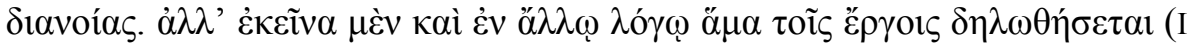
144, 2). Como el propio Tucídides indica, la segunda sección de esta explicación detenida de los aspectos desarrollados en el proemio ha de

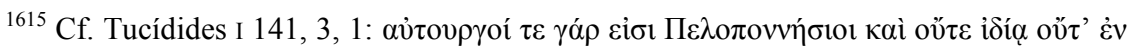

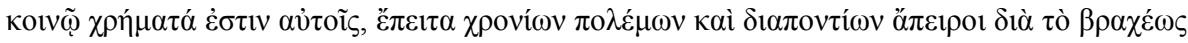

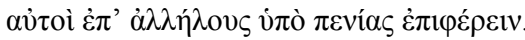


buscarse en el último de los discursos de Pericles, ya en el libro II, lo que

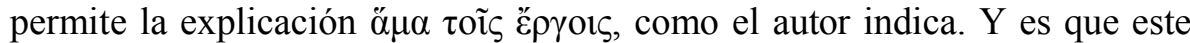
último discurso se produce, precisamente, en el momento en que cunde el desánimo entre la población ateniense, y Pericles aprovecha para exponer la

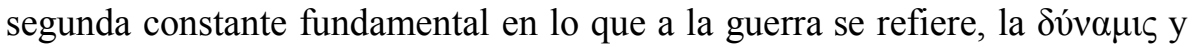
sus consecuencias.

El discurso se abre con una referencia a la primacía de lo colectivo frente a lo individual, aspecto que más tarde examinaremos, para pasar a valorar las consecuencias del ejercicio de la $\delta v ́ v \alpha \mu \iota$, esto es, el imperio. La fuerza es un instrumento que, como indicó Tucídides en la Arqueología, se ejerce por

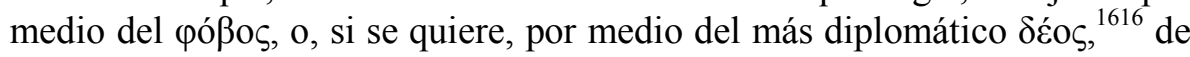
modo que los atenienses han de hacerse responsables del ejercicio de la

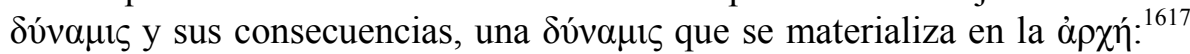

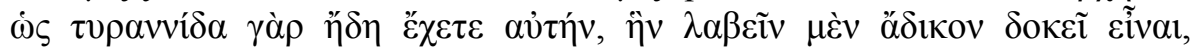

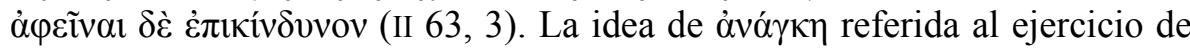
la $\delta$ v́vaı convertida en imperio es la explicación de la inevitabilidad de la guerra $\mathrm{y}$, en último término, de su grandeza, idea con la que Tucídides iniciaba el proemio.

Este planteamiento teórico del ejercicio del poder por parte de Atenas se enfrenta a un elemento convulsionante de índole plenamente humana, dado que la definición de la polis ateniense que tienen en mente Tucídides y Pericles nos lleva a uno de los conflictos que venían asolando Atenas desde el comienzo de la segunda mitad del siglo $\mathrm{V}$ a. C. y que hace que el proemio tucidídeo sea la otra cara de la imagen que mostraba el proemio a la obra de Heródoto.

En contra de lo que pudiera parecer, el discurso fúnebre es de poca ayuda de por sí para la definición de las tensiones existentes en el diseño de la oposición creada entre la necesidad de una sociedad cohesionada y presentada como un todo y las necesidades individuales. La famosa observación relativa a la igualdad de los ciudadanos a la hora de tomar parte

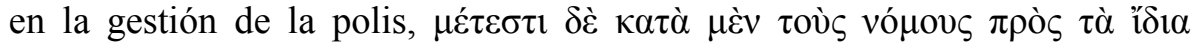

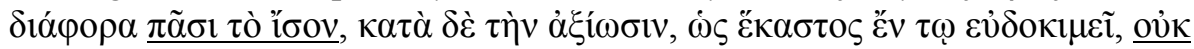

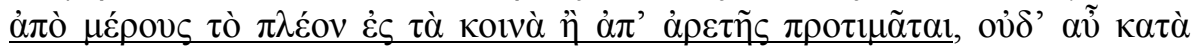

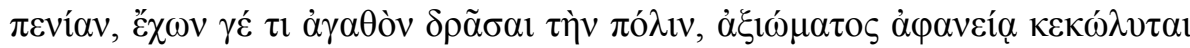
(II 37, 1), implica necesariamente la igualación no solo de los antepasados,

${ }^{1616}$ Cf. Tucídides, I 9, 3.

${ }^{1617}$ Cf. Woodhead, 1970, p. 39. 
sino la de los propios méritos. Tucídides y Pericles hacen repetidas referencias a la polis como una entidad a la que ha de subordinarse el

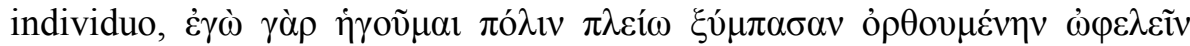

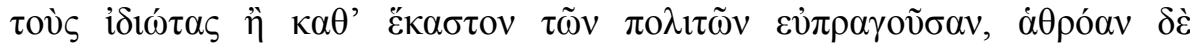
$\sigma \varphi \alpha \lambda \lambda \circ \mu \varepsilon \dot{\varepsilon} \eta \nu$ (II 60,2), siendo el objetivo último de la sociedad ateniense el salvar la polis incluso a costa de los propios intereses individuales: $\chi \rho \varepsilon \omega े v . .$.

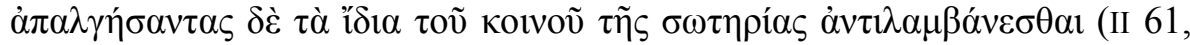
4). Todo ello nos lleva al desarrollo máximo de las tensiones que dejaba entrever la obra de Heródoto, lo que demuestra la cercanía y a la vez oposición de ambos autores.

Pero, más allá de este aspecto, la importancia de las ideas contenidas en estos discursos reside además en el hecho de que la totalidad de la obra se construye en torno a ellas, dado que los estadios fundamentales del ejercicio del imperio se diseñan en espejo sobre las ideas de Pericles. ${ }^{1618}$ De este modo, todas estas ideas nos conducen de nuevo, al igual que ocurría con Heródoto, al escenario político y social que dibujan los acontecimientos y la literatura del fin del siglo V a. C. El modelo político que recorre la obra de Tucídides, condicionado por los mecanismos inevitables de concentración y ejercicio de poder, se encarna en individuos que se distinguen por su capacidad de gestionar la población en aras de su conformación como un ente único, y que, paradójicamente, caen víctimas de la ópyŕ del pueblo. Bender señaló ${ }^{1619}$ la posición paradigmática de Pericles en el estudio de sus sucesores, que son continuamente sometidos al paradigma del gran estadista a lo largo de la obra. El análisis de los individuos al frente de la gestión de la polis determina una de las constantes organizativas de la obra, como bien vio Westlake. ${ }^{1620}$ Tucídides analiza a los diferentes individuos desde una perspectiva tanto intelectual como ética, en contra de la opinión de Westlake. ${ }^{1621}$ La idea de Westlake se debe, seguramente, a que la imagen que

${ }^{1618}$ Cf. Rengakos, 1984, p. 73, para los discursos de Cleón y Diodoto, y p. 90 para esta idea aplicada a los libros III-IV, y Westlake, 1968, p. 225, para la misma idea aplicada a Alcibíades.

${ }^{1619}$ Cf. Bender, 1938, p. 5: «Perikles ist in politische Tun und Denken das Vorbild aufgrund dessen Wissens [...] Thukydides an die nachperikleische Politik und die Träger dieser Politikkritisch herangehen kann».

${ }^{1620}$ Cf. Westlake, 1968. No creemos acertada la idea de interpretar, en virtud de lo ya visto en el análisis formal, el segundo proemio como una pausa, cf. p. 1.

${ }^{1621} \mathrm{Cf}$. Westlake, 1968 , p. 7: «[...] he is looking rather for military and political capacity

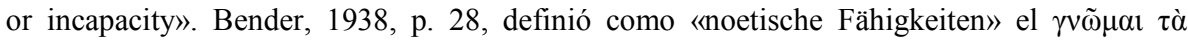

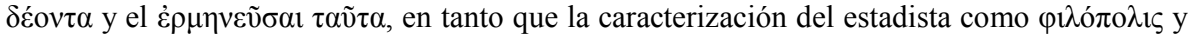


Tucídides ofrece de Pericles es ajena por completo a la descripción de sentimientos, ${ }^{1622}$ pero este hecho, como el continuo retraso de la entrada de Pericles, se explica por la naturaleza de paradigma de la imagen del estadista, que adquiere no tintes de arcaísmo, ${ }^{1623}$ sino de un hieratismo que perfila bien la idea de estadista que tiene Tucídides en mente. La entrada de Pericles se produce, precisamente, para exponer ${ }^{1624}$-en virtud de su

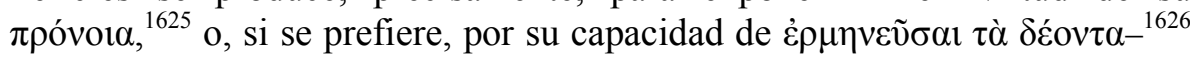
los condicionantes que regulan la guerra. Por eso se pospone al ejercicio necesario de sus funciones al frente de la ciudad, hecho que además se ve confirmado por la tendencia de los diferentes personajes a desaparecer de la obra sin mayores explicaciones. ${ }^{1627}$

La opacidad de los diferentes estadistas de prestigio, fruto de ser

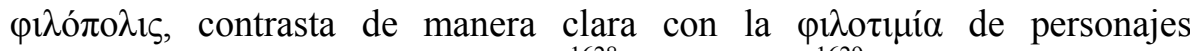
paradigmáticos como Alcibíades ${ }^{1628}$ y Cleón, ${ }^{1629}$ causantes de la desintegración de la polis. En definitiva, como ya indicó Finley, estamos ante la incapacidad de un sistema democrático para sustentar un modelo no acorde ya con las circunstancias ${ }^{1630}$ de avance del individuo.

La imagen del estadista implícita en el concepto de organización de la realidad en virtud del concepto de $\tau$ ò $\alpha \dot{v} \theta \rho \omega ́ \pi ı v o v$ tiene su contrapunto en una masa de individuos ausente prácticamente de la obra de Tucídides como entidad definida, y unas consecuencias claras en la evolución del concepto de individuo a lo largo de este periodo de finales de siglo. El individuo, que ya había alcanzado una posición fundamental tiempo atrás, está en el núcleo

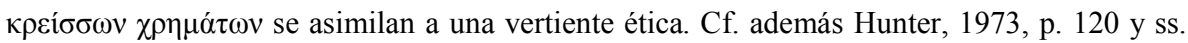
Leppin, 1999, p. 143 y ss., replantea estos criterios en términos de conocer, comunicar y amar a la ciudad.

${ }^{1622}$ Cf. Westlake, 1968, p. 23.

${ }^{1623}$ Como quería Westlake, 1968, p. 42.

${ }^{1624}$ Así, Westlake, 1968, p. 26: «Thucydides, being interested rather in the war strategy of Pericles than in his personality, postpones his entry until that strategy is about to be brought into operation».

${ }^{1625}$ El concepto de $\pi \rho$ óvora hace referencia a la acción representada por la facultad de la

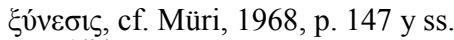

${ }^{1626}$ Cf. Bender, 1938, p. 5.

${ }^{1627}$ Cf. Westlake, 1968, p. 57.

${ }^{1628}$ Así, Bender, 1938, p. 78; Westlake, 1968, p. 212; y Leppin, 1999, p. 164.

${ }^{1629}$ Cf. Westlake, 1968, p. 60, quien destaca el hecho de que es de los pocos personajes que recibe una condena expresa, así como una gran cantidad de detalles acerca de su lejanía del paradigma pericleo, cf. p. 69 y ss.

${ }^{1630}$ Cf. Finley, 1967b, p. 304. 
de un conflicto que, en palabras de Ober, podemos definir como un enfrentamiento entre lo antiguo y lo moderno, ${ }^{1631}$ resumido en las tensiones internas existentes en el discurso fúnebre, ${ }^{1632}$ que termina por defender la idea de convertir a los ciudanos en $\dot{\varepsilon} \rho \alpha \sigma \tau \eta ́ \varsigma \pi \mathrm{o} \lambda \dot{\varepsilon} \omega \varsigma$, es decir, la cesión total del individuo ante la ciudad. ${ }^{1633}$ Es, precisamente, en este sentido de

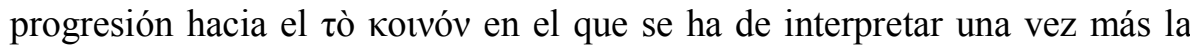
Arqueología ${ }^{1634}$ y la obsesión por analizar la concentración de poder en los estadios previos a la guerra narrada: Tucídides deja muy atrás la experiencia de las guerras médicas para afrontar los mecanismos de concentración de poder que se esconden detrás del funcionamiento de la democracia ateniense y de la gestión del imperio.

El conflicto es seguramente una realidad ya reflejada por la tragedia sofoclea, en especial en Antígona. Sin embargo, la perspectiva empleada, sea cual sea la cronología de Antígona, es por completo otra. Frente a la oposición existente entre norma tradicional y tendencia democrática, lo que tenemos en Tucídides es un análisis de la situación del individuo en el marco social de fines del siglo $\mathrm{V}$ a. C. La corriente aristocrática iniciada a mediados de siglo ha derivado en un problema de naturaleza psicológica relativo a la posición del individuo en la sociedad que observaremos con gran nitidez en Sócrates. La línea que discurre desde las aspiraciones individuales en Heródoto insertas dentro de un marco espiritual aristocrático y ancestral, y que desemboca en la historiografía del siglo IV a. C., tiene su momento clave en la evolución que ese pensamiento experimenta en Tucídides. En tal sentido, nos parece fundamental resaltar que, aunque quizá con unos tintes poco habituales, es innegable el contenido moral del diseño. Frente a las teoría de Calicles y el relativismo moral de la época, como ya señaló Hussey,

${ }^{1631}$ Cf. Ober, 2006, p. 143.

${ }^{1632}$ Cf. Crane, 1998, p. 312 y ss., especialmente p. 314.

${ }^{1633}$ Cf. Crane, 1998, p. 318 y ss. Rengakos, 1984, p. 40, definía ya esta relación como «Wohl und Wehe des einzelnen auf dem Los seiner Polis beruht». La idea de interpretar esta sumisión del individuo a la ciudad como un concepto médico que entiende la polis como un organismo como quiere Rechenauer, 1991, p. 286 y ss., si bien es aceptable para la imagen,

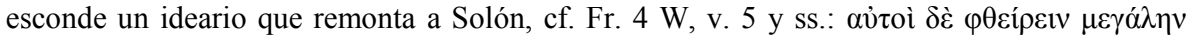

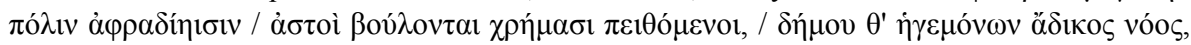

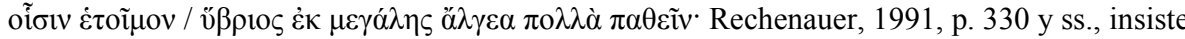
en que la descripción de la crisis de la polis se representa como un proceso médico, pero la aparición de términos como el de v̋ $\beta \rho ı$, de carácter moral y presente ya en Solón, han de hacer que nos replanteemos ese exceso.

${ }^{1634}$ Cf. Rechenauer, 1991, p. 304 y ss. 
el modelo tucidídeo sí presenta un fuerte valor moral no a nivel de individuo, sino de colectividad, que es necesario para el perfecto funcionamiento de esta. $^{1635}$

\subsection{Función y finalidad del proemio tucidídeo}

Un aspecto de especial relevancia en el proemio es la finalidad de la obra, derivada, lógicamente, de la interpretación total que se haga de ella. La crítica ha coincidido en su función educativa de proporcionar una formación adecuada a los futuros estadistas, ${ }^{1636}$ siempre desde una perspectiva práctica. ${ }^{1637}$ De ser correcta la interpretación, habría que aceptar una modificación en el diseño temporal de la obra de Tucídides. Si asumimos,

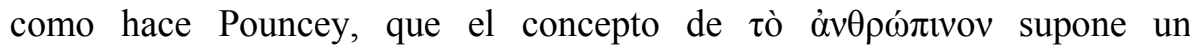
movimiento circular del poder, ${ }^{1638}$ sería inútil tratar de buscar una naturaleza educativa a la obra de Pericles, y con ello peligraría una de las cuestiones fundamentales de la definición del pensamiento proemial de Tucídides.

A nuestro entender, el concepto de $\tau$ ò $\alpha \dot{v} \theta \rho \omega ́ \pi ı v o v$ ha de ser entendido dentro del sistema general del proemio, lo que implica que debe ser evaluado dentro del marco político que define la finalidad de la obra. En este sentido, parece fundamental la definición propuesta por Cogan, ${ }^{1639}$ quien indicaba que estamos ante una regularidad del proceso, pero no del resultado: como hemos indicado, el concepto definiría el conjunto de procesos que se vinculan al funcionamiento de la sociedad y no a sus resultados. ${ }^{1640}$

El fresco es realmente complicado y lleno de tensiones, fiel reflejo del tiempo que narra Tucídides, un fresco materializado en un individuo, tipo ideal de estadista, y la colectividad. ${ }^{1641}$ El estadista ha de enfrentarse al ejercicio de su cargo al frente del Estado, como princeps optimus, de manera

${ }^{1635}$ Cf. Hussey, 1985, p. 133.

${ }^{1636}$ Cf. Finley, 1967b, p. 308 y ss.; Hunter, 1973, p. 120 y ss. Regenbogen, 1968, p. 31 : «Thukydides schreibt als Politiker für den politischen Menschen».

${ }^{1637}$ Así Jaeger, 2000, p. 352. Weidauer, 1954, p. 71.

${ }^{1638}$ Cf. Pouncey, 1980, p. 37.

${ }^{1639}$ Cf. Cogan, 1981, p. 231.

${ }^{1640}$ Así, Cogan, 1981, p. 241, en un nuevo sometimiento del individuo a la sociedad.

${ }^{1641}$ Así ya Regenbogen, 1968, p. 36. 


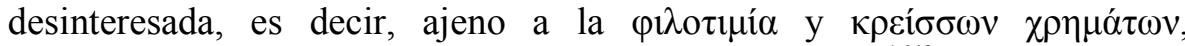

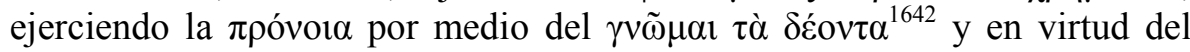

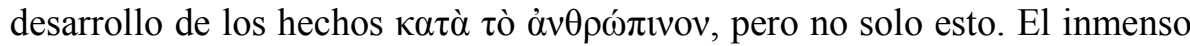

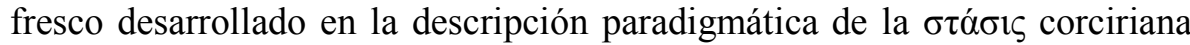
es el contrapunto de la imagen ideal que constituye el universo intelectual tucidídeo y representa además la prehistoria de la futura indagación moral que caracterizará la historiografía del siglo IV a. C. ${ }^{1643}$ Lo importante es señalar que el caso paradigmático de Corcira se presenta como el grado extremo de una degeneración ${ }^{1644}$ que se materializa como una realidad potencial de la sociedad, que parte de un ideal definido en la Asamblea en Esparta, ${ }^{1645}$ y que de ahí proviene el exceso de celo conservador de Tucídides. El famoso juicio sobre el gobierno de los Cinco Mil ha de ser entendido precisamente en este sentido, ${ }^{1646}$ y no hace falta recurrir a la idea de Ste. Croix ${ }^{1647}$ de considerarla una democracia moderada, sino asumir, como bien señala Donini, ${ }^{1648}$ que desde mucho antes del 429 el sistema ideal propuesto por Tucídides y representado, como antes señalábamos, de manera paradigmática en los libros I y II, había experimentado una degeneración considerable que solo había sido superada por el genio de Pericles, para terminar por ganar una posición de no retorno con el debate sobre Mitilene. ${ }^{1649}$

El diseño político de la obra de Tucídides ha de ser entendido como un juego de equilibrios bajo la dirección del estadista, que puede comprender y tomar la obra de Tucídides como un campo de trabajo para el análisis de los diferentes procesos acaecidos durante la guerra del Peloponeso. En este mismo sentido, el análisis de Jacqueline de Romilly del imperialismo ateniense como un proceso construido por medio de una progresión

1642 Cf. Bayer, 1968, p. 244, quien vio el esquema en Pericles.

${ }^{1643}$ Con la ópүí como concepto paradigmático, cf. Müri, 1968, p. 151.

${ }^{1644}$ La propuesta de Stahl, 2011, p. 35, respecto a la inexistencia de una progresión entre la asamblea del libro I y el desarrollo posterior hasta Melos no nos seduce. Cf. la postura reciente de Taylor, 2010, p. 115, si bien su análisis nos parece excesivamente alejado de las líneas interpretativas generales de la obra.

1645 Así, Regenbogen, 1968, p. 39 y ss. Cf. también Gundert, 1968, p. 115. El diseño de la colectividad en la asamblea espartana es una imagen social capaz de mantener y gestionar el imperio que ha de ser interpretada en compañía de la oración fúnebre.

${ }^{1646}$ Cf. Tucídides, VIII 97, 2. Cf. Donini, 1969, p. 2 y ss., para un examen de las interpretaciones propuestas.

${ }^{1647}$ Cf. Donini, 1969, p. 17.

${ }^{1648}$ Cf. Donini, 1969, p. 29.

${ }^{1649}$ Cf. Donini, 1969, p. 40 y ss. 
ejemplificada en diferentes acontecimientos elegidos y amplificados por Tucídides, ${ }^{1650}$ adquiere una especial importancia como sendero formativo a seguir por los lectores de Tucídides. ${ }^{1651}$

Con todo ello, se confirma la idea de una falta de progreso en la obra de Tucídides, que observa la realidad desde el punto de vista de los procesos, entendidos como una realidad siempre igual a sí misma, ${ }^{1652}$ fruto de la realidad humana emanada del individuo y disuelta en la colectividad. ${ }^{1653}$ Como indicó Bayer, el último discurso de Pericles ejemplifica la tensión entre el modelo eterno del dirigente y las convulsiones de la masa, ${ }^{1654}$ en una imagen artificial y aislada de la realidad: «eine Welt, aus der die Götter verbannt scheinen und die grossen Persönlichkeiten nur Namen und geschichtliche Rolle und Wirkung, aber kein eigentlich menschlisches leben haben $[\ldots]\rangle{ }^{1655}$

${ }^{1650}$ Así, Regenbogen, 1968, p. 33.

${ }^{1651}$ Cf. recientemente Nicolai, 2011, p. 159.

1652 En este sentido, las palabras de Regenbogen, 1968, p. 35, referidas a los discursos son aplicables a toda la obra: «Die Reden also bilden im wesentlichen den Rahmen, innerhalb dessen Thukydides in objetivierender Form, ohne selbst im eigenen Namen hervorzutreten, wie es bereits oven gefasst wurde, eine Statik un Dynamik des politischen Geschehens entwickelt $[\ldots] »$

${ }^{1653}$ Responsable del tinte gris y frío de la obra, como decía Strasburger, 1968a, p. 426.

${ }^{1654}$ Cf. Bayer, 1968, p. 256.

${ }^{1655}$ Cf. Strasburger, 1968a, p. 426. 



\section{LA CONSOLIDACIÓN DEL GÉNERO HISTORIOGRÁFICO: EL SIGLO IV A. C.}

\subsection{Constitución del texto de los autores fragmentarios}

Uno de los mayores obstáculos que ha de afrontar el estudio de la historiografía en su desarrollo diacrónico es, precisamente, el análisis de los autores del siglo IV a. C. La pérdida prácticamente total de la historiografía del periodo contrasta con la importancia que este momento tiene para la consolidación del género como tal. Es en este momento, y bajo el poderoso influjo de la riqueza cultural, filosófica y literaria de la época, cuando el género historiográfico definirá su forma canónica, que será sometida a lo largo de las generaciones a las tensiones propias de las muy dispares corrientes literarias, pero que permanecerá más o menos estable hasta el final de la Antigüedad.

La importancia del periodo es la que obliga a abordar una reconstrucción de los fragmentos proemiales para obtener una imagen aproximada de lo que presentaron sus autores. A pesar de lo delicado de un proceso tal, la amplitud y riqueza de los fragmentos permitirá obtener resultados concluyentes.

\subsection{1. ÉFORO}

Desde la aparición del tomo correspondiente de la edición de Jacoby contamos con un texto riguroso para el estudio de la obra de Éforo. En lo que a nosotros nos interesa, y más allá de este recurso, de gran valor, la crítica más reciente, salvo contadas excepciones, ha desechado ya por completo los intentos de Laqueur de reconstruir el complejo aparato de proemios que precedían a los diferentes libros ${ }^{1656}$ por medio del empleo de

${ }^{1656}$ Como nos dice Diodoro, XVI 76, 5. Cf. además Barber, 1935, p. 24. 
Diodoro. $^{1657}$ El avance en los estudios sobre la obra de Diodoro ${ }^{1658}$ ha revelado la independencia de este autor en muchos de sus puntos fundamentales, expresados, naturalmente, en los proemios.

Por ello y como norma general, el estudio de los proemios de los autores de este periodo, que por razones de economía acogerá a los autores fragmentarios desde fines del siglo V a. C. hasta Polibio, habrá de reducirse a la información transmitida por escritores que nos proporcionan testimonios y fragmentos literales.

En el caso de Éforo contamos con cuatro fragmentos que parecen corresponder al proemio de las Filípicas, los editados por Jacoby como F 7, 8,9 , y quizá el $\mathrm{F}$ 109. Parece seguro que todos ellos pertenecen al proemio inicial, ${ }^{1659}$ lo que nos priva de un conocimiento siquiera fragmentario de los proemios parciales de la obra. ${ }^{1660}$ La edición de Jacoby supuso un avance sustancial respecto a la edición de Müller, dado que por primera vez se trató de afrontar la identificación de los elementos pertenecientes al proemio principal, puesto que Müller simplemente encabezaba su edición de Éforo con un macroapartado referido a los proemios en general. ${ }^{1661}$

A nuestro entender, el primero de los fragmentos, F 7, no es como tal un fragmento proemial y tiene poca utilidad por ahora, de modo que retrasaremos su estudio para otro momento. Por su parte, el fragmento F 8 , que es recogido por Polibio, IV 20, 5 (Fr. 1 Müller) dice:

${ }^{1657}$ Cf. ya Barber, 1935, p. 69, quien defendía que la tesis de Laqueur era correcta, pero a la vez se mostraba reticente admitir que los proemios de Éforo estuviesen simplemente recogidos uno a uno en los proemios de Diodoro. Como indica el propio Barber en la nota 1 en el lugar citado, no hay siquiera equivalencia entre los libros de ambos autores.

${ }^{1658}$ Cf. e. g. las valoraciones de Sacks, 1990, p. 213. En el ámbito hispánico puede verse Lens, 1994, p. 47 y ss. Recientemente ha insistido en esta idea, de manera muy documentada, Parmeggiani, 2011, p. 148.

${ }^{1659}$ Cf., así, Parmeggiani, 2011, p. 84 y ss.

${ }^{1660}$ Para la naturaleza de este tipo de proemios, cf. infra, el apartado 6.3., dedicado a Timeo.

${ }^{1661}$ Cf. Müller, 1861, Fr. 1-6.

Monografias de Filología Griega, 22. ISSN 1136-0860 


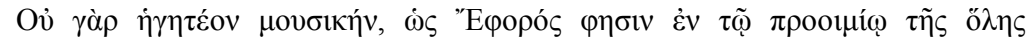

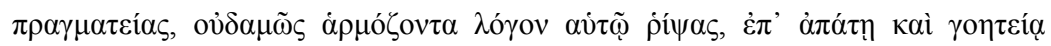

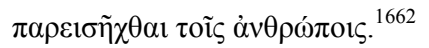

Jacoby, en su comentario, ${ }^{1663}$ alertaba de que este fragmento formaba

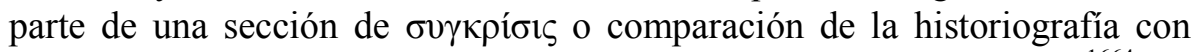
otras ciencias o disciplinas. La misma idea la encontramos en Meister, ${ }^{1664}$ y a nuestro entender, es acertada. Parece difícil la ubicación de un tema como este en una subsección del proemio diferente a la comparación y exaltación de la historiografía, lo que hizo que incluso en una reconstrucción conservadora como la de Barber fuera incluido en la nómina de los pertenecientes al proemio. ${ }^{1665}$

El siguiente fragmento perteneciente al proemio, el $\mathrm{F} 9$, es transmitido por Harpocratión, S. V. à $\rho \chi \alpha i ́ \omega \varsigma$ (Fr. 2 Müller): ${ }^{1666}$

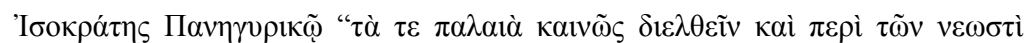

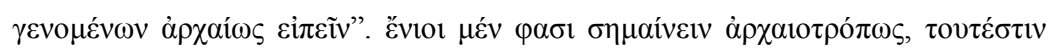

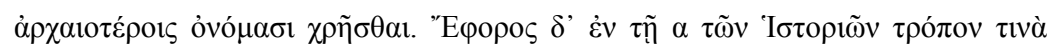

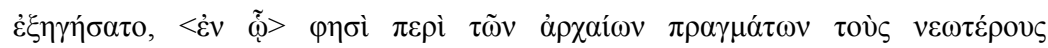
$\delta 1 \varepsilon \xi \dot{\varepsilon} \rho \chi \varepsilon \sigma \theta \alpha l^{\circ}$

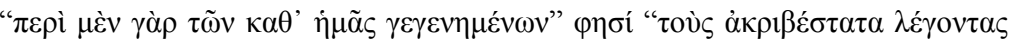

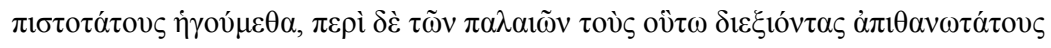

1662 «No se debe considerar, como dice Éforo en el proemio general de su obra, dejando caer un razonamiento en absoluto acorde con él, que la música fue introducida para engaño y encandilamiento de los hombres».

${ }^{1663}$ Jacoby, FGrHist, II C, Komm., p. 43.

${ }^{1664}$ Cf. Meister, 1975, p. 67 y ss.

${ }^{1665}$ Cf. Barber, 1935, p. 71.

1666 «De manera arcaica. En el Panegírico isocrateo: desarrollar hechos pasados en modo novedoso, y hablar sobre los acaecidos recientemente de forma arcaizante. Hay algunos que indican que quiere decir en modo arcaico, es decir, valerse de términos muy antiguos. Éforo, en el libro primero de las Historias, expone cierto modo por medio del cual dice que los autores más recientes desarrollan sus obras acerca de hechos antiguos: "pues creemos -diceque quienes escriben sobre lo acaecido en nuestro tiempo de manera más pormenorizada son los más dignos de confianza, pero a quienes lo hacen de ese modo sobre acontecimientos pasados, los consideramos los más faltos de credibilidad, ya que sospechamos que no es lógico que recuerden todos los hechos y la mayoría de los discursos después de tanto tiempo"». 


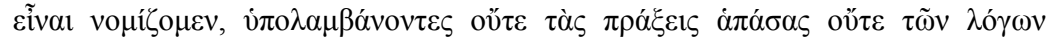

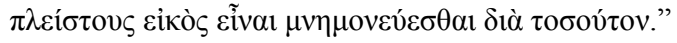

Jacoby, a diferencia de Barber, ${ }^{1667}$ dudaba, en lo que se refiere a la ubicación de este fragmento, entre su pertenencia al proemio general o una introducción parcial ${ }^{1668}$ como las que podemos ver en el caso de Diodoro. A nuestro entender, estamos ante un fragmento proemial referido a la elección del tema, el famoso retorno de los Heráclidas, y su ubicación en el proemio nos parece asegurada por lo genérico de sus planteamientos, dado que esas introducciones parciales tienen como contenido aspectos más concretos referidos al libro o, más bien, a la sección que encabezan.

Como prueba de esta consideración puede compararse el fragmento citado con el editado por Jacoby como F 109, de ubicación dudosa, que Müller editaba sin más examen y que procede, precisamente, de Diodoro I 9 , 5.1669

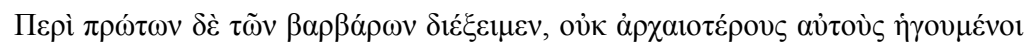

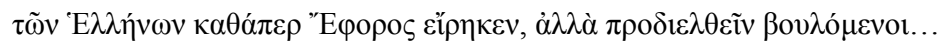

El examen de este fragmento en comparación con el anterior puede dar buena cuenta de la diferente precisión que corresponde a los planteamientos de un proemio general y a los de una introducción particular, a pesar de que Barber pensara que especialmente este fragmento pertenecía al proemio. ${ }^{1670}$ Por todo ello, nos parece lógico reservar el F 9 para el proemio y el F 109 para una introducción parcial, entendida esta como ligeramente diferente a un proemio.

Sin salir de la sección que nos ocupa, el contenido del fragmento F 110 se acerca a lo hasta ahora visto, con la particularidad de que hemos de

${ }^{1667}$ Cf. Barber, 1935, p. 71.

${ }^{1668}$ Cf. Jacoby, FGrHist, II A, Komm., p. 43.

1669 «Vamos a tratar de los bárbaros los primeros, no porque consideremos que son más antiguos que los griegos, como Éforo dice, sino porque queremos tratar con antelación [...]».

${ }^{1670}$ Cf. Barber, 1935, p. 71. 
admitir con Jacoby que su ubicación es dudosa. ${ }^{1671}$ Parece imposible determinar si estamos ante un fragmento del proemio inicial o de uno de los proemios particulares de cada libro, porque desconocemos por completo la factura de estos últimos. Sea como fuere, una vez más, estamos ante un fragmento, o más bien testimonio, transmitido por Polibio, XII 27, 7, editado por Müller como Fr. $3:^{1672}$

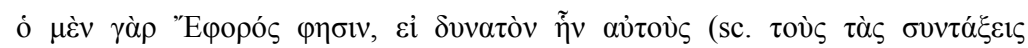

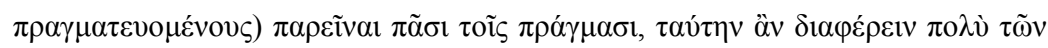
$\dot{\varepsilon} \mu \pi \varepsilon \rho 1 \rho i \tilde{\omega} v$.

La naturaleza proemial de este fragmento parece segura. Más difícil parece determinar su ubicación exacta, dentro de una obra del tamaño y la complejidad de la de Éforo.

Con este fragmento se completa la nómina de los editados como pertenecientes al proemio por Jacoby. Sin embargo, Müller recogía dos fragmentos más que parece interesante, al menos, examinar. Así, el primero de ellos, Fr. 4, procede del proemio al libro IX 1 de Polibio, y no es siquiera editado por Jacoby: ${ }^{1673}$

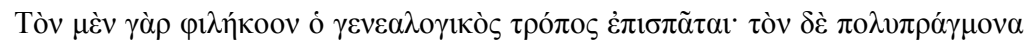

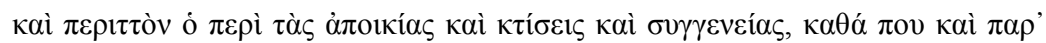

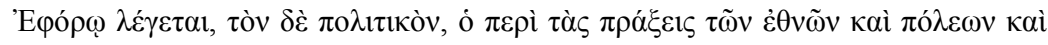
$\delta v v \alpha \sigma \tau \tilde{v}$.

${ }^{1671}$ Cf. Jacoby, FGrHist, II A, Komm., p. 63. Marincola, 1985, p. 65, al afirmar la ausencia de contenido biográfico en la obra de Éforo, parece confirmar esta idea, apuntando en nota 18 que tal razón apoya la aparición de la supuesta escuela isocrática, lo que nos parece excesivo.

${ }^{1672}$ «Y es que Éforo dice que, si fuese posible que estos [quienes se afanan en la composición de obras históricas] estuviesen presentes en todos los sucesos, esta sería la mejor con mucho de las experiencias».

1673 «Pues al oyente atento le atrae el narrar de genealogías, y al diletante, sin duda alguna, el que trata de colonias, fundaciones y hechos locales, como más o menos se dice en Éforo, y al lector ocupado en asuntos públicos, el género que se encarga de los hechos, pueblos y gobernantes». 
El presente testimonio pertenece, a nuestro entender, a un proemio parcial que podría preceder a un libro cuyo contenido se adapta a lo referido en el fragmento, si bien hemos de reconocer que poco más se puede extraer de él.

Finalmente, el fragmento Fr. 5 Müller, F 97, no creemos que pertenezca en modo alguno a los proemios, como bien edita el propio Jacoby.

\subsubsection{TEOPOMPO}

Ligeramente mayor es el número de fragmentos transmitidos del que era seguramente el proemio general y único de las Filípicas de Teopompo. Jacoby admitía y editaba como pertenecientes al proemio un total de cuatro fragmentos, F 24, 25, 26 y 27, que nos permiten un acercamiento realmente productivo a este, de un modo tal que el propio editor reconocía la existencia confirmada por ellos de secciones dentro del proemio. ${ }^{1674}$

Dejando para más tarde el F 24, el extenso fragmento F 25, transmitido por Focio, ${ }^{1675}$ es un rico resumen rápido realizado por el patriarca de una sección nueva en nuestro recorrido del proemio helenístico, la relativa al autor (Focio, Biblioteca, Codex 176, 120b30): $:^{1676}$

${ }^{1674}$ Cf. Jacoby, FGrHist, II B, Komm., p. 360.

${ }^{1675}$ Sobre la costumbre de recoger material de los proemios para los apuntes de la obra del patriarca, cf. Treagold, 1980, p. 59 y ss. Señala Treagold, p. 60, que esa recogida de datos se realiza habitualmente sobre un solo lugar dentro de la obra, lo que facilita la acumulación de material proemial.

1676 «Dice que fue coetáneo de Isócrates el ateniense, Teodectes el faselita y Náucrates el eritreo, y que estos poseían, al igual que él, las primicias de la formación retórica entre los griegos. Pero que Isócrates, a causa de la falta de recursos, y también Teodectes, escribieron discursos a cambio de dinero, y que trabajaban como maestros, formando a los jóvenes, a fin de obtener de ello beneficio; y que Náucrates y él, dado que gozaban de recursos, pasaban el tiempo con los jóvenes filosofando y deseando aprender, y que no sería algo descabellado que optase a la primacía en este aspecto, dado que compuso, desde luego, no menos de veinte mil líneas de discursos epidícticos, y más de ciento cincuenta mil en las que es posible tomar cuenta de la exposición de las acciones de griegos y bárbaros acaecidas hasta hoy. E incluso es más, que no hay lugar público griego, ni ciudad digna de consideración que no haya visitado personalmente, alcanzando gran renombre con las exposiciones de sus discursos». 


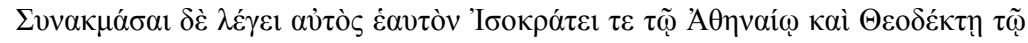

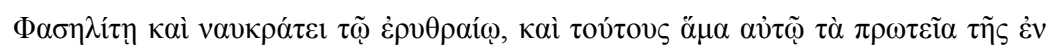

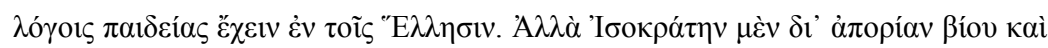

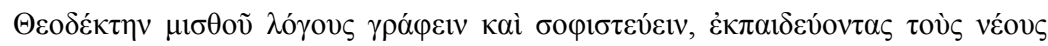

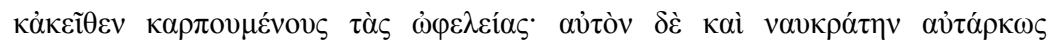

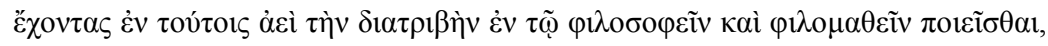

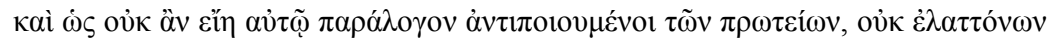

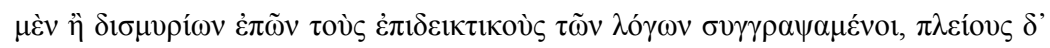

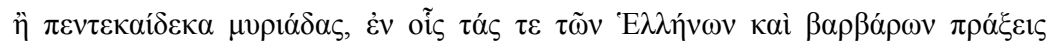

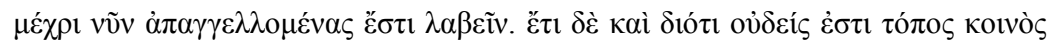

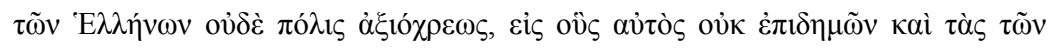

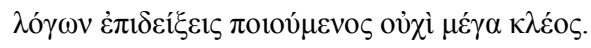

Como apéndice a este fragmento editaba Müller el que Jacoby presentó como F 24, que confirma, según indicaba ya Müller, ${ }^{1677}$ la procedencia del fragmento anterior del proemio de la obra (Dionisio de Halicarnaso, Antigüedades romanas, I 1, 1; Fr. 1b Müller): ${ }^{1678}$

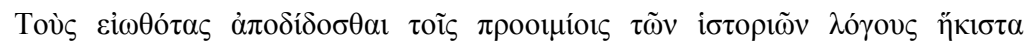

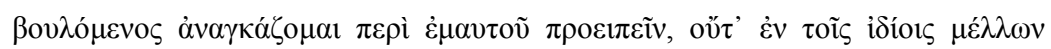

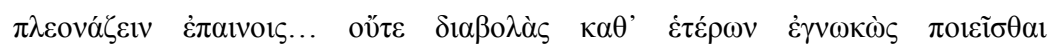

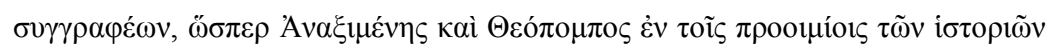

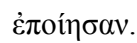

A este fragmento ha de añadirse el transmitido también por Dionisio de Halicarnaso en su Epístola a Pompeyo, 6, en el que de nuevo se nos proporciona información sobre el autor: ${ }^{1679}$

${ }^{1677}$ Cf. Müller, 1861, p. 282: «[...] quae indicio sunt antecedentia ex proemio aliquo Historiarum petita esse».

1678 «Dado que no quiero en absoluto ofrecer los planteamientos habituales en los proemios, me veo obligado a hablar en primer lugar sobre mí, y dado que tampoco voy a detenerme en los mismos elogios [...] y no sabiendo calumniar a otros historiadores, como hicieron Anaxímenes y Teopompo en los proemios de sus Historias».

1679 «Y es que está claro que, aunque no hubiera escrito nada, llevó a cabo para ello la mayor preparación, y realizó los mayores dispendios para el acopio de materiales, y además de ello fue partícipe de primera mano en muchos acontecimientos, y frecuentó la 


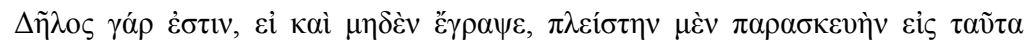

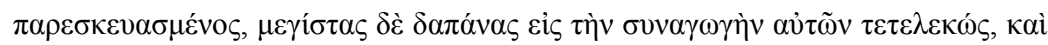

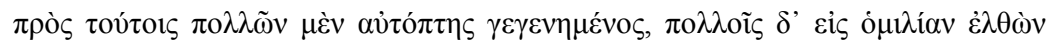

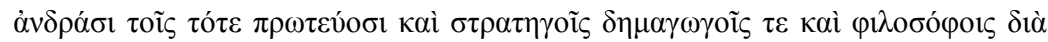

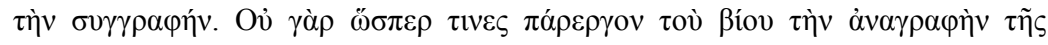

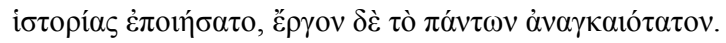

Como decíamos, todos estos fragmentos forman parte de una sección proemial relativa a la presentación del autor. Jacoby apuntó de manera certera que estamos ante una evolución de algo ya conocido en los proemios historiográficos. ${ }^{1680}$ Estamos, simplemente, ante la evolución de los apuntes personales esbozados por Tucídides en el proemio de V 26, lo que habrá de ser tenido en cuenta a la hora de interpretar la posible configuración del proemio. $^{1681}$

A la nómina de fragmentos editados por Jacoby para esta sección creemos que ha de ser añadido el Fr. 28 Müller, editado por Jacoby como $\mathrm{F}$ 342 , y que de nuevo nos es transmitido por Polibio, XII 27, 8-9: ${ }^{1682}$

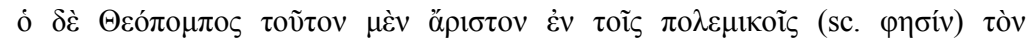

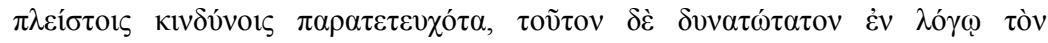

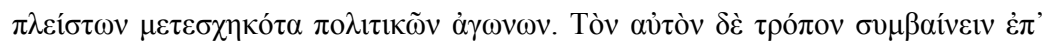
і $\alpha \tau$

conversación de muchos prohombres, generales, políticos y sabios con motivo de la redacción de su obra. Pues no consideró la composición de una obra histórica como algo accesorio en su vida, como algunos hacen, sino el empeño máximo».

${ }^{1680}$ Cf. Jacoby, FGrHist, II A, Komm., p. 360.

1681 Sobre la fosilización en época helenística de los «tópicos» tucidídeos, cf. Nicolai, 1995 , p. 10. Ya Gabba, 1981, p. 50, hablaba de cierta incomprensión de los principios metodológicos de Tucídides en la Antigüedad.

1682 «Teopompo dice que el mejor en los asuntos bélicos es quien ha estado presente en mayor número de peligros, y que el que ha participado en mayor número de contiendas políticas es el más poderoso en el discurso. Y que de igual manera ocurre con la medicina y la navegación». 
Por sí sola, la importante información del largo pasaje que nos proporciona Focio queda, a nuestro entender, sin justificación alguna. La ubicación por parte de Müller de este fragmento acto seguido de los que son habitualmente tenidos como pertenecientes al proemio nos parece acertada, ${ }^{1683}$ porque creemos que es esta la justificación de ese largo repaso por la formación y capacitación de Teopompo para escribir historia: así como otros han de gozar de cualidades propias para la realización de sus especialidades, la del historiador requiere también de unas cualidades adecuadas a esta labor.

El último de los fragmentos del proemio, el F 27, supone, como ya indicó Jacoby, el desplazarnos a una nueva sección, referida al contenido. El fragmento en cuestión es transmitido por Polibio, VIII 11, 1 (Fr. 27 Müller): ${ }^{1684}$

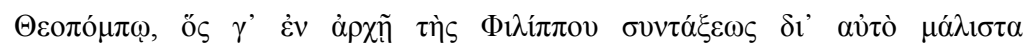

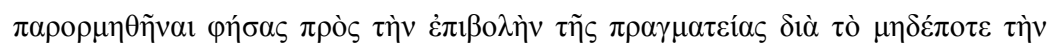

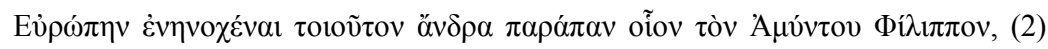

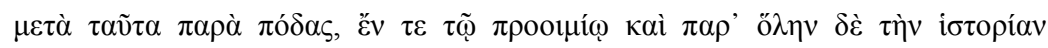

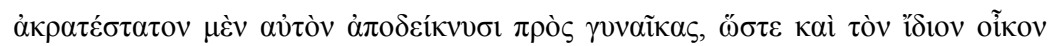

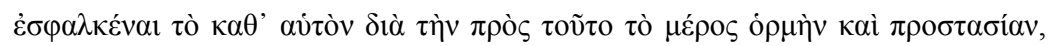

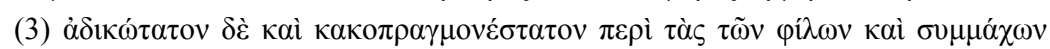

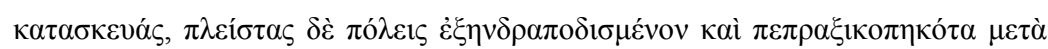

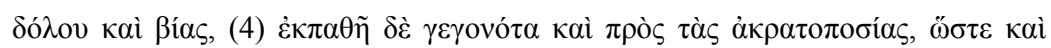

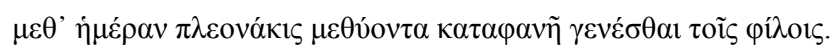

${ }^{1683}$ Shrimpton, 1991, p. 115, se muestra más cauto en este sentido, si bien acoge como posible su ubicación en el proemio.

1684 «[...] a Teopompo, que, como es sabido, una vez que ha dicho en el comienzo de su obra sobre Filipo que se vio llevado a la composición de la obra precisamente por el hecho de que jamás llevó las riendas de Europa hombre tal como Filipo el hijo de Amintas, (2) acto seguido lo presenta, tanto en el proemio como a lo largo de toda la obra, como el más desenfrenado con las mujeres - de modo que arruinó su posesiones en lo que a él incumbía por su impulso y patrocinio de este comportamiento-, (3) y como el más injusto y malvado en lo que se refiere al trato de los amigos y aliados, esclavizando ciudades una vez que se las hubo ganado por medio del engaño y la violencia, (4) y desenfrenado incluso en borracheras, de modo que habitualmente se mostraba a sus cercanos borracho todo el día». 
Dejando las cuestiones de interpretación para otro lugar, lo importante es que tenemos ante nosotros un fragmento que podemos asignar a otra sección del proemio, a la justificación de la elección del tema. Este apartado es también un lugar habitual ya en los proemios del siglo $\mathrm{V}$ a. C., pero lo interesante en el periodo que nos ocupa es su ubicación, al menos aproximada, dentro del proemio.

De nuevo, la falta de una delimitación clara de los fragmentos que Müller asignaba al proemio de Teopompo nos impide saber si el Fr. 29 Müller era considerado por este como perteneciente al proemio o, seguramente, al comienzo del contenido del libro primero. El fragmento, transmitido por Estrabón, I 2, 35, es editado por Jacoby como F 381: ${ }^{1685}$

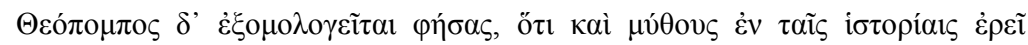

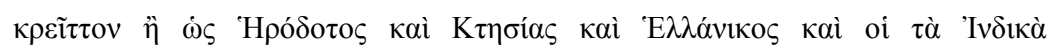

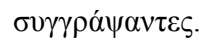

Con este fragmento hemos pasado, seguramente, a la sección final del proemio de las Filípicas, el apartado relativo a las cuestiones de estructura y contenido. El desarrollo del género hace que nos encontremos con obras de gran complejidad estructural, lo que determinará en la práctica que sea un hecho habitual a partir de este momento la dedicación de la última sección del proemio a cuestiones técnicas.

\subsubsection{CALÍSTENES}

Kunz da como segura la procedencia del F 44 del proemio de la obra histórica de Calístenes de Olinto. El fragmento, transmitido por Ateneo

\footnotetext{
1685 «Teopompo está de acuerdo al afirmar que también va a contar narraciones en sus Historias mejor que Heródoto, Ctesias, Helánico y quienes escribieron Índicas». 
Mecánico, p. 10, pertenece sin duda, como indican Jacoby y Kunz, a la habitual sección polémica del proemio: ${ }^{1686}$

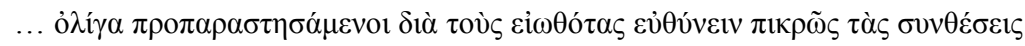

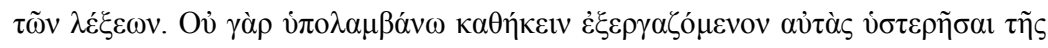

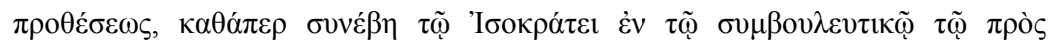

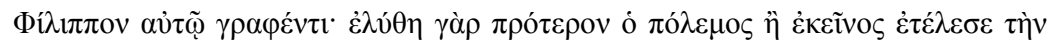

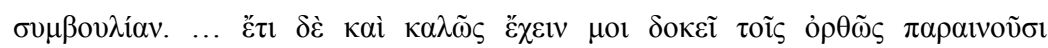

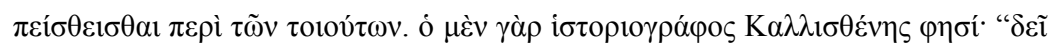

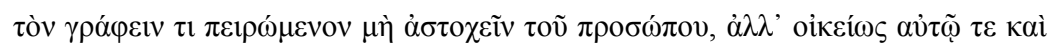

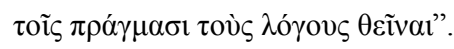

Como antes indicábamos, estamos ante un ejemplo más de la sección polémica del proemio, que se mantiene en la generación posterior a Éforo y Teopompo, a la que pertenece Calístenes.

Ante la duda acerca de la asignación del proemio a una de las dos obras mayores de Calístenes, creemos que la solución es realmente fácil. La propuesta de Pearson defendía su pertenencia a las Helénicas, obra de juventud de Calístenes. ${ }^{1687}$ Esta opinión, que parecería fácilmente refutable si tenemos presente que estamos ante unas helénicas, ha de ser, al menos, tenida en cuenta, dado que Diodoro nos transmite que las Helénicas de Calístenes comenzaban en el año 387 a. C. ${ }^{1688}$ La fecha hace imposible que estemos ante una simple continuación de la obra del de Olóro, lo que nos impide afirmar con seguridad que estas helénicas no tuviesen proemio.

Tanto el contexto de Ateneo Mecánico como el contenido del texto parecen hacer muy complicada una atribución fiable del texto a una de las

1686 “... tras detenernos un poco a causa de quienes acostumbran a examinar de manera inflexible el estilo. Pues temo que, mientras me afano en él, descuide el tema, como precisamente le sucedió a Isócrates en el discurso exhortativo escrito para Filipo: pues la guerra llegó a su fin antes de que aquel terminase la exhortación... E incluso todavía creo que es algo bueno el hacer caso a quienes nos aconsejan bien acerca de estos aspectos. Y es que el historiador Calístenes dice: "Es preciso que quien trata de escribir algo no desdibuje al personaje, sino que disponga sus palabras como corresponde al mismo y a sus asuntos".

${ }^{1687}$ Prandi, 1985, p. 127, apunta que en torno a la década de los cuarenta debió de iniciar la redacción de la obra, a nuestro entender en la más alta de las fechas posibles de esta década, dado que en el 334 a. C. Calístenes marcha con Alejandro ya como un historiador consagrado.

${ }^{1688}$ Cf. Diodoro, XIV 118, 7. 
dos obras, $\mathrm{y}$, si hemos de atender a los innegables resabios aristotélicos del pasaje, ${ }^{1689}$ no sería osado pensar en una posible influencia directa en las Helénicas, redactadas necesariamente en compañía de Aristóteles. ${ }^{1690}$ Pero este mismo hecho hace posible que la influencia se verificase en las $\dot{A} \lambda \varepsilon \xi \dot{\alpha} v \delta \rho \rho v \pi \rho \dot{\alpha} \xi \varepsilon \iota \varsigma$.

Por otra parte, la exploración de las posibles reminiscencias de Tucídides, I 21, 1 en este pasaje es además, a nuestro entender, poco productiva. Prandi defendió sin ambages la idea de que estamos ante una referencia a la composición de los discursos ${ }^{1691}$ al modo tucidídeo. Pero, como veremos, las referencias a la teoría de la $\mu$ í $\mu$ $\sigma ı \varsigma$ aristotélica son tan grandes que parece difícil asumir de entrada una propuesta que ya Ullman dejaba abierta. ${ }^{1692}$ Estamos no ante una simple preocupación por la congruencia de lo dicho, sino ante un afán de reflejar claramente el carácter del personaje.

La evidencia interna nos llevaría con facilidad a afirmar que estamos ante un fragmento perteneciente a la obra relativa a Alejandro. Esto es así porque la crítica ha tratado recientemente de valorar de manera más meditada la información relativa al diseño de la figura de Alejandro, de modo que este responde a algo más que la simple adulación que habitualmente se ha atribuido al de Olinto. Si realmente estamos ante el intento de reflejar al estadista, el ßíos $\pi 0 \lambda \imath \tau 1 \kappa o ́ \varsigma$ aristotélico, como dice Prandi, ${ }^{1693}$ todo ello dentro de la teoría de la $\mu$ í $\mu \eta \sigma \varsigma$, no parecería osado atribuirla a esta obra.

A este aspecto hay que agregar un dato también de importancia, como es el hecho de que esta información, con las cautelas debidas ante un texto fragmentario y por ello mutilado, se nos transmite en un texto abiertamente polémico, en lo que incide la idea ya señalada de Jacoby y Kunz sobre la pertenencia del fragmento a esa sección. Todo ello está en sintonía más con una obra como las $A \lambda \varepsilon \xi \xi \dot{\alpha} v \delta \rho o v \pi \rho \dot{\alpha} \xi \varepsilon l \varsigma$ que con las Helénicas, en abierto y necesario contraste con los incipientes tratamientos del personaje, surgidos prácticamente a pie de expedición. Como veremos con más detenimiento, el

\footnotetext{
${ }^{1689}$ Cf. Ullman, 1942, p. 35.

${ }^{1690}$ Cf. Brown, 1949, p. 227 ss., para los datos acerca del contacto entre el Estagirita y el de Olinto, que por estas fechas compartieron el dolor de la cruel muerte de Hermías.

${ }^{1691}$ Cf. Prandi, 1985, p. 133.

${ }^{1692}$ Cf. Ullman, 1942, p. 35.

${ }^{1693}$ Cf. Prandi, 1985, p. 75. 
propio título de la obra parece apuntar a que una reflexión relativa al diseño de caracteres tenía plena cabida en una obra como la que nos ocupa.

Sea como fuere, creemos que la evidencia no es lo suficientemente contundente como para poder determinar la ubicación exacta, pero, a pesar de ello, nos decantamos por la opción de las $A \lambda \varepsilon \xi \dot{\alpha} v \delta \rho o v \pi \rho \alpha \dot{\xi} \xi \varepsilon l \varsigma$.

\subsubsection{DURIS DE SAMOS}

El fragmento proemial de Duris de Samos, editado como Fr. 1 Müller y $\mathrm{F}$ 1, es, seguramente, uno de los que más discusión ha provocado en la crítica. Su interpretación, asociada desde muy temprano al concepto de $\mu i ́ \mu \eta \sigma ı \varsigma$, ha dado lugar a uno de los problemas más complejos de la historiografía helenística. En lo que ahora nos interesa, la edición del fragmento, transmitido por Focio, Biblioteca, Codex 176, es, a nuestro entender, la siguiente: ${ }^{1694}$

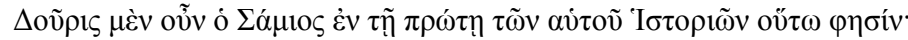

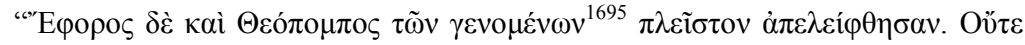

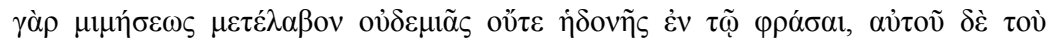

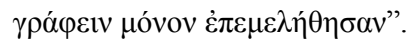

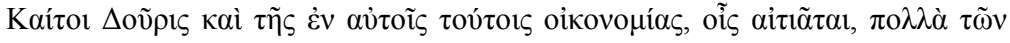

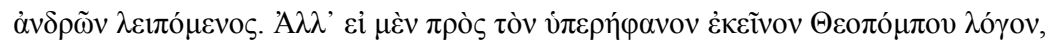

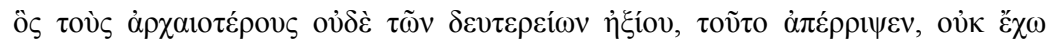

1694 «Así pues, Duris el samio se expresa de la siguiente manera en el primer libro de sus Historias: "Éforo y Teopompo se alejaron en gran manera de lo acaecido, pues ni se preocuparon por la mímesis ni por el placer en el narrar, sino que se ocuparon simplemente de escribir". Sin embargo, Duris también se queda atrás en lo que a la organización se refiere en los mismos términos en los que plantea su acusación. Pero si afirmó por arrogancia respecto a Teopompo que no consideraba dignos a los más antiguos ni de un segundo puesto, no lo sé. Pero sí afirmaría con seguridad que ninguno de los dos se ocupó de estos aspectos convenientemente».

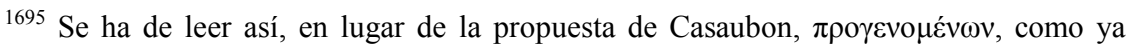
hacía, por otra parte, Susemihl, 1891, p. 591, y se admite de manera general desde Schwartz y Jacoby. Cf. Jacoby, FGrHist, II A, Text, p. 138. 


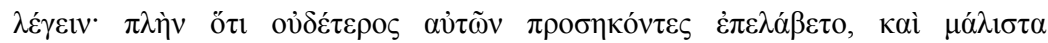

$\delta 11 \sigma \chi v \rho 1 \sigma \alpha i ́ \mu \eta v$.

Creemos que la mejor interpretación de este texto que podemos proporcionar es por ahora la traducción a pie de página. En lo que nos interesa, la constitución estructural del proemio, estamos, simplemente, ante un ejemplo más de la polémica con otros autores presente de manera generalizada en los proemios.

\subsection{La estructura del proemio historiográfico en el siglo IV a. C.}

Con lo poco conservado parece difícil proponer una reconstrucción cabal de lo que podría ser una estructura típica del proemio historiográfico en el periodo que se extiende desde fines del siglo IV a. C. hasta Polibio. Sin embargo, la evidencia interna, así como los interesantes testimonios de Focio, que aún leyó mucho de los autores que nos ocupan, nos permitirán trazar al menos una hipotética imagen del proemio, en cierta manera, lo que sería posible encontrar en el mismo.

En primer lugar, dos son los rasgos que llaman la atención. Por una parte, se ha de destacar la continuidad existente entre la imagen que nos proporcionaba Tucídides y la ahora presente. La fuerte evolución sufrida por la literatura, patente en su estado de evolución todavía en la obra de Tucídides, se nos muestra ahora en una estado de perfección tal que podemos dar por concluido el proceso de transición iniciado en el último cuarto del siglo $\mathrm{V}$ a. C. Los rasgos de composición arcaica, con sus sólidas composiciones anulares, que organizaban de manera prodigiosa el contenido, pero limitaban en cierta medida la capacidad de expresión, dan paso a un orden de pensamiento lineal en el que la libertad es mayor y la organización de los diferentes elementos ha de ser ponderada, cosa solo posible con una prosa lo suficientemente evolucionada.

El ejemplo de autores posteriores como Polibio o Dionisio de Halicarnaso, cuyo uso ha de ser muy prudente a la hora de reconstruir los proemios de sus predecesores, puede ser válido si los empleamos como testimonios. De este modo, Dionisio de Halicarnaso nos advierte de que era 
habitual recoger en los proemios alabanzas y ataques a los predecesores. Si bien Dionisio no dice que estas alabanzas y críticas encabecen los proemios de sus predecesores, creemos que la posición inicial en el proemio de este, así como las palabras de Polibio en el mismo sentido y lugar, solo pueden tener verdadera fuerza literaria si ocupaban esa posición en el proemio de sus predecesores. ${ }^{1696} \mathrm{~A}$ esta razón se añade otra de carácter propiamente estructural. Si el proemio tenía que admitir una crítica de los predecesores, o incluso una crítica de otras artes en su interior, creemos que su lugar debería situarse en el comienzo mismo del proemio. Esto es así en primer lugar porque diseñaría una idea inicial de alabanza de la historia, o los defectos a superar de los predecesores de un autor, a partir de lo cual sería relativamente fácil trazar una línea de pensamiento que diese cabida a los diferentes aspectos que presentan los fragmentos. Focio, en un testimonio que nos hemos reservado, define el proemio de Éforo y Teopompo en los

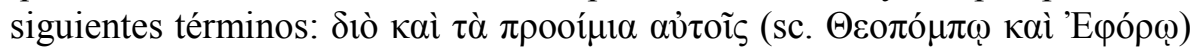

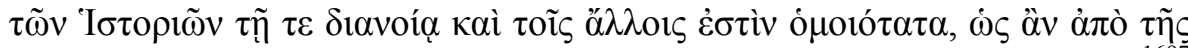

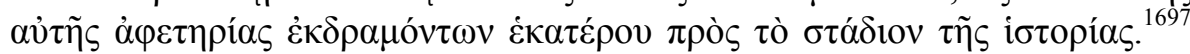
Este pasaje da una clara idea del concepto de evolución lineal del que estamos hablando, al tiempo de que nos informa de la fuerte semejanza existente entre ambos proemios.

Delimitada de este modo una primera sección, la polémica o exaltación de la historiografía, esta derivaría en un análisis y justificación de la grandeza del tema a historiar, en conexión con una posible alabanza previa de la historiografía, que se vería así concretada en el tema a tratar, o, en el caso de la crítica, se intentaría superar los defectos enunciados por medio de la redacción de la obra que encabeza el proemio. Con esta sección, además, se empezaría a concretar mucha de la información de importancia para el pensamiento del autor, pero, por desgracia, es realmente escaso lo que conservamos de esta parte. ${ }^{1698}$

Esta idea derivaría una vez más en el propio autor. El historiador daría cuenta de sus cualidades y medios, o incluso de su edad, como señala el

${ }^{1696}$ En este sentido, compárese el comienzo de Virgilio, Eneida, I, 1: «Arma uirumque cano, Troiae qui primus ab oris / Italiam fato profugus Lauiniaque uenit / litora [...]», y Ariosto, Orlando furioso, I, 1: «Las damas, héroes, armas, el decoro, / amor, audaces obras ahora canto / del tiempo en que pasó de África el moro /cruzando el mar...»

${ }^{1697}$ Focio, Biblioteca, Codex 176, $121 \mathrm{a} 30$.

${ }^{1698}$ Sería en estas secciones donde se situaría el contenido de carácter metodológico, cf. Parmeggiani, 2011, p. 86. 
Pseudo Luciano de Aristóbulo, ${ }^{1699}$ todo ello conformando lo que Dionisio de Halicarnaso definirá como à una evolución del segundo proemio tucidídeo. Su aparición en el proemio de la historiografía del siglo IV a. C., en un estado tan avanzado como el que parece apuntar el fragmento de Focio perteneciente al proemio de Teopompo, tiene especial importancia para la confirmación de la historiografía como género.

Finalmente, el proemio se cerraría con una sección dedicada a la configuración estructural de la obra. La gran complejidad y extensión de las obras historiográficas a partir del momento que nos ocupa -pensemos que, por muy variable que sea el tamaño de un libro de un historiador, la obra de Tucídides tiene ocho y la de Teopompo cuarenta- hará necesario, incluso por simples razones ecdóticas, la indicación detallada de la estructura de la obra para su perfecta comprensión y organización material. ${ }^{1700}$

Con todo ello, creemos que aproximadamente hemos indicado el que podría ser uno de los proemios habituales en esta época. La aparición de elementos que responden a secciones a lo largo de la cronología que nos ocupa -los autores examinados van desde la época de Isócrates hasta después de la aventura de Alejandro Magno- parece confirmar la consolidación de una estructura que, por otra parte, no dista mucho de lo que encontraremos en los autores posteriores. Creemos que ello es así porque la evolución de la prosa y de la técnica literaria alcanzará en esta época un grado de estabilidad que, a grandes rasgos, se mantendrá hasta el final de la Antigüedad. Por esta razón es crucial la imagen que el proemio presenta en esta época:

1) Comienzo.

Seguramente, empleo de una construcción sintácticamente compleja. Cf. e. g. Dionisio de Halicarnaso, I 1, 1; Polibio, I 1, 1; Demóstenes, Sobre la corona, 1.

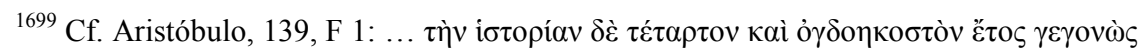

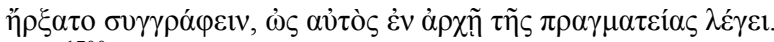

${ }^{1700}$ Cf. Parmeggiani, 2011, p. 81 y ss. Damos un esquema mucho más general que el propuesto, en lo que a contenido se refiere, por el autor en p. 147, que Parmeggiani centra, claro está, en Éforo. 
Como sección central de esta primera parte, crítica de los predecesores o alabanza de la historiografía.

Fragmentos: Éforo, F 8; Calístenes, F 44; Duris, F 1.

Testimonios: Teopompo F 24 .

2) Tema

El pensamiento iniciado en la sección anterior derivaría en el análisis del tema escogido para historiar, sea por sus posibilidades para superar los defectos de los predecesores, sea por ser adecuado para demostrar la valía del género historiográfico.

Fragmentos: Éforo, F 9 y Teopompo, F 27.

3) Autor

La labor historiográfica requiere de una especialización importante, que se verifica en las cualidades biográficas del autor.

Fragmentos: [Éforo, F 110] Teopompo, F 25; F 110.

Testimonios: Teopompo, F 24; F 26. Aristóbulo, F 1.

\section{4) Estructura}

La complejidad creciente de las obras hace necesario un examen previo y organizado del contenido y de la estructuración general de la obra. Cf. e. g. Diodoro, I 4, 6; Polibio, I 3, 1.

Fragmentos: Teopompo, F 381.

\subsection{Timeo de Tauromenio y los proemios menores}

Reservamos para el final de nuestra exposición a Timeo, del cual conservamos el único fragmento proemial de los autores que nos ocupan que no pertenece al proemio general de la obra, sino al del libro VI. Sabemos que este uso fue iniciado por Éforo en lo que fue una de las rupturas más importantes de la historiografía de la época, propiciada por la extensión de 
las obras. ${ }^{1701}$ La redacción de la obra de Éforo $\kappa \alpha \tau \grave{\alpha} \gamma \varepsilon \dot{v}$ os es un asunto de difícil solución, que ha sido entendido como referido a la redacción de la narración en torno a un tema central, idea derivada de la consideración del proemio al libro XVI de Diodoro como procedente de Éforo; ${ }^{1702}$ a una narración episódica ${ }^{1703}$ o a la agrupación geográfica de los acontecimientos. ${ }^{1704}$ Sin embargo, Drews en un examen de la evidencia, apoyándose en Diodoro, quien nos transmite esta información, apunta la idea

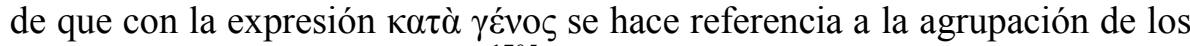

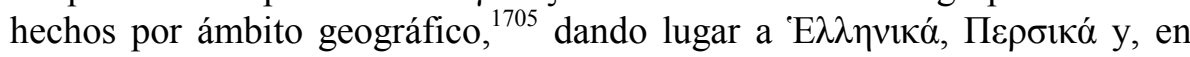
definitiva, a la inclusión de los diferentes pueblos y sus $\pi \rho \alpha ́ \xi \varepsilon 1 \zeta$ según el ritmo con el que entraban en contacto con los griegos. ${ }^{1706}$ Es innegable que con este planteamiento se actúa con un apriorismo vinculado con la idea de historiografía universal y la paternidad comúnmente atribuida de este tipo de historia a Éforo. ${ }^{1707}$

Sin embargo, la evidencia parece apuntar en otra dirección. En puridad,

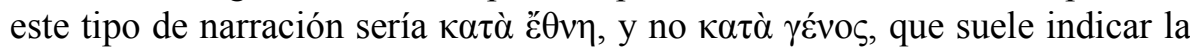

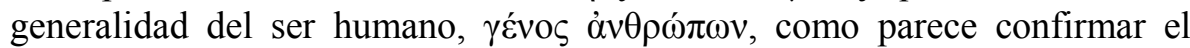
propio proemio. ${ }^{1708}$ De este modo, $\gamma \varepsilon ́ v o \varsigma$ tendría un significado ligeramente menos preciso que $\ddot{\varepsilon} \theta \mathrm{v \eta}$, lo que apoya la idea de Vanicelli, que, retomando la muy peligrosa evidencia de Diodoro como transmisor de Éforo, afirmaba

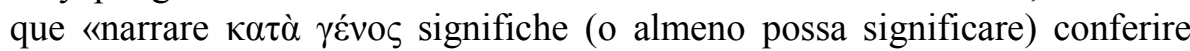
unità alla storia di un periodo ponendo in evidenza un tema centrale». ${ }^{1709}$ Los datos recogidos por el propio autor parecen, más bien, negar la idea de que sea posible hablar de organización geográfica, y sugiere una organización de

\footnotetext{
${ }^{1701}$ Para un análisis del número de libros de la obra de Timeo, cf. de Sanctis, 1957, p. 47.

${ }^{1702}$ Cf. Drews, 1963, p. 251.

${ }^{1703}$ Cf. Vanicelli, 1987, p. 170 y ss.

${ }^{1704}$ Cf. Vanicelli, 1987, p. 168 y ss.

${ }^{1705}$ Cf. Drews, 1963, p. 252.

${ }^{1706}$ Cf. Barber, 1935, p. 47, es decir, el mismo mecanismo presente en Heródoto.

${ }^{1707}$ Cf. e. g. Büdinger, 1895, p. 32. Esta idea, como señala Büdinger, p. 35, depende de las afirmaciones de Polibio al respecto.

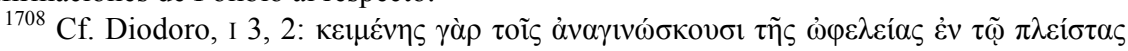

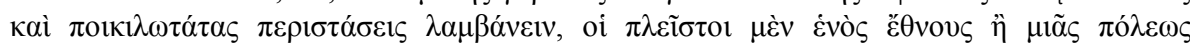

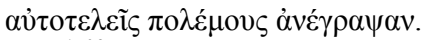

${ }^{1709}$ Cf. Vanicelli, 1987, p. 182. 
grandes temas que podrían, lógicamente, estar relacionados con las principales figuras de cada periodo. ${ }^{1710}$

Más allá de estas consideraciones, condenadas a no salir de la especulación, el propio Drews advertía de que este tipo de narración requería pausas entre unos libros que no solo acogían grandes extensiones de texto, sino temas muy diversos. ${ }^{1711}$ Ello determina necesariamente un cambio de perspectiva en lo que se refiere a la concepción no solo del proemio, sino de la totalidad de la obra.

Hemos señalado antes cómo el material heredado de los dos proemios tucidídeos era refundido y recogido en el proemio inicial general con un sentimiento claro de tradición, y no de funcionalidad de los diferentes elementos. El hecho hace que este proemio asuma ya de manera clara una función literaria total y unificada, que pase de ser un elemento inceptivo polémico, como ocurría en Tucídides, a ser una realidad, una sección literaria.

Este breve adelanto de las conclusiones de la presente sección nos ha de permitir valorar en su justa medida la funcionalidad de los posibles proemios parciales, habitualmente ignorados. ${ }^{1712} \mathrm{El}$ hecho de que se empiece a sancionar una información clara para el contenido del proemio inicial suscita la duda sobre el contenido de los proemios parciales. Hemos defendido la necesaria unidad de pensamiento entre los diferentes proemios no solo de una obra, sino de un autor, y ello hace que en este tipo de proemios se desarrolle de manera ejemplificada el pensamiento general recogido en el proemio inicial.

Así, el fragmento que nos ocupa, F 7, transmitido por Polibio, XII 28, 8, tiene como contenido reflexiones sobre el quehacer historiográfico, en concreto sobre la supremacía de la historiografía sobre la retórica, tema ya conocido por los proemios generales: ${ }^{1713}$

1710 Cf. Vanicelli, 1987, p. 182, con un cuadro que resume sus conclusiones. Parmeggiani, 2011, p. 178 y ss., abre el espectro de esos criterios organizativos con, a nuestro entender, buen tino.

${ }^{1711}$ Cf. Drews, 1963, p. 253.

1712 E. g. Lieberich, 1899, los excluye.

1713 «Y es que en el proemio al libro sexto dice que algunos sospechan que el género de los discursos epidícticos requiere de mayor espíritu, amor por el trabajo y preparación que el histórico. Dice que estas opiniones recayeron antes en Éforo, pero que, dado que no pudo salir al paso de manera correcta ante quienes defendían estas ideas, trataba por su parte de 


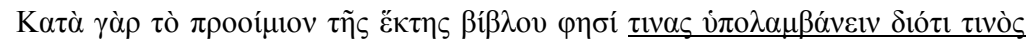

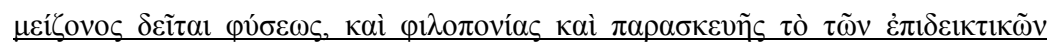

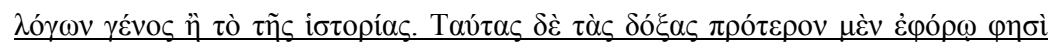

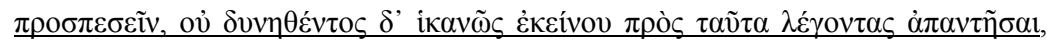

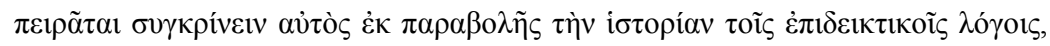

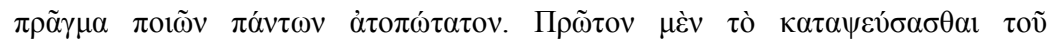

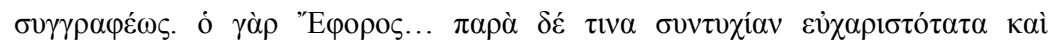

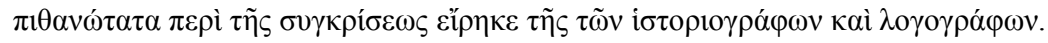

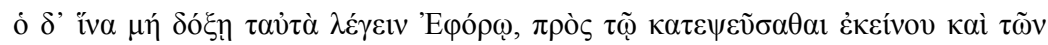

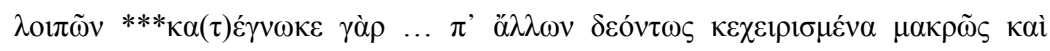

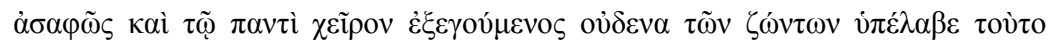

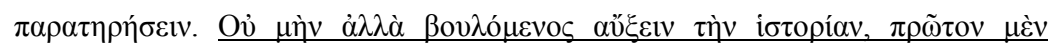

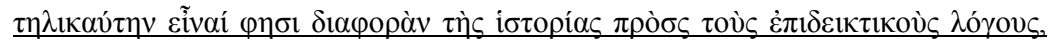

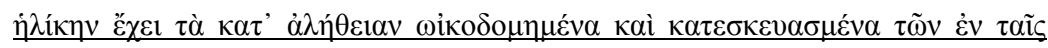

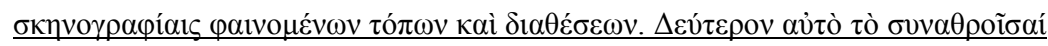

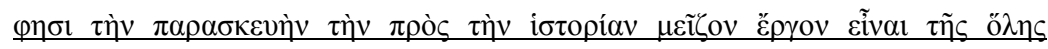

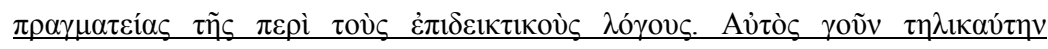

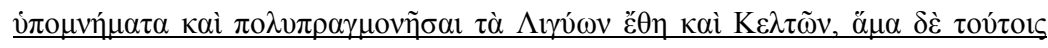

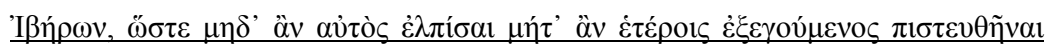

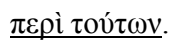

En este largo fragmento tenemos combinadas las palabras de Timeo, las del propio Polibio, e incluso parte del texto que el megalopolitano tuvo delante a la hora de valorar las palabras de Timeo, texto que bien pudo ser un pasaje cercano al fragmento $\mathrm{F} 8$ de Éforo antes visto, o el desarrollo de esas ideas en un posible proemio menor. ${ }^{1714}$ Sea como fuere, Polibio nos

comparar la historia con los discursos epidícticos, llevando a cabo la más extraña de las acciones. En primer lugar está el decir falsedades sobre el historiador. Pues Éforo... por cierta coyuntura había aducido muy gratas y persuasivas razones sobre la comparación entre los historiadores y los oradores. Pero este, para que no pareciera que decía lo mismo que Éforo, al decir falsedades contra aquel también de los restantes... Pues consideró... que aunque desarrollara temas que otros habían tratado correctamente de manera extensa a la ligera y por completo peor, sospechó que ninguno de los vivos se daría cuenta de ello. Y es que, queriendo ensalzar la historia, en primer lugar dice que existe tanta diferencia entre la historia y los discursos epidícticos como hay entre los acontecimientos cimentados y desarrollados según la verdad y los lugares y situaciones que se muestran en las representaciones teatrales».

${ }^{1714}$ Cf. Jacoby, FGrHist, II C, Komm., p. 64. 
transmite una información muy valiosa sobre la que parece ser una polémica entre Timeo y Éforo en un proemio menor que desarrolla ideas de un proemio general. Ello viene a confirmar la idea ya apuntada de la naturaleza complementaria de los proemios menores, lo que tiene un gran interés formal.

Por desgracia, el fragmento transmitido por Polibio, en realidad un testimonio, está lo suficientemente parafraseado como para que únicamente podamos señalar qué decía Timeo (subrayado en el texto), pero no cómo lo decía. A pesar de ello, podemos dar por relativamente seguro que la estructura de estos proemios no necesitaba una fuerte formalización, dado que su dependencia estructural de los proemios generales será, atendiendo a su también dependencia temática, muy elevada. Sea como fuere, la evidencia conservada es realmente escasa, y habremos de esperar al siglo I a. C. para poder observar, en un autor como Diodoro, el funcionamiento de estas estructuras.

Jacoby ${ }^{1715}$ avanzó la idea de que era importante considerar el contenido de este proemio en relación precisamente con su posición en la obra. Con el

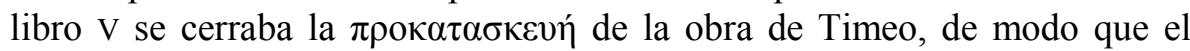
tratar la importancia de la historiografía frente a otros géneros -aspecto que hemos visto que suele ocupar posiciones en el proemio inicial- en esta sección supone delimitar claramente por medio de los proemios esa

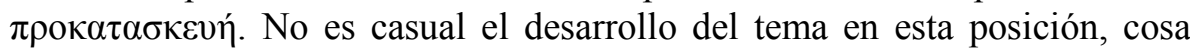
que podremos ver en un autor como Polibio, dado que es un recurso que permitirá retomar la narración tras las secciones introductorias de los diferentes autores, $\mathrm{y}$, en último término, respetar el principio de unidad de ideas a lo largo de los diferentes proemios, unidad que garantizará la de la obra.

\subsection{Hacia un modo de expresión regular: el estilo historiográfico}

Es sencillamente imposible realizar un análisis de estilo de estos autores a partir de lo poco conservado. Pero es fundamental comprender al menos uno de los problemas más complejos que afectan principalmente a Éforo y

${ }^{1715}$ Cf. Jacoby, FGrHist, III B Komm. p. 543. 
Teopompo. La posición de estos dos autores respecto a una posible dependencia de maestro y discípulos con Isócrates pasa simplemente del detalle biográfico al hecho de definición estilística, y con ello, prácticamente, a la definición de toda la prosa posterior.

Para empezar, no se puede negar el absoluto consenso de los testimonios antiguos a este respecto. ${ }^{1716}$ Sin embargo, hemos de ser prudentes en su manejo, principalmente por su clara dependencia de una fuente que parece retrotraerse a la biografía alejandrina, ${ }^{1717}$ cuya poca fiabilidad es conocida, y que en el caso de atribuciones como la presente -tenemos una larga lista de paralelos insostenibles- son debidos en muchos casos a la necesidad de arbitrar medios para garantizar el correcto orden cronológico de los autores.

Nunca se puede llegar a valorar a ciencia cierta la facilidad con que una idea puede extenderse en el mundo antiguo cuando proporciona las suficientes facilidades a las generaciones posteriores para articular el pasado de forma manejable. Pero más allá de los testimonios y de su fiabilidad, fue Eduard Schwartz el responsable del rechazo de esta idea. En el artículo sobre Éforo, el sabio alemán afirmaba: «Die Möglichkeit, dass Ephoros Isokrates gehört hat, lässt sich nicht so bestimmt bestreiten, wie sich die Unmoglichkeit erweisen lasst, dass Theopomp jemals in einem persönlichen Schülerverhältnis zu Isokrates gestanden hat; aber von "Überlieferung" soll man nicht reden: was so aussieht, ist kaum etwas anderes als die Umsetzung eines im grossen und richtigen Stilurteils in eine biographische Tatsache»». ${ }^{1718}$ Schwartz se refería precisamente al F 25 de Teopompo, en el que se dice claramente $\sigma v v \alpha \kappa \mu \alpha ́ \sigma \alpha l$ en referencia a Isócrates, lo que pone en relación a ambos autores pero difícilmente puede indicar una dependencia de maestro y alumno.

Quizá la reacción más significativa contra esta idea fue la tesis de Kalischek, quien defendió esa dependencia con un estudio de los aspectos formales que caracterizan los fragmentos de Éforo y Teopompo. Los datos derivados del examen de Kalischek, que en ocasiones parecen poco

${ }^{1716}$ Cf. Barber, 1935, p. 83, y los apartados de testimonia de ambos autores en la colección de Jacoby. Parmeggiani, 2011, p. 35 y ss. señala el detalle no menor de que no tenemos constancia de que los propios historiadores hubieran hecho esa afirmación.

1717 Cf., así, Kalischek, 1913, p. 77, quien habla de Hermipo de Esmirna, autor de una obra sobre los discípulos de Isócrates.

${ }^{1718}$ Schwartz, 1959, p. 3 y ss. Cf. también Schwartz, 1909, p. 495. 
contundentes, ${ }^{1719}$ ponen en relación los usos de recursos literarios presentes en Isócrates y principalmente Teopompo, para concluir que estos recursos provenían de Isócrates. ${ }^{1720} \mathrm{~A}$ nuestro entender, pensar que el uso de parísosis o de homeoteleuta son rasgos que unen a dos autores en relación de dependencia parece poco concluyente, en tanto que los datos relativos al léxico son difícilmente sostenibles tratándose de dos autores que cultivan géneros diferentes y ante el hecho de que hemos perdido prácticamente la totalidad de Éforo y Teopompo. ${ }^{1721}$

Seguramente, estamos ante usos sancionados de la prosa de la época, como vimos que Schwartz indicaba, lo que podría llevarnos a pensar que toda la prosa de la época es cultivada por discípulos de Isocrates. ${ }^{1722}$ Esta idea ha sido recientemente recuperada por Flower $^{1723}$ y, ante la escasez de elementos de juicio, parece ganar peso. Y ello es así por el hecho de que la afirmación de esa dependencia no hace otra cosa que lastrar nuestro conocimiento de la evolución de la prosa en la época y dotarnos de un inservible aparato de referencias que a ciencia cierta solo remonta a Cicerón. ${ }^{1724}$

Gracias a los avances en el estudio de la conformación de la prosa y de la evolución de la lengua griega en este periodo, podemos asumir con una mayor perspectiva la realidad de la prosa de estos autores. El proceso iniciado con Tucídides supuso la creación de una prosa flexible y cómoda para la expresión de temas muy diversos, adecuada a la caraterística $\pi 0 \lambda v \mu \alpha \theta i ́ \alpha$ de los autores de la época. Más que pensar en la habitual y poco

${ }^{1719}$ Dejamos atrás el controvertido tema del hiato, que creemos imposible de analizar en todos los textos y en especial en el caso de autores fragmentarios. Cf. Kalischek, 1913, p. 33 y ss., para datos poco conclusivos.

${ }^{1720}$ Cf. Kalischek, 1913, p. 54.

${ }^{1721}$ Cf. Kalischek, 1913, pp. 55 y 73, quien no puede defender una dependencia en este sentido, hecho que justifica por la condición de extranjero de Teopompo y los múltiples viajes. La idea de reinterpretar los viajes de Teopompo como una reforma de la tradición viajera de Heródoto y Tucídides por parte de Marincola, 1985, p. 67, nos parece demasiado forzada.

${ }^{1722}$ Cf. la afirmación extrema del propio Schwartz, 1909, p. 491: «Ephoros, Kallisthenes und Theopomp setzen alle drei die Ausbildung der Kunstprosa durch Isokrates voraus [...]»

${ }^{1723}$ Cf. Flower, 1997, p. 44: «Schwartz [...] rejected the tradition that Ephorus and Theopompus had been students of Isocrates and suggested that Hellenistic biographers and literary critics had invented the relationship because the historians wrote in the same prose style as Isocrates».

${ }^{1724}$ Cosa habitualmente olvidada por una crítica demasiado acostumbrada a indagar en los orígenes de esta tradición y que muy oportunamente recuerda Flower, 1997, p. 43. 
productiva ${ }^{1725}$ idea de que los autores de este periodo se inician en el ámbito retórico para después pasar a la historiografía llevando consigo todo el bagaje propio de este primer género, parece razonable considerar que no existen rupturas claras en el desarrollo de estos escritores: en definitiva, defender un antes y un después no sólo es artificial, sino que implica desconocer el carácter flexible de la prosa de la época. La consecución de unos patrones estables de expresión a nivel de periodo que permitieran la expresión fácil de pensamientos complejos es ya una realidad que regula toda la prosa del periodo. Que la ambivalencia de Isócrates y su versatilidad es un modelo a imitar es una realidad que ni tan siquiera Flower se atreve a negar. ${ }^{1726}$

En este sentido, y recurriendo necesariamente a más fragmentos que los atribuidos a los proemios, observamos la aparición de niveles de parataxis en sistemas causales-explicativos, con el empleo de la muy habitual partícula

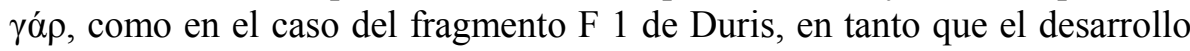
de niveles de complejidad sintáctica no alcanza grados de excesiva importancia, como ejemplifica el fragmento F 9 de Éforo. ${ }^{172}$

En el caso de Teopompo, no disponemos de ningún fragmento que refleje las palabras exactas del autor, por lo que tendremos que adentrarnos únicamente en la valoración de los fragmentos pertenecientes al cuerpo de las Filípicas. En lo que se refiere a las Helénicas, creemos que hemos de actuar con gran prudencia, por cuanto podemos estar ante una obra cuyo estilo sea deliberadamente sencillo y mecánico, cercano al de los comentarii, como parece ilustrar bien el fragmento F 13:

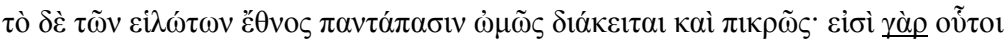

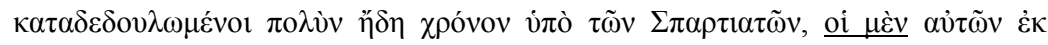

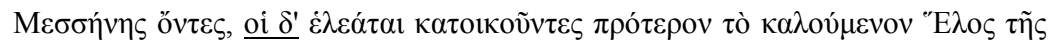
$\Lambda \alpha \kappa o v i \kappa \tilde{\eta} \varsigma$.

${ }^{1725}$ El propio Flower, 1997, p. 42, fue rotundo al afirmar: «The orthodoxy that fourthcentury historiography became corrupted and biased by historians who were also rhetoricians is more often asserted than demonstrated».

${ }^{1726}$ Cf. Flower, 1997, p. 47.

1727 Todo ello dentro de la lógica gradación del empleo de los recursos, como indica Parmeggiani, 2011, p. 135. 
El fragmento F 20, perteneciente al elogio de Lisandro, ejemplifica un modo simple y aséptico de retrato que, no obstante, no tiene que ver con el

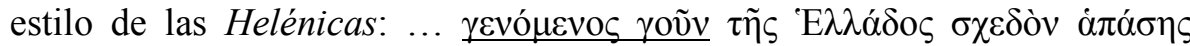

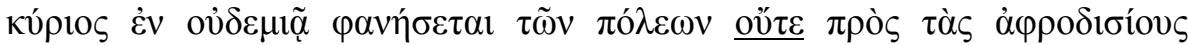

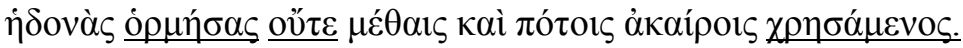

Sea como fuere, los fragmentos de las Filípicas nos permiten ver el desarrollo de un estilo más complejo en cuanto entran en juego las reflexiones del autor, como, por ejemplo, el caso del fragmento F 30 :

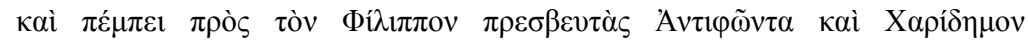

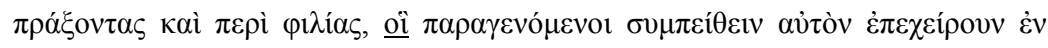

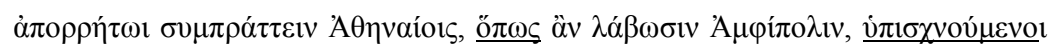

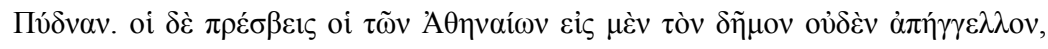

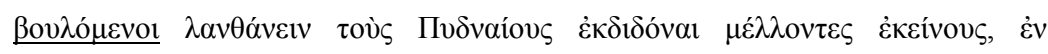

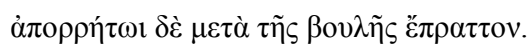

Este pasaje ejemplifica un buen caso de complejidad sintáctica moderada, basada en la introducción de las valoraciones del autor sobre el acontecimiento. Del mismo modo, el fragmento F 88 representa un buen ejemplo de cierta complejidad en secciones evidentemente narrativas:

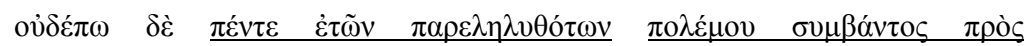

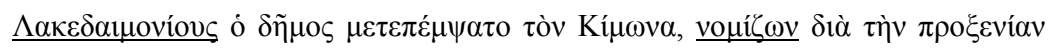

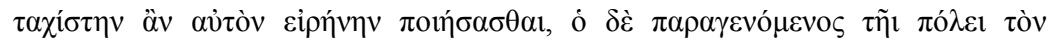
$\pi \hat{\lambda} \varepsilon \mu \mathrm{ov} \kappa \alpha \tau \varepsilon \dot{\lambda} \nu \sigma \varepsilon$.

Interesante también es el examen de un fragmento perteneciente al famoso excurso sobre los demagogos, relativo a Cimón, que permite ver un modelo más complejo de desarrollo de un retrato en acción, en un ejemplo a medio camino entre el fragmento anterior y el antes referido acerca de Lisandro (F 89): 


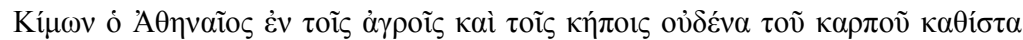

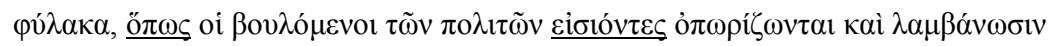

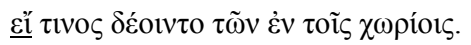

Fundamental es, a nuestro entender, el desarrollo del retrato de Nicóstrato, de una complejidad moderada pero de una elaboración retórica que lo acerca a los tonos isocrateos (F 124):

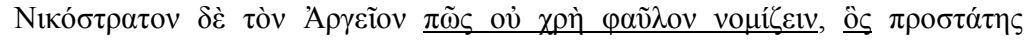

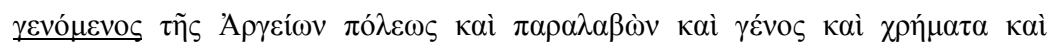

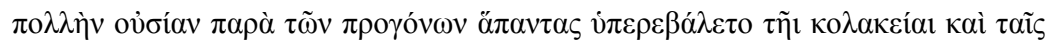

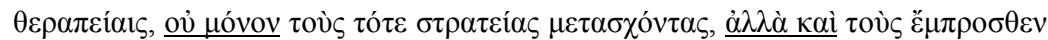

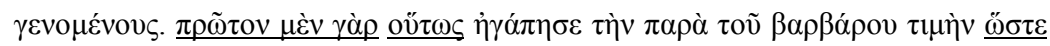

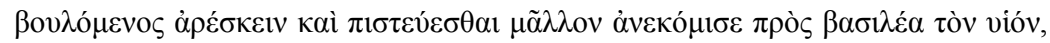

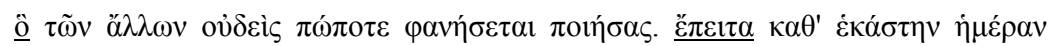

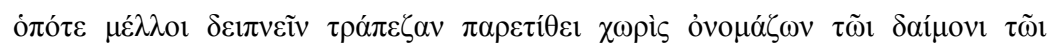

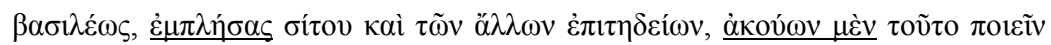

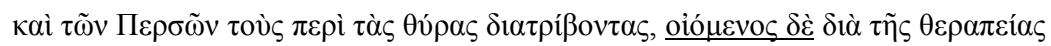

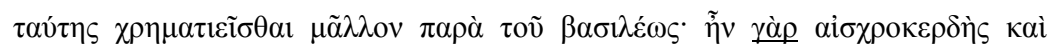

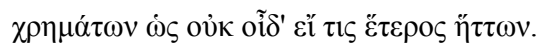

Este largo fragmento es un excelente ejemplo de una prosa normalizada y compleja que seguramente sería característica de los niveles estilísticos más elevados de Teopompo, y quizá no sea demasiado arriesgado suponer que el proemio presentaría un tono parecido al que podemos observar en este pasaje. Ha de notarse la presencia de estructuras paralelas, con el empleo de

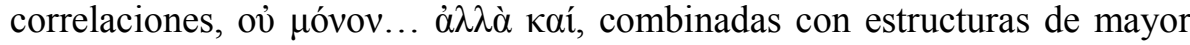
complejidad, como el empleo de oraciones subordinadas de gran extensión gracias al uso de participios, o el uso de estructuras trimembres, $\dot{\varepsilon} \mu \pi \lambda \eta \dot{\sigma} \sigma \alpha \varsigma .$.

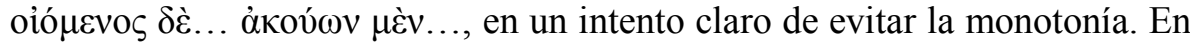
líneas generales, es un texto complejo y de aspiraciones literarias, que muestra lo que va a ser una constante habitual en los proemios historiográficos en adelante.

Así, se busca un grado de complejidad no excesivo que permita una expresión de un contenido medianamente sofisticado con el empleo de 
recursos literarios en un grado tal que suponga una elevación literaria del texto pero sin caer en el exceso.

El fragmento proemial de Duris, aun en su brevedad, nos permite ver algunos de esos rasgos. Así, en la segunda mitad del mismo leemos: ov̌ $\tau \varepsilon$

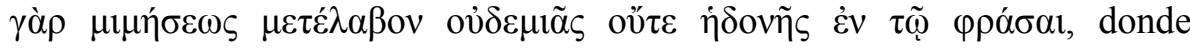
podemos observar la ruptura del posible esquema paralelo por medio de la prolongación de un segundo miembro gracias al infinitivo y la pérdida de un elemento además del consabido verbo.

Quizá el ejemplo más característico de lo que decimos lo presente el fragmento F 9 de Éforo. En él tenemos presente esa dualidad entre regularidad estructural de cuño tradicional, con los paralelismos correlativos que observamos en Heródoto, y la ruptura artística de las tediosas equivalencias exactas entre los miembros paralelos: la desaparición de un adverbio, la prolongación de un sintagma por la adición de otro más, la inversión del orden del núcleo y su adjetivo, o la sustitución de este último por un genitivo son usos generalizados que podemos observar una vez superada tanto la dependencia de los modelos tradicionales de prosa como los excesos fruto de la experimentación de finales del siglo $\mathrm{V}$ a. C.

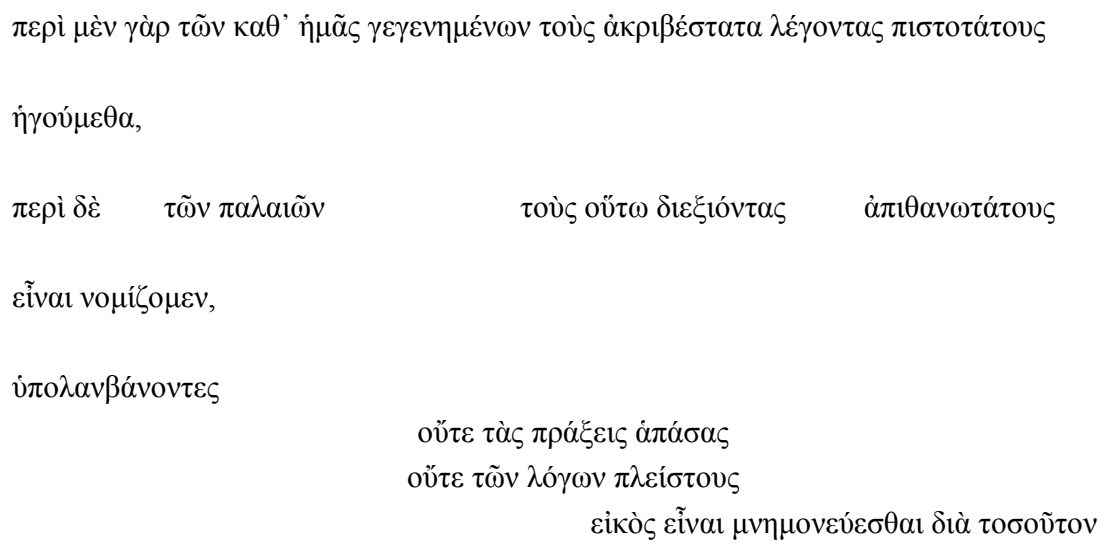

A pesar de lo poco conservado, creemos que la imagen general de los usos del periodo es en gran medida clara. Los rasgos señalados no apuntan tanto a una dependencia de Isócrates como al diseño natural de la prosa tras los fuertes cambios producidos desde finales del siglo $\mathrm{V}$ a. C. El progresivo 
abandono de los esquemas tradicionales dio lugar a un modo mixto de prosa, en la que la convivencia de elementos tradicionales y pertenecientes a estados en los que no eran necesarios esos recursos se combinan de manera clara. Hemos de asumir que todos los rasgos comentados en los autores que nos ocupan no son una novedad en la prosa griega, sino que estamos, simplemente, ante una reorganización de estructuras y usos tan viejos como la misma literatura griega,${ }^{1728}$ lo que hace que ya Blass combinara en la definición del estilo teopompeo un rasgo de Isócrates, como la preocupación por el hiato, y otro propio de Gorgias, sus famosas figuras. ${ }^{1729}$ Lo que Blass $^{1730}$ definiera como un proceso de corrupción de la retórica historiográfica a lo largo del siglo IV a. C. es seguramente tan solo la evolución de la prosa hacia unos usos normalizados que poco tienen que ver con lo que encontramos en Tucídides. ${ }^{1731}$ No hemos de olvidar que mucho de lo que sabemos del estilo de estos autores depende de los testimonios de Dionisio de Halicarnaso al respecto, que se mueve dentro de un proceso de reacción contra Tucídides, pero que también reacciona contra usos de estos autores, dueños de un estilo quizá excesivamente regular.

Que en este sentido Isócrates desempeña un papel fundamental es algo innegable si tenemos presente que lo hace no como padre académico de la prosa griega, sino como modelo de un modo de escribir dotado de $\mu \varepsilon \sigma o \tau$ ŕs y de una regularidad ${ }^{1732}$ que hace que mucho de ese modo estilístico esté necesariamente presente en la producción isocratea, ${ }^{1733}$ dotada de una regularidad aplastante. Esto explica los rasgos demosténicos vistos ya por

1728 En este sentido, es curioso cómo Norden, 1958, p. 121 y ss., tras afirmar la dependencia de Éforo y Teopompo de las enseñanzas isocrateas, presenta un bloque conformado por «Gorgias-Isokrates».

${ }^{1729}$ Cf. Blass, 1892, II, p. 419, siguiendo el testimonio de Dionisio de Halicarnaso, Carta

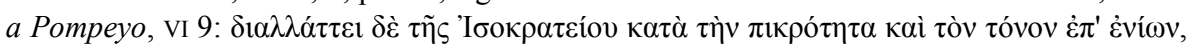

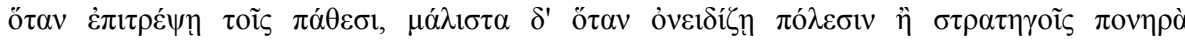

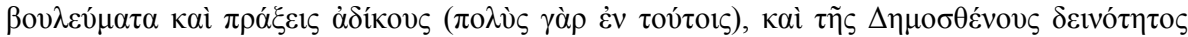

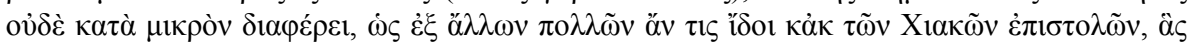

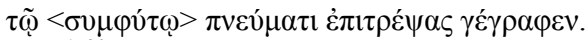

${ }^{1730}$ Cf. Blass, 1892, II, p. 440.

${ }^{1731}$ Que terminarán por igualar los estilos de la retórica al uso y los de la oratoria, lo que no significa que el empleo de frase periódica y paralelismos implique que la historiografía dependa estilísticamente de la oratoria, como quería e. g. Pédech, 1989, p. 244.

1732 Cf. Cole, 1991, p. 120.

${ }^{1733}$ En cierta manera, Barber, 1935 , p. 75, parecía apuntar a este idea al considerar que la influencia isocrática se extendía a unos límites mayores de los habitualmente señalados. 
Norden ${ }^{1734}$ en Teopompo, referidos al $\tilde{\eta} \theta 0 \varsigma$, pero materializados en empleos de léxico y frase, ${ }^{1735}$ con la aplicación de compuestos $^{1736}$ y de léxico que, a tenor de lo que muestran los fragmentos, debía tener una riqueza considerable. ${ }^{1737}$

\subsection{Crátipo}

Desde el artículo de Eduard Schwartz sobre Crátipo, se consideraba que las afirmaciones del autor que permitían determinar su cronología eran simplemente falsas. El propio Crátipo afirmaría su contemporaneidad con Tucídides, y ello sería una falsedad premeditada para buscar una mayor legitimidad para continuar la obra de Tucídides. ${ }^{1738}$ Esta afirmación sería desmentida por los rasgos estilísticos de la obra de Crátipo, con la particularidad no menor de que se tomaban las Helénicas de Oxirrinco como obra cratipea para la definición de los rasgos estilísticos: ${ }^{1739}$ «Er ist also als Fälscher entlarvt, der durch die Maske eines Zeitgenossen seinem Elaborat Ansehen verschaffen wollte». ${ }^{170}$

Más allá de esta afirmación de resabios decimonónicos, lo importante es asumir la presencia del proemio de Crátipo en el panorama de la historiografía del siglo IV a. C. Si Crátipo fue uno de los continuadores de la obra tucidídea, cosa innegable, hay que preguntarse el porqué de la presencia de un proemio en su obra, aspecto en el que también hay consenso. ${ }^{1741}$ Es fundamental determinar la posición de este autor y este proemio en el marco cronológico, y tratar de razonar la naturaleza del mismo y de su obra.

${ }^{1734}$ Cf. Norden, 1958, p. 122.

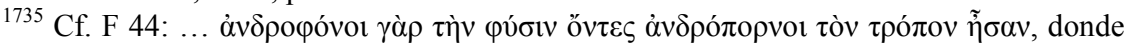
la fuerza del $\tilde{\eta} \theta$ o $\varsigma$ «demosténico» es innegable, como también es innegable su combinación con recursos del conglomerado Gorgias-Isokrates.

${ }^{1736}$ Cf. Blass, 1892, II, p. 436.

${ }^{1737}$ Cf. Pédech, 1989, p. 243.

${ }^{1738}$ Cf. Schwartz, 1909, p. 497.

${ }^{1739}$ Cf. Schwartz, 1909, p. 497.

${ }^{1740}$ Cf. Schwartz, 1909, p. 500.

${ }^{1741}$ Cf. Jacoby, FGrHist, II C, Komm., p. 2. 
La primera consideración a tener en cuenta es que no disponemos siquiera de un fragmento claro; solo existe una referencia de Dionisio de Halicarnaso que presumiblemente no fue realizada con el texto de Crátipo presente, es decir, que no se trata siquiera de una paráfrasis, repartida entre los fragmentos F 1 y 2. La información que nos transmiten estos dos textos, el primero y más importante perteneciente a Dionisio de Halicarnaso, y el segundo a la Vita Marcellini, se reduce básicamente a Tucídides y a los problemas de composición de la obra del de Óloro.

Es curioso observar cómo el gran sistematizador de la historiografía antigua que fue Diodoro no lo recoge en la nómina de los continuadores de Tucídides, cosa que señaló Jacoby, ${ }^{1742}$ lo que abre la puerta, teniendo presente la incompatibilidad entre proemio y continuación de Tucídides, a dos posibilidades: o que la obra no tuviese proemio, o que teniéndolo no fuese una continuación en el modo conocido, lo que conlleva necesariamente dos posibilidades: o que se tratase de un modo diferente de redactar Helénicas, o que estemos ante unas Helénicas tardías, como querían Schwartz y Jacoby.

El texto de Dionisio de Halicarnaso nos pone ante un debate sobre la actividad literaria del propio Tucídides que presenta no pocas complejidades cronológicas:

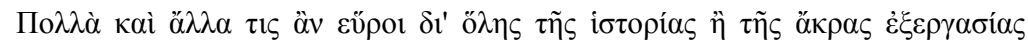

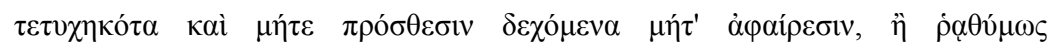

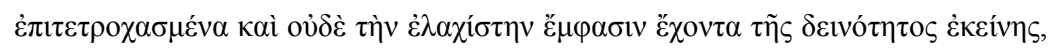

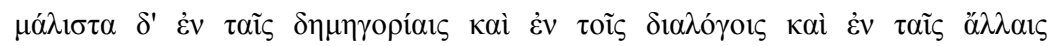

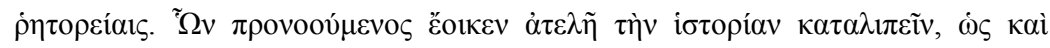

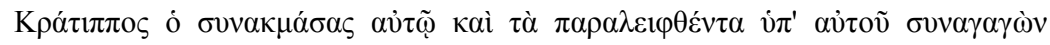

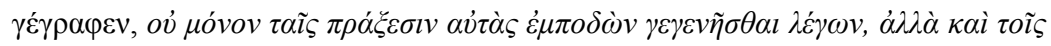

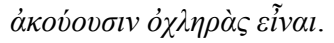

(Sobre Tucídides, XVI).

En contra de la opinión de Schwartz, ${ }^{1743}$ Gomme ya señaló que en ningún momento se habla de proemio, ${ }^{174} \mathrm{y}$ puso en claro que no tenemos seguramente mayor campo de actuación que hacer caso a los testimonios a

${ }^{1742}$ Cf. Jacoby, 1950, p. 6, quien señala que tampoco aparece en Dídimo.

${ }^{1743}$ Cf. Schwartz, 1909, p. 497.

${ }^{1744}$ Cf. Gomme, 1954a, p. 54 y s. 
nuestra disposición, o caer en la simple especulación. ${ }^{1745} \mathrm{Y}$ en este sentido un buen ejemplo fue la tesis de Stahl, ${ }^{1746}$ en la que defendió una cronología para Crátipo que nos llevaba ni más ni menos que a una contemporaneidad con el propio Dionisio de Halicarnaso, modificando el texto antes reseñado para poder leer ó $\sigma v v \alpha \kappa \mu \alpha ́ \sigma \alpha \varsigma<\sigma o l>\alpha v i \tau \tilde{\varphi}$, lo que situaba a Crátipo en la fiebre tucidídea de época de Augusto.

A nuestro entender, es quizá la evidencia interna la que puede permitir discernir lo que tenemos ante nuestros ojos. La afirmación de Gomme acerca de la posible no ubicación de esas afirmaciones en un proemio debe tenerse presente, aunque, en una redacción en la que no ha de haber obstáculo alguno para el lector, parece difícil ubicar una suerte de disertación erudita sobre la obra de Tucídides y sus discursos ${ }^{1747}$ en una situación semejante a la que presentan los juicios sobre Hecateo y Helánico en los dos historiadores del siglo V a. C., como quería Gomme, por lo que, considerando, además, que el sentido de lo afirmado requiere una posición inicial dentro de la obra de Crátipo, parece segura su naturaleza de proemio.

El carácter emulativo de las Helénicas es algo innegable, y parece realmente complicado -y más teniendo presente la significación que venimos observando en los proemios- pensar que en un momento de contemporaneidad con Tucídides se pudiera redactar un proemio en esos términos, cuya crítica literaria exige un desarrollo del género que es, simplemente, inexistente en época del de Óloro.

Si a tenor de esto último nos situamos en un marco necesariamente posterior, hemos de enfrentarnos al hecho de contemplar una obra historiográfica sin discursos. Pédech encontró en este aspecto un grave problema para ubicar cronológicamente a Crátipo, ${ }^{1748}$ pero, a nuestro entender, este no es tanto un problema -un historiador sin discursos y

${ }^{1745}$ Cf. Gomme, 1954a, p. 55.

${ }^{1746}$ Fácil acceso a esta teoría en Stahl, 1891, p. 32 y ss.

1747 Tema más que debatido y que se resuelve únicamente por medio de la mayor o menor credibilidad que se le otorgue no a Dionisio, sino al desconocido Crátipo, cf. Pritchett, 1975 , p. 67 y ss.

${ }^{1748}$ Cf. Pédech, 1970 , p. 33. Considerar que las alusiones a la inconveniencia de discursos en la epopeya presentes en la República platónica, 393a y ss., son un buen paralelo es algo simplemente imposible, dado que esta afirmación de Platón se sitúa dentro de un esquema reflexivo complejo y parece, simplemente, un intento de buscar un apoyo para la cronología elegida. 
proemio es difícil de ubicar en cualquier cronología- como una vía para tratar de situarlo.

Crátipo es un autor que continúa la redacción «literaria» de Tucídides, $\tau \grave{\alpha}$

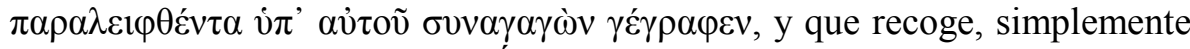

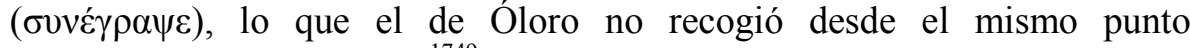
cronológico que Jenofonte, ${ }^{1749}$ pero tomando una perspectiva aparentemente ajena a las tendenciosidades de Jenofonte. ${ }^{1750}$ Es imposible determinar a partir del resumen que nos proporciona Plutarco el contenido de la obra y su posible mayor veracidad frente a Jenofonte, pero de lo que sí se puede tener algún grado de certeza es de que Crátipo abrigaba ciertas aspiraciones literarias, incluso teóricas, en lo que a la historiografía se refiere. Este es un escenario que tiene posible ubicación en el periodo que nos ocupa, pero necesariamente en la segunda mitad del mismo. Crátipo puede pasar perfectamente por un autor del siglo IV a. C., siempre y cuando retrasemos su cronología hasta un momento en el que la falta de discursos pueda ser tomada como un rasgo estilístico intencionado, lo que exige el conocimiento en perspectiva de la obra de Tucídides y del ciclo de Helénicas, lo que hace que como terminus post quem se deba fijar la segunda generación de autores del siglo IV a. C., exactamente el momento en que Calístenes critica a Éforo y a Teopompo.

\subsection{Polis, literatura e historiografía}

Los complicados procesos culturales iniciados en el último cuarto del siglo $\mathrm{V}$ a. C. dieron lugar a una serie de cambios que determinarán, a grandes rasgos, el desarrollo de la literatura a lo largo del siglo IV a. C. y, en lo que a la historiografía se refiere, las pautas tanto formales como reflexivas de los proemios. Aspectos como el individuo y su posición en la sociedad o la reflexión en torno a la obra literaria serán abordados desde una perspectiva de tintes profundamente filosóficos que nos recuerdan que estamos en un periodo en el que la literatura, la filosofía y la erudición van de la mano.

${ }^{1749}$ Cf. Pédech, 1970, p. 37 y ss., para un análisis de este aspecto.

${ }^{1750}$ Cf. Pédech, 1970, p. 42. 


\subsubsection{EDUCACIÓN Y SOCIEDAD}

A pesar de lo complejo de reconstruir el pensamiento de un autor fragmentario, los fragmentos transmitidos de la gran obra de Teopompo, las Filípicas, nos permiten vislumbrar algunas de las tendencias seguidas por la historiografía a lo largo del siglo IV a. C. Una de las grandes líneas puede adivinarse en el fragmento F 27 del quiota, en el que Polibio lamenta la incongruencia de Teopompo al elegir como tema para su obra la figura de Filipo. La crítica moral continuada presente en la obra que nos ocupa ha sido entendida en ocasiones como una característica de tono retórico, que era, por tanto, un buen ejemplo del sistema de laudationes y vituperationes heredado de la primera formación retórica del autor. ${ }^{1751}$ Esta dualidad de orador e historiador es una de las líneas fundamentales de interpretación del autor que creemos ha de ser abandonada. Ya Hirzel en un artículo de gran enjundia defendió que lo que teníamos ante nosotros no era, simplemente, una obra retórica, sino que estábamos ante una obra de tendencias cínicas que tenía mucho que ver con Antístenes. ${ }^{1752}$ La interpretación de los juicios morales representados a lo largo de la obra de Teopompo adquiría así una significación mucho más profunda, de modo que valores tales como la

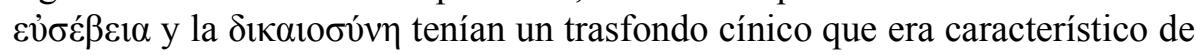
un autor como el citado filósofo.

Murray dio cuenta de que el único filósofo -que sepamos, añadiríamos nosotros- que es alabado por Teopompo es precisamente Antístenes. ${ }^{1753} \mathrm{La}$ edición de los fragmentos del filósofo por Decleva Caizzi ${ }^{1754}$ recoge un fragmento, el 3 Caizzi, que evidencia lo dicho por Murray. Pero, a nuestro entender, la cuestión es mucho más compleja que una simple dependencia sin fisuras de un ideario cínico. ${ }^{1755}$

La elección de la figura de Filipo como personaje central de la obra, figura que, según Pédech, fue el desencadenante último del inicio de la

${ }^{1751}$ Cf., así, Kalischek, 1913, p. 63, quien considera esta una prueba para la tesis isocratea.

${ }^{1752}$ Cf. Hirzel, 1892, p. 361.

${ }^{1753}$ Cf. Murray, 1946, p. 156.

1754 Caizzi, 1966 (citamos los fragmentos por su número seguido del nombre la editora).

1755 En este sentido, Flower, 1997, p. 94, habla ya de influencia, en una terminología mucho más moderada. 
redacción de la obra y determinó su estructura, ${ }^{1756}$ ha de ser entendida en una doble visión, moral y política. Kurt von Fritz apuntaba, ${ }^{1757}$ con los matices necesarios, la fuerte carga política de la historiografía del siglo IV a. C. La propia biografía del autor así como los datos que se desprenden de su obra son buen punto de apoyo para reconstruir, de manera unánime, ${ }^{1758}$ la imagen de un conservador en Teopompo, algo, por otra parte, no nuevo en la historiografía, hecho que además es seguramente el origen de su panhelenismo. El odio a Atenas, ${ }^{1759}$ que compartía con Antístenes, era un acicate más para la búsqueda de un hombre fuerte que garantizase el futuro de Grecia, y ese hombre solo podía ser Filipo. ${ }^{1760}$

Con estas premisas, la valoración de la elección de Filipo como personaje central de la obra adquiere un rango muy diferente. Filipo es un personaje $\delta \varepsilon ı v^{\prime} \varsigma^{1761}$ en el sentido sofocleo del término, de un modo tal que las valoraciones morales, incluso las negativas, que tanto disgustaban a Polibio, adquieren una significación particular en términos políticos. ${ }^{1762} \mathrm{La}$ obra se compone así de un inmenso fresco de individuos, ${ }^{1763}$ caracterizados, como nos indica Dionisio de Halicarnaso, por sus virtudes y sus vicios, ${ }^{1764} \mathrm{si}$ bien la imagen global ha de matizarse, principalmente por la simplicidad de un modelo moral al tiempo más extenso que el propuesto por Tucídides. ${ }^{1765}$ Frente a la valoración de las diferentes polis en juego como simples agentes políticos, Teopompo realiza un análisis de los distintos pueblos involucrados desde una perspectiva plenamente moral en términos modernos: la valoración del comportamiento de las sociedades, desde la misma estructura

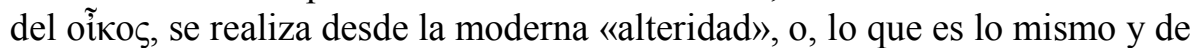
manera más sencilla, explorando la realidad propia por medio de su reflejo en negativo en las restantes sociedades, ${ }^{1766}$ en aras de justificar el estado de

${ }^{1756}$ Cf. Pédech, 1989, p. 65; Shrimpton, 1991, p. 90.

${ }^{1757}$ Cf. von Fritz, 1954, p. 45

${ }^{1758}$ Cf. Pédech, 1989, p. 238; von Fritz, 1954, p. 58.

${ }^{1759}$ Cf. von Fritz, 1954, p. 54.

${ }^{1760}$ Cf. von Fritz, 1954, p. 58 y ss.

${ }^{1761}$ Cf. la propuesta de Chávez Reino, 2009, p. 170, de emplear este concepto para el fondo de la obra de Teopompo.

${ }^{1762}$ Así, Bruce, 1970, p. 94: «Theopompus admired this [sc. de Filipo] political capacity of Philip, but Philip was a man of whose private conduct Theopompus, the austere moralist and admirer of Antisthenes the Cynic, strongly disapproved».

${ }^{1763}$ Así, Pédech, 1989, p. 207 y ss.

${ }^{1764}$ Cf. Pédech, 1989, p. 73, y Dionisio de Halicarnaso, Epístola a Pompeyo, 6 (=T 2).

${ }^{1765}$ Esta relación fue ya indicada por Flower, 1997, p. 82 y ss.

${ }^{1766}$ Cf. Shrimpton, 1991, p. 104 y ss. 
cosas. ${ }^{1767}$ Con este hecho tenemos un avance significativo en la constitución del modelo de análisis de la sociedad que nos lleva más lejos de lo que lo hacía Tucídides. El reflejo no es solo de las cualidades ideales e idealizadas del gobernante y del pueblo en bloque, sino que parece que se desarrolla el funcionamiento de la sociedad desde las mismas relaciones familiares y sociales, llenando uno de los mayores vacíos en la obra de Tucídides. ${ }^{1768}$ Por medio del diseño de opuestos se construye un modelo de valores de carácter fuertemente tradicional que cohesiona la obra y que refleja muy diferentes niveles de la existencia humana. ${ }^{1769}$ Ello se hace recurriendo incluso a narraciones de carácter tradicional ${ }^{1770}$ que nos recuerdan por momentos a Heródoto y a la historia de Creso, ${ }^{1771}$ diseñando así un mundo a medio camino entre la explicación mitológica tradicional y el modelo socráticoplatónico de educación, como el propio autor propone en el proemio. ${ }^{1772}$ Todo ello apunta a una construcción sistemática que aleja a Teopompo de la idea de ser simplemente un moralista, como ya señaló Flower. ${ }^{1773}$

Esta imagen, tal y como se nos presenta, pasaría perfectamente por una historiografía de tintes cínicos, pero para decidir este punto, debemos valorar lo que la tradición nos transmite del propio Antístenes. El filósofo cínico, cuya cronología es quizá muy alta como para influir de manera directa en Teopompo, dado que su fecha de nacimiento se sitúa no más allá del 466 a. C., ${ }^{1774}$ es un personaje a caballo entre ambos siglos, como también lo será, al menos espiritualmente, Platón. ${ }^{1775}$

La imagen que los escasos fragmentos conservados nos permiten reconstruir es lo suficientemente neutra como para poder adaptarse prácticamente a todo modelo moral en boga en la época. Este se sustenta en un ideal de virtud sostenido como un principio que, una vez adquirido, es

${ }^{1767}$ Así, Flower, 1997, p. 66.

1768 Sobre la nula relación de estos aspectos y el estilo de Teopompo, cf. las observaciones de Chávez Reino, 2009, p. 158 y ss., quien propone un claro desajuste en la intensidad del estilo empleado por Teopompo a la hora de reflejar esas críticas.

${ }^{1769}$ Así, Shrimpton, 1991, p. 133.

${ }^{1770}$ Cf. F 344 y Shrimpton, 1991, p. 134 y ss.

${ }^{1771}$ Cf. también Flower, 1997, p. 71.

${ }^{1772}$ Cf. Teopompo, F 381.

${ }^{1773}$ Cf. Flower, 1997, p. 65 y ss.

${ }^{1774}$ Cf. Rankin, 1986, p. 6.

${ }^{1775}$ Cf. Rankin, 1986, p. 1. 
imposible perder. ${ }^{1776}$ Estamos ante la reforma del concepto habitual de virtud que teníamos ya desde tiempos de Simónides y su moral del hombre tetragonal, analizada ya por el propio Sócrates. Sin embargo, esta idea causa un pequeño problema a quienes quieran ver una dependencia absoluta del historiador respecto al filósofo. Ya Pédech creyó advertir un modelo de degeneración moral en la obra de Teopompo en la figura de Cabrias, lo que difícilmente podría adaptarse a un ideario cínico. ${ }^{1777}$

A pesar de esta reticencia, la figura ideal del cínico, Heracles y su lucha por alcanzar la virtud, ${ }^{1778}$ es un modelo que crea ciertamente fisuras en planteamientos quizá menos extremos que los planteados por Sócrates. La virtud es, en definitiva, un concepto todavía de hechos y acciones, ${ }^{1779}$ cosa que se adapta bien a la obra de Teopompo: el testimonio antes citado de Dionisio de Halicarnaso nos confirma que las repetitivas imágenes de crítica moral transmitidas en los fragmentos son una realidad propia de la obra, y que su posición es fundamental a la hora de interpretar el complejo pensamiento de Teopompo.

Hirzel dio cuenta de la fuerte influencia del vocabulario propio de los cínicos en la obra del historiador que nos ocupa ${ }^{1780}$ Posteriormente, Pédech realizó un exhaustivo examen de la terminología moral empleada por Teopompo en sus fragmentos, concluyendo que conceptos como las

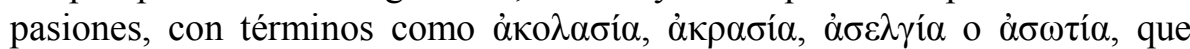
aparecen en Aristóteles y en ocasiones en Jenofonte, ${ }^{1781} \mathrm{o}$ la intemperancia,

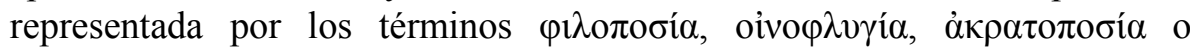

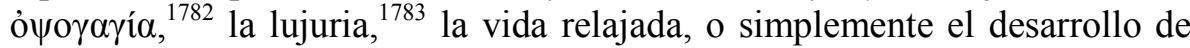
un comportamiento reprensible, tienen una riqueza léxica realmente

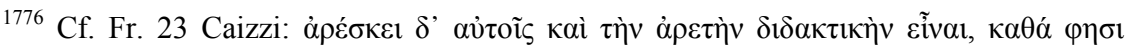

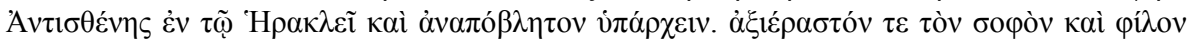
$\tau \tilde{\varphi}$ ó $\mu$ oí $\tau \varepsilon \mu \eta \delta \dot{\varepsilon} v \dot{\varepsilon} \pi \imath \rho \varepsilon \dot{\pi} \varepsilon เ v$.

${ }^{1777}$ Cf. Pédech, 1989, p. 209. Los fragmentos en cuestión serían F 105 y 213.

1778 Cf. Rankin, 1986, p. 101. Para los fragmentos de la obra de Antístenes titulada Heracles, cf. los fragmentos F 22-28 Caizzi.

${ }^{1779}$ Cf. Rankin, 1986, p. 102.

${ }^{1780}$ Cf. Hirzel, 1892, p. 386.

${ }^{1781}$ Cf. para todo ello Pédech, 1989, p. 226.

${ }^{1782}$ Cf. Pédech, 1989, p. 227.

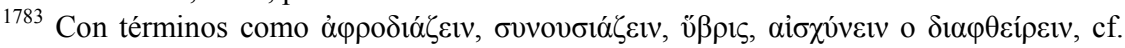
Pédech, 1989, p. 228. 
deslumbrante, aunque una vez más falla la sistematicidad, de modo que pretender crear un modelo filosófico ${ }^{1784}$ sobre este léxico es imposible.

El concepto de $\alpha \kappa \rho \alpha \sigma i ́ \alpha$ fue considerado por Shrimpton ${ }^{1785}$ como uno de los conceptos clave en la obra por su alto índice de aparición en los fragmentos. Lo importante de este concepto es precisamente su carácter en cierta manera neutral, lo que permite considerar, como antes indicábamos, a Filipo como $\delta \varepsilon ı v o ́ \varsigma$, dado que es precisamente esa falta de moderación la que da al traste con las cualidades del estadista. Estamos, pues, ante un modelo moral que poco tiene ya de aristocrático y de platónico. ${ }^{1786}$

Pero quizá donde mejor se manifiesta la complejidad del análisis es en la famosa digresión sobre los demagogos en el libro X de las Filípicas. El análisis seguramente se iniciaba con Temístocles, ${ }^{1787}$ uno de los estadistas privilegiados por Tucídides, que en el caso de Teopompo recibe no pocas críticas, ${ }^{1788}$ en lo que es una tendencia a no hacer separaciones entre los estadistas bien valorados del siglo $\mathrm{V}$ a. C. y los habitualmente tenidos por mediocres, ${ }^{1789}$ extendiendo esta mecánica de análisis hasta los personajes del siglo IV a. C. ${ }^{1790}$ Todo este complejo estudio tiene como hilo conductor, como ya señaló Connor, la capacidad de manipulación del pueblo por parte de los dirigentes. ${ }^{1791}$ La obsesión por los aspectos económicos no esconde, como ocurría con Tucídides, un análisis de los mecanismos de poder, sino de las consecuencias que la gestión del dinero tiene sobre el estado de la población. ${ }^{1792} \mathrm{Y}$ es que la continua gestión de los recursos con vistas a repartirlos entre el $\delta \tilde{\eta} \mu \circ \varsigma$ es la causa de la degeneración moral de la polis y

${ }^{1784}$ Cf. Shrimpton, 1991, p. 134.

${ }^{1785}$ Cf. Shrimpton, 1991, p. 136.

1786 Así, Shrimpton, 1991, p. 139. Sería realmente interesante saber si Teopompo consideraba la $\dot{\alpha} \rho \varepsilon \tau$ como algo enseñable, pero la única aparición del término señalada por Connor, 1968, p. 200, en el fragmento F 25 es incluso de atribución dudosa al autor, dado que es posible que estemos ante las palabras del propio Focio.

${ }^{1787}$ Así opina Connor, 1968, p. 71, quien señala el tiempo posterior a las guerras médicas como un buen arranque para el examen de los demagogos, idea que compartimos y que está en línea con la idealización que sufre esa etapa del pasado griego.

${ }^{1788}$ Cf. F 85, 86 y 87, y Connor, 1968, p. 20 y ss.

${ }^{1789}$ Cf. Connor, 1968, p. 47. En este sentido, es interesante destacar, como hace Flower,

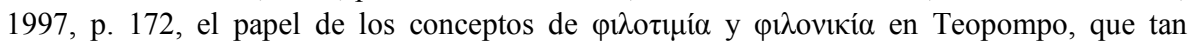
importante función tuvieron en Tucídides.

${ }^{1790}$ Cf. Connor, 1968, p. 65, quien indicaba esta continuidad.

${ }^{1791}$ Cf. Connor, 1968, p. 71: «They were demagogues in both the ancient sense and the modern».

${ }^{1792}$ Cf. Connor, 1968, p. 67 y ss. 
de sus individuos, lo que una vez más insiste en la idea de completar el análisis moral tucidídeo en términos generales y con aplicación a todos los sectores de la vida pública.

Pero pensar que Teopompo solo refleja un universo de decadencia a causa del gusto por el lujo y la $\dot{\alpha} \kappa \rho \alpha \sigma i \alpha^{1793}$ es seguramente confundir la imagen final del proceso con la justificación de la misma. El largo excurso del libro X es quizá una buena prueba de que la situación del momento es solo fruto de la degeneración progresiva del modelo social.

Con todo esto no podemos decir que estemos ante un bosquejo previo de lo que será la biografía, sino que los titubeos encaminados a la definición del individuo iniciados con Sócrates avanzan hasta un punto en el que se consigue, simplemente, la caracterización de las acciones del individuo, permaneciendo ese desarrollo estancado y dando lugar a rasgos particulares en aspectos como la política o la literatura, pero poco más. ${ }^{1794}$

Todo este universo parece tener una independencia claramente delimitada, y más aún si reconocemos que en el caso de Antístenes -aun a pesar de lo poco conservado- no se puede hablar de un sistema ético claramente delimitado, sino de unas pautas, unas líneas maestras a seguir. ${ }^{1795}$ Hemos de asumir una vez más que es necesaria una apertura del espectro de nuestra comprensión, y que, más que ante una corriente abierta y decididamente cínica, nos encontramos ante una obra que refleja mucho de lo que se pensaba en sectores conservadores de la Grecia del siglo IV a. C. Así, si volvemos por un momento a los aspectos puramente políticos de la obra y a la figura de Filipo como gobernante, solo hace falta comparar las palabras de Rankin acerca de Antístenes en este aspecto, ${ }^{1796}$ quien da cuenta de la búsqueda de un príncipe ideal de moral intachable, y la valoración que la elección de Filipo como modelo de salvador de Grecia mereció a Polibio, ${ }^{1797}$ para difícilmente alejar de nosotros el complejo debate que la crisis política que sumió a Grecia en la primera mitad del siglo IV a. C., con nombres como el de Platón o Jenofonte.

\footnotetext{
${ }^{1793}$ Así, Flower, 1997, p. 69.

${ }^{1794}$ Quizá más optimista, Kaerst, 1927, p. 55 y ss.

${ }^{1795}$ Cf. Rankin, 1986, p. 134.

${ }^{1796}$ Cf. Rankin, 1986, p. 135: «The search for a ruler who will possess the virtue and energy not only to save society from itself, but to make it more virtuous, was undoubtely understood by Antisthenes».

${ }^{1797}$ Cf. Pédech, 1989, p. 68 y ss. El pasaje es Polibio, VIII 11, 1 (=F 27). 
En este sentido, la famosa utopía contenida en las Filípicas, definida como el ideal político cínico por Hirzel, ${ }^{1798}$ ha de ser valorada a la vista de la profunda cercanía que existe entre la teoría política de Antístenes y los ideales platónicos del Estado, ${ }^{1799}$ profundamente conservadores y antidemocráticos. $^{1800}$

En este mismo sentido, y en lo que se refiere al empleo de mitos, referido en el fragmento F 381 y considerado por Hirzel como un resabio de su formación retórica ${ }^{1801}$-idea, a nuestro entender, insostenible-, creemos que su justificación ha de situarse en el contexto que estamos tratando de defender. Es verdad que una de las características del estilo de Antístenes era el empleo de $\mu \tilde{v} \theta o$, ${ }^{1802}$ pero también es verdad que el empleo de esos $\mu \tilde{\theta} \theta 0$ เ es, al menos para el lector moderno, patrimonio indiscutible de Platón. ${ }^{1803}$.

También nos lleva a pensar en Platón el fragmento F 8 de Éforo. La crítica a la música que Polibio tampoco entendía es un hecho que responde, al igual que ocurría con Teopompo, a la realidad concreta del tiempo en el que vivía el autor. La trayectoria iniciada por la poesía, y por extensión la música, a finales del siglo $\mathrm{V}$ a. C. apunta a su progresiva vulgarización, con un paulatino abandono de la importancia del aspecto puramente literario de las composiciones, y, con ello, un progresivo deterioro de la función educativa, que tanta importancia había tenido en épocas anteriores. ${ }^{1804} \mathrm{El}$ avance de este tipo de música fue lo que causó una reacción entre las élites ilustradas, que la condenaron, precisamente, por no servir para la educación. Creemos que es en este sentido en el que se ha de interpretar la crítica de Éforo, una más de las muchas reacciones que conservamos ante este tipo de degeneración del sistema cultural tradicional, ${ }^{1805}$ cuyo ejemplo palmario puede verse en el moderado Isócrates: ${ }^{1806}$

\footnotetext{
${ }^{1798}$ Cf. Hirzel, 1892, p. 380.

${ }^{1799}$ Cf. para todo ello Rankin, 1986, p. 142 y ss.

${ }^{1800}$ Cf. Rankin, 1986, p. 139.

${ }^{1801}$ Cf. Hirzel, 1892 , p. 370 y ss.

1802 Cf. Rankin, 1986, p. 151.

${ }^{1803}$ Cf. Droz, 1993, y Reinhardt, 1989b, p. 219 y ss

${ }^{1804}$ Cf. para todo ello West, 1992, p. 356 y ss.

${ }^{1805}$ Cf. para un breve repaso a esas críticas, excluida la de Éforo, West, 1992, p. 369 y ss.

${ }^{1806}$ Isócrates, carta VIII, 4.
} 


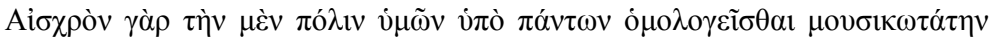

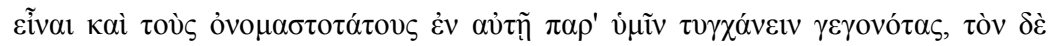

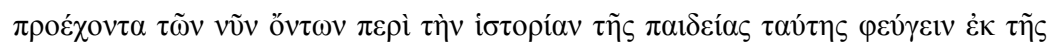

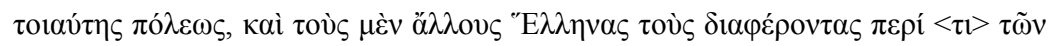

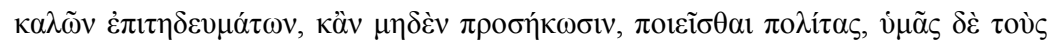

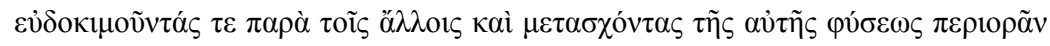

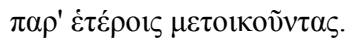

Con todo ello, los proemios de Éforo y Teopompo nos sitúan en las polémicas acerca de la educación y la moral en términos urbanos del siglo IV a. C. Ambos historiadores deberán ser un apartado más de los complejos procesos de reflexión que conocemos gracias a la filosofía de la época, situando, una vez más, al género historiográfico a la vanguardia del análisis de los problemas de índole política y social.

\subsubsection{LA HISTORIOGRAFÍA Y EL HISTORIADOR}

De especial interés es la valoración de las secciones relativas a la vida y formación del autor. ${ }^{1807}$ Ya indicamos, siguiendo a Jacoby, que estamos ante una sección que es, a grandes rasgos, el desarrollo de lo que encontramos en el segundo proemio de Tucídides. Pero la solución que pasa por afirmar que nos hallamos, simplemente, ante el desarrollo de una sección comprometida con la autoafirmación del individuo, iniciada en los ambientes socráticos en los albores del siglo, si bien no falta a la verdad, queda, a nuestro entender, lejos de la complejidad del periodo.

El largo fragmento parafraseado por Focio del proemio de las Filípicas es una detenida exposición sobre la formación de Teopompo, en un sentido claramente general, un curriculum vitae, que a nuestro entender, tiene implicaciones claras para la definición de la historiografía en este periodo. La dualidad orador-historiador de Teopompo, que tantos problemas causó a Hirzel en su definición del universo del historiador, ${ }^{1808}$ creemos que ha de

\footnotetext{
${ }^{1807}$ Que se pueda presentar prácticamente una prosopografía de los autores de la época como hace Meissner, 1992, p. 8 y ss., es buena prueba de esa importancia.

${ }^{1808}$ Cf. Hirzel, 1892, p. 360 y ss. 
ser tenida muy en cuenta, no para abordar una definición retórica de la historiografía, ${ }^{1809}$ sino para entender que las fronteras entre retórica e historia son, en cierta manera, inexistentes, ${ }^{1810}$ ya que una definición canónica de ambos géneros nos puede decir mucho a nosotros, pero, simplemente, no preocupaba a los antiguos. Todavía el concepto de finalidad goza de una fuerte semántica en el periodo que nos ocupa, y la historia y la oratoria $\mathrm{y}$, en último término, la política conforman un todo en el que es difícil trazar límites, y creemos que es desde esta perspectiva desde donde hemos de realizar nuestro análisis.

La famosa controversia acerca de la dependencia de Éforo y Teopompo de Isócrates, que ha dado lugar a la creación de la denominada historiografía retórica, ${ }^{1811}$ parece tener difícil solución. Igual de válidos son los argumentos propuestos a favor y en contra a este respecto, y el importante número de testimonios que nos indican que ambos historiadores fueron alumnos de Isócrates podrían ser concluyentes si no fuera por el hecho de que la cronología hace difícil esa relación, al menos en el caso de Éforo, que es prácticamente un contemporáneo de Isócrates, mientras que el propio Teopompo nos indica que compitió con el orador en los juegos en honor de Mausolo.

Ante esta complicada situación, lo más interesante parece ser tener presente el modo en el que este tipo de relaciones se construían en el imaginario griego. La dependencia de maestro y pupilo en la Antigüedad respondía en ocasiones a la semejanza de las posturas defendidas o, incluso, a la sucesión cronológica de dos autores. Con lo poco hasta ahora visto, parece claro que la función del orador y la del historiador -piénsese, sin ir más lejos, en Isócrates- tienen un punto de encuentro en la actividad pública. La tensión vista en la fuerte carga política de la historiografía del siglo $\mathrm{V}$ a. C. parece tener salida en la nueva deriva política de este periodo. Los ideales isocrateos de una filosofía orientada a una vida virtuosa como resultado de

${ }^{1809}$ Así, Susemihl, 1891, p. 532.

1810 Creemos que la opinión de Pani, 2001, p. 35, de considerar la retórica como un macrogénero es realmente adecuada en términos prácticos.

${ }^{1811}$ Puede verse una interesante y meditada crítica de este concepto, así como su historia en Parmeggiani, 2011, p. 37 y ss. 
una experiencia educativa ${ }^{1812}$ tienen, como indicó Pani, su claro trasunto en

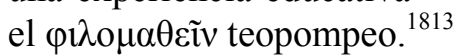

Es, pues, la educación uno de los fundamentos últimos de la preparación del historiador, que concibe su obra como un todo con una finalidad social clara. Resulta curioso comprobar cómo estamos ante una importante evolución en el pensamiento historiográfico antiguo, que solo es posible con el deterioro progresivo de los modelos educativos tradicionales. La figura omnipresente de Platón, el último gran bastión de la educación tradicional, se enfrenta a un grupo de autores prolíficos y dinámicos dotados de un realismo político sin precedentes, que han asumido la inoperatividad de los medios tradicionales de formación educativa de la sociedad. A pasos agigantados se abre camino una nueva figura, de vida efímera, que es la del vir bonus dicendi et docendi peritus, que tratará de copar esa laguna de la sociedad griega.

Es esta la razón por la que defendemos la asignación del fragmento $F$ 342 al proemio, porque, justamente, explica las ideas que estamos exponiendo. El orador no es un simple logógrafo al modo de lo que se puede ver en el siglo $\mathrm{V}$ a. $\mathrm{C}$., sino que adquiere unas dimensiones y unos compromisos que lo sitúan en el epicentro de la actividad política práctica de la comunidad.

Es precisamente en este periodo cuando se dan la mano la falsificación de documentos históricos ${ }^{1814}$ y el empleo sistemático del pasado como campo de trabajo, cosa que ejemplifica extraordinariamente bien Isócrates. ${ }^{1815} \mathrm{La}$ deriva política del primer aspecto y la más puramente educativa del segundo son síntomas evidentes de que la historiografía está adquiriendo progresivamente una funcionalidad clara dentro del complejo mundo social del siglo IV a. C. Como indicaba Kaerst, ${ }^{1816}$ hemos de asumir que el paso del siglo $\mathrm{V}$ al IV a. C. supuso la creación de un público amplio capaz de participar en los debates culturales en boga, y, en lo que a nosotros

1812 Cf. Pani, 2001, p. 65: la filosofía es entendida en este sentido por Isócrates, como «[...] indicativo de una virtuosa e saggia condotta di vita, al vertice quindi di tutta l'esperienza educativa».

${ }^{1813}$ Cf. Pani, 2001, p. 65.

1814 Cf. Welles, 1966, p. 5, quien alerta de este hecho. El trabajo fundamental sigue siendo Habicht, 1961, p. 14 y ss., quien analiza la contextualización del fenómeno.

1815 Cf. Welles, 1966, p. 16 y ss. La defensa de Nouhaud, 1982, p. 358, nos lleva a abogar, por nuestra parte, por una posición intermedia.

${ }^{1816}$ Cf. Kaerst, 1927 , p. 53 y ss. 
nos interesa, eso supone la redefinición de los ambientes que darán cabida al género. Esta, seguramente, es, junto con el paso a un escenario plenamente escrito, una de las razones fundamentales para la aparición de obras de gran extensión, adecuadas para los escenarios de carácter librario y abiertos a un público ligeramente más amplio.

Es precisamente en esta misma línea en la que ha de interpretarse el fragmento F 9 de Éforo. La reflexión sobre el pasado contenida en ese fragmento nos revela la creación de una conciencia clara de la existencia de un ideario historiográfico constituido como tal, y en esto, de nuevo, muchas son las semejanzas con Isócrates. La elección del retorno de los Heráclidas como punto de arranque ${ }^{1817}$ para la obra es, seguramente, un punto que se ha tratado con ligereza y que parece de difícil solución. El pasaje proemial parece hacer una separación clara entre la Zeitgeschichte y la historia mítica, si bien ya Barber alertó de que no estamos hablando, simplemente, de una separación entre periodo mitológico y periodo histórico, sino que es probable que todo dependa de la existencia de una fuente fidedigna para ese periodo. ${ }^{1818}$ Esta idea, sugerente, no termina de aportar excesivo sentido a la afirmación de Éforo, quien habla más de narración directa que de usos de

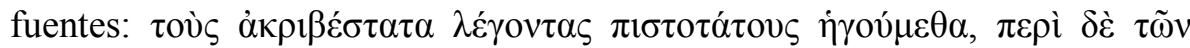

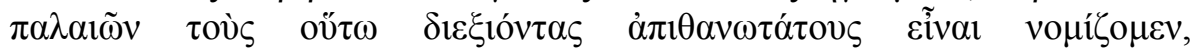

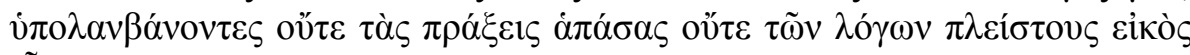

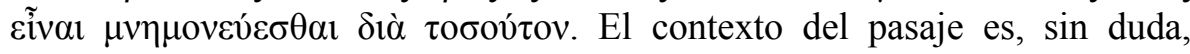
reducido, y la posibilidad de ofrecer un razonamiento lo suficientemente seguro parece ciertamente difícil. Sea como fuere, hemos de recordar que la obra de Éforo carece de una cronología regular. La estructuración de la misma, que contaba, como vimos, con proemios parciales, a diferencia de lo que ocurría con Teopompo, respondía a unidades temáticas. Su interés, centrado, como sucedía con Teopompo, en cuestiones de índole moral y política, ${ }^{1819}$ hacía difícil el tratamiento de periodos míticos en clave moral y política sin caer en la simple teoría. Heracles, el escalón anterior a la narración de Éforo, era objeto, como ya vimos, de especial atención en

${ }^{1817}$ Cf. Barber, 1935, p. 72.

${ }^{1818}$ Cf. Barber, 1935, p. 144 y ss. Cf. también Marincola, 1985, p. 32, quien presenta una argumentación poco consistente que vacila entre el uso de fuentes y la autopsia, dentro de una tendencia demasiado marcada a separar la Zeitgeschichte de la historia mítica.

${ }^{1819}$ Cf. Barber, 1935, p. 144 y ss., especialmente 155: «[...] his intention was to promote virtue and discourage vice; but his moral maxims were really only for the edification of statesmen». 
interpretaciones alegóricas y filosóficas del héroe ideal de la época. ${ }^{1820}$ Diferenciar entre lo que es historia y lo que es, simplemente, una imagen ideal fraguada es complicado en la época que nos ocupa. Isócrates llega a

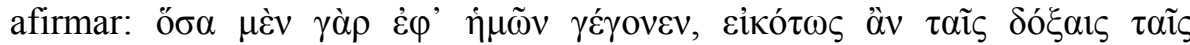

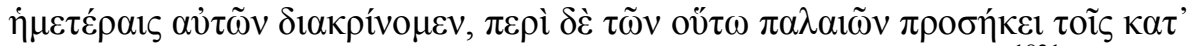

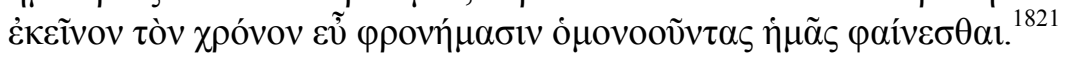

Hacíamos referencia antes a la aparición de la falsedad documental en este periodo, y, si bien la crítica se ha ocupado habitualmente de valorar la dimensión puramente histórica de dicho proceso, creemos que en nuestro caso lo realmente importante es su dimensión cultural. Más allá, como decíamos, de las connotaciones plenamente políticas del fenómeno, ha de tenerse en cuenta que supone también la creación de imágenes paradigmáticas de la historia y de los personajes del pasado. Estos paradigmas llevan asociados una carga moral y paidéutica realmente destacable. En línea con la fuerte carga ideológica de tintes morales presente en todas las referencias al pasado halladas en autores ajenos al mundo de la historiografía, asistimos a la creación de figuras arquetípicas modeladas sobre la vieja mitología griega, con Heracles como ejemplo canónico. Seguramente sea esta la razón por la cual Éforo retrasa el inicio de su obra hasta el retorno de los Heráclidas, para tener un campo de trabajo menos sometido a los dictados de modelo ideal historiográfico que se estaba creando.

\subsubsection{HISTORIOGRAFÍA Y CRÍTICA LITERARIA:}

\section{LA HISTORIOGRAFÍA TRÁGICA}

La muy lamentable pérdida de toda la historiografía sobre Alejandro Magno hace que con Duris, nacido aproximadamente dos décadas antes de la muerte de Alejandro, pasemos prácticamente de puntillas por toda una generación de la historiografía helenística, para llegar por fin al proemio del citado Duris, y con él a uno de los textos más complicados que nos van a ocupar y que además está muy relacionado con la historiografía anterior.

${ }^{1820}$ Así ocurre con Isócrates, cf. Welles, 1966, p. 15.

${ }^{1821}$ Isócrates, Encomio a Helena, 22; cf. además Welles, 1966, p. 14. 
Poco a poco la crítica ha ido abandonando la idea de un Duris autor de una obra repleta de prodigios y exageraciones que rozaban lo grotesco. El fragmento que vamos a estudiar, relativo a la crítica a los predecesores, es mejor medio para conocer la obra e inquietudes de Duris que para valorar los autores criticados, aspecto que no suele ser tenido muy en cuenta.

La interpretación de la denominada historiografía trágica pasa inevitablemente por reconstruir el recorrido de un concepto que debió de acuñar Polibio y que a todas luces no parece que gozase en el historiador de Megalópolis de un gran peso conceptual.

La realidad nos hace tener muy presente el hecho nada despreciable de la complejidad del momento en que desarrolló su obra Duris. La multiplicidad de los proyectos culturales en boga en la época y la nada despreciable posibilidad de que la gran Samos disfrutara de un nivel cultural lo suficientemente respetable como para tenerla presente a la hora de valorar las posibles influencias, hacen que no sea de extrañar el hallar posturas discordes o, simplemente, opuestas. $\mathrm{Y}$ es que, dado lo escaso de los fragmentos conservados, seguramente sea imposible delimitar como hemos hecho hasta ahora la compleja red de nexos trazados entre los proemios y el mundo literario y cultural en el que se desarrollaba la labor de los historiadores, pero la imagen es muy semejante a la que hemos visto. Simplemente, estamos ante un complejo eclecticismo de las diferentes tendencias y corrientes del momento histórico en el que se desarrollan las diversas obras.

Fue Eduard Schwartz quien llenó de contenido el concepto de historiografía trágica creado por Polibio. En dos estudios en cierta manera hoy olvidados sobre Salustio y Calístenes, Schwartz defendía la importancia de la influencia del teatro sobre la técnica historiográfica de época helenística, todo ello sobre la tramoya que proponía Aristóteles en la Poética. $^{1822}$

${ }^{1822}$ Cf. Schwartz, 1897, p. 560: «[...] ist die peripatetische Historiographie, wie sie praktisch von Kallistenes und Duris, theoretisch, wie man wenigstens vermuthen darf, in

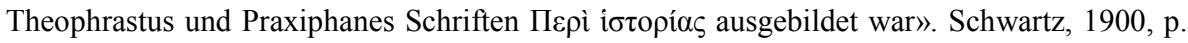
128: «Ferner kann diez Zusammentreffen dafür angeführt werden, dass die historiographische Technik der hellenistischen Zeit ihre Mittel von der Nühne entlehnt: Duris und Phylarch haben so gut Furch und Mitleid erregen wollen, wie das tragische Spiel nach Aristoteles soll». Cf. Diodoro, XIX 8, 4; Polibio, II 56, 7. 
Las bases sobre las que se asentaba esta teoría eran tan frágiles como puede ser una propuesta construida sobre la afirmación de un autor como Polibio, al que se toma como punto de partida para construir una teoría literaria de un autor no conservado a partir de un fragmento realmente ambiguo.

Con estas premisas, la reacción se verificó incluso en la dirección

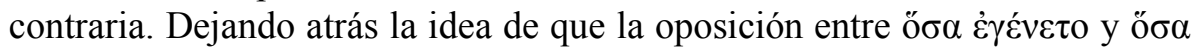

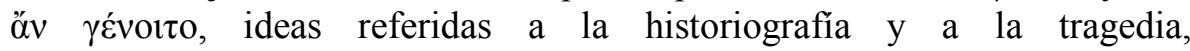
respectivamente, tiene cierto tono positivista debido más a la crítica moderna que a Aristóteles, ${ }^{1823}$ Ullman señaló muy acertadamente que Aristóteles no nos habla de historiografía salvo por oposición a la tragedia, ${ }^{1824}$ lo que determina una imagen ciertamente sesgada del género. ${ }^{1825}$ Este hecho fue el que llevó al citado autor a considerar nuevas vías de explicación para la historiografía trágica, y llegó a una perspectiva que ya nos es familiar. Detrás del nombre de Isócrates, el autor propuesto por Ullman para hacerse cargo de la responsabilidad de haber dado lugar a la historiografía trágica, ${ }^{1826}$ se esconde el modo de entender la historia y la imagen artificial, casi falsa, ${ }^{1827}$ que los oradores del siglo IV a. C. nos demuestran en sus obras. La idea de Aristóteles de que los elementos fantásticos, $\theta \alpha v \mu \alpha \sigma \tau \alpha$, son un medio para atraer la atención del público de un discurso ${ }^{1828}$ es un buen punto de apoyo a ojos de Ullman para el paso de la teoría de la mímesis a la historiografía por medio de Isócrates, quien hace un uso extenso de elementos históricos en sus discursos. ${ }^{1829}$ Isócrates sería, así, el padre de la historiografía trágica y el centro irradiador de la misma: «Not only did Isocrates write what is practically history in the tragic manner in some of his

${ }^{1823}$ Cf. Ullman, 1942, p. 27: «The tendency to deviate from strict truth in the interest of a good story is of course sufficient to explain the historians who failed to keep to the highest standards of truthfulness». El propio Ullman suaviza esta afirmación dando cuenta de hasta qué punto son imprecisas las fronteras que separan los diferentes géneros. Brink, 1960, p. 15, piensa lo mismo, si bien tiene presente el hecho de que estamos ante una oposición que es herencia de Platón y que causa no pocas complicaciones a Aristóteles.

${ }^{1824}$ Aunque proporcione la que, en términos clásicos, pueda ser la primera definición del género, cf. Scheller, 1911, p. 10 y ss.

${ }^{1825}$ Cf. Ullman, 1942, p. 28.

${ }^{1826}$ Cf. Ullman, 1942, p. 28 y ss.

${ }^{1827}$ O un simple depósito de leyendas y anécdotas, como refería Susemihl, 1891, p. 591.

${ }^{1828}$ Cf. Aristóteles, Poética, 1415 b2.

${ }^{1829}$ Cf. Ullman, 1942, p. 30. 
so-called speeches but he no doubt taught his pupils to write actual history in the same manner». 1830

Uno de los problemas que se plantean a la propuesta de Ullman y, en general, a todas las ideas aportadas en torno a la historiografía trágica es la indefinición de sus límites para la crítica moderna. Hay ocasiones en que se trata como referida al contenido de las obras y a los elementos fantásticos que acoge, ${ }^{1831}$ en tanto que en otras veces se habla de estilo grandioso o trágico sin mayores complicaciones. ${ }^{1832}$ Más allá de la asignación exacta de la paternidad de la historiografía trágica, algo realmente complicado, como veremos, dado que los vínculos entre lo isocrateo y lo aristotélico son mayores de lo que parece, ${ }^{1833}$ la definición en último término de la historiografía trágica pasa por la misma definición del concepto de $\mu$ í $\mu$ lis en el tiempo de Duris. Sabemos que tanto Duris como Calístenes gozaban de una formación literaria realmente impresionante. En el caso de Duris, tenemos constancia de su conocimiento de la gran tradición poética griega y, en lo que nos interesa, de su gran familiaridad con la literatura de su época y con Arisóteles. ${ }^{1834} \mathrm{La}$ labor de Duris sobre la literatura, nos recuerda Pédech, traspasó la simple familiaridad para alcanzar el estudio crítico de la misma. ${ }^{1835}$ Con estas ideas presentes, parece innegable que el uso que el

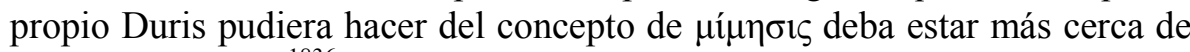
un sentido técnico ${ }^{1836}$ que lo que podamos encontrar en Polibio.

No es lugar este para desarrollar un estudio sobre el sentido de $\mu$ í $\mu$ $\sigma \iota \varsigma$ en Aristóteles, pero sí para dar algunas ideas. Es fundamental recordar, como

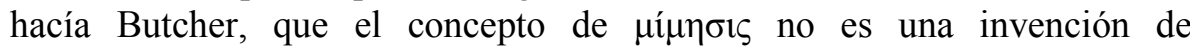
Aristóteles, sino que, quizá de manera vaga, está ya presente con anterioridad en la cultura griega. ${ }^{1837}$ Lo importante de la labor de Aristóteles

${ }^{1830}$ Cf. también Schmid y Stählin, 1920, p. 204 y ss.

${ }^{1831}$ Con Beloch, a la cabeza 1925, p. 480. Cf. para las opiniones a este respecto de la escuela de historiadores alemana, Schubert, 1914, p. 63 y ss.

${ }^{1832}$ Cf. Ullman, 1942, p. 32; Bury, 1909, p. 172.

${ }^{1833}$ Cf. incluso Ullman, 1942, p. 34.

${ }^{1834}$ Cf. Gattinoni, 1997, p. 65. Especialmente interesante sería el gran conocimiento de la literatura teatral, para lo cual cf. Ferrero, 1963, p. 75 y ss. Para el conocimiento de Aristóteles, cf. Ateneo, IV 128a, y Kebric, 1977, p. 5.

${ }^{1835}$ Cf. Pédech, 1989, p. 263.

${ }^{1836}$ En este sentido, la apertura del concepto de $\mu$ í $\mu$ $\sigma ı \varsigma$ más allá de la tragedia, señalada por Consolo Langher, 1986, p. 350, es crucial. Respecto a la necesidad de tener presente esta formación a la hora de valorar a Duris, cf. Vattuone, 1991, p. 41.

${ }^{1837}$ Cf. Butcher, 1898, p. 121 y ss. 
es su sistematización dentro de unas coordenadas que vienen definidas por

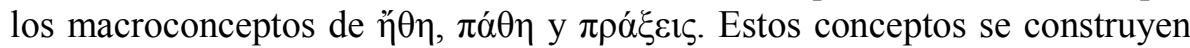
además de manera solidaria, de modo que el primero de ellos, la caracterización moral permanente del individuo, se manifiesta en el segundo -la actuación emocional del mismo-, que desemboca en las $\pi \rho \alpha ́ \xi \xi \varepsilon 1 \varsigma ~ o$ acciones del individuo. ${ }^{1838}$ Con esto queda definido un campo para la

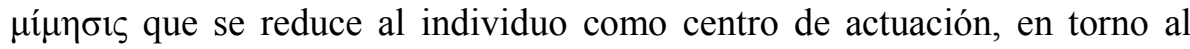
cual giran todos los demás elementos, que constituyen el escenario en el que se sitúa. ${ }^{1839}$ Esta idea es, a nuestro entender, fundamental para la

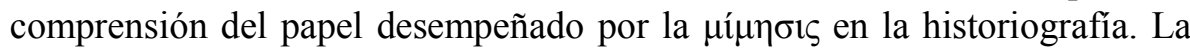
imitación no se refiere a los elementos inmanentes de lo imitado, sino a la percepción externa. ${ }^{1840}$ Que con esta afirmación estamos, una vez más, ante el núcleo primigenio y previo de lo que más tarde se denominará biografía parece innegable, aunque tengamos que asumir que la reacción en cadena

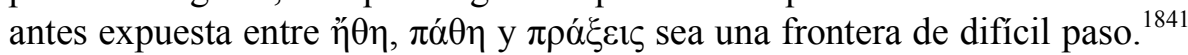
Esta conexión que creemos que se esconde detrás de la idea de lo universal presente en la poesía ${ }^{1842}$ puede desempeñar un papel no menor en el tema que nos ocupa. La idea del concepto de $\pi \rho \alpha ́ \xi \xi 1 \zeta$ al modo aristotélico presupone la existencia de un $\tilde{\eta} \theta$ os y una $\delta$ óvola $^{1843}$ que permiten en último término que la copia sea exactamente semejante a la realidad, por venir asegurada precisamente por el $\tilde{\eta} \theta$ os y la $\delta$ lóvota. $^{1844}$

Es, precisamente, en este sentido en el que se pronuncia Aristóteles en contra de la tragedia de su tiempo. El Estagirita afirma que es posible que exista tragedia sin $\tilde{\eta} \theta 0 \varsigma$, y que es algo que ocurre en su tiempo: ... övev $\delta \dot{\varepsilon}$

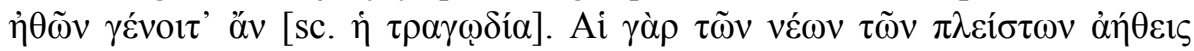

${ }^{1838}$ Cf. Butcher, 1898, p. 123.

${ }^{1839}$ Cf. Butcher, 1898, p. 124 y ss.

${ }^{1840}$ Cf. Butcher, 1898, p. 127.

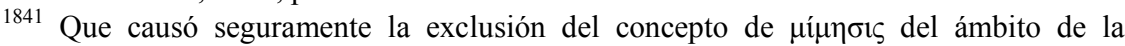
narrativa por parte de Platón, República, 393b. Bywater, 1909, p. 100 y ss., nos recuerda además la inconsistencia de Aristóteles en tal sentido, debida seguramente a este desajuste.

1842 Butcher, 1898, p. 149 y ss., piensa más en un concepto cercano al de idea. Oĩ ${ }^{2} \tilde{i} v \alpha$ $\delta \varepsilon \tilde{\imath}$ esconde, a nuestro juicio, no una simple materialización, sino el resultado de un proceso, alcanzado por las conexiones antes referidas. Sin embargo, el propio Butcher, p. 159, reconoce que la poesía solo puede ser filosófica por medio del conocimiento profundo del hombre. Cf. Gray, 1987, p. 467, quien hace una clara distinción entre el pensamiento platónico y el aristotélico.

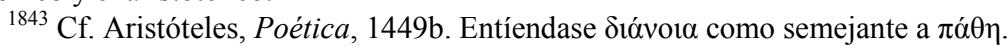

${ }^{1844}$ Cf. Bywater, 1909, p. 100, quien deja ver el origen ancestral de un concepto en el que creemos que hay mucho de religioso. 


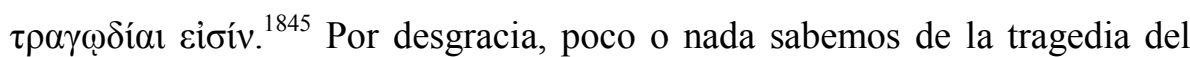
siglo IV a. C., pero la deriva tomada por el género en el cambio de siglo nos permite aventurar que la $\pi \varepsilon \rho \imath \pi \varepsilon ́ \tau \varepsilon ı \alpha$ era un valor fundamental en el desarrollo de las $\pi \rho \alpha ́ \xi \xi \varepsilon \zeta$. La complejidad presentada por algunas composiciones del Eurípides más tardío hacía que las acciones, las $\pi \rho \alpha ́ \xi \varepsilon \varepsilon \varsigma$, alcanzasen un grado extremo, que a ojos de Aristóteles -quien sin duda había leído un buen número de tragedias- tenía poco que ver con la tragedia por antonomasia, Edipo rey. En esta obra los caracteres, siempre con la precaución que se debe tener al hablar de este concepto en una época tan antigua, determinaban

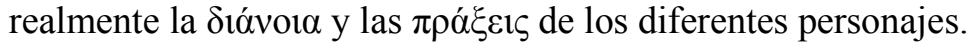

Obviamente, nada de esto se puede observar en la historiografía herodotea y tucidídea, ${ }^{1846} \mathrm{e}$ incluso el último de los autores presenta además la determinación de los rasgos de los personajes no por medio de su actuación, sino por medio de comentarios del propio autor. ${ }^{1847}$ Ya hemos visto que esta dinámica varía con el paso al siglo IV a. C., pero el ajuste en lo que al concepto de $\mu$ í $\eta$ бis se refiere no pasa solo por el esbozo de las acciones, reprochables o no, de los individuos. En este sentido, la propia clave la da Aristóteles en el famoso pasaje sobre Alcibíades y la

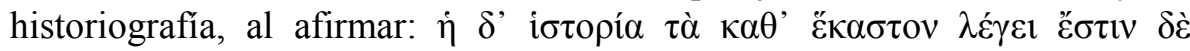

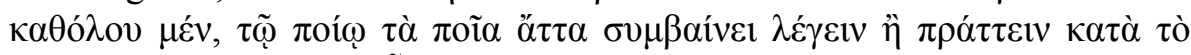

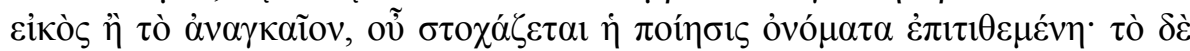

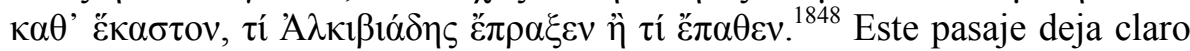

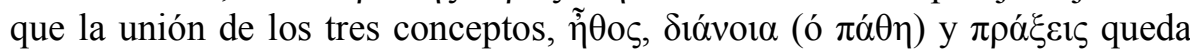
rota, precisamente, de la misma manera que Aristóteles nos decía que ocurría en el teatro de su época, lo que demuestra en qué sentido considera errada la $\mu i ́ \mu \eta \sigma ı \varsigma$ en la historiografía. La historiografía es, pues, menos filosófica porque solo recoge la imagen de lo ocurrido, lo concreto de un hecho, en tanto que la poesía, que aplica de manera sistemática la $\mu$ í $\mu$ $\sigma \varsigma$-dado que al

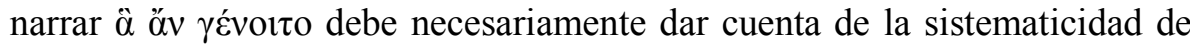
los tres elementos- narra lo general en el sentido de que da cuenta de

${ }^{1845}$ Cf. Aristóteles, Poética, 1450a27.

1846 Dionisio de Halicarnaso, Ad Pompeium, 18, otorgará a Heródoto el análisis de los $\ddot{\eta} \theta \eta$ y a Tucídides la palma en el estudio de los $\pi \alpha \dot{\theta} \eta$, para lo cual cf. Gray, 1987, p. 468, pero ello es simplemente la verificación de esa falta de conexión necesaria entre los tres elementos para alcanzar la $\mu$ í $\mu$ $\sigma \mathrm{s}$.

${ }^{1847}$ En este sentido, Westlake, 1968, p. 23, nos alertaba de que un personaje fundamental como Pericles estaba ausente en la obra en lo que a su caracterización individual se refiere.

${ }^{1848}$ Cf. Aristóteles, Poética, 1451 b7 y ss. 
acciones que, por verse construidas en virtud del $\tilde{\eta} \theta$ o $\varsigma$ de cada carácter, tienen un valor universal. ${ }^{1849}$

En el análisis de los fragmentos de Éforo y Teopompo hemos visto la filiación de este con tendencias de tinte cínico o, al menos, con un cierto tinte histriónico. La distorsión aparejada a esta tendencia es algo que difícilmente podría ser compatible con la idea de $\mu$ í $\gamma_{\sigma} \iota \varsigma$ que hasta ahora hemos estado viendo. En este sentido, el segundo de los supuestos padres de la historiografía trágica, Calístenes, nos recuerda en un fragmento proemial:

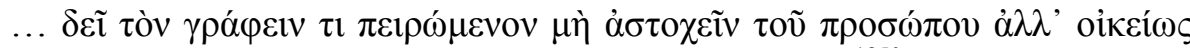

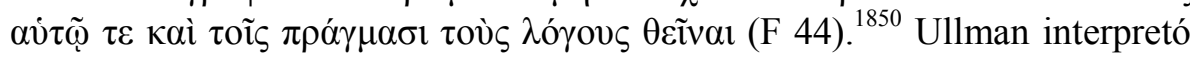
de manera correcta este pasaje, que se apoya claramente en la teoría

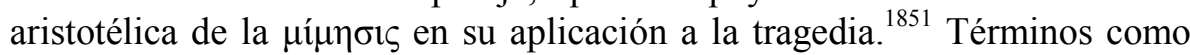

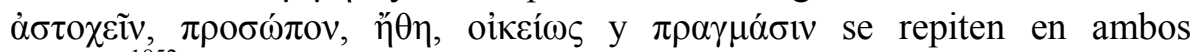
autores, ${ }^{1852}$ y nos recuerdan que la formación filosófica de Calístenes es un hecho innegable que dejó su huella en su labor como historiador. ${ }^{1853}$

A nuestro entender, la propuesta en ocasiones defendida que hace de este pasaje proemial una reminiscencia de Tucídides I 22,1 deja atrás un pequeño detalle que una comparación de ambos textos resolverá, al tiempo que nos ayudará a entender mejor qué nos quiere decir Calístenes:

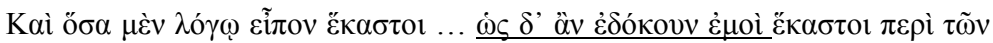

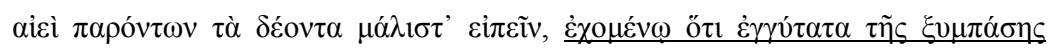

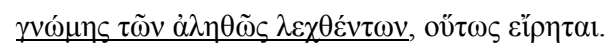

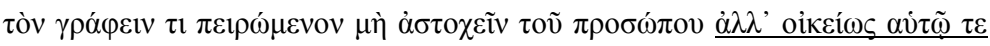

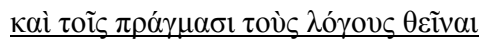

\footnotetext{
${ }^{1849}$ Cf. Aristóteles, Poética, 1451 b1 y ss.; Louis, 1955, p. 40 y ss., para el valor de lo universal y lo particular en la historiografía.

1850 «Es preciso que, quien trata de escribir algo, no deforme el rostro [sc. de un personaje], sino que redacte de una manera apropiada al mismo y a sus asuntos».

${ }^{1851}$ Cf. Ullman, 1942, p. 35.

${ }^{1852}$ Así, Ullman, 1942, p. 36, con indicación de los pasajes paralelos.

${ }^{1853}$ Cf. Prandi, 1985, p. 12 y ss., para los testimonios al respecto. La propia Antigüedad

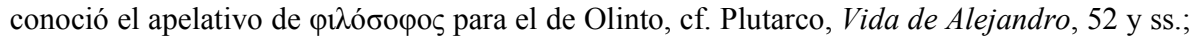
Arriano, Anábasis, IV 9, 5 y ss. Prandi, 1985, p. 121.
} 
El lector rápidamente se dará cuenta de que en el caso de Tucídides falta la referencia a la adaptación de las palabras al propio personaje, y que la actuación recae en ese caso sobre la persona de Tucídides. El hecho, aparentemente de escaso relieve, cobra una magnitud considerable cuando se tiene presente la importancia del diseño de los caracteres en esta época. Es muy probable que Tucídides y Calístenes se estén refiriendo a lo mismo, pero la perspectiva ha variado. La adaptación a la realidad de los discursos, cuyos usos lingüísticos esconden la teoría mimética aristotélica, se realiza no en virtud del todo cívico, sino atendiendo a los individuos concretos, lo que sitúa este proemio en la línea que venimos trazando desde Éforo y Teopompo.

Pero, obviamente, las dudas a la hora de interpretar la teoría de la $\mu$ í $\eta$ бı s surgen en lo que se refiere a la interpretación trágica de la historiografía, es decir, a los tradicionales excesos retóricos o efectistas que se achacan a la historiografía trágica. En este aspecto, es necesario hacer notar un hecho que puede llevarnos irremediablemente a una paradoja: prácticamente todos los autores del periodo caen en lo prodigioso o paradoxográfico. ${ }^{1854}$ Con esta realidad presente, parece difícil continuar con el habitual razonamiento que hace de Duris y Calístenes historiadores trágicos en el sentido despectivo del término, e interpretar que la crítica del proemio de Duris contra Éforo y Teopompo se debe a la falta de elementos prodigiosos en sus obras.

A nuestro entender, el problema reside en la existencia de un doble nivel de aplicación de la teoría de la $\mu$ í $\mu$ $\sigma ı$. Por una parte, estamos hablando de

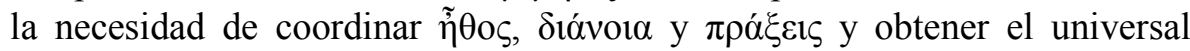
derivado de esta triple unión, y, por otra, la aplicación de ese mecanismo y sus gradaciones. El propio Aristóteles nos recuerda que es posible modular la $\mu i ́ \mu \eta \sigma ı \varsigma$ para representar a los personajes, mayores, iguales o menores a lo real. ${ }^{1855}$ Creemos que es esta segunda modulación, referida a lo imitado, ${ }^{1856}$ la que hace acto de presencia en la obra de Duris con mayor fuerza que en el caso de Éforo y Teopompo, lo que no impide que Duris aplique (o trate de aplicar) con mayor consistencia la unión entre los conceptos de $\tilde{\eta} \theta$ os, $\delta$ óv

${ }^{1854}$ Incluso el muy puntilloso Polibio lo hará, como bien demostró Walbank, 1985, p. 222.

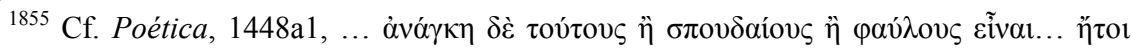

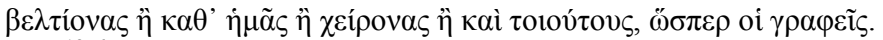

${ }^{1856}$ Es útil el esquema de Gudeman, 1934, p. 108. 
de la posibilidad de representar los personajes y los escenarios de manera amplificada, pero siempre teniendo en cuenta que estamos hablando de la gradación de un aspecto presente en todos estos autores, ${ }^{1857}$ como ya señaló Pédech. ${ }^{1858}$ Los fragmentos conservados de Duris han permitido a la crítica confirmar que, al igual que ocurría con Éforo y Teopompo, el material «biográfico» era el eje central de la obra. ${ }^{1859}$ Este hecho es seguramente una de las mejores pruebas de que la oposición entre los tres autores, Éforo, Teopompo y Duris, ha de registrarse en esta parcela concreta del quehacer historiográfico. Pero, a pesar de esta oposición, no creemos que deba pensarse en una separación entre los isocrateos o retóricos Éforo y Teopompo y los aristotélicos Duris y Calístenes. ${ }^{1860}$ Walbank ya nos recordaba que Isócrates estaba seguramente detrás de los rasgos morales de la historiografía de la época, ${ }^{1861}$ idea que en parte hemos rechazado, pero que, de ser aceptada, daría lugar a lo paradójico de la presencia de elementos morales en Duris ${ }^{1862}$ y Calístenes.

En este mismo sentido, y en lo que se refiere a Calístenes, es interesante atender al título de la obra, $A \lambda \varepsilon \xi \dot{\alpha} \alpha \delta \rho \rho v \pi \rho \alpha ́ \xi \varepsilon l \varsigma$. Plezia indicó lo extraño de la presencia del término $\pi \rho \alpha ́ \xi \varepsilon 1 \varsigma$ en el título de la obra de tres historiadores, Antípatro de Magneta (FGrHist, 69), Antípatro de Macedonia (FGrHist, 114) y el que nos ocupa, compartiendo además los tres formación filosófica. ${ }^{1863}$

Plezia avanza la hipótesis de que lo que trató de hacer Calístenes, y de

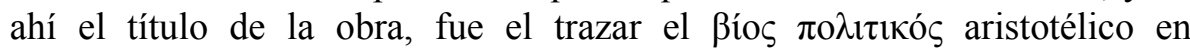
Alejandro. ${ }^{1864}$ Sea como fuere, y siendo muy posible que en esta idea haya mucho de verdad, ${ }^{1865}$ lo que es innegable es que el concepto es plenamente aristotélico, y además refuerza la posibilidad de que el fragmento proemial pertenezca a esta obra y no a las Helénicas.

\footnotetext{
${ }^{1857}$ Lo que dificultaría la idea de Ferrero, 1963, p. 96 y ss., quien defendía que lo trágico de la obra de Duris se debía a su especial interés por lo prodigioso. A nuestro entender habría que decir por su mayor interés.

${ }^{1858}$ Cf. Pédech, 1989, p. 381: «La volonté de peindre le réel même s'il doit faire horreur, a inspiré à Duris des scènes cruelles».

${ }^{1859}$ Cf. Pédech, 1989, p. 365; Gattinoni, 1997, p. 82.

${ }^{1860}$ Como defiende Torraca, 1988, p. 69.

${ }^{1861}$ Cf. Walbank, 1990, p. 255.

${ }^{1862}$ Cf. Pédech, 1989, p. 347 y ss

1863 Cf. Plezia, 1972, p. 264.

${ }^{1864}$ Cf. Plezia, 1972, p. 265 y ss.

${ }^{1865}$ Así, Prandi, 1985, p. 75. 


\begin{tabular}{|l|c|c|c|}
\hline & Duris & Éforo & Teopompo \\
\hline MIMH $\Sigma \mathrm{I} \Sigma$ & + & - & - \\
\hline TEPATEIA & + & + & + \\
\hline
\end{tabular}

Obviamente, lo importante es la verificación de lo hasta ahora expuesto en los fragmentos conservados, y, en el caso de Duris, la crítica tampoco ha estado, a pesar de la polémica, muy lejos de determinar una imagen clara del historiador. Fragmentos como el F 10 reflejan un mundo de acciones humanas delimitadas en un marco de actuación en el que no hemos de buscar algo tan burdo como la expresión literal de los conceptos que nos ocupan, sino atender a la narración de las acciones de un Demetrio presa de la falta de moderación en un ambiente capaz de dibujar unos perfiles nítidos y, esto es lo importante, no mecánicos de la actuación humana. Que tanto este fragmento como el F 12 presenten situaciones extremas de comportamiento, como la danza o los excesos con el alcohol, ${ }^{1866}$ o incluso el caso del fragmento F 14, con Pausanias tomando las vestiduras persas, son ejemplos no de una narración pintoresca, sino del trazo de una caracterización de los personajes por medio de sus acciones que bien podrían situarse en una escena dramática tradicional. Schubert ya indicaba extrañado que en la obra de Duris los personajes bailaban, se emborrachaban y, sobre todo, lloraban. ${ }^{1867} \mathrm{Y}$ señalaba también la aparente fijación de Duris por la vestidura de sus personajes, ${ }^{1868}$ detalle que nos ha de llevar por un momento a la noticia que nos transmite Aristófanes acerca de la adecuada vestimenta de los personajes en escena, en un furibundo ataque a Eurípides por parte de un Esquilo convencido de que un personaje había de verse caracterizado del modo que correspondiese a su persona. ${ }^{1869}$ Todo ello nos conduce una vez más a un escenario moral individual, pero que en este caso adquiere unos tintes poco habituales, y seguramente de difícil comprensión por parte del público, al menos del menos selecto. ${ }^{1870}$

\footnotetext{
${ }^{1866}$ Cf. Schubert, 1914, p. 64 y ss.

${ }^{1867}$ Cf. Schubert, 1914, p. 65.

${ }^{1868}$ Cf. también Pédech, 1989, p. 372.

${ }^{1869}$ Así, también Schubert, 1914, p. 69.

${ }^{1870}$ En este sentido, cf. Kebric, 1977, p. 10 y ss., para el conocimiento de Duris por parte de Cicerón.
} 
Lo hasta ahora defendido nos lleva, en primer lugar, a concluir necesariamente que Duris y Polibio hablan de cosas muy diferentes cuando escriben sobre la $\mu$ í $\mu$ $\sigma i \varsigma$ y la historiografía trágica. Walbank ya alertó en su día de que Polibio tenía una idea más bien vaga a la hora de hablar de historiografía trágica, ${ }^{1871} \mathrm{y}$, a nuestro entender, hemos de plantearnos seriamente si en el fondo tiene algún tipo de relación el concepto de $\mu$ í $\mu \eta \sigma 1 \varsigma$ de Duris y la teoría de la tragedia de Aristóteles, o más bien hemos de pensar en un paso previo que elabore a partir de esa teoría un modelo general de aplicación a la literatura. Seguramente, si nos decantamos por la segunda opción, habría que pensar en Teofrasto, como ya se ha hecho, ${ }^{1872}$ si bien el hecho de que esta idea pueda ser rechazada con la misma ligereza ${ }^{1873}$ con la que se defiende es buena prueba de que la total ausencia de fragmentos o

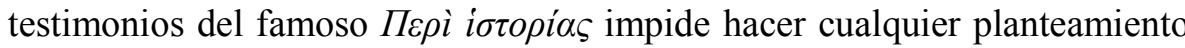
con mayor fundamento.

Parece difícil determinar si estamos ante un hiperrealismo en Duris, como quería Pédech, ${ }^{1874}$ y una narrativa histriónica en el caso de los autores denominados retóricos, principalmente en Teopompo, que debería, como hemos visto, esos rasgos a la escuela cínica. Seguramente sea más sencillo pensar que estamos ante un desajuste de la narración historiográfica y un ideal de $\mu$ í $\eta_{\gamma 1 \varsigma}$ construido para las representaciones dramáticas, con un amplio sentido religioso y tradicional todavía, ${ }^{1875}$ pero es realmente complicado ir más allá de una simple presentación de posibilidades, dado lo poco conservado. En este sentido, el tono homérico señalado ${ }^{1876}$ en la obra de Calístenes podría ser un buen punto de partida para un mayor grado de $\mu i ́ \mu \eta \sigma ı s$, teniendo en cuenta un posible parangón entre Alejandro y el mundo homérico, ${ }^{1877}$ pero, a las lógicas dudas ante lo poco conservado, hemos de unir el hecho de que ese tinte homérico tenía quizá demasiado de intelectual.

${ }^{1871}$ Cf. Walbank, 1985, p. 213: en definitiva, Polibio usa el término tragedia « [...] in a loose and vulgar sense [...], tragic is no more than a label selected by Polybius to vilify a school of historians [...]». Cf. también Schepens, 2005, p. 162.

${ }^{1872}$ Cf. Torraca, 1988, p. 59.

${ }^{1873}$ Cf. Pédech, 1989, p. 371; Gattinoni, 1997, p. 54.

${ }^{1874}$ Cf. Pédech, 1989, p. 382.

1875 Cf. Aristóteles, Poética, 1448a21 y 1460a9, para ese desajuste. Es interesante el análisis de Cole, 1991, p. 120, quien afirma: «The style of Duris and his followers [...] is explicitly characterized by later critics and more suggestive of oral discourse than Isocrates $[\ldots] »$.

${ }^{1876}$ Cf. Prandi, 1985, p. 76 y ss. También, Golan, 1988, p. 108.

${ }^{1877}$ Cf. en este sentido Pédech, 1984, p. 45 y ss. 
Con todo esto presente, creemos haber avanzado un poco más allá de las ideas que expuso Koller acerca de la vertiente musical del concepto de

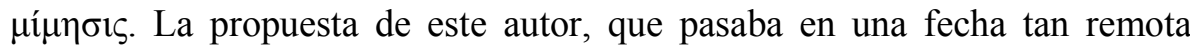
como 1954 por hacer depender el concepto de $\mu$ í música, ${ }^{1878}$ es un buen punto de partida para realizar un análisis de la idea desde la perspectiva, hoy ya perfectamente asentada, de la literatura oral. Sabemos que cualquier acto poético tradicional conllevaba una representación, fuese teatral o la simple puesta en escena de un poeta, y, con esta idea presente, se puede reinterpretar la idea de $\operatorname{Koller}^{1879}$ sobre la actuación de los personajes, adaptado a lo que Nagy define como «performance» oral. Todo ello implica incluso una perspectiva educativa que podemos reinterpretar como el mundo enciclopédico tradicional, tan presente en Platón, que el propio Koller presentaba de manera todavía rudimentaria. ${ }^{1880}$ En definitiva, el trabajo de Koller, eliminadas las afirmaciones demoledoras, que en último término poco aportan, ${ }^{1881}$ supone

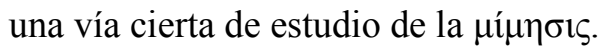

Volviendo a la historiografía, nos parece fundamental la apreciación que Koller hace de la poesía eólica y de simposio, que tanta importancia tuvo décadas atrás del momento histórico que nos ocupa en la definición del género historiográfico. Afirma el autor que «äolische Lyrik, Ausdruck von seelischen Vorgängen und Gedanken, realistische Naturschilderung, kann mit diesen Mimesisbegriff uberhaupt nicht erfast werden», ${ }^{1882}$ lo que abre un segundo apartado de la literatura arcaica, ajeno a la $\mu$ í $\mu \eta \sigma ı$, , en el que precisamente se situaría el germen de la futura historiografía. Ello nos llevaría, naturalmente, a la cuestión de si autores como Duris y Calístenes trataron de escribir historiografía con un manual de urgencia basado en la teoría del grupo de géneros miméticos, si bien cualquier afirmación en este sentido es simplemente especulación.

Lo que sí parece claro es que estamos ante un modo de hacer historiografía claramente delimitado, a pesar de las variaciones entre autores,

${ }^{1878}$ Cf. Koller, 1954, p. 11.

${ }^{1879}$ Cf. Koller, 1954, p. 16 y ss.

${ }^{1880}$ Cf. Koller, 1954, p. 57 y ss.

${ }^{1881}$ Cf. e. g. Koller, 1954, p. 104: «Wir müssen [...] einmal alles, was wir darüber gelesen haben, zu vergessen versuchen [...]». cf. la crítica de Else, 1958, p. 74 y ss., cuyo punto fuerte es el ataque a la idea de derivar todo el material del mimo.

${ }^{1882}$ Cf. Koller, 1954, p. 16. 
y que tiene al individuo ${ }^{1883}$ como eje central, eje en torno al cual pueden construirse muy diferentes planteamientos. Ante la insistente pregunta de qué grado de veracidad presentaban estos autores, hemos de asumir que, en último término, esta es una cuestión que debemos plantear a Polibio, no a los citados autores. ${ }^{1884}$ Un error habitual, a nuestro entender, es el hecho de confundir lo que es una teoría clara y únicamente estética y literaria, como es la de Aristóteles, con una interpretación positivista de la historiografía. ${ }^{1885}$ Weil, quien no acertó a comprender esta cuestión, se vio obligado a defender

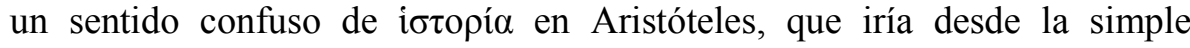
indagación, sentido verificado, sin ir más lejos, en las obras de zoología del Estagirita, ${ }^{1886}$ a la historiografía en sentido moderno, ${ }^{1887}$ al tiempo que dudaba de que Aristóteles se hubiera dedicado a ella, dado que es un género menor, ${ }^{1888}$ lo que constituye un claro ejemplo de lo confuso del intento de definición del concepto. La solución propuesta por el propio Weil, que difiere de la postura de Jaeger, quien ante la misma paradoja recurría al socorrido baile cronológico de las obras de Aristóteles para justificar el problema situando la labor «histórica» en su vejez, frente a la Poética como

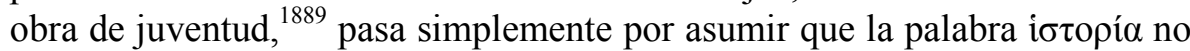
significa lo que entendemos en tiempos modernos. ${ }^{1890}$ Esta es una idea que

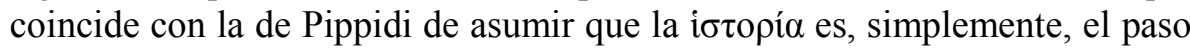

${ }^{1883}$ Para Duris, cf. Kebric, 1977, pp. 21 y ss., y 34.

${ }^{1884}$ Gattinoni, 1997, p. 85, alertaba ya sobre el extremo de que trágica no es sinónimo de falsa. En general, las palabras sensatas de Laistner, 1947, p. 6 sobre el uso de Polibio para reconstruir estos autores son un buen consejo a tener en cuenta, así como la tendenciosidad política de Polibio en sus críticas; cf. recientemente, Schepens, 2005, p. 147 y ss.

${ }^{1885}$ Un ejemplo de esta confusión es Louis, 1955, p. 39 y ss., quien, por lo demás, ve

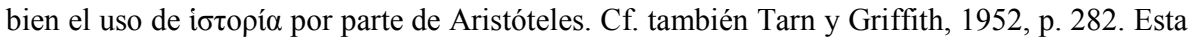
idea llega a tiempos recientes, y está detrás de planteamientos como los de Kebric, 1977, p. 16, quien, siguiendo en parte a Walbank, ve elementos trágicos en toda la historiografía, dado que entra en este concepto todo aquello que se aleje de la «realidad histórica».

${ }^{1886}$ Cf. Louis, 1955 , p. 40.

${ }^{1887}$ Cf. Weil, 1960, p. 89.

${ }^{1888}$ Cf. Weil, 1960, p. 164.

1889 Cf. Jaeger, 1955, p. 337 y ss., para las obras como composiciones a lo largo del tiempo; Weil, 1960, p. 89.

${ }^{1890}$ Cf. Weil, 1960, p. 166. 
previo a la filosofía, ${ }^{1891}$ de modo que Tucídides no haría historia y quedaría así salvado de la crítica aristotélica. ${ }^{1892}$

A nuestro entender, el problema es inexistente, dado que hemos de partir de la idea de que Aristóteles, e incluso Platón, realizan sus reflexiones sobre la literatura teniendo como arquetipo la literatura tradicional, a la que ya hemos indicado que no pertenece la historiografía. Esta idea, que deja abierta la posibilidad de que el género esté ya constituido aunque no tenga un reconocimiento como tal, es fundamental para entender las graves dificultades que Platón y Aristóteles, versados en la gran tradición griega oral, tenían ante un género como la historiografía. Está claro que Aristóteles

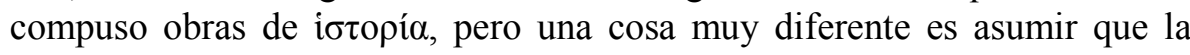
historiografía gozase de una posición semejante a la de los grandes géneros de la literatura clásica, porque no hay que olvidar que, como hemos señalado, Aristóteles habla de la tragedia pensando en Edipo rey y no en la tragedia de su tiempo. ${ }^{1893}$ Negar las semejanzas entre la labor del Estagirita y el gusto por el detalle, en ocasiones excesivo, que caracteriza a esta época ${ }^{1894}$ y que lleva a los autores a dar cuenta de detalles minúsculos o de poco interés, es algo simplemente imposible.

En este sentido, nos parece de especial interés atender, aunque sea por un instante, a la cronología de la época y los autores que nos ocupan. Con las variaciones posibles a tener en cuenta en asuntos cronológicos, Teopompo y Éforo se sitúan prácticamente en el cambio de siglo en lo que a su nacimiento se refiere, ${ }^{1895}$ ya que su $\dot{\alpha} \kappa \mu$ í se fija entre los años 360-340 a. C.,

${ }^{1891}$ Cf. Pippidi, 1948, p. 486 y ss.

${ }^{1892}$ Cf. Pippidi, 1948, p. 490. Este exceso de celo en defender la figura de Tucídides se puede observar también en Büdinger, 1895, p. 43, quien llegaba a negar que Aristóteles tuviera un buen conocimiento de la obra de Tucídides, en contra de lo cual baste citar el estudio de Ste. Croix, 1975, p. 50.

${ }^{1893}$ Lo que supone otro escollo no menor para la interpretación de la historiografía trágica en los términos habituales, dado que lo paradoxográfico, fundamental en la historiografía trágica, es por completo incompatible con la idea de una tragedia de temas históricos imitables por el espectador, como propone e. g. Giovannini, 1943, p. 311 y ss. Simplemente, es un ejemplo más de cómo toda la teoría se compone sobre un centón de conceptos de difícil amalgama.

${ }^{1894}$ Cf. Brown, 1949, p. 231 y ss.

1895 Cf., para Teopompo, Pédech, 1989, p. 21. La idea de Niese, 1909, p. 176, de considerar a Éforo prácticamente postalejandrino nos parece de todo punto fuera de lugar.

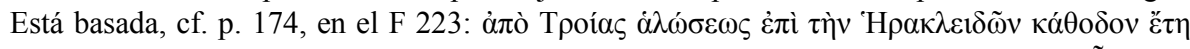

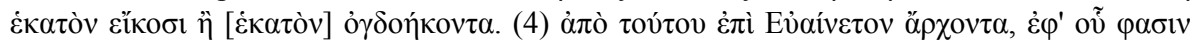

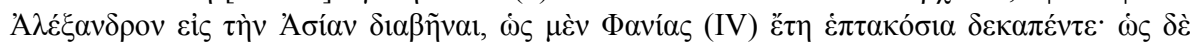


respectivamente. Aristóteles debió de componer la Poética poco después de la fecha límite antes apuntada, ${ }^{1896}$ y Calístenes y Duris nacieron, aproximadamente, en la década de los sesenta y los cuarenta, respectivamente, y estaban para esa fecha en el auge de su carrera. ${ }^{1897}$ Ello nos lleva a la clara conclusión de que es imposible que Éforo y Teopompo pudieran hacer uso de la Poética, en tanto que Calístenes y Duris tendrían su

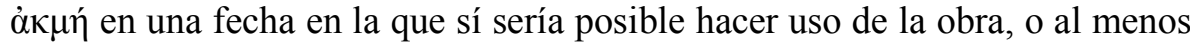
tener conocimiento de ella.

A este complejo mundo de ideas se ha de añadir también el fragmento conservado del proemio al libro VI de Timeo. Olvidado seguramente con gran facilidad por la crítica, este fragmento recoge la negación de la naturaleza retórica de la historiografía, no en los manidos términos de verdad o falsedad, al menos en la formulación habitual, sino desde una perspectiva

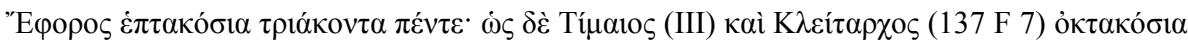

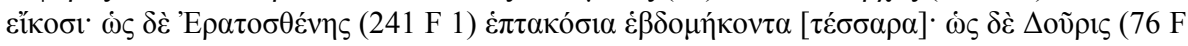

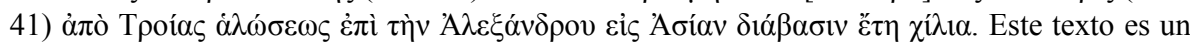
sincronismo que difícilmente nos puede llevar a situar el pasaje donde lo coloca el propio Éforo, el arcontado de Eváneto, además con la inseguridad de que tengamos que pensar que dicha afirmación la tuvo que hacer Éforo en un momento en que este año fuese transcendental ya a la luz de los hechos de Alejandro, dado que no sabemos si Éforo hablaba del arconte simplemente, o hacía referencia a Alejandro, respecto al que, por otra parte, no hubo que esperar mucho para dotar a sus acciones de valor. Por todo ello es arriesgado concluir que Éforo comenzó la redacción de la obra con posterioridad a la fecha propuesta por Meyer, 1909, p. 138 y ss., quien señala el uso importante que Aristóteles hace de la constitución cretense, una formulación que nos lleva en ocasiones al universo platónico, salvo por el muy importante hecho de que tanto Éforo como Aristóteles se mueven en un plano polémico respecto a Platón, al construir el sistema constitucional cretense como ideal y no simplemente como el menos imperfecto de los sistemas. Para todo ello cf. Jaeger, 2000, p. 729. Es precisamente esta idea la que nos induce a pensar que Aristóteles sigue a Éforo, como creía Meyer. A todo ello se ha de sumar el concluyente razonamiento de Schwartz, 1909, p. 491, quien afirma que nada hay de alejandrino o postalejandrino en la obra de Éforo, que difícilmente podría no haber sido sensible a la actuación de Alejandro en su historia universal de haber vivido en una época tan tardía.

${ }^{1896}$ Por estas fechas, Calístenes se encontraba con Aristóteles en Asso, un lugar cuyo ambiente intelectual refleja bien Brown, 1949, p. 227. Además, la inscripción SIG 275 prueba la relación de Calístenes con Aristóteles antes del año 334 a. C.

${ }^{1897}$ Calístenes marchó en el 334 a. C. con Alejandro ya como un historiador consagrado por la publicación de las Helénicas, y con una excelente formación fruto de su contacto con Aristóteles, cf. Prandi, 1985, pp. 15 y ss., y 35 para la influencia aristotélica en las Helénicas. Pédech, 1984, p. 15, y Berve, 1926, p. 191, proponían su nacimiento en el 370 a. C. Para los problemas relativos a la cronología del contacto de Calístenes con Aristóteles, cf. Berve, 1926, p. 191. 
plenamente literaria. Ya Vattuone ${ }^{1898}$ indicaba la similitud existente entre muchos de los rasgos que definen a Timeo con los ambientes culturales de polémica literaria de su época, $y$, una vez más, hemos de enfrentarnos a unas

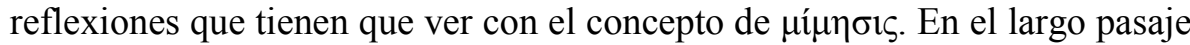
comentado por Polibio tenemos presentada la justificación del abismo que separa la retórica epidíctica de la historiografía. Timeo parte de un principio de verdad necesario en la historiografía que se define como sigue:

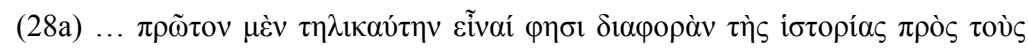

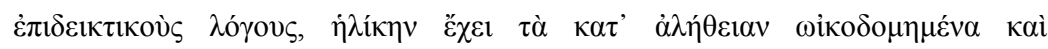

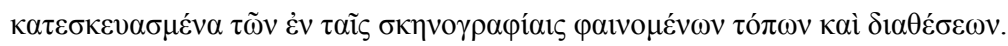

En este pasaje tenemos una referencia a un modo de verdad que poco tiene que ver con el concepto historiográfico moderno. Para Timeo la verdad tiene que ser modelada y construida no como las escenografías teatrales, y esto, dicho simplemente así, poco puede ayudarnos, y tampoco creemos que sea necesario sumergirse en una discusión sobre la escenografía teatral de la época. ${ }^{1899}$ La realidad histórica ha de construirse respecto a unos principios básicos que hacen que Timeo se aleje de la imagen habitualmente trazada por la crítica. ${ }^{1900}$ Así, el de Taormina nos está hablando una vez más, y con

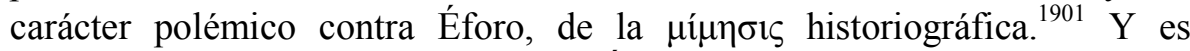
precisamente este tono polémico con Éforo el que nos debe llevar a pensar que estamos ante un hecho fuertemente relacionado con la crítica de Duris $^{1902}$ a los historiadores de la primera generación. Como acertadamente indicó Vattuone, estamos ante la diferencia existente entre objeto real y objeto representado, pero no en términos tucidídeos o de linealidad, como hemos venido defendiendo. Con las precauciones debidas cuando tratamos

${ }^{1898}$ Cf. Vattuone, 2002, p. 177.

${ }^{1899}$ Para lo cual cf. Pickard-Cambridge 1968, p. 177 y ss., y 1976, p. 175 y ss.

1900 Que hacía de Timeo un simple depósito de críticas y datos, cf. Susemihl, 1891, p. 571, siguiendo a Polibio, XII 26d1. Para todo ello cf. el juicio reciente de Vattuone, 2002, p. 185.

${ }^{1901}$ Lo que ha de hacer que reconsideremos las afirmaciones de Momigliano, 1959, p. 543, acerca de su lejanía de las diferentes escuelas filosóficas: el propio Momigliano, p. 532, señala que la Atenas a la que llega Timeo era la de Menandro y la de Demetrio de Falero.

${ }^{1902}$ Así, Vattuone, 2002, p. 189 y ss. 
de obras fragmentarias, es muy probable que estemos hablando una vez más de la necesidad de representar la realidad con arreglo a la verosimilitud que desde Aristóteles parece exigirse a las obras literarias. Si la crítica a Éforo se sustentaba en el exceso estático de sus narraciones, o si, por el contrario, estamos ante una crítica a los excesos histriónicos ${ }^{1903}$ de la obra de Éforo, es algo que cae, dado lo fragmentario de las obras, en el ámbito de la especulación.

\subsubsection{EL ESTILO LITERARIO Y SU ANÁLISIS EN LA HISTORIOGRAFÍA}

Un aspecto que aumenta aún más la complejidad del asunto es la habitual confusión que provoca la segunda sección del proemio de Duris, en

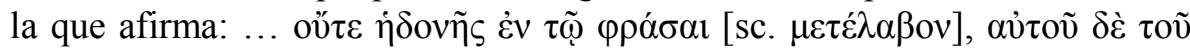

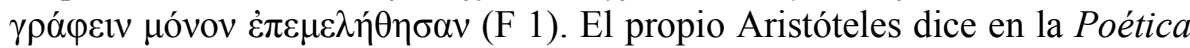
que uno de los medios de los que se vale el literato para desarrollar, y no para alcanzar, la $\mu i ́ \mu \eta \sigma ı \varsigma$ es precisamente lo que hoy entenderíamos por recursos estilísticos. ${ }^{1904} \mathrm{El}$ problema básico de la teoría aristotélica es que una vez más estamos ante planteamientos únicamente válidos para la literatura tradicional, dado que para Aristóteles los medios empleados son, básicamente, la armonía y el ritmo, y en tercer lugar el empleo de la palabra. ${ }^{1905}$

Obviamente, la teoría aristotélica da poca cabida a un desarrollo complejo de los aspectos puramente estilísticos -en un sentido moderno- en la prosa, y la tentación habitual ha sido la readaptación de esos principios a nuestra época, y con ello la explicación del pasaje de Duris por medio de la referencia a Dionisio de Halicarnaso y Longino. ${ }^{1906}$ La unión de la vertiente

${ }^{1903}$ Que el propio Timeo presentaba en su obra, cf. Momigliano, 1959, p. 545 y ss., lo que nos lleva una vez más a la reductio ad absurdum que rodea la historiografía helenística, dado que el propio Momigliano, p. 532, señala el interés por los aspectos morales de Timeo.

${ }^{1904}$ Cf. Gudeman, 1934, p. 108.

${ }^{1905}$ Cf. Aristóteles, Poética, 1448b20. Gudeman, 1934, p. 108.

1906 Así e. g. Gray, 1987, p. 471 y ss. La propia autora, p. 482 y ss., reconoce esta dificultad, que deja sin explicar la ingente labor que tienen que realizar Dionisio y Longino, e incluso antes el propio Cicerón, en lo relativo al nivel estilístico de la $\mu$ í obviamente es un argumento de mayor peso que dar cuenta simplemente de la semejanza de la

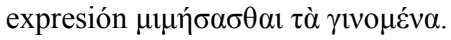


mimética y estilística del proemio de Duris ha llevado a considerar el concepto de $\mu$ í $\mu$ $\sigma \varsigma$ como simple imitación, reforzando nuestra comprensión del contenido del concepto, que quedaría así vacío de nuevo y explicaría las críticas a Éforo y Teopompo con un valor meramente formal y estilístico. ${ }^{1907}$

Los intentos de oponer los conceptos de $\varphi \rho \alpha ́ \sigma \alpha l$ y $\gamma \rho \alpha ́$ q́ modos diferentes de escribir desde un punto de vista estilístico ${ }^{1908}$ nos parecen errados, por cuanto ambos términos no significan lo mismo. El texto de Duris responde a un doble nivel de comprensión de la obra historiográfica, puesto que el placer se obtiene de la «narración» general del todo, conseguido finalmente por la $\mu$ í $\eta\rceil \imath \varsigma$ gracias a los medios conocidos,

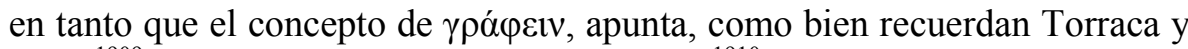
Gray, ${ }^{1909}$ en contra de lo indicado por Müller, ${ }^{1910}$ y Jacoby, a la composición

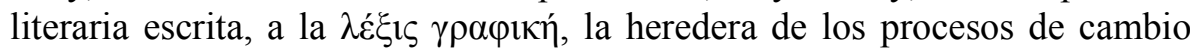
que vimos iniciarse en Tucídides, adecuada para la lectura y la exposición epidíctica en el sentido etimológico del término. ${ }^{1911}$ Para entender este concepto hemos de recordar que la gran literatura en la que pensaban tanto Platón como Aristóteles era una obra de arte en la que la música, la danza y la escenificación desempeñaban un papel imposible en el género que nos ocupa. El impacto estético ${ }^{1912}$ de una obra literaria ajena a ese mundo es relativamente menor, y superar la frontera de lo simplemente epidíctico en el sentido aristotélico es algo muy complicado. La narración grotesca, casi histriónica, de un Teopompo se movería en la escala de aquello que se imita,

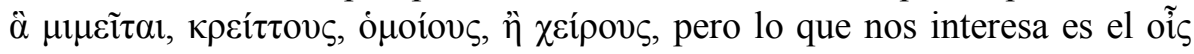

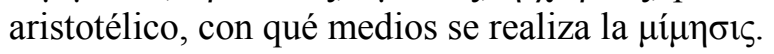

Con todo esto, se pueden comprender muchas de las reticencias de los críticos en lo que se refiere a la historiografía trágica. Teniendo presente que es muy probable que el uso que hace del término Polibio tenga poco que ver con Aristóteles -Polibio piensa en la tragedia del siglo IV a. C., con sus

${ }^{1907}$ Cf. Gray, 1987, p. 477. No creemos que sea de recibo invalidar la teoría mimética aristotélica para aplicar después la teoría de autores tan tardíos como Dionisio de Halicarnaso o Longino.

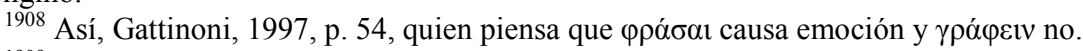

${ }^{1909}$ Cf. Torraca, 1988, p. 14; Gray 1987, p. 478. Cf. también Vattuone, 1991, p. 43.

${ }^{1910}$ Cf. Müller, 1868, p. 469.

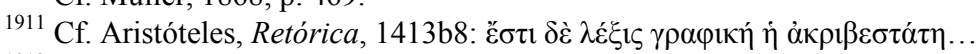

1912 Cf., en este sentido, las observaciones respecto al Fr. 57 de Duris por parte de Consolo Langher, 1986, p. 358: «indica [...] accanto all' interesse per il mimo, vivissimo fosse l'interesse dell'autore per la realizzazione scenica de essi come spettacolo [...]» 
peripecias y falta de profundidad, y Aristóteles en la del siglo V a. C. -, y que esta unión se debe a Schwartz, podemos tratar de esbozar algunas conclusiones. Como bien señala Brink, las referencias a la historiografía en la Poética aristotélica son mínimas, casi circunstanciales, ${ }^{1913}$ pero, a nuestro entender, ello no es excusa para que el concepto de $\mu$ í $\mu$ $\sigma ı \varsigma$ que tenemos en Duris no esté relacionado con Aristóteles. Parece muy complicado, dado el marco temporal, que Duris hablase de una $\mu$ í ver con Aristóteles, aunque esa relación fuese de simple polémica, o supusiese un desarrollo del concepto aristotélico que, en último término, poco tuviera que ver con el Estagirita. ${ }^{1914} \mathrm{Si}$ admitimos la idea de que

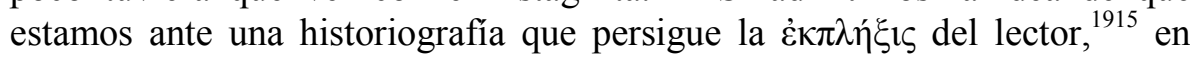
detrimento quizá de la función educativa en un sentido austero al modo polibiano, y tenemos en cuenta que, como indica el propio Walbank a la hora de negar la paternidad de la historiografía trágica al peripato, ${ }^{1916}$ el elemento emocional no viene de esta escuela -teniendo presente que sabemos que el

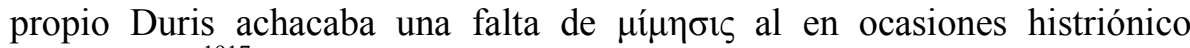
Teopompo- ${ }^{1917}$ creemos que es aceptable asumir como una posibilidad con visos de ser probable que Duris haya desarrollado en su obra la sección estilística de la teoría de la $\mu$ í idea. ${ }^{1918}$ Competir con la escenificación de una obra literaria oral es un reto no apto para cualquiera y algo cuyo resultado no es plato de gusto para autores de la austeridad de Polibio, que veían en esa abigarrada acumulación de hechos ${ }^{1919}$ algo cercano a la dramaturgia del siglo IV a. C. A nuestro

\footnotetext{
${ }^{1913}$ Cf. Brink, 1960, p. 17.

${ }^{1914}$ Brink, 1960, p. 18, separa la historiografía trágica de Aristóteles, pero, en el fondo, el autor se mueve todavía con el lastre que supone Polibio.

1915 Así, Walbank, 1955, p. 4, en su última reflexión sobre el tema, con un tono de mínimos seguros.

${ }^{1916}$ Cf. Walbank, 1955, p. 11.

1917 Recuérdese que, como indica Gray, 1987, p. 472, una de las críticas habituales a Teopompo es la monotonía de su narración.

${ }^{1918}$ Creemos que las palabras de Brink, 1960, p. 14, quien deja de lado la discusión sobre

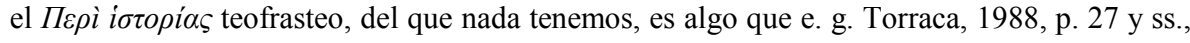
quien trata de ver en la Epístola a Luceyo un trasunto del tratado, debería tener presente. Obviamente, de esta última idea a la afirmación de Reitzenstein, 1906, p. 85, quien decía que esta carta era el único tratado helenístico sobre la historiografía conservado, hay un mundo. En este mismo hilo de pensamiento se han de valorar las palabras de Kebric, 1977, p. 5, acerca del testimonio de Ateneo, IV 128A acerca de la relación de maestro-alumno existente entre Teofrasto y Duris.

${ }^{1919}$ Cf. Torraca, 1988 , p. 16 y ss. 


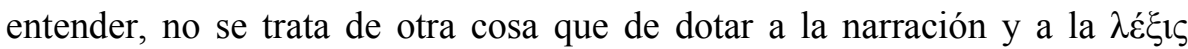
үрафкки́ de un sentido estético seguramente imposible.

Con todo ello tenemos un panorama más complejo que la obra de unos autores que dramatizan en exceso sus obras. ${ }^{1920}$ Estamos ante la que parece ser la primera teoría, o más bien el primer intento de teorizar sobre la historiografía. Hemos de olvidarnos por un momento de Polibio, y asumir que en el totum formado por los historiadores que van de Éforo y Teopompo a Duris y Calístenes hemos de trazar una línea clara de separación que el megalopolitano asume como inexistente. Si hemos de interpretar de manera coherente el proemio de Duris, hemos de pensar que la crítica a sus antecesores se debe a unos matices que Polibio no acierta a ver. La formación de Duris, seguramente de un nivel poco igualable por otros autores, nos ha de servir para recordar que la complejidad de las obras de este periodo es mucho mayor de lo que en ocasiones se ha querido ver, ${ }^{1921}$ pero, para ello, tenemos que olvidar de una vez por todas el fácil puerto que supone la denominación de la historiografía como retórica.

Los datos recogidos y examinados hasta el momento dan como resultado una imagen muy diferente de la que se suele tener de la historiografía helenística, plagada de apriorismos y de relaciones con poco sustento, que terminan por dibujar un panorama retórico, en el mal sentido del término, y puramente fantasioso.

A este respecto, el hecho de que Éforo y Timeo se plantearan la diferencia e incluso la supremacía de la historiografía respecto a la retórica es buena prueba de lo errado de pensar en una historiografía meramente retórica. La complejidad de las teorías literarias heredadas, fraguadas en el traumático paso del mundo oral al plenamente escrito, y el fuerte tono conservador de los dos grandes teóricos del momento, Platón y Aristóteles, quienes pensaban en una literatura fuertemente ritualizada, hacen que la complejidad de las primeras ideas sobre el género contenidas en estos proemios sea realmente elevada. Creemos que, en este sentido, la ayuda de un autor tan mediocre en estos asuntos como es Polibio sirve realmente de poco, y que simplemente hemos de atender a la importancia del concepto de $\mu i ́ \mu \eta \sigma ı \varsigma$ y a sus posibles connotaciones en la época, asumiendo que hablamos de un periodo que se extiende más de un siglo y que da cabida a

${ }^{1920}$ La definición está tomada de Laistner, 1947, p. 14. Cf. también Giovannini, 1943, p. 310 y ss., basándose en Polibio.

${ }^{1921}$ E. g. Laistner, 1947, p. 2. 
prácticamente tres generaciones bien diferenciadas de historiadores y críticos. $^{1922}$

Esta triple división del periodo a la que antes hicimos referencia es fundamental para comprender el carácter fuertemente polémico de la época y lo cambiante de un género y unos proemios que comienzan a asentarse. En último término, e incluso a pesar de que los autores que nos ocupan son ajenos al mundo alejandrino, como ya señalaba Fraser, ${ }^{1923}$ es fácil ver la cercanía entre el mundo polémico y altamente erudito de los poetas de Alejandría y la historiografía de la época, que hasta ahora caminaba alejada del resto de la literatura del momento. La crítica ha caído en la tentación de considerar con gran ligereza que autores como Calístenes o Duris criticaban fallos que eran encontrados, de manera global, por los estudiosos en todos los autores del periodo, llevados por el pantucidideísmo que impregna la idea que trata de determinar que Heródoto y Tucídides iniciaron dos escuelas de historiografía, y que fue el primero el responsable de todo lo prodigioso. ${ }^{1924}$

La realidad es, como siempre, más compleja. La deriva social e histórica del complicado siglo IV a. C. presenció a partes iguales la aparición del germen del futuro individuo y la calmada inestabilidad en lo político. ${ }^{1925}$ Los límites de Grecia quedaron borrados en una larga agonía de dependencias y relaciones políticas que diseñaron un escenario en el que todavía no se había traspasado la línea del helenocentrismo, concepto que se esconde detrás de la incorporación de los diferentes pueblos a la obra de Éforo en tanto en cuanto entran en contacto con los griegos.

Pero no es esta idea de expansión de los horizontes la que se esconde detrás de lo prodigioso o lo llamativo. Es la deriva moral del individuo, el fuerte cuño impreso por Sócrates, lo que hace que los historiadores terminen por sancionar la preocupación por los aspectos morales de sus personajes, que cobran una posición central ya visible en Tucídides. Lo histriónico, lo llamativo, lo pintoresco, e incluso la utopía, diseñan una narrativa de plena funcionalidad moral: los excesos cínicos de Teopompo o la preocupación

${ }^{1922}$ Hecho que permite que sean compatibles las críticas de Éforo a la música, referidas al estado de cosas de su época, y la defensa del concepto de $\mu$ í Duris, quien piensa no en la música de su época, ni en la de Éforo, sino en el gran momento

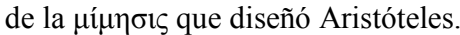

${ }^{1923}$ Cf. Fraser, 1972, p. 495.

1924 Así, Bruce, 1970, p. 89.

${ }^{1925}$ Cf. Kaerst, 1927, p. 56 y ss. 
moral de Éforo diseñan un mundo que conocemos por Isócrates, aproximación válida, sea este el maestro de toda la generación o uno más. La deriva del mito paidéutico platónico se verifica en elementos prodigiosos que dejan atrás lo tradicional y se arman con la $\dot{\varepsilon} \kappa \pi \lambda \eta \dot{\xi} \xi \varsigma$ ante un público al que había que formar en beneficio de la comunidad.

La primera generación de historiadores representada en la llamada escuela isocratea, Éforo y Teopompo, hace honor al orador griego en tanto que desarrolla una historiografía de fuerte dedicación social. Ya hace tiempo que el exemplum histórico en Isócrates fue definido como un medio propagandístico para la comunicación de valores y normas. ${ }^{1926}$ Sin un texto fundacional, sin un manual del buen ciudadano, Isócrates gozaba, a pesar de ello, de una idea muy clara de la forma de manejo del Estado ${ }^{1927}$ que hemos de buscar como explicación en la insistente presencia de cuadros de crítica moral a los grandes dirigentes del momento en los historiadores que nos ocupan. ${ }^{1928}$

El exceso cínico, materializado en Teopompo en lo prodigioso y exagerado, y en lo falso en Éforo, ${ }^{1929}$ la famosa «political bias», responde a la necesidad de dibujar en esperpento una realidad que seguramente golpeaba en exceso a unos autores realmente comprometidos. De este modo, hablar de discípulos de Isócrates es algo tan posible como imposible, porque lo hasta ahora expuesto incide, una vez más, en la vieja idea de Barber, quien pensaba que la influencia de Isócrates llegaba mucho más allá de lo habitualmente pensado, ${ }^{1930}$ lo que, a nuestro entender, es buena prueba de

${ }^{1926}$ Cf. Schmitz-Kahlmann, 1939, p. 118. Hamilton, 1979, p. 293, señalaba la presencia en Isócrates de una imagen clara y paradigmática de la historia hasta aproximadamente el 360 a. C., lo que incide en esas ideas. Por su parte, Nouhaud, 1982, p. 355, proponía una división con un primer periodo que llegaba hasta el comienzo del conflicto del Peloponeso, y un segundo que arrancaría con esta guerra, lo que en cierta manera responde más a la idealización de generaciones anteriores, dado que, como señala Nouhaud, el segundo periodo no había sido objeto todavía de idealización.

${ }^{1927}$ Cf. Schmitz-Kahlmann, 1939, p. 119.

${ }^{1928}$ Cf. Nouhaud, 1982, p. 354: «[En el siglo IV a. C.] il s'agit essentiellement d'une mise en parallèle du présent et du passé... cherchant à dégager une leçon pour l'immédiat [...] il n'est, jamais, en réalité, pensé autrement qu'en fonction de son utilité pour le présent et pour l'avenir».

${ }^{1929}$ Cf. Barber, 1935, p. 82 y ss.

${ }^{1930}$ Cf. Barber, 1935, p. 83. 
que estamos ante un fenómeno generalizado en la época, ${ }^{1931}$ que rápidamente desdibuja los límites de esas influencias.

El estilo de estos autores, a pesar del exceso histriónico, se debía mover

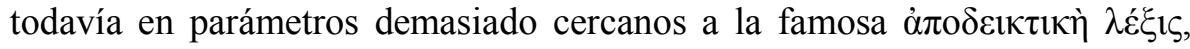
que ya hemos visto que poco tiene que ver con lo retórico y mucho con lo explicativo, estilo acorde con las necesidades que plantearía una narrativa del modo expuesto, y que poco tendría que ver ya con los modos literarios del siglo $\mathrm{V}$ a. $\mathrm{C}$.

La parte central del periodo está ocupada por la teoría aristotélica de la

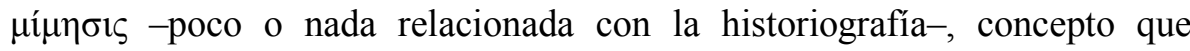
reaparecerá en la obra de Duris y Calístenes. Olvidándonos de Polibio, cuyas ideas en este sentido eran más bien escasas en profundidad, ${ }^{1932}$ tenemos una generación que debía moverse en los mismos parámetros morales, a juzgar por la aparición del mismo tipo de escenas morales y prodigiosas que en Éforo y Teopompo, pero que, en este caso, tiene preocupación por el

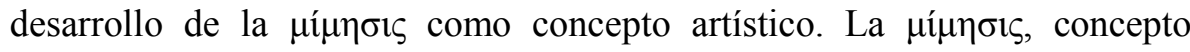
poético por antonomasia, se refiere exclusivamente a un ambiente ritual, a una dramatización, a una actuación que difícil aplicación puede tener en una obra historiográfica. Para dotar de ese sentido a la historiografía tendremos que esperar a Tácito, quien será capaz de dar alma y $\tilde{\eta} \theta$ o $̧$ a sus personajes, y trascender así la simple tipología de actuaciones, que es lo máximo que puede ofrecer la historiografía hasta el momento.

Seguramente, la actuación de Duris y Calístenes no pasó de una mayor profundización en la caracterización de los personajes, en un intento, si se quiere, por dotar de uniformidad a los personajes que aparecen en las obras, tratar en definitiva de hacer obras que no cayesen en un error presente en la dramaturgia del siglo IV a. C., creando $\ddot{\eta} \theta \eta, \pi \alpha ́ \theta \eta$ у $\pi \rho \alpha ́ \xi \varepsilon \varepsilon 1 \zeta$, pero el propio devenir de la biografía nos alerta de que, aunque se diesen estos tres elementos, parece difícil superar una frontera que el siglo $\mathrm{V}$ a. C. superó solo por medio de la ritualización.

${ }^{1931}$ En este sentido, aunque quizá estemos dando una transcendencia que no buscaban a sus palabras, parecen referirse a esta dimensión Tarn y Griffith, 1952, p. 281 y ss.

${ }^{1932}$ Puede ser útil la afirmación acerca de la profundidad histórica de Susemihl, 1892, p. 93: «Ein Studium der Geschichte in rein wissenschaftlichen Interesse liegt völlig ausser den Geschichtskreise des Polybios. Er erblickt vielmehr ihrer Zweck lediglich in der praktischen Lehren, welche sie giebt in ihren Nutzen». 
A ello hay que unir el hecho -recordemos el oర̋ $\varepsilon \varepsilon \ldots$ ov̌ $\tau \varepsilon .$. del proemio de Duris- de que la labor estilística de este autor necesariamente supone una

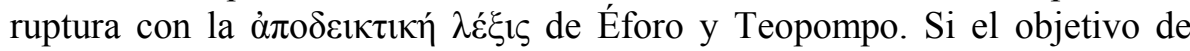
Duris era alcanzar el nivel de la poesía tradicional oral por medio de recursos estilísticos en prosa, el resultado sería, como ya indicamos, algo poco acorde con los usos habituales. Esto último, unido a las escenas prodigiosas, a la intensificación de los $\ddot{\theta} \theta \eta$ y $\pi \alpha ́ \theta \eta$, daría lugar a una obra realmente llamativa, que mereció el apelativo de trágica por parte de Polibio, una obra de un erudito literario demasiado preocupado por la teoría como para producir a nivel práctico algo para la posteridad.

Seguramente, y siempre y cuando lo ya expuesto en torno a Crátipo sea correcto, sería en este mismo escenario de reflexión literaria en el que se ubicase la figura de este autor y sus reflexiones en torno a la obra de Tucídides y los discursos, con lo poco que nos brindan los confusos fragmentos. Lo curioso es observar que el comienzo de la reflexión sobre la historiografía en los propios proemios presenta una cronología algo anterior a la gran eclosión cultural alejandrina, y que, a pesar de ello, es probable que estemos ante fenómenos no muy diferentes.

La dualidad que Prandi vio en la figura de Calístenes, a caballo entre la filosofía y la política, ${ }^{1933}$ es un hecho prácticamente aplicable a todos los autores de esta época. En definitiva, el mayor error de estos historiadores fue asumir una funcionalidad de la historiografía de pleno carácter educativo al precio que fuese, hecho que, combinado con un excesivo y en ocasiones pedante tono erudito, ${ }^{1934}$ hizo que la figura de Polibio, padre de una historiografía técnica, supusiera el fin de al menos cuatro generaciones de historiadores.

${ }^{1933}$ Cf. Prandi, 1985, p. 181: «Egli appare rappresentativo del periodo in cui visse, ed interessante come caso paradigmatico, perché ebbe una parte attiva nel fermento ideologico della seconda metà del IV secolo, riferendosi sempre a due realtà che in lui e la sua opera risultano interdipendienti e complementari: il rapporto con la cultura filosofica (se si dà al termine il suo significato etimologico e quindi più ampio) e il rapporto con il potere politico».

1934 Plutarco, Vida de Alejandro, 54, 2, cuenta que Aristóteles decía de Calístenes: $\lambda \hat{\gamma} \gamma \omega$

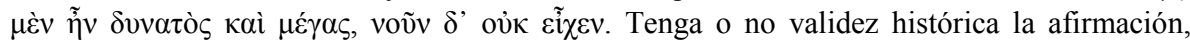
puede servir como buena definición de su obra. Cf. Prandi, 1985, p. 114 y ss. 



\section{EPÍLOGO}

Después de examinar los datos presentados, se pueden aventurar conclusiones que no apuntan precisamente en la línea más habitual de interpretación del género historiográfico. La denominación historiografia es una expresión anacrónica, dado que, con total seguridad, ninguno de los autores estudiados pensaba que hiciera algo diferente al resto de autores que protagonizaron la eclosión literaria y cultural registrada desde finales del siglo VI a. C.

De nuevo es necesario incidir en la importancia del paso del mundo oral al escrito en la comprensión no solo de la aparición de la historiografia, sino en del desarrollo de todos los géneros que no presentan una naturaleza oral y tradicional. El no tener un contexto claro, idea esta de contexto que casi se puede asimilar a la de género, ${ }^{1935}$ hizo que la vinculación de la historiografía a la escritura fuese fundamental.

Si hemos de señalar de manera clara el origen de estos proemios, deberemos mirar en primer lugar a las fórmulas de transición que se desarrollaron con motivo del fuerte extrañamiento que supuso para una sociedad oral el desarrollo de la escritura como soporte literario y de las opiniones de un individuo, y no como simple medio de transcripción: la cultura arcaica consideraba la voz como garante misma de lo dicho. La representación incluso pictórica de los individuos parlantes, o su sustituto, la

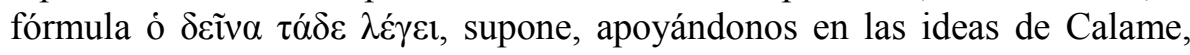
superar el salto conceptual que el mundo griego tuvo que abordar para, dentro de los grandes cambios que supuso la desintegración del mundo oral, ver la aparición de un género que recoge en su seno no solo la historiografía, sino una multitud de trabajos polémicos, de opinión y experiencia personal que, hoy perdidos, ${ }^{1936}$ podemos observar en los escasos fragmentos

\footnotetext{
${ }^{1935}$ Cf. Nagy, 1994, p. 9.
}

${ }^{1936}$ A nuestro entender, pues, en la disputa Nagy-Thomas, el posicionamiento de Bakker, 2002, p. 14 y ss., nos parece difícil de aprobar, dado que Heródoto no depende de préstamos de conceptos y términos tomados de ese macrogénero, sino que se inserta en él. Una afirmación como «is neither an oral storyteller nor an accomplished modern scientist. Or rather he is both, using the vocabulary of the latter to revolutionize the practice of the 
conservados y en los abundantes testimonios existentes. El siglo $\mathrm{V}$ a. C. esconde un complejo y rico mundo cultural ajeno a los grandes géneros literarios que, por desgracia, permanecerá siempre en el trasfondo de la gran literatura, en algunos casos incluso recogido bajo denominaciones quizá poco adecuadas, ${ }^{1937}$ pero que es necesario tener en cuenta para comprender en toda su profundidad los cambios que darán paso al siglo IV a. C., no solo en lo histórico, sino también en lo cultural. Es, pues, un género de naturaleza plenamente escrita, tanto por la forma del proemio como por su concurrencia con los géneros tradicionales de naturaleza oral.

Esa naturaleza escrita tiene como consecuencia que el estudio formal del género se tenga que encuadrar en el desarrollo de la prosa de la época, desarrollo que por su complejidad ofreció problemas pero también posibilidades muy interesantes. En el rápido estudio de la prosa realizado hemos tratado de defender la existencia real de lo que hemos denominado «retórica oral», que no es otra cosa que el conjunto de recursos que, con el mismo espíritu y condicionantes que presenta la poesía oral, determinaba la composición formal de las obras en prosa orales, perdidas hoy, pero cuyos rasgos son recuperables gracias a la fuerte influencia que ejercieron en los primeros pasos de la creación de una prosa escrita. La progresiva desaparición de las necesidades planteadas por una obra oral, resumidas en una cohesión suficiente de sus elementos que garantizase su supervivencia, dio paso a la entrada de rasgos de nivel conversacional en la prosa, con lo que se inició una etapa de experimentación que culminaría en el siglo IV a. C. con la creación de una prosa artística que hoy entendemos como clásica.

Así pues, en este escenario formal se desarrolla un género escrito que deja por primera vez de manera permanente testimonio de un pensamiento privado e individual en aspectos muy diversos de la reflexión humana, con un fuerte tono polémico en el cual reside la explicación de los usos de elementos como el $\delta \varepsilon ́$ apodíctico, que, en último término, responde a la interconexión en ese tono polémico de las diferentes obras: las relaciones entre los distintos autores quedan demostradas por las semejanzas de vocabulario y estructura, por lo que una vez más hemos de desechar en términos formales el establecimiento de un eje progresivo de desarrollo, y pensar mejor en unos desarrollos paralelos dentro de un género con obras

former», en p. 28 y ss., da por supuesto tanto la existencia de la historiografía como que esta tenía una metodología que pasaría a sustituir a otra anterior no definida.

1937 Thesleff, 1966, p. 102, hablaba de los «panfletos» de los sofistas, para indicar todo un rico mundo literario. 
interconectadas. Es dentro de este género donde se encuentra la historiografía, ajena a los límites que nuestra visión moderna le impone. ${ }^{1938}$

Pero el abandono de los mecanismos de expresión del mundo literario oral no fue total, y la en ocasiones pedestre expresión que los nuevos modelos traían consigo necesitó pronto el respaldo de la tradición, acción llevada a cabo por Heródoto. Un examen detenido de los datos antes reunidos nos permite reconocer que Heródoto nos es un elemento de fácil integración dentro del esquema que va de Hecateo y los primeros autores en prosa hasta Tucídides: el estado fragmentario de muchos de ellos puede hacernos dudar, pero la realidad es que Heródoto se separa de manera clara de ese esquema proemial antes señalado y recurre a la gran literatura para configurar el comienzo de su obra, en la que un completo mundo de reminiscencias relativas al tema clave de su obra sostiene su entramado formal. Es la épica, y con ella los esquemas compositivos orales, la que determina la estructuración del proemio de Heródoto, ${ }^{1939}$ de modo que la influencia, a pesar del testimonio de los antiguos, no se reduce al vocabulario. ${ }^{1940} \mathrm{El}$ empleo de una organización de los diferentes elementos parejo al presente en los proemios épicos añade la segunda gran influencia en el desarrollo del proemio historiográfico, lo que supone el primer gran paso para la separación del género historiográfico como tal de ese conglomerado al que antes hacíamos referencia. Esta influencia es claramente justificable si tenemos en cuenta la especial facilidad que para su adaptación ofrecía el modelo de pensamiento progresivo propio de la épica y que antes hemos señalado, a lo que se añaden los pasos dados por Simónides en la readaptación de esos esquemas en el ciclo de las guerras médicas, con lo que el proceso experimentó un sustancial avance, dada además la relación de contenido existente.

Decía Longino que Heródoto era el más homérico de los autores, y no nos cabe duda de que podemos incluso dar más peso a las palabras de este autor de lo que en un comienzo pareciera. Heródoto fue, que nosotros sepamos, el primero en plantearse la configuración de una obra de arte

\footnotetext{
${ }^{1938}$ Cf. recientemente Nicolai, 2011, p. 168, para la idea de estudiar a los historiadores como si fuesen sofistas, es decir, como los veían sus contemporáneos.

${ }^{1939}$ Recuérdese que Woodman, 1988, p. 2 y ss., reducía a los simples «tópicos» retóricos los rasgos que influyen en Heródoto, y la supuesta novedad de los rasgos homéricos aducida por Woodman ha quedado demostrado que no es tal, a la vista de los datos incluso de la Antigüedad.

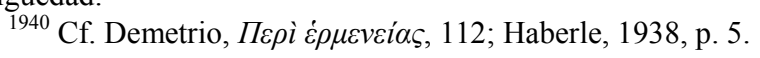


literaria fuera de los géneros habituales en la época, respaldados por una tradición que los dotaba de unos recursos literarios. Para ello, y recurriendo a ese buen conocimiento de la literatura de que antes hablábamos, empleó los recursos compositivos de la antigua épica y de la narrativa oral, al tiempo que a todo ello añadía recursos propios aún sin configurar en el plano literario que terminarían por dar lugar a la aparición de la prosa clásica griega tal y como la conocemos. Esos recursos, presentes de manera clara en el proemio y que demuestran el carácter mixto del género historiográfico, parecen ser repetidos por los historiadores posteriores y en algunos tratados hipocráticos de la época, lo que nos da idea de la aparición de una configuración consciente de un tipo literario muy heterogéneo en su temática, pero que con el tiempo acabará albergando únicamente el género historiográfico, mientras que la progresiva especialización técnica del resto de escritos, como los médicos, hará que dejen de perseguir un nivel literario como fin.

En lo relativo a la cronología, no podemos determinar con exactitud si Heródoto fue el primero en emplear estos recursos, pero todo parece apuntar a que fue así, y que los dos autores posteriores, Antíoco (si nos atenemos a la reorganización de los fragmentos realizada, a la vista de la idea que de una Ringkomposition podía tener Dionisio de Halicarnaso) y después Tucídides, harán uso de esa estructuración, al tiempo que el progresivo desarrollo de una prosa no oral hará que los modos de expresión herodoteos sean abandonados para iniciar una etapa de experimentación que dará como resultado la caracterización estilística del siglo IV a. C. Solo en el comienzo mismo de los proemios podremos observar todavía el empleo de la conformación propia de los primeros pasos de la literatura aislada de lo oral, quizá sentida esa caracterización todavía como un elemento clave para la afirmación de un género que no tenía carta de naturaleza segura, pero que ya empezaba a rotular unas lindes claras en el momento en que Tucídides y antes Antíoco readaptan, abandonando gran parte de los rasgos de mayor peso literario, una estructuración anular nítida, presente, como vimos, en los poemas homéricos y aún rastreable en Tucídides.

La aparición de nuevas necesidades de pensamiento implicaba la búsqueda de nuevos medios formales para favorecer su expresión, lo que lleva a que sea precisamente en los proemios donde se desarrolla de manera más clara esa evolución de la prosa, principalmente porque es ahí donde más patentes se hacían las carencias de los anteriores recursos de la prosa para la expresión de las ideas que los proemios recogen, y será en ellos donde más 
se extreme la experimentación a nivel de frase de los autores, como ejemplifica una oposición entre las secciones narrativas y las explicativas de los proemios de Heródoto y Tucídides, respectivamente.

Respecto al vocabulario, se puede observar cómo las concomitancias son mayores de lo que parecen entre Heródoto y Tucídides, lo que echa por tierra la tradicional primacía de Tucídides en el género, dado que muchos de los conceptos programáticos presentes en el proemio tucidídeo aparecieron ya en la obra de Heródoto, si bien no en el proemio, sino en el cuerpo de la obra. A pesar de ello, hemos de reconocer que precisamente por esto la precisión de Tucídides es mayor, y que seguramente esa posición en la transición entre la prosa oral y la escrita fue el aspecto clave para poder dar salida a unas ideas difícilmente expresables en moldes herodoteos.

La imagen que proyectan los proemios de Heródoto y Tucídides es, seguramente, muy diferente a la que habitualmente se ha tenido, y ello ha sido así por la necesidad de articular sobre estos autores un modelo que no corresponde a la realidad de la literalidad de los textos.

Paradigmática de este hecho es la poca preocupación por el pasado como algo digno de conservar: en el caso de Hecateo, todo parece apuntar, simplemente, a un interés por plantear una opinión o interpretación personal del pasado mítico, no a una reorganización en términos racionales del mismo. En el caso de Heródoto y Tucídides, la complejidad de sus obras no nos puede llevar a considerar que es un afán de salvar el pasado o un deseo de objetividad respecto a los acontecimientos el que regula sus obras. El complejo devenir de la sociedad griega del siglo V a. C. y, en especial, el mundo ateniense, son circunstancias fundamentales para la determinación de dos líneas de pensamiento esenciales en la configuración del pensamiento proemial historiográfico.

Y ello es así por la fuerte vinculación que ambos tienen con la realidad del momento que acoge sus obras: es casi necesario valorar los acontecimientos acaecidos prácticamente década a década para comprender unas obras que no nacieron pensando en un público amplio o en el futuro. Tanto la fuerte carga polémica que presentan los proemios en el plano formal como lo heterodoxo y poco sistemático de los mismos llevan a un escenario de carácter reducido, un escenario sometido a unas preocupaciones que en ocasiones son imperceptibles en el estudio de la realidad cultural y social de la época, y que predicen muchos de los futuros procesos. El historiador, denominación ajena al periodo que nos ocupa, actúa desde una 
perspectiva fuertemente subjetiva, entendida esta como un análisis de la realidad desde una visión plenamente personal y propia, con cuya suma se obtiene un mundo vivo de polémica. En este sentido, la historiografía es la respuesta al interrogante acerca de la desaparición de la poesía de tono personalista con la llegada del siglo $\mathrm{V}$ a. C., y de la democracia, diríamos nosotros. El pasado, o el presente, como en el caso de Tucídides, se toman como tramoya para la edificación de un modelo de Weltanschauung propio y personal, y esto solo es posible cuando los mecanismos tradicionales de interpretación de estos hechos fallan. La necesidad que lleva a Heródoto a preocuparse por el recuerdo del pasado es su interpretación desde una clave decididamente política e incompatible con los modelos tradicionales y aristocráticos del pasado. Así, la interrupción drástica de una corriente espiritual vinculada a una concepción aristocrática de la realidad es la que lleva al de Halicarnaso a sancionar un modelo de comprensión del mundo tan antiguo como los ideales agonales, pero al tiempo, y gracias precisamente a esos procesos de disolución, Heródoto crea algo nuevo que no es simplemente la interpretación de la realidad en la antigua clave arcaica.

Precisamente, el contrapunto de esta imagen herodotea nos la ofrece Tucídides, quien relativamente pocos años después traza en su obra la imagen contraria, la Weltanschauung de la democracia ateniense en funcionamiento, en un momento en el que la crisis es ya lo suficientemente compleja como para deparar únicamente la quiebra del mundo hasta entonces conocido. La imagen tucidídea de la realidad sobrecoge precisamente por los tintes grises de un mundo idealizado y sistematizado, por la delimitación de una realidad de funcionamiento casi matemático, con una imperfección propia de la irrealidad y que detiene el funcionamiento del mundo como quien presta atención al mecanismo de un reloj y no advierte el movimiento de sus agujas, ensimismado en la precisión de su maquinaria.

La interpretación de todos estos aspectos se realiza no en virtud de conceptos de percepción de la realidad vinculados con la verdad, no constituida en finalidad en esta época, sino por medio de una gradación de comprensión de la realidad presente en la filosofía y la literatura arcaica que se presenta aplicada de manera clara en Heródoto y de manera menos precisa en Tucídides. En ambos autores, por otra parte, se observa el empleo de estructuras de especial importancia en el cuerpo de la obra para la exposición de los aspectos fundamentales del proemio, de modo que la escena de Solón y Creso o el falso proemio al libro VII tienen su paralelo, en una forma propia del tema tratado, en los discursos de Pericles, en lo que es un recurso 
todavía arcaico de explicación de la obra. ${ }^{1941}$ Esta dinámica, de una complejidad reseñable, es un rasgo que encontrará su conclusión en los autores que nos ocupan, de modo que en épocas posteriores asistiremos, simplemente, a la organización de los hechos narrados en virtud de su significación en cada época y para cada autor. De este modo, la primacía metodológica de acercamiento a la realidad que la crítica ha atribuido a estos autores es innegable, tanto como imposible el separarla del arcaísmo griego.

Pero asumir, simplemente, que estamos ante la puesta por escrito de acontecimientos históricos en clave de modelos tradicionales o de ideología democrática es quedarse en una de las caras del proceso. La complejidad de los proemios de Heródoto y Tucídides reside, precisamente, en el hecho de que son fruto de las múltiples influencias y condicionantes de su época, dando lugar a modelos fuertemente personales. Estos modelos llevan aparejados una serie de interrogantes que se convertirán en universales a lo largo de la historia del género y ante los que se plantearán respuestas adaptadas, como es natural, a los diferentes momentos en que se den. Este carácter dinámico es una de las razones fundamentales que llevan a los diversos autores a poner en tela de juicio los planteamientos de sus predecesores, de modo que el carácter polémico, casi agonal, que caracteriza a la literatura en prosa de esta época se extiende al desarrollo del género a lo largo de las diferentes generaciones de historiadores.

La preocupación por el concepto del tiempo histórico, fuertemente ligado a los conceptos aristocráticos, como bien ejemplifica Heródoto en su proemio, o el establecimiento de la dimensión física del escenario en el que se desarrollan los hechos, que va desde la obsesión por las fronteras herodoteas hasta la comprensión del mar como escenario de expansión y las referencias a los movimientos de población de Tucídides, definen dos de las líneas fundamentales del pensamiento historiográfico griego que remontan incluso a Hecateo, el autor con el que abríamos esta sección, y que proceden de la literatura presocrática griega, a medio camino entre la especulación científica, la simple necesidad práctica $\mathrm{y}$, en ocasiones, el gusto por lo diferente o prodigioso.

Dentro de estas dos constantes se encuadra un diseño mucho más complejo que, en los autores que nos ocupan, se mueve dentro de una innegable relación con los conflictos existentes entre el individuo y la

${ }^{1941}$ Con la sola diferencia de girar la exposición en torno a la justicia en el caso de Heródoto, y en el de Tucídides, en torno al poder, cf. Saïd, 2011, p. 63 y ss. 
colectividad. ${ }^{1942}$ La consideración habitual de que el desarrollo de la centralidad del individuo es un proceso tardío lastra la comprensión de la fuerte tensión existente en este periodo y los autores que nos ocupan. Heródoto y Tucídides representan en este sentido dos modelos a superar por su vinculación a unas circunstancias en exceso convulsas que derivarán en su superación en el periodo siguiente.

En este mismo sentido, la presencia de la esfera de lo religioso, o, si se prefiere, de elementos sobrenaturales, viene determinada por la casuística individual de cada autor. Frente a la fuerte religiosidad de Heródoto y el

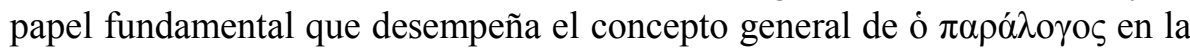
obra del de Halicarnaso, la presencia de este elemento en el diseño de Tucídides es ciertamente marginal, ${ }^{1943}$ principalmente por la necesidad de eliminar cualquier factor que pudiera vulnerar la perfección de un diseño con afán de eternidad.

Es este mismo afán de atesorar un modelo de realidad permanente, que era, por otra parte, una obsesión de la época, el responsable del modelo de tiempo presente en ambas obras. Tanto el diseño herodoteo como el de Tucídides no pueden plantear, por su propia coherencia interna, un modelo de tiempo histórico que acoja un tiempo determinado por la idea de progreso. El tiempo se construye en un sistema doble de operación en el que se superpone un modelo estático de la realidad a la sucesión de acontecimientos, rigurosamente subordinados a la primacía de ese modelo. De este modo, se combinan dos modelos, asemejados a los movimientos de rotación y translación de la Tierra, definiéndose unas constantes básicas siempre permanentes, unos hechos que no suponen desplazamiento alguno respecto a los factores fundamentales.

En definitiva, y en contra de lo habitualmente considerado, la mayor diferencia existente entre los proemios de Heródoto y Tucídides es seguramente la mayor concentración del contenido metodológico en el proemio del último, ${ }^{1944}$ hecho probablemente debido a la mayor evolución formal de la obra tucidídea, pero incluso esas ideas metodológicas son en gran medida semejantes en ambos autores, que constituyen por ello el punto final de complejo mundo intelectual que desemboca en la Atenas clásica.

\footnotetext{
${ }^{1942}$ Cf. los apuntes referidos a Tucídides de Taeger, 1925, p. 199.

${ }^{1943}$ Cf. Taeger, 1925, p. 123, y Hornblower, 2011b, p. 34.

${ }^{1944}$ Cf. Murari Pires, 1998, p. 107. 
En conclusión, de entre la maraña de escritos de fuerte tono polémico -esta es una de las claves-, surgen unos textos con una profundidad formal mayor que lo que habitualmente se puede observar en otros autores, preludio de lo que será el futuro género. La historiografía no existe todavía como género independiente ni con unas normas claramente delimitadas, ${ }^{1945}$ pero su evolución ha comenzado.

El largo periodo que se extiende desde el final del siglo V a. C. hasta la aparición de la obra de Polibio solo puede ser entendido, en su estado actual, por medio de su estudio en bloque. Esta necesidad ha sido además la causa de la condena a la historiografía helenística perdida a ser ninguneada y atenazada por las grandes figuras de Tucídides y Polibio, que constituyen además dos modelos de historiografía acordes con las preferencias de la moderna disciplina.

$\mathrm{Si}$ algo caracteriza a la primera generación, representada por Éforo y Teopompo, es su marcada reacción frente a la negación del individuo vista en Tucídides. ${ }^{1946}$ Ambos autores, desde tendencias fuertemente filosóficas, en el sentido más amplio del término, que es como seguramente hemos de aplicarlo en este periodo, presentan una preocupación casi obsesiva por la actuación del individuo, en un tono, si se quiere, casi experimental, como demuestra la aparición como personaje central de las Filípicas del rey macedonio. Ambos autores representan además a la perfección el ideal político en el sentido etimológico del término, que podemos ver en los dos bastiones culturales de la época, Platón e Isócrates, con una preocupación urbana que tiene excelente reflejo en sus ocupaciones retóricas. Sin embargo, lo importante de ambos autores es la idea de una regeneración de la polis desde las actuaciones individuales, lo que nos sitúa en un escenario que recuerda en gran medida al desarrollo histórico del siglo IV a. C.

La deriva hacia la narración mitológica platónica, entendida como fundamento educativo, es crucial en la comprensión del complejo mundo de la paradoxología presente en estos autores. Los excesos, considerados habitualmente como simples guiños al divertimento del lector, han de ser

${ }^{1945}$ Así, Dover, 2009, p. 55. El hecho de que el estudio de Wehrli, 1947, p. 54 y ss., se inicie en una etapa tan tardía como Polibio es buena prueba de ello.

${ }^{1946}$ Lo que se vería facilitado por esa continuidad del género recientemente subrayada por Parmeggiani, 2011, p. 705, una vez superado el apriorismo de la consideración negativa de toda la historiografía del siglo IV a. C. 
entendidos como la muy responsable recogida del testigo legado por una cultura tradicional fabulística representada en la comedia, e incluso en la tragedia. El siglo IV a. C., a pesar de la rica tradición urbana que posee, no presenta un modelo educativo tan fuerte como el siglo anterior, y esos excesos y, en definitiva, el empleo de lo fantástico son, simplemente, el desarrollo de un modelo de formación de los lectores por medio del esperpento literario. Lo grotesco y desencajado actúa desde una perspectiva casi cínica que no está tampoco muy lejos de Sócrates y su admirable cualidad de sumir en la perplejidad a sus interlocutores.

La llegada a su plenitud de una figura de la importancia de Aristóteles marcó de manera inigualable la evolución del género, con una nueva reacción frente a los autores anteriores. Pero Aristóteles no desarrolló jamás una teoría sobre la historiografía, y su trabajo sobre las constituciones no ha de ser entendido más allá de los naturales límites de la labor previa a una redacción filosófica del pensamiento político del autor.

Lo que sí desarrolló Aristóteles fue un complejo estudio de la literatura tradicional griega, en concreto del teatro, la máxima manifestación literaria de Grecia y, en este sentido, es fundamental recordar que Aristóteles estaba pensando en la gran tragedia y comedia del siglo $\mathrm{V}$ a. C. Y hacer esto supone necesariamente pensar en un modelo de literatura fuertemente vinculado a la actuación, a la manifestación ritual de la misma. El desarrollo de un modo de literatura escrito en una sociedad que todavía estaba abandonando los usos literarios orales supuso un extrañamiento entre la teoría y la práctica, entre la realidad de lo que se cultivaba y lo que se escribía que tuvo sus consecuencias en el desarrollo de la historiografía, con claros reflejos en sus proemios.

En la propia generación de Aristóteles y en las posteriores tenemos la aparición de un grupo de autores de una formación realmente exquisita que

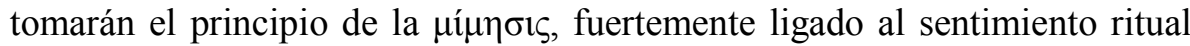
de la literatura oral, como rasgo supremo de la obra de arte literaria. Con esta premisa es natural que autores como Duris o Calístenes reaccionaran con fuerza contra el modo desencajado de hacer literatura de Éforo y Teopompo, como un Sófocles reaccionaría contra los excesos de un Prátinas. Pero, obviamente, el resultado que autores de prácticamente la segunda mitad del siglo podrían ofrecer es cualquier cosa menos satisfactorio a ojos de un crítico moderno. La formación literaria de un Duris o un Timeo y la observancia casi enfermiza de los rasgos miméticos depararían una obra en 
la que lo prodigioso y lo minucioso se darían la mano, de modo que la grandeza heroica de Alejandro pudiese representarse dentro de la más pura tradición homérica, o que se presentasen detalles que pueden llegar a sobrecargar al lector, aunque en su origen simplemente se persiguiera la reconstrucción realista, y no de tramoya, como dice Timeo, de la realidad.

Pero todos estos planteamientos pertenecen a un mundo, lugar y tiempo que, con el progresivo deterioro de la situación política de Grecia, se verán necesariamente llamados a ser superados.

La figura de Polibio, que se presenta en soledad como contrapunto de todos los autores anteriores, no podría ser más opuesta por formación y espíritu a los eruditos y elevados autores del siglo IV a. C. La desaparición del mundo urbano griego hasta entonces conocido se vio acompañada de una reacción realmente brusca por parte de Polibio, que supuso la condena total de las obras de los autores que le precedieron.

Es en estos momentos, en este convulso juego de acciones y reacciones, en el que podemos afirmar que la historiografía ha alcanzado la madurez de su evolución. La consolidación de sus estructuras formales, con un estilo formal sancionado que adquiere tintes de clásico y que se mantendrá a lo largo de la historia del género, ${ }^{1947}$ así como el desarrollo con entidad propia de los planteamientos reflexivos, hacen que el género historiográfico sea una realidad independiente y unificada. El hecho de que ese universo polémico que siempre había caracterizado al género se comience a referir a la propia historiografía es el mejor ejemplo de lo que decimos.

En definitiva, el nacimiento y la consolidación del género historiográfico es una realidad inseparable de los procesos culturales y literarios del momento histórico, así como de la realidad vista desde el prisma de cada uno de los autores. Estos rasgos, presentes desde el origen mismo del género, serán las características que definirán la historiografía a lo largo de su dilatada historia.

${ }^{1947}$ Cf. Scheller, 1911, passim, si bien creemos que la sistematización es mucho más laxa de lo que podría desprenderse del trabajo de Scheller. 



\section{BIBLIOGRAFÍA}

Allison, J. W., Power and Preparedness in Thucydides, Baltimore, 1989.

Alsina, J., Tucídides, historia, ética y política, Madrid, 1981.

- « ¿Un modelo literario de la descripción de la peste de Atenas?», Emerita, 55, 1987, pp. 1-13.

ALY, W., Volksmärchem Sage und Novelle bei Herodot und seinen Zeitgenossen, Gotinga, 1921.

- «Herodots Sprache. Ein Beitrag zur Geistesgeschichte der Jahre 450-430», Glotta, 15, 1927, pp. 84-117.

- Formprobleme der frühen griechischen Prosa, Leipzig, 1929.

ANDERSON, G., The Athenian Experiment: Building an Imagined Political Community in Ancient Attica, 508-490, Ann Arbor, 2003.

ANDrEweS, A., «Thucydides on the Causes of the War», $C Q, 9,2,1959$, pp. $223-$ 259.

ARMAYOR, O. K., Herodotus' autopsy of the Fayoum: Lake Moeris and the labyrinth of Egypt, Ámsterdam, 1985.

Asheri, D., Medaglia, S., y Fraschetti, A., Le Storie, libro III, La Persia, introduzione e commento di David Asheri, testo critico di Silvio M. Medaglia, traduzione di Augusto Fraschetti, Milán, 1997.

- y ANTElAMI, V., Le storie, Libro I, La Lidia e la Persia, testo e commento a cura di David Asheri, traduzione di Virgilio Antelami, Milán, 2001.

- Lloyd, A., y Corcella, A., A commentary on Herodotus: books 1-4, Oxford, 2007.

- «General introduction», en D. Asheri, A. LlOYD, y A. CorCELlA, A commentary on Herodotus: books 1-4, Oxford, 2007, pp. 1-56.

Astin, N., Helen of Troy and her shameless phantom, Nueva York, 2008.

Aujac, G., Opuscules rhétoriques, tome IV, Thucydide, Seconde lettre à Ammée, París, 2002.

AVENARIUS, G., Lukians Schrift zur Geschichtsschreibung, Fráncfort, 1956.

BABUT, D., La religion des philosophes grecs, de Thalès aux stö̈ciens, París, 1974. 
BADIAN, E., «Thucydides and the outbreak of the Peloponnesian war: a Historian's brief», en From Plataea to Potidaea. Studies in the history and historiography of the Pentecontaeteia, Baltimore, 1993, pp. 125-162 (= J. W. Allison, ed., Conflict, antithesis and the ancient historian, Columbus, 1990).

BAKKER, E. J., «How oral is oral composition?», en E. A. Macklay (ed.), Signs of orality: the oral tradition and its influence in the Greek and Roman World, Leiden, 1999, pp. 29-48.

- «The making of the history: Herodotus' Histories Apodexis», en E. J. Bakker, I. de Jong y H. van Wees (eds.), Brill's Companion to Herodotus, Leiden, 2002, pp. 3-31.

Balcer, J. M., Herodotus and Bisitun. Problems in Ancient Persian Historiography, Stuttgart, 1987.

BARAgWanATH, E., Motivation and narrative in Herodotus, Oxford, 2008.

BARBER, G. L., The historian Ephorus, Cambridge, 1935.

BARret, W. S., Hippolytus, edited with introduction and commentary by W. S. Barrett, Oxford, 2001 (= Oxford, 1964).

BARTH, H., «Zur Bewertung und Auswahl des Stoffes durch Herodot (Die Begriffe

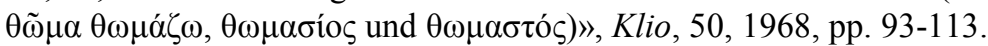

BAUER, A., Die Entstehung des herodotischen Geschichtswerkes, Viena, 1878.

BAYER, E., «Thukydides und Perikles», en H. Herter (ed.), Thukydides, Wege der Forschung, Stuttgart, 1968, pp. 171-259 (=Würz. Jahrb., 3, 1948).

BECK, I., Die Ringkomposition bei Herodot und ihre Bedeutung für die Beweistechnik, Hildesheim, 1971.

BELOCH, K. J., Griechische Geschichte, zweiter Band, bis auf die sophistische Bewegung und den peloponnesischen Krieg, erste Abteilung, Estrasburgo, 1914a.

- Griechische Geschichte, zweiter Band, bis auf die sophistische Bewegung und den peloponnesischen Krieg, zweite Abteilung, Estrasburgo, 1914b.

- Griechische Geschichte, vierter Band, Die griechische Weltherrschaft, erste Abteilung, Berlín, 1925.

BENDER, G. F., Der Begriff des Staatsmannes bei Thukydides, Wurzburgo, 1938.

Bergk, T., Poetae Lyrici Graeci III, recensuit Theodorus Bergk, Leipzig, 1882.

Bernardette, S., Herodotean Enquiries, La Haya, 1969. 
BERNAYS, J., «Neue Bruchstücke des Heraklit von Ephesus», en H. Usener (ed.), Gesammelte Abhandlungen, Leipzig, 1885, pp. 74-101 (= RhM, 9, 1854).

BERTELLI, L., «Hecataeus: from genealogy to historiography» en N. Luraghi (ed.), The historian's craft in the age of Herodotus, Oxford, 2001, pp. 67-94.

BERVE, H., Das Alexanderreich auf prosopographischer Grundlage, Teil II, Múnich, 1926.

BÉTANT, E. A., Lexicon Thucydideum, Hildesheim, 1969 (= Ginebra, 1843-1847).

BEUTLER, R., «Okellos», RE, XVII 2, 1937, cols. 1361-1380.

BICHLER, R., Herodots Welt. Der Aufbau der Historie am Bild der fremden Länder und Völker, ihrer Zivilisation und ihrer Geschichte, Berlín, 2001.

BICKNELL, P., «Thucydides I 22: a provocation», AC, 70, 1990, pp. 172-178.

BISCHOFF, H., Der Warner bei Herodot, Marburgo, 1932.

BIZER, F., Untersuchungen zur Archäologie des Thukydides, Darmstadt, 1968 (= Tubinga, 1937).

BLASS, F., Die attische Beredsamkeit, vols. I, II, III 1 y III 2, Leipzig, 1887.

- Grammar of the New Testament Greek, Londres, 1905 (= Gotinga, 1896).

Bodei Giglioni, G., Erodoto e i sogni di Serse: l'invasione persiana dell'Europa, Roma, 2002.

BOEDEKER, D., «Simonides on Platea: narrative elegy, mithodic history», ZPE, 107, 1995, pp. 217-229.

- «Epic Heritage and Mythical Patterns in Herodotus», en E. J. Bakker, I. de Jong y H. van Wees (eds.), Brill's Companion to Herodotus, Leiden, 2002, pp. 97-116.

BoER, W. den, «Herodot und die Systeme der Chronologie», Mnemosyne, 20, 1967, pp. 30-60.

- Progress in the Greece of Thucydides, Ámsterdam, 1977.

BowIE, E. L., «Early Greek Elegy, Symposium and Public Festival», JHS, 106, 1986, pp. 13-35.

- «Ancestors of Historiography in Early Greek Elegiac and Iambic poetry?», en N. Luraghi (ed.), The historian's craft in the age of Herodotus, Oxford, 2001, pp. 45-67.

Bravo, B., «Il Patrios Nomos di Jacoby, la critica del testo, il cimitero del Kerameikos nell' immaginario civico ateniese», en C. Ampolo (ed.), Aspetti dell'opera di Felix Jacoby, Pisa, 2006, pp. 109-132. 
BRINK, C. O., «Tragic history and Aristotle School», PCPS, N.S. 6, 1960, pp. 14-19.

BROWn, T. S., «Callistenes and Alexander», AJP, 70, 1949, pp. 225-248.

BRUCE, I. A. F., «Theopompus and Classical Greek Historiography», History and Theory, 9, 1970, pp. 86-109.

BRUNT, P. A., «On historical fragments and epitomes», en J. M. Alonso Núñez (ed.), Geschichtsbild und Geschichtsdenken im Altertum, Darmstadt, 1991, pp. 335362 (=CQ, N.S. 30, 1980).

BÜDINGER, M., Die Universalhistorie im Alterthume, Viena, 1895.

BURKERT, W., «Herodot über die Namen der Götter: Polytheismus als historisches Problem», $M H, 42,1985$, pp. 121-132.

- «Herodot als Historiker fremder Religionen», en G. Nenci. y O Reverdin (eds.), Hérodote et les peuples non grecs: neuf esposés suivis de discussions, Ginebra, 1990, pp. 1-32.

BURY, J. B., The ancient Greek historians, Londres, 1909.

BuchHolz, E. A. W., Anthologie aus den Lyrikern der Griechen für Schul- und Privatgebrauch erklärt und mit literarhistorischen Einleitungen versehen, Leipzig, 1909.

Busolt, G., Griechische Geschichte, bis zur Schlacht bei Chaeroneia III, die Pentekontaëteie, Gotha, 1904.

BUTCHER, S. H., Aristotle's theory of poetry and fine art: with a critical text and translation of the Poetics, Londres, 1898.

BYWATER, I., Aristotle on the art of Poetry, Londres, 1909.

Caballero López, J. A., La lengua y el estilo de la República de los atenienses del Pseudo-Jenofonte, Ámsterdam, 1997.

CAgnazzI, S., «Tavola dei 28 Logoi di Erodoto», Hermes, 103, 1975, pp. 385-343.

CAIZZI, F. D., Antisthenis Fragmenta, Milán, 1966.

CALAME, C., Le récit en Grèce ancienne: énonciations et représentations de poètes, París, 1986.

Calhoun, G. M., Athenian clubs in politics and litigation, Nueva York, 1913.

CANFORA, L., Tucidide continuato, Padua, 1970.

- Totalità e selezione nella storiografia classica, Bari, 1972.

- «Le préface de Thucydide et la critique de la raison historique», $R E G, 90,1977$, pp. 458-460. 
CANFORA, L., «Il ciclo storico», en L. Canfora, La storiografia greca, Milán, 1999a, pp. 61-91 (=Belfagor, 26, 1971).

- «Tucidide erodoteo», en L. Canfora, La storiografia greca, Milán, 1999b, pp. 114123 (= Quaderni di Storia, 16, 1982).

- «Scrivere la storia in Grecia e a Roma», en R. Uglione (ed.), Scrivere la storia nel mondo antico: atti del convegno nazionale di studi, Alessandria, 2006, pp. 3139.

CArtledge, P. y Greenwood, E., «Herodotus as a Critic: Truth, Fiction, Polarity», en E. J. Bakker, I de Jong y H. van Wees (eds.), Brill's Companion to Herodotus, Leiden, 2002, pp. 351-372.

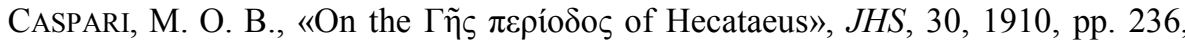
248.

CAWKell, G., Thucydides and the Peloponnesian war, Londres, 1997.

CHANiOTIS, A., Historie und Historiker in den griechischen Inschriften, Wiesbaden, 1988.

Chantraine, P., Dictionnaire étymologique de la langue grecque: histoire des mots, París, 1999.

ChÂTElet, F., El nacimiento de la historia: la formación del pensamiento historiador en Grecia, México, 1978 (= París, 1962).

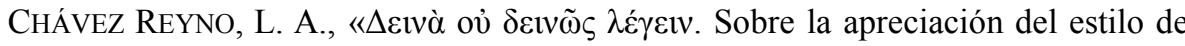
Teopompo en Dionisio de Halicarnaso», en E. Lanzillotta, V. Costa y G. Ottone, (eds.), Tradizione e trasmissione degli storici greci frammentari, Roma, 2009, pp. 143-179.

Clairmont, C. W., Patrios Nomos: public burial in Athens during the fifth and fourth centuries B. C.: the archaeological, epigraphic-literary and historical evidence, Oxford, 1983.

ClASSEN, J., Thukydides, Band 1: Einleitung, erstes Buch erklärt von J. Classen, 3. a ed., Berlín, 1879.

- y STEUP, J., Thucydides, Band 1: Einleitung, erstes Buch erklärt von Johannes Classen, bearbeitet von Julius Steup, Hildesheim, 1969. (=Berlín, 1919).

- Thucydides, Band 2: zweites Buch erklärt von Johannes Classen, bearbeitet von Julius Steup, Hildesheim, 1969 (= Berlín, 1914).

- Thucydides, Band 3: drittes Buch erklärt von Johannes Classen, bearbeitet von Julius Steup, Hildesheim, 1969 (= Berlín, 1892). 
Classen, J., y Steup, J., Thucydides, Band 4: viertes Buch erklärt von Johannes Classen, bearbeitet von Julius Steup, Hildesheim, 1969 (= Berlín, 1900).

- Thucydides, Band 5: fünftes Buch erklärt von Johannes Classen, bearbeitet von Julius Steup, Hildesheim, 1969 (= Berlín, 1912).

- Thucydides, Band 6: sechstes Buch erklärt von Johannes Classen, bearbeitet von Julius Steup, Hildesheim, 1969 (= Berlín, 1905).

- Thucydides, Band 7: siebtes Buch erklärt von Johannes Classen, bearbeitet von Julius Steup, Hildesheim, 1969 (= Berlín, 1908).

- Thucydides, Band 8: achtes Buch erklärt von Johannes Classen, bearbeitet von Julius Steup, Hildesheim, 1969 (= Berlín, 1922).

CLEEF, F. L. van, Index Antiphonteus, Nueva York, 1895.

COBET, J., Herodots Exkurse und die Frage der Einheit seines Werkes, Wiesbaden, 1971.

- «Wann wurde Herodots Darsterllung?», Hermes, 105, 1977, pp. 2-27.

- «The Organization of Time in the Histories», en E. J. Bakker, I. de Jong, y H. van Wees (eds.), Brill's Companion to Herodotus, Leiden, 2002, pp. 387-413.

Cochrane, C. N., Thucydides and the Science of History, Londres, 1929.

Cogan, M., The Human Thing. The Speeches and Principles of Thucydides' History, Chicago, 1981.

COLE, T., The origins of rhetoric in ancient Greece, Londres, 1991.

Collingwood, R. G., The Idea of History, Oxford, 1970.

COLLINS, D., Master of the game: competition and performance in Greek poetry, Washington D. C., 2005.

Columba, G. M., «Antioco, storico del V secolo a. C.», Archivio storico siciliano, XIV, 1889, pp. 84-107.

CONNOR, W. R., Theopompus and fifth-century Athens, Washington, 1968.

- Thucydides, Princeton, 1985.

- «A post-modernist Thucydides?», en J. S. Rusten (ed.), Thucydides. Oxford readings in Classical studies, Oxford, 2009, pp. 29-43 (=CJ, 72, 1977).

Consolo Langher, S. N., «La vicenda storiografica e letteraria di Duride di Samo. Poetica e teoresi storica», en Studi tardoantichi, II (Hestiasis), 1986, pp. 347386.

Cope, E. M., The Rhetoric of Aristotle, Londres, 1887. 
Corcella, A., Erodoto e l'analogia, Palermo, 1984.

CORCElla, A., «Ecateo di Mileto così dice», QdSt, 43, 1996, pp. 295-301.

CORNFORD, F. M., Thucydides mythistoricus, Londres, 1907.

CRAHAY, R., La littérature oraculaire chez Hérodote, París, 1956.

CRANE, G., Thucydides and the Ancient Simplicity, Berkeley, 1998.

Crespo, E., Conti, L. y MaQuieIRA, H., Sintaxis del griego clásico, Madrid, 2003.

CREUZER, F., Die historische Kunst der Griechen in ihrer Entstehung und Fortbildung, Leipzig y Darmstadt, 1845.

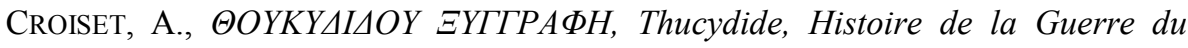
Péloponnèse, texte grec publié d'après les travaux plus récents de la philologie avec un commentaire critique et explicatif et précedé d'une introduction par Alfred Croiset, livres I-II, París, 1886.

CUGuSI, P., «L’epistolografia: modelli e tipologie di comunicazione», en G. Cavallo, P. Fedeli y A. Giardina (eds.), Lo spazio letterario di Roma antica, vol. II, La circolazione del testo, Roma, 1990, pp. 379-419.

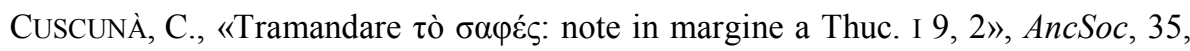
2005, pp. 59-77.

CWIKLINSKI, L., «Über die Enstehungsweise des zweiten Theils der thukydideischen Geschichte», Hermes, 12, 1877, pp. 23-87.

DARBO-PESCHANSKI, C., Le discours du particulier. Essai sur l'enquête hérodotéenne, París, 1987.

- «L'historien grec ou le passé jugé», en N. Loraux y C. Miralles (eds.), Figures de l'intellectuel en Grèce ancienne, París, 1998, pp. 143-189.

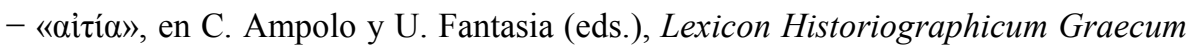
et Latinum (LHG\&L) I, Pisa, 2007a, pp. 22-32.

- L'Historia. Commencements grecs, París, $2007 \mathrm{~b}$.

DEBNAR, P., Speaking the same language. Speech and audience in Thucydides' Spartan debates, Ann Arbor, 2001.

DefradAs, J., Les thèmes de la propagande delphique, París, 1972.

Degani E. y Burzacchini, G., Lirici Greci. Antologia. Florencia, 1980.

Denninston, J. D., Greek Particles, Oxford, 1960.

- Greek Prose Style, Londres, 2000 (= Oxford, 1960). 
Detienne, M., Les ruses de l'intelligence. La mètis des Grecs, París, 1974.

Detienne, M., Los maestros de verdad en la Grecia arcaica, Madrid, 1981 (= París, 1967).

Dewald, C., «Narrative Surface and Authorial Voice in Herodotus' Histories», en D. Boedeker y J. Peradotto (eds.), Herodotus and the Invention of History, 1987 (Arethusa, 20), pp. 147-170.

- Thucydides' War Narrative, Berkeley, 2005.

- «The figured stage: focalizing the initial narratives of Herodotus and Thucydides», en J. S. Rusten (ed.), Thucydides. Oxford readings in Classical studies, Oxford, 2009, pp. 114-147 (= T. Falkner, N. Felsen y D. Konstan (eds.), Contextualizing the Classics: Ideology, Performance, Dialogue: Essays in honor of J. Peradotto, Lanham, 1999).

DIELS, H., «Herodot und Hekataios», Hermes, 22, 1887, pp. 411-444.

DIENER, O., De sermone Thucydidis quatenus cum Herodoto congruens differat a scriptoribus atticis, Leipzig, 1889.

Dihle, A., «Herodot und die Sophistik», Philologus, 106, 1962, pp. 207-220.

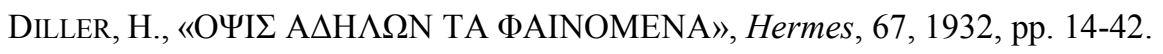

DoDDS, E. R., Los griegos y lo irracional, Madrid, 1985 (= Berkeley, 1951).

DoninI, G., La posizione di Tucidide verso il governo dei cinquemila, Turín, 1969.

DoRaTI, M., Le Storie di Erodoto: etnografia e racconto, Pisa y Roma, 2000.

Dover, K. J., «La colonizzazione della Sicilia in Tucidide», en H. Herter (ed.), Thukydides, Wege der Forschung, Stuttgart, 1968, pp. 344-367 (= Maia, VI, 1953).

- Thucydides, new surveys in the Classics, Oxford, 1973.

- The Evolution of Greek Prose Style, Oxford, 1997.

- «Thucydides as History and as literature», en J. S. Rusten (ed.), Thucydides. Oxford readings in Classical studies, Oxford, 2009, pp. $44-59$ (= History \& Theory, 22, 1983).

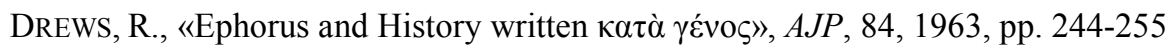

DREXLER, H., Herodot Studien, Hildesheim, 1972.

DROZ, G., Los mitos platónicos, Barcelona, 1993 (= París, 1992).

DUMBAR, N., Aristophanes' Birds, Oxford, 1995. 
EBeling, H., Lexicon Homericum, Hildesheim, 1963 (= Leipzig, 1880-1885).

ECKER, U., Grabmal und Epigramm: Studien zur frühgriechischen Sepulkraldichtung, Stuttgart, 1990.

EDMUNDS, L., «Thucydides in the act of writing», en J. S. Rusten (ed.), Thucydides. Oxford readings in Classical studies, Oxford, 2009, pp. 91-113 (= R. Pretagostini (ed.), Tradizione e innovazione nella cultura greca da Omero all'età ellenistica: scritti in onore di Bruno Gentili, Roma, 1993).

Egerman, M., «Zum historischen Ziel des Thukydides», Historia, 10, 1961, pp. 435-447.

Ehrenberg, V., Sophocles and Pericles, Oxford, 1954.

Eldestein, L., The Idea of Progress in Classical Antiquity, Baltimore, 1967.

EliAde, M., The myth of the eternal return, or, Cosmos and history, Princeton, 2005.

ELLENDT, F., Lexicon Sophocleum, Leipzig, 1835.

ELLIS, J. R., «The structure and argument of Thucydides' Archaelogy», ClAnt, 10, 2, 1991, pp. 344-376.

ELSE, G. F., «Imitation in the fifth century», $C P, 53,2$, 1958, pp. 73-90.

ELter, A., «Epigraphica», RhM, 66, 1911, pp. 199-225.

ERBSE, H., «Das erste Satz im Werke Herodots», en Festschrift Bruno Snell, 1958, Múnich, pp. 209-222.

- «Sieben bemerkungen zu Herodot», en Ausgewahlte Schriften zur klassischen Philologie, 1979a, Berlín, pp. 139-179. (Versión aumentada y revisada del original publicado en $R h M, 98,1955$, pp. 99-120).

- «Über das Prooimion (1, 1-23) des Thukydideischen Geschichtswerkes», en Ausgewahlte Schriften zur klassischen Philologie, 1979b, Berlín, pp. 245-268 (Versión revisada del original publicado en $R h M, 133,1970$, pp. 43-69).

- Studien zum Verständnis Herodots, Berlín, 1992.

Evans, J. A. S., «Herodotus IX 73.3 and the publication date of the Histories», $C P$, $82,3,1987$, pp. 226-228.

- Herodotus, explorer of the past. Three essays, Princeton, 1991.

FEHLING, D., Die Wiederholungsfiguren und ihr Gebrauch bei den Griechen vor Gorgias, Berlín, 1969. 
- «Zur Funktion und Formgeschichte des Proömiums in der älterem griechischen Prosa», en Hans Diller zum 70. Geburtstag, Atenas, 1975, pp. 61-75.

FEHLING, D., Herodotus and his «sources», Leeds, 1989 (= Berlín, 1971).

FERRERO, L., «Tra poetica ed istoriografia: Duride di Samo», en Miscellanea di studi alessandrini in memoria di Augusto Rostagni, Turín, 1963, pp. 68-100.

FERTONANI, R., «Ecateo di Mileto e il suo razionalismo», PP, 7, 1952, pp. 18-29.

FINLEY, J., Thucydides, Cambridge, 1967a.

- Three Essays on Thucydides, Cambridge, $1967 \mathrm{~b}$.

FINLEY, M. I., «Mito, memoria e historia», en Uso y abuso de la historia, Barcelona, 1979 (= Londres, 1971), pp. 11-44.

FINNEGAN, R., Oral poetry: its nature, significance and social context, Cambridge, 1977.

FISHER, N. R. E., Hybris: a study in the values of honour and shame in Ancient Greece, Warminster, 1992.

FLORY, S., «Who read Herodotus Histories?», AJP, 101, 1980, pp. 12-28.

FLORY, S., The archaic smile of Herodotus, Detroit, 1987.

Flower, M. A., Theopompus of Chios: History and Rhetoric in the fourth century B. C., Oxford, 1997.

FOCKE, F., Herodot als Historiker, Stuttgart, 1927.

FoHL, H., Tragische Kunst bei Herodot, Leipzig, 1913.

FORNARA, C. W., Herodotus: an Interpretative Essay, Oxford, 1971a.

- «Evidence for the date of Herodotus’ publication», JHS, 91, 1971b, pp. 25-34.

- «Herodotus knowledge of the Archidamian war», Hermes, 109, 1981, pp. 149156.

- The nature of history in ancient Greece and Rome, Berkeley, 1983.

- «Commentary on Lateiner and Marincola», en D. Boedeker y J. Peradotto (eds.), Herodotus and the Invention of History, 1987 (Arethusa, 20), pp. 139-142.

Forrest, W. G., «Herodotos and Athens», Phoenix, 38, 1984, pp. 1-11.

Foster, E., Y LATEINER, D., «Introduction», en E. Foster y D. Lateiner (eds.), Thucydides and Herodotus, Oxford, 2012, pp. 1-9.

FOWLER, R. L., «Herodotos and his Contemporaries», JHS, 116, 1996, pp. 62-87. 
FOWLER, R. L., «Early Historiē and Literacy», en N. Luraghi (ed.), The historian's craft in the age of Herodotus, Oxford, 2001, pp. 95-115.

- «Herodotos and Athens», en P. Derow y R. Parker (eds.), Herodotus and his world: essays from a conference in memory of George Forrest, Oxford, 2003.

FRÄNKEL, E., Aeschylus Agamenon, Oxford, 1974.

FRÄNKEL, H., «Die Zeitauffassung in der Frühgriechischen Literatur», en H. Fränkel, Wege und Formen frühgriechischen Denkens, Múnich, 1960a, pp. 1-22 (= Beilagenheft zur Zeitschrift für Ästhetik und allgemeine Kunstwissenschaft, 1931).

- «Eine Stileigenheit der frügriechischen Literatur», en H. Fränkel, Wege und Formen frühgriechischen Denkens, Múnich, 1960b, pp. 40-96 (= Gött. Nachr. 1924).

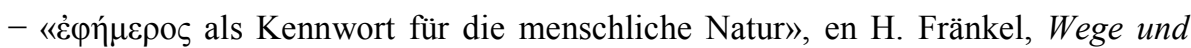
Formen frühgriechischen Denkens, Múnich, 1960c, pp. 23-39 (=TAPhA, 77, 1946).

- Poesía y filosofía de la Grecia Arcaica: una historia de la épica, la lírica y la prosa griegas hasta la mitad del siglo quinto, Madrid, 1993 (= Múnich, 1962).

FrASER, P. M., Ptolemaic Alexandria, Oxford, 1972.

FRISCH, P., Die Träume bei Herodot, Meisenheim am Glan, 1968.

FRITZ, K. von, «Herodotus and the Growth of Greek Historiography», TAPhA, 67, 1936, pp. 315-340.

- «Die politische Tendenz in Theopomps Geschichtsschreibung», $A \& A, 4,1954$, pp. 45-64.

- Die griechische Geschichtsschreibung, Von den Anfängen bis Thukydides, Berlín, 1967.

- «Discussion [de] K. Latte, Die Anfänge der griechische Gescchichtsschreibung», en Histoire et historiens dans l'Antiquite, Roma, 2004 (= Ginebra, 1956), pp. 21-37.

FUSAI, S., Il processo omerico, dall' histōr all'historiēe erodotea, Padua, 2006.

GABBA, E., «True history and false history in Classical Antiquity», JRS, 71, 1981, pp. 50-62.

GattinOni, F. L., Duride di Samo, Roma, 1997.

GEFFCKEN, J., «Simonides», en RE, III A 1, 1927, cols. 186-194.

Gentili, B. Poesía y público en la Grecia antigua, Barcelona, 1996 (= Bari, 1984). 
Gentili, B., y CERri, G., Storia e biografia nel pensiero antico, Bari, 1983.

GEHRKE, H. J., «Myth, history, politics-Ancient and Modern», en J. Marincola (ed.), Greek and Roman historiography. Oxford readings in Classical studies, Oxford, 2011, pp. 40-71 (= Saeculum, 45, 1994).

Giovannini, G., «The Connection between Tragedy and History in Ancient Criticism», $P h Q, 22,1943$, pp. 308-314.

GiTTI, A., «Sul proemio delle Genealogie di Ecateo», $R A L, 8,6$, 1952, pp. 389-398.

Golan, D., «The fate of a Court Historian, Callistenes», Athenaeum, 66, 1988, pp. 99-120.

GoldhILL, S., The invention of Prose, Oxford, 2002.

GOMME, A. W., Essays in Greek history and literature, Oxford, 1937.

- A historical Commentary on Thucydides, vol. I, Introduction and Book I, Oxford, 1950.

- «Who was Kratippos?», CQ, 4, 1954a, pp. 53-55.

- The Greek actitude to poetry and history, Los Ángeles, 1954b.

- A historical Commentary on Thucydides, Vol. III, books IV-V 24, Oxford, 1956.

- A historical Commentary on Thucydides, vol. II, Books II-III, Oxford, 1962.

- More essays in Greek history and literature, Oxford, 1962b.

- Andrewes, A., y Dover, K., A historical Commentary on Thucydides, vol. IV, books V 25-VII, Oxford, 1970.

- Andrewes, A., y Dover, K., A historical Commentary on Thucydides, vol. V, book VIII and Appendices, Oxford, 1981.

Gommel, J., Rhetorisches Argumentieren bei Thukydides, Hildesheim, 1966.

Gomperz, T., Pensadores griegos: una historia de la filosofía de la Antigüedad. Tomo I, De los comienzos a la época de las luces, Barcelona, 2000 (= Berlín, 1893).

Gould, J., «Herodotus and Religion», en S. Hornblower (ed.), Greek Historiography, Oxford, 2004 (= 1994), pp. 91-106.

GRAY, V., «Mimesis in Greek Historical Writing», AJP, 108, 1987, pp. 467-486.

- «Herodotus and images of tyranny: the Tyrants of Corinth», AJP, 117, 1996, pp. 361-389. 
GRAY, V., «Herodotus literary and historical method: Arion's story (I 23-24)», AJP, 122, 2001, pp. 11-28.

GREENWOOD, E., Thucydides and the shaping of history, Londres, 2006.

Groningen, B. A. van, "The Proems of the Iliad and the Odyssey», Med. Ned. Ak. Afd. Letterk., 9, 8, 1946, pp. 279-294.

- La composition littéraire archaïque grecque, procédés et réalisations, Ámsterdam, 1958.

Grosskinsky, A., Das Programm des Thukydides, Berlín, 1936.

GRUnDY, G. B., Thucydides and the history of his age, Oxford, 1948 (= Londres, 1911).

Gschnitzer, F., Die sieben Perser und das Königtum des Dareios. Ein Beitrag zur Achaimenidengeschichte und Herodotanalyse, Heidelberg, 1977.

Gudeman, A., Aristoteles ПЕPI ПOIHTIKHL, mit Einleitung, Text, Adnotatio critica, exegetischen Kommentar... von Alfred Gudeman, Berlín y Leipzig, 1934.

GUNDERT, H., «Athen und Sparta in den Reden des Thukydides», en H. Herter (ed.), Thukydides, Wege der Forschung, Stuttgart, 1968, pp. 114-134 (= Die Antike, 16, 1940).

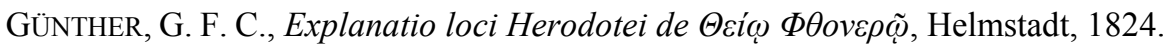

GUTHRIE, W. K. C., Historia de la filosofía griega. I. Los primeros presocráticos y los pitagóricos, Madrid, 1984 (= Cambridge, 1962).

GuTSCHMID, A. von, «Index fontium Herodoti», en Kleine Schriften IV, Leipzig, 1893. pp. $145-187$.

HABerle, J., Untersuchungen über den ionische Prosastil, Múnich, 1938.

HABICHT, C., «Falsche Urkunden zur Geschichte Athens im Zeitalter der Perserkriege», Hermes, 89, 1961, pp. 1-35.

Hagel, D., Das zweite Prooimion des herodoteischen Geschichtswerk, ErlangenNúremberg, 1968.

Hamilton, C. D., «Greek Rhetoric and History: the case of Isocrates», en G. Bowersock, W. Burkert, y M. C. J. Putnam (eds.), Arktouros: Hellenic studies presented to Bernard M. W. Knox on the occasion of his 65th birthday, Berlín, 1979 , pp. 290-298.

HAMMOND, N. G. L., «The arrangement of thought in the proem and in other parts of Thucydides», $C Q$, N. S. 2, 1952, pp. 127-142. 
HARRIS, W. V., Ancient literacy, Londres, 1989.

HARRISON, T., Divinity and History: the Religion of Herodotus, Oxford, 2002.

HART, J., Herodotus and Greek history, Londres, 1982.

HARTOG, F., «Myth into logos: the case of Croesus, or the historian at work», en R. Buxton (ed.), From Myth to Reason, Studies in the Development of Greek Thought, Oxford, 1999, pp. 183-196.

- El espejo de Heródoto. Ensayo sobre la representación del otro, México, 2003 (= París, 1980).

Hauvette, A., Hérodote, historien des guerres Médiques, París, 1894.

Havelock, E. A., Prefacio a Platón, Madrid, 1994 (= Cambridge, 1963)

HeIDEgGer, M. y FinCK, E., Heráclito, Barcelona, 1987 (= Berlín, 1970).

HeIDEL, W. A., «Hecataeus and Xenophanes», AJP, 64, 3, 1943, pp. 257-277.

Heinimann, F., Nomos und Physis. Herkunft und Bedeutung einer Antithese im griechischen Denken des 5. Jahrhunderts, Darmstadt, 1980 (= Basilea, 1945).

HellmanN, F., Herodots Kroisos-Logos, Berlín, 1934.

Herkommer, E., Die Topoi in der Proömien der römischen Geschichtswerke, Tubinga, 1968.

Herter, H., «Freiheit und Gebundenheit des Staatsmannes bei Thukydides», en H. Herter (ed.), Thukydides, Wege der Forschung, Stuttgart, 1968, pp. 260-281 $(=R h M, 93,1950)$.

Hicks, E. L., y HiLl, G. F., A manual of Greek historical inscriptions, Londres, 1901.

HIRZEL, R., «Zur Charakterisk Theopomps», RhM, 47, 1892, pp. 359-389.

- Themis, Dike und Verwandtes: Ein Beitrag zur Geschichte der Rechtsidee bei den Griechen, Hildesheim, 1966 (= Leipzig, 1907).

HoffMEISTER, K., Sittlich-religiöse Lebensansicht des Herodotus, Essen, 1832.

Hoht, P., «Die Schuldfrage der Perserkriege in Herodots Geschichtsswerk», Arctos, 10, 1976a, pp. 37-48.

- The interrelation of speech and action in the Histories of Herodotus, Helsinki, 1976 b.

Hollmann, A., The master of signs. Signs and the interpretation of signs in Herodotus' Histories, Washington, 2011. 
Hommel, H., «Herodots Einleitungssatz: ein Schlüssel zur Analyse des Gesamtwerks?», en G. Kurz, D. Müller, y W. Nicolai (eds.), Gnomosyne. Menschlisches Denken und Handeln in der frühgriechischen Literatur. Festschrift für W. Marg zum 70. Geburtstag, Múnich, 1981, pp. 271-288.

HÖPKEN, E., De Thucydidis proemii compositione, Emden, 1911.

HoRnBlower, S., Thucydides, Londres, 1987.

- A commentary on Thucydides, vol. I books I-III, Oxford, 1991.

- A commentary on Thucydides, Vol. II books IV-V 24, Oxford, 2004a.

- «Introduction; Summary of the papers; The story of Greek historiography; Intertextuality and the Greek historians», en S. Hornblower, Greek Historiography, Oxford, 2004b (= 1994), pp. 1-72.

- Thucydides and Pindar. Historical narrative and the world of epinikian poetry, Oxford, 2004c.

- «Narratology and narrative techniques in Thucydides», en S. Hornblower, Greek Historiography, Oxford, 2004d, pp. 131-166.

- A commentary on Thucydides, Vol. III, books V 25-VIII, Oxford, 2008.

- «Introduction», en S. Hornblower, Thucydidean themes, Oxford, 2011a, pp 1-20.

- «The religious dimension to the Peloponnesian war, or, What Thucydides does not tell us», en S. Hornblower, Thucydidean themes, Oxford, 2011b, pp. 25-53 $(=H S C P, 94,1992)$.

Hout, M. Van den, «Studies in early Greek Letter-Writing», Menmosyne, 2, 1949, pp. 19-41.

How, W. W. y Wells, J., A commentary on Herodotus, volume I (books I-IV), Oxford, 1912.

- A commentary on Herodotus, volume II (books V-IX), Oxford, 1912b.

HowALD, E., «Jonische Geschischtsschreibung», Hermes, 58, 1923, pp. 113-146.

HUART, P., TNQMH chez Thucydide et ses contemporains, París, 1973.

HUBER, L., Religiöse und politische Beweggründe des Handels in der Geschichtsschreibung des Herodot, Tubinga, 1965.

HUG, A., «Symposion-Literatur», RE, IV A 2, 1932, cols. 1274-1282.

HUNTER, V., Thucydides the artful reporter, Toronto, 1973.

- «The composition of Thucydides History: a new answer to the problem», Historia, 27, 1977, pp. 269-294. 
- Past and process in Herodotus and Thucydides, Nueva York, 1982.

HuSSEY, E., «Thucydidean history and democritean Theory», en P. Cartledge y F. D. Harvey (eds.), Crux: Essays in Greek History, Londres, 1985, pp. 118-138.

IGLESIAS ZoIDO, J. C., «Acercamiento a la polémica sobre Tucídides I, 22, 1», Anuario de Estudios Filológicos, 12, 1989, pp. 125-132.

- La argumentación en los discursos deliberativos de Tucídides y su relación con la normativa retórica del siglo IV, Cáceres, 1995.

IMMERWAHR, H. R., «Aspects of Historical Causation in Herodotus», TAPhA, 87, 1954, pp. 16-45.

- «Ergon, history as a monument in Herodotus and Thucydides», AJP, 81, 1960, pp. 261-290.

- Form and Thought in Herodotus, Cleveland, 1966.

- «Pathology of power and the speeches of Thucydides», en P. Stadter (ed.), The Speeches in Thucydides. A collection of original studies with a bibliography, Chapel Hill, 1973, pp. 16-31.

IRIGOIN, J., Le livre grec des origines à la Renaissance, París, 2001.

ISAGER, S., «The Pride of Halicarnassos. Editio Princeps of an Inscription from Salmakis», ZPE, 123, 1999, pp. 1-23.

JACOBY, F. «Hekataios», RE, XIV, 1912, cols. 2667-2750.

- «Herodotos», RE Suppl. II, 1913, cols. 205-520.

- Atthis: the local chronicles of ancient Athens, Oxford, 1949.

- «The authorship of the Hellenica of Oxyrhyncus, with an appendix by P. Maas», $C Q, 44,1950$, pp. 1-11.

- Die Fragmente der Griechischen Historiker, Leiden, 1954 y ss. (FgrHist).

- «Über die Entwicklung der griechischen Historiographie und den Plan einer neuen Sammlung der griechischen Historikerfragmente», en H. Bloch, (ed.), Abhandlungen zur griechischen Geschichtschreibung, Leiden, 1956a, pp. 16-64 (=Klio, 9, 1909).

- «Patrios Nomos: State Burial in Athens and the public Cemetery in the Kerameikos», en H. Bloch (ed.), Abhandlungen zur griechischen Geschichtschreibung, Leiden 1956b, pp. 260-315 (=JHS, 64, 1944).

JAEGER, W., Aristoteles, Grundlegund einer Geschichte seiner Entwicklung, Berlín, $1955(=1923)$. 


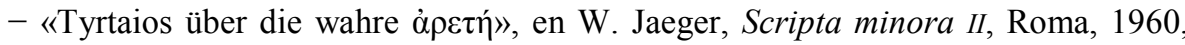
pp. $75-114$ (= Sitzungsberichte der Preuss. Akad. der Wissench. Phil-Hist. Kl., Berlín, 1932).

- Paideia, los ideales de la cultura griega, México, 2000 (=1946).

JANSSENS, E., «Thucydide, I 23 ou la démystification de la guerre», AncSoc, 29, 1998-1999, pp. 5-19.

JeBB, R. C., Oedipus in Colonnus, Londres, 2004 (= Cambridge, 1906).

JEFFERY, L. H., The local scripts of Archaic Greece: a study of the origin of the Greek alphabet and its development from the eighth to the fifth centuries B. C., Oxford, 1961.

JOHNSON, W. A., «Oral performance and the composition of Herodotus’ Histories», GRBS, 35, 1994, pp. 229-254.

JoLY, R., Hippocrate, tome VI, partie 2: Du régime des maladies aigues; Appendice; De l'aliment; De l'usage des liquides, París, 1972.

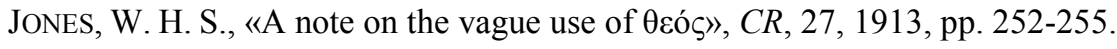

JoNG, I. de, A narratological commentary on the Odyssey, Cambridge, 2001.

JoUanNA, J., Hippocrate, Tome II, le partie, L'ancienne médecine, París, 2003a.

- Hippocrate, Tome II, 2 e partie, Airs, eaux, lieux, París, 2003 b.

KAERST, J., Geschichte des Hellenismus, Leipzig, 1927.

KAHN, C. H., The art and thought of Heraclitus, Cambridge, 1987.

KALISCHEK, A., De Ephoro et Theopompo Isocratis discipulis, Münster, 1913.

Kallet-MarX, L., Money, Expense, and Naval Power in Thucydides' History I 5 24, Berkeley y Oxford, 1993.

KATIČIČ, R., «Die Ringkomposition in ersten Buch des thukydideische Geschichtswerkes», WS, 70, 1957, pp. 179-196.

KEBRIC, R. B., In the Shadow of Macedon: Duris of Samos, Wiesbaden, 1977.

KIRCHHOFF, A., Über die Entstehungszeit des Herodotischen Geschichtswerkes, Berlín, 1878.

KIRK, G. S., The Iliad. A Commentary: Books 1-4, Cambridge, 1985.

- RAVEN, J. E., y SCHOFIELD, M., Los filósofos presocráticos. Historia crítica con selección de textos, Madrid, 1987 (= Cambridge, 1983).

KIRKWOOD, G. M., «Thucydides’ words for cause», AJP, 63, 1, 1952, pp. 37-61. 
KleberG, T., «Comercio librario y actividad editorial en el Mundo Antiguo», en G. Cavallo (ed.), Libros, editores y público en el Mundo Antiguo, Madrid, 1995 (= Roma, 1982), pp. 51-108.

KoEnEN, L., «Der erste Satz bei Heraklit und Herodot», ZPE, 97, 1993, pp. 95-96.

Koller, H., Die Mimesis in der Antike, Berna, 1954.

KOWERSKI, L., Simonides on the Persian Wars: a study of the elegiac verses of the «new Simonides», Nueva York, 2005.

KRISCHER, T., «Herodots Prooimion», Hermes, 93, 1965, pp. 159-167.

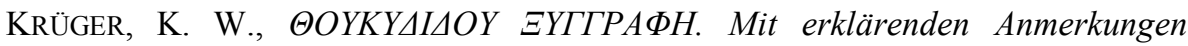
herausgegeben von K. W. Krüger, Berlín, 1860.

- Attic Greek Prose Syntax, Guy L. Cooper III, after K. W. Krüger, Ann Arbor, 1998.

LA Roche, P., «Über das Prooemium vor den Geschichtsbüchern des Herodotos», Philologus, 14, 1859, pp. 281-287.

LAISTNER, M. L. W., The greater Roman historians, Los Ángeles, 1947.

LAMB, W., Clio Enthroned, a study of prose form in Thucydides, Cambridge, 1914.

LAMBERTS, E., Studien zur Parataxe bei Herodot, Viena, 1970.

LANG, M., Herodotean Narrative and Discourse, Cambridge, 1984.

- Commentary on Nagy and Boedeker, en D. Boedeker y J. Peradotto (eds.), Herodotus and the Invention of History, 1987 (Arethusa, 20), pp. 203-207.

LASSERRE, F., «L'historiographie grecque à l'époque archaïque», QdSt, 4, 1976, pp. 113-142.

LATEInER, D., The Historical Method of Herodotus, Toronto-Londres, 1989.

LEGRAND, P., Hérodote, Histories, introduction, París, 1932.

LENDLE, O., Einführung in die griechische Geschichtsschreibung, von Hekataios bis Zosimos, Darmstadt, 1992.

LENDON, J. E., «Historians without history: against Roman Historiography», en A. Feldherr (ed.), The Cambridge Companion to the Roman historians, Cambridge, 2009, pp. 41-61.

LENS, J., «Sobre la naturaleza de la Biblioteca Histórica de Diodoro de Sicilia», en J. Lens, (ed.), Estudios sobre Diodoro de Sicilia, Granada, 1994, pp. 33-61 (= $E G F, 1,1986)$.

LEPPIN, H., Thukydides und die Verfassung der Polis, Berlín, 1999.

Monografias de Filología Griega, 22. ISSN 1136-0860 
LESKY, A., Historia de la literatura griega, Madrid, 1989 (= Berna, 1962).

LÉVY-BRUHL, L., La mentalidad primitiva, Buenos Aires, 1972.

LEYDEN, W. von, «Spatium historicum», en W. Marg (ed.), Herodot, Berlín, 1962, pp. 169-181 (= Durham University Journal, 11, 1949-1950).

LIEBERICH, H., Studien zu Proömien in der griechischen und byzantinischen Geschichtschreibung, I. Teil, die Griechische Geschichtschreiber, Múnich, 1899.

LILJA, S., On the Style of the Earliest Greek Prose, Helsinki, 1968.

LiNFORTH, I. M., Solon the Athenian, Berkeley, 1919.

- «Herodotus' Avowal of Silence», University of California Studies in Classical Philology, 7/9, 1924, pp. 269-292.

- «Greek Gods and Foreign Gods in Herodotus», University of California Publications in Classical Philology, 9/1, 1926, pp. 1-25.

- «Named and Unnamed Gods in Herodotus», University of California Studies in Classical Philology, 9/7, 1928, pp. 201-243.

LIPSIUS, J. H., Das attische Recht und Rechtsverfahren: mit Benutzung des Attischen Prozesses, Hildesheim, 1984 (= Leipzig, 1900-1915).

LLOYD, A. B., Herodotus, book II, introduction, Leiden, 1975.

- y FraschetTI, A., Le storie. Vol. 2, libro II, L'Egitto, introduzione, testo e commento a cura di Alan B. Lloyd, traduzione di Augusto Fraschetti, Milán, 2000.

LLOYD, G. E. R., Polarity and analogy: two types of argumentation in early Greek thought, Londres, 1987.

- Magic, Reason, and Experience, Londres, 1999 (= Cambridge, 1979).

LLOYD-JONES, H., The Justice of Zeus, Berkeley, 1971.

LÖFFLER, H. Fehlentscheidungen bei Herodot, Tubinga, 2008.

LONG, T., Repetition and Variation in the Short Stories of Herodotus, Fráncfort del Meno, 1987.

LÓPEZ EIRE, A. «Un poeta llamado Estesícoro, su encuadramiento cronológico», EstClas, 18, 1974, pp. 27-60.

- «Tucídides y la Koiné», en A. Bernabé (ed.), Athlón, Satura Philologica in honorem Francisci Rodriguez Adrados, Madrid, 1984, pp. 245-262. 
LÓPEZ EIRE, A., «Formalización y desarrollo de la prosa griega», en G. Morocho (ed.), Estudios de prosa griega, León, 1985, pp. 37-64.

- «De Heródoto a Tucídides», Studia Storica, Historia Antigua, 8, 1990, pp. 75-96.

- «La mitología de los héroes y la cronología», Humanitas, 57, 2005, pp. 57-116.

- «Retórica e historiografía en Grecia», en J. C. Iglesias Zoido (ed.), Retórica e historiografía. El discurso militar en la historiografia desde la Antigüedad hasta el Renacimiento, Madrid, 2008, pp. 63-124.

- y SCHRADER, C., Los orígenes de la oratoria y la historiografia en la Grecia clásica, Las Palmas, 1997.

LORAUX, N., «Thucydide n'est pas un collègue», QdSt, 12, 1980, pp. 51-81.

- L'invention d'Athènes: histoire de l'oraison funèbre dans la «cité classique», París, 1981.

- «Thucydide a écrit la Guerre du Péloponnèse», Métis, 1, 1986, pp. 134-161.

LORD, A., The Singer of Tales, new edition by S. Mitchell and G. Nagy, Cambridge, 2003.

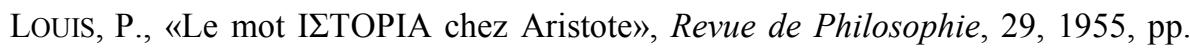
$39-44$.

LÜDTKE, W., Untersuchungen zum Satzbau des Thukydides (Das sog. Anakoluth), Altona, 1930.

LuginBILL, R. D., Thucydides on War and National Character, Oxford, 1999.

LURAGHI, N., «Author and Audience in Thucydides" "Archaeology". Some Reflections», HSCP, 100, 2000, pp. 227-239.

- «Antioco di Siracusa», en R. Vattuone (ed.), Storici greci d'Occidente, Bolonia, 2002, pp. 55-89.

- «Thucydidides and Spartan power in the Archaeology and beyond», en G. Rechenauer y V. Pothou (eds.), Thucydides $-a$ violent teacher? History and its representations, Gotinga, 2011, pp. 185-197.

LusChNAT, O., «Thukydides der Historiker», RE Sup. 12, 1970, cols. 1085-1354, y RE Sup. 14, 1974, cols. 760-786.

MACAN, W. R., Herodotus, the seven, eighth and ninth books, with inntroduction, text, apparatus, commentary, appendices, indices, maps by R. W. Macan, vol. I, part I, Introduction, book VII, Nueva York, 1973a (= Londres, 1908). 
MACAN, W. R., Herodotus, the seven, eighth and ninth books, with inntroduction, text, apparatus, commentary, appendices, indices, maps by R. W. Macan, vol. I, part II, books VIII and IX, Nueva York, 1973 b (= Londres, 1908).

MAdDAlENA, A., Interpretazioni erodotee, Padua, 1942.

- Thucydidis Historiarum Liber primus, Florencia, 1972.

Malitz, J., «Thukydides' Weg zur Geschichtsschreibung», Historia, 31, 1982, pp. 257-289.

Maltomini, F., «L'indagine di Jacoby sugli usi funerari ateniesi», en C. Ampolo (ed.), Aspetti dell'opera di Felix Jacoby, Pisa, 2006, pp. 93-108.

Marchant, E. C., Thucydides, book I, Londres, 1905.

MARINATOS, N., Thucydides and religion, Königstein, 1981.

Marincola, J., Autobiographical statements in the Greek and Roman Historians, Ann Arbor, 1985.

- «Herodotean Narrative and the Narrator's Presence», en D. Boedeker y J. Peradotto (eds.), Herodotus and the Invention of History, 1987 (Arethusa, 20), pp. 121-138.

- "Genre, Convention, and Innovation in Greco-Roman Historiography», en C. Kraus (ed.), The limits of historiography: genre and narrative in ancient historical texts, Leiden, 1999a, pp. 281-324.

- Authority and Tradition in ancient historiography, Cambridge, 1999b.

- Greek Historians, Oxford, 2001.

- «Ancient audiences and expectations», en A. Feldherr (ed.), The Cambridge Companion to the Roman historians, Cambridge, 2009, pp. 11-23.

- «Introduction. Constructing the Past: myth, memory and history», en J. Marincola, (ed.), Greek and Roman historiography. Oxford readings in Classical Studies, Oxford, 2011, pp. 1-15.

Marrou, H., Historia de la educación en la Antigüedad, Madrid, 1985 (= París, 1948).

MEIER, C., «Historical answers to Historical Questions: the Origins of History in Ancient Greece», en D. Boedeker y J. Peradotto (eds.), Herodotus and the Invention of History, 1987 (Arethusa, 20), pp. 41-58.

MEISSNER, B., Historiker zwischen Polis und Königshof, Gotinga, 1992.

MeISTER, K., Die Gnomik im Geschichtswerk des Thukydides, Winterthur, 1955. 
- Historische Kritik bei Polybios, Wiesbaden, 1975.

- La storiografia greca: dalle origini alla fine dell'Ellenismo, Bari, 1992 (= Stuttgart, 1990).

Merrit, B. D. y WAdE-Gery, H. T., The Athenian tribute lists, Cambridge, 1950.

MEYER, E., Forschungen zur alten Geschichte, vol. II, Halle, 1899.

- Theopomps Hellenika, Halle, 1909.

Mikalson, J. D., Herodotus and religion in the Persian Wars, Chapel Hill, 2002.

Moles, J., «Anathema kai Ktema: the Inscriptional Inheritance of Ancient Historiography», Histos, 1999 (formato electrónico).

Momigliano, A., «Atene nel III secolo a. C. e la scoperta di Roma nelle Storie di Timeo di Tauromenio», RSI, 71, 1959, pp. 529-556.

- «Ancient history and the antiquarian», en Studies in historiography, Londres, 1969, pp. 1-39.

- «Friedrich Creuzer and Greek historiography» en Studies in historiography, Londres, 1969a, pp. 75-90.

- «Tradition and the classical historian», en Quinto contributo alla storia degli studi classici e del mondo antico, Roma, 1975, pp. 13-31 (= History and Theory, 11, 1972).

- «The Rhetoric of history and the history of Rhetoric: on Hayden White's Tropes», en Settimo contributo alla storia degli studi classici e del mondo antico, Roma, 1984a, pp. 49-59 (= Comparative criticism: a year book, vol. 3, Cambridge, 1981).

- «Los historiadores del mundo clásico y su público: algunas indicaciones», en A. Momigliano, La historiografía griega, Barcelona, 1984b, pp. 105-121.

- «El lugar de Heródoto en la historia de la historiografía», en A. Momigliano, La historiografia griega, Barcelona, 1984c, pp.134-150.

- «Algunas observaciones sobre las causas de la guerra en la historiografía antigua», en A. Momigliano, La historiografia griega, Barcelona, 1984d, pp. 151-167 (= Acta congressus madvigiani, 1954).

Mondolfo, R., Heráclito. Textos y problemas de su interpretación, México, 1971.

MORA, F., Religione e religioni nelle Storie di Erodoto, Milán, 1985.

MorAleJo, J. J., «La "Archaeologia” de Tucídides: balance crítico», en J. J. Moralejo et al., Nuevos estudios de Literatura griega, Madrid, 1981, pp. 9-52. 
Mordtmann, J. H., «Epigraphische Mittheilungen. II Archaische Inschrift aus Kyzikos», Hermes, 15, 1880, pp. 92-98.

Morris, I., Death-ritual and social structure in Classical Antiquity, Cambridge, 1992.

Most G., «From Logos to Mythos», en R. Buxton (ed.), From Myth to Reason? Studies in the development of Greek thought, Oxford, 1999, pp. 25-47.

Müller, C. ,y Müller, T., Fragmenta Historicorum Graecorum, París, 1841 y ss.

Müller, D., Satzbau, Satzgliederung und Satzverbindung in der Prosa Herodots, Meisenheim am Glan, 1980.

- «Herodot-Vater des Empirismus? Mensch und Erkenntnis im Denken Herodots», en G. Kurz, D. Müller, y W. Nicolai (eds.), Gnomosyne. Menschlisches Denken und Handeln in der frühgriechischen Literatur, Festschrift für W. Marg zum 70. Geburtstag, Múnich, 1981, pp. 299-318.

MunRO, D., Homeric grammar, Londres, 2003 (= Oxford, 1891).

MüRI, W., «Beitrag zum Vertändnis des Thukydides», en H. Herter (ed.), Thukydides, Wege der Forschung, Stuttgart, 1968, pp. 135-170 (= MH, 4, 1947).

MurRAY, G., «Theopompus or the cynic as Historian», en G. Murray, Greek Studies, Oxford, 1946, pp. 149-170.

MurRAY, O., «Herodotus and oral history», en N. Luraghi (ed.), The historian's craft in the age of Herodotus, Oxford, 2001, pp. 16-44 (= H. Sancisi Weerdenburg y A. Kuhrt (eds.), Achaemenid history II, Leiden, 1987).

NAGY, G., «Herodotus the Logios», en D. Boedeker y J. Peradotto (eds.), Herodotus and the Invention of History, 1987 (Arethusa, 20), pp. 175-184.

- Pindar's Homer: the Lyric Possession of an Epic Past, Baltimore, 1994.

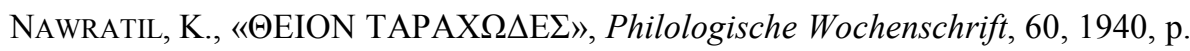
125.

NENCI, G., «La filobarbarie di Ecateo nel giudizio di Eraclito», RFIC, 27, 1949, pp. 107-227.

- «Ecateo da Mileto e la questione del suo racionalismo», $R A L, 8,6,1951$, pp. 5158.

- «Il motivo dell'autopsia nella storiografia greca», SCO, 3, 1953, pp. 14-46.

- Hecataei Milesii Fragmenta, Florencia, 1954.

Nestle, W., «Gab es eine jonische Sophistik?», Philologus, 70, 1911, pp. 242-266. 
- «Thukydides und die Sophistik», en Griechische Studien. Untersuchungen zur Religion, Dichtung und Philosophie der Griechen, Stuttgart, 1948, pp. 321-373 $(=N J A, 33,1914)$.

- Vom Mythos zum Logos: die Selbstentfaltung des griechischen Denkens von Homer bis auf die Sophistik und Sokrates, Stuttgart, 1966.

NICOLAI, R., La storiografia nell'educazione antica, Pisa, 1992.

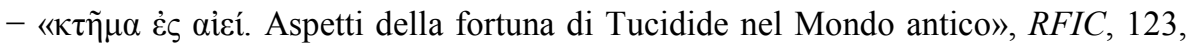
1995, pp. 5-26.

- «Pater semper incertus. Appunti su Ecateo», QUCC, N. S. 56, 2, 1997, pp. 143164.

- «Thucydides' Archaeology: between epic and oral traditions», en N. Luraghi (ed.), The historian's craft in the age of Herodotus, Oxford, 2001, pp. 263-285.

- «The place of History in the Ancient World», en J. Marincola (ed.), A companion to Greek and Roman historiography, Londres, 2007, pp. 13-26.

- «Logos Didaskalos: direct speech as a critical tool in Thucydides», en G. Rechenauer y V. Pothou (eds.), Thucydides $-a$ violent teacher? History and its representations, Gotinga, 2011, pp. 159-169.

NIEBUHR, B. G., Vorträge über alte Geschichte, an der Universität zu Bonn gehalten, Berlín, 1847.

NIESCHKE, A., De Thucydide Antiphontis discipulo et Homeri imitatore, Münden, 1885.

NIESE, B., «Wann hat Ephoros sein Geschichtswerk geschrieben?», Hermes, 44, 1909, pp. 170-178.

NIKITAS, A., Zur Bedeutung von prophasis in der altgriechischen Literatur: Dichtung, Historiographie, Corpus Hippocraticum, Maguncia, 1976.

Nilsson, M. P., Geschichte der Griechischen Religion, I. Die Religion Griechenlands bis auf die Griechische Weltherrschaft, Múnich, 1967.

NiSSEN, H., Italische Landeskunde I, Berlín, 1883.

NORDEN, E., Agnostos Theos, Untersuchungen zur Formengeschichte religiöser Rede, Darmstadt, 1956 (= Leipzig, 1913).

- Die Antike Kunstprosa, Darmstadt, 1958 (= Leipzig, 1898).

Notopoulos, A., «Parataxis in Homer: a New Approach to Homeric Literary Criticism», TAPhA, 80, 1949, pp. 1-23.

NouHaud, M., L'utilisation de l'histoire par les orateurs attiques, París, 1982. 
OBER, J., «Thucydides and the Invention of Political Science», en A. Tsamakis y A. Rengakos (eds.), Brill's Companion to Thucydides, Leiden, 2006, pp. 131-159.

ONG, W. J., Orality and Literacy. The technologizing of the word, Londres, 1982.

OtTerlo, W. A. A. van, Untersuchungen über Begriff, Anwendung und Entstehung der griechischen Ringkomposition, Ámsterdam, 1944.

PAGE, D., «Thucydides' description of the Great Plague at Athens», CQ, 3, 1953, pp. 97-113.

PAGEL, K. A., Die Bedeutung des aitiologischen Momentes für Herodots Geschichtsschreibung, Leipzig, 1927.

Paley, F. A., The Epics of Hesiod, with an English commentary by F. A. Paley, Londres, 1883.

PANI, M., Le ragioni della storiografia in Grecia e a Roma, Bari, 2001.

PARMeggiani, G., Eforo di Cuma. Studi di storiografia greca, Bolonia, 2011.

PARRY, A., «The language of Thucydides' description of the plague», BICS, 16, 1969, pp. 106-118.

- «Thucydides’ use of abstract language», YFS, 45, 1970, pp. 3-20.

- The making of Homeric verse: the collected papers of Milman Parry, Oxford, 1971.

PARSONS, P. J., The Oxyrhynchus papyri LIX, ed. with translation by E. Handley et al., Londres, 1992.

PASCUCCI, G., «El surgimiento de la prosa jonia: historiografía y ciencia», en R. Bianchi (ed.), Historia y civilización de los griegos II, Barcelona, 1982 (= Roma, 1970), pp. 298-329.

PATZEK, B., «Mündlichkeit und Schriftlichkeit im Geschichtswerk Herodots», Klio, 84, 2002, pp. 7-26.

PATZER, H., Das Problem der Geschichtsschreibung des Thukydides und die thukydideische Frage, Berlín, 1937.

PAYEN, P., Les îles nomades. Conquerir et résister dans l'Enquête d'Hérodote, París, 1997.

PEARSON, L., Early Ionian Historians, Oxford, 1939.

- «Prophasis and Aitia», TAPhA, 83, 1952, pp. 212-215.

- The Greek historians of the West: Timaeus and his predecessors, Atlanta, 1987. 
PEEK, W., Griechische vers-inschriften, grab-Epigramme, Chicago, 1988 (= Berlín, 1955).

PEDECH, P., «Un historien nommé Cratippe», REA, 92, 1970, pp. 31-45.

- Trois historiens meconnus: Théopompe, Duris, Phylarque, París, 1989.

Pelliccia, H., «Sappho 16, Gorgias' Helen, and the preface to Herodotus' Histories», en F. M. Dunnn y T. Cole (eds.), Beginnings in Classical literature, Cambridge, 1992, pp. 63-84.

PELling, C., Literary texts and the Greek historian, Londres, 2000.

PFEIFFER, R. «Gottheit und Individuum in der frühgriechischen Lyrik», Philologus, 84, 1928, pp. 137-152.

PICKARD-CAMBridge, A., The dramatic festivals of Athens, Oxford, 1968.

- Dithyramb, tragedy and comedy, Oxford, 1997 (= Oxford, 1962).

PIPPIDI, D. M., «Aristotle et Thucydide en marge du chapitre IX de la Poétique», en Mélanges de Philologie, de littérature et d'Histoire anciennes offerts à J. Marouzeau par ses collègues et élèves étrangers, París, 1948, pp. 484-496.

PIRES, F. M., «The Rhetoric of method (Thucydides, 1.22 and 2.35)», AHB, 12, 1998, pp. 106-112.

PleZIA, M., «Der Titel und der Zweck von Kallisthenes’ Alexandergeschichte», Eos, 60, 1972, pp. 263-268.

PoDLECKI, A. J., The political background of Aeschylean Tragedy, Londres, 1999.

PoHLEnZ, M., Herodot der erste Geschichtschreiber des Abendlandes, Darmstadt, 1961 (= Leipzig, 1937).

- «Thukydidesstudien», en Kleine Schriften II, Hildesheim, 1965, pp. 210-280 (= $N G G, 1919-1920)$.

Poppo, E. F., Thucydidis de Bello Peloponnesiaco libri octo, de arte huius scriptoris historia exposuit; eius vitas a veteribus grammaticis conscriptas addidit; codicum rationem atque auctoritatem examinavit; graeca ex iis emendavit; scripturae diversitates omnes, commentarios rerum geographicarum, scholia graeca et notas tum Dukeri omnes atque aliorum selectas tum suas; denique indices rerum et verborum locupletissimos subiecit E. F. Poppo, Leipzig, 1821 (cuatro partes en once tomos).

- De historia tucydidea commentatio, Leipzig, 1856. 
Poppo, E. F., y Staht, I. M., Thucydidis de Bello Peloponnesiaco libri octo, ad optimorum librorum fidem editos explanavit E. F. Poppo, editio tertia, quam auxit et emendavit I. M. Stahl, Leipzig, 1886 y ss.

PORCIANI, L., La Forma proemiale. Storiografia e pubblico nel mondo antico, Pisa, 1997.

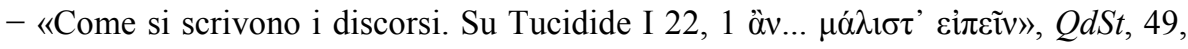
1999, pp. 103-135.

- Prime forme della storiografia greca, Stuttgart, 2001.

- «Allusioni erodotee. A proposito della "pubblicazione" delle Storie», en M. Giangiulio (ed.), Erodoto e il modello erodoteo, Trento, 2005, pp. 1-60.

Pouncey, P. R., The Necessities of War. A Study of Thucydides' Pessimism, Nueva York, 1980.

Powell, J. E., The History of Herodotus, Cambridge, 1939.

- A Lexicon to Herodotus, Hildesheim, 1977 (= Cambridge, 1938).

PRANDI, L., Callistene: uno storico tra Aristotele e i re macedoni, Milán, 1985.

PRICE, J. J., Thucydides and internal war, Cambridge, 1997.

PritchetT, W. K., Dionysius of Halicarnassus, On Thucydides, Los Ángeles, 1975.

- The liar school of Herodotus, Ámsterdam, 1993.

RAAFLAUB, K. A., «Herodotus' political thought and the meaning of history», en D. Boedeker y J. Peradotto (eds.), Herodotus and the Invention of History, 1987 (Arethusa, 20), pp. 221-248.

RANKIN, H. D., Anthisthenes Sokratikos, Ámsterdam, 1986.

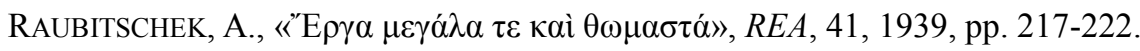

RAWLINGS, H., A semantic study of prophasis to 400 B. C., Wiesbaden, 1975.

- The structure of the Thucydides' History, Princenton, 1981.

Rechenauer, G., Thukydides und die hipokratische Medizin, Hildesheim, 1991.

- «Polis nosousa: politics and disease in Thucydides -the case of the plague», en G. Rechenauer y V. Pothou (eds.), Thucydides $-a$ violent teacher? History and its representations, Gotinga, 2011, pp. 241-260.

REDFIELD, J., «Herodotus the tourist», CP, 80, 1985, pp. 97-118.

Regenbogen, O., «Herodot und sein Werk. Ein Versuch», en W. Marg (ed.), Herodot, Berlín, 1962, pp. 57-108 (=Die Antike, 6, 1930). 
Regenbogen, O., «Thukydides als politischer Denker», en H. Herter (ed.), Thukydides, Wege der Forschung, Stuttgart, 1968, pp. 23-58 (= Gymnasium, 4, 1933).

REINHARDT, K. «Herodots Persergeschichten. Östliches und Westliches im übergang von Sage zu Geschichte», en K. Reinhardt, Vermaechtnis der Antike. Gesammelte essays zur Philosophie und Geschichtsschreibung, Gotinga, 1989a, pp. 133-174 (= Geistige Überlieferung, Berlín, 1940).

- «Platons Mythen», en K. Reinhardt, Vermaechtnis der Antike. Gesammelte essays zur Philosophie und Geschichtsschreibung, Gotinga, 1989b, pp. 219-295.

REITZENSTEIN, R., Epigramm und Skolion: ein Beitrag zur Geschichte der alexandrinischen Dichtung, Giessen, 1893.

- Hellenistische Wundererzählungen, Leipzig, 1906.

Rengakos, A., Form und Wandel des Machtdenkes der Athener bei Thukydides, Stuttgart, 1984.

- «Narrative and history: the case of Thucydides», en G. Rechenauer y V. Pothou, (eds.), Thucydides - a violent teacher? History and its representations, Gotinga, 2011, pp. 49-60.

RHODES, P. J., «In defence of the Greek Historians», G\&R, 41, 1994, pp. 156-169.

- «Herodotean chronology revisited», en P. Derow y R. Parker (eds.), Herodotus and his world: essays from a conference in memory of G. Forrest, Oxford, 2003, pp. 58-72.

- «Biaios Didaskalos? Thucydides and his lessons for his readers», en G. Rechenauer y V. Pothou (eds.), Thucydides $-a$ violent teacher? History and its representations, Gotinga, 2011, pp. 17-28.

RHYS ROBERTS, W., Longinus on the Sublime. The Greek Text edited after the Paris Manuscript, Cambridge, 1899.

RIDLEY, R. T., «Exegesis and Audience in Thucydides», Hermes, 109, 1981, pp. 25 46.

ROLLINGER, R., Herodots babylonischer Logos. Eine kritische Untersuchung der Glaubwürdigkeitsdiskussion, Innsbruck, 1993.

Romilly, J. de, Thucydide et l' impérialisme athénien, París, 1951.

- Histoire et raison chez Thucydide, París, 1956.

- «La vengeance comme explication historique dans l'œuvre d'Hérodote», REG, 84, 1971, pp. 314-337. 
Romilly, J. de, La guerre du Péloponnèse, tome III, livres IV et V, texte établi et traduit par J. de Romilly, París, 1973.

- La construction de la vérité chez Thucydide, París, 1990.

- L'invention de l'histoire politique chez Thucydide, París, 2005.

RooD, T., Thucydides, narrative and explanation, Oxford, 1998.

- «Rhetoric, Reciprocity, and History: Thucydides' Historical Method», en A. Tsamakis y A. Rengakos (eds.), Brill's Companion to Thucydides, Leiden, 2006, pp. 225-249.

Ros, J., Die Metabole als Stilprinzip des Thukydides, Ámsterdam, 1968 (= Nimega, 1938).

RÖSE, Hat Herodot sein Werk selbst herausgegeben?, Giessen, 1879.

RöSLER, W., «The Histories and writing», en E. J. Bakker, I. de Jong y H. van Wees, (eds.), Brill's Companion to Herodotus, Leiden, 2002, pp. 79-94.

RUTHERFORD, R. B., «Structure and meaning in epic and historiography», en E. Foster y D. Lateiner (eds.), Thucydides and Herodotus, Oxford, 2012, pp. 13-38.

SACKS, K. S., Diodorus Siculus and the first century, Oxford, 1990.

SAÏD, S., «Myth and historiography», en J. Marincola (ed.), A Companion to Greek and Roman historiography, Londres, 2007, pp. 76-88.

- «Reading Thucydides' Archaeology against the background of Herodotus' preface», en G. Rechenauer y V. Pothou (eds.), Thucydides - a violent teacher? History and its representations, Gotinga, 2011, pp. 61-78.

SANCHO, L., «Acerca del uso del argumento Eikos en la historiografía griega del siglo V a. C.», Veleia, 13, 1996, pp. 93-114.

Sancisi Weerdenburg, H., «The Persian Kings and History», en C. Kraus (ed.), The limits of historiography: genre and narrative in ancient historical texts, Leiden, 1999, pp. 91-112.

SANCTIS, G. de, «Intorno al razionalismo di Ecateo», Riv. di Fil. Class., N. S. 11, 1933, pp. 1-15.

- «Il logos di Creso e il proemio della storia erodotea», Riv. di Fil. Class., N. S. 14, 1936, pp. 1-14.

- Ricerche sulla storiografia siceliota, Palermo, 1957.

SAYCE, A. H., Great empires of the East, Herodotus I-III, Londres, 1883. 
SCANLON, T. F., «The clear Truth in Thucydides I 22, 4», Historia, 51, 2002, pp. 131-148.

SchadewaldT, W., Die Geschichtsschreibung des Thukydides, Berlín, 1929.

- Die Anfänge der Geschichtsschreibung bei den Griechen: Herodot, Thukydides, Fráncfort del Meno, 1982.

- «Die Anfänge der Geschichtsschreibung bei den Griechen», en M. J. Alonso Núñez (ed.), Geschichtsbild und Geschichtsdenken im Altertum, Darmstadt, 1991, pp. 63-89 (= Die Antike, 10, 1934).

Schelima, R. von, Die Wassergrenze im Altertum, Breslau, 1931.

SCHELlER, P., De hellenistica historiae conscribendae arte, Leipzig, 1911.

SCHEPENS, G., L'autopsie dans la méthode des historiens grecs du Ve siècle avant $J$. C., Bruselas, 1980.

- «Polybius on Philarcus' "Tragic" Historiography», en G. Schepens y J. Bollansée, (eds.), The Shadow of Polybius. Intertextuality as a Research Tool in Greek Historiography, Lovaina, 2005, pp. 141-164.

- «Some aspects of source theory in Greek historiography», en J. Marincola (ed.), Greek and Roman historiography. Oxford readings in Classical Studies, Oxford, 2011, pp. 100-118 (=AncSoc, 6, 1975).

SCHICK, C., «Studi sui primordi della prosa greca», $A G I, 40$, 1955, pp. 89-135.

SCHMID, W., y STÄHLIN, O., Geschichte der griechischen Litteratur, zweiter Teil: Die nachklassiche Periode der griechischen Litteratur, Múnich, 1920.

- y STÄHLIN, O., Geschichte der griechischen Literatur. I, 5: Die Klassische periode der griechischen Literatur. Die griechische Literatur zur der zeit Attischen Hegemonie nach dem Eingreifen der Sophistik, zweite Halfte, zweiter Abschnitt, Múnich, 1948.

Schmitz-Kahlmann, G., Das Beispiel der Geschichte im politischen Denken des Isokrates, Leipzig, 1939.

SCHNEIDER, C., Information und Absicht bei Thukydides, Gotinga, 1974.

SCHOELl, R., Die Anfänge einer politischen Literatur bei den Griechen: Festrede gehalten in der offentlichen Sitzung der K.b. Akademie der Wissenschaften zu Munchen am 15. November 1889, Múnich, 1890.

SCHRADER, C., «El mito de Maratón», CIF, 7, 1981, pp. 17-54.

- «La investigación histórica en Heródoto», en Estudios en homenaje al Dr. Antonio Beltrán Martínez, Zaragoza, 1986, pp. 667-677. 
SCHRADER, C., «Heródoto», en J. A. López Férez, (ed.), Historia de la Literatura griega, Madrid, 1988, pp. 503-536.

- Concordantia Herodotea, Hildesheim, 1994.

- Concordantia Thucydidea, Hildesheim, 1996.

- y LÓPEZ EIRE, A., Los orígenes de la oratoria y la historiografia en la Grecia clásica, Las Palmas, 1997.

SCHRÖDER, S., Plutarchs Schrift De Pythiae oraculis. Text Einleitung und Kommentar, Berlín, 1990.

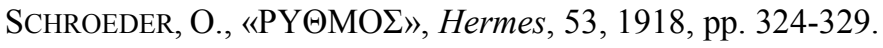

SCHUBERT, R., Die Quellen zur Geschichte der Diadochenzeit, Leipzig, 1914.

SCHWABL, H. «Aufbau und Struktur des Prooimions der Hesiodischen Theogonie», Hermes, 91, 1963, pp. 385-415.

SCHWARTZ, E., Quaestiones ionicas, Leipzig, 1891.

- «Die Berichte über die Catilinarische Verschwörung», Hermes, 32, 1897, pp. 554608.

- «Kallisthenes Hellenika», Hermes, 35, 1900, pp. 106-130.

- «Die Zeit des Ephoros», Hermes, 44, 1909, pp. 481-502.

- «Über das Verhältnis der Hellenen zur Geschichte», en Kleine Schriften I, Berlín, 1938a, pp. 47-66.

- «Geschichtschreibung und Geschichte bei den Hellenen», en Kleine Schriften I, Berlín, 1938b, pp. 67-87.

- Griechische Geschichtschreiber, Leipzig, 1959.

- Das Geschichtswerk des Thukydides, Hildesheim, 1969 (= Bonn, 1929).

SCHWEIGHAEUSER, J., Herodoti Musae, sive Historiarum libri IX. Ad veterum codicum fidem denuo recensuit, lectionis varietate, continua interpretatione Latina adnotationibus Wesselingii et Valckenarii aliorumque et suis illustravit Iohannes Schweighaeuser, París, 1816.

SCHWINGE, E. R., Komplexität und Transparenz. Thukydides: eine Leseanleintung, Heidelberg, 2008.

SCHWYZER, E., Griechische Grammatik II, Múnich, 1959.

SCOTT, L., Historical commentary on Herodotus, book 6, Leiden, 2005. 
SCULLION, S., «Herodotus and Greek Religion», en D. Boedeker, y J. Peradotto (eds.), Herodotus and the Invention of History, 1987 (Arethusa, 20), pp. 190206.

SEALEY, R., «Thucydides, Herodotos, and the Causes of War», CQ, 7, 1-2, 1957, pp. $1-12$.

SHAPIRO, S. O., «Proverbial Wisdom in Herodotus», TAPhA, 130, 2000, pp. 89-118.

SHILleto, R., Thucydidis I with collation of the two Cambridge Mss. and the Aldine and Juntine editions, by Richard Shilleto (con comentario), Cambridge, 1872.

Shimron, B., Politics and Belief in Herodotus, Stuttgart, 1989.

SHrimpton, G. S., Theopompus the Historian, Montreal, 1991.

- «Accuracy in Thucydides», AHB, 12.3, 1998, pp. 71-82.

SIDER, D., «The blinding Stesichorus», Hermes, 117, 1989, pp. 423-431.

SLINGS, S. R., «Oral Strategies in the language of Herodotus», en E. J. Bakker, I. de Jong y H. van Wees, (eds.), Brill's Companion to Herodotus, Leiden, 2002, pp. pp. 53-77.

SNELl, B., «Die Sprache Heraklits», Hermes, 67, 1926, pp. 353-381.

- The Discovery of Mind, Londres, 1982 (= Hamburgo, 1948).

- Die Ausdrücke für den Begriff des Wissens in der vorplatonischen Philosophie, Hildesheim, 1992 (= Berlín, 1924).

SolSeM, F., Two crucial Decisions in Herodotus, Ámsterdam, 1974.

Sommerstein, A., Aeschylus' Eumenides, Cambridge, 1989.

SOURDILLE, C., Hérodote et la religion de l'Égypte, comparaison des données de Hérodote avec les données égyptiennes, París, 1910.

Spath, T., Das Motiv der doppelten Beleuchtung bei Herodot, Viena, 1968.

STADTER, P. A., «Thucydides as reader», en E. Foster y D. Lateiner (eds.), Thucydides and Herodotus, Oxford, 2012, pp. 39-66.

StaHL, H. P., Thucydides: man's place in history, Swansea, 2003 (= Múnich, 2003).

- «War in Thucydides: veneer remover - veneer fabricator», en G. Rechenauer y V. Pothou (eds.), Thucydides - a violent teacher? History and its representations, Gotinga, 2011, pp. 29-48.

- «Herodotus and Thucydides on blind decisions preceding military action», en E. Foster y D. Lateiner (eds.), Thucydides and Herodotus, Oxford, 2012, pp. 125153. 
Stahl, J. M., «Kratippos und Thukydides», Philologus, 50, 1891, pp. 31-42.

StARR, CH. G., The awakening of the Greek historical spirit, Nueva York, 1968.

Ste. Croix, G. de, «Aristotle and Poetry (Poetics 9, 1451a36-b11)», en B. Levick, (ed.), The Ancient Historian and his Materials, Farnborough, 1975, pp. 45-58.

- «Herodotus», G\&R, 24, 1977, pp. 130-148.

SteIN, H., Herodotos; erklärt von Heinrich Stein, Band 1: Buch 1 und 2, Hildesheim, 1962 (= Berlín, 1901 y 1902).

- Herodotos; erklärt von Heinrich Stein, Band 2: Buch 3 und 4, Hildesheim, 1962 (= Berlín, 1893).

Stein, H., Herodotos; erklärt von Heinrich Stein, Band 3: Buch 5 und 6, Hildesheim, 1962 (= Berlín, 1894).

- Herodotos; erklärt von Heinrich Stein, Band 4: Buch 7, Hildesheim, 1962 (= Berlín, 1908).

- Herodotos; erklärt von Heinrich Stein, Band 5: Buch 8 und 9, Hildesheim, 1962 (= Berlín, 1893).

StRASBURGer, H., «Herodot und das perikleische Athen», Historia, 4, 1955, pp. 125.

- «Herodots Zeitrechnung», Historia, 5, 1956, pp. 129-161.

- Die Wesensbestimmung der Geschichte durch die antike Geschichtsschreibung, Wiesbaden, 1966.

- «Die Entdeckung der politischen Geschichte durch Thukydides», en H. Herter, (ed.), Thukydides, Wege der Forschung, Stuttgart, 1968a, pp. 412-476 (= Saeculum 5, 1954).

- «Thukydides und die politische Selbstdarstellung der Athener», en H. Herter (ed.), Thukydides, Wege der Forschung, Stuttgart, 1968b, pp. 498-530 (= Hermes, 86, 1958).

- «Umblick im Trümmerfeld der griechischen Geschichtsschreibung», en T. Reekmans (ed.), Historiographia Antiqua. Commentationes Lovanienses in honorem W. Peremans septuagenarii editae, Lovaina, 1977, pp. 3-52.

- «Herodot als Geschichtsforscher», en Studien zur alten Geschichte 2, Hildesheim, 1982 pp. 835-919 (= Herodot, Geschichten und Geschichte, übersetzt von W. Marg, Hg. Von G. Strasburger, Múnich, 1980).

StUPPERICH, R., Staatbegräbnis und Privatgrabmal im klassischen Athen, Múnich, 1977. 
SUÁREZ DE LA TORRE, E., «La epistolografía griega», EstClas, 33, 1979, pp. 19-46.

SuSEMIHL, F., Geschichte der Griechischen Litteratur in der Alexandrinerzeit I, Leipzig, 1891.

- Geschichte der Griechischen Litteratur in der Alexandrinerzeit II, Leipzig, 1892.

TARN, W. W., y GRIFFITH, G. T., Hellenistic Civilisation, Londres, 1952.

Tasolambros, F. L., In defence of Thucydides, Atenas, 1979.

TAEGER, F., Thukydides, Stuttgart, 1925.

TÄUBLER, E., Die Archaeologie des Thukydides, Leipzig, 1927.

TAYLOR, M., Thucydides, Pericles, and the idea of Athens in the Peloponnesian war, Cambridge, 2010.

THESLEFF, H., Studies in the styles of Plato, Helsinki, 1966.

ThOMAs, G. S., De particula ஸ́ৎ usu herodoteo, Leipzig, 1888.

Thomas, R., Oral tradition and written record in classical Athens, Cambridge, 1989.

- Herodotus in Context: Ethnography, Science and the Art of Persuasion, Cambridge, 2000.

TODD, O., «On the Date of Herodotus’ Death», $C Q, 16,1922$, pp. 35-36.

TORRACA, L., Duride di Samo. La maschera scenica nella storiografia ellenistica, Salerno, 1988.

TOZER, H. F., A history of ancient geography, Cambridge, 1897.

TOZZI, P., «Studi su Ecateo di Mileto II», Athenaeum, 41, 1964, pp. 101-117.

Treagold, W. T., The nature of the Bibliotheca of Photius, Washington, 1980.

TRENKNER, S., Le style KAI dans le récit attique oral, Assen, 1960.

TSAKMAKIS, A., Thukydides über die Vergangenheit, Tubinga, 1995.

- «Von der Rhetorik zur Geschichtsschreibung: das Methodenkapitel des Thukydides», RhM, 141, 3-4, 1998, pp. 239-255.

TURNER, E., «Los libros en la Atenas de los siglos V y IV a. C», en G. Cavallo (ed.), Libros, editores y público en el Mundo Antiguo, Madrid, 1995 (= Roma, 1982) pp. 25-50.

UlLman, B. L., «History and Tragedy», TAPhA, 73, 1942, pp. 25-53.

UlRICH, F., Zur Erklärung des Thukydides, Leipzig, 1846. 
UlRICI, H., Charakteristik der antiken Historiographie, Berlín, 1833.

UnTERSTEINER, M., I Sofisti, Milán, 1967.

- I Sofisti, testimonianze e frammenti, fascicolo primo: Protagora e Seniade, introduzione, traduzione e commenti a cura di M. Untersteiner, Florencia, $1967 \mathrm{a}$.

- I Sofisti, testimonianze e frammenti, fascicolo terzo: Trasimaco, Ippia..., introduzione, traduzione e commenti a cura di M. Untersteiner, Florencia, $1967 b$.

VANICELLI, P., «L'economia delle Storie di Eforo», RFIC, 115, 2, 1987, pp. 165191.

VANSINA, J., Oral tradition as History, Londres, 1985.

Vattuone, R., Sapienza d'occidente. Il pensiero storico di Timeo di Tauromenio, Bolonia, 1991.

- «Timeo de Tauromenio», en R. Vattuone (ed.), Storici Greci d'Occidente, Bolonia, 2002, pp. 177-232.

- «Western Greek Historiography», en J. Marincola (ed.), A Companion to Greek and Roman historiography, Londres, 2007, pp. 189-199.

VERDIN, H., De historisch-kritische Methode van Herodotus, Bruselas, 1971.

VERDIN, H., «Les remarques critiques d'Hérodote et de Thucydide sur la poésie en tant que source historique», en T. Reekmans (ed.), Historiographia Antiqua. Commentationes Lovanienses in honorem W. Peremans septuagenarii editae, Lovaina, 1977, pp. 53-76.

VEYne, P., Cómo se escribe la historia, Madrid, 1984.

VIDAL-NAQUeT, P., «Temps des dieux et temps des hommes», en La Grèce ancienne, l'espace et le temps, París, 1991, pp. 135-164 (= Revue de l'histoire des religions, 1960).

VignOlo Munson, R., «Herodotus' use of prospective sentences», AJP, 114, 1993, pp. 27-44.

- Telling wonders, ethnographic and political discourse in the work of Herodotus, Ann Arbor, 2001a.

- «Ananke in Herodotus», JHS, 121, 2001b, pp. 30-50.

- Black doves speak: Herodotus and the languages of barbarians, Washington, 2005. 
VogT, J., «The portrait of Pericles in Thucydides», en J. S. Rusten (ed.), Thucydides. Oxford readings in Classical studies, Oxford, 2009, pp. 220-237 (= HZ, 182, 1956).

WACKERNAGEL, J., «Miszellen zur griechischen Grammatik», Zeitschrift zur vergleichende Sprachforschung, 33, 1895, pp. 2-62.

WALBANK, F. W., «Tragic history. A reconsideration», BICS, 2, 1955, pp. 4-14.

- «History and tragedy», Historia, 9, 1960, pp. 216-234.

- «The Greek historians of Sicily», Kokalos, 14-15, 1968-1969, pp. 476-497.

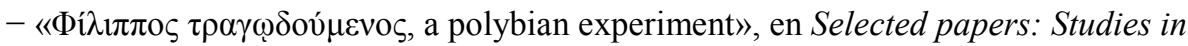
Greek and Roman History and Historiography, Cambridge, 1985, pp. 210-223.

- «Profit or Amusement. Some thoughts on the motives of Hellenistic Historians», en G. Verdin, G. Schepens y E. de Keyser (eds.), Purposes of History. Studies in Greek Historiography from the 4th to the 2th B. C., Lovaina, 1990, pp. 253-266.

WARDMAn, E. A., «Herodotus on the cause of the Greco-Persian wars», AJP, 82, 1961, pp. 133-150.

WATERS, K. H., Herodotus the historian, Londres, 1985.

WEBER, H. A., Herodots Verständnis von Historie: Untersuchungen zur Methodologie und Argumentationsweise Herodots, Múnich, 1976.

Webster, T. B. L., «A Study of Greek Sentence Construction», AJP, 62, 1941, pp. 385- 415.

WeEs, H. van, «Herodotus and the Past», en E. J. Bakker, I. de Jong y H. van Wees (eds.), Brill's Companion to Herodotus, Leiden, 2002, pp. 321-350.

WeHrli, F., Lathe biōsas: Studien zur ältesten Ethik bei den Griechen, Leipzig, 1931.

WeHRLI, F., «Die Geschichtsschreibung im Lichte der antiken Theorie», en Eumusia: Festgabe für Ernst Howald zum Sechzigsten Geburstag am 20. April 1947, Zúrich, 1947, pp. 54-71.

WeIDAUER, K., Thukydides und die Hippokratischen Schriften, Heidelberg, 1954.

WeIL, R., Aristote et l'histoire. Essai sur la Politique, París, 1960.

WeIR SMYTH, H., Greek Melic poets, Londres, 1899.

Wellauer, T., Lexicon Aeschyleum, Leipzig, 1830. 
WeLles, C. B., «Isocrates view of History», en L. Wallach (ed.), The Classical tradition, literary and historical studies in honor of M. Caplan, Nueva York, 1966, pp. 3-25.

WeLls, J., Studies in Herodotus, Oxford, 1923.

WERnER Müller, C., «Protagoras über die Götter», Hermes, 95, 1967, pp. 140-159.

WEST, M. L., «Stesichorus», CQ, 21, 1971, pp. 302-314.

- Hesiod, Theogony, edit with prolegomena and commentary by M. L. West, Oxford, $1982(=1966)$.

- Ancient Greek Music, Oxford, 1992.

- The making of the Iliad, Oxford, 2011.

WEST, S., «Herodotus’ Epigraphical Interests», CQ, 35, 1991a, pp. 278-305.

- «Herodotus’ portrait of Hecataeus», JHS, 1991b, 111, pp. 144-160.

WestlaKe, H. D., « $\Omega \Sigma$ EIKO $\Sigma$ in Thucydides», Hermes, 113, 1958, pp. 447-452.

- Individuals in Thucydides, Cambridge, 1968.

- «The two second prefaces of Thucydides», Phoenix, 26, 1972, pp. 12-17.

- «Thucydides and the uneasy peace: a study in political incompetence», en J. S. Rusten (ed.), Thucydides. Oxford readings in Classical studies, Oxford, 2009, pp. 295-311 (=CQ, 21, 1971).

WHITE, H., Metahistoria. La imaginación histórica en la Europa del siglo XIX, México, 2001 (= Baltimore, 1973).

WICK, T. E., «A note on Thucydides I 23, 6, and $\dot{\eta} \alpha \lambda \eta \theta \dot{\varepsilon} \sigma \tau \alpha \tau \eta \pi \rho o ́ \varphi \alpha \sigma \iota \varsigma », A C, 44$, 1975, pp. 176-183.

WiEdemann, A., Herodots zweites Buch mit sachlichen Erlauterungen, Berlín, 1890.

WILAMOWITZ-MÖLlENDORF, U. von, «Die Thukydideslegende», Hermes, 12, 1877, pp. 326-367.

- «Hippias von Region», Hermes, 19, 1884, pp. 442-452.

- Greek historical writing; and, Apollo, two lectures delivered before the University of Oxford, June 3 and 4, 1908, Oxford, 1909.

- Herakles. Einleitung in der griechische Tragödie, Darmstadt, 1959 (= Berlín, 1907).

- Aristoteles und Athen, Hildesheim, 1985a (= Berlín, 1893). 
- Sappho und Simonides. Untersuchungen über griechische Lyriker, Hildesheim, 1985b (= Berlín, 1913).

WILlE, G., «Zur Stil und Methode des Thukydides», en H. Herter (ed.), Thukydides, Wege der Forschung, Stuttgart, 1968, pp. 683-716.

WILSON, J., «What does Thucydides claim for his Speeches?», Phoenix, 36, 1982, pp. 95-103.

Wiseman, T. P., Clio's cosmetics. Three studies in Greco-Roman literature, Exeter, 1979.

WiSEMAN, T. P., « Lying historians: seven types of mendacity», en J. Marincola (ed.), Greek and Roman historiography. Oxford readings in Classical Studies, Oxford, 2011, pp. 314-336 (= C. Gill y T. P. Wiseman, eds., Lies and Fiction in the Ancient World, Exeter, 1993).

WoLF, E., Griechisches Rechtsdenken I, Vorsokratiker und frühe Dichter, Fráncfort, 1950.

WölfFlin, R., Antiochus von Syrakus und Coelius Antipater, Leipzig, 1872.

Woodbury, L., «Helen and the Palinode», Phoenix, 21, 1967, pp. 157-176.

WoodHeAD, A. G., Thucydides on the nature of Power, Cambridge, 1970.

Woodman, A. J., Rhetoric in classical historiography: four studies, Londres, 1988.

ZIOLKowski, J. E., Thucydides and the tradition on funeral speeches at Athens, Nueva York, 1981. 


\section{INDEX LOCORUM}

Alcmeón de Crotona. B 1: 36.

ANDóCIDES. Sobre la paz, 2: 323 n. 1430 .

ANTIFONTE. En contra de la madrastra, 1: 119 n. 434. 2: 304 n. 1341. 7: 304 n. 1341. 11: 304 n. 1341. 17: 304 n. 1341. 18: 304 n. 1341. Tetralogía 1, I 1: 119 n. 434. 2: 304 n. 1341. II 5: 304 n. 1341; 306 n. 1362. 6: 304 n. 1341. 7: 304 n. 1341. 8: 306 n. 1362. IV 5: 304 n. 1341. Tetralogía 2, I 2: 119 n. 434. IV 1: 304 n. 1341. Tetralogía 3, III 3: 306 n. 1362. Sobre la muerte de Herodes, 1: 119 n. 434. 4: 304 n. 1341. 14: 306 n. 1362. 26: 304 n. 1341. 27: 304 n. 1341; 306 n. 1362. 28: 304 n. 1341; 306 n. 1362. 43: 304 n. 1341. 45: 306 n. $1362.48: 304$ n. 1341. 49: 304 n. 1341. 50: 304, n. 1341. 63: 304, n. 1341. 73: 304 n. 1341. 74: 304 n. 1341. 81: 306 n. 1362. 84: 306 n. 1362. Sobre el coreuta, 1: 119 n. 434. 2: 306 n. 1362. 43: 306 n. 1362.

Antíoco de Siracusa. F 2: 211; $212 ; 213 ; 214$.

Antístenes. Fr. 3: 401. Fr. 22 y ss.: 404 n. 1778. Fr. 23: 404 n. 1776.

ANTOLOGÍA GRIEGA. VII 251: 132. 677: 103; 104.

Apolonio de Rodas. 5: $69 \mathrm{n}$. 237; 125 n. 470.
ARISTÓbULO. F 1: 384 n. 1699; 385.

ARISTófanes. Asambleístas, 6: 306 n. 1359. 493: 303 n. 1340. Arcanienses, 426: 86; 87. 703: 303 n. 1340. Aves, 186: 239 n. 1035. 962: 86. Avispas, 585: 306 n. 1359. 690: 306 n. 1359. Caballeros, 952: 306 n. 1359. Lisístrata, 1118: 303 n. 1340. Nubes, 369: 306 n. 1359. 1374: 303 n. 1340. 1418: 303 n. 1340. 1439: 303 n. 1340. $P a z, 736: 303$ n. 1340. 761: 303 n. 1340. 990 y ss.: 243. Pluto, 258: 303 n. 1340. 662: 303 n. 1340. 1122: 303 n. 1340. 1208: 303 n. 1340. Ranas, 697: 303 n. 1340. 933: 306 n. 1359. 1060: 303 n. 1340. Tesmoforias, 278: 306 n. 1359. 582: 303 n. 1340. 722: 303 n. 1340. 839: 303 n. 1340. 974: 303 n. 1340. 1011: 306 n. 1359. 1144: 303 n. 1340.

ARISTóteles. Retórica, 1409a: 50 n. $154 ; 51$ n. $163 ; 52 ; 54$ n. 174. Sobre el alma, 411a7: 173 n. 709. Poética, 1413b: 429 n. 1911. 1415b 2: 414 n. 1828.1448 a: 419 n. 1855 ; 422 n. 1875 . 1448b: 428 n. 1905. 1449b: 416 n. 1844. 1450a 27: 417 n. 1845. 1451b: 417 n. 1848; 418 n. 1849. 1460a: 42 n. 1875.

ARQuíloco. Fr. 96W: 121 n. 449. 128W: 157. 177W: 186 n. 780.

Arriano. Anábasis, IV 9.5 y ss.: 418 n. 1853. 
AteneO. IV 128: 415 n. 1834; 430 n. 1918. XV 50: 95 n. 337.

Ateneo el Mecánico. p. 10: 379.

BAQUílIDES. Ditirambos, III 80: 132 n. 499. Epinicios, IX 40: 132 n. 499. XIII 32: 132 n. 498. XIII 50: 132 n. 498 .

Calístenes. F 44: 378; 385; 418.

CARONTE de LÁMPSACO. F 1: 54.

Cecilio de Caleacte. F 2: 29 n. 51.

Cicerón. Sobre las leyes, I 5: 33 n. 65. II 65: 191 n. 808.

\section{CORPUS HIPPOCRATICUM.} Prognosticon, I 1: 326 n. 1436. 25: 301. De aere, aquis et locis, I: $304 \mathrm{n}$. 1343; 311. II: 311. IV: 304 n. 1343. V: 304 n. 1343. VI: 304 n. 1343. VII: 304 n. 1343 . VIII: 304 n. 1343. X: 304 n. 1343. XII: 304 n. 1343. XVI: 304 n. 1343. XXI: 304 n. 1343. XXII: 304 n. 1343. XIII: 304 n. 1343. XXIV: 304 n. 1343. De prisca medicina, I: 311 . III: 304 n. 1344. XVIII: 306 n. 1360. XX: 304 n. 1344; 306 n. 1360. De diaeta in morbis acutibus, I: 312. II: $306 \mathrm{n}$. 1361; 311. III: 312. IV: 312. VIII: 304 n. 1345. IX: 304 n. 1345; 311. X: 306 n. 1361. XII: 306 n. 1361. De iudicationibus, XVI: 305 n. 1352. De septimestri partu, IX: 305 n. 1352 De articulis, X: 305 n. 1352. De oficina medici, XVI: 305 n. 1352.

CrÁtipo. F 1: 398. F 2: 398.
Critias. B 38: 39.

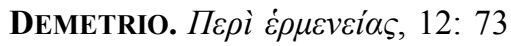
n. 241. 17: 53 n. 163. 112: 439 n. 1940.

DEMÓCRITO. B 33: 326 n. 1439. 34: 327. 119: 326 n. 1439. 191: 326 n. 1439. 256: 55 .

DEMÓSTENES. Sobre la corona, 1: 384.

DiOdORO DE SiCILIA. I 3.2: $386 \mathrm{n}$. 1708. I 4.6: 385. I 9.5: 372. XIII 46: 222. XIV 118.7: 379 n. 1688 . XVI 76.5: 369 n. 1656 . XIX 8.4: 413 n. 1822.

Diógenes de Apolonia. B 1: 37.

DIÓGENES LAERCIO. VIII 85: 36 . IX 54: 90 n. 315; 96 n. 346.

Dionisio DE HALICARNASO. Antiguedades romanas, I 1: 375 . I 12.3: 212; 384. Ad Pompeium, III 11: 18 n. 10. IV 9: 396 n. 1729. VI: 375; 402 n. 1764. XVIII: 417 n. 1846. De Ordine verborum, XXII: 63 n. 213. De Thucydide, IX: 245 n. 1058. XVI: 398. XX: 63 n. 213; 212. XXIV: 268 n. 1161 .

DOXOPATRO. II 199: 213 n. 886.

DURIS DE SAMOS. F 1: 381; 385; 392; 428. F 10: 421. F 12: 421. F 14: 421. F 57: 429 n. 1912.

ÉFORO. F 7: 370. F 8: 370; 371; $385 ; 388 ; 407$. F 9: 370; 371; 372; 385; 392; 395; 411. F 10: 370; 385. F 97: 374. F 109: 370; 372. F 110: 372. F 223: 425 n. 1895. 
ESQUILO. Agamenón, 160: $174 \mathrm{n}$. 715; 176 n. 727. 575: 303 n. 1336. 586: 303 n. 1336.717 y ss.: 188. 487 : 132 n. 502. 788: 181. 789: 181. 1098: 132 n. 502; 194. 1355: 306 n. 1356. 1356: 132 n. 500.1410 y ss.: 181 n. 751. Coéforas, 834: 308 n. 1372. Euménides, 194: 303 n. 1336. Persas, 50: 178 n. 735. 511: 308 n. 1372. Prometeo encadenado, 842: 306 n. 1356. Los siete contra Tebas, 519: 303 n. 1336. Suplicantes, 218: 306 n. 1356. 506: 306 n. 1356. Fragmentos, 162 Radt: 129 n. 481.

ESTESÍCORO. Fr. 15 PMG: 30.

ESTRABón. Geografia, I 2: $48 \mathrm{n}$. $134 ; 378$.

EURÍPIDES. Electra, 65: 308 n. 1374. 585: 306 1358. Fenicias, 962: 308 n. 1374. Heraclidas, 70: 303 n. 1338. Hércules, 714: 306 n. 1358. Hipólito, 280: 280 n. 1217. 615: 303 n. 1338. 627: 308 n. 1374. 925: 306 n. 1358. 1434: 303 n. 1337. Ifigenia en Áulide, 501: 303 n. 1338. 563 y ss.: 348 n. 1558. 1400: 303 n. 1338. Ifigenia en Táuride, 808: $306 \mathrm{n}$. 1358. 822: 306 n. 1358. Ion: 227: 306 n. 1358. 329: 306 n. 1358. 349: 306 n. 1358. Medea, 106: 308 n. 1374. 345: 303 n. 1338. 517: 306 n. 1358. 871: 303 n. 1338. 909: 303 n. 1338. 1197: 308 n. 1374. 1386: 303 n. 1338. Orestes, 350: 308 n. 1374. 539: 303 n. 1338. 734: 308 n. 1374. 855: 308 n. 1374. 1129: 308 n. 1374. Troyanas, 886: 98 n. 358; 176 n. 727.
Fr. 497 Nauck: 129 n. 482. Fr. 553

Nauck: 200 n. 846.

FERÉCIDES. B 2: 54; 63 n. 215; 66.

FilolaO. B 1: 36; 75; 117, 118.

FocIO. Biblioteca, 176.120b30: 734; 381; 383. 190.148b: 99 n. 365.

Gorgias. En defensa de Palamedes, 1: 119 n. 435. Encomio de Helena, 119 n. 435.

HeCATEO de Mileto. F 1: 74; 75; $76 ; 77 ; 78 ; 79 ; 80 ; 81 ; 82 ; 83$. F 9: 31. F 19: 74 n. 247. F27a: 32. F 27b: 74 n. 247.

HerÁClito. B 1: 35. 5: $173 \mathrm{n}$. 706. 32: 158. 40: 78. 41: 78; 157; 158 n. $628 ; 159.53: 55.77: 158.108:$ 158. $117: 158$ n. 623.

Heródoto. Pr. 75; 105; 106; 107; $124 ; 125 ; 127 ; 204$. I 1: 108; 109; $110 ; 125 ; 127 ; 134 ; 176$ n. $728 ; 212$; 260 n. 1137 . I $2: 111 ; 112 ; 125 ; 127$. I $3: 112 ; 113 ; 127$. I $4: 113 ; 114 ; 125$; 127. I $5: 114 ; 117 ; 118 ; 119 ; 120$; $125 ; 137 ; 138 ; 161 ; 166 ; 311 ; 313$. I 18.2: 308 n. 1377. I 20: 130 n. 486; 137; 150. I 23.1: 164 n. 652. I 29 2: 328 n. 1450. I 30: 102; 154. I 31: 119 n. $436 ; 176$ n. 728 . I $32: 119$ n. 436 ; 155; 168 n. 674 . I $34.1: 304$ n. 1346 . I 38.2: 144 n. 556 . I 39.1: 139 n. 534 . I 57.3: 308 n. 1376. I 60.3: 305 n. 1349. I 68.4: 304 n. 1346. I 70.2: 131. I 87: 174 n. 716 . I 94.1: 164 n. 652 . I 94.6: 309 n. 1380. I 105.3: 305 n. 1349. I 106.2: 308 n. 1377. I 108.1: 139 n. 534. I 142.1: 164 n. 652 . I 
178.2: 164 n. 652. I 193.4: 130 n. 486; 131 n. 492. I 75.1: 131 n. 492. I 131.1: 130 n. 487. I 140.2: 130 n. 487. I 171.2: 144 n. 556. I 189: $186 \mathrm{n}$. 780. I 192.1: 308 n. 1377. I 207.2: 166. I 209.1: 139 n. 534. I 209.3: 139 n. 534. II 1.1: 240 n. 1040. II 5.2: 308 n. 1376. II 12.3: 130 n. 487. II 9.2: 308 n. 1377. II 17.1: 130 n. 487. II 23: 130 n. 487. II 26: 149. II 29.1: 144; 144 n. 556. II 33: 303; 308 n. 1377 . II 43.4: 165 n. 658. II 44.3: 305 n. 1349; 309 n. 1380 . II 44.5: 141; 150 n. 588; 308 n. 1376. II 50: 174 n. 721. II 51: 174 n. $721 ; 308$ n. 1377. II 52: 174 n. 721. II 53: 174 n. 721. II 54.2: 309 n. 1380. II 55.2: 167 n. 674. II 58.1: 301 n. 1324. II 69.3: 304 n. 1346. II 86.2: 305 n. 1351. II 99.1: 138 n. 527; 141; 149. II 101.2: 308 n. 1377. II 104.2: 304 n. 1346. II 104.4: 301 n. 1324 . II 106.5: 304 n. 1346; 308 n. 1376. II 116.6: 308 n. 1376. II 117.1: 308 n. 1376. II 118.1: 148. II 119.3: 148. II 122.2: 130 n. 487. II 123.1: 144 n. 556. II 139.2: 139 n. 534. II 145.3: 308 n. 1377. II 146.1: 149. II 147.1: 139 n. 527. II 148.6: 144 n. 556. II 149.2: 308 n. 1376. II 150.2: 130 n. 487. II 182.1: 304 n. 1346. III 1.1: 131; 131 n. $492 ; 240$ n. 1040. III 28.3: 304 n. 1346. III 30.2: 131 n. 492; 139 n. 534. III 42.2: 168 n. 674. III 42.4: 168 n. 674. III 59.1: 131 n. 492. III 61.1: 130 n. 487. III 63.3: 130 n. 490. III 65.2: 139 n. 534. III 69.4: 130 n. 486. III 71.5: 130 n. 486. III 72.1: 130 n. 487 . III $80: 119$ n. 436 . III 80 y ss.: 188 n. $795 ; 275$. III 82.4: 308 n. 1376.
III 94.2: 164 n. 652. III 108: 186 n. 708. III 115.1: 130 n. 487. III 119.1: 130 n. 491. III 120.1: 131 n. 492. III 120.2: 131. III 122.1: 131 n. 492. III 122.2: 131. III 124.1: 139 n. 534. III 139.1: 131 n. 492. III 146.2: 130 n. 490. III 159.2: 308 n. 1377. IV 15.1: 130 n. $487 ; 149$ n. $587 ; 156$ n. 617 . IV 16.1: 144 n. 556. IV 16.2: 144 n. 556. IV 34.1: 130 n. 487. IV 31.2: 304 n. 1346. IV 35.5: 130 n. 487. IV 36.2: 308 n. 1377. IV 42: 301 n. 1324; 308 n. 1376 . IV 45.5: 301 n. 1324 . IV 46.1: 130 n. 487. IV 53.4: 301 n. 1324. IV 69.2: 130 n. 491. IV 76.6: 130 n. 487. IV 79.1: 332 n. 1475. IV 80.2: 130 n. 491. IV 81: 138 n. 527; 308 n. 1377. IV 99.5: 308 n. 1377. IV 111.2: 304 n. 1346. IV 129.2: 308 n. 1377. IV 132.2: 304 n. 1346. IV 133.1: 304 n. 1346. IV 133.3: 130 n. 490. IV 140.1: 309 n. 1380 . IV 155.2: 130 n. 486 . V 9.1: 301 n. 1324. V 10.1: 301 n. 1324. V 21.2: 309 n. 1380. v 36.4: 150; 308 n. 1377. v 55.1: 139 n. 534. V 56.2: 177 n. 733. V 57.1: 305 n. 1349. V 62.3: 305 n. 1351. V 78.1: 308 n. 1376. V 80.2: 150. V $90 \beta$ 2: 189 . V $92 \delta$ 1: 309 n. $1380 . \mathrm{v} 92 \eta$ 5: 130 n. 487. V 102: 170 n. 691. V 105.1: 130 n. 486. V 106: 130 n. 486. VI 17: 130 n. 486. VI 47.2: 309 n. 1380. VI 69.3: 169 n. 674. VI 69.4: 167 n. 674. VI 123.2: 308 n. 1377. VI 131.2: 187. VII 7 y ss.: 176; 176 n. 728 . VII $8 \alpha$ 1: 178 n. 738 . VII $8 \beta$ 3: 178 n. 738 . VII $8 \gamma$ 1: 177. VII $8 \gamma$ 2: 178 . VII 9: 119 n. 436. VII $9 \alpha$ 1: 178 n. 739 . VII $10 \varepsilon: 178$. VII 10క: 179. VII 12.1: 139 n. 534 . VII $16 \gamma$ 
2: 167 n. 674. VII 17.2: 180; 308 n. 1377. VII 18.2: 179. VII 20.2: $25 \mathrm{n}$. 38; 228; 255 n. 1110. VII 21.1: 24 n. 38. VII 26: 55. VII 26.2: 130 n. 487. VII 28.2: 305 n. 1349. VII 49.2: 304 n. 1346. VII 96.1: 140; 140 n. 536. VII 106.2: 304, n. 1346. VII 108.1: $308 \mathrm{n}$. 1377. VII 118.1: 309 n. 1380. VII 129.4: 301 n. 1324. VII 133.2: $130 \mathrm{n}$. 491. VII 137.2: 168 n. 674. VII 152.3: 137. VII 159: 130 n. 487. VII 170.1: 309 n. 1380 . VII 175.2: 130 n. 487. VII 184.1: 305 n. 1349. VII 187.2: 305 n. 1349. VII 203.1: 177 n. 733 . VII 204: 202 n. 855. VII 213.3: 130 n. 491. VII 214.2: 130 n. 490. VII 217.2: 308 n. 1377. VII 225.2: 187 n. 792. VII 226: 201 n. 853. VII 228: 103; 104 n. 384. VII 239.2: 304 n. 1346. VIII 30.1: 305 n. 1349. VIII 60: 119 n. 436. VIII 65.2: 168 n. 674. VIII 78: $130 \mathrm{n}$. 486. VIII 80.1: 130 n. 487. VIII 94.2: 168 n. 674 . VIII 101: 128 n. 477 . VIII 109.3: 170 n. 687 . VIII 116.2: $130 \mathrm{n}$. 491. VIII 120.1: 301 n. 1324. VIII 131: 202 n. 856. VIII 144.2: 304 n. 1346. VIII 214.2: 130 n. 487. IX 16.2: 152 n. 602. IX 17.4: 304 n. 1346. IX 21.2: 130 n. 487. IX 32.2: 304 n. 1346; 308 n. 1377. IX 34.1: 304 n. 1346. IX 43.1: 130 n. 487. IX 42.3: 131; $131 \mathrm{n}$. 492; 152 n. 602. IX 42.4: 131. IX 43.2: 130 n. 487. IX 45.2: 304 n. 1346. IX 68.1: 308 n. 1376. IX 70.4: 130 n. 491 . IX 71 y ss.: 201 n. 853 . IX 71.3: 130 n. 490. IX 73.3: 87. IX 84.1: 130 n. 487. IX $94.2: 130$ n. 487.
Hesíodo. Teogonía, 1: 61 n. 203. 22: 61 n. 203. 45: 61 n. 203. 81: 61 n. 203. 27: 23 n. 29; 81 n. 273. 901: 183 n. 759. Trabajos y días, 792: 146.

Himnos hOMÉRICOS. A Apolo, 20: 119 n. 437. A Afrodita, 9: 119 n. 437. A la Madre de los dioses, 6: 123. A Ártemis, 7: 123. 8: 123.

HiPIAS. B 6: 117; 118.

Homero. Ilíada, I 1: 62; 65; 67; $69 ; 71 ; 72 ; 125$ n. 467; 127. I 2: 65; 71. I $3: 65$. I 5: 70. I 5: 127. I 6: 70; 125 n. $467 ; 127$. I 7: 125 n. 469. I 8: 119 n. 441; 127. I 11: 70. I 12: 70; 120 n. 442. I 52: 70; 125 n. 469. I 53: 70; 127. I 56: 68. I 234: 43 n. 105. I 322: 64. I 609: 237 n. 1027. II 276: 64. II 761: 65. II 831: 103 n. 383. IV 55: 171 n. 698. v 197: 65. v 444: 64. V 876: 64. IX 103: 306 n. 1365. IX 314: 306 n. 1365. IX 413: 19 n. 831. XI 55: 64. XII 735: 306 n. 1365. XIII 8: 65. XIII 735: 306 n. 1365. XVI 432: 175 n. 726. XVI 621: 66. XVIII 496: 147 n. 577. XVIII 497: 146. XXII 257: 65. XXIII 486: 146. Odisea, I 1: 62; $65 ; 67 ; 68 ; 72 ; 125$ n. $467 ; 127$. I 2 : 66; 69. I 3: 66; 69 n. 118. I 4: 66; 69. I 5: 66; 69. I 6: 68; 69; 120 n. 445; 127. I 7: 69. I 8: 69. I 9: 68; 125 n. 467; 127. I 10: 60; 68; 69; 70; 125 n. 469 . I 11: 68, 69. I 25: 68; 69; 125 n. 469 . I 26: 69. I 27: 69. I 346: 171 n. 698. I 420: 66. II 33: 307 n. 1365. VI 68: 171 n. 698. IX 149: 171 n. 698. IX 165: 65. IX 297: 72 n. 238. IX 381: $171 \mathrm{n}$. 698. X 15: 65. X 330: 65. X 458: 65 . 
XIII 154: 307 n. 1365. XXIII 130: 306 n. 1365 .

ÍBICO. Fr. 1 PMG: 196 n. 831.

INSCRIPTIONES GRAECAE. I ${ }^{2}$ 404: 43 n. 109. $\mathrm{I}^{2}$ 410: 43 n. 109. $\mathrm{I}^{2} 428: 43$ n. 109; $\mathrm{I}^{2} 444: 43$ n. 109. $\mathrm{I}^{2}$ 455: 43 n. 109. $\mathrm{I}^{2}$ 455: 43 n. 109. $\mathrm{I}^{2}$ 472: 43 n. 109. $\mathrm{I}^{2}$ 497: 43 n. 109. $\mathrm{I}^{2}$ 503: 43 n. 109. $\mathrm{I}^{2}$ 927: 43 n. 109. $\mathrm{I}^{2}$ 928: 192 n. 813. I ${ }^{2}$ 990: 101. I 1-2, 503/504: 196. $I^{3} 1-2,1162$ : 102 n. 736; 197. I $1-2$ 1179: 102 n. 376; 197. II / $\mathrm{III}^{2}$ 3.2.6288.8: 102 n. 375. 11780: 102.

INSCRIPTIONES SAMI. MDAI (a) 1926, 26-28, no 1: 196.

ION DE Quíos. B 1: 37. FGrHist, F 6: 189 n. 801 .

ISÓCRATES. Encomio a Helena, $\mathrm{X}$ 64: 32 n. 63; XXII; 412. Carta VIII, 4: 408 .

JENOFONTE, Simposio, 8.11: 281 n. 1220 .

[JENOFONTE]. La república de los atenienses, 1: 38; 117.

SAN Jerónimo. Cronografía, Ol. 83.4: 94 n. 332.

LICOFRÓN. B 1: 156 n. 616.

LUCIANO. Heródoto, 3: 91 n. 320. Falaris, II 10.11: 311 n. 1387.

Nuevo Testamento. Mateo, 1.1: 53 n. 167.

ÓCELO. 1.1: 279.
OXYRHYNCUS PAPYRI. XLIX $\mathrm{n}^{\circ}$ 3965: 121 n. 452.

Pseudo LongINO. XXIII 3: $18 \mathrm{n}$. 10.

QUINTILIANO. X 1.31: 271 n. 1166.

PaUSANias, I 29.4: 43 n. 109.

PínDARO. Olímpicas, I 23: $132 \mathrm{n}$. 498. I 93: 132 n. 498. VI 11: 119 n. 439. VIII 10: 132 n. 498. VIII 55: 172 n. 700. IX 101: 132 n. 498. X 4: 119 n. 439. X 21: 132 n. 498. X 95: 132 n. 498. XII 4: 119 n. 439. XIII 6: 119 n. 439. XIV 6: 119 n. 439. Píticas, I 10: 119 n. 439. I 66: 132 n. 498. I 85: 172 n. 700. II 16: 119 n. 439. II 111: 132 n. 498. IV 125: 132 n. 498. V 73: 132 n. 498. VII 9: 119 n. 439 . VIII 7: 119 n. 439. X 11: 119 n. 439. Nemeas, III 83: 132 n. 498 . VII 63: 132 n. 498. VII 38: 132 n. 498. IX 39: 132 n. 498. Ístmicas, v 8: 132 n. 498. VI 25: 132 n. 498. VII 29: 132 n. 498. VII 39: 172 n. 700. Fragmentos, 52 Snell: 132 n. 498.

Platón. Critón, 44a: 281 n. 1220. Parménides, 127a: 95 n. 336; 97 n. 357. Teeteto, 192c: 281 n. 1220. 204e: 281 n. 1220. Fedro, 234e: 343 n. 1524. Menéxeno, 242e: 244 n. 1047. Fedro, 277e5: 31 n. 58. Hipias Mayor, 285d: 91 n. 321. Protágoras, 314b: 95 n. 336. Crátilo, 396a: 158 n. 628. República, 393a: 399 n. 1748. 393b: 416 n. 1841. Gorgias, 448c: 117 n. 428.449 b: 95 n. 336. 
Plutarco. Vida de Cimón, IX 2: 95 n. 338. Vida de Alejandro, LII y Ss.: 418 n. 1853 . LIV: 435 n. 1934. De Pythiae oraculis, 406e: 48 n. 134. De Malignitate Herodoti, 864d: $91 \mathrm{n}$. 321.

PoetaE EPICI. Pequeña Ilíada, 1: 62. Tebaida, 1: 62.

Polibio. I 3.1: 385. II 56.7: $413 \mathrm{n}$. 1822. IV 20.5: 370. VII 11.1: 377 . VIII 11.1: 406, n. 1797. IX 1: 373. XII 26d 1: 427 n. 1900. IX 27.7: 373. XII 27.8 y ss: 376 . XII 28.8: 387.

Protágoras. B 1: 39 n. 87. B 4: 39; 74; 117; 118; 157. B 32: 39 n. 85.

SAFo. Fr. 44: 196 n. 831.

SCHOLIA AD THUCYDIDEM. I 1.1: 213.

SEXTO EMPíRICO. Adversus Mathematicos, VII 132: 35 n. 72.

SEMÓNIDES. Fr. 1: 184.

SIMÓNIDES. 16 [521] PMG: 200. 22 [527] PMG: 201 n. 850. 26 [531] PMG: 103 n. $380 ; 132$ n. $500 ; 196$, n. 832; 199. $11 \mathrm{~W}: 121 ; 122 ; 124 ; 127$. Epigrammata, 6: 200 n. 844. 7: 200 n. 844. 9: 200 n. 844. 20: 200 n. 844. 62: 200 n. 844.

SófoCles. Antígona, 257: $306 \mathrm{n}$. 1357. 498: 133 n. 503. 998: 306 n. 1357. Áyax, 55: 308 n. 1373. 756: 133 n. 503. Edipo en Colono, 94: 306 n. 1357. 342: 303 n. 1337. Edipo rey: 77: 308 n. 1373. 710: 306 n. 1357. 1059: 306 n. 1356. 1440: 308 n.
1373. Electra, 24: 306 n. 1356. 60: 133 n. 503. 886: 306 n. 1357. 985: 133 n. 503. Filoctetes, 230: 303 n. 1337. 251: 133 n. 503. 361: 303 n. 1337. 498: 303 n. 1337. 763: 303 n. 1337. 1331: 133 n. 503. Traquinias, 55: 309 n. 1379. 56: 303 n. 1337. 368: 303 n. 1337. Fragmentos, 314: 305 n. 1353.

SoLón. Fr. 4W: 185 n. 778; 364 n. 1633. 13W: 183. 183 n. 763.183 n. $765 ; 185$ n. 775.

SUDA, II p. 393: 323.

SYLLOGE INSCRIPTIONUM GRAECARUM. 1: 46 n. 118. 2: 44; 44 n. 116 ; 464: 44 n. 112 . 3: 45 n. 118. 4: 45 n. 118. 275: 426 n. 1896.

TeOGNIS. 159: 200 n. 846. 246 y s.: 196 n. $831.668: 183$ n. 758.

TEOPOMPO. T 2: 402 n. 1764. F 1: 89 n. $307.2: 89$ n. $307.3: 89$ n. 307. 4: 89 n. 307. 13: 392. 20: 393. 24: 374 ; 375; 384; 385. 25: 374; 385; 390; 405 n. 786. 26: 374. 27: 374; $377 ; 385 ; 407$ n. 1797. F 30: 393; 401. F 44: 397 n. 1735. F 85: 404 n. 1788. F 86: 404 n. 1788. F 87: 404 n. 1788. F 88: 393. F 89: 393. F 105: 404 n. 1777. F 124: 394. F 213: 404 n. 1777 . F 342: 376; 410. F 344: 403 n. $1770 . F$ 381: 378; 385; 403 n. $1772 ; 407$.

Timeo de TAUROMENIO. F 7: 387 ; $388 ; 426 ; 427$.

TIRTEO. Fr. 1W: 102 n. 377. 
Tito LiVIO. I 3.6: 53 n. 167.

TUCÍDIDES. I 1: 220; 251; 256; $257 ; 263 ; 266 ; 278 ; 279 ; 280 ; 281$; $282 ; 283 ; 285 ; 294 ; 302$ n. $1325 ; 305$ n. $1348 ; 311$ n. $1393 ; 320 ; 324$. I 2 : 228; 251; 254; 256; 260; 261; $261 \mathrm{n}$. $1140 ; 283 ; 283$ n. 1231; 284; 292; 294; 320; 340 n. 1510; 354. I 3: 226; 252. I 10: 223; 230; 257; 261; 284; 294 n. 1295; 302 n. 1325; 307 n. $1369 ; 308$ n. $1371 ; 320 ; 321 ; 360$. I 4 : 252; 258; 261; 285; 291; 291 n. 1288; 291 n. 1289; 302 n. 1332. I 5: 261; $262 ; 283$ n. 1231; 285; 291; 308 n. 1371. I 6: 262; 285; 286; 291; $291 \mathrm{n}$. 1289; 305 n. 1355. I 7: 262; 286. I 8: 252; 257; 258; 262; 283 n. 1231; 293; 293 n. 1294; 294; 294 n. 1296. I 9: 262; 302 n. 1325; 307 n. 1369; 308 n. $1371 ; 339$ n. $1501 ; 339$ n. 1502; 340 n. $1505 ; 340$ n. $1507 ; 361$ n. 1616 . I 10: 228; 262; 286; 302 n. 1333; 305 n. 1355; 306 n. 1369; 308 n. 1371; 341 n. 1515. I 11.2: 222 n. 926; 258; 262; 286; 308 n. 1371. I 12: 256; 258; 263; 321. I 13: 252; 256; 258; 283 n. 1231; 287; 291; 291 n. 1288; 308 n. 1371. I 14: 263. I 15: 259; 263; 287; 291; 294 n. 1295. I 16: 291. I 17: 259; 263. I 18: 252 n. $1087 ; 259 ; 263 ; 287$; 288; 340 n. 1511; 341. I 19: 252 n. $1087 ; 259 ; 260 ; 263 ; 288 ; 320$. I 20 : 226; 257; 263; 264; 288; 291; 302 n. 1325; 305 n. 1348; 309; 323; 324; 325; 348 n. 1557. I 21: 91 n. 319; 222 n. $917 ; 254 ; 255 ; 264 ; 288 ; 293 ; 302$ n. $1325 ; 305$ n. $1348 ; 305$ n. 1355 ; $311 ; 323 ; 343$ n. $1520 ; 380$. I 22: 227;
229; 252; 264; 276 n. 1196; 288; 289; 294; 295; 305 n. $1348 ; 311 ; 355 ; 359$; 418. I 23: 223; 226; 228; 230; 235; $237 ; 240 ; 252 ; 252$ n. 1087,$255 ; 256$; 259; 264; 266; 289; 329; 330; 330 n. 1459; 331 n. 1469. I 23: 333. I 34.3: 302 n. 1325 ; 322. I 54.2: 283 n. 1231. I 57.5: 287 n. 1264. I 66: 288. I 73.5: 302 n. 1325; 322. I 76.2: 340. I 89.1: 246. I 87.1: 322. I 93.5: 223. I 97.2: 246 n. 1061. I 101.2: 287 n. 1265. I 118.2: 246. I 126.2: 308 n. 1371. I 132: 302 n. $1325 ; 305$ n. 1355; 306 n. 1363; 306 n. 1364. I 140.1: 359. I 141: $360 ; 360$ n. 1615. I 142.4. 360. I 144: 359; 360. II 1: 221. II 34.2: 222. II 15.4: 302 n. 1325. II 17.2: 307 n. 1370. II 37.1: 361. II 39.2: $302 \mathrm{n}$. 1325. II 41.4: 305 n. 1355. II 42.1: 305 n. 1355. II 50: 302 n. 1325; 308 n. 1371 . II $53.2: 281 ; 281$ n. 1219 . II 54: 222 . II $60: 349 ; 362$. II $61: 362$. II 63: 361. II 65: 224 n. 943. II 68.5: 287 n. 1264. II 87.1: 302 n. 1325. III 26.3: 87 n. 301. III 53.2: 302 n. 1325; 322. III 66.1: 302 n. 1325. III 82.4: 352; 352 n. 1576. III 86.2: 222. III 87.2: 222. III 92.5: 287 n. 1265; III 104: 302 n. 1325; 308 n. 1371. IV 8: 287 n. 1265. IV 48.5: 222. IV 53.2: $287 \mathrm{n}$. 1265. IV 114.5: 283 n. 1232. IV 123.2: 302 n. 1325; 322. v 1: 308 n. 1371. v 20: 247 n. 1067. v 20.3: 242. V 24: $221 ; 238 ; 239 ; 240 ; 241 ; 243$; 248; 305 n. 1348 . v 25: 223; 228; 239; 240; 243; 266; 267; 349. v 26: 219; 228; 238, 239, 239 n. 1034; 241; 245 n. $1058 ; 256 ; 305$ n. $1348 ; 376$. V 27 : 241. v 47.5: 283. v 81.2: 224 n. 943. 
V 116.1: 280 n. 1218. V 120.3: 305 n. 1355. V 123.2: 281; 281 n. 1219 . VI 7 : 224 n. 945 . VI 26.2: 222 n. 926. VI 28.2: 302 n. 1325. VI 53.2: 309 n. 1378. VI 54.2: 353. VI 55.3: $307 \mathrm{n}$. 1370. VI 105: 244 n. 1055. VII 18: 224 n. 945 . VII 27.4: 222 n. 926. VII 57.1: 309. VII 65.1: 321. VIII 6.4: $287 \mathrm{n}$. 1265. VIII 50.5: 283 n. 1232. VIII 58.1: 308 n. 1378; VIII 66.2: 309 n. 1378. VIII 68: 273. VIII 97.2: 366.

VIRGILIO. Eneida, I 1: $383 \mathrm{n}$. 1696. 



\section{Monografías de Filología Griega. Normas de publicación.}

Todas las monografías deben incluir un Abstract (breve resumen en inglés del contenido del volumen), un Index verborum y una Bibliografía general.

Tamaño del papel: ancho: $17 \mathrm{~cm}$.; alto: $23 \mathrm{~cm}$.

Tamaño del texto: ancho $12 \mathrm{~cm}$.; alto: $18 \mathrm{~cm}$.

Encabezado superior: a $1 \mathrm{~cm}$. del texto.

Folio numérico: tamaño 10 (página izquierda par; página derecha impar).

Folio explicativo: tamaño 8, mayúsculas, cursivas.

Encabezado inferior: a $0,7 \mathrm{~cm}$. del texto.

Título de la revista, número, ISSN: tamaño 8 , minúsculas, cursiva.

Texto: fuente Times New Roman o Garamond; Unicode para los textos griegos.

Tamaño de la fuente: 11; párrafo: mínimo 13 puntos; sangría de párrafo de $0,6 \mathrm{~cm}$.; 6 puntos entre párrafos.

\section{Títulos de capítulos y partes:}

En página aparte:

tamaño 13 , mayúscula, negrita, centrado y párrafo mínimo 15 puntos.

Dentro del texto:

primer rango: tamaño 11, mayúscula, negrita, centrado y párrafo 13 puntos

segundo rango: tamaño 11, minúscula, negrita, párrafo 13

tercer rango: tamaño 11, mayúscula, cursiva, párrafo 13.

Citas: tamaño de la fuente: 9; párrafo: mínimo 11 puntos; sangría de texto de 1,2 cm. (izda. y dcha.) y sangría de primera línea de $0,6 \mathrm{~cm}$.; citas en párrafo aparte sin comillas; citas poéticas en párrafo aparte en letra redonda; partes omitidas indicadas con puntos suspensivos encorchetados [...].

Notas: tamaño de la fuente: 9 ; párrafo: mínimo 11 puntos; n. $^{\circ}$ de nota con sangría primera línea $(0,6 \mathrm{~cm}$.) y tabulador texto $(1 \mathrm{~cm}$.).

Referencias bibliográficas: Sistema Harvard (autor-año).

Las referencias bibliográficas pueden insertarse en el texto o desplazarse a nota.

Autor, año, páginas (más de una obra en el mismo año se diferencia mediante una letra: 1995a, 1995b). Los signos que enlazan los datos son aleatorios:

A. López Eire, 1999, pp. 234 ss. / A. López Eire (1999, pp. 234 ss.).

Bibliografía final: tamaño de la fuente: 10; párrafo: mínimo 12 puntos; sangría francesa de $0,6 \mathrm{~cm}$; apellidos en versalitas. Ejemplos:

ALY, W., «Herodots Sprache», Glotta, 15, 1926, pp. 84-118.

LÓPEZ EIRE, A. y C. SCHRADER, Los orígenes de la oratoria y la historiografia en la Grecia Clásica, Zaragoza, 1994.

Schrader, C., V. RAmÓn y J. Vela (eds.), Plutarco y la Historia. Actas del V Simposio Español sobre Plutarco (Zaragoza, 20-22 de junio de 1996), Zaragoza, 1997. 



\section{MONOGRAFÍAS DE FILOLOGÍA GRIEGA}

\section{VOLÚMENES PUBLICADOS}

1. Ana MAGALlÓN y Vicente RAMÓN, Plutarco. 'Sobre la malevolencia de Heródoto', 1989, VII+105 págs. (agotado)

2. José VELA, Estudio sobre la lengua de la 'Poliorcética' de Eneas el Táctico, 1991, XIV+378 págs.

3. Vicente RAMÓN, Plutarco y Nepote. Fuentes e interpretación del modelo biográfico plutarqueo, 1992, VIII+301 págs.

4. Carlos SCHRADER, Arriano: 'Indiké'. Concordancia lematizada, 1994, XIII+491 págs. (reeditado, con modificaciones [Concordantia in Flavii Arriani Indicam Historiam], en ed. Olms, Hildesheim, 1995.)

5. Antonio LÓPEZ EIRE y Carlos SCHRADER, Los orígenes de la oratoria y la historiografía en la Grecia Clásica, 1994, 201 págs. (reimpreso en Hakkert, Las Palmas, 1997.)

6. Jorge BERGUA, Estudios sobre la tradición de Plutarco en España (siglos XIII-XVII), 1995, VIII+303 págs. (agotado)

7. Vicente RAMÓN, Estudios sobre Tucídides. Ensayo de un repertorio bibliográfico (1973-1995), 1996, 142 págs. (agotado)

8. Carlos SCHRADER, Vicente RAMÓN y José VELA (editores), Plutarco y la Historia. Actas del V Simposio Español sobre Plutarco (Zaragoza, 20-22 de junio de 1996), 1997, XII+506 págs.

9. Carlos SCHRADER, Carlos JORDÁN y José Antonio BELTRÁN (editores), DIDASKALOS. Estudios en homenaje al Profesor Serafín Agud con motivo de su octogésimo aniversario, 1998, XXVI+354 págs.

10. Carlos JORDÁN, Introducción al celtibérico, 1998 , XI+259 págs. (agotado)

11. José VELA, Post. H.R. Breitenbach: Tres décadas de estudios sobre Jenofonte (1967-1997). Actualización científica y bibliográfica, 1998, VIII+224 págs.

12. Juan Francisco MARTOS MONTIEL, El tema del placer en la obra de Plutarco, 1999, 175 págs.

13. Rafael J. GALLÉ CEJUDO, El escudo de Neoptólemo. La paráfrasis filostratea del escudo de Aquiles (Philostr. Jun., Im. 10.4-20 - Hom., Il. 18.483-608), 2001, 155 págs.

14. Carlos SCHRADER, Los historiadores griegos del siglo V. Textos lematizados (Versión Macintosh), 2001, CD-ROM, edición no venal.

15. Jorge BERGUA, Introducción a los helenismos del español, 2002, 454 págs. (agotado)

16. Carlos JORDÁN, Celtibérico, 2004, IV+476 págs.

17. Ana VICENTE SÁNCHEZ, Las Cartas de Temístocles. Lengua y técnica compositiva, 2006, 484 págs.

18. Alberto Bernabé y Eugenio R. Luján, Introducción al griego micénico. Gramática, selección de textos y glosario, 2006, 363 págs.

19. Francisco J. GONZÁLEZ PONCE, Periplógrafos griegos I. Épocas Arcaica y Clásica 1 : Periplo de Hanón y autores de los siglos VI y V a.C., 2008, 288 págs.

20. Ana VICENTE SÁNCHEZ, Mal de amores en las Cartas eróticas de Filóstrato : teoría retórica y teoría epistolar, 2011, 164 págs.

21. Irene PAJÓN LEYRA, Entre ciencia y maravilla : el género literario de la paradoxografía griega, 2011, 368 págs. 